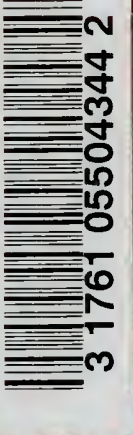

ST HELENA.

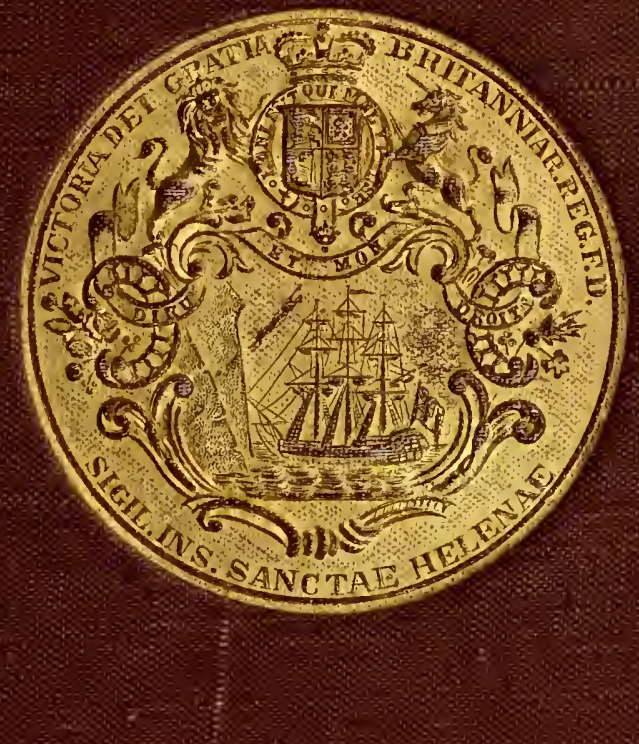


$\ldots$ 


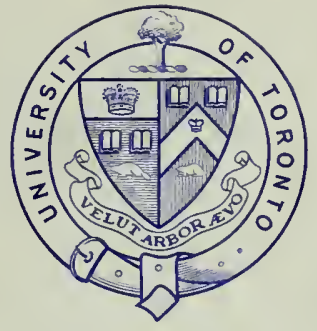

Hresented to

The Tithrary of the

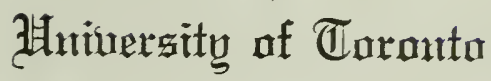
by

Freeman M. Tovell, Esq. 


\section{Digitized by the Internet Archive}

in 2008 with funding from Microsoft Corporation 
soln 4 dosin 

ST. HELENA 



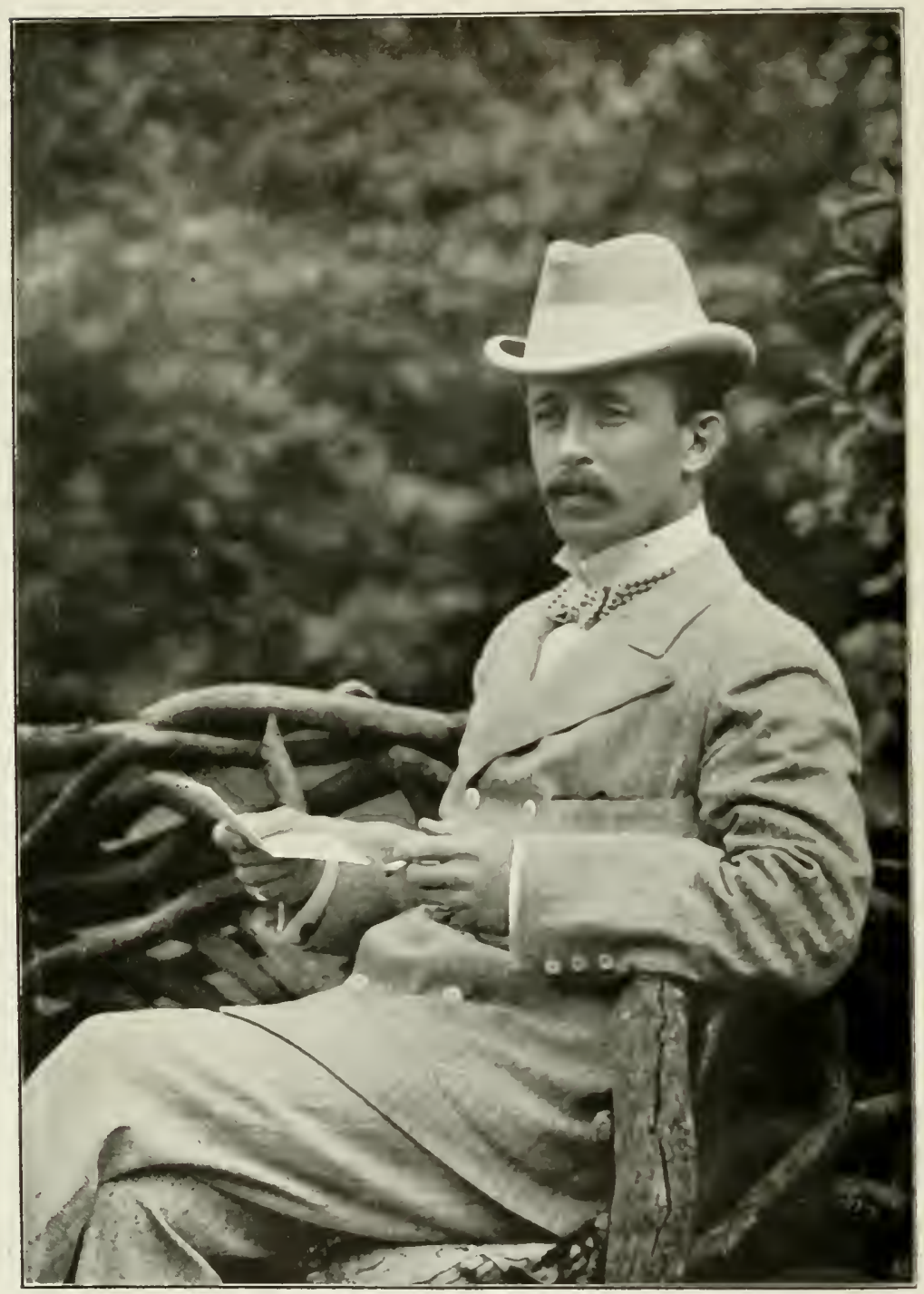

His Excellexcy Colonei. Gaiway, C.MI.G., I).S.().

(Governor of St. He'ena, 1903.) 


\title{
ST. HELENA:
}

\section{THE HISTORIC ISLAND}

\author{
FROM ITS DISCOVERY TO \\ THE PRESENT DATE
}

BY

E. L. JACKSON

LONDON

WARD LOCK \& CO. LIMITED

NEW YORK AND MELBOURNE 


$$
\frac{532584}{16.7 .56} \frac{D T}{671}
$$


Contents

Historical AND GeOgRAPHICAL .

PAGE

9

DESCRIPTION

DESCRIPTIVE

JOTTINGS FROM St. HelENA RECORDS

Chappell Valley .

- 132

ON SLÁVERY AND THE WORK OF H.M. CRUisers ON THE West COAst of Africa

259

TRISTAN D'ACUNHA .

309 




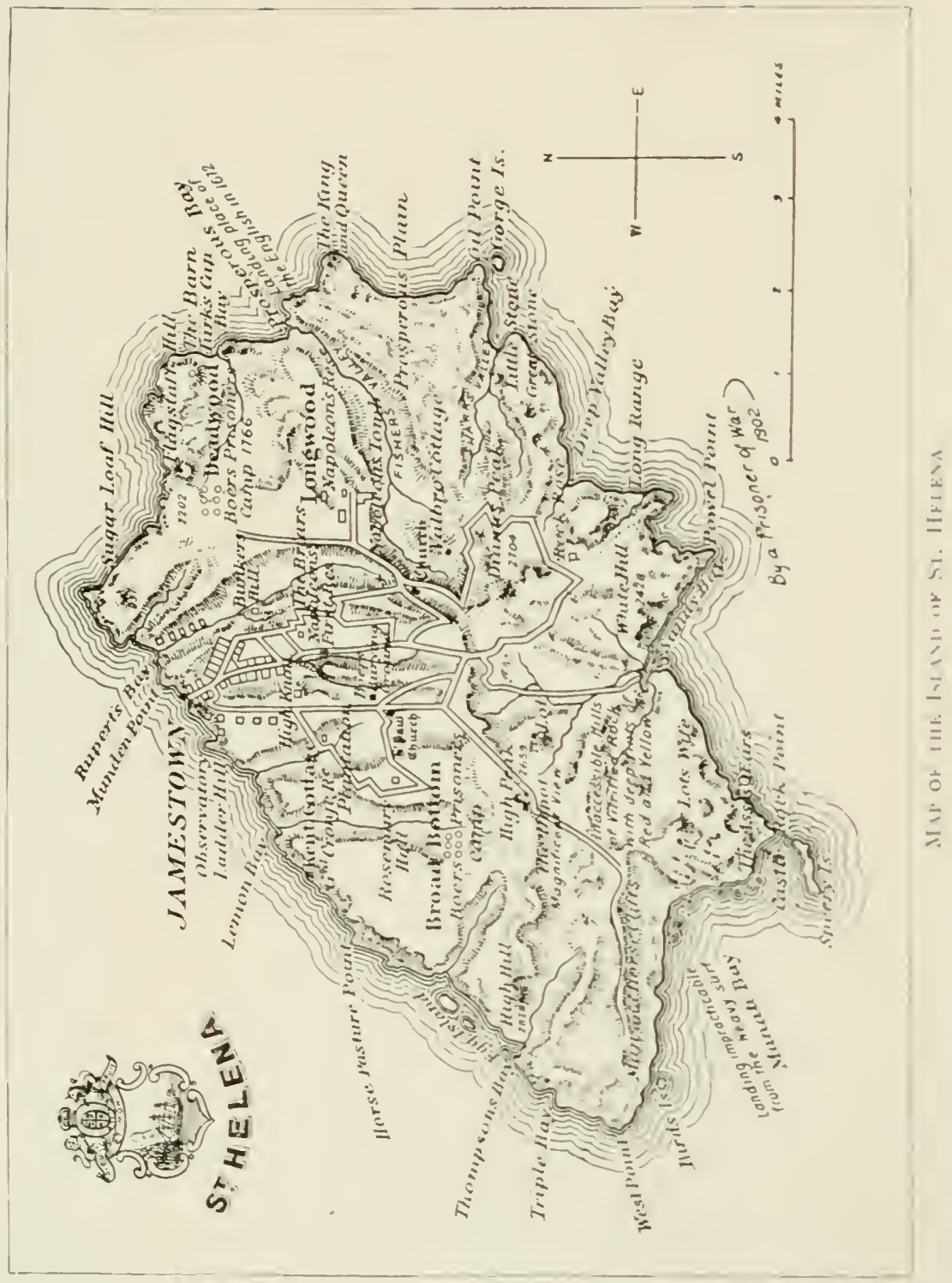




\section{ST. HELENA}

\section{HISTORICAL AND GEOGRAPHICAL}

THIS most solitary island, probably an extinct tertiary

1 volcano, is one of the peaks of a range of mountains traversing the South Atlantic Ocean, Ascension, with Green Mountain, and Tristan d'Acunha, with peak 8,00o feet high, being parts of the same range.

Geologists have been unable to fix with exactness its chronological position, from the circumstance of its fossils being peculiar to the island, and therefore furnishing no clue to the geological age of the formations in which they occur. The volcanic forces which have produced the complicated disturbances so conspicuous throughout the island must have ceased at a very remote period, as it has evidently retained for ages its existing conformation. At the height of many hundred feet above the level of the sea, shells in considerable numbers are found, embedded in the soil; these shells were formerly supposed to be of marine origin, but a more careful examination has shown them to be (altogether) of a land species, and of a kind no longer found in a living state. Their destruction, which has been imputed to the clearing away of the original forests, is more probably owing to geological causes. The principal component of the island is a dark lava, the successive streams of which are very distinctly marked on the faces of the abrupt cliffs which form the coast.

In its central and higher parts, a different series of rocks has, from extreme decomposition, produced a clayey soil, which, where not covered with vegetation, is seen in bright bands of colour. Some of this mud or clay presents a wonderful appearance, the tints being of all shades. On one side is seen the beautiful mauve and violet peculiar to the pansy, on another the shaded reds and pinks of geraniums, and, at a distance, the colourings appear suitable for pigments, but on inspection are found to be of a very coarse nature. 
In the year I502, when the island was first discovered by Juan de Nova Castella, the commodore of a Portuguese fleet, the interior was a huge forest, even some of the precipices overhanging the sea being covered with gum wood trees. The day of its discovery was the anniversary of the birthday of Helena, the mother of Constantine the Great, so the island by the Portuguese was called St. Helena, a name which it has always retained. In the first record the word is, however, spelt Hellena.

These early navigators, always on the outlook to find islands which they could use as watering places for their vessels, and which would generally supply them with vegetables, meat, and fruit, were eager to stock and colonize them. On the occasion of the discovery of St. Helena, we find they were prepared, for they left at the island some goats, asses, and pigs; but at this visit there is no mention of colonization. Eleven years after, a Portuguese fleet called on its way home from India, and left here the first human inhabitant. He was Fernandez Lopez, a nobleman who, having incurred disgrace through desertion, was condemned, and punished to the extent of having his nose, ears, right hand and the little finger of the left hand cut off. We can well imagine he preferred to be left here, rather than to endure the reproach and ignominy which awaited him at home. Thus, he was the first Governor of St. Helena, and, according to the rccords, was provided with a few negro slaves, pigs, goats, poultry, partridges, guinea-fowl, pleasants, peacocks, vegetables, roots, fig, orange and peach trees. (It is a mystery how the small vessels of that date were able to keep on board all these animals, poultry, and food.) Here he spent four years, being then recalled by Portugal. That nation, however, continued to use the island as a place of call for vessels homeward bound.

Captain Cavendish in I588 anchored off Chapel Valley (Jamestown), and an interesting account of his visit will be found in a later chapter. There were then a few good buildings, and a Roman Catholic Church. He found that the Portuguese had been very successful in introducing useful trees and plants, and that fig, lemon, orange, pomegranate, shaddock, and date trees, as well as parsley, sorrel, mustard, and radishes were plentiful; there were also 
partridges, pheasants and turkeys, with a large number of goats and wild pigs. We do not read again of the visit of an English ship till I59I, when Captain Kendall (of the ship Royal Merchant), who commanded one of the first three ships which set out for India, could, owing to sickness in the fleet, get no further than the Cape of Good Hope. These first three ships were the Royal Merchant, the Penelope (Captain Raymond) and the Bonaventure (Captain Lancaster). It was deemed advisable by them that the Royal Merchant should return with the sick men of the squadron who were exhausted by scurvy; so on her passage home she called at the island, where her debilitated sailors derived much benefit. The other two ships were afterwards separated in a gale, and the Admiral (Raymond) was never heard of more. Lancaster, however, reached India. Returning after many disasters he reached St. Helena on April 3, I593, making a stay of nineteen days. According to the accounts given of his visit, it was not the place of plenty and beauty described by Captain Cavendish. When the sailors landed, their attention was attracted by a voice singing within the chapel, which they entered. Their sudden appearance greatly alarmed the forlorn singer, until he found they were his own countrymen, and, to add to his delight, he recognized amongst them some of his old companions. This man (John Legar) was one of those whom it had been deemed necessary to send home in the Royal Merchant, but his disease on the voyage had made such progress that he had been left by Captain Kendall at St. Helena, as the only chance of saving his life. His comrades had made him two suits of goat skins, and his diet, together with the climate of the place, had completely restored him to bodily health; but the sudden transition from a state of apprehension that he might never return to his native land, to joy, at the sight of his countrymen, and the contemplation of once more seeing his home, was too much for him; for having taken no rest nor sleep during eight days, he died from exhaustion and debility.

In I603, Captain Lancaster made another call. He was then in one of a fleet of four ships outward bound in the interests of the East India Company. At this time the island was the resort of Dutch and Spanish ships as well as 
English, and the Portuguese, busy with fresh conquests, deserted the island. It was, however, quite a favourite post office with the captains and crews of passing ressels. The letters were usually placed under a boulder, and the boulder made conspicuous, so that people coming on shore could not help seeing it. In this way the crews of homeward bound vessels took news to England of the outward bound.

The Dutch traders were the next to take an interest in and to make use of this solitary spot, and until the year I65 1 , they found it very useful; but, after establishing a colony in the Cape of Good Hope, they deserted St. Helena, and the East India Company of Merchants in England, being by this time fully aware of its great value, at once annexed it with a capital of $£ 72,000$, part of which was laid out in the equipment of four ships, viz. the Dragon, Hector, Ascension, and Susan, all under the command of Captain Lancaster, and a fort was erected by Governor Dutton. The incorporition of the East India Company-that event so memorable in the commercial annals of England-took place in the year I600, under the auspices of Queen Elizabeth. For ten years they held the island, and ultimately obtained from King Charles II a charter, which secured it to their use and benefit. This charter is still kept at the Castle in Jameslown.

ExtRACT FROM THE CHARTER OF KING CHARLES I, Dated $3 r d$ April, 1661.

And, that it slull and may be lawful, to, and for the said Governor and Company, and their successors from lime to time, and at all times fron lienceforth, to crect and build such castles, fortifications, forts, garrisons, colonies or plantations at St. Helena; as also elsewhere within tlic limits and bounds of trade granted unto the said Governor and Company, as aforesaid, as they in their discretion shall think fit and require, and for the supplying of such as shall be requisite to kcep and be in the same, to send out of this kingdom to the said castles, fortifications, forts, garrisons, colonies or plantations, all kinds of clothing, provision of victuals, ammunition, and implements necessary for such purposes, with. out paying of any custom, subsidy or other duty, for the same; as also to transport and carry over such number of men (being willing thereunto) as they shall think fit; as also to govern them in such legal and reasonable manner as the said Governor and Company shall think fit; and to inflict punishment for misdemcanours, or impose such fines upon them for breach of thcir orders, as in these presents are formerly cxpressed. 
On the Company assuming sole right, they at once established a small colony, fortifications were erected, and emigrants came from England bringing cattle, trees, plants, etc.., and in a short time the place seemed thriving. This prosperity excited the covetousness of the Dutch; so, in 1665 , they attacked it, and were successful in gaining possession. But the English were not easily to be driven out of the colony they had worked hard to form, and within twelve months were again in full possession. They had, however, learnt a lesson, and at once commenced fortifications. The original fort, built by Dutton, was demolished (a stone record still remains of this, built into the wall of the present building close to the entrance) and another built. This was triangular, and is supposed to form the basement part of the present Castle.

The place then took the name of Fort James in compliment to the Duke of York (afterwards King James II), and from this time the valley is termed James' instead of Chapel Valley - the usual term now in speaking of the valley is Jamestown. This year saw the great fire of London, and many ruined families sought refuge in St. Helena.

For nearly ten years the East India Company kept no records of their transactions - at any rate no written accounts can be found-but, by tradition, we know the island was governed successively by men of the names of Dutton, Stringer, Swallow, Coney and Bennett. After them came Anthony Beale, and while he was Governor in 1673 , the Dutch again took possession, but only after great resistance from the islanders, who fought valiantly. This time the invaders gained a footing in Lemon Valley (near Jamestown), but they met such a furious shower of rocks and boulders from the hillsides, that it was impossible for them to proceed, and they were driven to take shelter in their ships. Even in these times such a fusilade would be most formidable, but it did not daunt the Dutch, who waited till night. Then, espying a light on the coast, they made for it, and landed at a place called Bennett's Point in Swanley Valley, where they found a planter fishing on the rocks attended by a slave. This slave was coerced by threats to guide them through the intricate parts of Swanley Valley to the moun- 
tainous land near High Peak; but the islanders were again on the alert, and prepared to meet them with a force of 500 men from the island garrison. The Battle of High Peak then took place, and the islanders had to retire, the Dutch forcing their way down towards Fort James, into which the Governor and the islanders had retired. The besieged Governor and men resisted the attack for some time, but eventually gave in, and made their escape on some ships in harbour which were bound to the coast of Brazil. Very fortunately they fell in with a British squadron commanded by Captain Munden (afterwards Sir Richard).

He was proceeding outward to convey to England the East India homeward bound fleet, but on learning what had occurred at St. Helena he determined to recapture it, and accordingly set sail for the island, arriving on May I4, I673. Unobserved and quite unexpected by the Dutch, he landed at "Prosperous Bay" on the east, with about 200 men, under command of Captain Kedgewin.

Fortunately they had a slave, who had escaped with Governor Beale, named Black Oliver (of whom an account will be found in "Jottings from Records"). He was well acquainted with the island, and made a good guide up the steep and rugged rocks till they came to a perpendicular cliff of great height, now called "Hold-fast Tom." This seemed an insurmountable difficulty, but one of the party, named Tom, taking with him a large ball of twine, and exhorted and encouraged by his companions, accomplished the difficult feat of scaling it. By the help of the twine a rope was drawn up, and he was able to assist his companions to the summit. Captain Kedgewin, with his little army, was then enabled to travel by Hutt's gate toward Longwood heights. On the way they refreshed themselves at the houses of the cottagers, and passing Longwood, took up a position on the top of Rupert's Hill, cast of, and above, Jamestown.

By this time Captain Munden had sailed across to the north and appeared in front of Fort James about the same time as Kedgewin appeared on the heights, and the Dutch were so taken by surprise that they immediately surrendered.

On landing, the English placed two guns in position on a 
hill to the eastward of Fort James, to protect the town from attack on that side: and this was the beginning of the Battery known to this day as Munden's, mentioned again in the chapter "Jottings from Records."

In those days of slow communication, intelligence of the surrender had not reached Holland before a Governor had been sent out to succeed the Dutch officer (supposed to be named Duke), who was temporarily in charge. When the Dutch Governor arrived, he anchored with his fleet of several richly-laden vessels, in total ignorance of what had occurred. Captain Munden had the satisfaction of taking him prisoner, and making prizes of the valuable cargoes. After this Munden left the island in charge of Captain Kedgewin.

King Charles II again in 1673 granted by charter, dated December I6, the rights and possessions of the island to the East India Company, as lords proprietors of the island. This charter, as well as that of I66I, is still preserved at the Castle.

It is well known that St. Helena was successively occupied by Portuguese, Dutch and British, as a store island for ships from India, China, etc., up to the time of the opening of the Suez Canal, and in these old times many regulations and orders were sent from England, as under :-

"You are particularly enjoined to render every acre of ground capable of cultivation, as productive as the nature of the soil will admit."

As early as 1675 Directors of the East India Company wrote :-

"We find there is wanting industry and painstaking in many of the inhabitants, which we will not permit to continue amongst you : for they that will not plant, and take care for provisions of their own, we will not supply them: but rather send them home under the title of drones."

This threat was actually executed by Governor Roberts

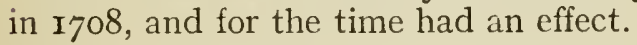

Copy of the Charter granted to the Company by His Majesty KING Charles II.

Dated I6th December, 1673.

Preamble. Charles II by the grace of God King of England, Scotland, France and Ireland, Defender of the faith, and so forth, to all those whom these presents shall 
come greeting, whereas at the suit of our well beloved subjects the Governour and Company of Merchants of London, trading into the East Indies, and for the honour and profit of this our realme, and in the encouragement of trade in those remote parts, We have, by our Ruyall Charter, or letters patent bcaring date at

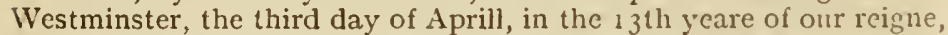
granted unto the said Governour and Company of Merchants of London trading into the East Indies, and their successors; that they, and their successors and their factors, servants and assigns, in the trade of merchandise for them, and on their behalfe, not otherwise, shall for ever have, use and enjoy the whole, and entire and only trade, and trafique, and the whole entire and only liberty, use, and privilege of trading, and traffiquing and using the feate and trade of merchandise to and from the saicl East Indies, and toe and from all the islands, ports, havens, citics, towns and places within their said Charter, that is to say, to and from the East Indies, in the countries of Asia, Africa and America, or any of them beyond the Capc of Bona-Esperanza to the streiglits of Magellan, where any trade or traffique of mcrchandise may be used or had; and that it should and may be lawful to and for the same Governour and Company and their successors from time to time, and at all times, henceforth to crect and build such castles, fortifications, forts, garrisons and to erect such collonies, and make such plantations at St. Helena as also clsewhere within the limits and bounds of trade granted unto the said Governour and Company as aforesaid, as they in their discretion shall think fit and requesit and for the supplying of such as should be requested to keep or be in the same, to send out of this Kingdom to the said Castles, fortifications, forts, garrisons, collonies or plantations all kinde of clothing, provision or victuals, ammunition and supplyments nccessary for such purpose without paying of any custom, subsidy (or other) duty for the same; as also to govern them in such

To send Provi- legal and reasonable manner as the Governour sionsthither and Company shall think fitt; and to inflict without paying punishment for misdemeanours, or impose such any Duty. fines upon for breach of their orders as in our said Charter are expressed. And whereas also by our said Royal Charter or letters patent, We have ordained that there shall be a Government and twenty foure Committees of the said Company, to be elected and appointed in such forme as therein is expressed, who shall from time to time have the directions of the voyage of and for the said Company, and the provision of the shipping and merchandise thereunto belonging, and also the saile of all merchandise goods and other things returned in all or any of the voyages of ships of or for the said Company, and the manageing and handling of all other businesses, affairs and things belonging to the said Company, and likewise that it shall and may be lawfull to and for the said Governour and Company for the time being, or the major part of them present at any publique meeting, commonly. called the Generall Court, holder for the said Company, the said 


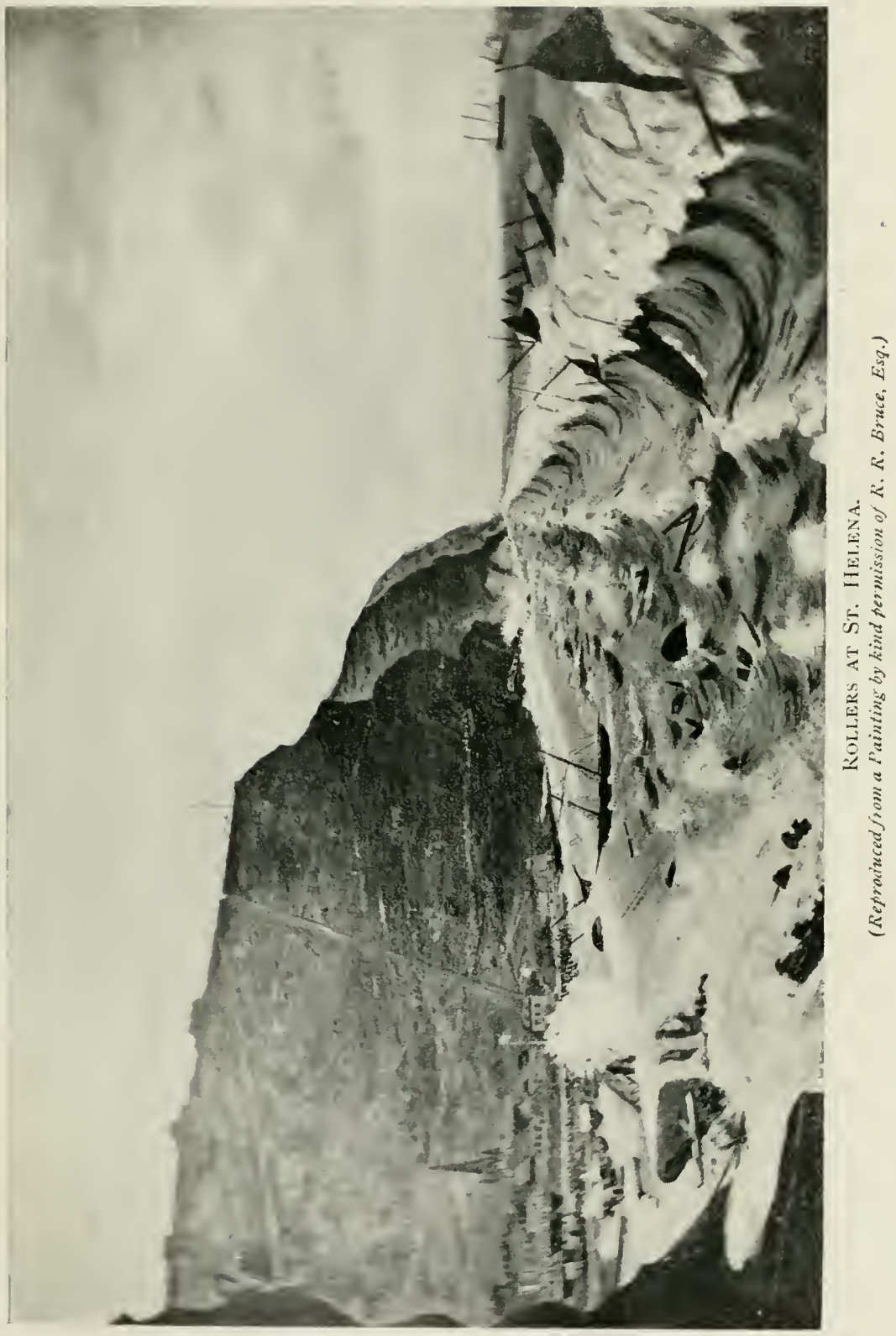



Governour for the said Company alwaies being one from time to time, elect, nominate and appoint one of the said Company to be the Deputy to the said Governour, who from time to time, in the absence of the said Governour shall exercise and execute the office of Governour of the said Company, in such sort as the said Governour ought to do, as by our said Charter letters patent, reference thereunto being had amongst divers others, grants liberties immunities, priveleges and pre-eminences, may more fully appear; and whereas in pursuance of our said Royal Charter, the said Governour and Company did, at their own cost and charge erect severall forts and fortifications as aforesaid being an island situate in or near Africa, beyond the line and on this side the Cape of Bona-Esperanza, and placed a garrison there and were proceeding to plant and people on the same, and for that purpose had transferred divers of our subjects who were willing thereunto to inhabit there; but our said subjects inhabiting the said island were lately, in the time of war between us and the states of the United Provinces, by force of arms dispossessed thereof by the subjects and forces of the said States, and the said States and their subjects had and kept the quiet posetion thereof for severall months together; and whereas

Referred to the by the grace of God on our royall ships and capture of forces under the command of Sir Richard Munden,

St. Helena by the the said island, and all and singular the forts, Dutch. fortifications and other the appurtenances thereunto belonging were retaken from the said states and their subjects, and a garrison of our subjects placed there, by virtue or reason whereof the said island, and all and singular the forts and fortifications, erections and buildings thereon, with the appurtenances vested in us, our heirs and successors in the write of our crowne, all artillery, arms, armour, weapons, ordinance, munition, magazins, stores, goods, chattles and moveables whatsoever which were there found at the time our said forces retook the same as aforesaid, do of right belong unto us, and no other; and whereas the said island hath been found by experience to be very necessary and commodious for our loving subjects, the said Governour and Company of Merchants trading into the East Indies for refreshing of their servants and people in their returns homewards, being often then weak and decayed in their health by reason of their long voyages under their hot clymes, whereupon our subjects, the said Governour and Company, have besought us to regrant and confirme the same unto them: Now know yee, that forasmuch as we have found by much experience that the said trade into the East Indies hath bin managed by the said Governour and Company to the honour and profitt of this our realme, and to that end, and out of the earnest desires that the said Governour and Company may, by all good and lawfull means and waies, be encouraged in their difficult and hazardous trade and traffique in these remote parts of the world, Wee, therefore, of our especial grace, certain knowledge and meer motion have given, granted and confirmed, and by these presents for us, our heirs, and successors, 
do give, grant and confirme unto the said Governour and Company of Merchants of London trading in to the East Indies, their successors and assigns, all that the said island St. Helena, with all the rights, profitts, territories and appurtenances whatsoever; and the soyle, lands, fields, woods, mountains, farms, lakes, pools, harbours, rivers, bays, isles, islets scituate or being within the bounds, or limitts thereof, with the fishing of all sorts of fish, whales, sturgeons, and all other royall fishes in the seas, bayes, isletts, rivers, within the premises and the fish therein taken; and all the seines, maines, quarryes, as well royall mines as the mines whether the same be already discovered or not discovered, and also all the gold silver veines and precious stones, and all others whatever, be it of stones, metales, or any thing whatsocver, found, or to be found, within the veines, mines or quarryes, of the said island and premises aforesaid, and all and singular royalties, revenues, rents, customes, castles, forts and buildings, and fortifications, erected and to be erected, on the premises, or any part thereof, and all priveleges franchises, immunities, preheminences, and heridants, whatsoever within the same or to them, or any of them belonging or in any wise appertaining in as large and ample a manner, to all intents and purposes and constitutions, as Wee now ourselfe have and enjoy the same by virtue and force of our said conquest thereof, or otherwise howsoever; and them the said Governour and Company of Merchants of London, trading into the East Indies, their The Company of successors and assigns, Wee do, by these presents, Constituted

Lords Proprietors of St. Helena reserving to the Crown the faith and Allegiance of the Company and inhabitants. for us, our heirs and successors make, create, and constitute the true and absolute Lords and Proprictors of the island and premises aforesaid, and every part and parcell thereof, saveing and alwaies reserving to us, our heirs and successors, the faith and allegiance to us due and belonging and our royall power and soverignty of and over our subjects and inhabitants there, to have, hold, possess and enjoy the said island, and all and singular other the premises hereinbefore granted unto them, the said Governour and Company of Merchants of London trading into the East Indies their successors and assigns for ever to the only use of then the said Governour and Company and their assigns for ever more to be holders of us our heirs and successTo be holden in ors as of the manner of East Grecnwich in the the samemanner county of Kent in free and common socage, as East Green- and in capite not by Knight service : and know wich in the County of Kent. ye further that Wee of our mose especiall grace, certaine knowledge and meir motion, have given, granted and confirmed, and by these presents do give, grant and confirm unto the said Governour and Company and their successors and assigns to their own proper use and benefitt all that artillery and all and singular arms, weapons and ordinances, munition powder and shott, victuals, magazins, stores, ammunition and provision of war, and other provisions whatsoever, and 


\section{ST. HELENA}

singular ships, vessels and boats and all manner of merchandise and wares, clothing, implements, beasts, cattle, horses and mares which are or remaine upon or within the premises, or any part thereof, and belonging unto us in any manner or wise, and Wee are pleased, and do by these presents for us, our heirs and successors, grant unto the said Governour and Company of Merchants of London trading into the East Indies, that for the better supply of the said island (being a place of no trade or traffique) and of the castles erected and placed and to be erected and placed in or upon the said island or within the premises or limitts thereof and of the inhabitants thereof to send of this kingdom to the said island and to the castles, fortifications, forts, garrisons, collonies, plantations and inhabitants thereof, all kinde of clothing, provisions, victuals, ammunition, ordinance and supplyments necessary for such purpose without paying any custom subsidy or other duty for the same; as also to transport and carry over such number of men being willing thereunto as they shall think fitt; and forasmuch as Wee have made such grant of the said island and premises to the said Governour and Company of Merchants of London trading into the East Indies and their successors as before is mentioned, it is therefore needfull such powers, and premises and jurisdictions be granted unto them as be requisite for the good government and safety thereof, and of the inhabitants thereof; Know yee therefore further, that reposing especiall trust and confidence in theire fidelitye, justis, wisdome, provident circumspection, have granted and by these presents for us, our heirs and successors, do grant unto the said Governour and Company of Merchants of London trading into the East Indies, and their successors that it shall and may be lawfull to and for the said Governour and Company of Merchants of London for the time being, or the major part of them, present at any publique assembly, commonly called the Generall Court for the said Company, the Governour of the said Company or Deputy being alwaies one, or for the said Governour or his Deputy or Committees for the time being or the major part of them, present att any assembly commonly called the Generall Court of Committees holden for the said Company, the Governour or his Deputy likewise being alwaies one from time to time ordain, make establish, and under theire common seal to publish any laws, orders, ordinances and constitutions, whatsoever, for the Government and other use Company's of the said island and premises and the inhabitants Legislative thereof; and the same, or any of them againe Power. and from time to time to revoak, abrogate and change, as they in their directions shall think fitt and convenient; and also to impose, limitt and provide such paines, punishments, and penalties by fines, amerciaments, imprisonments of body, and where the quality of the offence shall require, by taking away life and member as to the said Governour and Company for the time being, or the majority of them present at any such Generall Court or to the said Governour, or his Deputy 
or Committecs of the said Company or the major part of them present at any such Court of Committees as

To the extent of aforesaid, the said Governour or his Deputy being Life and Limb. alwaies one shall seem necessary requisite and convenient for the observation of the sanje laws, constitutions, orders, and ordinances and for the punishment of offenders against the same; so also as the said laws constitutions orders ordinances pains, punishments penalties be consonant to reason and not repugnant nor contrary, but as neer as may be agreeable to the laws of this our realme of England and subject to the saveings therein contained. And also of our further especiall grace, certain knowledge and meer motion, Wee do by these presents, for us, our heirs and successors, give and grant unto the said Governour and Company and their successors, that it shall and may be lawfull to and for the said Governour or his Deputy and the said Committees of the said Company for the time being, or the major part of them, at any of them said Courts commonly called the Court of Committees, holden for the said Company from time to time to nominate, make and constitute and ordain and confirme by such name or names, stile or stiles, as to them Power to appoint shall seem good such Governour or Governours, Governours and or Ministers cheife factors, and agents or other other Ministers. factors or agents as shall be by them thought fitt and needfull to be made and used for the Government, and other use and uses of the said island St. Helena, and of the Castles, forts, fortifications, and other the premises hereby granted and such Governour and Governours, Officers and Ministers, Factors or agents at their directions to revoake, discharge, alter and change, and also to discharge, alter and change all and singular the Governour, Governours officers and Ministers as heretofore have bin by us made and appointed for the Government and other use of the island of St. Helena, or any of the forts, fortifications, limmetts, etc., or presincts therefore; and Wee are also pleased, and by these presents for us, our heirs and successors do give and grant unto the said Governour and Company, and their successors that it shall and may be lawfuli to and for the said Governour or his Deputy and Committees of the Company for the time being, or the major part of them, by themselves or by their Governour or Governours, Officers or Ministers, Factors and agents, to be ordained and appointed as aforesaid, according to the nature and limitts of their respective offices and places within the said island

St. Helena, the territories and presincts thereof, Judicial Powers. to correct, punish govern and rule, all and every the subjects of us our heirs and successors that now do, or any time hereafter shall inhabit within the said island and presincts thereof, according to such laws, ordinances, orders and constitutions, as by the samesaid Governour and Company at any Generall Court, or Court of Committees as aforesaid shall be established and to do all and every other thing and things which is to the complete establishment of justice doth belong by court 
sessions of judicature and manners of proceedings thereunto like unto those established and used in our realme of England. Although in these presents express mention be not made thereof, and by Judges and by their officers, by them the said Governour, or his Deputy and Committee of the said Company, or the major part of them, or by the said Chief Governour or Governours of the island St. Helena to be delegated to award process, hold please, judge and determine all actions, suitts, and causes whatsoever of any kind or nature, and to execute all and every such judgements, alwaies the said laws, ordinances and proceedings be reasonable and not repugnant or contrary, but as near as may be to the laws, statutes, governments and policy, of our kingdom of England, and subject to the saveings herein. And Wee do also confirme and grant unto the said Governour and Company, and their successors, as also to all and every such Governour or Governours of officers Ministers and Commanders as shall be appointed by the said Governour, or his Deputy, or Committees of the said Company as aforesaid, to have power and authority of Government and command in and over the said port and island and they and every of them shall and lawfully may, from time to time, and at all times hereafter, for their several defence, and safety, encounter, expell, repell, resist, subdue, retayne and possess by force of armes as well by sea as by land, and by all waies and means whatMilitary Power. soever, all and every such' person or persons whatsoever, as without the special license and authority of us, our heirs and successors, or of the said Governour and Company or their successor shall attempt to inhabit within the presincts and limmitts of the said island, and also every such person and persons whatsoever as shall enterprize or attempt any destruction or invasion, hurt, detriment, or annoyances thereunto or to our subjects inhabiting within the same or any part thereof, or to them, or any of their goods, merchandize, interests, property, or estates whatsoever; and Wee do further, for us, our heirs and successors, hereby declare, ordayne and grant that such principall Governours of the said island as shall from time to time be duly authorized and appointed, in manner aforesaid, shall have full powers and authority in their respective places and charges to use and exercise all such powers and authorities in their respective places, in such cases of rebellion, mutiny, or sedition, of refusing to serve in wars, flying to the enemye, forsaking the colours or ensignes or other officers, law custom and disaplene, military in as large and ample a manner, to all intents and purposes whatsoever, as any Captain General of our Army, by virtue Governor to have of his office, have used and accustomed, and the power of may or might do; and of our more especiall Captain General. grace, certain knowledge and meer motion, Wee do, for us, our heirs and successors, further ordaine and grant, that it shall and may be lawfull to and for the said Governour of the said Company, or his Deputy for the time being, or the appointment of the major part of the Committees 
for the said Company assembled in any of their said Courts commonly called their Courts of Committee from time to time and at all times hereafter, to administer such a formall legall

Power to

administer

Oaths. oath as by their directions shall be reasonably devised with any person or persons to be employed in, for, or concerning the said island St. Helena, or any part thereof, as well as for the true and faithful execution and performance of their respective offices and cmployment as also for the rendering a just, true and perfect account of writeing of all such goods, monies and other things as by reason of their said offices and employments, shall come to their respective hands unto the said Governour and Company to such person or persons as shall be by them appointed to take the same account; and also to all Governours, Officers, Ministers, Agents, Factors of what nature soever or by what title soever they shall be called which shall be lawfully sent or placed in the said island St. Helena, as well for the good Government thereof and the inhabitants there, as for the ordering, safe keeping and true accomping of and for all such laws, goods, profitts, commodities, matters and things whatsoever, as shall be committed to their charge, or any of their Government, charge, care and custody ; and also to such persons as the Governour or said Deputy, with the major part of the said Committees for the time being shall think meet for the examination of, or clearing the truth in any case whatsoever concerning the said Company and relating to the said island St. Helena, or concerning any prisoner from thence procecding or thereunto belonging; and Wee do, for us our heirs and successors, give and grant unto the said Governour and Company, and their successors, that the Chief Governour or Governours resident in the said island of what names or title soever they be called, shall have the like power to minister a formall and legall oath to all other officers and inferior Ministers whatsoever on the said island St. Helena for the just true and faithful discharge of their severall places, duties and services as also unto any other person or persons whatsoever for the examination, satisfying and clearing the truth in any cause as well concerning the said Island St. Helena as any other particular business there arising for the maintaining and administration of peace and justice amongst the inhabitants of the said island, or any other person in that place : and our pleasure is, and Wec do, for us, our heirs and successors declare by these presents, that all and every the persons being our subjects which do or shall inhabit within the said port or island, and every their children and posterity which shall happen to be Natives of St, borne within the presincts thereof, shall have Helena to be and enjoy all liberties, franchises, immunities, Free Denizens capacities and abilities, of franchises and natural of England. subjects within any of our dominions, to all intents and purposes as if they had been abiding and borne within this our realme of England or in any of our dominions; and lastly our Will and pleasure is, and Wee do by these 
presents, for us, our heirs and successors, ordain and grant unto the said Governour and Company of Merchants of London trading into the East Indies, that these our letters patents, and all and singular grants and causes therein contayned, shall be and continue firme, strong and sufficient and available in the law, and shall be contayned, reputed and taken as well to the meaning and intent as to the words of the same most graciously and honourably for the best advantage and benefitt of the said Governour and Company, and their successors, although express mention be not made herein of the true yearly value and certainty of the premises, or any part thereof or of any other gifts or grants made by us, or any of our ancestors or predecessors, to them the said Governour and Company or any other person or persons whatsoever or any omission or defect herein or any law, statut, act, provision, order, ordinance published, ordayned, or provided, or any other cause, matter or things whatsoever to the contrary thereof, or in any wise notwithstanding. In witness whereof, Wee have caused these our letters patent to be made witness ourselfe at Westminster the I 6 th day of December in the five and twentieth yeare of our reigne.

By writt of privy seal,

(Signed) PIgGotr.

The pay of the Government Officers was as follows, from I673 to I687 :-

Captain Field, Governor and Captain of a Company, Fifty pounds, also gratuity Fifty pounds, i.e. One hundred pounds per annum.

Captain Beale, Deputy-Governor, Captain and Store Keeper, Fifty pounds per annum.

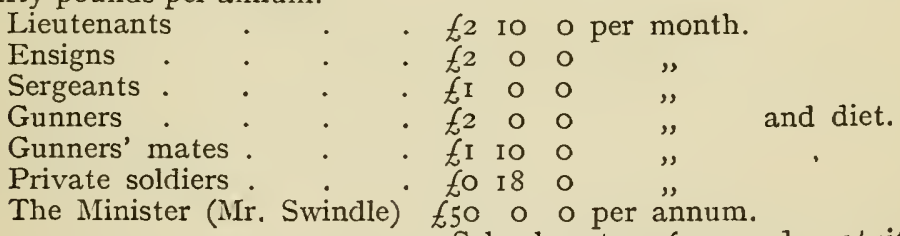
¿25, making one hundred pounds.

The Chirurgeon, Twenty-five pounds, gratuity twenty-five, making Fifty pounds.

The Minister and Chirurgeon besides their diet were each allowed the same proportion of land as other settlers.

In returning the salutes of foreign guns, it was directed that no more than seven guns should at any time be fired, and only three, to ships in the Company's service; but interlopers were not on any account whatever to be saluted. An extract from a letter addressed to the St. Helena Government by the home authorities reads :- 
We find by the list of guns fired, sent us by Captain Beale, three hundred and odd guns which is so strange a waste that we could not think our Governor would have been guilty of ; especially considering that island cost us forty thousand pounds, without one penny profit, hitherto, more than refreshment to our ships, which all strangers have had as well as ourselves. But most impulent it was to salute interlopers; and as vile for our Minister, Mr. Church (if our information be true) to be first on board the interloper Pills that came in last voyage, and to entertain him at his house.

As taxes, every English vessel trading to Madagascar had to leave a negro slave on the island and also to pay a duty of $2 s$. $6 d$. for every ton measurement, $5 s$. anchorage, the latter being paid by all ships. This charge, however, was not levied on Dutch ships, as long as a similar exemption was allowed to English East Indiamen at the Cape of Good Hope. Ships in the Company's service were obliged to deliver a barrel of gunpowder. The orders of the East India Company were that ships of interlopers were not to be supplied with water or refreshment until they paid in money or goods to the value of 20 s. per ton. No refreshment was allowed them unless they agreed to resign ship and cargo to the Company's disposal-and until cach surrender was made, all traffic and communication between them and the inhabitants was prohibited, under a penalty of $£ 20$ from a member of Council, and $£$ Io from any other person in the island, who should disregard these orders. Many ships under Ostend colours were refused stores of any kind, and scarcely allowed water sufficient to preserve the lives of their crews, and were often fired upon either to prevent their entry into the roads or to hasten their departure.

A constant succession of showers is more necessary for the process of vegetation in a hilly country like St. Helena than on flat ground, and from the idea which prevails, that trees on the summits of mountains have an attractive influence on the clouds, as well as from consideration of the value of timber, the preservation of wood was at these early times deemed an object of great importance, and regulations were formed for its preservation. A great quantity of wood was used for the distilling of spirit from potatoes - a manufacture in which many stills in the island were employed, and which doubtless occasioned many 


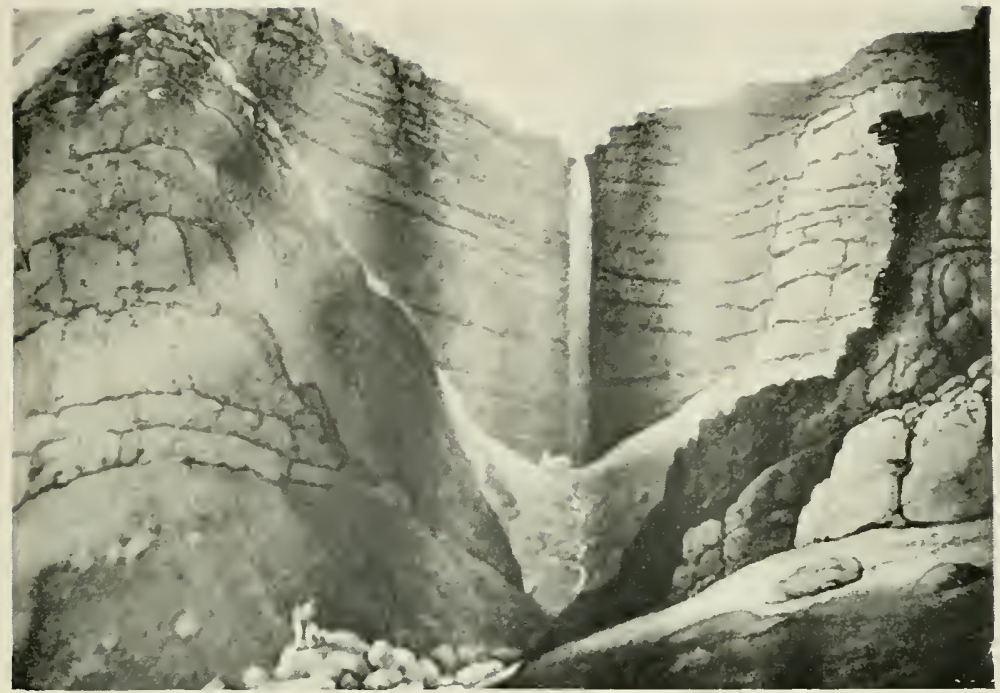

HEART-SHAPEI) WATERFALI.

(From an (sld Print.)

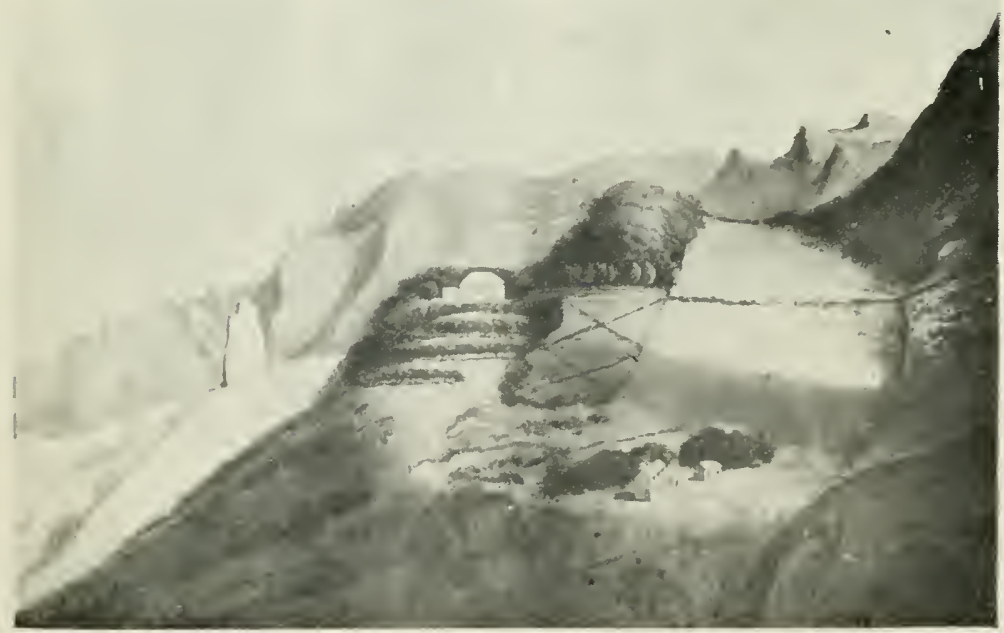

VIEW TOWARDS SANDY BaY.

(From an Old Print.) 

abuses and disorders. To suppress the excessive use of the wood, an impost was levied of twelve pence for every hundredweight of wood appropriated to distillation, beside fourpence for every gallon of liquor.

The chaplains appointed by the East India Company of this time seem by the following to have been of a most turbulent disposition.

Dr. Sault scurrilously insulted the Council, contemned their authority, and by his disrespectful and insolent demeanour, to which the Governor too tamely submitted, fostered a discontent productive of the most serious and alarming mutiny that had hitherto disturbed the settlement. The Company had spared neither expense, ordinances nor exhortations to promote virtue and religion, but their good endeavours were frustrated by the behaviour of a succession of clergymen, whose principles and conduct counteracted the tenets of their sacred profession. In the official correspondence we find one mentioned as an encroaching avaricious person, threatened with dismissal, and afterwards sent to England for refusing to marry a couple, after the Governor had signed the licence. Comment from the Company's letter:-

And if it be true, as we have been informed, that he did refuse to marry Mr. Smoult's daughter, upon the license of the Governor, it is a great sign of his weakness as of his pride; for if he understands our constitution he must knowe that noe lawes are of force in that island, till they are lawes made by us. And therefore, if any Minister shall refuse to marry any couple upon our Governor's license, we would have our Governor and Council immediately to dismiss him from our service, and send him home.

Dated Ist Aug., 1683.

In 1676 the island was visited by the celebrated Dr. Halley for the observing - and for the completing of the catalogue of fixed stars, by the addition of those near the South Pole.

From his observatory on the hill which has since borne his name he had an opportunity of distinctly seeing a transit of Mercury over the sun's disc, and the report of this transit induced the astronomers of Europe to watch with greater attention the memorable transit of Venus in I76r.

Captain Kedgewin was now relieved by Captain Field as Governor. The East India Company gave the slave 
Oliver, who had done such good service in leading their troops, his freedom; and in other ways they showed their appreciation of the valuable services of Captain Kedgewin.

In 1684 occurred the Dennison insurrection, in which Bowyer and Clarke were tried for sedition and mutiny, and werc hanged. Five more were executed in the following year, and several were banished to Barbadoes; and in 1687 the King's flag was substituted on the Fort for that of the Company.

At this time we read that the island was very productive and fresh provisions were so abundant as to ensure a regular demand; therefore a clause was inserted in the charterparties of ships in the Company's scrvice, obliging their owners to purchase a certain quantity of becf, the price of which in the year $\mathrm{I}_{68} 3$ was $16 s$. per civt., alive. But as the demands upon the island increased with the prosperity and trade of the Company, so the value of provisions became cnhanced, and the price of beef in the year 1707 was $25 \mathrm{~s}$. per cwt. The market rates of other articles in the same year were:-

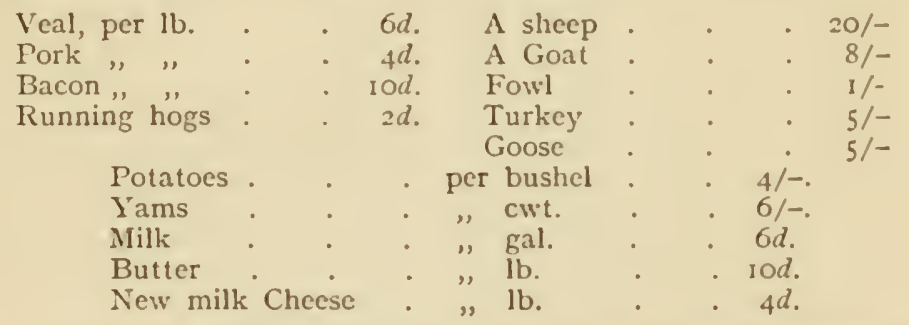

Shortly after the establishment of the colony a species of yam had been introduced from Madagascar. Planted in the valleys it throve wonderfully well, as it requires a constant soak of water for fiftecn months to bring it to perfection. In its raw state it has an acrid, almost a caustic, property, but after several hours' boiling it becomes wholesome and nourishing food, and for many years formed the chief sustenance of the slaves, as well as food for the numerous hogs and poultry. These yam plantations are now almost without exception thrown into pasture and other grounds enclosed for cultivation of potatoes, which find a ready sale, but which in earlier days were generally bartered for grain. 
Cabbages, peas, beans, cauliflowers, turnips, carrots, beetroot, cucumbers, lettuce, tomatoes were raised in abundance. The land was portioned out to various settlers, and in 1679 it was ordained that when a soldier married a free planter's widow, and became entitled to her deceased husband's land, he should be given ten acres and one cow from the Company; and if he married a farmer's daughter or a young woman sent out from England who had no land, he was in such case to have twenty acres and two cows. Every unmarried man sent out from England as a settler was to have ten acres of land and one cow, and ten acres more and another cow if he married a planter's daughter or an Englishwoman.

If a planter's son married an Englishwoman during his father's life-time, he became entitled to twenty acres and two cows ; but if the marriage took place after his father's death, the son being possessed of the whole or a part of his father's land, he had then given him only ten acres and one cow. A planter's son or any Englishman resident on the island (not being in the Company's pay, nor having been assigned lands) was allowed, on his marrying a planter's widow, ten acres and one cow, if his wife had children living by her former husband; but, if she had no child, no further allotment was granted. On every ten acres of land one cow at least was to be maintained, and if a farm was not occupied and improved in twelve months after possession, or if, being occupied, it became deserted for six months, it could be seized by the Company and granted to some one of more industrious habits. Some who were dispossessed for this reason were sent off the island as drones. No lands could be sold or disposed of by the proprietors until after they had improved and occupied them for a period, which at first was fixed at four years, then at seven years, but in 1683 was altered to five years. For every ten acres of land the holder was obliged to maintain on the premises an Englishman who was capable of bearing arms for the defence of the island, and who was occasionally to do garrison duty; while for twenty acres, two men were required to be maintained, one of whom was to take turn in mounting guard. In I683, however, this service was remitted on payment of $2 s$. per acre, afterwards reduced to Is. per acre; but the planters themselves were 
not by this payment exempted from bearing arms in common with all other persons, when danger was apprehended, or from appearance at general musters, on penalty of a fine according to the offence. On these conditions grants of land were made to the holders, their heirs and successors, and a register was kept of all grants and alienations. Settlers from England added to the numbers and formed a militia, which the East India Company preferred to regulars. They reduced the regulars to fifty men, allowing those not chosen the option of remaining as planters or of returning to England. Before this reduction the regular garrison was in two companies, one commanded by the Governor, and the other by the Deputy-Governor; but now the fifty men formed one company, quartered on the inlabitants at the rate of ten shillings per month for each man. Officials generally filled both military and civil appointments. For example, the Deputy Governor was captain of a company, and also a storekeeper; the third in Council, who was a subaltern officer, was Surveyor-General. The clerk of the company, or secretary, was an ensign, and voted as a Member of Council, while the storekeeper's assistant was sometimes a commissioned officer, and sometimes a sergeant. Those of the Council wlio were not upon the regular military establishment held brevet commissions under the Government signature, and were assigned military commands in all cases of general alarm. Since the batteries were built and guns mounted, no disturbance of British power has taken place.

Field was succeeded by Governor Blackmore in I69o. It will be seen by illustration of first record book that three of the Members of Council being unable to sign their names, affixed their mark. Governor Blackmore slipped on a path near Chubb's spring and was killed. An account of this is given under the heading "Putty Hill." He did much good in the island and established a Court of Justice to be assembled four times in the year; trial by jury was used only for offences where life, limb, or land was at stake; all other cases were decided by the Governor and Council. In I69I Captain Dampier visited the island of which he gave a highly favourable description. A great number of plants, shrubs, and fruit frees were imported, including the peach, 
apple and mulberry; and vines were planted in Horse pasture under the management of the French refugees.

When Blackmore died, the succession fell on the DeputyGovernor, Captain Joshua Johnson. The colony was prosperous, and Johnson was a good man, but disliked by the soldiers whose excesses he endeavoured to check. Crime in those days consisted generally of what we should call trivial things, such as slander, debt, unfairness in dealing, cruelty to animals, and at times the whole of the inhabitants would be called up for inspection. Governor Johnson was warned of an intended attack on him by the soldiers-this we find in the records-but, taking no notice, he retired as usual to rest. Amongst the state guard on that night was a soldier named Jackson, who planned with three of his companions to rob the Treasury and escape. At dead of night they let soldiers who were in their scheme enter, and then sent messages to the other guards, getting them there one at a time. All who objected to their plans were at once cast into a dungeon under the fort which had been built for "securing villinous and desperate blacks." Governor Johnson always delivered the keys in person to the Sergeant of the Guard, and came early as usual in his "gowne and slippers." It is thought they only intended to place him in the dungeon; but he resisted, and three of the party fired at him, mortally wounding him. They, however, hit Jackson as well, wounding him in the arm. Finding themselves in power, these ruffians with great haste threw the wounded Governor into the guard-house; but his wife was by this time aroused, and in order to quiet her they allowed her with her two negro servants to drag the body up to her own room. They then permitted the surgeon (who had been brought up from the dungeon) to dress Jackson's wound; and afterwards, when they were convinced of the mortal nature of the Governor's hurt, that was also attended to, but death ensued that night. Fearful that the news of their misdeed would get to the ears of those in authority, they secured all the roadways; and the soldiers, as they came into the fort on duty, were locked up (there were fifty found in the dungeon). After spiking all guns which overlooked the anchorage, they got the Governor's chest, and with whatever treasure they could find they went on board a 
little vessel called the Francis and Mary, then in harbour. They took with them as prisoners the Lieutenant-Governor and several others, and also placed under arrest the master of the vessel, retaining them prisoners in order that they might procure, by exchange, necessary provisions for their journey. One of their party was sent on shore to negotiate, and to state that if their demands were not complied with they would kill their prisoners. Thus they obtained the provisions which were placed at a spot halfway between the ship and shore, out of range of fort guns. Unfortunately their terrible scheme was a success and they escaped, and it is supposed they landed in Ireland.

On the death of Governor Johnson, Captain Richard keeling, Lieutenant-Governor, assumed command, but the success of this diabolical plot had raised a mutinous spirit all through the Colony, and he had to keep a great check both on the garrison and on the slaves. He was evidently a man swift to act, and directly he heard rumours that the blacks meant to murder the Europeans, and follow out Jackson's acts, he, without waiting to ask permission of his Honourable masters, and going on the adage of "Prevention is better than cure," secured three whom he considered to be the moving spirits. One he hanged alive in chains at Ladder Hill and allowed him to starve to death; the other two he "hanged, but cut down alive, and their quarters and heads being placed in the publique crossway for the publique view of all the negroes."

In 1697 Governor Keeling, after a very severe illness died, and Captain Stephen Poirier succeeded him ; little of interest occurred, but the number of private stills so increased, and became such a nuisance that by orders from England they were all suppressed.

War was at this time declared between France and England, and news came here ; but two of the Company's ships lying at anchor, the Queen and the Dover, were cut off in the roadstead by French boats, which came in commanded by Mons. Desduquières under Dutch colours in broad daylight. When their nationality was discovered, orders were issued by the Governor that they should be fired upon, but the powder was not at hand, and the sponges did not fit the guns, so the French ships were soon out of sight. 
After this a large board was placed at Buttermilk Point, (I am told it is still there, but illegible); it directed that all ships coming round should send first a boat to Bankses - the board is very huge, and on it were painted the words "SEND A BOAT."

The East India Company spent much money on the island, and did all they could to keep it in a state of prosperity; it was fortified in almost every spot that cannon could be put. During Poirier's time, as well as during that of his successor, Goodwin, the island was in a state of unrest through their injudicious management.

In 1707 the old and new East India Companies were incorporated, under the title of the United Company of Merchants of England, trading to the East Indies; and St. Helena was transferred to them as Lords Proprietors.

An extract from Record Book, October I707, shows us that an article of sustenance or luxury was derived from the numerous eggs laid by sea-birds on the detached rocks round the coast. The shores and neighbourhood abound in these sea-fowl, which deposit their eggs in the cliffs. Their haunts, covered with white dung, present a fantastic appearance, especially upon an isolated rock called Shore Island, which has often been mistaken for a ship under sail. The eggs, collected in the months of October and November, are in flavour somewhat like those of a plover. One species of this fowl however prefers making its home in the woody central eminences of the island, and at times the birds may be seen flying across country with fish in their beaks. The property in the eggs was considered as one of the Company's royalties; and certain days in the week were specified, when the inhabitants were permitted to collect them. This permission being abused, notice was issued by proclamation that any person taking eggs, except on the appointed days, should forfeit their privileges for the remainder of the season.

The Record states:-

Whereas there was usually granted by the Governor from time to time, as he thought fit, liberty to gather eggs upon the Right Honourable Company's Lords Proprietors' egg islands, which for some years past have been appointed by the late Governor to be Tuesdays, Thursdays and Saturdays, which days are still allowed 
by the present Governor. But finding there has been (notwithstanding they have thercby granted them as much as the said Lords Proprictors) eggs gathered upon those day's when they should not ... It is therefore hereby declared, that if any person shall presume any more to gather eggs upon any other but their granted day's; that then such boat and people therein offending, shall lose their said privilege for the whole season.

Sea-cows were also a royalty, for it was proclaimed :

That from the ist September next, whatsocver free planter or other inhabitants shall find any of the sayd fish called sea-cows, or other of the like nature and quality; on the shore of any part of the sayd island, he may boyle the same and convert it into oyle and take it to his owne proper use and behoof; previded always that he forthwith send, or cause to be sent, the eighth part, or gallon, of all the sayde oyle so made unto Fort James, and deliver it to the Governor, or such as he shall appoint, as an acknowledgement of the said Honourable Company's royalty and property and for their use and service. Further it is ordered that from the said time if any officer or soldier in the sayd Honourable Company's pay shall find any such fish, he may convert it into oyle, and send one third part or share thereof to Fort James, the other two-thirds he may dispose of as he pleaseth, provided, and it must always be remembered, that all persons concerned in this matter be just and right in the division and distribution of this commodity betwixt the Company and themselves.

In 1708 Governor Captain John Roberts arrived, and with the help of Captain Nashbourne soon caused a healthy reaction, and his attention was at once turned to defensive work. Laws and ordinances were republished, trial by civil law and by jury extended, extensive works were commenced, and the Battery on Munder's Point was begun, as well as the present castle in Jamestown. Lime quarries were found, and lime was burnt. The planting of sugar-cane and other produce, together with the making of tiles and bricks, received attention. In fact, a general improvement of the island dates from his arrival, and the islanders were fully employed. He first turned his attention to the defences. An cngineer came out from England, and on the day he landed he received instructions to send in a plan for a battery to be erceted at Munden's Point; and two days after a resolution was passed in council to construct the present fort in James Valley, and also to build Government House.

Mud mortar was the cement generally used for ordinary buildings, but it was thought better to obtain superior 


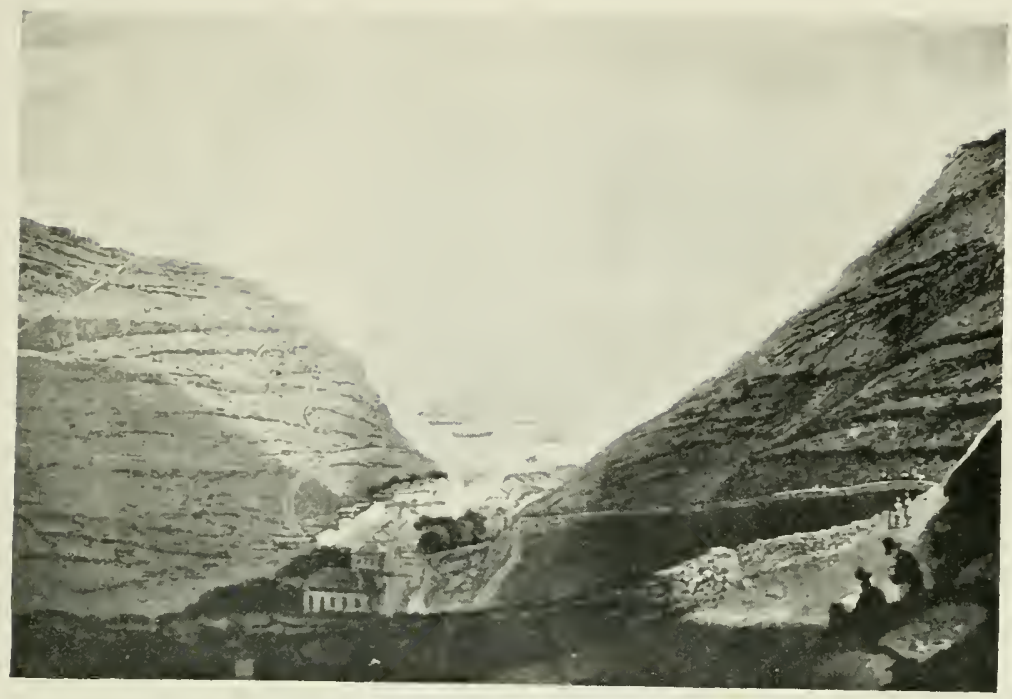

The ANChorage From the SIDE PATH.

(From an Old Print.)

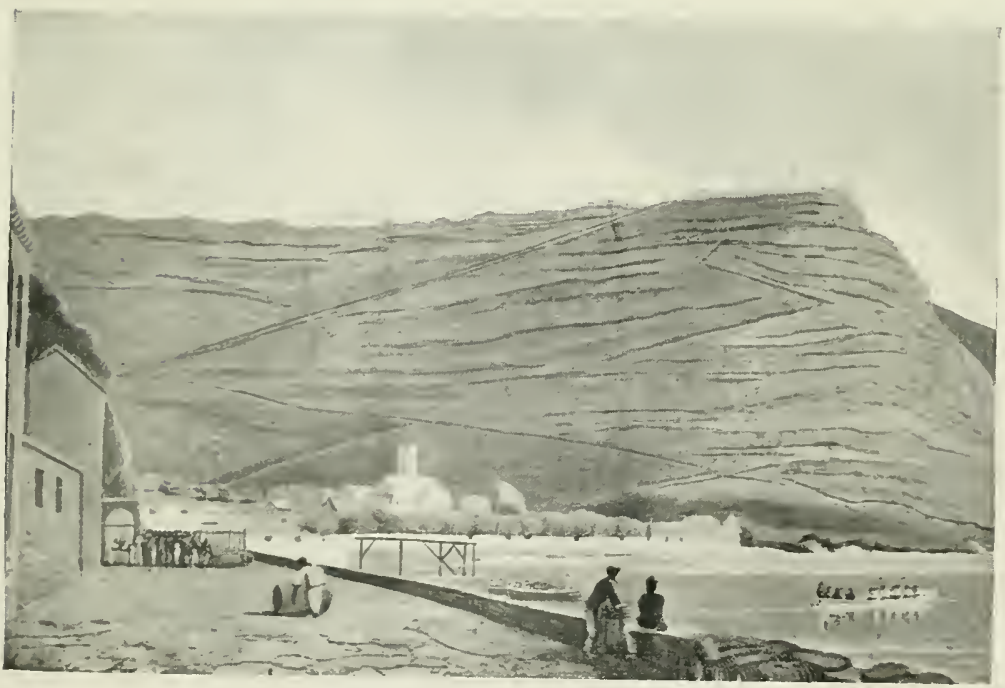

The Wharf aNh Sea Front.

(From an Old Print.) 

cement. On former occasions chalk had been imported from England, and had been burnt into lime in St. Helena ; but this was expensive as well as inconvenient, and a reward fs one hundred dollars was offered for the discovery of lime. Aaron Johnson, a soldier, was successful, but the quantity found was not considered sufficient to entitle him to the reward. Part of the reward was however given to him to stimulate others to further exertions. But excitement was at a great height when signs of gold and copper ore were discovered by Captain Nashbourne, a member of Council, who was searching for limestone. Later on we find the engineer did not give satisfaction, for we read that the Governor reported to the Council that

"He observes the Engineer to be useless running headlong about business without his directions," which being fully considered in Council give their opinion of him-" That Christian Frederick Vogell is rather pioneer than engineer, and no Gentleman by his actions and behaviour, and is altogether useless to serve the Honourable Company in any capacity, as being idle, ignorant and lazy, not knowing how to obey orders, or give directions, by which means our Honourable Masters have suffered. Resolved that the said C. F. Vogell be dismissed the Honourable Company's service from this day.'

Governor Roberts laid out plantations for yams near Friar's Valley, and conveyed water there, but this land was allowed afterwards to go untilled. He planted sugar-canes in Sandy Bay, manufactured sugar, rum, wine and brandy. He also made "bricks and tyles." On August I5, I710, he exhibited to the Council samples of St. Helena sugar, whereupon the following resolution was passed :-

That a pound or two be sent to our Honourable Masters by the next shipping, and that they may be acquainted that we have found the following articles since Governor Roberts came here, viz. lime, tyles, brick, cutstone for building, sugar, rum, minerals of several sortes, upon which we are now resolved to fire nine guns; to drink our Honourable Masters' good health and success to the island; for we are well satisfied this island will turn to account, and not be a dead charge, as it ever has been, if our Honourable Masters will be pleased to encourage it, and supply these people with necessaries; and then there will be no aversion against improvements, but showers of blessings of these people will come to them.

The East India Company were continually sending out orders, but so little attention had been paid to them that it 
was doubtful whether the orders or regulations were in force or obsolete.

Land owners were also many of them ignorant of even the terms on which they retained possession of their properties. Two members of Council were therefore entrusted with the work of arranging all the orders which had been issued from time to time; and were instructed to engross them in a book, to be entitled Laws and Ordinances.

When they reported their work finished, a meeting was convened of thirty-six of the principal inhabitants at the country church, and there the code of laws was read to them, and copies of the same distributed by the churchwardens. They were then notified that propositions for the amendment of these laws should be delivered in writing to the Government for consideration. Out of the thirty-six inhabitants twelve were chosen as a committee to examine the laws and to comment thereon, and on June I4, I709, they presented their report and desires as under :

\section{Propositions ANd AdDREss to THE GOVERNor AND COUNCIL.}

ARIS.

1 stly.

They desire the chief families may have armes in their houses.

\section{ASSEMBLIES.}

2ndly.

In their friendly meetings and merry makings, it may not be decmed as riots; and that upon any time, by order of the Governor they will separate if ever it should enter into his thoughts such meeting is for any evil intention; which they say God forbid it should.

\section{ALARMS.}

3 rdly.

They desire they may not be corporally punished in case any neglect their duty; but to be punished in their purses.

4 thly.

\section{BLACKS.}

They humbly desire that when their Blacks are run away from them, they may not be obliged to pay fourfold for what they steale, but only to make satisfaction for the thing stole to the person injured. 
5 thly.

\section{MARKET HOUSE.}

They desire if there be a market house built, they mayn't be obliged to bring their goods out of the country to a publick market.

6thly.

\section{BEEFE.}

They desire to have free liberty to sell beefe to ships.

DOGGS.

7 thly.

They desire that themselves may not be obliged to lead their doggs in a string, but are willing their servants shall do it.

CATTLE.

8thly.

They desire the toll of cattle may be taken off, that they sell to one another, which is two shillings per head; for that the trouble of giving such accounts is more burdensome to them than the thing itself.

9thly.

They desire that the trouble they are put to when they kill any cattle in carrying the hide, hornes and ears to persons that has been appointed for that purpose, may be redrest.

rothly.

\section{FENCING LAND.}

They desire they may not be obliged to fence in their land at all, it being a new thing they never heard of before.

I I thly.

$$
\text { JURYS. }
$$

They desire all other matters may be tried by Jurys, besides life, limb, and land as the plaintiff shall think fitt.

I 2 thly.

\section{WHOLESALE.}

They desire that the liquors, etc., called wholesale, being three gallons, may be reduced to one gallon arrack; four pounds sugar, and one or two pounds of tobacco; and this be deemed a wholesale.

I 3 thly.

\section{LIQUOR RETAYLED.}

They desire that there should be established a certain rate upon liquors retayled by the punch houses.

CAUSES.

I 4 thly. law.

They desire to be tryed by the civill law and not by martiall 
15 thly.

\section{SHIPPS.}

We desire the liberty, as we always had, of going on board shipps without the Governor's leave.

16thly.

\section{BLACKS.}

They desire to be eased something in the tax of paying ten shillings every year for each black they have.

17 thly.

GAME.

They desire that each chief of family that has guns allowed them, may for their diversion have liberty to go ashooting.

18 thly.

\section{GREAT WOOD.}

They desire liberty to make use of the great wood and common, otherwise they will be ruined.

rothly.

\section{LESSEES.}

They desire lessees may vote for parish officers, and also serve in their turns.

And all these grievances they humbly begg may be redrest as by their address in the following manner :

IsLand of St. Helena.

That whereas your worshipp and council was pleased on the 16 th day of April last past to summons Thirty-six of the principal inhabitants to the Church in the country, and there to hear the laws read over, which was accordingly done; and forasmuch as we were a long time kept in the dark, and knew nothing of it : the inhabitants so summoned did, by a consent, chose twelve of us to inspect into them, and to make our remarks upon the province of your worshipps and Council, that in case of any grievance which appeared reasonable, that your Worshipp and Council would be pleased to make address to the Lords Proprictors for redress, and this day we do with submission present the same to your Worshipp and Council with our remarks thereon, and hope you will find them reasonable.

And in the meantime we shall be obedient to those laws and orders delivered to the Churchwardens on the 26 th A pril last past. . . A And we hope that every one of us and all together will do our utmost endeavours to do everything for the preservation of this island, and the good of the Honourable Company ; and we promise that we will not be remiss in our military dutys; but when occasion shall present, wee will not be frugal of our blood, but ready to spill cvery drop of it for the preservation of the island, our wives and families, against any enemy that shall come here to invade us. And finally we give your Wor- 
leave or license first obtained from the Governor, under hand and seale, upon penalty of twenty shillings to the Honourable Company, and having the same seized and taken from them by any person licensed thereunto for their owne use, and to receive such corporal punishment as the Governor and Council shall think fit; and that no licensed person do lead or permit any person to make use of their armes; upon the penalty of having their license and armes forfeited. Dated the 3ist day of May, 1709, at the United Castle in St. James' Valley.

(Signed) per order of the Governor and Councill, JoHN Alexander.

Affixed by Committee: "They are sattisfied."

2ndly.

\section{ASSEMBLYS.}

God forbid that any merry meetings and innocent diversion should be deemed riots ; it's not the intent of the law.

"Sattisfied."

$3^{\text {rdly. }}$

\section{ALARMES.}

You shall not suffer corporal punishment for not coming to alarmes; except it be in time of war.

"Sattisfied."

\section{BLACKS.}

4 thly.

We shall dispense with that law of fourfold, and desire the Lords Proprietors to repeal it.

$$
\text { "Sattisfied." }
$$

5 thly.

\section{MARIETTS.}

As this law is not penall, we cannot see how it can be a grievance; and although marketts have never bin used, and not beneficial to the inhabitants, it's no rule that it should ever be in your favour.

"We shall write to our Masters about it."

\section{BEEFE.}

6thly.

You desire free liberty to sell beefe. Wee shall srite to our Masters in your favour about it.

\section{DOGGES.}

7thly.

You desire not to lead your dogges yourselves, but your servants. Wee shall dispense with it.

"Sattisficd." 


\section{ST. HELENA}

8thly.

\section{CATTLE TOLLED.}

You desire the toll of Cattle may be taken off, for that it creates you a great deal of trouble. It is necessary that wee should know how you sell your cattle to one another, because of our Common, that it may both prejudice you and us too by not knowing it.

9thly.

\section{CATTLE.}

You desire that the trouble you are put to when you kill any cattle in carrying the hides, hornes and eares to persons appointed may be redrest. Wee design to make this trouble easier to you; a man kills a beast, and sends for his next neighbour, he being a reputed man, and warranted by the Governor to have armes in his house; he has shewn him the mark of his beast that he has killed-that shall be a testimony sufficient without going any further. Now the usefulness of it-A man loses a beast and gets a warrant to search suspected houses, in which houses if they find any beefe, if he cannot bring his testimony that he killed it at such a time, by such substantial men as aforesaid, or where he had the same, such person ought to be convicted. And we believe if it went as far as hoggs, goats, and sheep, it would be much to your benefit for (if we are rightly informed) several suspected persons eat more flesh than we think in reason and conscience they are able to do if they come by it honestly.

$$
\text { "Sattisfied." }
$$

And ordered that a new statute be penned accordingly, and sent home by this shipping to the Honourable Lords Proprietors for their concurrence, and that it takes force from the publication.

Iothly.

\section{LANDS.}

You desire you may not be obliged to fence in your lands at all, it being a new thing you never heard of before.

This law has bin made above twenty-seven years ago, and no doubt but it hath bin published, for it is what you hold your lands by. And we must say by this law, that what land is not fenced in, is, by course, the Lords Proprietors' ; we have no other way to know which is your land and which is theirs.

However because you say you have bin so long kept in the dark by not knowing anything of it, we shall for this time neglect our duty of making seizures, and will intercede with the Lords Proprietors that the time appointed for enclosing may begin anew from the $25^{\text {th }}$ March last. In the meantime wee friendly advise you to enclose as fast as you can, lest wee should be checkt for this our neglect of duty, and receive orders from them to make seizures. 
I ithly.

\section{CAUSES BY JURYS.}

You desire all other matters may be tryed by jurys besides life, $\operatorname{limb}$ and lands, as the plaintiffs shall think fitt. No Governor and Councill will trouble themselves to give sentence upon intricate matters, and that may be of great importance, as you urge, by giving a definite sentence, which, though never so just, seldom pleases both parties, and creates an odium to the Governor and Councill, when the same thing may be judged by yourselves. As the Governor is Judge of that Court, he ought to be the Judge of what shall be tryed by Jurys and what he himself will try in Councill; otherwise a litigious man that hath wealth and a cause depending with a poor man, although a trifling one, shall come and demand to be tryed by a jury, which will create the poor man such a charge that he will rather sit down in his wrong.

The Governor would willingly put you in mind that he hath refused to try severall causes in Councill, as some of you know. And indeed to take all this matter aright, we look upon it as a burden our Masters has laid upon us to ease you.

"Sattisfied that the Governor shall be judge of what shall be tryed in Councill, and what in Court, except life, limb and land."

12 thly.

\section{LIQUOR.}

You desire that the liquor called wholesale, being three gallons, may be reduced to one gallon arrack, four lbs. sugar, and one or two lbs. of tobacco to be decmed wholesale. We cannot see what occasion there is to deem anything wholesale less that what is exprest in the law, without prejudice and wrong to those who pay for license. And you all know very well that you may have what small quantities you please out of the stores, even to a lb. or a quart of anything.

"Sattisfied."

13 thly.

\section{LIQUOOR RETAILED.}

You desire that we would establish certaine rates upon liquor retay'led by the punch houses.

Ordered,

That the following declaration be issued out :

"These are to give notice to all lycencees or retaylers of strong liquors, that a bowle of punch, made with one pint of arrack, with sugar and lemon, be from the date hereof, sold at $2 /$ - per bowle and no more, while arrack is at $6 /-$ per gallon and if any one presumes to exact more, shall upon information thereof given to the Governor and Councill forfeit their lycence, and double the value. Which pint of arrack aforesaid is to be put into such sizable bowle as will not be too strong, nor 


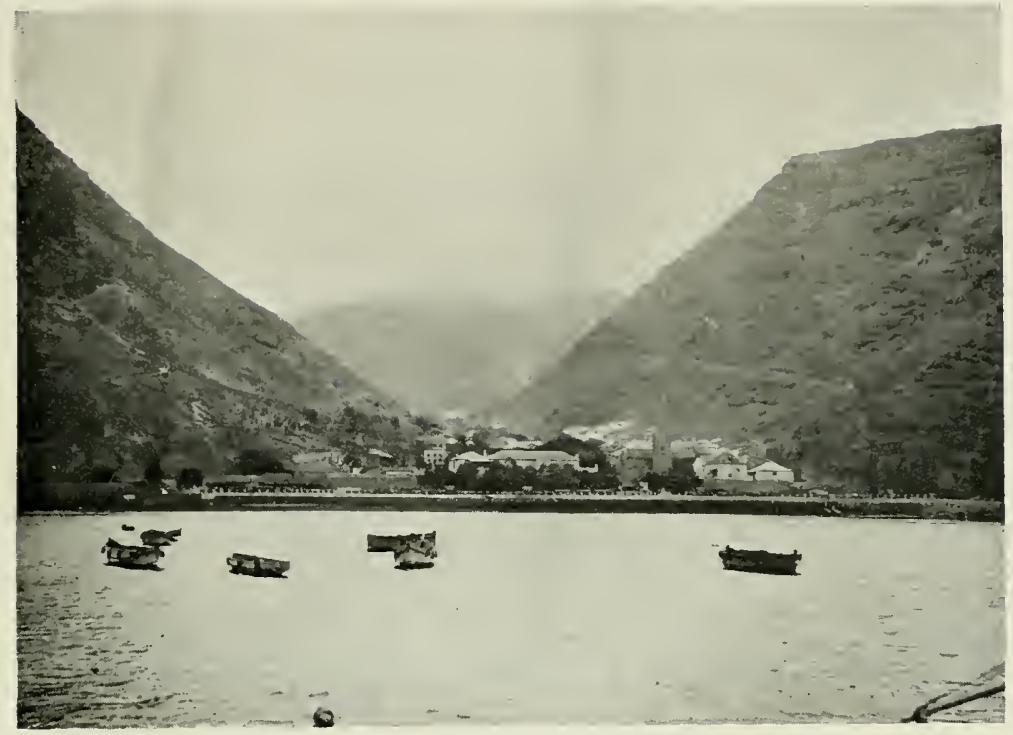

St. Helena from the AXchorage.

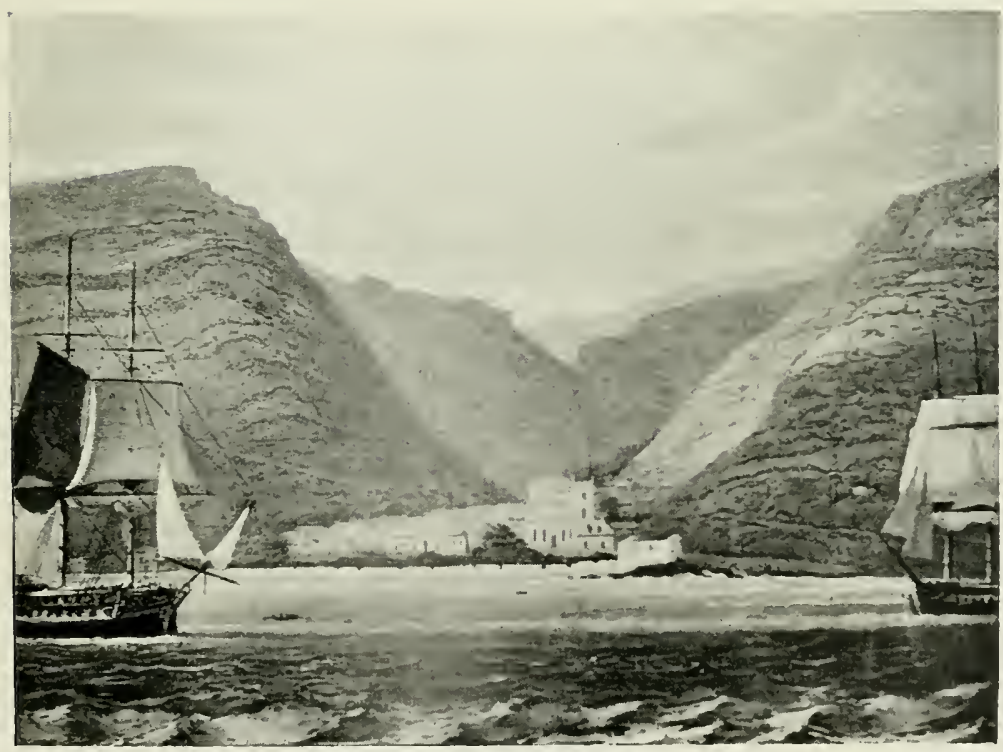

St. HeleNa From the ANCHORAGE.

(From an Old Print.) 

yet too weak, but palateable and pleasant for the buyer. But if any lycencee or retayler of liquor shall think this not a sufficient profitt, they may deliver up their lycences, paying proportionable for the time they have had it, after the rate of Four pounds per annum, which all such retaylers are to do within eight days from the date hereof.

$$
\text { "Sattisfied." }
$$

14 thly.

\title{
MARTIALL LAW.
}

You desire to be tryed by civill law and not by martiall law. We shall write to our Masters about it; we think it is but reason that the planters should be tryed by civill law except it be in time of war and action, or, that we hope never to see, rebellion, cowardice, neglect of duty, which may be the ruin of the island, and several other misdemeanours in time of action which cannot be judged by the Civil law; and we likewise design in our Court Martiall to choose worthy people of this island to be of it.

\author{
"Sattisfied."
}

I 5 thly.

\section{GOING ON BOARD SHIPPS.}

You desire the liberty that you always had of going on board any ship or shipps in the road, asking the Governor's leave. It is what our Masters say was never done at the Cape, or as we know of, done in any other Dutch factory in India, however, if there be any urgent occasion, the Governor at that time will not deny them leave.

"Sattisfied."

I6thly.

\section{BLACK TAX.}

You desire to be eased something in the tax of ten shillings every year for each black you have. There is no nation under the hopes of Heaven, nay, we are apt to believe if there be any wild people, they contribute to their own safety in some measure. And if any man will look into our Mother country, England, we shall there find the four shillings in the pound tax alone gives the Queen every fifth year their whole estate; beside taxes of windows, lights, parish duties, and parson's tythes, and sundry other taxes, which every Englishman knows that has five hundred pounds per annum, never gets in above three hundred pounds, and very well if that. And now that the Honourable Company has for six years last past paid for fortifications, by employing the blacks and artificers of this island, about fifteen hundred pounds a year, beside the constant charge of the garrison, etc., for your preservation. We shall only now give you our Masters' reasons'; but must 'tell you we little expected at this time of day such an article from 
you, which indeed, we find, by a medium of six years last past amounts but to fifty-eight pounds per annum : a great mite to such a vast charge. The reason of which order is as the Negros increase upon the island, it will be necessary for the Honourable Company proportionably to increase the garrison and soldiers for the security of the inhabitants as well as the island.

17 thly.

\section{LYSENCE TO SHOOT.}

You desire that each chicf of a family that have guns allowed you, may have liberty to go ashooting for your diversion.

You must keep within the law of the preservation of game. But if any person should desire any further privilege, they are not to presume to do it without leave first had of the Governor, which is left to his pleasure to give or let alone.

$$
\text { "Sattisfied." }
$$

18 thly,

\section{GREAT WOOD.}

You desire leave of the Great Wood and Common. Provided you will agree to make a law to plant one acre of wood in every ten acres of land you possess, otherwise you shall have no benefit of our wood or common as our published order.

$$
\text { "Agreed to and Sattisfied." }
$$

19thly.

You desire lessees may vote for election of parish officers, and serve in their turn. We shall dispense with that, and write to the Lords Proprictors to repeal that law, and loope they will comply.

$$
\text { "Sattisfied." }
$$

Judging from the I 8 th clause, the landowners readily acceded to any terms rather than lose the advantage of so valuable a common; and the proposition of the Council on this subject, as well as on the other articles submitted to their consideration, appears to have met with the acquiescence of the Company ; but the law which required the hide, ears, and horns of every beast slaughtered to be exhibited to certain specified persons was enforced with greater rigour than before, as will be seen by the following :

\section{A LAW FOR tUE BetTer PREveNTION AND APPREHENdiNg OF FELONS.}

Whereas great and grievous complaints have been made by severall good people of the island, that divers felonyes, larcenys and pelfrages, and such like offences are many times done, to their great loss and prejudice. And that severall idle and evil-disposed 
persons do kill and eat more flesh than they can be reasonably supposed to do conscientiously and honestly; and we are further credibly informed, and inclined to believe, that the clandestine way and method used in this island among the people of killing, offering and putting to sale, their cattle, goods and other merchandise, in private manner and obscure places-not bringing the same to markett, or selling the same in open shopps or stalls is a great cause of such enormitys: for that such private and secret sales and slaughters are found to be the means of encouraging many thieves, who easily convey the said goods, by them stolen and pilfered to shipping and strangers; that there can be nothing found against them to their conviction. For remedy whereof and for the better detecting and apprehending of all such lewd persons and bringing them to condign punishment. We do absolutely enjoin all and every person and persons inhabiting the said island, that from henceforth when they kill for their own use, or others, or kill, exchange or part with any kind of beaste or cattle, as oxen, runts, steers, kine, heifers, calfes, sheep, lambs, goates, kidds, hoggs, they shall be obliged to repair to, or send for, and give notice thereof to some person or persons warranted by the Governor to keep armes, who are hereby appointed and empowered to view, inspect, search and examine the ears, hides, hornes of every beast so killed, or to be sold, whereby to be informed and sattisfied that it hath the true and proper mark of the owner, or possessor, or that the disposer or seller hath a property therein. And if any person or persons shall presume or endeavour fraudulently to hide or conceal any such sale or slaughter, or kill or dispose of any beaste, without notice given, and search made, as aforesaid, otherwise than according to this law and be thereof lawfully convicted, he, they, and every one of them shall be, and are hereby declared, and shall be deemed and adjudged as felons, and the beast so concealed, not viewed, and unlawfully killed or made away, shall be forfeited, the one half to the Honourable Company and the other half to the informer or prosecutor. And we do further declare that any person or persons warranted by the Governor to keep armes, shall have power to enter into and search (as for stolen goods) the houses of all and every unlicensed person whom they shall vehemently suspect by circumstance, or otherwise, fraudulently and clandestinely to kill any meat, and where any flesh or skins of a beast shall be found, of which they can give no reasonable or good account how they came by the same, or produce the party of whom they bought the same, or some credible witness of the sale thereof; he, or they shall be subject to the forfeiture and penaltys of clandestinely and feloniously killing a beast, as if thereof convicted. And we do hereby further declare that any person not licensed to keep armes, shall be obliged to get two licensed persons to view and examine the marks; but when any person, having the Governor's warrant for armes do kill, sell, or dispose of any, the testimony of one single person shall be sufficient. And we do further declare and enjoin every inhabitant do at the marking of the cattle, procure one or 
more sufficient witness to be then and there present: but always the unlicensed person to have two present as witness of their actions, upon the penalty aforesaid. And we do further declare that the informer or prosecutor shall have over and above the half of the beasts forfeited and clandestincly made away with, as aforesaid, half the fourfold, being part of the penaly's inflicted on felons.

In I7Io a stream of water was laid from the springs at Plantation to New Ground, for the purpose of establishing a yam plantation, and we read that the drones were sent off the island, their lands being allotted to better workers.

Very, very unfortunate was it that Roberts' successor, Captain Bouchier ( $17 \mathrm{II}$ ), proved so unfit for his post; he allowed the beautiful gardens of plantations to lay waste, and threw a great deal into pasture for his asses, of which he kept a numerous stud. His favourite occupation, that of riding them in all weathers, caused him to erect a shed 400 feet long at the Company's expense. When leaving it is said that "he stripped Government House of all that was portable, even the locks and the keys from many of the doors, as well as everything that might be serviceable to him on his voyage home. The population was then 832 , whites and blacks being about equal, increasing at the rate of forty-five to fifty each year.

Witcheraft in these days was punished severely. Quakers were not allowed to remain on the island, neither were lawyers, lest the people should occupy their minds with litigation.

After Governor Bouchier came Captain Matthew Bazett (acting), I 7 I 4, and Captain Isacke Pike, also I7I4. Governor Pike was a great agriculturist, and strove to rectify all the harm committed by Governor Bouchier. In General Roberts' time the red wood and ebony were specially cared for, and Governor Pike continued to devote much attention to it. Concerning forests the records contain the following :

Forasmuch as the red wood, and ebony wood whose barks are fit for tanning feather, are most of 'em destroyed by the tanners, that for laziness never took the paines to bark the whole trees, but only the bodies, leaving the rest of the bark on the branches, which means has destroyed all those trees, at least three for one; and therefore to prevent the like for the future, and to preserve and recover so uscful and necessary a thing for the island use: Ordered 
that no more hides be sold to the people: for that we are about to engage one John Orchard, a tanner who has offered himself to $\tan$ and dress those hides at three shillings and sixpence a piece: all other skins at the prices following :

A calf's skin at $1 / 6$

A sheep's skin at $I / 6$

and goat skins at sixpence each: and have supplied him with one of the Honourable Company's blacks to help and assist him; it being too much work for himself; and the said Orchard hath obliged himself to learne and teach the Black his trade of a tanner and currier : and that articles of agreement be drawn accordingly. The advantageous proposals to our Masters in this matter are thus :First, the preservation of the trees; secondly, as we used to do, to sell those hides to tanners at three shillings apiece, and that, when tanned sold them again from twelve to fourteen shillings apiece, so that with one another we may probably clear seven shillings a hide : and if shipping comes we may be able to tan two hundred in a year (besides all other skins) which will clear seventy pounds a year, if sold out; besides the advantage of the small skins; and if wee employ shoemakers to work 'em up, wee are apt to believe that this article will yield our Masters one hundred pound a year at least : the loss of the work of the black and all other charges deducted.

He also made a safe roadway from town to country by means of Ladder Hill. In a letter to the East India Company dated I7I5 it is stated that two Spanish gentlemen, one a priest and the other an engineer, arrived on the island from Mexico. They professed a knowledge of mining and reported: "There are certainly some rich mines of metal here." These Spaniards stayed several months, and Governor Pike was much interested in the search for gold. After five months' search he had not abandoned the idea, but complained that want of labour prevented their getting to a sufficient depth. Another record of this hoped-for gold mine was, in an official letter dated June I5, I7I6, as follows :

The Governor has employed most of his time since the arrival of the Heathcote with Mons. Olievier, a Spaniard, who has dwelt a considerable time both in Mexico and Peru, amongst the Spanish mines, and he has set some of your Honour's slaves to work at digging on the north-east part of this island, near a place called Turk's Cap, where we have found a sort of mineral earth which the Spaniard says is a sure sign of a mine of metal. We have sent home musters of it by the Heathrote, and are assured by Mons. Olievier that as we go deeper, we shall find clearer and more evident proofs of metal. We wish we had hands to spare that we might keep some employed in digging on this occasion, because we desire 
nothing better than to make the island yicld to your Honours some reasonable recompense for the great expense and trouble you have been at to improve this hitherto unprofitable place.

(We do not hear again of this gold mine until ISro, in Governor Beatson's time.) Pike is the Governor who in I 7 I9 considered it necessary to publicly reprimand the parson in church "for making great alterations and omissions in the Church service," and he writes: "Since then, to make amends, he has read the prayer for the Honourable Company, but leaves out their being Lords Proprietors of the island." "And whereas before it was used by all chaplains that has been here to insert immediately after the petition for those in the Company's service abroad these words, 'more especially the Governor and Conncil of this place,' and since he constantly omitts that sentence and has given out by his brother that 'he don't think them worth praying for,' the Governor says there is an old proverb, 'No penny, no paternoster,' so we say 'No paternoster, no penny,' and are very well contented, because we think the prayers of such a fellow can do us but little good." The parson seemed to be the worse for being kept without his money, for the record says :

He was locked up and confined for persisting in reading the Collect for ist Sunday in Advent, after the Governor called (according to his statement), in a very mild manner, "Doctor, you are wrong, this is the second Sunday in Advent." A full account of this will be found under the heading of "Jottings from the Records."

The immediate charge and superintendence of the Company's lands and plantations were entrusted to the Governor. From the produce of these a publick table was kept up, at which not only the Governor and Council, with principal servants and officers, but even the head artificers and sergeants of the Guard sat in the order of their ranks. This is shown by the following extract, October, I717:

Likewise in the Governor's absence, there shall stand a salt upon the table which shall be placed below the Council and Chaplain. Those who sit above that salt shall always drink as they think proper, cither wine or punch, but those who sit below that salt shall have to two persons, one common bowl of punch (which contains about three pints); if but three, the same; if four, two bowls; if five, no more; and if six persons, three bowls of punch ; or in case of wine, instead thercof, one bottle for each bowl of punch. 
This rule continued, and was in force in 1783 .

There were some bad seasons at this time, and a drought, much sickness amongst both blacks and whites, and a very strange thing happened for St. Helena-the wind continued for three whole weeks to blow from the north-east. Such a thing had not then been known, nor has been known since.

Governor Pike was rather severe, and his severity was often resented. Some soldiers, who considered they had been unjustly punished, escaped in an open boat. After performing a voyage of 1,498 leagues they arrived safely at the island of Nevis, in the West Indies. Governor Pike was withdrawn, and sent to Bencoolen. He however was appointed Governor of St. Helena again at a later date.

In I7I9 Mr. Edward Johnson became Governor, and a terrible drought set in. A most destructive flood also took place, owing, it is supposed, to a waterspout breaking over the island, causing a deluge which is thus described :

The water descended with mighty floods and torrents, carrying away the soil in an incredible manner, with both grass, trees, yams and stone walls before it. It brought down rocks of a mighty bulk, and covered abundance of fruitful land with stones.

Notwithstanding this the drought continued till I723, and the poor islanders were reduced to famine. Johnson died, and was succeeded for a time by Mr. Ed. Byfield. Then Captain Smith arrived, but he was decidedly unpopular, and orders were sent out in I727 for Mr. Byfield to again assume command, which he kept until I732. He paid attention to the Redwood plants, and protected them till they had borne seed, which he again planted and nursed. He also had the furze planted, which has ever since been so valuable as firewood. Goats and sheep were destroyed, or enclosed for ten years, and it is said that plants and trees shot up and the island became well wooded, where before it was very barren. When he retired from office in I73I he had done much good work for the Company, but a powerful party was formed in the island against him, and he retired in disgust. The day on which he embarked for England, in a letter to the Directors, he says :

We have had a fine season, and the place plentifully abounds with yam and beef, and idle fellows. 
At this time a Mr. Benjamin Hawkes, an officer in the civil and military services, and Mrs. Margaret Tovey were sentenced by Governor John Smith to stand in the pillory together "from the hour of eleven till twelve at noon." Governor Pike again was appointed Governor, and was even more disliked than at first. In I736 "Old Will," who had arrived as a slave at the first settlement under Governor Dutton, 1657 , died at the age of 104 years.

After Pike's death Mr. Goodwin, who was senior member of Council, was made Governor, but he died in about a year, when Duke Crisp, who had been the second in Conncil, took office. He managed to rob the Government to the amount of $f 6,284$. When the Company got to hear of his evil doings, they sent out Mr. Robert Jenkins, a commander in one of their vessels, to investigate. On the way out his ship was boarded by Spaniards, who tortured him by tearing off one of his ears. Duke Crisp not only had to give up the Governorship, but the whole of the Council, excepting Powell, were dismissed out of the Company's service for malversation. Their estates were seized, and Mr. Jenkins administered the Government until I7\&I, when the new Governor, Major Thomas Lambert, arrived on March 22.

On the return of Jenkins to England he exhibited his torn ear before the House of Commons. Being asked by a member what he thought and did when they mangled him, he made the memorable reply, "I committed my soul to God, and my cause to my country."

Lambert erected a hospital on its present site, but he died only four months after his arrival, and the senior member of Council, Mr. George Powell, succeeded.

Evidently he had not benefited from, or he did not rementber, the punishment meted out to Crisp and his fellowmembers of Council, for he exhibited a very unprincipled character. Following him came Governor Dunbar, who, although he only held the reins of Government for three years, did a great deal for the island.

Rats were a great scourge at this time, and the oats, barley and wheat were devoured by them. In 1756 they also barked the trees at Longwood for food; but in I 700 they must have been worse, for it is written in the records of the island that they deroured their own species, and that 


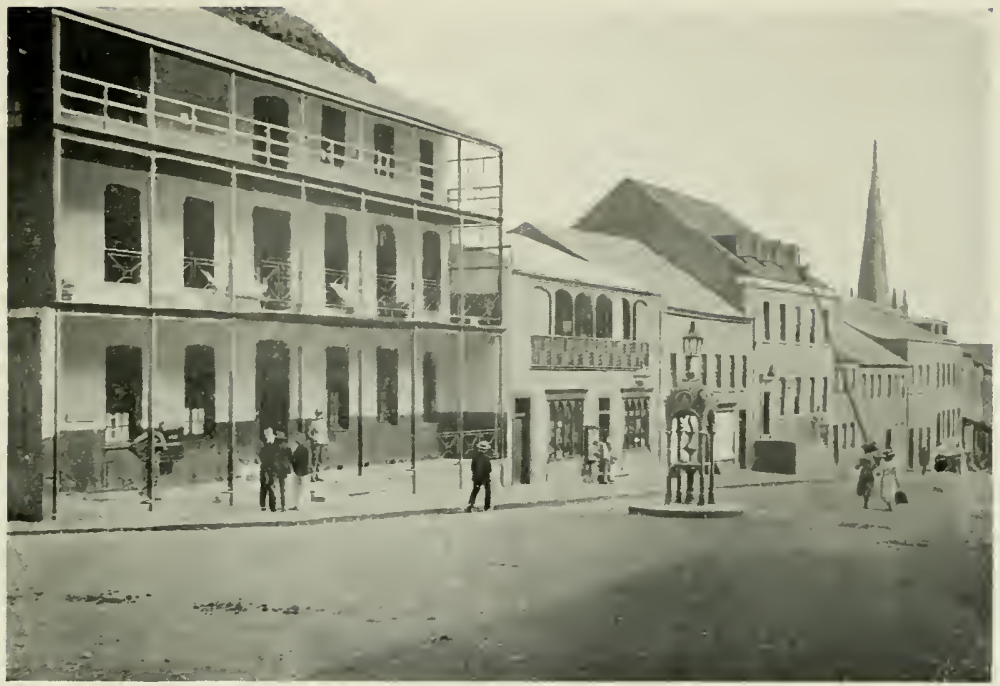

MAN S'TRERT, SHOWMG OFFICERS' MESS.

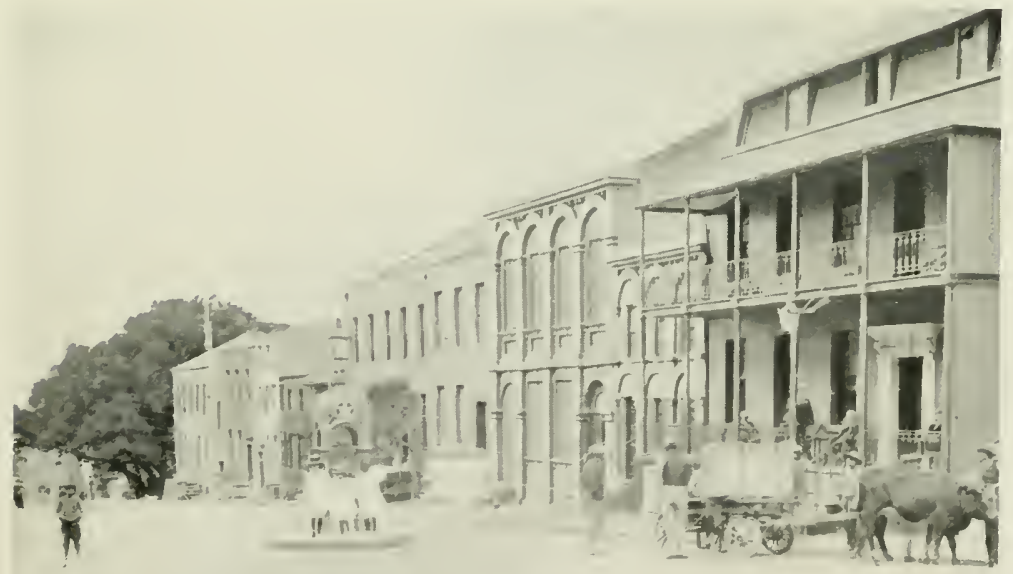

Malx Street, Shomixg St. Helfexa Ciub. 

consequently the island was nearly cleared of these rodents.

A barn was erected at Longwood which afterwards was converted into a residence for the Lieutenant-Governor, and which ultimately became the residence of the Emperor Napoleon I. An avenue of peepul trees was planted through the streets of Jamestown; many of these are still standing.

Goats were introduced in $\mathrm{I}_{5} \mathrm{I} 3$, and in 1588 there were thousands of them. They ate all the young trees-even the old trees were not spared, if they were within reach. To the goats therefore the dearth of wood on this formerly well wooded island is primarily due. Goats were then brought from Bombay and Surat, in order to improve the species, and in a few years they had multiplied to such a degree that they were regarded as wild animals. From the scanty patches of herbage on the heights contiguous to the sea, neither black cattle, nor sheep, even had nature fitted them for traversing such giddy heights and craggy precipices, could derive much sustenance; but, inaccessible as these cliffs are to man, the goat finds excellent browsing, and thrives where other animals would perish. They are at the present time only allowed to range over certain lands; and on specified days the owners impound and cut their several marks in their ears. This is a task of difficulty and danger to any but those inured to it from childhood.

A record of January I, I686, reads :

Starling and others are rewarded for the capture of one Richard Hancock that had lived in ye woods 22 months and was a principal agent in the late rebellion.

A thick wood occupied Half Tree Hollow, and "some persons who advanced therein lost their way and perished."

An old inhabitant says the wood was full of monkeys, who pelted stones at passers-by.

The following extract of a letter from the Government of St. Helena by Governor Dunbar to the Court of Directors, dated July 9, I745, affords a positive proof that the disappearance of the forests was due to the goats, and not to any physical change.

Finding that quantities of ebony trees which grew in and about Peak Gut in their tender growth were barked and destroyed by 
the goats that ranged there, we thought it for your Honours' interest, for the preservation of wood, and the welfare of the island, to order the goats there to be killed.

To this the Court replied:

The goats are not to be destroyed, being more useful than ebony'.

But the most remarkable testimony to the existence of huge forests is that of July 1709 , when in conference it is stated :

Our necessity is so great for want of coals that we thought it would put a full stop to our work, but do find that ebony wood will burn lime extraordinary, and just by where the wood lies are mountains of lime stone, and it will be cheaper to our honourable Masters to bring lime from thence ready burnt (being light), than to fetch that sort of wood (which is very hear'y) and bring it to Jamestown.

This is clear evidence that the island abounded with trees, but of those huge forests, alas, very little remains. Ebony, redwood, white cedar and cotton were all indigenous; the principal trees were the gumwoods, which formed the lower portion of the forest contiguous to the sea, and higher above mingled with these were ebony and redwood. Above the latter, succeeded the cabbage-trees, extending up the central ridge to its summit, where they were joined as at present by the tree-ferns. Few gumwoods now remain, except at Longwood, where they were planted within an enclosure by Government in I 1 So, when the decrease of wood had occasioned great alarm. The ebony has become entirely extinct, and is only found in small pieces on a few spots of the island. The red wood narrowly escaped the same fate, and is very scarce; the honour of its preservation is due to Governor Byfield, who, having accidentally met with two young trees in 1730 , caused them to be removed to plantation grounds, and protected till they produced seed.

The original Flora of St. Helena should be carefully distinguished from that which has been gradually formed on the introduction of numerous plants from various countries. The association of plants in this island will be found extremely curious, and the circumstances, which enable species of very different habits to flourish equally well in the same spot, notwithstanding their constitutional diversity, are deserving of particular attention. Tree ferns are found 
both at St. Helena and at Hobart's Town. Those of this island have the stems destitute of external fibres, except near the ground, while the tree ferns of Hobart Town are thickly covered with similar fibres from the very summit. The particular interest attached to St. Helena flora is mentioned in Lyell's Geology I840, "Vegetation of Islands."

In islands very distinct from continents the total number of plants is comparatively small, but a huge proportion of the species are such as occur nowhere else. In the flord of St. Helena which is so far distant even from the western shores of Africa, there have been found out of sixty-one native species, only two or three which are to be found in any other part of the globe. It is a pity, that some of the most ornamental and elegant of the woods, as redwood, ebony and stringwood, should stand such danger of becoming extinct. Fruit trees of every sort, vines and sugar cane flourish; lettuces, we read, were so plentiful that they were used as food for hogs.

After Dunbar, came Charles Hutchinson, who, in consideration of his valuable services for eighteen years, was allowed by the East India Company an annuity of $£ 300$ per year.

In I749 acorns were planted, and many Scotch and spruce firs, oaks and cypress-trees were introduced.

On June 29, I756, a heavy flood came down the valley, and, overflowing its channel, forced its way through the churchyard and so into the streets of Jamestown. A slight earthquake occurred before this on June 7. The following passage occurs in the records :

On the 7 th June, I756, a little before seven o'clock in the morning, were sensibly felt, in several parts of the island, two small shocks of an earthquake, but did no manner of harm.

In 1758 three French ships were cruising round the island for several weeks endeavouring without success to capture our returning East Indiamen, and in the same year a dreadful sickness broke out amongst the cattle, whereby nearly all were destroyed.

It was in $176 \mathrm{r}$, during the useful career of Governor Charles Hutchinson, that the island was visited for the observance of a transit of Venus on June 6, when it was calculated that the planet Venus would pass over the sun's disc. It was in consequence of an appeal to his Majesty that measures were adopted for observing the transit from St. Helena. Dr. Maskelyne and Mr. Wadding- 
ton were appointed for that purpose, and instead of building their observatory on low land, they placed it on the high ridge near Halley's Mount, which is very often covered in clouds and vapours.

After Governor Hutchinson obtained his pension, Governor Skottoe followed the good example of his predecessor, and gave his time and attention to the preservation of trees. He instituted the Courts of Oyer and Terminer, and Gaol delivery.

In 1763 a commission was granted by the Governor to the vessels Mcrcury and Fly to proceed to Madagascar to obtain slaves for St. Helena.

An earthquake took place on May 21 , which was so strong.on the south part of the island that china and loose articles were shaken off the shelves, but no houses were damaged.

A good carriage road was made to Ladder Hill, and Jamestown Barracks were constructed. After eighteen years Skottoe resigned his post to Mr. Daniel Corneille, I 782.

Pipes were laid down from Chub's Spring for the supply of water to the town and for shipping. In this year another sensation of earthquake was felt by a number of people, who described it as a trembling of the earth, accompanied by a noise resembling distant thunder. The glasses and china in houses were agitated, and struck against each other, while in the fields a number of blacks employed on a yam plantation were so terrified that they abandoned their work.

Corneille issued new regulations, which deprived the soldiers of their punch-houses, and prevented excessive use of spirits. This caused a mutiny in the garrison, which, owing to its indecision, assumed large proportions, and which might easily have been prevented had he acted decidedly at first. It was on Christmas Eve that the insubordination commenced, and for days the men were turbulent and riotous. They (about 200) met under the direction or command of a Sergeant Tooley, and with arms declared their intention of seizing Ladder Hill Fort. Fortunately the Governor and the Lieutenant-Governor, Major Graeme, wcre at the time returning by Ladder Hill road to the town, and happening to look over the wall saw the movements of 
the mutineers. Major Graeme was sent back to Ladder Hill Fort to give alarm, and to procure arms, while the Governor proceeded on his journey to town, where he met them.

His reasoning had some effect, but he was foolish enough to open the punch-houses again for them. The evil effect of giving way to them was soon apparent. When too late the Governor saw it, and repenting of his leniency secured Sergeant Tooley as a prisoner. He then went with the main guard to the barracks, hoping to find the mutineers, but they were cunning, and had gone off to the country to seize Alarm House, which overlooked the town and near which was a guard with guns. Major Graeme was sent on horseback to cut off the mutineers. He galloped up Side Path, and taking short cuts with his horse, was enabled to reach Alarm House before them, as they had started on foot up a steep circuitous path. At one time he was dangerously near them, and they fired several shots at him. With the assistance of the six men on duty he fired grape-shot on the mutineers; but it was getting dark, and they knew sufficient to throw themselves flat when the discharge came. They succeeded in surrounding him, and chased him some distance, firing several times. Eventually he arrived again in Jamestown.

In the meantime the Governor had sent off Major Bazett and seventy men, who went by an indirect road, hoping to take the mutineers unawares; but he found them well prepared, with their position fortified on all sides by the Alarm House guns. They received him with a discharge of grape, but, nothing daunted, he and his party rushed and secured the gun from which they were firing, threw the gunners into confusion, and, following up the attack quickly with musketry, they overcame the rebels. Many of the mutineers in the darkness deserted their side, and joined Bazett; the others took refuge in the Alarm House. On Major Bazett's side two were killed, several mutineers were wounded, and I03 taken prisoners. These were all tried by Court Martial, and, except fourteen, were condemned to death; the sentence was however remitted for many. Only nine, including Burnet, suffered death. Tooley was isent off the island in a ship bound for England; this was wrecked off Salby and every soul perished.

Mr. Corneille resigned, and was followed by Colonel 
Robert Brooke, I787. St. James' church was built on a site adjacent to the present church (now occupied by three military quarters).

A serious accident occurred at the laboratory near the Castle. A rocket took fire whilst driving; two men were killed and three wounded.

In the first year of Colonel Brooke's Government, pineasters were introduced; they have flourished ever since. At this time the island had gained a name for the acclimatizing of troops on their way to India. So reinforcenents came for infantry and artillery, and improvements went on. Ladder Hill was adopted as a military fort, and water was conveyed there in an open drain of cutstone. The lower wharf and crane were constructed, and in r79r the foundation of Plantation House was laid. On the other side of the country improvements were also being made, for we read that "water was conveyed to Longwood in an open drain."

In 1792 the terrible curse of slavery was partially removed from the island, for the further importation of slaves was interdicted.

In I795 intelligence was received of the Dutch joining in the war against England, and very soon after, eight richly laden Dutch ships homeward bound came in for provisions. H.M.S. Sceptre was in harbour, and with it and the assistance of the crews of several of the Company's ships, Brooke succeeded in capturing and making prizes of them all. He then sent off troops from the garrison, about 400 men with guns and ammunition, $f_{10,000}$ in specic and a quantity of provisions, to assist in the reduction of the Cape of Good Hope, for he knew the garrison there was not sufficiently strong.

He was highly commended by the Company, and in recognition of his services he was presented by the Marquis Wellesley, Governor-General of India, at the head of the garrison of St. Helena, with a sword taken in the palace of Seringapatam. The presentation was made by Honourable Henry Wellesley.

Brooke retired owing to ill-health in $\mathrm{I} S 00$, and LieutenantColonel Robson took his place for a short time, until Governor Patton could arrive. Just at this time the Mary whaler arrived in charge of two of her officers, who whilst 
on parole had recaptured her from the Dutch in Table Bay. Governor Patton highly disapproved of this act, and seized the vessel, sending information to Governor Jansen that he had done so.

Patton much improved the water of the island by puddling them with a mixture of lime, gravel and clay, which he named puzzolana; he attended also to the state of the fortifications, and one battery, the site of which can only now be seen, was called Patton's Battery.

Three hundred men were sent in 1805 to assist in the attack on Buenos Ayres under General Beresford.

The Government schooner Jolly Tar was stolen from her anchorage in the harbour, on October II, by three Spanish officers (prisoners on parole), together with ten foreigners who were serving in the garrison. They murdered Mr. Swete, the commander, and took the schooner to Rio de Janeiro.

Governor Patton instituted a system of telegraphy invented by himself.

The rapid spread of the blackberry plant caused much trouble, and we read that the grand jury at quarter sessions represented the devastation caused by the spread of these plants to be such as required the immediate attention of Government; but the blackberry trouble was soon swallowed up in the measles outbreak. Almost the whole population were stricken at one time, and this naturally caused great distress. The epidemic was also very fatal to life.

Just above the Government garden a walk, which still exists, was cut out of the hillside by Patton, who wished to provide a retired promenade for his two daughters; this has always borne the name of Sisters' Walk.

Much more attention was now given to trade with shipping, and agriculture began to be neglected. Labour was dearer and scarce, and the price of a good slave increased from about $£ 40$ to $£$ I 5 O.

Governor Patton fell into ill-health, and went home. His duties were undertaken by Lieutenant-Colonel Lane until the arrival, on July 4, I808, of Governor Beatson. He was a very energetic man, of high intellect, who did his utmost for the welfare of the people and island. He it was who greatly developed agriculture. First he imported farm labourers 
from England, and about 650 Chinese from Canton: the Chinese proved such excellent workmen that some of their work even now remains. They had a Chinese settlement in the grounds of Plantation House, where, until lately, the remains of their joss-house was to be seen. In the Museum are some interesting tiles taken from the joss-house. Their burying-place was at New Ground.

Beatson shows clearly in his tracts, that the soil was most productive if properly treated. He caused the goats running wild to be destroyed, and made compensation to the people. He states that in ISoS eighty-eight acres in gardens and potato grounds was the total cultivation; this only produced a very scanty supply for the shipping, to which it was sold at most exorbitant rates, the inhabitants $(3,600)$ themselves living almost wholly upon the public stores, and obtaining most of the necessaries of life in profusion, at prices not exceeding onc-third of the primary cost. This was checked by Governor Beatson.

Between the years ISoo and ISoS the imports for these inhabitants rose from $\{51,030$ to $£ 114,961$ per annum first cost-ireight to be added at $£ 30$ per ton from India, and somewhat less from England, making the total in ISoS, f157,356. This Beatson altered, for he found there had been no sanction of the directors to issue to the people from the public stores at such a low rate. It will be scarcely credited, but so determined were the growers to keep up the prices, that rather than lower potatoes from 10s. or 12s. per bushel, the crops were allowed to rot, and many cart-loads thrown into the sea. The markets in St. Helena are always deranged by the arrival of shipping, and from captains and passengers high prices are demanded. If prices were regulated and kept within certain bounds, industry would be encouraged, and more land cultivated. In ISI I the Government did interpose, and prohibited any one from demanding, or receiving more than 5s. for a fowl; potatoes also were lowered from I2s, to 6 s. per bushel. The prices in 1810 were-beef, $15.2 d$. per pound; turkeys, 32s. to 42s. each; geese, $21 s$. to 25s.; sheep, 40s. to Gos. each.

In the year I Sog tanks or reservoirs were made in stiff clay on the south side of High Kinoll, chiefly to supply 


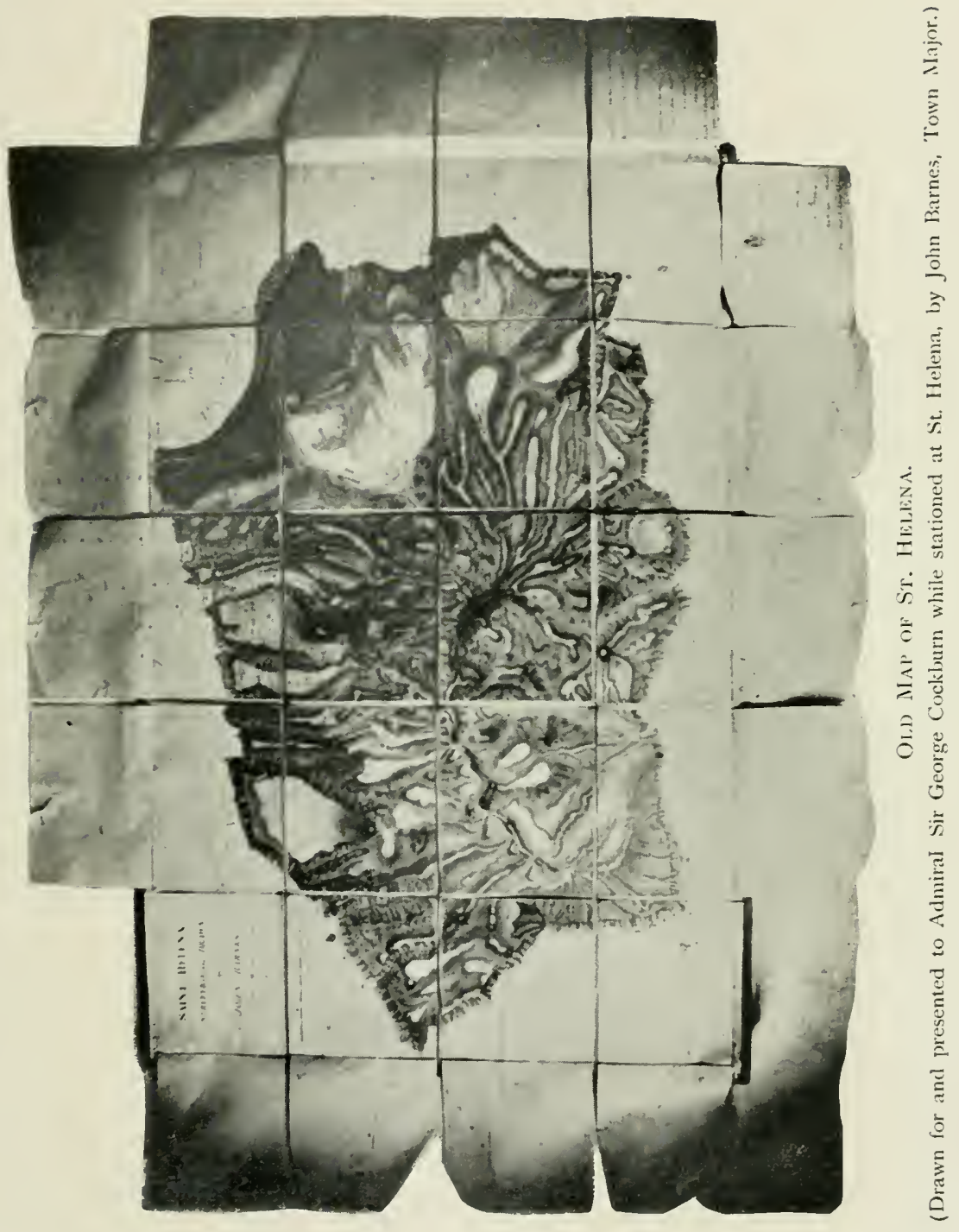



Ladder Hill Fort. These tanks were fed by channels cut on High Knoll, and also on the adjoining hill, "Merriman," a space of several acres. In the map (drawn for Admiral Cockburn by Major Barnes) will be seen this reservoir or tank near High Knoll. The S.E. wind coming down the valley kept the water in agitation, and prevented its becoming stagnant. It was originally intended only to supply the soldiers of Ladder Hill, who before this time, r8og, had been stinted in water, having to fetch it all in kegs from Jamestown. One reservoir contained 4,000 tons, and "Beatson," writing of it, says :

It may be expected to be filled tivice a year (during two rainy seasons); the total annual supply will be 8 ,0oo tons. Allowing ten tons a day for Ladder Hill, there would remain 4,000 or 5,000 tons for intermediate gardens.

The descent from tank to fort is one foot in ten, and a cutstone watercourse has been laid the whole distance of 2,800 yards.

At Plantation, in $18 \mathrm{ro}$, from a few seeds sown in October, there was raised from the first crop 3,583 lb. of pumpkins. Several of them weighed seventy pounds each.

As well as devoting a deal of time to agriculture, Beatson also looked after the welfare of the soldiers and islanders. He saw the terrible effect of the incessant spirit drinking, and checked it by preventing any further importation of rum, substituting for it beer, which was island-made. The Brewery was at the head of Jamestown, and had the reputation of supplying excellent beer. He also imported Cape wine, but the dissatisfaction grew at his prohibiting rum, and the peace of the little community was disturbed. Governor Beatson showed great firmness; when threatening letters came to him he took precautions, and his account of the mutiny will be found interesting. It is a pity that his most interesting book has been allowed to pass out of print. Governor Beatson relates as follows :

A most daring mutiny having broken out in the St. Helena infantry on the night of the 23 rd December, I8I I, for the avowed purpose of seizing my person and subverting this Government, it becomes my duty to lay before you a general view of the causes which led to these licentious and highly criminal proceedings. ... Your Honourable Court is well aware of the state of St. Helena at the time you did me the honour to appoint me to this Government. On my arrival in July, I 808 , I found a population of 3,600 living 
almost wholly upon the public stores: and obtaining most of the necessaries of life in profusion at prices not exceeding one third of the prime cost. The consequences of so unprecedented a system were the neglect of cultivation, the decline of industry, and an immense augmentation in the annual charges of the island. I found a garrison as well as many of the inhabitants immersed in the grossest intemperance, from the facility of obtaining, and their excessive use of, spirituous liquors; and I found that abuses obtained in some of the departments. . . While I was carrying forward my official duties, upon principles of strict justice between the Company and individuals, I was often assailed with reports of intended mutinies. These were sometimes conveyed in anonymous papers, and circulated, no doubt, with a view of intimidating me from persevering in a system of reform, which had become necessary, and which I was firmly resolved to pursuc. Although these vile means evinced a general dissatisfaction, yet, conscious of the uprightness of my conduct, I totally disregarded thein; and these factious and discontented men who took the lead in these despicable and seditious attcmpts, finding that their mean and unbecoming artifice had not the desired effect, were apparently lulled for many months past. Very lately, however, when a temporary inconvenience was lelt arising from our reduced stock of Bour, and the total want of rice in the public stores, this occasion was eagcrly' laid hold of, and became a plea for the revisal of unreasonable demands, accompanied with menaces of mutiny and rebellion The want of corn-bread was the pretended cause of dissatisfaction, but circuinstances have since clearly shown that the sole object of the late violent measures was to compel this Government to givo spirits to the garrison; an object in which every drunkard on the island felt a deep and warm interest. I delivered orders to the Town Major to be issued, and then opened a sealed anonymous paper which during the night was slipped under Mr. Doveton's door. I was at the same time informed by the Town Major that the regiment was prepared to inutiny, for the purpose of seizing iny person and sending me on board the Camperdown. (The Camperdown was a cutter hired by the Company and attached to the island in iso8. She was occasionally sent to the Capo of Good Hope and to South America on public service.)

\section{The following is a copy of the anonymous letter addressed} to the Governor and Council :-

\section{Gentlemen of the Couscil, -}

His it still your intension to percevere in your oppression and tyranny towards the troops in this garrison has hitherto you have done? if so, you can cxpect nothing but an open rebellion. I am hereby autherized by the troops of this island to inform this Council if they do not immeadatly soply this garrison with liquor and provisions in the same manner has Governor Brooks did (whose regulations you have voilated) you shall be made answerable for what 
may follow, except you make your escape good from this settlement. It is in your power to prevent the impending vengeance which now hangs over your heads, and save the lives of many poor souls which will inevitably fall a sacrifice.

This seditious paper was written in a feigned hand. Beatson thereupon sent off the Camperdown, reinforced High Knoll and Ladder Hill, and placed guard at Plantation, for the artillery were all true, and to be depended on.

It was settled by the mutineers, that when the troops paraded for relieving guard, the whole of the regiment, including the main guard, should, after seizing their officers, go to Plantation and seize the Governor. His preparations and knowledge of their intentions necessarily changed their tactics, and the ringleaders, feeling there was no time to lose, proceeded to Longwood to get possession of field-pieces and ammunition. The narrative continues:

I sent an express to the Lieut.-Governor suggesting the advance of some field pieces to oppose the mutineers if they should move in that direction. The Lieut.-Governor lost no time in taking up an advantageous position with the field-pieces manned by the guard at Longwood: but at the moment the advanced gun was loading the mutineers surrounded him and his party and took them prisoners. It was three-quarters past nine at night when the general alarm fired. By this time some of the volunteer artillery, to whom secret orders had been sent, had arrived, and by midnight Plantation contained a garrison of I 30 men, which I considered enough to repel the most formidable attack of mutinous troops. On the ground floor every window and door was guarded by three or four armed men, parties of rifle volunteers lay behind the parapet on the roof, and the rooms on the upper floor were prepared for occupation at the instant the mutineers approached. Mrs. Beatson and my children were placed in security against musketry in one of the upper rooms. After the alarm fired, a judicious movement was made from Jamestown by parties of artillery and infantry to reinforce me, the former under the command of Major Kinnaird, and the latter under Capt. Sampson, two excellent officers who had both been extremely active in bringing back a number of soldiers to a sense of duty. Captain Sampson halted at Red Hill, and Major Kinnaird about twelve at night had passed Plantation House, and took up a commanding position in advance with field pieces. Capt. Barnes' company and some other artillerymen were upon the roads, on which the mutineers must pass in coming from Longwood. Capt. Desfountain, with three guns and the volunteer artillery, occupied another position in the rear of Major Kinnaird. Although Capt. Sampson had expressed a confidence in his men, yet I could not but entertain the strongest suspicion of the whole of the infantry; 
I therefore gave positive orders that if any troops advanced near my post without permission they should be fired upon. These suspicions were not without cause, for Archibald Nimmo, who had been one of the most daring and active in seducing the soldiers and administering the oath and obligation to seize the Governor and send him off the island, had the audacity to range himself among the friends of the Governor who came to reinforce Plantation House. He had hoped to turn those friends into foes, and seemed at one time, when the Longwond mutineers approached, to be on the eve of making the attempt, but perceiving he was suspected, and closely watclied by a non-commissioned officer with a drawn sword inamediately behind him, he was thus deterred from putting his designs into execution. About one in the morning two lights and a number of men were discerned moving slowly alnngside of the hills, two miles east of Plantation House. Major Doveton, command:ant of volunteers, lespatclied two active men to gain intelligence. John Bayley and Kennedy were selected, but imnediately a black mes. senger brought in news that Colond Broughton and his party were taken prisoners. I therefore wrote a pencilled note to Capt. Sampson to advance with thirty men to form an ambuscade on the left thank of the mutineers' column, and commence attack by one fire, in a manner so as to avoid Coloncl Broughtion, and immediately after to rush on them with the bayonet. .lajor Kinnairt was to support this attack. These orders were just given when Major Wright arrived with the news that the mutmeers had halted within sixty yards of kinnaird, and sent forwars the terms on which they would surrender. The negotiations ended in the unconditional surrender of the whole party. The first proposals sent by the mutineers were that grievances must be redressed, and a promise given that soldiers should have regular issues of spirits from the stores. I replied, I would grant no terms, I could not treat witls rebels, and if they did not instantly surrender I would put every man to the sword; then they said all they would ask now was my promise of pardon; this I positively refused, and at the same time informed them that if they did not yield unconditionally Major Kinnaird had orders to put the whole of them to deatls. It was now daylight, and seeing a superior force opposed to them they surrendered, saying they would trust to my inercy. Of 20 ) men who had sallied from Jamestown on the mad enterprise only seventyfive remained in the morning; the others seem to have repented and returned to their barracks. The prisoners were put in close confinement at High kinoll. The discomfiture of these rebels had not subdued the mutinous spirit of their associates outside, and it was reported that an attempt would be made to rescue the prisoners. So I sent across orders to Colonel Smith to occupy two strong positions, which commanded with cannon the barracks and the roads leading to the interior.

General orders were issued :-

"25th December, 18ir. A considerable portion of the St. Helena 
regiment having been guilty of mutiny and rebellion on the night of the $23 \mathrm{rd}$, by outrageously seizing the Lieut.-Governor and avowing their desperate intention of attempting to seize the Governor: it is therefore the Governor's positive orders that the men keep in their barracks, and that the main guard shall not get under arms without the sanction of the Commanding Officer of Ladder Hill, who has been ordered to depress guns loaded with grape, and to fire upon the main guard if it shall presume to get under arms without his previous permission. Under the present state of affairs, the Governor deems it expedient to notify to the troops that if any non-commissioned officer or soldier shall be guilty of disobedience to his officers, or shall evince by words or actions the smallest symptoms of mutinous spirit, he will instantly be seized, tried by Drumhead Court Martial, and hanged.

"By order of the Governor,

$$
\text { "C. R. "G. Hodson, }
$$

Then a general Court Martial was called, and nine prisoners tried upon a charge of mutiny; names-Henry Sisell, Thomas Berwick, Archibald Nimmo, Robert Anderson, privates ; and Arthur Smith, Thomas Edgeworth, Peter Wilson, and John Seager, corporals in St. Helena regiments, and Richard Kitchen, gunner in Artillery. All these prisoners were found guilty and condemned to death. Six were executed at High Knoll at sunset, and Wilson, Seager and Kitchen were remanded. The general Court Martial reassembled on the 26 th for the trial of three others; and of these one, Hewitt, was ordered to be executed. The whole garrison was drawn up in lower parade, and prisoners led along the front. The 'Dead March" was played, and Hewitt hanged. Sefton and Lindsay were pardoned under the gallows.

This awful scene made a strong impression: the mutinous spirit was gone and obedience restored. In order however to prevent a return of such disgraceful proceedings, I gave orders to seize and confine every man who had been active in the late mutiny. Between twenty and thirty have been placed in close confinement, whom it is my intention to send off the island by the first favourable opportunity. On the 3oth December I granted an amnesty to the remainder of prisoners taken in arms. They were paraded at Plantation House, and after admonishing them to behave in future like good soldiers, and telling them that I freely forgave them, although they had taken up arms against me, I ordered their return to their duty.

\section{In an after report Beatson says :-}

The Governor feels much satisfaction and pleasure in publicly expressing to the officers of St. Helena his warmest approbation of their conduct ; and he requests that they will accept his best acknowledgement and thanks for the signal and important services they have rendered. The uniformly steady conduct of the corps of 
Artillery, who almost to a man escaped the contagion that spread around them, deserves the highest praise. The late occasion is the first that has occurred by which judgment could be formed of the St. Helena voluntecrs. Their loyalty in the support of public authority, their alacrity in reinforcing the Gosernor, their determined spirit to stand by him to the last extremity, their eagerness to do their duty, and to guard his person and family for several nights after he considered the danger was past, will ever be remembered by him with sentiments of the warmest gratitude. He requests therefore that these his sentiments and his best thanks may be conveyed to all the officers, non-commissioned officers, and privates of the St. Helena volunteers by their worthy commandant and leader, Major Doveton.

That Beatson gained his point with regard to excessive spirit-drinking may be seen, for the houses for retailing spirits were abolished on May 15, ISog. The garrison at that time consisted of about I, $250 \mathrm{men}$, of whom I 30 were ill and in hospital. In four months, under his abolition of spirits, the patients were reduced to forty-eight.

With regard to his extermination of the goats he was not so successful, for he could not get his orders carried out regularly, and so in a few years they increased in such numbers that not only indigenous plants and young trees were devoured, but all vegetation suffered.

In 18 ro attempts were made to again find gold, and Governor Beatson, remarking on the letter written by Governor Pike in 1719 , says:-

I employed three men under the direction of Capt. Henry Pritchard, a very intelligent officer, to examine the hills in the vicinity of Turk's Cap, and to dig where was a likelihood of ore. Pritchard's report say's: "I would propose, after having penetrated 50 or to fect, and carcfully examining each strata, to commence cutting directly down the ravine, as our pit is on the top of a hill 250 feet high, by which means we shall be able to explore better the properties of the interior.

It seems very probable that the researches of these times would have been of much more value, had the pits or shafts been made nearer the base of the hill instead of 250 feet above the sea level.

Beatson will always be remembered for his untiring energy in planting the islands, and importing good trees. We read in his book that "the gardens produced excellent grapes, peaches, apples, guavas, oranges, plantains and 
other fruit, and all sorts of esculent vegetables." The apples were of high flavour, some of them measuring sixteen inches in circumference. How very different from the present day, when bananas and figs are almost the only fruit which escapes the ravages of the worm, and oranges, apples, grapes, and lemons are also imported.

At the end of five years Beatson retired, leaving his work to Colonel Mark Wilks, who fortunately was a man of wide views, and concurred in general with Governor Beatson's plans for improving both people and island.

Colonel Wilks arrived on the island on June 22, I8I3, and his Government is memorable as being that during which occurred the arrival of Napoleon. The St. Helena library was formed in this year, and in I8I4 the Benevolent Society for the education and relief of the poor was established. In this year also the celebrated Dr. Roxburgh recommended the introduction of Cinchona officinalis from South America, also that young plants be raised here for transmission to India. A list of the plants found and reported on by Dr. Roxburgh will be found at end of book, as well as a report in I869 of the cinchona planting.

Napoleon Bonaparte, Emperor of the French, arrived in October I8I5. His arrival was totally unexpected, and caused a great sensation on the generally quiet and monotonous little rock. There is so much of interest concerning his enforced residence and sad lonely death, that I have considered it advisable to place it under a separate heading.

In I8I6 Lieut.-General Sir Hudson Lowe arrived to take over the Government from Colonel Wilks. Sir Hudson Lowe was of course appointed by the Crown, not by the Company. The island however was still to belong to the East India Company, but, as the expense of keeping it up would be so much more, it was decided that the Company should only bear as much expense as was the average of several years, and that the Crown should bear the remainder. It was during Sir Hudson Lowe's Government that the waters of Diana's Peak were conveyed to Deadwood, and again from a stream near that beautiful spot, Oakbank, to Francis Plain. In both instances this was done with a view to supplying troops then encamped at these places. One good law attributed to him was that which decreed that 
all children born of any slave woman should from and after Christmas Day I 8 i 8 be free.

The introduction of slavery on the island itself appears to have originated with the first settlement ; but according to the records, restrictions were early placed on any further importation, as a fear gained ground that their number would exceed those of the Europeasis. Some years after however permission was again granted to import slaves, on condition that the purchaser should maintain a white man for the militia, or in default should pay the Government Ios. per head for each slave. There was a law that each Madagascar slip calling for stores should be compelled to land a negro-cither man or woman (whichever was decided by the Governor)-for service in the Company's plantations.

The laws made for white people did not extend to the blacks, who were hardly considered above the animals, except for their value as workers. This will be seen from some of the laws and orders constituted for the negro slaves by the inhabitants of the island, with the approbation of the Governor and Council. They are as under, and are supposed to have been framed either in Governor Field's time or in the early part of Mr. Blackmore's Government.

That no Black or Blacks upon any pretence whatever shall wander from his master's plantation upon Sundays without a lawful occasion granted by their said masters or mistresses, either by writing or some other token that shall be known by the neighbourhood, upon the penalty of ten lashes on his naked body for the first offence, fifteen for the second, twenty for the third, and so for every offence thereafter committed; but if the master of the said slave or slaves should refuse to comply with this said order, the person who shall have taken the said slave or slaves acting contrary to this said order, shall be obliged to complain to the Governor and Council whom we desire to fine him or them that shall so offend at discretion.

That negro, or negroes, that shall be known to

For pilfering steal the value of eighteen pence, shall have and stealing. twenty lashes on their naked body, inflicted by the master or masters of such slave or slaves in the presence of the person so offended; but, if the theft should amount to three shillings, the lashes aforesaid are to be increased to thirty ; and if six shillings, to sixty, and the party so prejudiced shall receive the value of the thing so stolen in specie, or in money from the owner of the said slave or slaves; and if the theft amounts to above six shillings and under thirty shillings, the offender shall 


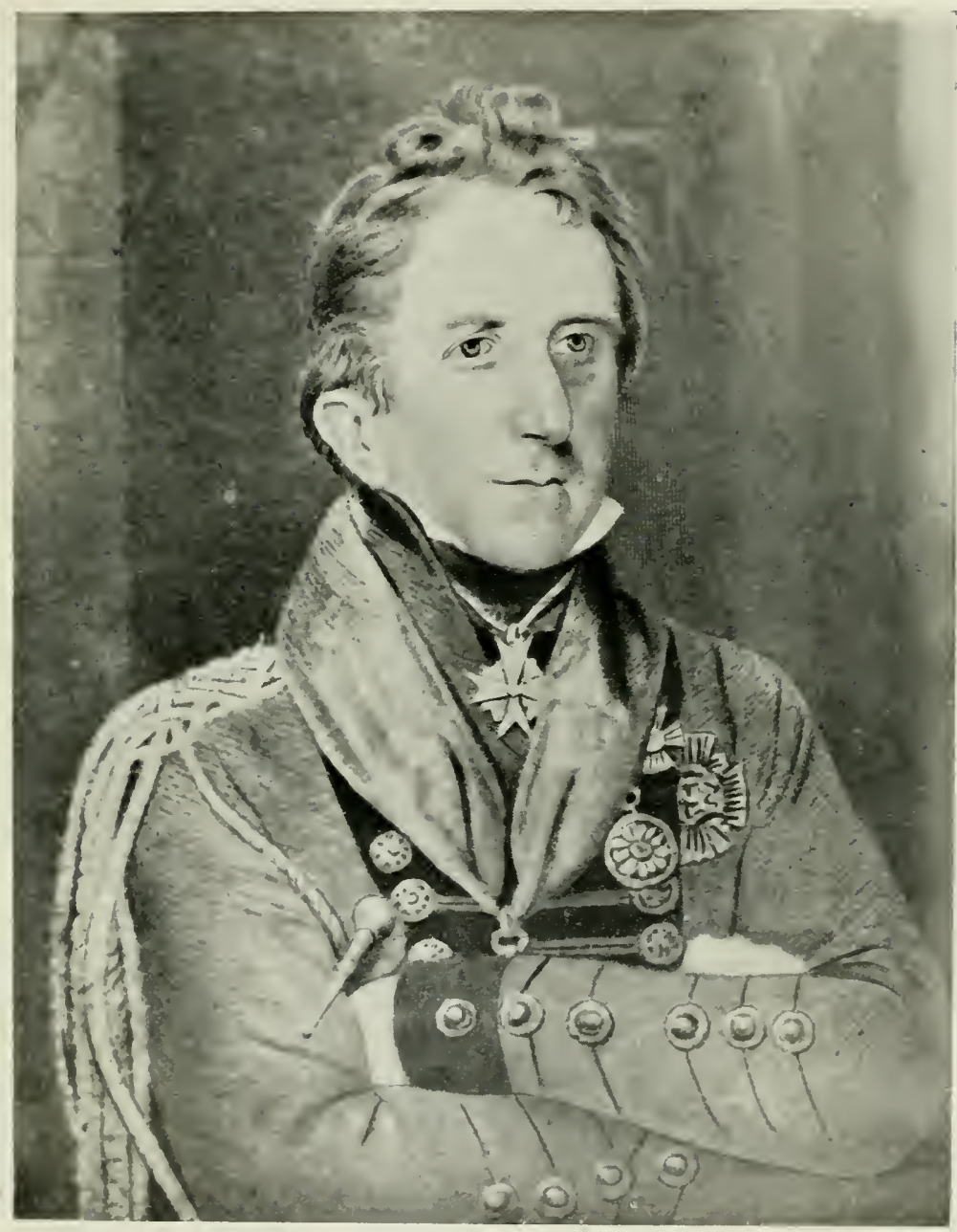

LietT.-GeNeral Sir Hunsox LOWf, K.C.B., Governor of st. Helena, April, I816, to Julv, i821. (Reproduced from a Print now in Castle Jamestonen. 

be seized and brought to the Fort, where he shall immediately receive fifty lashes on his nalied body, and secured; two days after he shall receive thiriy lashes, and two days after that twenty more ; and the master of the black shall pay the value stolen as aforesaid.

Those that absent their master's service three

Absentees and runaways.

For breaking open houses. days and three nights shall be punished according to the last foregoing article and the master make satisfaction for what they have stolen as aforesaid.

For the first offence of this kind, the master or masters shall make satisfaction for what is stolen and repair all damages doine by the slave or slaves; so soon as taken he shall be brought to the Fort, and immediately receive on his naked body one hundred lashes, then secured; four days after that thirty; six days after that twenty more, and branded in the forehead with the letter $R$. For the second offence of this kind he shall be punished as aforesaid and wear for one year a chain and clogg of thirty pounds weight; and for the third offence, satisfaction shall be made as aforesaid to the loser or losers, and the slave or slaves shall suffer death, at the discretion of the Governor and Council.

In case any male slave from the age of sixteen

In velation to years and upwards shall presume and attempt to striking or strike or assault any white person whatsoever, assaulting any correcting him or otherwise, for any cause whatwhite person. soever, shall for the said offence or offences (though without weapon or dangerous instrument) undergo and suffer the punishment of castration; and in case any such slave or slaves shall chance to die under the punishment aforesaid, or before he be well, then the country and public shall bear the loss and make good the value of the said black, according to an appraisement made by the Governor and Council for the time being ; further, but in case the said slave or slaves should die through neglect of the master or owner, then, upon proof thereof, the said master or owner to bear their own loss of the said slave or slaves and the whole charge of everything relating thereto; and if the said slave live, the master to be at all charges.

That if any negro slave, male or female, shall

In velation to those that shall give saucy

language, resist or oppose or strike any white person. presume to resist any white person whatsoever in the taking or pursuit of them upon any lawful occasion, the slave or slaves so offending and resisting as aforesaid for the first offence shall be immediately conveyed to the Great Fort and secured till they have undergone double punishment according to the constitution of runaway negroes, and branded in the forehead with the letter $\mathrm{R}$; and for a second offence in this nature, the said slave or slaves so offending shall suffer the same punishment as is adjudged and ordered in the case of striking ; but if a female, to be severely whipped and both ears to be cut off, and branded in the forehead and both cheeks. 
And in case any slaves, male or female, shall presume to strike any white person whatsoever with any weapon, they shall suffer death, except those white persons who demean and debase thenselves in conversing, corresponding and gaining with the blacks, as if they were equals, which we judge shall have no more benefit of those laws than blacks themsclves.

And in case any negro slave shall presume to give saucy or inpertinent language or answer to any white person (except those white persons aforcsaid) shall, upon complaint thereof to the master or owners of the said slave, be severely whipt in the presence of the party offended, to his satisfaction; and if the said master or owner of the said slave shall refuse or neglect to punish the said slave so offending, then the party offended may complain to the Governor; and so cause the said slave to be apprehended and conveyed to the Fort, and punished accorling to the nature of the offence.

That no negro slave shall truck, barter or exAguinst one cliange anything, without the forcknowledge and blackbartering consent of the owners of the said negroes, both with another. the sellers and buyers, deliverers and receivers of any commodity whatsoever to the value of one shilling, upon the penalty of ewenty lashes or more, if it should exceed that value according to the judgment of the Governor and Council, severely to be inflicted on them at the Flagstaft, upon tho complaint of any one aggrieved by such a clandestine way of one negro dealing with another.

That no white person whatsocver shall truck, Against any barter or exchange any commodity whatsoever white person with any negro or negroes, to sell to them nor buy towching or of them any sort of commodity, without the forebartering teith knowledge and consent of the owners of the said blacks. negro or negroes upon the penalty of being ad. judged accessory to felony, and so consequently liable to a fourfold restitution to the owners of the said negro or negroes, besides a fine to the Lords Proprietors; nor no negro shall alienate any commodity or thing whatsocver to any white person whatsoever, without the leave and consent of the said negroes" master or mistress before had, upon the penalty of severe correction according to the judgment of the Covernor and Council.

That no negro whatsoever shall prescribe or

No blacks

to prescribe

physic to

each other. administer any physic or medicine whatsoever to any negro or negroes without the consent of his or their master or mistress of that negro unto whom he shall prescribe or administer any physio or medicine upon the penalty of severe correction, according to the judgment of the Governor and Council; neither shall any negro whatsocver take or reccive any physic or medicine, or follow the rules or prescriptions of any pretended black doctor whatsocver, without acquainting their master or mistress therewith, upon the penalty of the like pain and punishment as the black doctor who pretends to pliysic is liable to. 
In 1792 laws for the better government of slaves were issued.

These were embodied in forty-two articles, ordering slaves to be diligent and obedient, and to demean themselves as faithful servants. These laws certainly much improved the condition of the blacks.

They ordained :-

That masters and mistresses shall treat their slaves with kindness and protection, with good and wholesome provision, and in sickness, necessary medicines, care and attention.

That masters and mistresses are to be allowed to correct slaves moderately for wilful neglect or turbulence or abusive language ; the punishment not to exceed twelve lashes with a cat-of-nine-tails.

That for faults and crimes of greater enormity than above, they should be carried before the justices of the peace and punished by their orders.

That if masters and mistresses inflicted heavier punishment than was authorized for the offence, or punish without reasonable cause, that they should be considered as guilty of assault as if the offence had been committed against a free person.

That in case the proprietors of slaves did not supply them with proper clothing, medicine, etc., it shall be lawful for the slaves to make complaint to the justices of peace-the Governor to be oneand if necessary, the proprietors to be fined.

All slaves, except those employed as household servants, shall be allowed Sunday to themselves, and not be required to work thereon for their masters.

And that household slaves also shall be spared from labour on Sundays as much as may reasonably be consistent, and to be allowed alternately one Sunday in two for themselves.

And that no slaves shall be allowed to collect or earry wood on a Sunday, either for their masters or mistresses or for themselves, on pain of being punished by the order of two justices of the peace.

Sir Hudson Lowe aimed at the progressive abolition of slavery. It might, it is true, have been abolished by legislation, but that would have been at an enormous cost, besides which, a sudden freedom of all restraint on those who had been born and brought up in slavery would have led to grave consequences in many cases. The slave-owners listened with respect to Sir Hudson when he addressed them on this matter, and pointed out that St. Helena was then the only spot under British Government where slavery existed. He owned that in no part of the world did slavery exist in a milder form than in this island; still it would be 
in perpetuity, if the present system remained, which decreed that the child of a slave was also a slave.

He showed that in Ceylon it had been decreed "that all children born of slave parents after a certain date would be free from birth," and it was this he wished them to imitate. He left the matter to their deliberations; and after a discussion of not more than ten minutes, the slaveowners carried by acclamation the adoption of his suggestion, and a committee of thirteen persons was appointed to frame resolutions, and in four days these were submitted to the Governor and Council with a request that they might pass into law. This was complied with, and by these laws-

All clildren born of a slave woman from and after Cliristmas Day 1818 were frec, but considered as apprentices to the proprietors of the mothers, if males, until the age of eightecn years; and if females, until the age of sixtecn years : and that masters and mistresses were to enforce the attendance of free-born children at church and Sunday school.

So by degrees a great difference was seen in favour of the slave population. Importation of slaves had before been prohibited, and those now in slavery were allowed many privileges. Teaching in religion and morality had not been in vain, for a Benevolent Society was formed by Governor Wilks for their education. Statistics show too that whipping was not as frequent, though it was still in use; but Governor Vialker devised a treadmill which did away with the demoralizing punishment of the lash. The treadmill is described as follows:-

The part upon which the culprits tread is a horizontal circular plane, revolving upon a vertical axis or spindle. The labour is similar to that of pushing with their hands. A cross-bow is placed about the height of the head or a little higher. At every step the wheel recedes from behind them, and there is a contrivance for kecping their bodies in a position leaning forward. The exercise probably is not so severe as that in the English tread-whecls, but augmented punishment can alway's be administered by making the offenders work in shackles, or by prolonging the duration of the sentence. The purpose to which the machinery is applied is that of grinding lime; a process requisite to give to the lime of St. Helena the qualities of a good cement.

Slaves were also at this time allowed to attend church, and alterations had to be made in the interior arrangements 
of the churches to accommodate them. The following was a proclamation issued by the Governor and Council on August 20, I823 :-

None, it is presumed, will be disposed to question that regular attendance at public worship will, in time at least, produce some degree of respect for divine ordinances; and whatever may be the inattention of many, it can hardly be supposed that all will continue insensible to impressions so liable to be excited by the habitual hearing of the Word of God, and witnessing a congregation uniting in prayer and adoration. It is by teaching a slave the duties of religion that he will learn his duty towards his master, and acquire a proper respect for his own character. It is only, in short, by obliging slaves to go to church, that Sabbath-breaking, and all the demoralizing vices that accompany idleness can be prevented. The same proclamation in which these objects have been urged to the attention of the inhabitants also states that "Although due regard for religion and its institutions forms the chief ground-work of good conduct, yet we are not to reject the aid of other means to promote the advancement of morals, decency, and industry among the slave population of this island." Slaves, we must remember, are men, and are here to be governed, not less by rewards than by punishments. With this view the Governor and Council propose to revive the humane and judicious plan of Governor Patton, by allotting premiums and rewards to meritorious slaves. The Benevolent Society instituted by Governor Wilks did good work; it was well supported also by General Walker. One of the purposes of the society is relief for pecuniary distress; but the main object was to rescue from ignorance and vice the children of slaves, free blacks, and the poorer children of the community.

At this time the island may be looked upon as at the height of prosperity. Still the prosperity was, as I heard it called in a speech by Governor Grey Wilson some years back, a "fictitious inflation"; for the great increase in the circulation of money caused by Napoleon's residence made the islanders lavish and careless, and drew their attention away from the cultivation of the soil to more easy, but less certain, methods of earning a living.

The same thing is again seen at the present time. The soil is totally neglected owing to the high rate of wages paid by military authorities for services required in connexion with the prisoners of war from South Africa. This artificial prosperity is always short-lived, and the present generation seem to have lost the knowledge and value of the soil of their beautiful and productive island. In September I8I7 two successive and almost instantaneous shocks of earth- 
quake were felt, which lasted ten seconds. They were strong enough to set the church bell ringing. The rumbling sound which accompanied them was described as the noise which accompanies an extended blaze of fire. It awakened Napoleon Bonaparte, who at first thought H.M.S. Conqueror had blown up. The shock was also felt by those on board ship, but it occasioned no injury.

The 66th Regiment were here at this time, and at Turk's Cap a heavy sea swept away two of the officers. In ISI8 Barry O'Meara, surgeon to Napoleon, was dismissed by the Governor, and on his return home published his journal A Voice from St. Helena.

Pipes were laid down for the carriage of water to Longwood, and in the same year a quarrel arose between the Chinese natives of Macao and those of Canton, in the employ of the East India Company. Turtle is caught still near the shores of the island, but the number has fallen off considerably even in the last ten years. Those caught are of average size, but in 1819 one was caltught which weighed $800 \mathrm{lb}$. It made the staple dinner for the messes of two regiments for three days, and the shell afterwards formed the roof of a hut in which lived a soldier and his wife. The foundation of Longwood New House was laid for the occupation of Napoleon, who however died before it was finished. In I822 the lower wharf was greatly enlarged and improved, and the foundation-stone of the head school was laid. At this time the island was most valuable for purposes of trade with India, as it made a halfway house for the shipping.

The next Governor was Brigadier-General Walker, a distinguished Indian officer. He brought with him all the methods which had produced such a good result in the Bombay Presidency; and his efforts to improve the slaves morally and religiously, as well as the agricultural fairs, plougling matches, etc., which he instituted, made the inhabitants once more rely on the produce of the soil, and did much to prevent poverty being felt for lack of work and of money, caused by the death of Napoleon and by the withdrawal of his suitc.

In 1828 the building of the military parade was commenced, and Mr. Brooke again took the reins of Government until Brigadier-General Dallas arrived. He was an officer of 
very high merit, and having a good executive Council, he carried through works of improvement which could not otherwise have been done. An observatory was built at Ladder Hill, the site of the present officers' mess, and furnished with instruments at a great expense; but when the island was transferred to the Crown the instruments were taken to Canada. The inclined plane from Jamestown to Ladder Hill was built. Governor Dallas was fully alive to the great cost and labour of conveying goods and produce from town to country, or from country to town; he therefore, to lessen the expense of conveying manure up, and of bringing produce down, caused this plane to be erected. It was carried out under the personal supervision of Lieut. G. W. Mellis, an artillery officer, and consisted of a ladder 900 feet in length with about 700 steps, placed against the face of the cliffs between Jamestown and Ladder Hill, at an angle of $39^{\circ}$ or $40^{\circ}$. On either side was a tramway, upon which wagons (worked by machinery and ropes at the top) travelled up and down. This train service of St. Helena was only for the conveyance of goods, but in these days of engineering power it could have been made also to carry passengers.

Many years since it had fallen into disuse and bad repair, and was ultimately demolished in the days of adversity which came on the island. This is greatly to be regretted, for during the late South African war it would have been of inestimable value. A railway there to convey stores up a perpendicular height of 600 feet, a storage depôt at the summit, on the direct way to Broadbottom Camp, would have saved much money, labour and health ; for the cost of transport here for the past three years has been very great, as also has been the strain on the transport officers. A similar railway might have been easily constructed also from Rupert's Valley direct to Deadwood Camp, but nothing in the way of improvement in traffic or roads has been done, although several thousand men were here, eager to labour, and so to relieve the monotony of camp life. The roads in use are inconvenient, and the incline much greater than would be the case if the roads were replanned by modern engineers.

In 1829 we read that the mina bird, much in estimation 
as a destroyer of insects, made its appearance. These must have died out many years since, as there were none when Miss Moss a few years ago let some free to propagate; these seem to be increasing and fourishing. It was hoped that these minas would have caused the destruction of white ants, but unfortunately these pests increased on the island to such an extent that many houses became unsafe, and at last Government made ordinances compelling the owners to cut down and burn any trees containing white ants. This was a check, and the substitution of teak and other hard woods for the soft wood which is so quickly devoured by these termites, together with the use of iron wherever it could be used in building, has considerably lessened their numbers.

To Governor Dallas was due the building of barracks in the town for the infantry. He also sank a well to the depth of eighty-three feet in Rupert's Valley, and obtained a strong spring of water which was most useful in fertilizing that part of the island. In I90I another well was sunk in Rupert's Valley by Mr. H. Miller, constructing engineer of the condensing works erected by the Imperial Government, for the purpose of supplying the troops and prisoners of war camped at Deadwood.

During the Government of General Dallas the Government schooner St. Helena left the island March 3, and on April 6 she was captured by a pirate felucca Despedago. Captain Harrison and Doctor Waddell, with eleven of the crew, were murdered, but the pirate was afterwards caught on the coast of Africa.

In 1831 the theatre in Jamestown was destroyed by fire, and at this time fire-plugs were laid throughout the town.

Now occurred the liberal act of the East India Company in the abolition of slavery in the island. The valuation of the 6r 4 slaves in St. Helena was computed at over $\{28,000$, and their freedom was the end of slavery except for the liberated $A$ fricans, who a little later were brought here from the slavers captured by British cruisers, an account of which is given later. Advertisements of this kind were frequent.

St. Helena Monthly Register.

At the same time will be let for five years two women servants, two girls, and a good fisherman. 


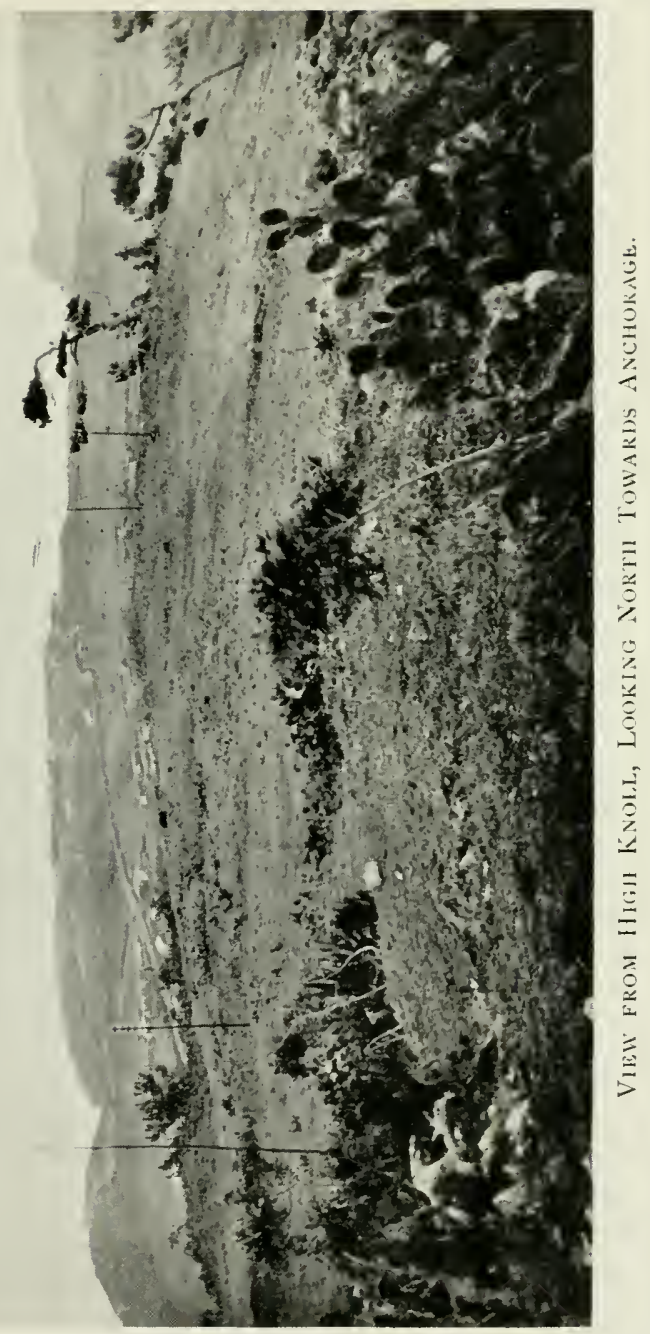



Also will be sold at the said house a slave boy, aged nine years, and a slave girl, aged seven years, with a few articles of furniture.

Every effort was made by the East India Company to advance the welfare and prosperity of the little island, and this will be seen when it is stated that the annual expenditure in the island by the Company was between eighty and ninety thousand pounds. They kept the St. Helena Regiment 700 strong (four companies), and the St. Helena Artillery (three batteries), besides a strong force of militia. The island was a flourishing and peaceful colony when, as Mellis states, a heavy blow fell on them, a blow from which the colony has never recovered. In 1833 the islanders received the unexpected and unwelcome news that, by act of Parliament dated August 20, the East India Company's rule would end on the following April 22, I834. In this short time the Government was broken up and the garrison disbanded, some taking service with the new Government, others receiving pensions, and it is said that many who had been living in comfort were reduced to bitter straits. In fact, so much poverty ensued that many of the Company's servants, who had been in the first rank, were to be seen tilling the ground side by side with their own negro servant in order that they might support their families. Remonstrances against the inadequacy of the pensions granted by Government, and petitions to the East India Company for grants to their discarded officers, who had served them for so long, were disregarded for nine years, and then the repeated appeals to their humanity wrung from them the trifling grant of $\$ 740$ annually among thirty-three of their servants. By their arrangement of this pittance their army captains who had served twenty-three years received rod. per day, or $\AA^{5} 5$ 6s. per annum; subalterns of nineteen years standing $\delta$ I 3 Igs. per annum, and the rest were paid in the same ratio. Nor was this the full extent of the injustice done for the unfortunate St. Helena establishment. They had been compulsorily removed from situations which they had been led to believe would be permanent, and would form a provision for life, and then found themselves undeservedly deprived of all employment, without which they were unable to support and educate their families, whilst all their appeals to the East India Company ended in their 
being referred to the British Government, who replied to their requests for employment :- "We must employ our own servants first, and we have only sufficient employment for them." The East India Company saved annually $£ 90,000$ by relinquishing the island, and yet most ungenerously made no arrangement with the British Government for the provision of their civil and military servants. Major Middlemore arrived on February $24,1 S_{3} 6$, and took possession of the island for William IV. The first reginent sent was His Majesty's gist.

$£ 9,000$ per year had been the East India Company's pay for the Governor here, but this was all cut down to about $£ 2,000$. On this it was impossible to keep up such an establishment as had been and should be kept with such a beautiful residence and grounds. Reduction was made in salaries of all Government officials. Not only the officials, but the labouring classes quickly felt the difference, and emigration took place. Many families and about i Io other persons, consisting chiefly of lads who hired themselves for a period of from five to seven years to agriculturists at the Cape of Good Hope, left the island.

During this year, when His Majesty King William's Government took charge of the island from the East India Company, 648 vessels called, and during the first six months of the year $1 S_{45}$, ending June 30 , the crews and passengers of no fewer than 890 vessels of all nations sought and obtained refreshment, recreation and health amidst the perfect scenery, and in the beautiful climate of this island. Yet so happily is the island situated, that during the whole of the above period of nearly nine years, during which of course many thousand vessels visited the roadstead, not one catastroplie occurred.

In I 838 a grandson of the King, Prince William Henry Frederick of Holland, visited the island.

The supreme Court was established by Her Majesty Queen Victoria's order in Council on February 13,1837 , and by law slavery was for ever abolished within this colony in I 339 .

Cotton and coffee were amongst the objects of culture at this time. This is shown by the following interesting reports :- 
The St. Helena coffee has descended from the true Mocha stock imported by the East India Company, is of excellent quality, and the trees bear wonderfully well considering that they are never manured. The dry seasons seem to be favourable to them, for the crops are then exceptionally heavy : it is said that a small patch of coffee in Plantation ground, containing about 286 bushes, yielded about $428 \mathrm{lb}$. of dried coffee, an average of about $1 \frac{1}{2} \mathrm{lb}$. per bush, but in Sandy Bay the yicld of coffee per bush is nearly double. Our late Governor, His Excellency R. A. Sterndale, is of opinion, confirmed by a practical tea-grower from Assam, that tea could also be grown to a limited extent for home consumption.

Coffee is grown in small patches, and its cultivation is capable of great improvement. Mr. Melliss states that some of the islandgrown coffee took the first prize for best quality at the Exhibition of 1851. Dr. Morris reports in 1883: "At Plantation House, Terrace Knoll, Bambu Grove, Elliott's Prospect and Oaklands I saw very fine patches of coffee, somewhat neglected, it is true, but indicating the capabilities of the island to grow in sheltered hollows a fair quantity of very good coffee."

One pound of St. Helena cotton in the bole contains five ounces of lint cotton and eleven ounces of seed. Thirty-five pounds of lint to the hundredweight, or one ton of $2,240 \mathrm{lb}$. of cotton out of the field, will make a bale of $700 \mathrm{lb}$., valued at $£_{\mathrm{I}}$ I I $3 s .4 d$. more or less. This is not including $1,540 \mathrm{lb}$. of seed. One hundred pounds seed gives two gallons of oil, $48 \mathrm{lb}$. of oil-cake, $6 \mathrm{lb}$. of fatty oil, for soapmaking, while the residue is a first-class manure ; and yet this cotton tree is wholly neglected and the pods burst year after year, discharging their precious cargo in vain.

The following letters show the opinion of experts of coffee and cotton :-

To Messrs. Wm. Burnie \& Co., London. From St. Helena. GentLemen,- -

We have submitted the sample of coffee received by you from St. Helena to the Trade, who have tested it, and pronounced it to be of a very superior quality and flavour, and if cultivated to any extent would no doubt amply repay the grower. In the present state of the market the value would be from I $25 /-$ to $130 /-$ per cwt., and under any circumstances we consider that it would realize from $100 /-$ to $110 /-$ per cwt. There is but one objection, and that, of a very trivial nature, viz. that it is not sufficiently cleaned from the thin silvery skin; if your friends will pay a little more attention to this point, it would enhance the value here $5 /-$ to $10 /-$ per cwt., and ultimately prove a very valuable and secure source of income to them.

We are, gentlemen,

Your most obedient servants,

BURROW AND KeRKMAN.

London, MAY 16, I839. 
Reports on cotton samples received from Messrs. Burnie and Co. :-

\section{St. Helena Collon.}

The first quality cleaned. The fibre or staple has been injured or broken in the process of cleaning, and the value is thereby lessened; it is now worth about $9 d$. per lb.

The second quality partially cleaned. It appears to be of the same description with the fibre more perfect, and, although inferior in colour, with more dirt: the value is now $10 d$. to $11 d$. per Ib.

The two samples rough from the tree. It will be quite useless to send it in this state. The sale would be very uncertain and the value not more than $7 /-1010 /-$ per cwt. The growth of this is decidedly superior, and I am of opinion that, with attention in the process of cleaning to preserve the staple it will take a rank above the best Brazilian growth, and nearly, if not quite, equal the best Egyptian. I would recommend a lew bags to be sent over as speedily as possible, in order that a fair trial may be made by our manufacturers.

LONdON, OCTOBER 30, 1839 .

$$
\begin{aligned}
& \text { Signed, David Richards, } \\
& \text { Cotton Broker. }
\end{aligned}
$$

In I8ło commenced a scason of excitement, Africans from the west coast of Africa, captured in slave vessels by Her Majesty's cruisers were brought here and cared for until able to work. This led to the establishment of a ViceAdmiralty Court for the trial of vessels engaged in the slave trade on the W'est coast of Africa. Constantly the cruisers were bringing their freight of human misery; and so much of interest is to be found with regard to the British Navy and their successes in these waters that it has been thought best to devote a chapter to it.

It is said that the white ant was brought here in some of these slave vessels, and Melliss says (what is the opinion of all who have noted the destruction of property and the consequent ruin of many island families) :-

The St. Helenians naturally feel the strong claim they have upon Great Britain ; their island home having aided so much in building up her (i.e. Great Britain's) commercial greatness and prosperity, but apart from this, they very reasonably expect aid from England, because it was through her successful efforts to suppress the slave trade on the W'est Coast, that the white ants have added so greatly to the impoverishment of the place.

On October I 8 fo His Royal Highness Prince de Joinville and suite arrived in the frigate La Bille Foulc, accon- 
panied by the corvette Favourita in order to convey to France the remains of the late Napoleon Bonaparte. The exhumation of the body from Tomb Vale took place on October I5, and on the same day it was with military honours placed on the frigate which remained at anchor until Sunday the I8th, when she sailed for France. (Further account under heading of Napoleon.)

In this year a magnetic observatory was erected at Longwood, the windward side of the island, $I, 760$ feet above the level of the sea, for the purpose of taking meteorological observations. Those observations were continued for five years by officers and non-commissioned officers of the Royal Artiliery specially selected for the purpose. The report issued from the observatory says :-

The mean temperature derived from the five years of observation is 614 . A maximum is obtained about the middle of March, and a minimum early in September. The progression from maximum to minimum and from minimum to maximum is continuous.

The mean is passed through, at nearly equal intervals, viz. early in June and about the middle of December. The mean height of the thermometer in the different months, ranged from $57^{\circ} 07$ in September to 66.24 in March, being a difference on the average of only 9.17 between the hottest and coldest months. The extreme range in the five years was:-

Highest $77^{\circ} 6$, March 3 rd, I $84^{2}$; lowest, $5^{\circ} 0$, September 5 th, 1845 . By simultaneous hourly observations on 2nd May, I841, at the Observatory and at level of the sea with thermometer freely exposed to the air, but protected as far as possible from disturbing influences, the temperature was found to be 7.07 higher at the sea-side. Both stations are on the windward side of the island. The observatory was at an elevation of 1,765 feet and two and a half miles from the sea on a nearly level and naked plain. The greatest temperature at Longwood is less than Jamestown on the average of the year by 9.125 .

The barometric pressure from the five years' observation has a minimum in the beginning of March, and a maximum towards the end of July, and between these periods the progression is continuous and uninterrupted.

The mean pressure in the five years was 28.285 inches; lowest in March, 28.232; July highest, 28.367.

The greatest depression on March $14^{\text {th }}, 1843$, was 28.097 , and the greatest elevation gth July, 1842 , was 28.497 .

In 1842 Governor Middlemore was succeeded by Colonel H. Trelawney and five companies, raised in England 
especially for this island under the title of the St. Helena regiment, arrived to replace the line regiments.

In I $8+3$ measles again broke out, causing much mortality. At this time a new steeple wats built for St. Janses' Cluurch, which was also considerably altered and repaired; the market was established in the centre of the town, where it now stands; and the Court of Commissioners was established by writ of the Privy Council for the trial of offences on the high seas. The notice of this court was given as follows :-

To wit.

\section{Island Saint Helena.}

These are in her Majesty's name to notify to the inhabitants of the said island that a sessions of the Court of Commissioners appointed ly I.etters Patent under the Great Seal, bearing date the 2.4 th day of October in the seventh year of her Majesty Queen Victoria, for the trial within the Colony of offences committed on the high seas, and other parts in the said letters patent mentioned, will be holden, and kept at the Sessions Hall of the Supreme Court in Janestown, on Wednesday, the $24^{t h}$ day of this present month of June, by nine $0^{\prime}$ clock in the forennon of the said day. All per. sons therefore within the said island who are bound over to prosecule any prisoner or prisoners within the gaols of the said island and all persons bound over there to appear and answer, are herelyy reguired to be present at the time and place aforesaid.

All paid, special, or petit jurymen summoned to inquire on $\mathrm{Her}$ Majesty's behalf and all gaolers, constables and bailiffs are 10 be then and there personally present to do such matters and things as shall then and there be given them in charge.

Hercof fail not.

Given under my hand and seal this sixth day of June in the year of our Lord one thousand eight hundred and forty-six.

(Signed) W. T. Jurlo,

Juno 18.46 .

Provost Marshal.

In 1845 a loss of life occurred from a rock which has since been called Emily's jump, a precipice overlooking the lower part of the town. The St. Helena Gazcttc of September 20 says :-

On Tuesday, 16th inst., Mr. T. B. Kinipe held an inquest in the Moon Tatern, Jamestown, upon the body of James Emily, who had fractured his skull by throwing himsell over a precipice on the side of Ladder Hill, that morning about six o'clock. The deccased was for many years a private soldier in H.MI. orst Regiment, and was discharged at his own request with a good character and a 
gratuity. For the last six years he has been employed as a master blacksmith, under the orders of the commanding engineer, and was always considered a sober steady man. On the morning of his death he absented himself from work, and was seen walking from H. T. Hollow towards town with a man named Henry Leo. Policeman William Smith and Private Hardy of the St. Helena Regiment, who were at the upper part of Jamestown, saw the deceased climb over the wall, walk deliberately to the edge of the precipice in the highest part, and throw himself head foremost, a height of more than 30 feet. His body was with difficulty removed, and his remains were interred between nine and ten o'clock that night in the Upper Churchyard, Jamestown, without the rites of Christian burial.

And now occurred the memorable rollers which caused so much damage to the wharf and glacis, and destroyed no less than fourteen ships in six hours, an account of which will be found on page 250 .

In May Colonel Trelawney died, and was succeeded by Colonel George Brodie Fraser, R.A., the senior officer commanding the troops, but shortly afterwards Colonel John Ross came to take command of the St. Helena Regiment, and as he was senior in the army he took the reins of Government until November, when the newly-appointed Governor Sir Patrick Ross arrived.

The fine building of the present Civil Hospital was begun in 1847 , chiefly for the use of the merchant service. Many poor stricken sailors owe their lives to this hospital, which of late years, under the direction of Governor Gray Wilson, was enlarged and fitted with many conveniences for the comfort of the patients. In the Jubilee year of Queen Victoria it was supplied with an ambulance stretcher, which added greatly to the comfort of the patients, who were formerly conveyed to the hospital in a chair carried by two men. At every step the poor sufferer must in many cases have endured great pain. (It was a sight which attracted my attention just after I landed here, and has never left my memory.)

The arrival of the Governor was announced in the St. Helena Gazette of November 22 as under :-

His Excellency Major-General Sir Patrick Ross, Q.C.M.G. and K.C.B., arrived on Sunday morning last at ten o'clock, in the ship Boyne from the Cape of Good Hope. He landed at one o'clock p.m. under a salute of seventeen guns from Ladder Hill. Lieut.-Colonel Ross, the senior officer in command of troops, and administering 
the Government for the time being, with his Aide-de-Camp and Town Major went on board the Boyne to wait on his Excellency. On his Excellency landing he was received by a guard of honour consisting of 100 rank and file of the St. Helena regiment, under the command of Capt. Ieating, which was drawn up on the landing place. His Excellency with his family, after a short stay at the Castle, went direct to Plantation House, the official residence of the Governor. The following day he was sworn in, and his commission rear in the town Square adjoining the Castle, the St. Helena Regiment under the command of Capt. Woollard forming three sides of a syuare, the fourth composed of civil and military officcrs of the colony (not under arms), and a numerous body of the inhabitants of the island; after which his Excellency retired to the reception rooms at the Castle, where he received the cilil authorities, the militar, and such of the respectable inliabitants as presentecl themselves. Sir Patrick tonk great interest in island affuirs, and agriculture was encouraged by the holding of agricultural and horticultural exhibitions. One of the reports says :-

"Pize for labnurers' neat collaces. - We do not think anv of the four canclidates reach the standard which would justify a recommendation to the high reward offered.

"Mr. Chas. Smith's cottage would come ne.trest the mark if it belonged to a labouring man. Richards deserves much praise for making a profitable garden-well worth secing among the heaps of rocks.

"Peggy" Bagley's coltage indicates in the interior habits of neatness fitly characterizing a good old domestic servant.

"On the whole, Benjamin of lFisher's Valley seems to us to direct his labour in a manner best calculated to combine eventually the requisites of a neat cottage, and, without recommending the Socicty's handsome reward, we think a gratuity of \& would be well deserved, with a view to stimulate his further exertions.

"Signed, Richard Kemptiorse,
"Tilos. C. LUXMOKE."

Governor Ross also caused to be constructed the road from the lower waterfall up over Cat's Hole, around Peak Hill to Francis Plain. This road was made by liberated Africans and prisoners under the direction of Major Barnes, whose name the road still bears. The St. Helena militia were in $18+7$ presented with new colours. The ground selected for the occasion was Francis Plain, the headquarters of the corps. On the arrival of the new colours in front of the regiment, two ficld picces were placed muzzle to muzzle and the colours laid on them, a temporary altar of drums being placed near. Immediately after the consecration by R. M. Kempthorne, M.A., Colonial chaplain, 


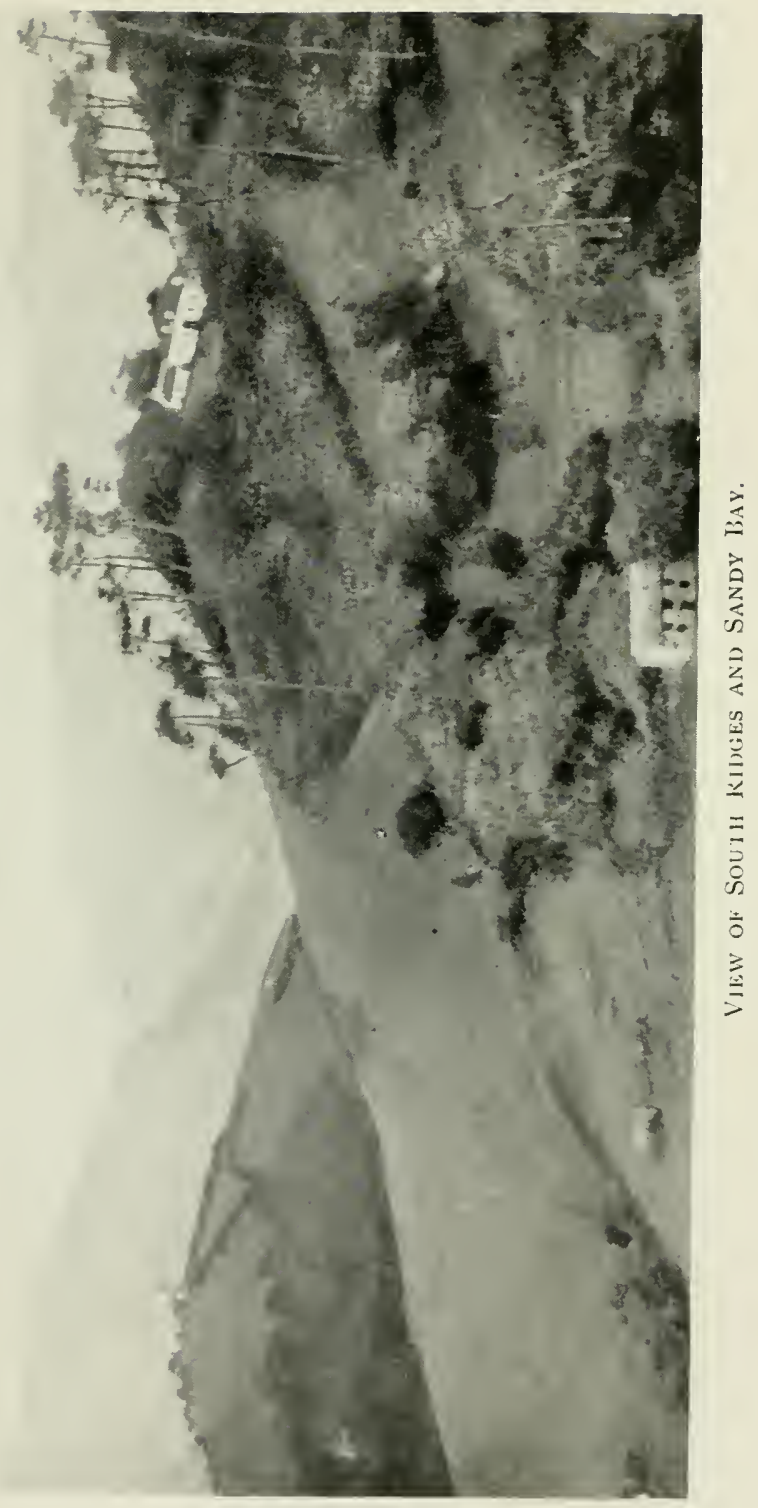



they were handed by Captains H. Doveton and Kennedy to Miss Ross, who handed them to the ensigns elected to receive them. She made a short speech on delivering them, and they were then trooped down the front of the line attended by the guard, who took their appointed stations, when the old colours were conducted to the messhouse. The governor commented upon the absence of Lieut.-Colonel Lambe, who was suffering from severe indisposition, and stated that, as the memory of the late Sir William Doveton, under whose command the St. Helena militia served for many years, was held dear, not only by the regiment but by all classes of island people, he had directed that the old colours, under which the corps had so often meritoriously and so gallantly conducted themselves, at the time when the security of the island was seriously threatened, should be placed over the monument of that patriotic individual, as a memorial of the esteem of his countrymen.

Distressing accounts of the destitution in Ireland and in the Highlands of Scotland came to the island, and we find that the non-commissioned officers and men of the St. Helena regiment nobly came forward with a day's pay each (which a soldier can ill afford in this colony) for the relief of their destitute countrymen. This offering, with the contributions of the officers, made the sum of $£ 40$, which was forwarded to London for the sufferers, and the receipt of it was acknowledged with warm and sincere thanks. At this time the Chinese barracks in Plantation grounds were pulled down, but the cut blue stone and other valuable relics were preserved. These are now in the museum.

The foundation-stone of the present country church was laid on February 6, I850, by Major-General Sir Patrick Ross, and in $185 \mathrm{I}$ a printing company was formed. Up to this time all writing had been under the control of the Government, and this was the first free press imported from England for use in the island.

In August a fire broke out on the premises of Mr. Gigney, but, under the indefatigable labours of Mr. Gigney himself, together with Town-Major Barnes and troops, it was extinguished. 
Dissent was introduced in 18.7 by a Scotch Baptist minister and soon spread, being popular amongst the native population.

In December, 1847 , St. Helena was included in the See of Cape Town. The Letters Patent stated :-

We do by these our Letters Patent, under the great seal of our United Kingdom of Great Britain and Ireland crect, found, make, ordain, and constitute our said Colony or settlement of the Cape of Good Hope, with its dependencies, and our said Island of St. Helena to be a Bishop's Sec and Diocese, and do fairly hereby declare and ordain that the same shall be called the Bishoprio of Cape Town. And we, having confidence in the leading moral probity and prudence of our well-beloved Robert Gray, Doctor in Divinity, do name and appoint him to be ordained and consecrated Bishop of the said See.

As the Bishop did not reside on the island, an ordinance was passed to determine the authority of the Governor of St. Helena to grant marriage licences.

On the death, in August, I850, of Sir Patrick Ross, Colonel Clark, offreer commanding Royal Artillery, acted as Governor until the arrival of Colonel (now Sir Thomas) Gore Browne, C.B. He only remained three years, for he was promoted to the Governorship of New Zealand. He worked hard at St. Helena making changes in the civil establishments to reduce expenditure. This policy has been carried on from that time to the present day, much to the detriment of the island.

He built a gaol in Rupert's Valley, and tried to form a village there, to do away with overcrowding in Jamestown. A new road was cut to Rupert's, and water was carried to the valley in iron pipes from over the Briars.

Colonel Vigors took office on the departure of Governor Gore Browne and family, and during his régime interments were prohibited within the limits of Jamestown.

Sir Edward Drummond Hay arrived on October Io, I 856 . In the same year a flour mill was imported by Government, and extensive alterations were begun at the Batteries and Lines, Jamestown. The foundations were dug out for St. John's Church, and in 1857 the corner-stone was laid by Lady Drummond Hay, wife of the Governor. This church was built mainly by the untiring devotion and exertions of Lady Ross (widow of the late Governor, 
Sir Patrick) together with many other ladies of the island.

A new Custom House was also erected on the Lower Parade, and works commenced for the better drainage of the town.

In 1858, by ordinance of his Excellency Sir Edward Drummond Hay, Governor in Council of date March I8, ratified and confirmed by order of the Queen in Council, on May 7 thereafter, the lands in this island forming the site of the tomb of His Majesty Napoleon, the first late Emperor of the French, and also the land forming the site of the tenement of Longwood and its appurtenances, formerly the residence of the late said Emperor, are vested in His Majesty Napoleon III., the then Emperor of the French, and his heirs for ever, as absolute owners thereof in fee simple.

The first Bishop of St. Helena was appointed in 1860 to be resident on the island (the diocese to include the neighbouring island of Ascension, the British residents at Rio and other similar places situated on the coast of South America). Bishop Piers Claughton was an energetic man, devoted to his work; he mapped out the island into various parishes, and by degrees got a church in each parish. His influence was a thoroughly good one, and he did much to raise the moral tone of the islanders, who regretted deeply his transfer to the See of Colombo.

Sir Edward Drummond Hay built dwellings for the poor in Jamestown, which still retain the name of Drummond Hay Square. He also gave much attention to the improvement of the militia.

St. Matthew's church was built, and in September I860 H.R.H. Prince Alfred, first Duke of Edinburgh, and afterwards Duke of Saxe-Coburg and Gotha arrived. He was then an officer serving in the Royal Navy, on board H.M.S. Euryalus. His visit of course threw the island into a fever of excitement. Triumphal arches, etc., lined the wharf and streets, and, all preparations completed, they awaited the Prince; but the ship not arriving the day expected, the vexation of the people was great. However, after three days' suspense the Prince landed, and the people of St. Helena were able to render a hearty welcome, and to give vent to their excitement. 
The Prince honoured the Governor by dining at Plantation. He attended a ball at the Castle, and sailed again on the evening of the same day he arrived.

In I 862 St. John's Church was opened on January 24, and St. Matthew's at Hutt's Gate on February 24.

Governor Drummond Hay was succeeded by Admiral Sir Charles Elliott on July 3, 1863. He administered the Government for seven years, and continually endeavoured to advance the welfare of the island. He had to contend with many difficulties, especially with the diminishing revenue. White ants at this time again gave great trouble, and he was indefatigable in his warfare against them. Many of the government buildings were repaired or rebuilt with stone, iron and teak. The water-works were not neglected, but were augmented largely to supply the necessary quantity of water in case of fire or for shipping.

A great number of Mexican pines, Norfolk pines and Bermuda cedars were reared, and Dr. Hooker, the Director of the Royal Gardens at Kew, when commenting on the possibilities of the island, advised the culture of cinchona plants on the mountainous parts of the island. The Governor agreed with his plan, and a skilled gardener, J. H. Chalmers, was sent out from Kew, and cinchona planting rapidly progressed. At the end of the year I 869 there were 10,000 cinchona plants raised from seed and cuttings in all stages of growth, of which 545 were in the plantations, vigorous and in good health, approaching three feet in height. These promised a great source of profit, but Sir Charles being recalled, was succeeded in I8 70 by $\mathrm{Ad}$ miral Patey, who seemed unable to see the advantage of the undertaking, and the plantation was neglected, and afterwards totally abandoned. The following report on the cinchona planting by J. H. Chalmers fully explains the work :-

RePort oN the Experianent of EstablishiNg the CinchoNa Plast IN St. Helesa,

From ith July, 1868, 10 i 7 th December, 1869.

J. H. Chaldiers,

Superintendent of the Cinchona Plantation and Public Nursery. On the 7 th July, 1868, after the erection of a small propagating 
house and certain other preliminary arrangements, I entered upon the duties of this experiment by sowing a quantity of cinchona seed of the two species succirubra and officinalis. In the course of fourteen days these seeds began to germinate, and by the middle of August many had attained a size to admit of handling. I then pricked out the small plants into boxes of about four inches deep, and conveniently large size, placing them, with the young plants in them, in the propagating house, where they remained until large enough for removal to the open-air nursery at the Peak. By December we had increased our stock of seedlings to something over 2,000 plants, the greater number exceedingly healthy and from three to six inches in height. This number completely filled the house, and many required to be moved on account of having too little space to grow in, so it became necessary to select a site for a nursery, and for a plantation somewhere on high land. A spot near Newfoundland Cottage was fixed on, as combining the greatest number of requisite points in respect to the object for which it was chosen. It has almost the greatest altitude of any part, has a southern aspect, is well sheltered, is rich in native vegetation, having good soil. A road from the low lands runs along one side and there is a cottage for a resident workman. This spot is a portion of the south face of "Acteon," which is in the centre and highest part and fortunately also is central in relation to the localities likely to be found available for the cultivation of the cinchona plant. It rises to a height of 2,700 feet above the level of the sea, and is one of the dampest regions to be met with here. The character of the ground is for the most part precipitous and rocky. The soil, consisting chiefly of rich black peat or vegetable mould, rests upon a bed of reddish soft volcanic rock, in some places of considerable thickness, in others shallow, varying according to the inclination of the ground. The indigenous vegetation with which it is clothed is composed principally of what are here popularly called cabbagetrees (Solidago sp. and Melanodendron integrifolium), "dog wood" (Hedyotis arborca); tree ferns (Dicksonia aborescens), and several species of smaller ferns, grasses, etc. These cabbage-trees constitute the native bush and seldom exceed 25 to 30 feet; the average height is about 18 or 20 feet.

The following gives temperature of air as deduced from a register of the thermometer kept at Newfoundland Cottage, altitude 2,400 feet, during the months of August, September, October, and November of I 869 .

August.

September.

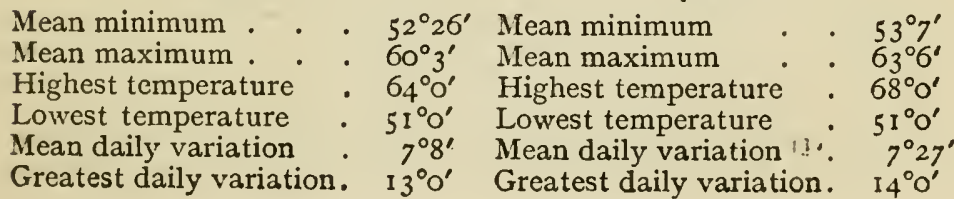


October

Mean minimum Mean maximum . Highest temperature Lowest temperature Mean daily variation Greatest daily variation.

$51^{\circ} 20^{\prime}$
$61^{\circ} 24^{\prime}$
$67^{\circ} 0^{\prime}$
$51^{\circ} 0^{\prime}$
$8^{\circ} 3^{\prime}$
$14^{\circ} 0^{\prime}$

\begin{tabular}{|c|c|}
\hline November. & \\
\hline Mean minimum & \\
\hline Mean maximum & \\
\hline Highest temperature & \\
\hline Lowest temperature & \\
\hline $\begin{array}{l}\text { Mean daily variation } \\
\text { Greatest daily variation }\end{array}$ & \\
\hline Greatest daily variation & \\
\hline
\end{tabular}

Seedlings to the number of 1,500 were removed from the propagating house at Plantation and placed under a temporary shading of fern leaves at Newfoundland, where they stood till beds were ready. The beds were formed on terraces on the hill-side at about 250 feet below the summit, the soil here being a light vegetable mould of a reddish colour. The plants were then carefully set out in the beds in rows six inches apart. No shading was at first given; but when severe drought set in and they appeared to be suffering from the power of the sun, I had trec-fern fronds stuck in all over the beds to shield them. The drought still continued, so I removed them to other nursery beds which we had prepared at the top of the Peak : in this case more under the shade of the forest, and in a damper, cooler situation. I did not however remove all; thereby I had an opportunity for testing the fitness of the two localities. The plants were treated in precisely the sarne manner in both cases, with this result: Of those shifted to the new situation, not more than five or six per cent. died, whereas of those remaining in the lower ground more than half perished. So we abandoned the lower and confined ourselves entirely to the Peak, where we succeeded without difficulty. After establishing these nurseries and making walks through the forest to facilitate future operations we proceeded to prepare ground for permanent planting. It was found that shelter and shade are both highly essential to the success of cinchona in the earlier stages of their growth; and as it seems there is no better way of securing these than by allowing a portion of the native forest trees to stand, I made it a point in preparing for planting never to destroy more of the indigenous vegetation than is necessary in order to give room to the young plants. By this system the ground is shaded and retains more moisture than if laid open to the sun by clearing away the forests, and the young cinchonas are in a comparatively cool and damp atmosphere. From this, do not infer that the plants are under dense foliage, or in the drip of high trees, for in the one case we find they become very delicate and slender, and in the other dic away altogether. Independently of shading, I find it necessary to have them shaded with trec-fern leaves. This serves to keep the earth and air cool, and consequently to prevent evaporation. Preparing the ground for the reception of the plants is a simple and casy operation. The ground is very soft and loose, and a spade may be forced down by mere hand-pressurc. Pits ot about three fect in diameter and from eighteen inches to three fect decp, are prepared at distances of from six to nine fect apart, varying on account of forest-trees, ctc. This was done during the dry season 
namely the period between the end of September and the beginning of April; though in the neighbourhood of the Peak the term dry cannot be applied in any season. The only real difference between dry and wet seasons is simply that the one is characterized by lighter rains and higher temperature, the other by heavy rains and a somewhat low temperature. A whole fortnight of really dry weather is quite an unusual occurrence at any season. From the beginning of April to the end of September is the period most favourable to transplanting.

The planting out of our young cinchona-trees was commenced on May I 869, and continued to the end of September. Total number set out was 540 plants. The failures in this lot have not exceeded 5 or 6 per cent. and the greater portion of them are in a very promising condition at the present time. The tallest plant (a $C$. succirubra) measured twenty inches, the average being fifteen inohes. Since September their growth has been rapid and is every day increasing. The following shows the total number and condition of the cinchona plants at Newfoundland on 9 th December :-

C. succirubra planted out . . . . . 506

Do. in nursery beds . . . . . I,IO9

Do. in boxes under glass . . . . 2,035

Officinalis planted out . . . . . . $\quad 25$

Do. in nursery beds . . . . 575

Do. in boxes under glass. . . . I,700

C. calisaya planted out . . . . . . . IO

Do. in nursery beds . . . . 12

C. pahudiana planted out . . . . . . . IO

Do. $\quad$ in nursery beds . . 44

Seedlings of officinalis and succumbra in boxes under glass

Total

- 4,000

10,026

In consequence of having so little labour at my disposal, I have not increased the stock of plants beyond that which we can manure, but should it be found advisable to do so there will be no difficulty in raising plants. The different seeds of cinchona supplied so generously by Dr. Hooker generally germinate freely; so while these are to be had there does not appear the necessity for propagating by cuttings. The latter mode of propagation might, however, be resorted to if circumstances recommended it, and it may be noted as an interesting fact that several cuttings of a $C$. officinalis taken off the parent plant and stuck into the earth in the open air without any protection whatever have emitted roots and are growing freely. Since erecting the first propagating house at Plantation I have erected another something like a cucumber-frame. Should it answer, we shall be able to carry on the whole work of culture at the Peak, and the house at Plantation will be devoted to the rearing of new and useful plants for the colony.

Having so far summed up the course of our proceedings, it remains to be seen what prospects of success there are in the undertaking. 
It might seem premature to offer an opinion in respect to this, at so short a time from the commencement of the experiment, but considering the progress the plants have made, the extraordinarily long period of drought to which they were subjected during the very earliest stages of their growth, and perhaps, too, at times not the most favourable treatment resulting from inexperience on my part, I can express myself well satisfied with their present promising state. In comparing the growth of our plants with those of the same age raised in India and elsewhere, it ought to be remembered that owing to the limited extent of our propagating department it is necessary for us to remove them to the open air at a very early stage, and consequently they do not acquire solarge proportions in the first year as plants kept six months or so under glass. As an evidence of this, I planted on the 6th March in prepared soil, in the bed of the propagating house at Plantation, one cinchona plant of each of the four species in cultivation here for the purpose of watching their development under glass. I measured them on the thirteenth of this monih and found that the larger(sp. C. succumbra) had reached a height of 4 feet 6 inches, with a circumference of 4 inches round the stem. The next in size (a C. pahudiana) is 4 feet 5 inches with a stem of 3 inches in circumference, and C. calisaya is 2 feet 10 inches and very healthy. The other plant (C. officinalis) was cut down a few day's ago, and measured 4 feet 8 inches, but was not so robust and healthy as the other trees.

J. H. Chalmers,

Supt. of Cinchona Plantation and Public Nursery.

A great reduction in the Civil Government took place on Admiral Patey's arrival. It was represented that the Civil establishment was larger than necessary, and retrenchment was the order of the day; so, when Patey had been here two years, the Home Government recalled him, and considerably reduced the salary, appointing the then Colonial Secretary, Hudson Ralph Janisch, Esq., as Governor of the island.

In I87 I there occurred a terrible flood, chiefly from the sides of Ladder Hill and Rupert's Hill, causing great damage to the houses situated at the base on either side. About roo persons emigrated to the Cape of Good Hope, owing to the great distress of trade here, and a Commission was appointed to inquire into the causes of the financial depression. The chief causes assigned were the reduction of the naval and military establishments, for H.M. ships had made it their headquarters during the suppression of the slave trade, and thousands of pounds annually circulated. Another cause was the opening of the Suez Canal. Living 


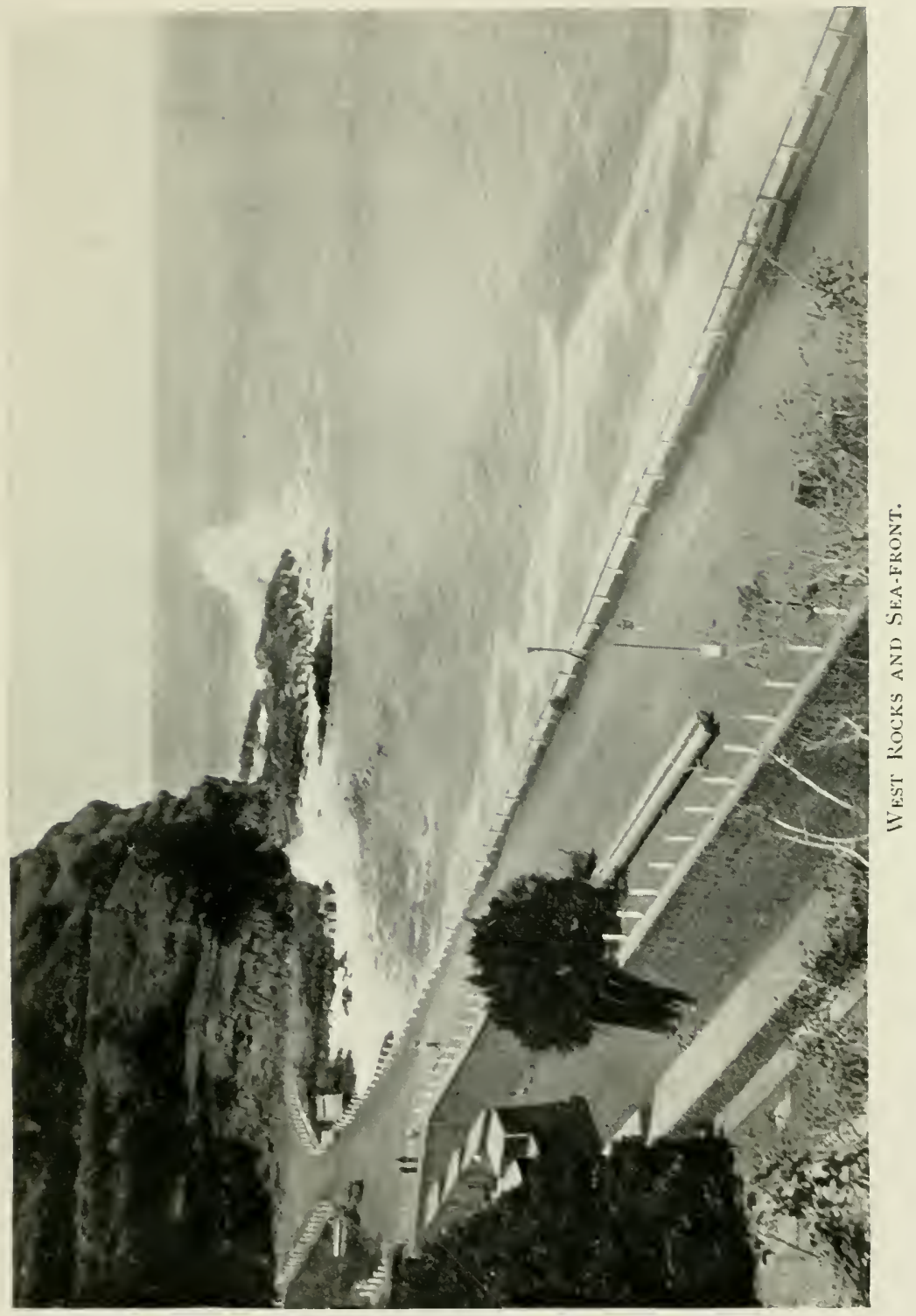



became so difficult that another 200 emigrants went to the Cape, and 260 liberated Africans still on the island petitioned to be allowed to return to their own homes. The delivery of them to their various homes could not be carried out, as they came from so many different places, but they were conveyed in ships either to Lagos or to Sierra Leone, where R. P. Pooley, Esq., our present U.S. Consul, says he met many who had formerly been on the island. The troubles of the islanders became more and more general, very few ships called, and gunboats were very occasional, and, to crown all, in 1873 another destructive flood occurred. This came from the north side of Sandy Bay ridge, and caused very much damage to properties in the valley of Jamestown and Lemon Valley. In Friar's Valley a cottage was washed away, and the family, consisting of a father and seven children, were carried to sea by the torrent and drowned.

I874 saw the construction of a flax-works, and a steam flax machine of the Colonial and Fibre Company was introduced. This was erected in Jamestown close to the sea, but soon had to be closed as unprofitable. The flax was brought in its raw state on donkeys to the flax-works. Had the works been built near where the flax grew, the experiment might have succeeded, for the flax is undoubtedly of good strength, but the difficulty was the water-power required. Flax was cultivated in large quantities, and much attention also was given to the growth of coffee and cotton.

\section{THE FURCROEA GIGANTEA,}

unlike the New Zealand flax, will grow anywhere in the island, and in fairly good soil attains huge proportions. In the Aloe Walk, Government House Grounds at Plantation, the average length of the leaves is between 7 and 8 feet, with a width of 6 inches; on the arid hill-sides of Jamestown they are barely half the length. A sample of the St. Helena fibre which was submitted by Dr. Morris, C.M.G., assistant-director of Kew, to Messrs. Collyer and Co., Fenchurch Street, was reported on as follows: Good length, full strength, rather dull colour, generally well cleaned, but with some runners untouched and barky; value $£ 28$ to $£ 30$ per ton. They went on to say that in some respects it was more suitable for cord. age than the Mauritius fibre, that is, more like Manilla hemp. Some leaves of the furcroea are quite 9 feet in length. 
In 1875 a barque, the Elizabeth, was fitted as a whaler and manned chiefly by island men, but the whaling industry has slackened much in these waters since that date. In I 878 another heavy flood occurred, and, bringing luge boulders before it, rushed through the culvert and overflowed, spreading destruction in its course. It broke through the churchyard into the streets of Jamestown, ruining much house property as well as the stores of the merchants. Two lives were lost. The water, after rushing through the main street, spread on the lower parade, rising to a great height before it could make its way through the line gate, in the pillars of which a stone is placed marking the height to which the water rose.

In 1879 came the terrible news of the disaster at Isandhlwana, and the troops from the garrison were immediately embarked on H.M.S. Shah for Natal on February 12.

In I880 the Empress Eugenie called here on her way from her visit to the grave of her son in South Africa. She was entertained by the Governor at the Castle, but no festivities marked her call, out of respect to her deep mourning. She visited the tomb and Longwood, and then re-embarked on the Trojan.

In this year tou, his Royal Highness Prince Albert Heinrich of Prussia (grandson of Her Majesty Queen Victoria) arrived in the German frigate Prinz Adalbert.

I8S I saw the arrival of Sir Frederick Roberts. He was on his way to the Cape, but landed to distribute the South African war-medals to the detachment of 9rst Highlanders who had lately returned from Zululand. The new road leading from the upper part of Jamestown direct to Ladder Hill was cut in I882, and the poorhouse, with a lunatic asylum attached, was built in the town. On Governor Janisch's death Colonel Blunt, then commanding the Royal Engineers, was appointed; and during his term of governorship the Hon. W. Grey Wilson was Colonial Secretary. When Colonel Blunt returned to England, Grey Wilson was appointed Acting Governor, and under his able administration the island was relieved of its burden of debt. In this year, I887, a serious outbreak of measles took place. As it was forty years since the last visitation, 
the consequences were very serious, there being scarcely a house unvisited by the scourge, which was of a virulent type. Much suffering ensued, but hardly a death occurred, and this speaks volumes for the climate. The same year was the memorable one of our late good Queen Victoria's Jubilee, and the people on the appointed day were early astir, decorating their houses and the streets in honour of the joyful event. H.M.S. Rifleman was in harbour, and presented a pretty sight when dressed from stem to stern. The troops were under the command of Major Miles, R.A., and assembled on the Lower Parade ground. The Governor, attended by his staff and many officials, was received by a guard of honour of the Royal Scots, under command of Lieut. Brush. A special thanksgiving service was held in St. James' Church, which was attended by the Governor and Militia, as well as by the inhabitants, after which the troops were drawn up in line on parade. The Governor, attended by Captain Bruno, Staff-Surgeon Gunning and Lieut. Pollock-Gore, inspected the line, after which a salute of fifty guns was fired from Ladder Hill under command of Captain Reynolds, R.A. After the seventeenth, thirtyfourth and last round came a feu de joie from the troops on parade, and simultaneously from the decks of the Rifleman.

The various societies of the island were present, and marched vigorously with banners flying. By all, the Jubilee Anthem was vigorously sung, followed by "God save the Queen." Before dispersing, an address was given by the Governor, and after presentation of arms the troops marched off to the music of the St. Helena band. The old and sick were not forgotten, for the poorhouse was inundated with meats, drinks, tobacco, pipes, etc., etc. It was intended that all the children of the island should have had a tea on the same day, but, owing to the outbreak of measles, many were weak, and it was thought better to postpone it. In the following month, when all were well and hearty, the children had their merrymaking in Plantation grounds, where everything possible was done to ensure their enjoyment. The Jubilee day was brought to a close with a fine display of fireworks.

In July of this year occurred a disastrous fire, whereby the counting-house and adjoining dwelling-house of Messrs. 
Solomon were destroyed. A robbery took place of over $£ \mathrm{r}, 000$, but much of this was recovered, the thief having lost coins as he ran off. How the fire occurred is a mystery which has never been cleared up.

In the church of St. James will be seen the colours of the late St. Helena regiment delivered over to the Vicar (the Rev. Stephen Johnson Ellis) and the churchwardens for safe keeping in October 1887.

Up to this time, although there were many charitable and provident societies for the inlabitants, there was not one whereby sick cliildren might benefit; but now Mr. Edward J. Watson brought forward a scheme, which was readily put into action by the workers in the parish of St. James. The St. Helena Guardian of December I5 says:-

A crowd of children may be seen on Saturday mornings at the Mess House (then the residence of Colonel Woodward, R.E.) to pay their small subscriptions of halfpenny per week to the hon. treasurer (Mrs. Woodward).

This Society is still in a most flourishing condition: it affords weekly relief to sick children; gives a burial allowance; and when the members are too old for their rules, pays the entrance fee to any one of the adult societies chosen. Its present good standing is greatly due to the assiduity with which its originator, Mr. Watson, has worked.

In March ISSS lamps were erected between the lower burial ground and the hospital. Before this time, that part of the town had been in total darkness after nightfall, and the inhabitants carried lanterns to guide their footsteps when they had occasion to be out of doors after dark.

Robbery is not of frequent occurrence on the island, but in this year the Court House at the Castle was broken into, and a safe containing Gorernment money was stolen. The remains of the safe, with a part of the money, were found at Sampson's battery. No trace of the culprit could be discovered for some time, but the Governor having his suspicions, had the lock of the door examined, and in it was found a minute piece from the point of a blade of a knife. He suspected a man who had just left the island for the Cape, and the police sergeant ${ }^{-}$(Mr.? Harrison) was shipped off to arrest him. When the arrest was made 
the knife, to which the small piece belonged, was on the person of the thief, and this completed the evidence. $\mathrm{He}$ was brought back to the island and there sentenced.

Trade was very depressed in this year, and the revenue of the colony was at a low ebb. Governor W. Grey Wilson, in remarking on it, writes :-

In point of climate St. Helena will compare favourably with any other British Colony, and the soil is remarkably productive. The potato harvest in this year (1888) was the largest known for many years past, and the price came down to $6 /-$ per $100 \mathrm{lb}$. Nearly all English vegetables grow to perfection. The revenue of the Colony is at a very low ebb, and the depression is due to four causes :

1. The opening of the Suez Canal, which diverted so large a proportion of trade to the East.

2. The substitution of steam for sailing vessels.

3. The very great economy aimed at by shipowners in the face of low freights. This natural economy has developed the tinned provision trade to an enormous extent, and rendered ships more or less independent of the ports of call.

4. The elimination of defective ships due to recent imperial legislation, by which excellent measures this colony has been deprived of much of the harvest cleared from vessels in distress.

In 1889 engravings of Her Majesty Queen Victoria and of the Prince Consort were sent out to be placed in the Government House.

In July I889 the officers and eleven of the crew of the Lindores Abbey were charged by the master with piracy and mutiny on the high seas. Verdict was given that the crew were justified in securing the captain in irons on the night of July 8 , and there was no evidence of undue violence. Verdict passed, "Not guilty."

After this came a counter trial.

The master of the bark Lindores Abbey was charged with shooting at Charles Godfrey, seaman, with intent to kill. Verdict, "The master was justified in self-defence."

In this year Mr. Reginald Antrobus came from England to administer the Government during the absence on leave of Governor Grey Wilson.

The year I8go was marked by a terrible fall of rocks, which caused loss of life. The town is on three sides surrounded by high rocky precipices which completely shut it in, the only open space being northward towards the sea. 
The roads to the interior are made along these rocks, which are in many places loose and intersected with shale. After heavy rains, or after a very hot season, huge masses detach themselves and fall into the valley. There have been many falls of rock, but none so terrible as that which occurred on April 19, I890, when the inhabitants were roused in the dead of a night of perfect darkness by a low rumbling sound, gaining quickly in force, until, with a deafening roar, hundreds of tons of rock were precipitated on the houses in the town, burying sleeping men, women and children. The remembrance of this is even now terrifying to the people who fled from their homes panicstricken, not knowing from what quarter danger threatened. Nine persons were killed, many seriously hurt, and a great number saved in a most miraculous manner. To the memory of the dead, and as a thanksgiving for the escape of so many, a memorial fountain was erected in the main street.

In I 892 the island was advertised through the arrest of Deeming, alias Williams, alias Ward, who in IS88 landed here from the Barossa. He had, it appears, killed eight women and several children before he was arrested. It will be remembered that while he was here he frequently frightened girls who were in the garden. Just prior to his leaving the island he applied for a situation as clerk to Messrs. Solomon and Company, the negative reply most probably saving some fearful tragedy amongst St. Helenians.

St. Helena at this time was at a very low ebb, and there appeared to be no outlook of better things, though the people are described by Governor Grey WVilson to be bravely battling against poverty and suffering, being unable to leave the island in consequence of the high rates charged by the steamer companies for passage.

In I8go the Chief of the Zulu tribe, Dinizulu, son of Cetewayo, arrived, together with his two uncles Undabuka and Tchingana, his wives and servants. All three chiefs were fune specimens of the Zulu tribe. Dinizulu himself had a great ambition to become English, and made rapid strides in his education, and before long he was able to read and write with ease. He was greatly interested in music, and while on the island learnt to play the piano. It was terribly ludicrous to see his earnestness, but by taking great pains he soon became 
able to play hymns. His uncles were much more unsociable, and had set their faces steadily against any innovations, continually endeavouring to keep Dinizulu a slave to their own uncivilized ways: they would not use chairs, tables, nor beds, neither would they wear European dress except on occasions when they walked abroad, and were compelled to do so. Dinizulu, on the contrary, was very particular over the fit, etc. of his clothes, and while on the island sent to the Cape for the measurements of his relatives. On receiving them he sent to England, and got out a fashionable costume for each. These were sent to the Cape. Before ordering, he carefully studied the colour and quality of the material, and selected with great care the style he preferred from the latest fashion-books. The Zulus were first domiciled at "Rosemary Hall," but this was found cold as the rainy season set in; then they were moved to Maldivia; but as the uncles made it unpleasant for Dinizulu, he was allowed to set up housekeeping for himself. He then moved to the cottage on Francis Plain. Visitors calling there were always treated to tea and cake in English style. Many amusing anecdotes are told of their simplicity while learning ; more especially are these tales told of the uncles. The vicar of St. Paul's was their instructor, and Undabuka, finding he could not learn his lesson, asked what his teacher would do to an English boy to make him learn it. The reply came-"I should stand him on the form." To his great surprise, on turning round, he found the huge Zulu standing unsteadily on the seat of a chair. After remaining there some time, he quietly got down and again looked at the book; then, finding that he could not say anything more of the lesson, he upbraided his teacher for deceiving him, remarking "that he had no faith in him now."

While they were here Miss Colenso paid them a visit. Her account of it is very one-sided. She says :-

She called at St. Helena and found the chiefs there in very poor health. They suffered extremely from the climate. The place where they were located was in a valley, or, as they call it, a "pot," and the heat was excessive. The Governor of St. Helena and the people generally were however very kind to them. Until she brought some one to assist them in their reading, the chicfs sat on the verandah and wished they were somewhere else. To get out of the place where they were situated was like climbing a precipice. 
About a fortnight before she arrived at St. Helena they had received an intimation that they were to start for Zululand, but this order was suddenly cancelled. Miss Colenso believes this was owing to communications which passed between the Colonial Office and the Natal Ministry. The chiefs had a strong desire to get back to their own country in a proper position. They wished to be on good terms both with the Imperial and the Natal Government, and not to be misunderstood by either. She believed their return would contribute to the further settlement and peace of Zululand. No doubt Miss Colenso was rery earnest in her efforts to obtain the release from exile of the Zulu chiefs, but she should not have made a statement from which an inference can be drawn far from the truth. "Maldivia," in which the prisoners lived, and which possibly Miss Colenso has, biassed by her zeal for the Zulu cause, been brought to consider a "pot," is the most healthy residence in Jamestown, and the "excessive lieat" at no time registers 80 degrees in the shade. Miss Colenso was here during the hottest season of the jear. The poor health of the prisoners, which was apparent only to Miss Colenso, was probably only disappointment at the cancelling of the order for their return. They complained of the cold when at Rosemary, and of the lieat in Jamestown. After a great deal of agitation, both in England and Natal, for the return of the Zulu exiles (Prince Dinizulu and the chiefs Undabuka and Tchingana), the Natal Government determined upon their return, and the establishment was broken up, the exiles, with wives, children and attendants, going on board the steamer Umbilo (Captain Cox), from London bound to Natal, which was chartered to convey the Zulu exiles.

They left on December 24; the party included Miss Colenso, Mr. Madden (the interpreter), Chief Dinizulu, and two female attendants with five children; Tchingana, wife and three children; Undabuka and wife; Umbodiya, an old nurse; Paul Mlinkula, wife and child; Mkolokoto, Mhofana, Myosana ; Xamandolo, wife and child; and Magema Magwaza.

During the time they were on the island they were gradually weaned from their uncivilized and savage life, until at the time of their departure they were as much civilized 


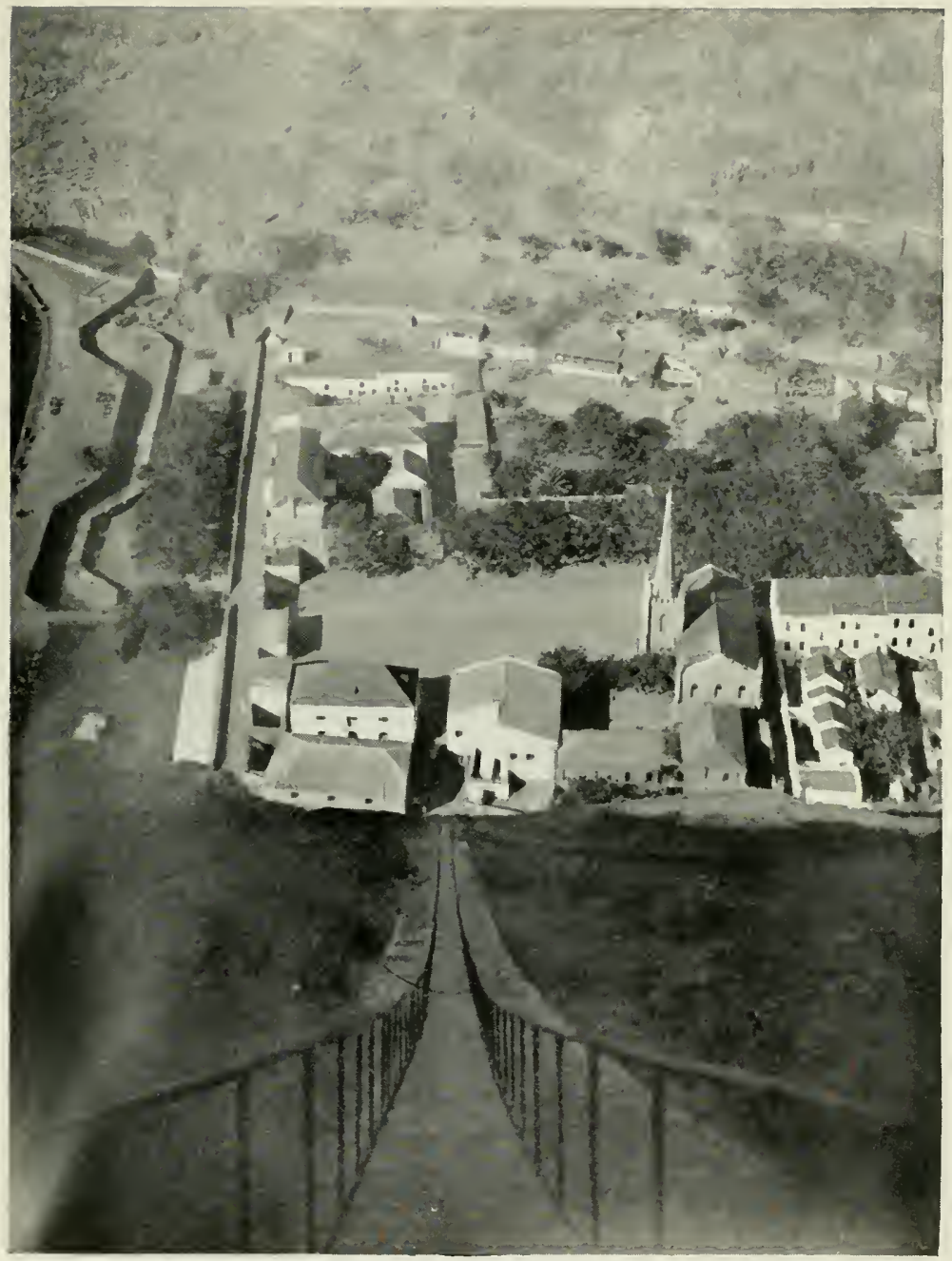

JAMESTOWN FROM TOP OF THE LADUER (LOOKING DOWN). 

and attached to civilized customs as could be expected in such a short time. This can be said especially of the young Prince, who became more refined, his gentlemanly manners and bearing promising well for the tribe over which he may hold sway. Dinizulu was liked by all who knew him, and he left many friends and well-wishers in the island.

Financially, the island suffered much by the departure of the Zulus, as considerably over a thousand pounds a year were expended upon their establishment, a loss the Colony continued to feel until the arrival of the Boer prisoners.

It is understood that the terms on which Dinizulu and his uncles Tchingana and Undabuka returned to Zululand are as follows :-

Dinizulu will take the position of an Induna of the first rank, shorn, however, of the power, but acting as confidant or adviser, ex-officio, of the Administration. He will be made chief of a district of Zululand, over which he will exercise the authority which is granted at the present moment to a district chief in Natal. He will not, however, be permitted to exercise paramount authority over any of the other Zulu chiefs. He will be salaried by the local Government, furnished with a house of his own, and in general well appurtenanced, the sole proviso being that he shall behave himself in due accordance with the laws of the colony. A further condition is attached in connection with the stipulation as to the non-exercise of paramount power, namely, that neither he nor his headman shall visit his former opponent, Usibebu, but on the clear understanding that neither Dinizulu nor Usibebu should have any ground of complaint left to them.

A Cape Times correspondent, writing from Zululand on June I4, says that Dinizulu's return is already creating a disturbing influence. He asks: "Will Dinizulu be able to withstand the varied influences which undoubtedly will be brought to bear upon him ?" His journey from Etshowe to Nongoma was a triumphal march. His people, including Government chiefs from remote quarters in vast numbers, met him along the route, giving in their allegiance, and presenting him with money. One of the most striking facts in connection with this is that the Colwas, or so-called Christian Zulus, were as eager in their protestations and monetary gifts as the veriest heathen. Such a fully spontaneous outburst of loyalty could not fail to impress this young man with a sense of his power. His people are 
urging him to give up his European habits, to cease wearing clothes, and to return to the primitive costume of his illustrious ancestors. Tchingana, one of his uncles, whom we have been accustomed to see clothed and seated like the rest, lias within a month of returning to his kraal, cast off the cumbersome apparel of civilization, and taken to his " moucha " and "nongoma." Dinizulu is in the heart of Zululand, and far away from Etshowe and officialism. He is here surrounded on all sides by his faithful and still savage people, and his journey thither has impressed him with the fervour of the Zulu nation's attachment. Undabuka is with him, and is known to be a cunning and unscrupulous man. Has the leaven of civilization got hold of Dinizulu to that degree as to defy natural incentives, which at present are everywhere urging him to return to heathendom, and all that it means?

\section{A Supreme Test.}

The Government have fondly hoped and thought that Zulu power was finally broken, that under the system of petty chieftainship into which the country is divided an end had been put to the concentration of power and organization. It may be so, but the time is at hand when that belief is to stand a supreme test, and one is amazed at the easy nonchalance with which everywhere his return has been viewed, Dinizulu at Nongoma is allowing his thoughts to run riot, and there comes back to him the time when he, as a boy, single-handed, penetrated the fastnesses of the eneny's camp-that enemy that hat twice vanquished lis powerful father, and having made his plans, returned, and gathering these same Usuto, led them to victory by the knowledge thus gained. This was an event to be proud of, which stamped him as a true descendant of a kingly line: this as a boy, what ambition is in the man? In dealing with Zulu minds we are dealing with an unknown and devious quantity. The whole nation awakes in a night, and that first night or two is usually a bad time. These things have happened before, and every one was aghast. There is absolutely nothing to prevent it happening again.

During the debate on the Estimates in the Natal Parlia- 
ment, on consideration of an item of $£ 500$ for Dinizulu, Mr. Schofield asked whether Dinizulu was at home, and was behaving himself properly. There was a rumour that he was rambling about the country and that the authorities had no control over him. The Prime Minister said the general rumour was absolutely incorrect. For a time Dinizulu was in the house provided by the Imperial Government, and after a certain time he was allowed by the Chief Magistrate to go to his own kraal, and ine was there for some little time. The Government had been kept fully informed of all his movements. His conduct had been very good, and there was no foundation for the rumour. Mr. Schofield said he referred to the matter because it was stated that a large kraal was being built for him. The Natal mail brought an interesting letter from Miss Colenso Writing from Pietermaritzburg, she says :-

At last I have got back to the land of tables and chairs, from a four months' visit to Zululand. I went straight on with the chiefs when we landed at Durban, and found it desirable to stay through their settling in. That is now, I think, safely accomplished. They have been greeted rapturously by the Zulus generally-almost universally. Even Zibeba went to welcome them. His messengers were well received, Ndabuko greeting them as friends, which was much more than I expected, and I think that in time even that breach may heal also. Before I left, a good many Zulus had come in to welcome us from Dutch Zululand. When I parted from Mr. Saunders, the Special Commissioner at Etshowe, a fortnight ago, he said that he was well satisfied with the way in which things had settled down, and considered that much of the credit for this was due to Dinizulu. It is too soon yet to say that all is going on well, and there are many possibilities for mischief, but on the whole things seem to be shaping fairly in this corner.

In I893 many of the islanders emigrated to Port Nolloth, to work at the copper mines, others in search of domestic service went to the Cape.

The year I 895 brought great rains, which carried away three of the large beds of rushes which grew on the hillside above Maldivia House garden. In this year also the old convict ship Success called on her way from Australia to the East India Dock, Blackwall, London, where she was put on exhibition. The vessel belonged to the old system of treating prisoners with barbarous cruelty bordering on inhumanity. She was built in I798 in India, of solid teak 
of great thickness, and was used as an East Indiaman, and then as an emigrant ship, but in 1852 , when the goldfields were being opened up in Australia, she was converted into a convict ship, and anchored off Williamstown, Victoria. There were five of these convict ships moored together, in order to safely keep the worst of the bad characters from all quarters, and the convicts who were escaping from the penal settlements to get to the gold fields. The Success was called the Dark Coll Drill ship, and was fitted with solitary cclls admitting no light. It is wonderful that she safely reached home: she took five months and a half to complete the voyage.

The quarters occupied formerly by the warders were on the quarter-deck, where were to be scen rusty muskets, pistols, leg-irons and manacles, and an original copy of a ticket of leave signed by the Governor of the Colony. Between decks there were cells on each side, each cell made for three prisoners; and on the lower deck, where no light and very little air could penetrate, were the solitary cells, which must have been living tombs. A small space at the end of each cell was railed off, and called the tiger's cage; this was used for dangerous occupants. Often murder was committed in the gloom of these awful tombs, as the result of quarrels, or of an old grievance. There also were iron necklets by which the malefactors were fastened in a line. In the torture cells the chains prevented the poor wretches from either sitting, knceling, or lying down. The convicts were of the worst type; still, such barbarity could only have hardened them, and in 1857 they found an opportunity of revenging themselves by assassinating the official head inspector, General Price. Public fceling then revolted against the system on these convict ships, and they were, in $\mathrm{I} S 59$, broken up, with the exception of the Success. She was scuttled in Sydney harbour, then was raised and exhibited at various ports in Australia after which she was taken to England.

On Sunday, October 13, 1895, threc artillerymen (a bombardier and two gunners), two of whom were on the main guard, boarded the Luna, a water-tank, and took her out to sca. Before leaving guard, they locked the remaining man on guard in the cells, and filled in the guard 
report with facetious remarks; they then took a gig, which had the day previous been hoisted for cleaning, and rowed off to the Luna. They had three carbines, a large amount of ammunition, their kits, supplies of bread, oatmeal, tinned meat, and a map with a straight line drawn from St. Helena to America.

About three a.m. the Luna was missed by the night watchman, who got a man to help, and they went after her with the intention of bringing her into the moorings, but when within twenty yards they were fired at. Repeated firing went on, one bullet going through the roof of Signalman Ward's quarters, while others fell so near that Ward and the sergeant of artillery had to keep their heads below the parapet to avoid being shot. As daylight grew stronger the men were seen to be Bombardier Longman and Gunners Bush and Richards. For over two hours messages were passing between the owners of the tank (Messrs. Solomon and Co.), the police magistrate, Captain Bateman of the Royal Artillery, and the sergeant of the police, as to what steps were to be taken to get back the men and tank, but neither civil nor military authorities cared to take the initiative, and nothing was done. An end was put to the affair by the men themselves (finding they were sea-sick and quite unable to sail the tank) getting into the gig which they had fastened astern, and rowing for the shore, where they arrived in harbour and landed, to be taken in charge by the military police. They had I 93 rounds of ammunition still in their possession, and they had fired about roo rounds while in the tank. They were tried by court-martial for leaving their post while on guard, making away with a water-tank and a gig, taking Government carbines and ammunition, also firing round after round at their barracks, every action tending to the presumption that they intended to desert.

Two were sentenced to two years' hard labour, and the third to eighty-four days'; but on the day following the Officer Commanding troops remitted half of the first sentence, much to the astonishment of the community.

In the December following the Boys' Brigade was formed by the Rev. Canon Ellis, vicar of St. James'; this corps is still in existence. 
The next year was remarkable for its trade depression, as also for the marked decrease in the number of calling vessels, and for the fact that there were in port at one time four damaged vessels: the steamship Port Phillip on fire (this vessel was taking emigrant girls to Australia), the steamer Strathmore with broken shaft, The Madeline Rickmers on fire, and the Houden (now a lulk in harbour, and lately used as a quarantine station) leaking.

The year is also remembered as a time of great reduction in the prices of imported goods, and also of reduction in postage from $6 d$. to $2 d d$. per half-ounce. This was again reduced in Igor to $\mathrm{I} d$. per half ounce.

In 1897 , while shooting on the barn, some men made an interesting discovery. Following a goat along a vein on the west side, just on the verge of a precipice immediately overhanging the sea, they came suddenly on a hole or cave which was built up, only leaving an entrance sufficiently large to allow of a man squeczing through, and so very near to the edge of the precipice that the slightest push from any one standing in the doorway would land an intruder 300 feet or more below. It is supposed that the cave is the much talked of place of abode of an eccentric person called "London's Ben," who was subject to occasional fits of mania, and who would absent himself from civilization for lengthened periods, living a wild and hermit-like life. It was known that he lived on the barn, because, when he began to feel what he termed "that way," he always said "the white goat on the bam called him," and then made his disappearance. He had been missed twenty-three years when the cave was discovered. On entering the cave there was found a bag containing about ten pounds of salt, a razor perfectly good, and wrapped in flannel, a large quantity of island tobacco nicely done up in rolls, quite good, some cooking utensils, a chopper made from the heel of a scythe, a whetstone, tinder-box, flint and steel, some jerked beef in a perfect state of preservation, together with many other things, including a bottle of water, which also was good. The bed was framed of rough stone, the top being of flat slatelike stones, large quantities of which are found on the barn in a beautiful smooth state. There was a pair of blue cloth trousers, which fell in pieces when touched, and by the 
bed was a stone club about eighteen inches long and three inches in diameter. The walls of the cave were shelved with flat slabs of stone supported by spikes, driven into the rock, and near by was another cave evidently used as a kitchen.

In September I897 the island was subjected to a very high wind, which it is said travelled at the rate of forty miles an hour, its force being eight pounds to the square foot. Fortunately this rate is unusual, or St. Helena would in all probability be denuded of trees or placed on a par with the Falkland Islands, which possess very few trees taller than furze bushes. Many trees were uprooted by the wind, one especially deserving mention. It stood in a field at Longwood called the Black Field, and for nearly twenty years it had, by the kindness of Mr. Deason of Longwood Farm, been fenced in. This tree is referred to by Mr. J. C. Melliss, C.E., in his admirable work on St. Helena, at page 286 , and a plate respecting it given between pages $294-5$. The quotation is under the heading "Esiadia Jacq," as follows:-

$P$. rotundifolia, Hk. f., Solidago rotundifolia, Roxb. Only one tree of this species is now known to exist in the world, and that grows in a field to the left of the entrance gate at Longwood, called the "Black Field." Roxburgh states that the islanders called it Bastard Gumwood or Cabbage-tree. After a careful search, extending over a year or more, the plant above mentioned was discovered in the year 1868 . It is a tree about twenty feet in height and apparently very old. It grows side by side with the gumwood, and without close examination might be mistaken for that species; indeed I discovered it only by riding up to it to look for the blossoms of the gumwood, and was surprised to find it covered with small white flowers of a different plant. It is much to be desired that a plant of such singular interest should be propagated before it is entirely lost. It flowers in May and June.

The advice given by Mr. Melliss was followed by Mr. Deason, who tried to propagate the species by planting the seeds; some were also sent to Kew and were planted; but all have turned out failures. The tree from its appearance was very old, and for a long time was hollow, leaving merely a decayed woody fibre covered by a thick bark; in all probability to this cause the sterility of the seeds is due; the species being now entirely lost.

A thunder-storm at St. Helena is a thing almost unknown, 
yet in about a month after the extraordinary wind the island was visited by a thunder-storm which continued over two days, and was accompanied by much rain and hail-of hail up to this time there has been no record in St. Helena, yet now, hail-stones half an inch in diameter were picked up on the south-west part of the island, where the country was thick with them.

On Thursday, April I4, I898, the arrival of Captain Joshua Slocum in his little yacht Spray constituted an event as unique in the history of St. Helena as the fact of a man making alone a voyage round the globe in a nine-ton boat probably is in the history of the world.

The Spray made her appearance after a smart run of sixtcen days from Cape Town, the news of her arrival causing a commotion among the community of the island, and many visited the boat in which a feat requiring rare pluck and skill had been so successfully accomplished-a feat which in its extreme daring, amounted to foolhardiness.

Captain Slocum hailed from Boston, from which port he started on his voyage three years before, on April 24, I 895 . He called successively at Fayal, Gilbraltar, Pernambuco, Rio de Janeiro, Montevideo, Buenos Ayres, Straits of Magellan (twice), thence to Juan Fernandez (Robinson Crusoe's island), Samoa, Newcastle and Sydney (New South Wales), Melbourne, Launceston (Tasmania), Torres Straits across the Indian Ocean to the island of Keeling, thence to Rodrigues, Mauritius, Natal and Cape Town, and lastly St. Helena, whence he proceeded to the United States.

At the Garden Hall the Captain gave a very interesting and humorous lecture on his voyage, illustrated by a series of beautiful lantern-views of the various places he had visited, and the classes of people met with. Mr. R. P. Pooley, United States Consul, having introduced the Captain to the audience with a few amusing remarks, the lecturer began by narrating an account of his voyage, telling in a highly humorous manner the many and various incidents which occurred on his voyage. His reason for coming alone, he said, was because he could not get the one he wanted to come with him. He could get lots of others, but he didn't want them. He considered the failure of many a great expedition was due to there being too many 


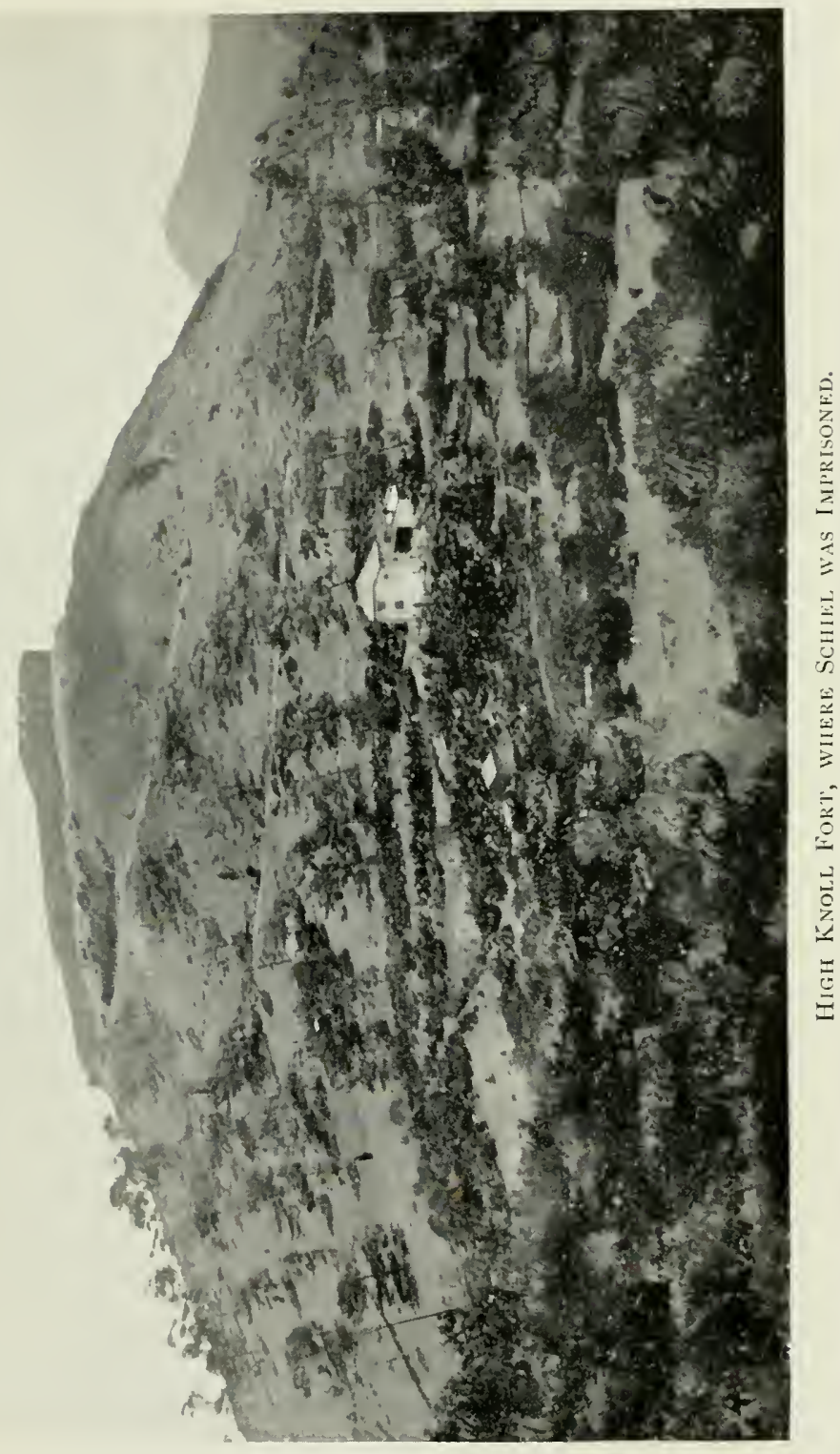



who wanted to be master. Columbus' expedition was an instance of this : if Columbus had been alone, he would have discovered America long before-in fact, he added, America would have discovered itself. The Spray he had built himself; there was not a nail in her he had not driven, and she took thirteen months to build. When he determined to make the voyage alone, he put all hardships behind him, and having been twenty-five years a ship-master knew pretty well what he undertook. Up to the present he had not regretted having done so; not even when in a violent storm off Cape Horn (in which three vessels were lost-one the City of Philadelphia) did he regret his undertaking. His boat had lived through it; in fact, being so light she would live through a storm that many another vessel would not survive, for she sat like a duck on the water. He had never felt any extra fatigue-never once felt over-worked. The course he came was by deliberation, not by chance; he pricked off on his chart the course he meant to take, and he followed it. His chronometer was a watch which went all right when he did not neglect to wind it. Everything was done by dead reckoning. The biggest run the Spray made was I,200 miles in eight days in a gale. He spoke two vessels, one the Java. The Captain of this vessel asked him how long it had been calm. He replied, "I don't know; I haven't been here long." "How long are you out ?" was the next query. "Eight days from Boston." $\mathrm{He}$ went below, says Captain Slocum, to fetch his mate to hear this "Yankee Skipper" tell fish-stories! The Captain humorously described some of his experiences with the native pirates in the Straits of Magellan, a place where the wind is so strong that not a vestige of moss can grow on the rocks-strong enough at times to "blow the hair off a dog's back," he aptly termed it. "I left my hat there," remarked the Captain reflectively, as he felt the bald spot on the top of his head! At Gibraltar he was very cordially received, and was shown through the fortifications. "These works are," he adds, "said to be worthy of the Russians ; I say they are worthy of John Bull alone!" he also paid a visit to Juan Fernandez, the uninhabited island on which Alexander Selkirk, better known as Robinson Crusoe, spent four and a half years. He went to the look-out 
place, and also brought a stone from the fireplace of the cave.

Among many of the views shown was one of Government House, Pretoria, a building which, says the Captain, would grace any city in the world. He went to see Oom Paul, who, when he was told that the Captain had been round the world, said, "You mean across the world!" Mr. Kruger believes the world is flat, and is quite positive on this point.

In speaking of the objects of his voyne, the Captain frankly admitted that one of them was to make money; as he cutely remarked, any man with his head screwed on in the right place wants to do that; then again he possesses a spirit of adventure.

Altogether the lecture was really interesting and amusing, and the lantern views superb. At the conclusion cheers were given for the lecturer, who was entertained at dinner by His Excellency the Governor and Mrs. Sterndale at Government House, Plantation.

In 1899 , the Eastern Telegraph landed a submarine cable ex Ss. Anglia, which brings the island into direct communication with England and with the Cape; during the war with the Transvaal it has been of inestimable value. It is shored at Rupert's Valley, where also are the office and plant; but the Briars House and valley has been acquired, and offices, together with residences for the staff, are now in process of erection there.

Since the removal of the Zulu prisoners the island had been very tranquil and quiet, but on the breaking out of war in the Transwal there arose the necessity of secure confinement for the prisoners taken in the war. St. Helena was chosen.

On April 5, I900, His Excellency R. A. Sterndale, C.M.G., published the following proclamation :-

In a few days the troopship Milwauke, escorted by H.M.S. Niobe, will arrive with prisoners of war.

No unauthorized persons will be allowed on the wharf at the time of disembarkation. The police will assist as far as they can the military, acting under the orders of the officer commanding the troops, in keeping order. H.E. the Governor expresses the hope that the inhabitants will treat the prisoners with that courtesy and consideration which should be extended to all men who have fought 
bravely in what they considered the cause of their country, and will help in repressing any unseemly demonstration which individuals might exhibit.

This proclamation was posted in various parts of the island, one being near the landing-steps of the wharf. I have been told by more than one of the prisoners how they dreaded landing on the formidable looking rock, how they shrank from the march through the streets of the town in view. Very many of them were able to read English, and when landed on the wharf, and while waiting for the successive boat-loads of comrades, this notice appealed so much to them after their hardships, that some few entirely broke down.

Expecting harshness, rudeness and ill feeling from the inhabitants, they discovered from the proclamation so kindly issued by the Governor they might anticipate courtesy and respect. Not a jeering sound, or rude remark was heard from the crowds of islanders congregated to see them pass on their way to Deadwood Camp, which had been prepared for them. Amongst the number of prisoners (5I4) landed from the Milwaukee on April I4, Igoo, were General Cronje with his wife. "Cronje," instead of being taken to Deadwood Camp was allowed to live at "Kent Cottage," but under a strong military guard changed every day. A guard of the militia (4th North Staffordshire) escorted them as far as Ladder Hill, where they met a guard of the Royal Garrison Artillery, who took charge of the prisoners and conveyed them to Kent Cottage, not far from High Knoll Fort. On April 2r the steamship Lake Evie arrived, bringing 394 prisoners, including thirty-four Boer officers; then on May I the British transport Bavarian brought $\mathrm{I}, 099$ to add to the increasing numbers. One hundred and ten more, including twelve officers, arrived on June 26 by the transport Mahratta, and in July Lieut.-Colonel von Braun was brought by the British transport Manchester Port. The Idaho, another British transport, brought I89 men and seven officers; the last arrival in 1900 being the Victorian, on December Io, with I99 prisoners; but early in Igor, on January I2, arrived the Columbia with 200 ; on January 24 the Bavarian with r,337; and on February 3 came the Mongolian with 649 . 
For some time I had been teaching the children of the island the art of pillow-lace making, and was anxious that they should have an opportunity of cxhibiting, and perchance of disposing of their work. This idea, enlarged, became a scheme for the holding of an exhibition of industrial arts in the island. A committee, headed by His Excellency the Governor, the Bishop, the United States Consul and others was formed; when, to further extend the exhibition, I proposed that the prisoners of war might also be allowed to exhibit. This met with unanimous approval, ind after securing the consent of the Officer Commanding troops, the prisoners were asked to contribute, not as competitors, but as exhibitors with a view to sale. The idea was eagerly taken up by them, and so numerous were their exhibits that a separate room was allowed for their contributions. A committee was clected from their number on parole, and these carried out their part of the work so well that the section was a great credit to their management.

Models of carts, model of stamping machinery, carved caskets, boxes, pipes, sticks, etc., etc., all found ready sale. The tools with which these were made were also exhibited, being old table knives madc into saws, umbrella wires as fret-saws, stone hammers, etc.

The drawings, paintings, and etchings were very beautiful, as also was the writing, illuminations, manuscript music, etc. The exhibition was opened on November Io, I 900 , for five days, and was a great success. Island-made pottery (by His Excellency the Governor), carving, models, island-made preserves, plain and fancy needlework, and pillow, Torchon, Honiton, and Point lace, photographs, paintings, etc., well filled the section devoted to the islanders, the little lace-workers and wood-carvers gaining especial praise, as well as substantial remuneration for their work.

It was a pleasant change from the antagonism still going on in South Africa to the peaceful rivalry of the industrial arts, and it was a subject for wonder that such beautiful results could have been obtained from the rudest of implements and material. The exhibition caused a break in the monotony of the prisoners' lives, and caused a better feeling to spring up between them and the islanders. 

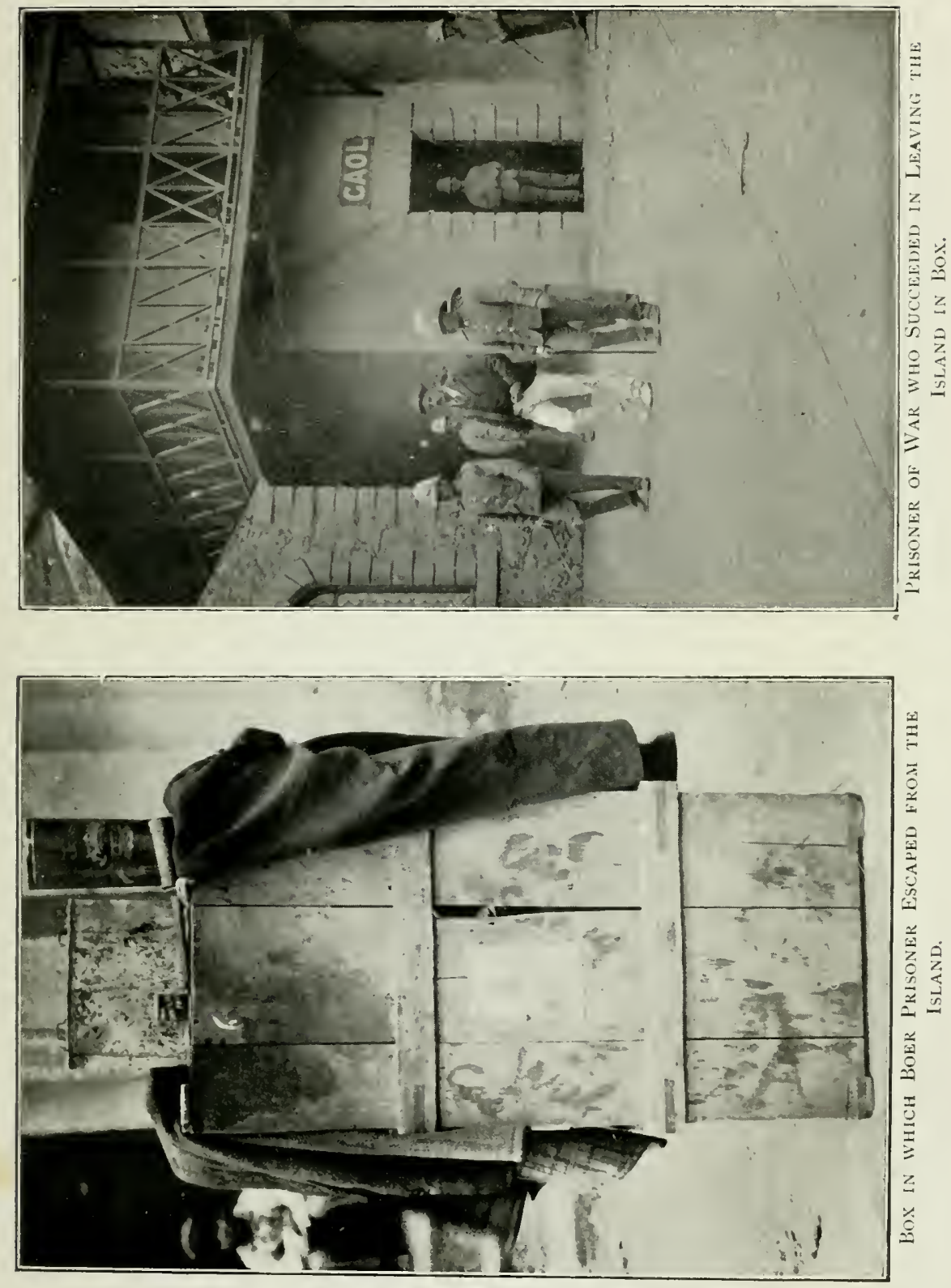

On the night of February 2, I90I, a very determined attempt to escape from the island was made at Sandy Bay, by four of the Boer prisoners of war, one of them being the grandson of President Kruger (Commandant P. Eloff). The men had a quantity of provisions with them, and seized an old fishing-boat at Sandy Bay. The fishermen, who had just landed, took away the oars, and a struggle ensued between the prisoners and fishermen for possession of them, the latter succeeding in retaining them. The prisoners got into the boat sand tore up the bottom boards to make paddles of, but finding them useless they again landed, and tried to bribe the fishermen by offering a goodly sum for the boat and oars, but without avail. While this was going on a messenger sped on his way to report the occurrence, and in the early dawn of the morning (Sunday) a guard from Broadbottom Camp arrived and took the men into custody. This attempt was an extremely foolhardy one, for the boat was in such a condition that it would have been in half before they were many miles from the shore. In fact, it broke in half a fortnight after the occurrence.

Another escape was attempted by two Frenchmen amongst the prisoners. They bathed from the beach at Rupert's and attempted to swim to a ship in harbour. Being seen by the guardship the guns were directed on them and they were hailed. One turned and swam back to Rupert's Beach, the other swam to the steps of Jamestown wharf, where he was taken in charge and escorted to camp.

The American whaler, Morning Star, Captain King (226 tons), arrived in June from whaling, bound to New Bedford with a catch of 900 barrels of sperm-whale oil. With such success it is hoped the whaling fleet will again visit these waters.

An outbreak of bubonic plague occurred in Igor in South Africa.

All vessels touching at the Cape ports were therefore under quarantine regulations when they called at St. Helena-no passengers were allowed to land except for the island, and then only under strict quarantine. No cargo was brought by steamers, no parcel post allowed. This was a terrible loss to the island in the matter of trade. 
Rats have from the earliest times been a pest on the island, and the fear of plague made the Government offer a sum of one penny per head; then of twopence, and, when they became scarcer, of threepence per head. This to a great extent cleared the country of these troublesome rodents.

Deadwood Plain, which lies due east of the island, becane filled with the tents of the Transvalers and of the $4^{\text {th }}$ Battalion Gloucester Regiment, which was commanded by Licut.-Colonel Earl Bathurst, so it was found necessary to form another camp. Broadbottom, a large plain on the western side of the island, was chosen, and here the Orange Free Staters were located.

In April rgor Captain Mciklejoln arrived per R.M.S. Raglan Castle. In this month also His Excellency and Mrs. Sterndale left for England on sick leave, Colonel Evans assuming the reins of government. Governor Sterndale returned again in August.

In January I 902 the British steamship Oricnl arrived with I,050 prisoners, followed on the $25^{\text {th }}$ by the Brilannia, which brought thirty-nine Boer officers, amongst them General Ben Viljoen, who had done so much for the Boers in the field!

February brought the British transport Victorian with the last batch of prisoners, consisting of twenty officers and fifty-seven rebels.

The camps were nicely laid out and girdled by three separate fencings of barbed wire separated by tangled barb, and guarded outside by patrolling soldiers; for such a number congregated together there was very little trouble given by the majority; but, as is usual in all communities, there were bound to be agitators and ill-conditioned men. Usually the prisoners would settle their little disturbances amongst themselves, but some cases required the decision of the British commandants. Several of the untractable were confined in High Knoll, one amongst these being Eloff. Schicl also was confined there for a short time.

By degrees the moneyed men amongst the prisoners, dissatisfied with sharing tents, built for themselves snug little huts. Some of them were well constructed, the majority being composed of parafin tins soldered together 
or overlapped; these, lined out in some cases with wood, in others with cloth, were most comfortable.

The commandants on parole were allowed to live outside the camp in comparative freedom, very little restriction being placed on their movements so long as they were well conducted and reported themselves at stated times.

Amongst the prisoners were clever musicians, teachers, architects, builders, engineers, carpenters, cabinet makers, as well as steady labourers; and many of these obtained employment with the farmers and merchants, who were responsible for them during working hours. Camps were formed in the Government garden and in the Botanical garden in the town, so that the workers might return there after their day's work instead of having to report at Deadwood or Broadbottom, five to seven miles up in the interior. But many of good conduct were allowed to find their own lodgings on condition that they were indoors at a certain time; others, such as shop assistants, bakers, grooms and household servants lived altogether at their employers' residences.

Many regulations were formed for the safe-guarding of the prisoners, and censors were appointed to overlook the correspondence. Some of the rules were as under :-

\section{PORT REGULATIONS}

made by

\section{HIS EXCELLENCY THE GOVERNOR IN COUNCIL}

under

"THE HARBOUR ORDINANCE, I894."

Whereas by the Harbour Ordinance of 1894 it is enacted that the Governor in Council " may from time to time make, alter or repeal regulations."

AND WHEREAS during the detention at St. Helena of prisoners of war it appears essentially necessary to adopt some additional precautions for the preservation of the Port of Jamestown and the management of vessels and boats within the waters of the Colony, and particularly by night, I do hereby proclaim, declare and make known that I have framed the following regulations, and I further proclaim that the regulations shall come into force and have effect from the date hereof:-

I. Every boat going to and coming from all vessels in port or lying in the offing must first report alongside the senior naval 
officer's ship, and state to the officer on duty the number of persons in such boat, and further to answer correctly all questions that may be put to persons or person therein.

2. No person whatever shall be permitted to board, nor shall any boat go alongside any ship or vessel in the offing, or approaching or coming to the island, or being in the roadstead or harbour, until such ship or vessel shall have been visited by the Harbour Master and the White Flag hoisted at the maintop-gallant masthead.

3. Any person in charge of any boat wishing, for the purpose of fishing or otherwise, to leave the harbour of Jamestown, including Rupert's, must report himself alongside the senior naval officer's ship in leaving or coming to the port of Jamestown specifying the description of the boat and the use generally made of her.

4. It shall be lawful for the senior naval officer to post a seaman guard at the gangway of all British vessels arriving at St. Helena, provided pratique has been given by the harbour-master.

5. That all persons wishing to board any vessel arriving in the port of Jamestown shall produce a pass signed by the Colonial Secretary or Garrison Adjutant, which pass must be produced to the naval guard alongside the ressel.

6. It shall not be lawful for any person to leave any oars, sails, bottom boards, rudders and other fittings belonging to any boat moored in Jamestown harbour, or on the wharf, or near the landing. place, without a permit from the harbour-master.

7. All boats moving out of the harbour between sunset and sunrise must exhibit a light at the bow not less than three feet above the boat.

8. That no master of any vessel silall receive any person for the purpose of taking sucl person from the island, without giving to the undersigned twenty-four hours' previous notice of the intention of such person to leave the island, nor shall any person be taken from the island, or taken on board such vessel, agaiust whom any prohibition or order shall be given to the master in writing.

9. The operation of these regulations as regards movements of boats between sunrise and sunset does not apply to foreign consuls, officers of His Majesty's Services in uniform, Custom House officers, and the harbour-master.

10. No person shall be allowed to leave the island except by tho landing-steps of the wharf. Any person in a boat taking any one of the rocks will be liable to a penalty.

11. Any person not complying with these orders shall be liable to a penalty not excecding $£ 50$.

12. The port regulations dated 25th day of January, 1902, are hereby repealed.

Made by the Governor in Council this 7 th day of April, 1902.

(Signed) ROIBT. R. BRUCE, For Colonial Secretary.

The Castle, St. Helexa, 7th Aprib, 1902. 


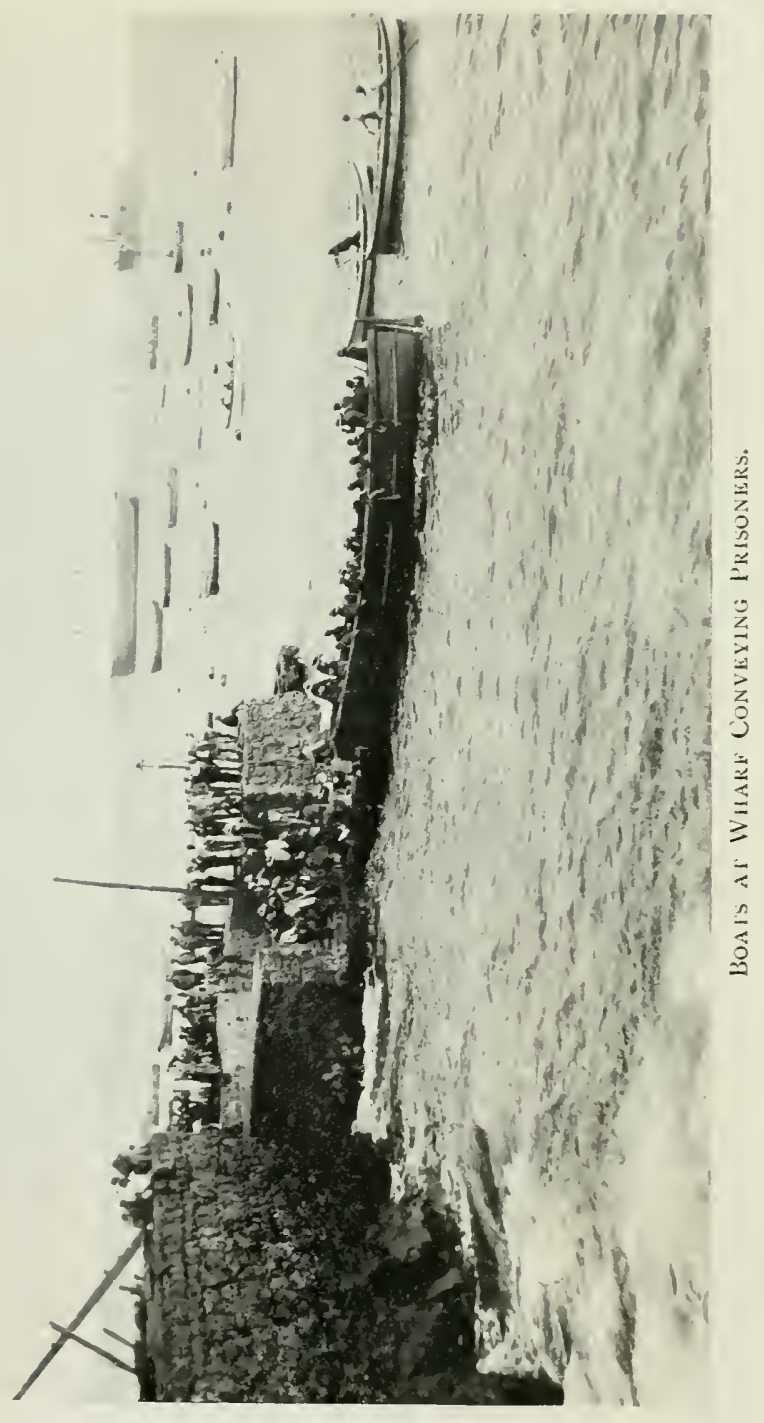





\section{ST. HELENA}

In the second year of the reign of His Majesty

KING EDIVARD VII

Robert Armitage Sterndale, Esquire,

Governor and Commander-in-Chief.

25 th April, 1902.

AN ORDINANCE for the better preservation

Title. of the custody of prisoners of war and for the prevention of smuggling of illicit correspondence.

Whereas it is expedient during the present

Preamble. condition of this island as a place of safe custody for prisoners of war, that certain regulations be promulgated and passed into law for the time being for the purpose of more efficiently exercising a check over correspondence to and from the said prisoners of war, and for providing a penalty for those who aid and abet the said prisoners in sending away letters surreptitiously.

BE IT ENACTED by the Governor of St. Helena as follows :-

I. That any person who assists any prisoner of Aiding prisoners war in evading the regulations of the censcrship of war to evade by undertaking to post and carrying out the posting regulation of or delivery of any letter, parcel or other article

the censorship. through the post, or otherwise, with the intent of evading the censorship, shall on conviction of the same be liable to a penalty not exceeding $£ 5$ for every such offence as aforesaid.

2. That it shall be lawful for the postmaster Postmaster may during the detention of prisoners of war to detain letters and hand over to the military authorities any letters, hand them over newspapers, or parcels, which he has reason to to the military suppose are intended for the prisoners of war authorities. though addressed to residents of this island with intent to evade censorship of the same, if posted by any resident surreptitiously for any prisoner of war.

Penalty for Any person convicted of carrying any letters, carrying letters, on board any vessel, or of conveying any prisoner etc. to any such vessel, shall on conviction be liable to a penalty not exceeding $£ 50$, or imprisonment not exceeding six months.

4. Any person trading for arms or ammunition Import of arms or accepting any firearm or weapon and ammuniprohibited. tion shall on conviction be liable to a penalty not exceeding $£$ Io.

5. Any person possessing arms and selling or Selling arms to lending the same to any prisoner of war shall on prisoners of war. conviction be liable to a penalty not exceeding six months' imprisonment. 


\section{Registration \\ of arms.}

6. After the passing of this ordinance every person possessing any firearm of any description whatsocver shall register the same at the Castle and deliver the same for safe custody to be returned to the owner after the necessity for this restriction is over. Excepted always officers and men entitled to bear arms, members of volunteer corps and such persons as the Governor may consider should be allowed to retain weapons for sporting or other purposes. Any person hiding or omitting to bring up such arms for registration shall be liable to a fine of $\{2$ and confiscation of the weapon.

7. Any constable or other authorized person Conshubles may may, under the orders of the Governor, a magisenter any house in trate, or justice of the peace enter into and search for arms. examine any house in which there is reason to suppose arms are secreted.

8. The Governor may at any time prohibit the Regulations may importation of firearms, weapons, ammunition or be made by the Governor. explosive articles, and may make, vary or rescind regulations with reference to every matter in connexion with this ordinance.

9. Any person convicted of a contravention of

Penalty. a prohibition or of a regulation made by the Governor under the preceding clause shall for a first offence be liable to a penalty not exceeding $\& 50$ or imprisonment not excceding six months.

10. AND WHEREAS the welfare of His MaTohare jesty's subjects within the said island urgently immediate requires that this ordinance should have immediate operation. opcration therein. NOW BE IT THEREFOIRE ENACTED that this ordinance shall take effect and be in force from and after the date of the promulgation thereof.

GOD SAVE THE KING.

Civen under the public seal of the island of St. Helena this $25^{\text {th }}$ day of April, 1902.

By command of His Excellency the Governor,

(Signed) ROBT. IR. BRUCE, For Colonial Secrelary.

(Signed) R. A. SterNide.

As time went on many who had been commandeered, some who had taken arms against Britain through ill advice, and many who considered they would benefit by so doing, gave in their names to the military as being desirous of peace. It is said that a number, anxious to be on the winning side, offered, if allowed to go back, to fight for Britain; and this all caused a great stir and excitement amongst those who were staunch to their own cause; naturally it was a matter for contention, and so bitter did 
the feeling become, that the authorities were compelled to form another camp (called No. 2 or Peace Camp), where those admitting their desire to become British subjects might be located quite apart from the general camp. These men called themselves "Loyalists," but by their fellow prisoners they were termed "Traitors." A number of men were allowed liberty each day from the camp at Broadbottom and Deadwood. These in parties rambled all over the country, their rations and kettles with them; they picnicked where they pleased. In groups of ten, twenty, forty or more, they might be seen lighting their fires and boiling their coffee, grilling their steaks, and thoroughly enjoying themselves. There were one or two disturbances with the members of No. 2 Camp; and then the rule was made that the liberty from the different camps should be on different days, and thus friction was avoided. As the early months of 1902 passed, the camps became greatly excited over the war news; the more enlightened amongst them, coming to the conclusion that a continuation of the struggle was futile, but the majority maintained obstinately that they could not and would not lose their independence. That seemed to be their one thought (Independence); they never contemplated terms. Owing to an absence of rain and wind, sickness broke out in the camp; this however affected the soldiers and officers more than the prisoners. A number of nurses, with additional (medical) aid arrived, and the enteric gradually declined; still, there were many deaths.

On June I came the cable "Peace," with no mention of terms. Prisoners and British were alike loud in their demonstrations, and the stock of champagne in the island was speedily lessened. Britishers were confident the Peace was in their favour; prisoners also were quite as confident they had at last gained their independence. For hours the suspense and excitement was great; then on the following day came the terms, and with them the downfall of the Boers' hopes.

On Sunday, June 8, thanksgiving services for Peace were offered in the Churches. At the Cathedral a detachment of Royal Garrison Artillery, who had returned from South Africa, attended, and instead of the usual organ 
music, the Band of the "Buffs" accompanied the hymn, and played the National Anthem. After service the Artillery lined up near Plantation House, when H.E. the Governor distributed to them the medals and clasps so hardly won in South Africa, and made them a most impressive speech.

All this time preparations had been going forward for the Coronation festivities; but by the cable news it was known that the King was far from well, and on June 24 was reccived the following cable: "The Coronition is postponed indefinitely, owing to the indisposition of the King, who is suffering from perityphlitis-surgical operation is necessary." This caused great depression, and all preparations for ball, regatta, teas, etc., etc., were at an end. The regatta however came off the following week, and was a great success, mainly due to the cheerful energy of Mr. R. R. Bruce, Naval Agent.

A loyal Coronation address had been illuminated by H.E the Governor and forwarded to England in a most beautiful casket of island ebony. The casket was elaborately carved by one of the prisoners of war, many of whom excelled in the art of carving. It was as follows:-

\section{FROM THE ISLAND OF ST. HELENA.}

May it please your Gracious Majesty, we, your loyal subjects of this your most ancient Colony of St. Helena, beg humbly to lay at the foot of your throme this our expression of decp loyalty and devotion to your Majesty and to our beloved Queen, your most gracious Consort, offering you our heartfelt congratulalions on this auspicious occasion of your Coronation, and praying Almighty God to bless you both with long life and unalloyed felicity and prosperity beyond measure.

After the declaration of Peace and publication throughout the camps of the terms by which the war was ended, notices were posted in English and Dutch throughout the island, and arrangements made for the taking of an oath of allegiance to Great Britain.

The following Copy of Telegram from Secretary of State to the Governor St. Helena, dated 5th June, I902, is published for general information :- 


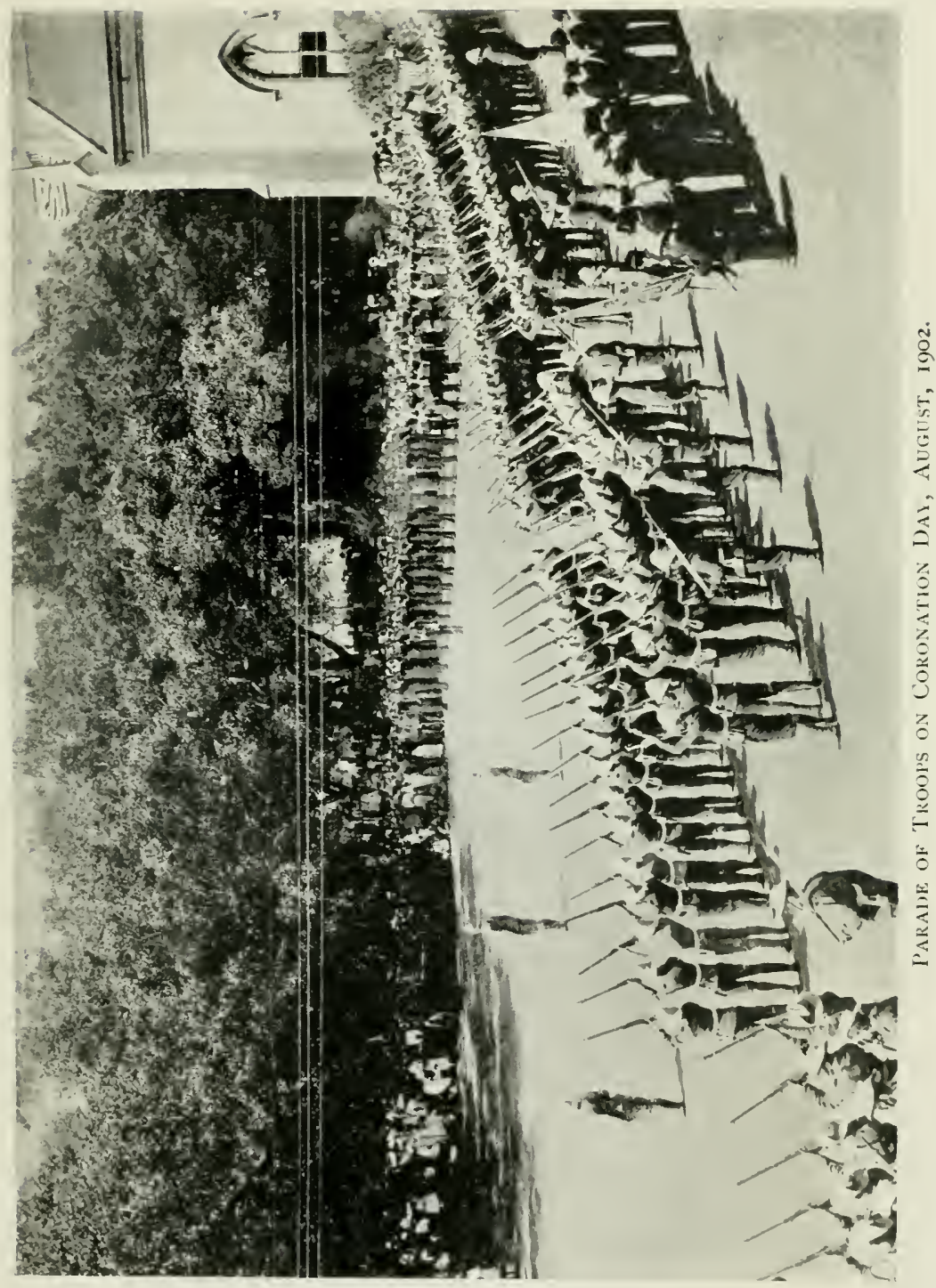



By order,

ROBERT R. BRUCE,

The Castle, St. Helena,

For Colonial Secretary.

gth June, 1902.

Terms of surrender of Boers are contained in the document signed 3 Ist May, of which following is the substance. Begins :-

His Excellency General Lord Kitchener and His Excellency Lord Milner, on behalf of the British Government; and General C. R. de Wet, Judge J. B. M. Hertzog, J. Brebner, and General C. Ollivier, acting as the Government of the Orange Free State; and Messrs. S. W. Burger, F. W. Reitz, General Louis Botha, J. H. de la Rey, Lucas Meyer, Krogh, acting as the Government of the South African Republic; on behalf of their respective burghers, desirous to terminate the present hostilities, agree on the following :-

\section{ARTICLE I.}

Burgher force will forthwith lay down arms, giving up all munitions of war, and desist from further resistance to the authority of His Majesty King Edward VII, whom they recognize as their lawful sovereign.

\section{ARTICLE II.}

All Burghers in the field outside the limits of the Transvaal, and Orange River Colony, and all prisoners of war at present outside South Africa, who are burghers, will, on duly declaring their acceptance of the position as subjects of His Majesty King Edward the Seventh, be gradually brought back to their homes as soon as transport can be provided, and their means of subsistence secured.

\section{ARTICLE III.}

Burghers surrendering will not be depriyed of personal liberty or property.

\section{ARTICLE IV.}

No proceedings to be taken against Burghers surrendering for bona fide acts of war, except in case of certain acts notified to Boer generals by Commander-in-Chief.

\section{ARTICLE V.}

Dutch language to be taught in schools where parents desire it, and to be used in courts of law where necessary. 


\section{ARTICLE VI.}

Possession of rifles for their protection to be allowed to persons taking out licence.

\section{ARTICI.E VII.}

Civil Government to be introduced as soon as possible, followed by representative, leading up to sell-govermment.

\section{ARTICLF: VIII.}

No franchise for natives till after introduction of self-government.

\section{ARTICLI: IN.}

No special land-tax in Transvaal and Orange River Colony to pay for war.

\section{ARTICLE X:}

His Majesty's Government will set aside 3,000,000 pounds (sterling) for restoration of population to thcir homes and for making good war losses. Bona fule possession of commandecring reccipts, or South African IRepublican Govermment notes will be taken as evidence of war losses. In addition His Majesty's Governnent will make advances on loan to burghers for same purpose.

Please make these terms known to prisoners of war and inform them that preparation will be commenced as soon as possible for their gradual return, but that owing to the dentuled state of the comntry it will take time belore all can be brought back.

NotA Bexe.-This is the only recognized notification.

\section{E.R.}

\section{VIERTALING.}

fermen van overgave van Bocren zyn bevat in liet document geteckend $31 \mathrm{Mci}$ 1902, waarvan het navolgende de gecst is :-

Z. E. Generaal Lord Kitchener, en Z. E. Lord Milner ten behoeve van de Britsche Regecring; en Generaal C. IR. Je Wet, Rechter J. B. MI. IIertzog, J. Brebner en Generaal C. Olivier, agcerende als de Regeering van de Orange Vry Stant; en de Hecren S. W. Burger, F. W. Reitz, de Gencraalen Louis Botha, J. H. de la IRey, Lucas Meyer, en lirogh, agecrende als de Regeering van de Z. A. R., ten behoeve van hunne respecticve Burgers begecring de tegenwoordige vyandelky heden te cindigen, komen overeen over de navolgende artikelen :-

\section{ARTIKEL 1 .}

Burgermacht moet dadelyk wagenen nederleggen, opgevende alle Krygsbehoefte afzien van verdere tegenstand te en de autoritcit van Zyne Majestcit Koning EDWARD VII, wien zy als bun wettig Sonverin crkennen. 


\section{ARTIKEL 2.}

Alle Burgers in het veld buiten de"grenzen der Transvaal en Orange River Colonie, en alle Krygsgevangenen thans buiten Zuid-Afrika, die Burgers zyn, zullen by behoorlyke verklaring hunner aanneming der positie als ondeerdanen van $Z$. M. Koning EDWARD VII trapsgewyze terug genomen worden naar hunne woniger zoodra voor transport voorziening gemaakt kan worden, en hun levensonderhoud gewaarborgt is :-

\section{ARTIKEL 3 .}

Burgers, zich overgevende zullen niet van persoonlyke vryheid of eigendom ontbloot worden.

\section{ARTIKEL 4.}

Geen stappen zullen worden genomen tegen Burgers zich overgevende voor bona fide Krygsdaden, uitgezonderd in het gevat van zekere daden ter kennisse van Boer Generalen door den Opperte velhebber gebracht.

\section{ARTIKEL 5.}

De Hollandsche taal in scholen to worden onderwezen, indien ouders zulks begeeren, en alwaar noodig in Gerechtshoven te worden gebruikt.

\section{ARTIKEL 6.}

Bezit van geweren voor hunne protectie te worden toegelaten aan personnen licentie witnemende.

\section{ARTIKEL 7 .}

Civiele Regeering zal ingesteld worden zoo spoedig mogelyk door vertegenwoordiging opleidende naar eigen Regeering.

ARTIKEL 8. ing.

Geen stemrecht aan Naturellen tot na instelling van eigen Regeer-

\section{ARTIKEL 9.}

Geen speciale plaatsbclasting in Transvaal en Orange River Colonie zal geheven worden voor oorlogskosten.

ARTIKEL IO.

Zyner Majesteits Regeering zal Drie Millioen Ponden Sterling toestaan ter herstelling der bevolking van hunne wonigen, en vergoeding van Oorlogs-Schaden. 
Bona-fide bezit van Commandeer-Kwitanties of Zuid-AfrikaanscheRegeerings Noten, zullen als bewys voor oorlogs Schaden aangennen worden.

Bovendien zal Z. M. Regecring leenings voorschotten ann Burgers voor het zelfde doel maken.

Gelicve deze termen aan Krygsgevangenen bekend to stellen, en hen in kennistellen dat voorbereidsdlen zoo spoedig mogelyk gemaakt zullen worden voor hunne trapsgewye terugzending maar dat ten gevolge van den verwoesten toestand lands, zal het tyd nemen, voor dat allen terug genomen kunnen worden.

Nota Bexe.-Dit is de cinigste herkennende kennisgeving.

E.R.

KENNISGEVING.

Van af Woensdag den i 8 de dezer, worden Burgers van de gewezene Oranje Vricjstaat en Zuid Afrikaansche Republiek, begeerig om den eed van getrouwheid af te leggen aan Zijne Majesteit Koning Edward VII, verzocht om aanzoe daartoc te doen in het Gerechts-Hof te Jamestown, tusschen de uren van 11 tot 1 voormiddags, en van 2 tot 4 namiddags (Zondagen en líroningsdag, 26sten Jun izijn uitgesloten).

Permitten voor dit doel zullen worden uitgegeven door liamp Commandanten.

De eed van getrouwheid zal worden afgenomen door Kool. $\Lambda$. J. Price, C.II.G., en Kapitein John Proctor, C.G.A., die aangesteld zojn als Speciale Commissarissen.

The Castle, St. Helena, Jahestowi,

A. J. PRICE, Kolonel, O.C.T. i4de J16ni, 1902.

\section{NOTICE.}

From and after Wednesday, 18 th inst, those burghers of the late Orange Free State and South African Republic who are desirous of taking the oath of allegiance to His Majesty King Edward VII are directed to attend at the Court House, Jamestown, between the hours of is to i p.m., and from 2 p.m. $10+$ p.m. daily, Sundays and Coronation Day (26th June) excepted.

Permits for this purpose will be granted by Commandants at each camp.

The oath of allegiance will be administered by Col. A. J. Price, C.MI.G., and Capt. John Proctor, C.G.A., who have been appointed Special Commissioners.

The Castle, St. Helena,

A. J. PrICE, Colonel, O.C.T. $14^{\text {th }}$ day of June, 1902 . 


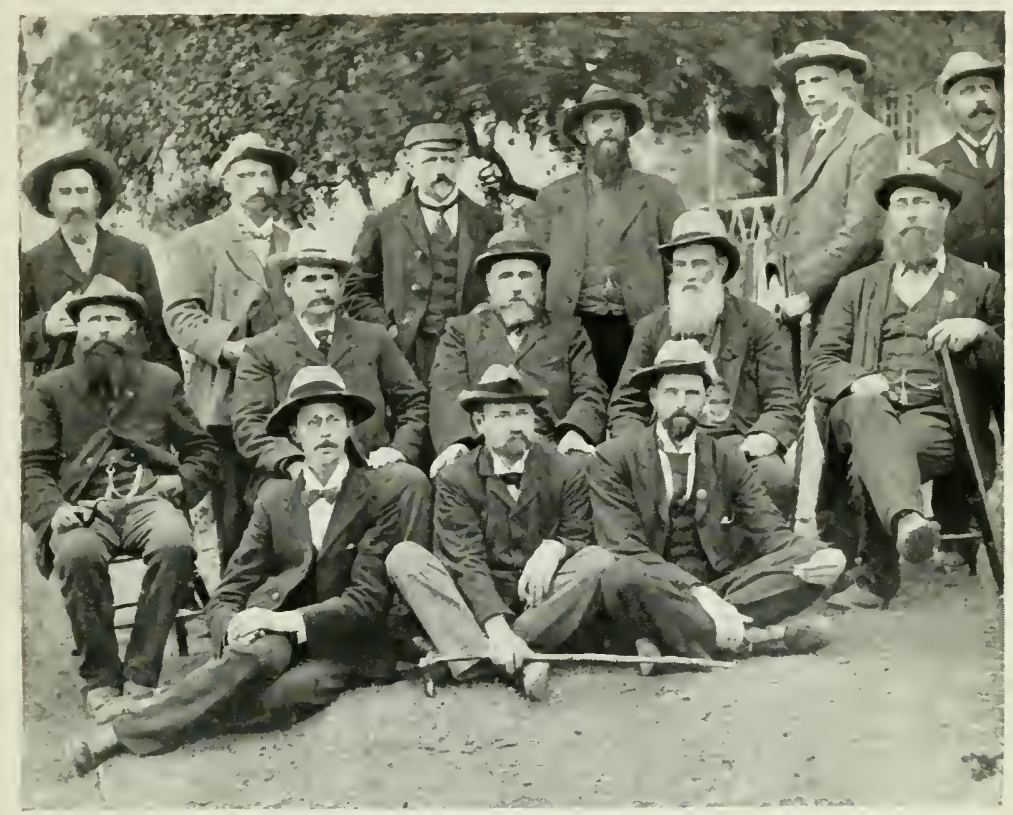

CRONJE ANI HIS OFFICERS.

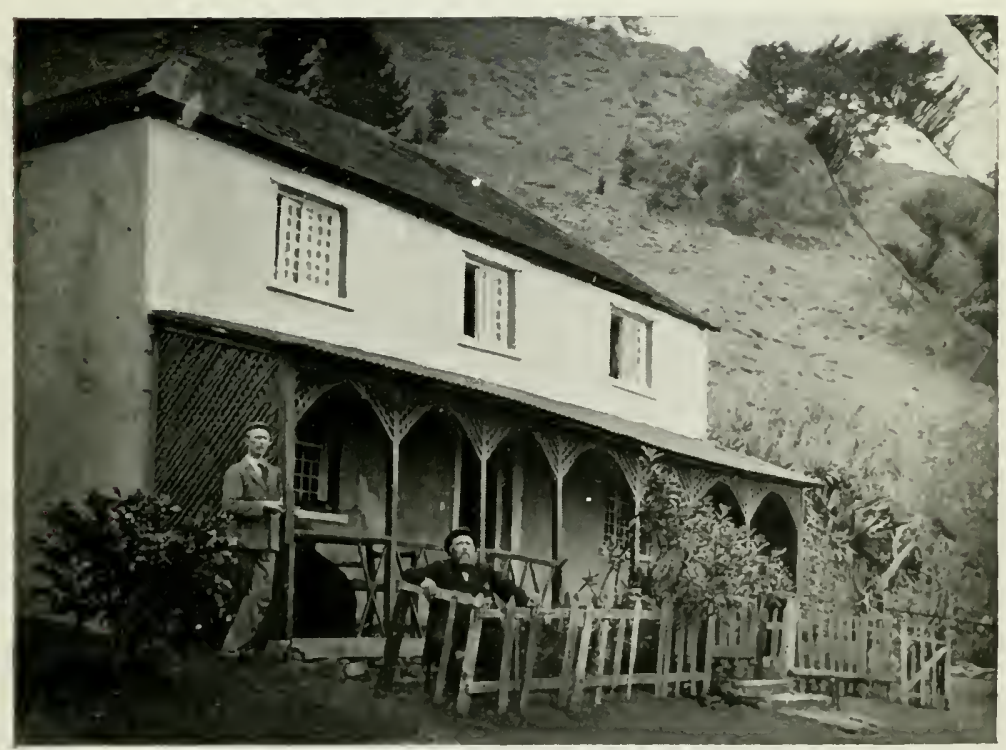

Kent Cottarf, Cronje’s Howe in St. Hfiena. 

The taking of the Oath was more universal than had been anticipated, though several hung back; amongst these, Woolmarans, who urged the prisoners strongly not to take it.

On the 25th June H.M. transport Canada arrived, 5,70I tons, from England (Capt. Maddox), also the British steamer Wakool, 3,I47 tons, from South Africa (Capt. Thomas); the latter was in quarantine, and brought the 3 rd Battalion Royal Sussex Regiment, taking a few days later the Buffs, with their genial Colonel Theodore Brinckman. On the 26th there was great excitement in the town, when over 470 who had taken the oath came from the camp to embark on the Canada for South Africa. They were escorted by the band of the 3 rd Wilts, and they marched down with Union Jacks flying. Before going off they assembled on the Lower Parade (see illustration), where H.E. the Governor bade them farewell. He said he was glad to have an opportunity of saying good-bye, and of wishing them good luck in the future. It was a mark of regard on the side of the Government that they were being sent home first, and on arrival at the Cape they would meet the loyalists from Ceylon, and so the first one thousand men to land on their native shores would be those in whom the Government felt confidence. Had all been of their opinion, and refrained from countenancing a hopeless contest, their country would not have been in the same sad condition as it now was. He felt sure, however, that under the firm and just rule of England prosperity would come again, and that all would be firm friends. His Excellency concluded by saying: "I trust we shall always be friends and grow in prosperity day by day. You have been here now over two years and we part with you with regret. We have admired the fortitude and constancy with which you have borne exceptional trials, and I feel that amongst you I am parting with some personal friends of whose welfare in the future I shall always be glad to hear. And now I bid you all good-bye, and wish you all good fortune in the years to come." This was translated in short sentences to the prisoners by Captain Froctor, C.G.A., and was replied to by Commandant Jooste on behalf of himself and his fellow loyalists. He thanked the Governor 
for all his kindness to them, and then with three cheers for the King, three again for the Governor, and another three for Colonel Wright and other officers, they marched down the parade along the wharf, headed by the band playing "Auld Lang Syne."

They were hardly able to control their excitement at the thought of seeing all those from whom they had been so long parted and of reaching their native shores after their tedious and enforced exile.

On July + His Excellency received a deputation from the German residents of Deadwood Camp, late prisoners of war. Lieut.-Colonel Hind, Camp Commandant, introduced the deputation, and Colonel von Braun presented a beautifully carved casket containing an illuminated address, which was read out by Captain Weiss as follows :-

\section{Deadwoon Casis, June 2.4 th, 1902 .}

To His Excellency R. A. Surndale, Governor of St. Helena. Your Excrlanicy, -

Having heard that peace has been proclaimed and that the prisoners of war are soon to leave the island, the undersigned take the liberty of addressing your Excellency.

In the first place we wish to express our heartfelt thanks for the kindness and consideration shown to the prisoners of war by your Excellency in issuing to the inhabitants of the island a scasonable proclamation exhorting them to treat us with the respect due to an honourable foc.

Secondly, we beg your Excellency to convey to the inhabitants of the island our sincerest thanks for the noble manner in which they have responded to your Excellency's appeal.

The kindness shown to the prisoners of war one and all by the people of the island, with very few exceptions, is a fact which will long be remembered and cherished by them as a bright speck in the gloomy days of captivity in St. Helena.

We have the honour to remain,

Constantix ron Braus, Oberst (Colonel),

Otto vos Albidyl, Commandant Z.A.R.

R. E. RUNGE,

C. Werss (Captain),

F. W. REICHARDT (Licul.)

A. GraAF,

P. ERNST,
Your Excollency's obedient servants,

R. C. SCHLEsinger, JOSEF WEIL, OtTo Schmid, JUl. Fulliard, JoHANNES ENGEL, iV. F. PLAGE, WiLnelm SCHUTte-BrockHoF, OtTo SCHEFFLer, etc., etc., etc. 
Having received the address, His Excellency replied :-

Colonel von Braun, Captain Weiss, and Gentlemen,-

It is a most agreeable surprise, for which I thank you very much, to receive from you this beautifully illuminated address in such an elegantly carved casket, both of which will always be carefully preserved by me and my family as a valued memento of the past two years.

I thank you heartily, on behalf of myself and the inhabitants of St. Helena, for the kindly sentiments conveyed in the address, and I trust that those friendly feelings which have grown up by the intercourse of the past two years will continue to our lives' end, and bear good fruit in helping to bind our two nations in closer bonds of friendship.

As the time of your departure approaches, I feel I lose some personal friends, who will not, I trust, forget me in the time to come; and to you all I wish good fortune in the future, and a bright, happy meeting at home with those who are so anxiously looking out for a re-union after the weary time, which has now, I am glad to say, passed.

On June 30 General Cronje came into the town, accompanied by his secretary, to the Castle, and there took the oath of allegiance. At his own request, his guard, which had never been withdrawn, was allowed to remain, as many of the prisoners, still obdurate, were very bitter against him. On August 22 he left the island for the Cape in the transport Tagus, with 994 other prisoners.

Many incidents tend to show the good feeling which sprung up between the prisoners and the military staff in St. Helena.

To Dr. Casey, who was in charge of the medical ward at Deadwood Camp, was presented a very handsome album by some of his Boer patients, J. Noorthout, F. J. Fick, Max Treunissen, C. E. Schutte, and J. Frus. In accepting this, he spoke very highly of his patients. His speech shows how manliness and nobility of character were predominant throughout their time of suffering: "I never had any patients who were more appreciative and grateful for even the slightest attention, and far from any grumbling or complaining spirit amongst them, they were more disposed to hide their troubles and suffer on in silence.

"Who could help admiring the fortitude of such men? Who could refuse to extend a helping hand in the hour of their need?" 
Before leaving for South Africa a public letter was written by the prisoners to the St. Hclena Guardian. In this they say :-

We find it impossible to leave St. Helena unless we contribute our share of thankfulness to His Majesty's officers placed over us from time to time, for what they have done to make us take courage to fight the future. Much is owed to His Majesty's officers for the kindness and consideration accorded by them since January 12 th, 1901, and the conclusion has been made that the prisoners of war have been squarely and gentlemanly treated. The calm Licut.-Col. Paget; the placid and collected Licut.-Col. Barclay and Hind; the manly attitude taken up by Col. Price, C.M.G. ; the even and courteous Licut. Carden, will never be forgotten; nor will they ever cease to respect the genial Captain Meiklejohn and his staff. Our heartfelt thanks go to the gentlemen mentioned for the kind and courtcous way they have received and met us from time to time-kindness that was a sweet drop in our bitter glass. Their general attilude towards us prisoners of war will always be recounted with pleasure-an attitude at once firm and manly; and worthy of admiration-and why' Because 'politeness" was evinced in all their actions and doings.

Very quickly were the preparations made for the removal of the prisoners. The special court constructed for the administering of the Oath of Allegiance, opened directly after the declaration of peace, continued till September, when it terminated according to the following public notice.

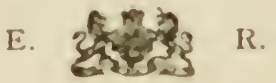

\section{Notice.}

Notice is hereby given that by order of H. E. the Governor, Colonel A. J. Price, C.II.G., the special Court constituted for administering Oath, or taking declaration of allegiance to His Majesty Fing Edward VII by the burghers of the late South African Republic and Orange Free State will close on Saturday next, the 6th of September, 1902, at 12 o'clock noon.

By Order,

JoH: Proctor, Captain,

Special Commissioner.

Court House, Jamestow:, and Sept., Igoz. 


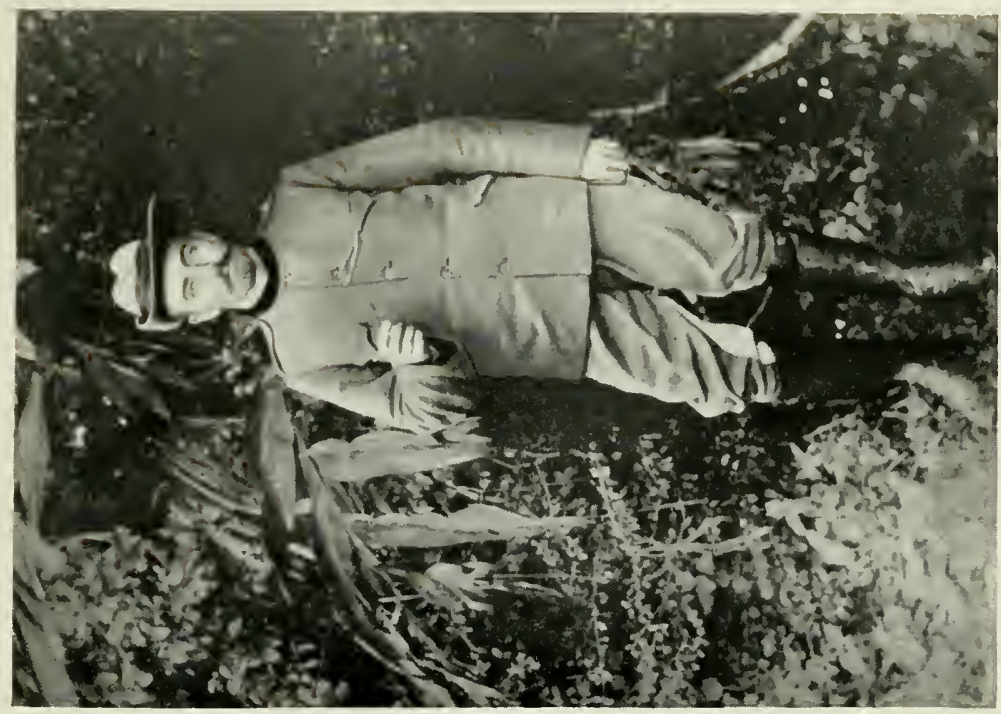

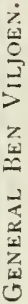


<smiles>CCC[As]CC</smiles> 
This was also posted in Dutch :-

Op last van Z.E. de Governeur Kolonel A. J. Price, C.M.G., jal het special Hof gemachtigt tot bet afnemen van de eed of declaratie van getrouwheid aan Zijner Majesteit Koning Edward de Zevende van Burghers van de gewezane Zuid Afrikaanche Republiek en Orange Vrij Staat worden gesloten op Zaterdag de 6den Sept., 1902.

Op last, John Proctor, Kapt.

By this time very few remained obdurate concerning the oath, and the greater number had already embarked after their enforced sojourn of considerably over two years. The Golconda in October took the last batch, and one can imagine how varied were their thoughts, while they travelled back as British subjects to the two republics which have become part and parcel of the British Empire. The ships conveying the prisoners were as under :-

Canada left St. Helena on June 26, taking 370 (Peace Camp) and I Io others.

Kirkfield left St. Helena on July 7 , taking 1 I.

Goorkha left St. Helena on July 25, taking French prisoners to Europe.

Abaka left St. Helena on August I, taking 20 prisoners of war.

Avondale Castle left St. Helena in August, taking 20 prisoners of war.

Tagus left St. Helena on August 2I, taking 994 prisoners of war.

Canada left St. Helena on August 2I, taking 984 prisoners of war. Malta left St. Helena on August 30, taking 990 prisoners of war,

Goorkha left St. Helena on September 18, taking 12 prisoners of war.

Orotava left St. Helena on October 8, taking 990 prisoners of war.

Braemar Castle left St. Helena on October 12, taking 2 prisoners of war.

Golconda left St. Helena on October 2 I, taking remainder,

but leaving the Cape rebels and a few unpardoned men still on the island. General Ben Viljoen left in July, and Cronje, as before stated, in August by the Tagus. During the whole time the prisoners were on the island steamships were constantly arriving with live cattle (and provisions such as potatoes, onions, and the usual tinned rations, as well as medical comforts and stores). It is said each beast cost about $£ 25$ in England, which, with about $£ 25$ freight, made the sum expended in beef alone for military and prisoners no small item. 
In August His Excellency Governor Sterndale had been compelled through ill-health to leave his post, the Governorship being undertaken by Colonel Price, C.M.G., O.C.T., and it was with profound and deep regret that the inhabitants received a cable announcing his death in England of sudden failure of the heart, on October 3. for he had been cxpected to arrive again in the island in November. For five years he had administered the Government, and his courteous kindly manner will always be remembered by all classes of society. The fountain in the garden, the road round the West Rocks, the improved wharf, the muscum, which it is greatly to be hoped will be kept up and added to, and the new drainiage system will testify to his many works of improvement. In Novenber Lieut.-Colonel Henry Lionel Gallwey, C.M.G., D.S.O., scnior division, was appointed Governor.

The West India Regiment had been ordered to St. Helena to replace those regiments stationed there during the war, but the inhabitants, having suffered before from the mutinous conduct of this regiment, petitioned against the order. The Colonial Secretary therefore refused to allow them to proceed on account of the objection raised, and the War Office accordingly decided to send two companies of the South African line regiment in their place.

The following postal statistics are of interest as showing the work done by the postal staff, which is small. The heading, Money Orders, shows a decrease, but in every other department there is a substantial increase, especially in the number of mail bags, there being an increase of 443 during the eight months of I902 as compared with the same months of Igor. The increase of monies received in the island is also worthy of notice :- 
Comparative Statement of the Working of the Post Office for the FIRST EIGHT MONTHS OF THE YEARS I9OI AND 1902.

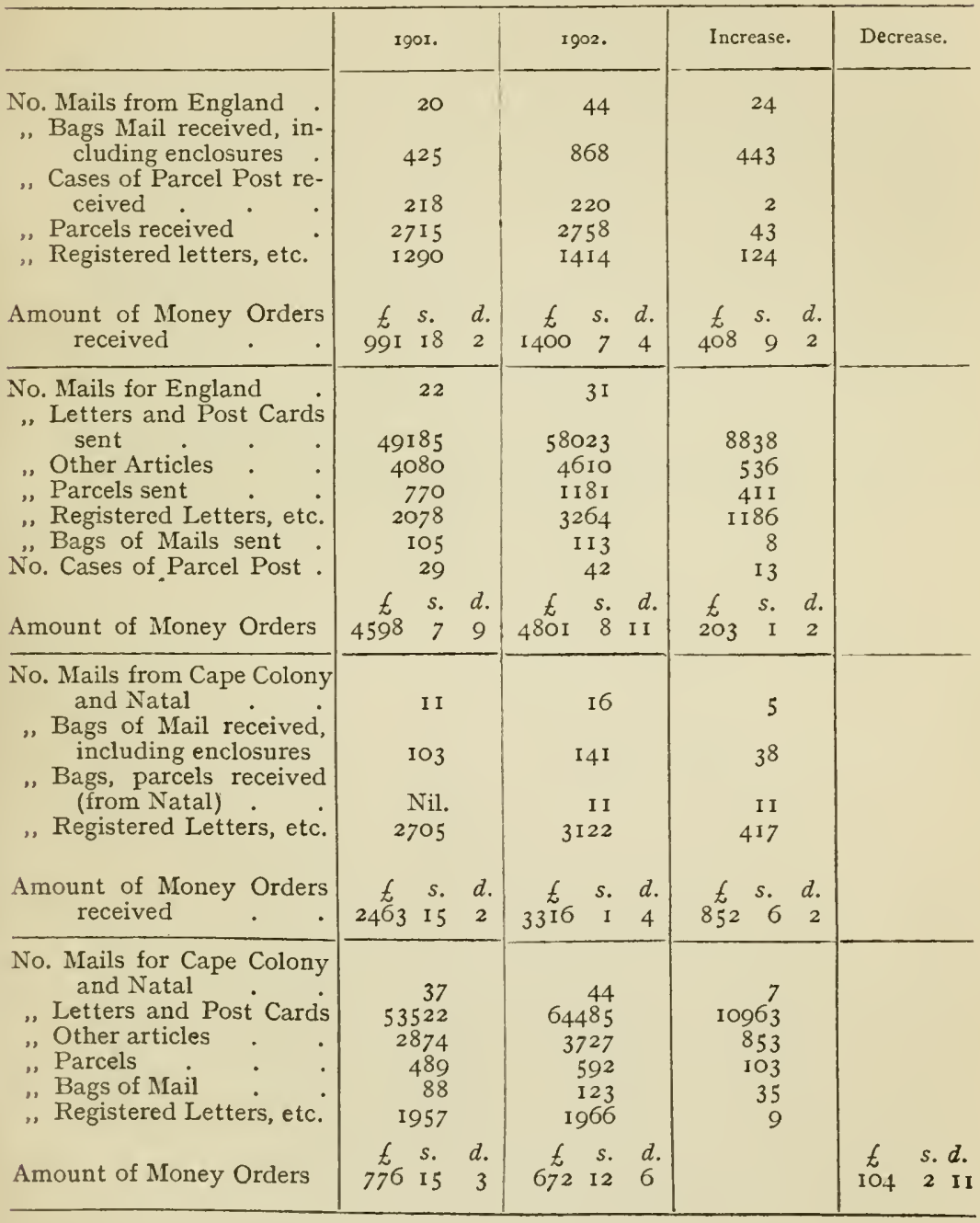


Tue Accounts of tile Parisil of St. Helexa for tue The Overseer of Poor in account with the Parish of

Dr. April 1, เ901.

To Cash in hand,

"Rates for qr. ended June 30, 1901

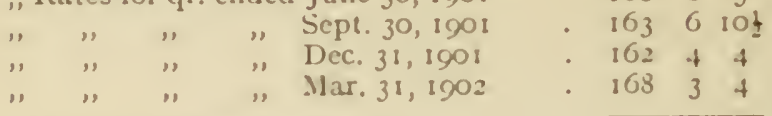

Arrears of rates collected-

,Q Qr. cnding June 30,1901

Sept. 30, 1901

Dec. 31,1901

Mar. 31,1902

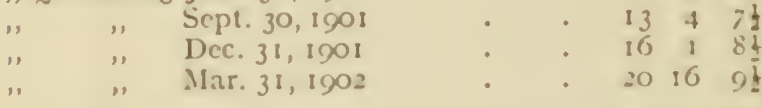

$£$ s. $d$. . $\quad 8515 \quad 91$ $654 \quad 0 \quad 91$

, Relief from Women's Society for

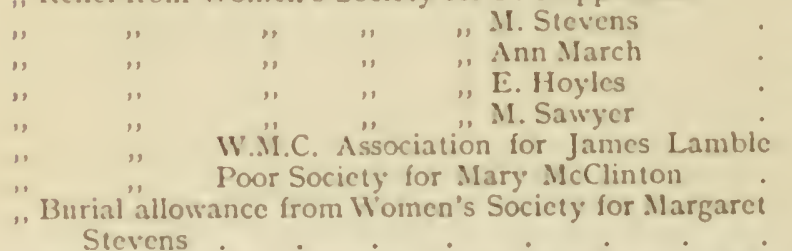

„Burial expenses refunded, John Fuller, 6s.; Jas. Lamble, 24 ; Jemima Phillips, LO . . .

$\begin{array}{lll}6 & 4 & 7 ! \\ 2 & 1 & 2 \\ 2 & 0 & 4 \frac{1}{2} \\ 2 & 1 & 2 \\ 2 & 1 & 2 \\ 2 & 0 & 4 \frac{1}{2} \\ 0 & 9 & 2 \\ 0 & 4 & 6\end{array}$

, Maintenance Jane Flagg

"Police fines

"Amount overcharged refunded

"Cash from Colonial Govern-

ment on account of Dog

Tax, 1901 . $\$ 12100$

"Less $10 \%$ Commission . $\ell^{2} 50$

"Cash from Colonial Govern-

ment on account of Dog

Tax, 1902

„, Less 10\% Commission : $\quad 664 \%$

$$
400
$$

1060

1160

7160

$\begin{array}{lll}0 & 15 & 0\end{array}$

$\circ 90$

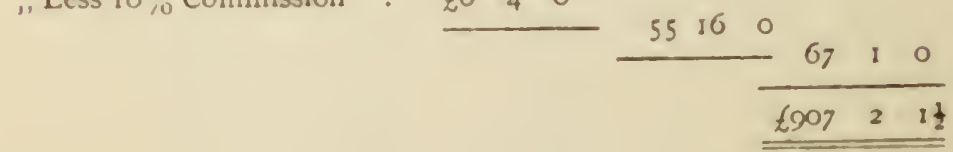




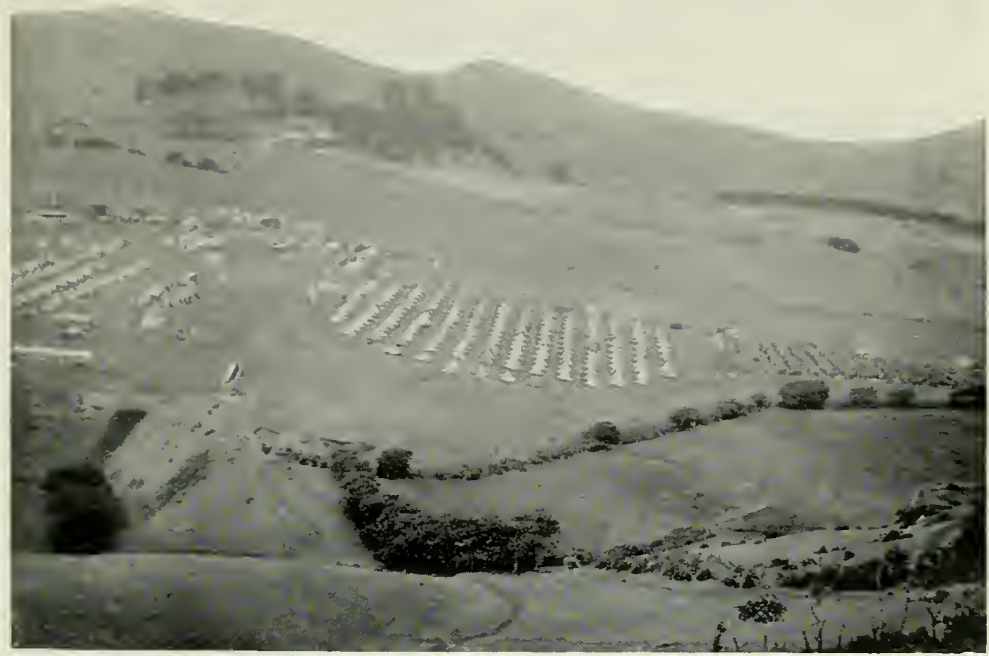

Broanbotrom CaMP.

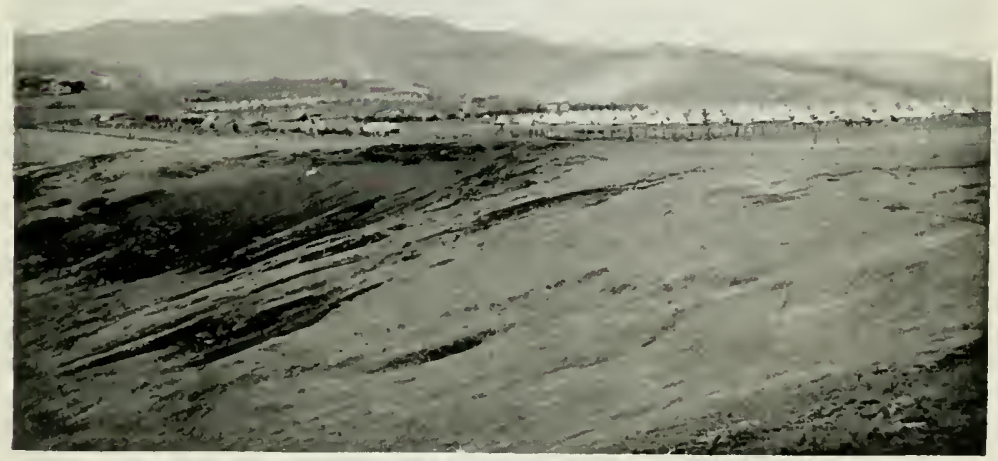

DEAINOON CAMP. 



\section{ST. HELENA}

Year endiNg March, 1902, GIVE THe following :St. Helena for year ending March 3I, 1902.

$\mathrm{Cr}$.

March 31.

By paid Surgeon ", paid Dispenser

, paid Assistant Overseer

, Mratron Poor House

„Matron Lunatic Asylum

", Keeper

"Weekly relief"

"Monthly ",

"Casual ",

"Maintenance of Leper

„Coffins

„, Burial expenses

„, Hospital

"Printing and" advertising

"Clothing and Bedding for inmates

Medicines

, Fire insurance to I 5 th February, 1903

", Water rate

,, Sanitary repairs.

"Repairs and making cells in Lunatic Asylum

"Provisions

", Incidental expenses

"Cash in hand

$\lcm{6907 \quad 2 \quad 1 \frac{1}{2}}$

Examined in detail and compared with vouchers and found correct,

T. L. M. Adans, Chairman.

Thos. JACKSON,

WM. HARRISON,

O. W. BAgLEY. 
Assets of the Parish of St. Helexi, April $1,1902$.

Arrears outstanding-

To Dec. 31, 1901

, Mlar. 31, 1002 .

"Assessment on $£ \$, 000$ (1) $5 d$. in \{

"Cash in hand
\& s. d.

$$
\begin{array}{lll}
217 & 11 & 61 \\
212 & 9 & 91
\end{array}
$$

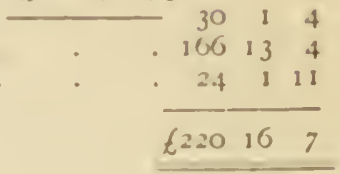

The Oicerseer of the Poor in accownt with the Parish of St. Helena

To Cash in hand

, Government contribution

„Rates collected-

Quarter ending June $30,1 \mathrm{~m}$,

$$
\text { ", ", }
$$

" $\quad$ Dec. 31, 1001

Sept 30, 1001.7128

Mar. 31,1102

"Arrears of Rases collected-

Quarter ending June 30, 170

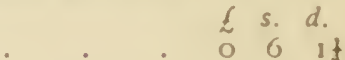$$
\text { , , , }
$$$$
\text { " , }
$$$$
\text { Sept. 30, } 1001
$$$$
\text { ", ," }
$$

Dec. 31,190

Mar. 31, 1902

$$
\begin{aligned}
& \text { f s. } d \text {. } \\
& \text { - } 7117 \\
& \text {. } 7186 \\
& \text { - } 716 \text { o) } \\
& \text { \& s. } d \text {. }
\end{aligned}
$$$$
3012 \quad 6 !
$$

"Amount achanced by Assistant Overseer

\begin{tabular}{rrrr}
0 & 0 & 5 & 71 \\
0 & 11 & 71 \\
0 & 13 & 5 \\
1 & 10 & 01 \\
\hline
\end{tabular}


Estimated Liabilities for Quarter ending June 30, 1902.

Salaries

Outdoor paupers

Provisions

Hospital expenses .

Coffins and Burial expenses

Printing and advertising

Incidental expenses t s. $d$.

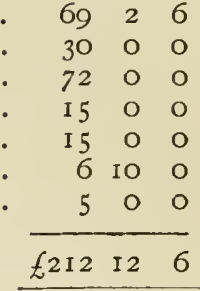

for the Lighting of Jamestown for year ending March 3I, 1902. Chimneys and wicks $\quad \cdot \quad \cdot \quad \cdot \quad \cdot \quad$\begin{tabular}{lll}
0 & 5 & $7 \frac{1}{2}$ \\
\hline & 0 & 0
\end{tabular} "Repairs to lamps . . . . . . $\quad . \quad 286$

"Making new lamps . . . . . . . . . o I6 6

New burners . . . . . . . . . 0 . 076

"Oil $\quad . \quad . \quad . \quad . \quad . \quad .2136$

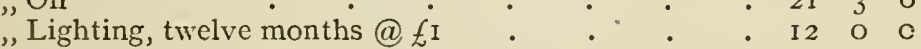

Assistant Overseer, keeping account : $\quad: \quad 600$

"Incidental expenses . . . . . $\quad . \quad 070$

$£ 44$ I $7 \quad 5 \frac{1}{2}$

A. L. Innes, Overseer.

Examined and found correct,

A. McIntyre, Auditor. 


\section{DESCRIPTION}

TuE natural strength of the island lies in its compact form and size together with its inaccessible coast, formed by an almost uninterrupted belt of rocks which rise perpendicularly to the height of about 600 to 1,200 feet. It appears, when viewed from vessels at a distance, to defy entrance; the lofty barren hills divided by huge fissures and deep gorges with a total absence of any regetation other than a few patches of samphire and cactus, present a most formidable appearance; for none of the beautiful woods and pastures of the interior can be seen from the sea.

Melliss, in his work on the island, says :-

Its isolated position, its peculiar fauna, and its very remarkable insular flora, together with its geological character, present strong reasons for placing St. Helena amongst the oldest land now existing on the face of the globe. It is said that out of sixty-one native species, only two or three are found in any other part of the globe.

On nearer approach the gorges appear as valleys which narrow as they wind inland toward the central ridge. Bankses, Rupert's Bay (the sea shore of Seine Valley), Chapel Valley or Jamestown, Lemon Valley or Spragues on the north side of the island, and Sandy Bay on the south, are the places suitable for landing from boats or ships. Jamestown in Chapel Valley is almost due north, and its site was probably selected from its being the largest ravine and the most sheltered. There is a good anchorage from twelve to twenty-five fathoms deep. A chart issued by Mr. G. Thomas, who was here in the Northumberland with RearAdmiral Sir George Cockburn in the year I8I5, shows that the soundings are very various. The sea-bottom slopes gradually for a distance of one to one and a half miles to sixty or seventy fathoms, after which the depth is about 


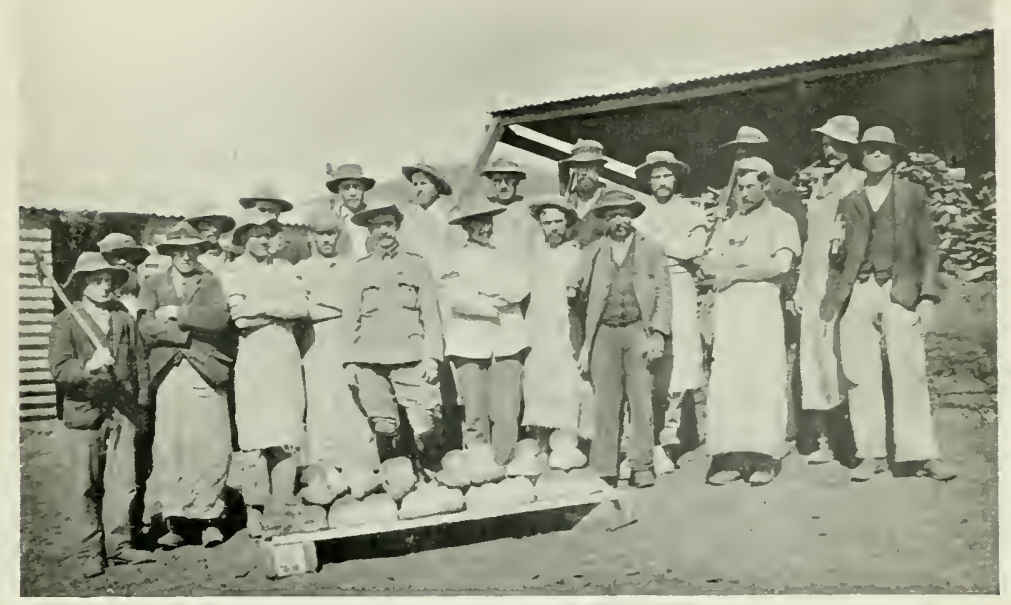

BAKERY, BROALBOTTOM CAMP.

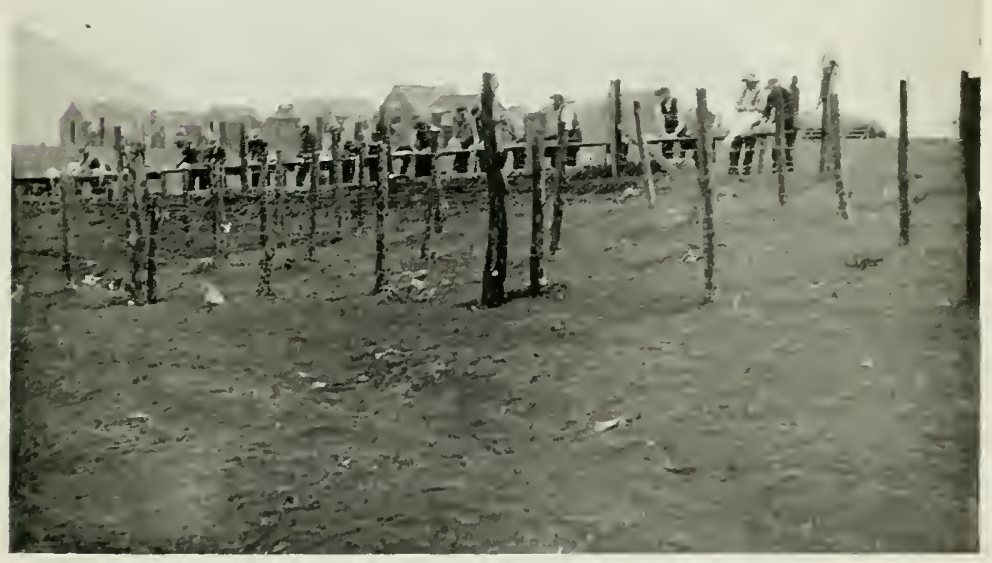

Scene ta Came, Washing hay.

(Showing Barbed Wire Fencing.) 

250 fathoms, while in many places it is such that no soundings can be obtained. Along the coast are many caves, some high above the water-mark, others below, so that the sea penetrates far into the base of the island. In these holes or caves the air is so strongly compressed by the inrush of water that wherever there is a crack or ontlet in the rock the water emerges in a strong jet or fountain, similar in appearance to the spoutings of a whale. In many cases these spouts of water are near the sea-level, in others they appear on the face of the cliff sixty or seventy feet above ; this is the case near Egg Island.

Several islands lie near the coast, but none of any size, Egg Island, Sperie and George Island being the largest. Guano is collected from these and from the cliffs, and was formerly exported ; of late years the constant employment of the labouring class by the Government as mule-drivers, messengers, etc., has caused the collection of this to be neglected. Of fish it is computed that seventy-six species frequent the coast. These are :-

The whale, groundshark, shovel-nosed shark, dog shark, mackerel, sunfish, albicore, porpoise, bottle-nosed porpoise, white conger, red conger, speckled conger, green conger, yellowtail, cavalli, coal fish, stone bras, beard, striped, shrimp, cunning fish, flying fish, trooper, two kinds of green fish, old wife, silver fish, five fingers, gurnet, three sorts of mullet, three sorts of bull's eyes, two kinds of jacks, pilot cavalli, bonita, dolphin, pilot, soldier, baracoota, pike, serpent, parrot, turtle, sword, thrasher, kingson, sandspear, rockfish, trumpet, sole, cat-fish, flying cat-fish, sucking, lantern-fish, bottle-fish, two kinds of hog-fish, cod, devil, lathercoat, bream, snake, flounder, two kinds of eels, crayfish, rock oyster.

The albicore (which in the Mediterranean is called the tunny, and in which great trade is done) can be caught plentifully all the year round. The bonita is also very abundant. Conger-eels abound and salt well.

It is said that the livers of mackerel yield a valuable oil which is worth $f_{1} 2$ per ton.

Sharks come so close to the shores that they prevent much sea-bathing. These, if caught, might be a constant source of considerable profit, and fisheries have been established 
in various parts of the world for the express purpose of capturing sharks, whose oil and skins command good prices, the fins also being a valuable article of commerce in China, who draws her supplies chichy from Australia.

Long legs and stumps or cray-fish resemble the lobster in taste and colour and have the same kind of tail.

Rock oysters in some situations are hardly distinguishable from the rock.

The coal-fish is so cilled from the black hue of its skin; it is from two to three feet or more in length, and very thick about neck and shoulders; highly flavoured and delicate, being not unlike a salmon in taste. The fish is not very abundant, and when obtainable fetch 25 . to 3 s. each.

The flying fish about the shores are often chased by porpoise, shark or other voracious enenies, and frequently meet their death by jumping out of the water on to the hard shelving rock. They measure sometimes more than two feet in length, a size which I am told they do not attain elsewhere.

Between the monthis of December and March, turtle frequent the island, but of late years they have been very seldom caught.

Whales are not infrequently seen, and they have been caught in the roads by the South Sea whalers. There is no doubt, if a few expert fishermen were employed, a considerable number might be caught each year. The species frequenting the island is called the "race-horse" whale, and yields, it is said, about five tons of oil.

In the early days the only mammal was the manatee, or sea-cow (probably the Manatus australis, or $M$. Senegalcnsis), the former being the American, and the latter the African species. It may however lave been peculiar to the island; from the earliest times it has been killed when found, the last one mentioned being in ISIO, and there is not even a bone left for the study of the naturalist.

With such a variety of fish there is no doubt that the establishment of a proper fishery would be of great advantage to the island. The general mode of fishing practised is that of hook and line; and generally from open boats moored near the shore or upon the banks and ledges situate around the const.

The most productive of these banks is called New Ledge, 
the centre part of which lies about two miles to the south west and is composed of rocks and sand. Its soundings are from forty to sixty fathoms and only useful for fishing in calm weather. About one and a half miles from land is Sperie Ledge, over which there are four fathoms of water. Here the sea breaks at times with great violence.

Barn Ledge lies about one mile off Turk's Cap. The soundings here run from four to twelve fathoms; the sea here breaks also with violence.

There is another bank to leeward about a mile distant, where the soundings are from forty-three to forty-eight fathoms.

Forts were placed on the different points of the island, and in the old days were well fortified. We read before the arrival here of Napoleon "these are well fortified by fleur d'eau batteries provided with furnaces for heating shot and flanked by cannon placed upon the cliffs far above the reach of ships' guns. Mortars and howitzers for showering grape upon ships' decks or upon boats attempting to land are also provided." The dismantled forts remain, and at Bankses is still one of the iron furnaces used for heating shot. Munden's Battery is now well fortified, as are also Ladder Hill and High Knoll.

The island is $10 \frac{1}{2}$ miles long by $6 \frac{3}{4}$ broad and lies in lat. S. $15^{\circ} 55^{\prime}$. Long. W. $5^{\circ} 46^{\prime}$. It contains forty-seven square miles.

Its distance from the west coast of Africa is

South America

I,200 miles.

\begin{tabular}{|c|c|c|c|}
\hline & & South America & 1,800 \\
\hline & ," & Tristan d'Acunha . & 1,200 \\
\hline & ", & the Isle of Ascension & 700 \\
\hline & " & England . & 4,400 \\
\hline & $"$ & Cape of Good Hope & 1,750 \\
\hline
\end{tabular}

The surface is very diversified, and distinctly of volcanic origin, having no trace of continental land nearer than I,200 miles, and possessing plants, insects, birds and shells found nowhere else.

A mountainous ridge, varying in height to upwards of 3,000 feet, crosses the island from S.E. to S.W., dividing it distinctly into two parts, the slopes leading from it being the most fertile spots, and, forming the chief and richest pasture lands, present a very marked contrast to the barren rugged rocks surrounding them. The majesty of one part, 
the beauty and repose of another, and the horror of a third cannot fail to delight and astonish every admirer of nature.

The northern side is divided by spurs of ridge-land, but it slopes gradually, divided into narrow clefts which widen and become as they near the coast deep huge ravines and valleys; c.g. Rupert's Valley, Jamestown Valley, Lemon Valley, and Deep Valley. On this central ridge are situated the three highest points of the island:-

Diana's Peak

Cuckold's Point

Acteon

2,740 fect.

2,672 "

2,704

These are all clothed in a forest of old-world flora-treeferns, dogwood, gum, and cabbage-trees. Half way up the peak of "Diana" is "Taylor's Flat," a favourite spot for picnics, and near this was the valuable plantation of cincliona, now utterly neglected.

To the East are Halley's Mount

Iilag Staff

The Barn

2,467 feet.

2,272

2,015

The other points of interest are :-

Sandy: Bay IRidge .

Long Range

Alarm House

High Knoll

Longwood House

Columuar Ple "Lot"

Columnar Pile "Lot's Wiíe"

Base of the Friar

Coffec Grove and Bamboo Hedge in Sandy Bay.

Turk's Cap

Ladder Hill

And the Calcarcous vein on the north-west of Flag-

staff Hill in which the fossil shells are found . 1,61

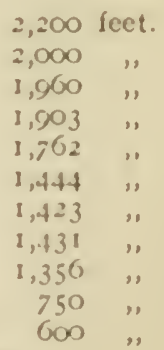

The plain of Longwood and Deadwood, the eastern end of the central ridge, comprises I,500 acres of land, 2,000 feet above the sea, and has a south east slope. Here were placed the camps for the military and for Boer prisoners in I 900 , and here it is contemplated, in course of time, to make barracks. There were in the town extensive barracks which were pulled down. At an enormous expense bricks were imported by the Imperial Government, although the 


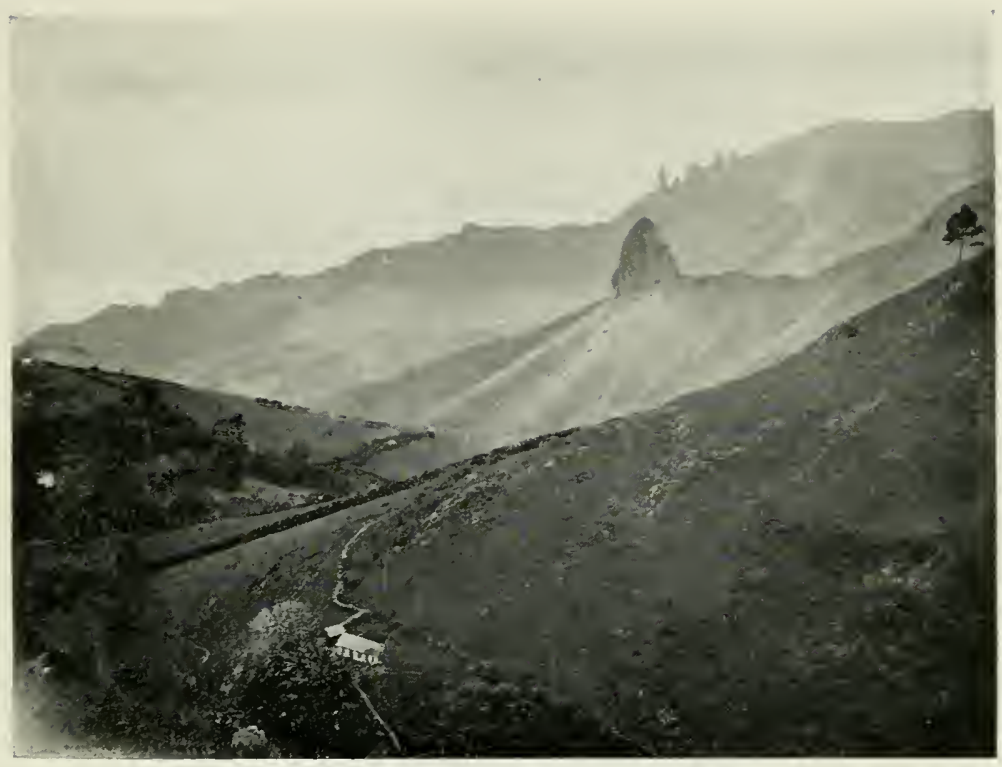

VIEN OF SANIY Bay, LoOkixg South.

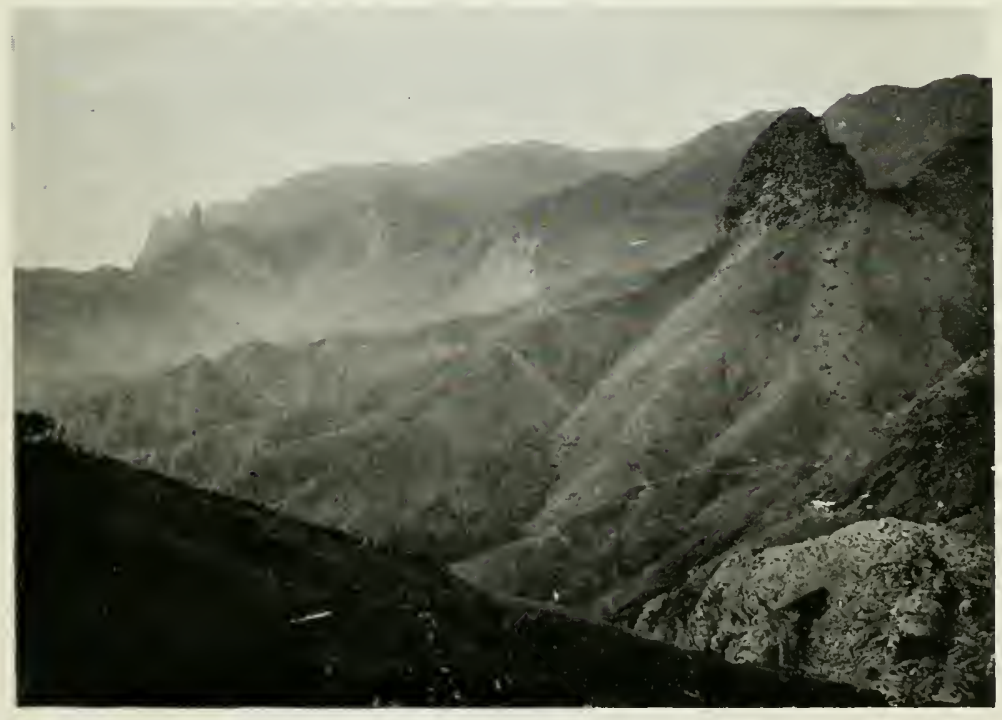

Closer view of Sandy Bay. 

island abounds with good building-stone. Foundations were dug and walls to the height of a few feet built; this building was then abandoned, and the unfinished walls surrounded by unused and broken bricks still remain, an eyesore to the community.

To the south of the central ridge lies an enormous basin called Sandy Bay, measuring about four miles across. This forms part of the huge crater which existed at the volcanic period.

Thick vegetation, for the most part of indigenous growth, clothes the high central ridge, extending down the sides of the southern slope for about a mile, where suddenly it merges into barren ground, with a few struggling shrubs and thin grass, which gradually disappears, leaving the stretch to the sea a scene of rugged, barren and desolate splendour. To stand on the ridge looking south over Sandy Bay is one of the most enjoyable sights to a pedestrian. The cool tradewinds weeps up the valley over the ridge; at the edge of the precipice it is strong, almost more than one can stand against, yet a few feet back, only a breath of balmy air is perceptible. Of course only a bird's-eye view can be obtained from such a height, but it is a view which never fails to silence the sightseer.

Brooke, in his history of St. Helena, describes it graphically. He says :-

The hills on the left (i.e. Diana's Peak and Acteon), richly clothed with trees to the very summits, display a wonderful contrast to the wild and grotesque nakedness that triumphs on the right, where shelving cliffs, surmounted by huge perpendicular or spiral masses of rock, are multiplied under every shape and aspect.

\section{Another writer says :-}

On the right great rugged mountains, black and naked, stretch their craggy peaks heavenward, the rocky summits being split and rent into the most fantastic outline, and seeming in their huge uprising to have shivered the strata through which they forced their way, and sent the boulders rolling into the vast abyss below in all directions.

The downward view consists of a variety of ridges, eminences, and ravines, converging towards the sea into one common valley. 
Conspicuous in the centre of the huge basin, the rocky pyramids of Lot and Lot's Wife shoot their weather-worn pinnacles abruptly out of the surrounding scoria, while at a short distance from these is the peculiar columnar pile "Asses' Ears." Lot is a monolith of hard grey stone shaped like a cone, situated on a ridge about $I, 4+f$ feet above the sca, and rising from a base 100 feet in diameter to a height of nearly 300 feet. About a mile to the south-west lies Lot's wife, another monolith about 260 feet high, and $1,55^{\circ}$ feet above the sea; this has the peculiarity of being narrower at the base than at the top.

On the gentle slope, where vegetation is rife, there are houses and cultivated grounds, vegetable and corn-fields all snugly placed amid thick groves of trees; the coffee grown on this slope is the best obtainable, while the pasturelands, dotted with grazing cattle and sheep, form a contrast incleed to the lower part, where the prospect closes in with the distant sea, whose narrow fringe of surf rushes in between the black and craggy cliffs, whitening them with its spray. Beyond lies the vast Atlantic Ocean. From the small beach which it washes, a party of prisoners of war tried to effect an escape in an open fishing-boat which they endeavoured to buy from the fishermen. The latter, it is said, held the prisoners in parley while one of their number went to the camp and reported the matter. The arrival of a military guard, under whose escort they were marched to camp, ended the matter. Had they taken the boat, there is no cloubt but that all would have perished, for it was very old and dilapidated, and, not a fortuight after, during a heavy sea, became entirely unfit for use except as firewood.

Limestone of an excellent quality is in abundance in Sandy Bay, and is said to be a concretion of shells with sand or sometimes clay. The heights close to Sandy Bay beach are chiefly composed of it. Lot's Wife beach is covered with a white sand consisting almost entirely of fragments of limestone. On the opposite side of the island (north) in Rupert's Bay, and Bankses Battery, lime is also found. That it was burnt and in use as late as I 886 may be seen from the following advertisement culled from the St. Helcna Adrertiscr:- 


\section{ST. HELENA}

NOTICE.

To be had on the shortest notice and quick despatch at the store of the undersigned :- "Island lime."

July 6, I 866.

(Signed) N. D. Sмiтн.

But neither lime nor shells are found in the interior.

The subsoil throughout the island is clay, of various kinds. One is called marl, but it does not effervesce upon the application of acids. When divested of its superincumbent earth, it has often the appearance of stone, but on exposure to the atmosphere it soon separates. It is frequently used as a substitute for gravel on the roads and does not generally clog like clay; it is however very slippery in wet weather. Lands near the coast, when not entirely rock, have a thin covering of loose friable earth, which if well watered is very productive, particularly in the valleys. The soil upon the summits and steep sides of the hills in the interior is rich, though light and of no great depth. The surface-covering of other parts is various-from soil as light as dust to heavy black clay, the greater part of the intermediate lands between the verdant heights and the barren outskirts being of a fine loamy soil from four inches to three feet deep, upon a stratum of good yellow or red clay. A good deal of plaster of Paris has been found in Prosperous Valley. It is dug from the rock not more than a foot below the surface, and is very easily reduced to powder. It makes a good plaster and also a beautiful shining whitewash for walls. Sand and gravel are rarely met with except near the coast.

Governor Beatson (I8I5), in his book, says :-

Many of the soils of the island are wholly destitute of sand, and this circumstance is that which causes all attempts to make bricks a failure.

Bricks of good quality have however since been made. Mr. Thomas Deason, of Longwood, manufactured bricks of good quality with which he built a windmill tower. This, although more than twenty years old, still is in excellent condition, the bricks showing no signs of deterioration. Bricks also have of late years been made in Friar's Valley and used in the renovation of Friar's Lodge; these latter were made by the Boer prisoners of war. 
Iron ore has been found in some parts of the island, but any idea of its fusion is precluded by scarcity of fuel. As shown in Governor Pike's time, appearances of gold and copper were discovered and near Turk's Cap there are veins of a stone which takes a most beautiful polish and which will bear cutting for scals.

The clays and earth of the interior are most interesting. On the sides of the ravines in the eastern and southern part, the infunite diversity of the tints of red, white, blue, purple and grey which overspread the whole of this extraordinary panorana are marvellous in their shading, and of such brilliance when the sun is on them, that descriptions by pen or even by brush is difficult. The strata of red soil which is so often seen throughout the island contains a large mixture of salt. A few hours' boiling separates the latter from the red soil, and filtrations through these beds will possibly account for some of the brackish springs to be found; yet not for all. One spring near Longwood contains a considerable quantity of sulphate of magnesia, and is noticed to be rather warmer than the surrounding atmosphere; this water operates as a carthartic, and is said to resemble the Bristol Hotwells in taste. In 1887 a small quantity of water trickled over the rock on the side of Peak Hill, so small a quantity that there was hardly a llow; this was so salt that it was not drinkable, whereas, now, in I902, flows over the same rock a little stream, hardly to be termed brackish, and very pleasant to the taste. The stroam has developed to the extent of placing a drinking trough for animals under its fall. Clear and wholesome springs issue from the sides of almost every hill; but as they have not much volume, nor any length of current, they form only small rills. The island is a mass of hills and valleys, and from this circumstance visitors might expect to find a number of picturesque cascades, yet there are no waterfalls of any magnitude. One stream projects itself from Francis Plain r,250 feet above the sea level into the valley of Jamestown below, a height of 260 feet; but as a general thing the stream is so thin that it becomes a shower of mist before reaching the cavity below; still, after heavy rains it is swollen to a torrent and descends in a continuous stream. At such times, however, its effect and beauty are greatly 
marred by the mud which it gathers during its course. It is somewhat remarkable that while many of the streams, springs and rills abate considerably, or are entirely dried up during a dry season, some few remain undiminished, and it is said that two, one in Fisher's Valley and another at the Briars, are enlarged during the continuance of dry weather, and at such times seem to glide with increased velocity at the same time remaining transparent and pure.

The drinking-water in Jamestown is remarkably pure and good and is conveyed in pipes from a spring at Chubb's Spring. Fresh pipes have been lately laid during the presence on the island of the prisoners of war; and although the first workers have now left the island, this water system is being greatly extended at the present time (I902) by the prisoners still remaining.

St. Helena contrasts strongly with Ascension as regards water, for there are over 200 springs discharging fresh water. The climate is one of the finest in the world, even being drier in parts than Madeira; and its effect on weak-chested and consumptive patients has been most beneficial. Virulent diseases, such as smallpox, yellow fever, do not live even if brought by the shipping, of which there is little fear owing to the strict quarantine regulations. Its situation accounts for this in the sweep of the always fresh and healthy south-east trade-wind; it is far removed from any malarial influence, and is kept so much cooler than the position and latitude would lead one to suppose. Many Europeans wear the usual English soft caps, yet sunstroke is unknown.

The temperature, too, is greatly lessened by the cool current of water which flows from the Antarctic regions toward the island; but about twice in the year, which is generally at the time known as the "roller season," the current sets strongly from the Equatorial regions, when there is a closeness and oppression causing amongst Europeans a depression of spirits. Often at this time a stagnant calm prevails, or it may be a slight wind from the north, which is almost unbearable in the town; then natives may be seen with their heads bound, and on asking why, you would invariably receive the answer: "The wind is blowing the wrong way" - and wrong indeed it seems to be, for it 
brings weariness and headache in its train. Still, it does not last long enough to produce serious consequences; in a few hours the wind will once more shift to its usual quarter, and again the pure breeze sweeps over the land bringing coolness, relief and comfort. When this breeze is stiff and accompanied by rain, it sweeps all impurities from the island and is aptly termed the "Parish Doctor." Across Longwood and Deadwood it occasionally travels with great velocity, sweeping through the ravines and valleys with such force as to uproot trees and unroof shaky cottages. The tents of the camp at Deadwood are at such times continually overthrown, but this unpleasantness is entirely forgotten in the effects of its purifying and invigorating influence.

Clouds sometimes hang over the island for a few days, very high up; these veil the sun, causing what the islanders term "covered days," which are the most enjoyable times for out-door excursions. It is difficult to define the seasons, which glide from spring to summer, again to autumn and winter with very little to mark the change. The chief sign of spring is the bright cheerful sunny weather which previtils, varied occasionally by gentle refreshing showers; with a minimum temperature of $55^{\circ}$ and a maximum of $68^{\circ}$.

The oaks burst into full leaf, and with gorse, narcissus, mimosa, acacia and other plants, give the season much of the charm and character of an linglish spring. Summer of course brings hotter weather, the temperature rises to over $72^{\circ}$ on the highlands, while in the town of Jamestown it registers $\delta 2^{\circ}$ to $S_{4}^{\circ}$. The radiated heat from the rocks here makes the summer more trying, and during the months of January, February and March the mosquitoes add much to the discomfort. The temperature being quite $10^{\circ}$ lower in the country, makes that part no hotter than the English summer.

Autumn, which is characterized as in England by the fall of the oak-leaf, brings the slight rain or mist which gives the ridges so close a resemblance to the Scotch Highlands. The country throughout, but especially Plantation, Oaklands, and Oakbank, is very beautiful in its russet-tinted dress.

Winter finds the temperature as low as $50^{\circ}$ on the heights, 
and fires are generally welcomed. Jamestown and other valleys are then just sufficiently cool to be pleasant, and fireplaces are unknown in the houses, except where necessary for cooking. Visitors find the mildness of the climate sometimes too relaxing, but this is quickly remedied by going from one part to another in the hills, for the different parts possess great differences of climate. The rainfall varies much in different years, and also differs greatly according to locality. Taking $\mathrm{I} 898$ as an average, $36 \cdot 06$ inches fell at Mount Pleasant near Sandy Bay ridge; but only 4.82 inches in Jamestown.

A prisoner of war, in one of his humorous contributions to the little paper issued in Deadwood Camp, De Krijgsevangene, says :-

There are two seasons: (I) the rainy season, in which rain is the rule and sunshine the exception; (2) the dry season, which resembles the rainy one so much that the mistaking of one for the other has never yet been ascribed to ignorance.

But this, it must be admitted, was written after an exceptionally wet summer.

The length of day varies with the different seasons about one hour. The longest day is December 2I, when darkness falls about 7.30 p.m., the shortest day being June 21 , when the sun sets about six o'clock. There is scarcely any twilight, night closing in almost immediately after sunset.

The soil is very productive, and trees and shrubs from all parts of the world flourish. In the grounds of Plantation House there are not only the plants and trees indigenous to the island, but trees from Europe, Asia, Africa, Australia, and Polynesia.

The Araucaria excelsa or Norfolk island pine, so commonly seen as a pot-plant in English conservatories, grows here to a height of over roo feet. Side by side with a tree from Ceylon may be seen the South Sea Island pandamus or screw pine; the oak, the cedar, the apple, the guava, the peach and banana mingle their foliage, while here and there an indigenous tree stands amidst a host of aliens-the mimosa of New South Wales, the Scotch firs and the bamboo of India, with the pines of the North and the Australian blue gum or eucalyptus, seeming to outvie each other in the luxuriance of their growth. 
Here is entertainment indeed for the botanist. Almost anything will grow. Flax, aloes, sugar-cane, and cotton, together with coffee and tobacco, are to be seen, and nearly all English vegetables as well as Cape produce. Two crops of potatoes are raised yearly. In the roofs of the old buildings cabbage-tree wood was much esteemed for its durability. This grows on all the interior heights.

The red wood (Dombeya crythroxylon) is a beautiful spreading tree rising to a height of about thirty feet with long pendant blossoms of the bell kind, white, pink and red. It was valuable for building, but the white ant so attacked it that there are only a very few trees remaining.

Of the same genus is the dwarf ebony (Dombcya melanoxylon), which low shrub is quite different to the black heavy wood called ebony in the records, of which there are at present only a few isolated dry pieces.

In some of the most rocky and barren places grows a bushy tree with small pale green leaves called the wild rosemary (Philica rosmarinifolia). It is said that nothing will flower beneath its shade. The wild olive (Philica elliplica) is of the same genus as the wild rosemary; it bears a sinall dry berry, but neither of them answers the description of the rosemary and olive of other countries.

An astrigent shrub called the St. Helena tea (Bealsonia portulacifolia) is often to be found on the sides of rocky, inaccessible heights, bearing a little white blossom. It has been used witl great success for tanning.

Myrtle in some situations attains the height of twenty feet. In the grounds of Oakbank are to be found most beantiful trees; the camellia trees which form the southern boundary being of great height, the China date and Chilian pine being also of wonderful growth. The latter is a very pretty mood for furniture and house decoration, and is said to resist the attacks of white ants.

A great variety of curious ferns is obtainable, the most remarkable being the tree fern (Dicksonia arborescens) rising to between fifteen and twenty feet, in appearance resembling a palm. In the museum in Jamestown may be seen a beautiful collection of ferns made by Captain Thomson of the Bengal Pioneers. 


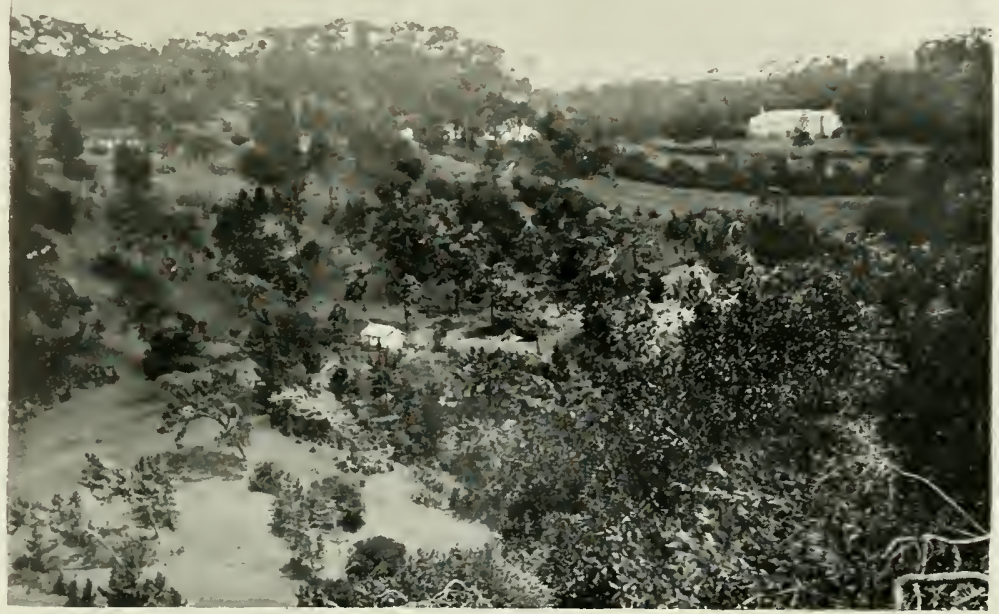

Plantation or Goverxinext House and Grounds.

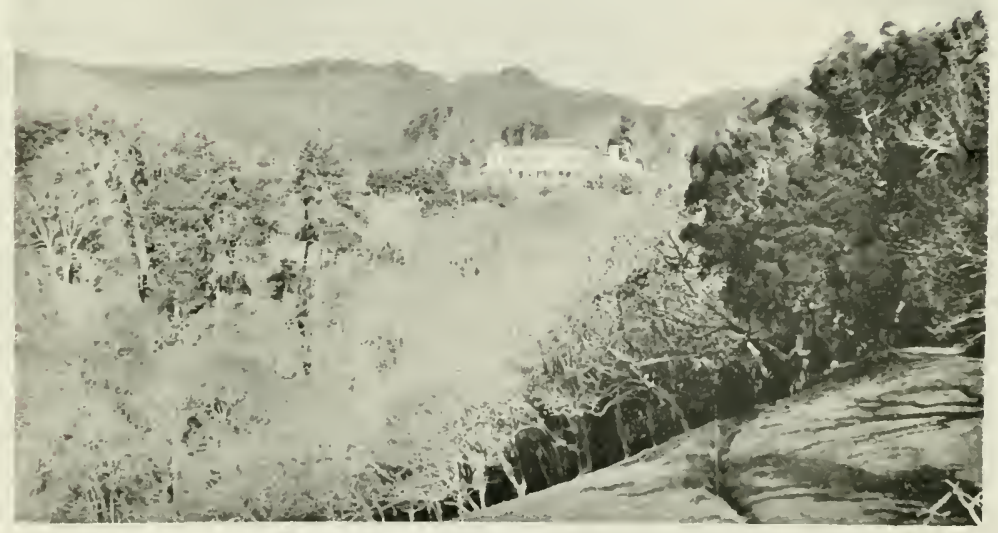

OAKВANK HOUSF ANI) GROUNDS. 

The salsola or samphire, which produces barilla, is abundant on all parts near the sea.

The palma Christi, or physic nut (castor oil plant), yields a fine oil and grows wild, but is not made use of.

Amongst the various lichens is the valuable kind called orchel, much used in dyeing. In I743 this was sent to London and sold for $£ 50$ to $£ 60$ per ton. In 1815 we read that it had risen in price to four times that amount, yet no notice is taken of it.

Fine trees of olives (Olea Europoea) grow on the Briars estate, lately bought by the Eastern Telegraph Company, and are annually laden with fruit. From them large quantities of oil might be prepared, and the cultivation of them might be extended with profit.

Tobacco has been tried and failed for want of proper manuring of the soil. Mr. Chalmers, the skilled gardener, who was sent out in 1869 for the cinchona industry, but who was unfortunately recalled when great reductions were made in the island establishment, expected the tobacco industry would become a permanent one.

At the present time a start has again been made and very good tobacco is prepared. The seed for this was brought from South Africa during the enforced stay of the Transvaalers and Orange River colonists.

Coffee is grown in small plantations, that of "Coffee Grove" in Sandy Bay being of the most excellent quality. The cultivation is capable of much extension; at the English exhibition of I85I island-grown coffee took the prize for first quality.

The English furze and blackberry overrun the island and mingle with the snowy blooms of the arum lily, while in gardens the begonia, petunia, geranium spider and annunciation lilies, thunbergia, camellias, roses, carnations, nasturtiums, magnolias, gardenias, etc., etc., grow in profusion and make the country-house lands very beautiful. Pineapples, apples, pears, grapes, oranges, lemons, peaches, custard apples, bananas, dates, figs all grow, but fruit is scarce through the ravages of insects ; in fact, many fruittrees and gardens have been totally destroyed.

In the débris of a condemned Brazilian slaver there happened to be a colony of white ants which grew and 


\section{6}

multiplied in their new home so quickly that Jamestown was almost ruined-these, spreading to the country attacked fruit and fir trees, together with all soft wood trees, to such an extent, that it was considered necessary to burn the trees wherever they were found. Not content with denuding the forests and lessening the supply of fruit these active workers entered the houses, continuing their work until a great number had to be rebuilt. This was generally done with teak-wood and with iron, and as the destruction by burning was well carried out the ants are now considerably fewer than formerly.

The fruit-trees have for many years been ravaged by insects; the peach was the first attacked, and since then almost every kind of fruit has suffered; so that it has been considered best to destroy the greater number, especially of peach, guava, pear and orange-trees. The only real cure would be to burn, as was done several years since in Tas. mania, where, owing to the maggots in the peaches, an ordinance was promulgated enforcing the total destruction by fire of all peach-trees in the colony. For three years not a peach was grown, but in the fourth year the result made itself apparent; the new peaches were larger, of excellent flavour and free from pest. The following letters and notes are added as being of interest to fruit-growers :-

\section{DOWNING StREET, Ist June, 1896 .}

SiR, - I have the honour to inform you that your despatch No. 23 , of the fourth of April last, with the accompanying specimens of an insect which had attacked the peach crop in St. Helena during the past year, was referred to the Director of the Royal Gardens at liew, and I now transmit to you a copy of a letter with a report by Mr. IV. F. H. Blandford, F.R.S., which we have received in reply.

2. I shall be interested to learn what measures are taken to lessen the ravages of this pest.

I have the honour to be, sir,

Your most obedient servant, J. Chamberlais.

The Officer Administering the Government of St. Helena.

ROYAL GARDENS, KEW, 21 st May, 1896.

SiR,-I have the honour to acknowledge the receipt of your letter of the 30 th ultimo $(9000 / 96)$, forwarding a copy of the des- 
patch and specimens of an insect received from the Acting-Governor of St. Helena.

2. At my request the insect has been identified by Mr. W. F. H. Blandford, F.R.S., as a dipterous fly (Ceratitis capitata), known in Malta and elsewhere as the orange fly. In addition, Mr. Blandford has prepared a useful summary of information respecting its distribution and the best means for treating it. This is enclosed herewith.

3. It is probable that the fly has been destructive to fruit crops in St. Helena for many years. Hence this interesting island is practically destitute of many tropical fruits that in other places afford a considerable addition to the food supply of the inhabitants. If Mr. Blandford's suggestions are fully carried out there is little doubt that it may be possible to lessen the ravages of the insect and save a good deal of fruit that is at present destroyed It is, however, necessary to secure the intelligent co-operation of the people and carry on experiments for two or three years in order to produce satisfactory results.

$$
\text { (Signed) W. T. Thiselton Dyer. }
$$

Edward Wingfield, Esq., B.C.L., C.B.,

Colonial Office, Downing Street, S.W.

Notes on a Dipterous Insect Destructive to Peaches in St. Helena.

This insect, of which $I$ have received specımens in alcohol, forwarded to the Royal Gardens, Kew, by the Acting-Governor of St. Helena, is Ceratitis capitata, Wied, commonly but less accurately referred to as Ceratitis citriperda, Macd., the well known orange fly.

The insect is a very characteristic and easily recognizable form, distinguished amongst other features by the presence, on the head of the male, of two long hairs ending in lozenge-shaped plates. A great deal has been written about it, but for present purposes I have not thought it necessary to do more than refer to the more recent writings on the subject.

The fly has a very wide range in warm countries, having been recorded from South Africa, Mauritius, the Azores and other Atlantic islands, including Bermuda, Central America, etc. A. S. European species, C. hispanica, Breme, is probably identical with it, and one of the two species (if there be two) has been very destructive to the orange crop in Malta.

According to Penzig, the Mediterranean species is found in Spain, Algiers, Sicily, Italy and Malta, and is distinct from C. capitata. From information given in Insect Life, iii. p. 6, it appears that a commission was appointed in Malta, which is stated to have issued a report in 1890 .

About the year 1866, the late entomologist, Edward Newman, found a ceratitis, then identified as $C$. citriperda, very destructive to 
pears in his garden at Peckham. It was no doubt imported, and established itself for a short time only.

The question of the specific identity or not of the forms found in different countries is of no immediate moment, but is of importance as regards the distribution of the species and any variation in habits which may characterize them.

The fruits on which attacks have been observed are the orange, lemon and other species of citrus, the peach, apricot, plum, Surinam cherry, the fig, the pear, and possibly the apple. With regard to the last mentioned confusion with an allied species of fly may have arisen.

Attack on very young fruit, as mentioned in the letter of the Acting-Governor of St. Helena, appears to be untsual. An African grower, Mr. J. B. Hellier, in a letter from Grahamstown, quoted by Miss Ormerod, says :- "The perfect insect may beseen flying about very swiftly, and depositing some half-dozen eggs in a fruit. They do not deposit their eggs till the fruit is turning, that is, getting sweet. The maggots are never found in green apricots used for making pies, neither are they found in sour apples."

In some districts one or other fruit escapes. "The oranges at Uitenhage (South Africa) in October and November, 1886 , were infested and maggoty, but the apricots and peaches which came ripe in December and January, were comparatively free."

On the contrary, in Liguria, in 1882 , the fly was observed to damage peaches, but its presence in oranges or lemons was not verified.

This is likely to depend on the respective degrees of ripeness of the fruit at the time of the oviposition of the flies. On this latter point, and on the time passed by the fly in its various stages, and on the number of broods in the year, there is not sufficient information; and these circumstances are likely to vary in country and climate, and should be ascertained on the spot.

Professor Riley wrote with reference to attack on peaches in May in Bermuda :- "With our knowledge of the habits of the insect, derived from writings of those who have mentioned it as an orange pest, it seens altogether likely that there is more than one generation, and that the flies issuing from peaches in May oviposit in some other fruit, and in this event the destruction of the peaches will only prove a partial remedy, unless it should turn out that a generation in the peach at this time is necessary to fill a gap in point of time in the life-history of the insect. He adds that, judging from the rapid development, there should be six or eight generations in the course of a season, provided that food is at hand.

Few additional details of importance as to the life-history of the insect are to be gathered from those who have written on it. It appears that the egg is laid by the fly within the skin of the fruit at a depth of one to three millim.; and this appears to exclude the use of arsenical insecticides, which have been so largely employed to prevent the somewhat similar mischief caused by the codlin moth, the larva of which, however, has to bore its way 
through the skin and is poisoned in so doing. But in any case, the use of arsenical preparations on so tender a plant as the peach, and one of which the fruit-skin is so downy, would be a risky proceeding.

The attacked oranges (and other fruits) soon fall to the ground, and in the space of fifteen days, more or less, the larvæ issue, either through the original opening or through another one made for the purpose, and enter the ground, where they transform to pupæ, remaining in this condition only a few days." (Insect Life, iii. p. 8o.) This condition lasts for ten days (Ormerod). Moreover, the fly is active by daylight, resting at night, and does not move far from the trees or bushes. There is no indication in any account of any definite natural conditions which modify the liability of the fruit to be attacked. Absence of insectivorous birds and bats has been before suggested in the case of insular attacks, but there is really no evidence to show that this is a factor. The insect is destructive in South Africa, and its importance in islands may really be due to the extensive part which fruit-growing plays in their industrial conditions.

I have no suggestions to make on treatment, but the following methods have been suggested and employed, and agree with my own independently formed ideas.

I. REMEDial.-In so far as no means exist for checking the work of the maggot after the egg is laid, no remedial measures are practical.

2. Preventive.-(a) Direct-The only method which has proved successful in preventing egg-laying is that of tying up the fruit or fruiting trees with what is termed mosquito-netting. This can only be done on a small scale.

No insecticide is likely to be of use, except such as by its odour might repel the flies; and I cannot suggest, at present, one which shall be innocuous, and at the same time possess so lasting a smell as to be of practical use. The smell of any insecticides, such as kerosene emulsion, is necessarily evanescent. At present, therefore, the use of an insecticide appears to be out of the question.

(b) Indirect.-Here the most suitable remedy is the collection and immediate destruction of all attacked fruit, at least of all which has fallen. Penzig suggests its burial in a ditch, covered with a layer of quicklime; after six months the mass is converted into a valuable fertilizer. He very properly urges concerted action and energetic measures on the part of the authorities, and indeed it is evident that the whole value of this promising method depends on the thoroughness with which it is carried out.

The Maltese Commission (Henslow, Gard. Chron., May 24, I890) also recommends the destruction of fallen fruit and the strewing of the surface of the ground under the trees with one part of finely powdered sulphate of lime to twenty-four parts of sand, and subsequent watering.

Of course, if the larvæ of certain breeds do not leave the fruit to pupate, the infested fruit must be picked. Miss Ormerod suggerts 
that, if not badly damaged, part of it might be utilized. This point may be left to growers to decide.

The only means of dealing with the fy is in a suggestion of Miss Ormerod's that, if the flies are sluggish and inactive when basking on the leaves (which is certainly doubtful), their numbers might be reduced "by shaking them down on sticky clothes or by syringing with good soft soap, or whalc-oil soap washes."

No suggestions whatever for the introduction of animal enemies (birds or insects) to the fly can be made on present knowledge.

Lastly, there remains the question whether, as suggested by the Acting-Governor, an entire crop of fruit may be destroyed.

The idea is not one to be dismissed; but such destruction, to be carried out with prospects of success and as little loss of property as possible, should be done only when sure knowledge has been gained of the distribution of the insect upon various specics of fruit-bearing trees, of its length of life, number of broods, regularity of those broods (i.e. whether the flies emerge together or are to be found indifferently throughout the greater part of the year), and the stage in which it hibernates.

If these points were known it might be possible to destroy a brood by the destruction of some fruit, not necessarily the peach, at a particular season. It is not absolutely necesssary that they shall be known; but if they are not, there is more risk of failure and of expense to growers. And, moreover, it must be recollected that the insect occurs in Madeira, the Azores, Cape Verde Islands and Africa, and may always be re-introduced.

On the whole the desiruction of infested fruit, as recommended and carried out clsewhere, appears to give the most promise; and although the specimens sent were bred from a peach, it does not follow that the maggots of at least some generations do not pupate in the ground. I append a list of the more important recent accounts or notes on the insect.

(Signed) II. F. H. BLANDFORD.

Henslow.-Gardener's Chrovicle, 1890 , vol. vii. p. 655.

Newman. The Ficld (circa 1866). I have not the cxact reference.

Ormerod.-Observations on Injurious... Insects of South Africa. London, 1899, Pp. 49-56.

Penzig.-Studi Botasici sugli Agruni e sulle Piante affine. (Anmali di Agricollura, pp. \&(69-477.)

Riley.-Insed Life, iii. pp. 5-8, and notes, pp. 80-1, 120.

Westwood.-Gardener's Chronicle, 18\$8, p. 604.

There are no birds of prey, but insectivorous birds are greatly necded. The only indigenous land-bird is a small one of a plover family (Acgialitis Sanctax Helcna) called locally the wire-bird. It inhabits the interior, and is found in considerable numbers. In appearance and habits it 
resembles the lark of Europe, but is not migratory; its name was given it from its remarkably long legs like wires, which enable it to run very swiftly over the ground.

The white people of the island are for the most part the descendants of the old English officials who settled in the island, together with present military and Government officials and merchants.

St. Helenians proper are of mixed race, quiet, tractable, and inoffensive. Crime is small. Governor Sterndale states, that during fourteen criminal sessions over which he presided as Chief Justice, he had white gloves presented to him on all but two occasions.

Strict laws were in force in old times concerning gossip by women, but the men seem to have enjoyed the use of their tongues without rebuke. The following law is interesting:

Whereas several idle, gossiping women make it their business to go from house to house, about the island, inventing and spreading false and scandalous reports of the good people thereof, and thereby sow discord and debate among neighbours, and often between men and their wives, to the great grief and trouble of all good and quiet people and to the utter extinguishing of all friendship, amity, and good neighbourhood; for the punishment and suppression whereof, and to the intent that all strife may be ended, charity revived, and friendship continued, we do order that if any woman from henceforwards shall be convicted of tale-bearing, mischief-making, scolding, drunkenness, or any other notorious vices, they shall be punished by ducking or whipping, or such other punishment as their crimes or transgressions shall deserve, as the Governor and Council shall think fit.

Many of the islanders love their church and attend regularly. The Church of England is paramount, but there are also Roman Catholics, Baptists, and members of the Salvation Army.

The Church of England is presided over by a bishop, assisted by three priests, who have charge of the districts of St. James', St. Paul and St. Matthews'. There is also the Church of St. John's in the upper town of Jamestown, built at a time when the military force was too large to be accommodated at St. James' ; and the Roman Catholic Chapel is presided over by a military chaplain.

The Baptists have their own minister and place of worship. 
None of the churches can lay much claim to architectural beauty, the most imposing is that of St. James', which it is generally considered should be the Cathedral, seeing that it is situated where the greater number of people are compelled tolive, and also that it is in all probability the site, or very near the site, on which the first chapel was built by the Portuguese.

St. Paul's is utterly deroid of architectural beauty outside or in, but it is commandingly situated on a hill above and at the back of Government House, and is surrounded by the cemetery.

St. Matthew's is a small iron church at Hutt's Gate, on the road to Longwood.

There are two hospitals, military and civil, the latter presided over by trained nurses.

St. Helenians are fond of music, and generally possess good voices; they are also very loyal.

Canaries are wild and numerous, and are charming songsters, and there is a beautiful little finch called the "cardinal." "Avadarats" and Java sparrows abound, as well as small doves. Other imported birds are fowls, peacocks, guinea-fowls, turkeys, ducks, geese, pheasants, partridges, minors and pigeons. A beautiful white gull also makes its home on the island, the feathers of which are used for boas, capes, etc., and make very pretty trimmings.

There are no snakes, nor any noxious reptiles, reptilia being represented by some harmless little lizards, two enormous tortoises of fabulous age (which live in plantation grounds, and are said to be over 150 years of age); and a small species of frog, which is quite a recent introduction, but which has spread wonderfully all over the island. In some of the valleys a few scorpions and centipedes are found, but their sting; although painful, is not dangerous.

Bees are kept, and the honey is of very good flavour. With so favourable a climate and a never-failing supply of honey-producing flowers, St. Helena might rival Jamaica, which annually exports over $£ 8,000$ worth of honey and wax, the bee farmers there being chiefly negroes. It is a cottage industry, and would therefore be well suited to the St. Helenians. The breed of cattle and sheep on the island was originally English. It is still kept up by importation 


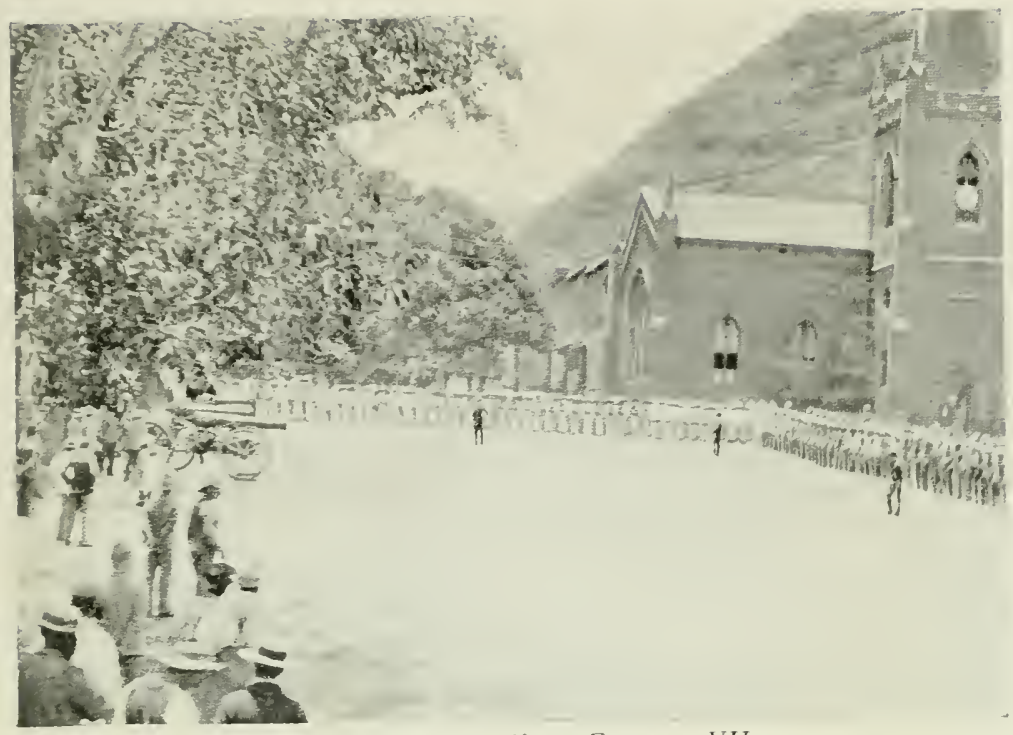

Proclamation of Kigg EDIIARD VII.

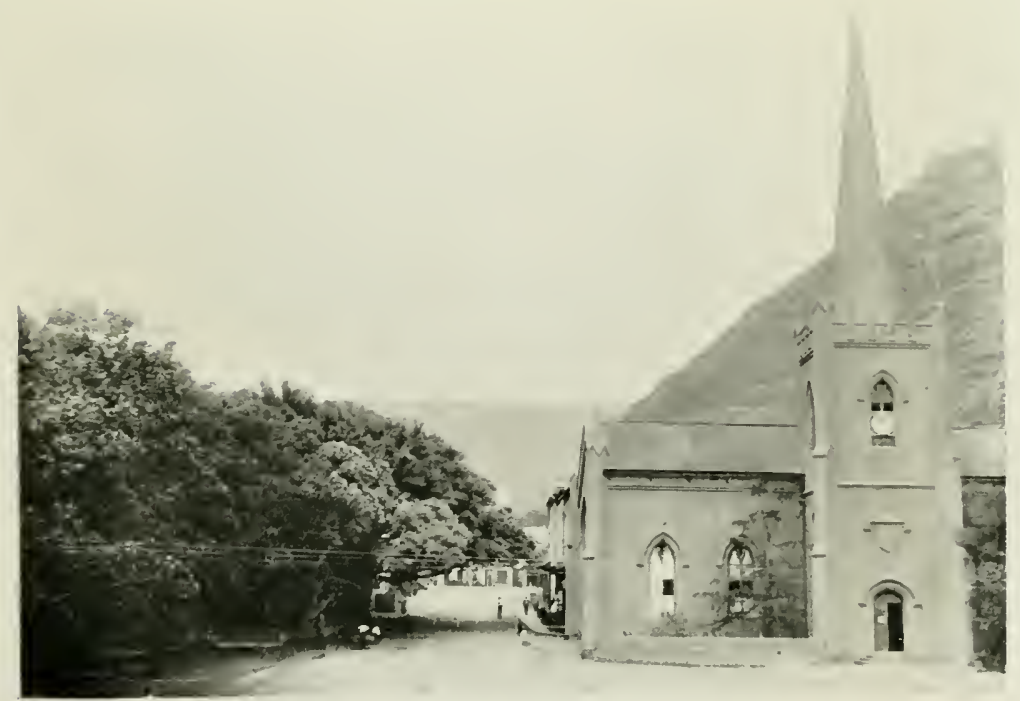

St. James' Church oN LOWER Parade. 

from England, and the beef is of good quality. Sheep are numerous, and provide sweet and tender mutton. Pigs are kept in the country and their flesh when well fed is good. Goat-meat is often procurable, and of good flavour. Fowls are reared in numbers, but ducks, geese, and turkeys are not so plentiful. Eggs are as a rule plentiful, but poultry and eggs have been more scarce during the increased population of military and of Boer prisoners. Vegetables also were quickly bought up by them. Prices given during this time were $6 \dot{d}$. to Is. for cabbages, 40s. per bag for potatoes, $2 s .8 d$. per lb. for fresh butter.

The language spoken is English (and with a purity not often found in the rural districts of England); the islanders however find a difficulty with the letter " $v$ " and " $w$," calling a veil a wale, a person said to be vain is described as wain, while a child named Willie will become Villie; in this respect they are no worse than uneducated Londoners. The letters "th" also are a stumbling block, the native children using the expressions de, dis and dat for the, this and that. 


\section{DESCRIPTIVE}

THE town of Jamestown-that tiny city which enjoys the unique position of being at once the capital and only town of St. Helena-is situate on the north and leeward side of the island, where there is good anchorage of from eight to twenty-five fathoms. It lies between two formidable, frowning rocks, Mundens on the east and Ladder Hill on the west, both fortified with cannon. From the fort of Ladder Hill, which contains commodious barracks and is connected with the town by a ladder of seven hundred steps as well as by a good carriage road, floats the Union Jack.

That "St. Helena has only one entrance and no exit" is said by many, who have grown so to love the old rock that they retain no wish to leave it. Viewed from the sea, the town resembles that of St. Peter's Port, the capital of the island of Guernsey in the English Channel ; and very conspicuous stands the white church spire with, at the summit, a fish in place of the usual weathercock. The white houses, which are seen stretcling away up the narrow valley, seem to nestle comfortably in the mighty cleft, and present from sea board a most picturesque appearance; but on closer acquaintance, although there are some good and substantial buildings, there are others merely whited sepulchres-houses which at different times have been burnt out and never rebuilt.

The sea front is protected by a well built wall, which has, during the residence on the island of the Transval prisoners of war, been added to very considerably on both sides, east and west. A road from the landing steps of the wharf, bordered on the land side by a deep moat, leads over a moated drawbridge, through an arched portcullised gateway (where is still stationed a military guard) on to a spacious square called the lower parade. Here the troops assemble on such holidays as the King's birthday, the 
appointment of a governor, for proclamations, parades, drills, etc. Here the proclamation of the death of our good Queen Victoria, on January 22, I90I, was made, together with that of the accession of our gracious Sovereign Edward VII as follows :-

\section{PROCLAMATION.}

By His Excellency Robert Armitage Sterndale, Esquire, Governor and Commander-in-Chief of the Island of St. Helena, etc., etc., etc. Whereas it has pleased Almighty God to call to His mercy our late Sovereign Lady Queen Victoria, of blessed and glorious memory, by whose decease the Imperial Crown of the United Kingdom of Great Britain and Ireland, and all other Her late Majesty's dominions, is solely and rightfully come to the High and Mighty Prince Albert Edward.

We, Robert Armitage Sterndale, Governor and Commander-inChief of the island of Saint Helena; John Garroway, Lord Bishop of Saint Helena; Thomas Julian Penrhys Evans, Lieut.-Col. R.M.L.I. commanding the troops in St. Helena;

George Nathaniel Moss, Member of the Executive Council of St. Helena ;

William Joseph Williams, Member of the Executive Council and Sheriff of St. Helena;

Therefore do now hereby with one full voice and consent of tongue and heart publish and proclaim that the High and Mighty Prince Albert Edward is now by the death of our late Sovereign, of happy and glorious memory, become our only lawful and rightful liege Lord Edward the Seventh, by the grace of God King of the United Kingdom of Great Britain and Ireland, Defender of the Faith, Emperor of India, and supreme Lord in and over this ancient Colony of the Island of Saint Helena, to whom we do acknowledge all faith and constant obedience, with all hearty and humble affection, beseeching God by whom Kings and Queens do reign to bless the Royal Prince Edward the Seventh with long and happy years to reign over us.

\section{God SADE THE King.}

Given under my hand and public seal of the island of St. Helena this 26 th day of January, I901.

(Signed) R. A. Sterndale,

By command of His Excellency the Governor. Governor.

(Signed) RoBt. R. BRUCE, For Colonial Secretary.

The message sent by His Most Gracious Majesty to his colonists was :-

To my people beyond the seas. The countless messages of loyal sympathy which I have received from every part of my dominions over the seas testify to the universal grief in which the whole Empire 
now mourns the loss of my beloved mother. In the welfare and prosperity of her subjects throughout Greater Britain, the Queen ever evinced a heartlelt interest. She saw with thankfulness the steady progress which, under a wide extension of sclf-government, they had made during lier reign. She warmly appreciated their unfailing loyalty to her throne and person, and was proud to think of those who had so nobly fought and died for the limpire's cause in South Africa. I have already declared that it will be my constant endeavour to follow the great example bequeathed to me. In these endeavours I shall have a conficlent trust in the devotion and the sympathy of the people and of their several representative assemblies throughout my vast colonial dominions; with such loyal support I will with God's blessing solemnly work for the promotion of the common wellare and security of the Great Empire over which I have now been called to reign.

Wixdsor Castle,

(Signed) EDWARD R. AND I. th February, ixol.

The square is flanked on three sides by buildings, the chicf being the Fort or Castle, the first of which was built under the superintendence of Captain Dutton, the first English Governor.

This ancient fort is closely described by the narrator of the voyage of Mons. Rennefort, who saw it in 1666 :-

Its form was triangular with three bastions. On two of the bastions were mounted seven pieces of heavy iron cannon, pointed toward the sea. Four guns were placed on the 3 rd which was upon the land side, and was calculated to serve as a kind of citadel in the event of the other parts of the work being captured. The two bastions next the sea were flanked by two redoubts with two pieces of ordnance on each, nearly on a level with the water's edge.

Up to this time the valley was called Chapel Valley, from the chapel built by the Portuguese, the ruins of which were still to be seen when the island was first settled by the English. But the Castle or Fort was named Fort James, probably in compliment to the Duke of York (afterwards James II.) for he was an active patron of commerce and at the head of an African Company.

The site of Fort James was in all probability that of the present Castle, which appellation was seemingly derived from its being enclosed within a high quadrangular wall or rampart (built in 1707), and surmounted with battlements or small embrasures. In the walls of this building are built several stones bearing inscriptions as under, which 
sufficiently indicate them to be relics of Governor Dutton's work.

Stone No. I.

CAPT IOHN DUTTON

GOVERIOR OF THIS ISLE

First ERECTEd this Fortification

FOR THE ENGLISH EAST

INdia CoMpy IvNe Ye AN : Dom. III59

Opera Testantur de Me.

Stone No. II.

The above stone alludes

To $\mathrm{A}$

Fort Built in 1659. Taken Down

AND

The Present Castle Built

By Governour RoBerts in I708.

The Honble Brigd General Dallas

The Last Governor

OF THE

Honble United East India Company.

In clearing away found it upside down in part of the foundations of this Castle and restored it as now placed A.D. I 854 .

Stone No. III.

Tho Coleman, workman in chief of this fortification FOR THE USE OF THE ENGLISH EAST INDIA COMPY.

I CAME ON THE MariIDUCK MaN OF Ware

MaY ye 51659.

Stone No. IV.

Iohn Iefreys the Masters Mate

of THE AdVICE. Octo-

-BER Ye 16 I 659 .

The Castle contains a suite of furnished rooms intended for the use of the Governor when in town. In the basement are stored all the record books of the island, the contents of which are very interesting, and extracts from which will be found on pages $169-80$.

Over the portcullised gateway, parallel with the sea and moat, is a spacious walk called the "Terrace." From this terrace, entrance is gained to the upper floor of the Castle; from it also there is access to the Government garden, and to the paths cut on the hill sides, which were planted with trees by Governor Dallas as a promenade for his two daughters, and which still retains the name of "The Sisters' Walk." 
From this terrace the square or lower parade presents a very pleasing appearance. On the left is seen the Castle and post-office, the commissariat yard, police court and sessions room. There are shaded by a row of most beautiful trees, under which stand several large cannon; on the right are the guard room, the custom house, the garrison offices and the gaol, as well as a large store now called the "Rickmers" which was formerly a story higher, and well known as "Lawler's Hotel."

The Church of St. James forms the southern boundary of the square, and is a plain, unpretentious building. The Portuguese are supposed to have been very anxious to conceal the situation of St. Helena from the knowledge of other nations, and they succeeded until it was visited by Captain Cavendish. (This is known from a manuscript containing extracts and memoranda collected by Lieut. Thos. Leach, a native of the island.) Captain Cavendish called in I5SS on his homeward way during a circumnavigating voyage. On the day of arrival he was prevented from landing by a breeze, but on the following morning a boat was put off to ascertain the most convenient anchorage. That selected was off Chapel Valley, in itwelve fathoms of water. The narrator of the voyage of Captain Cavendish writes:-

The same day about two or three o'clock in the afternoon we went on shore, where we found an exceeding fair and pleasant valley wherein divers handsome buildings and houses were set up; and one particularly which was a church, was tiled, and whitened on the outside very fair, and made with a porch; and within the church at the upper end was set an altar, whereon stood a very large table, set in a frame, having on it the picture of our Saviour Christ upon the cross, and the image of our Lady praying, with divers other histories painted curiously on the same. The sides of the Church were hung round with stained cloths having many devices drawn on them.

\section{The narrative continues:-}

There are two houses adjoining to the church, on each side one, which served for a kitchen to dress meat in with necessary rooms and houses of office. The coverings of the said houses are made flat, where is planted a very fair vine and through both the said houses runneth a very good and wholesome stream of fresh water. There is also over and against the church a very fair causeway made up with stones reaching unto a valley by the sea-side, in which valley is planted a garden wherein grows a great store of pompions 
and melons and upon the said causeway is a frame erected whereon hang two bells, wherewith they ring to mass, and near to it a cross is set up, which is squared, framed, and made very artificially of freestone, whereon is carved in cyphers what time it was built, which was in the year of our Lord I $57 \mathrm{I}$.

The valley is the fairest and largest low plot in all the island and is exceedingly sweet and pleasant, and planted in every place eicher with fruit or with herbs. There are fig trees which bear fruit continually and very plentiful, for on every liee you may see blossoms, green figs and ripe figs all at once, and it is so all the year long.

The reason is that the island standeth so near the sun. There is also great store of lemon trees, orange trees, pomegranates, pomecitron trees, and date trees, which bear fruit as the fig trees do, and are planted carefully and very artificially with pleasant walks under and between them, and the said walks are overshadowed with the leaves of the trees, and in every void place is planted parsley, sorrel, basil, fennel, aniseed, mustard seed, radishes and many very good herbs. The fresh water brook runneth through divers places of this orchard and may with very small pains be made to water any tree in the valley. This fresh water stream cometh from the top of the mountains and falleth from the cliff into the valley, the height of a cable and hath many arms issuing out of it that refresh the whole island and almost every tree in it.

The island is altogether high mountains and steep valleys except it be on the tops of some hills and down below in some of the valleys, where great plenty of all those fruits before spoken of do grow. There are much more growing on the tops of the mountains than below in the valleys, but it is very toilsome and dangerous travelling up unto them and down again, by reason of the height and steepness of the hills.

There are also upon this island great store of partridges which are very tame, not making any great haste to fly away, though one come very near them, but only run away and get up into the cliffs. We killed some of them with a fowling-piece. They differ very much from our partridges which are in England both in bigness and also in colour, and live in coveys, twelve, sixteen and twenty together. You cannot go ten or twelve score paces but you shall spring one or two coveys at least.

There are likewise no less plenty of pheasants in the island which are also very big and fat, surpassing those which are in our country in bigness and numbers in a company; they differ not very much in colour from the partridges before spoken of. We found moreover in this island plenty of guinea-cocks which we call turkeys, of colour black and white with red heads; they are much the same in bigness with ours in England; their eggs are white and as big as a turkey's egg.

There are in this island thousands of goats which the Spaniards call cabutos, which are very wild. You shall see one or two hundreds of them together, and sometimes you may see them go in a 
flock almost a mile long; some of them (whether it be the nature of the breed of them or the country I know not) are as big as an ass with a mane like a horse and a beard hanging down to the very ground; they will climb up the cliffs, which are so steep that a man would think it impossible that any living creature could go there. We took and killed many of them for all their swiftness, for there are thousands of them upon the mountains. Here are in like manner great store of swine, which are very wild and fat and of great bigness; they keep all together upon the mountains, and will very scldom abide any man to come near them, except it be by mere chance, when they are found asleep or otherwise, according to their kind, or taken lying in the mire. We found in the house at our coming three slaves who were negroes and one who was born in the island of Java, who told us that the East India fleet, which were in number five sail, the last whereof was in burden eight or nine hundred tons, all laden with spices and callicut cloth, with store of treasure and very rich stones and pearls, were gone from the island but twenty days before we came hither.

When the Portuguese touch at the island, they have all things in plenty for their relief by reason that they suffer none to inlabit there that might eat up all the produce of the island, cxcept some very few sick persons of their company, whom they suspect will not live until they come home; these they leave to refresh themselves, and take them away the year following with the other fleet, if they live so long.

Between the Custom House and Rickmer's store is a path which leads to the ladder. This, with its 700 steps, leads to Ladder Hill Fort.

To one not accustomed either to ascending or descending, the mere sight of that vast staircase, without a break or turn, causes a sensation of giddiness; yet the islanders pass up and down two or three times a day. Small boys are to be found who are willing to slide down the whole distance of 600 feet. With their heads on one handle rail, their feet on the other, grasping loosely over their heads, they execute a feat most indescribably terrible to watch. At the top of the ladder is the signal station, reigned over by an old and trusted servant of the Government (George Ward). In its vicinity are the main fortifications, barracks, and quarters of the military establishment.

After passing St. James' Church the main street is entered, to the left of which stands the Government garden, nicely railed in; this contains some beautiful trees, shrubs and plants. A few years since it was in good order, but the use of it as a camping ground during the stay of the 


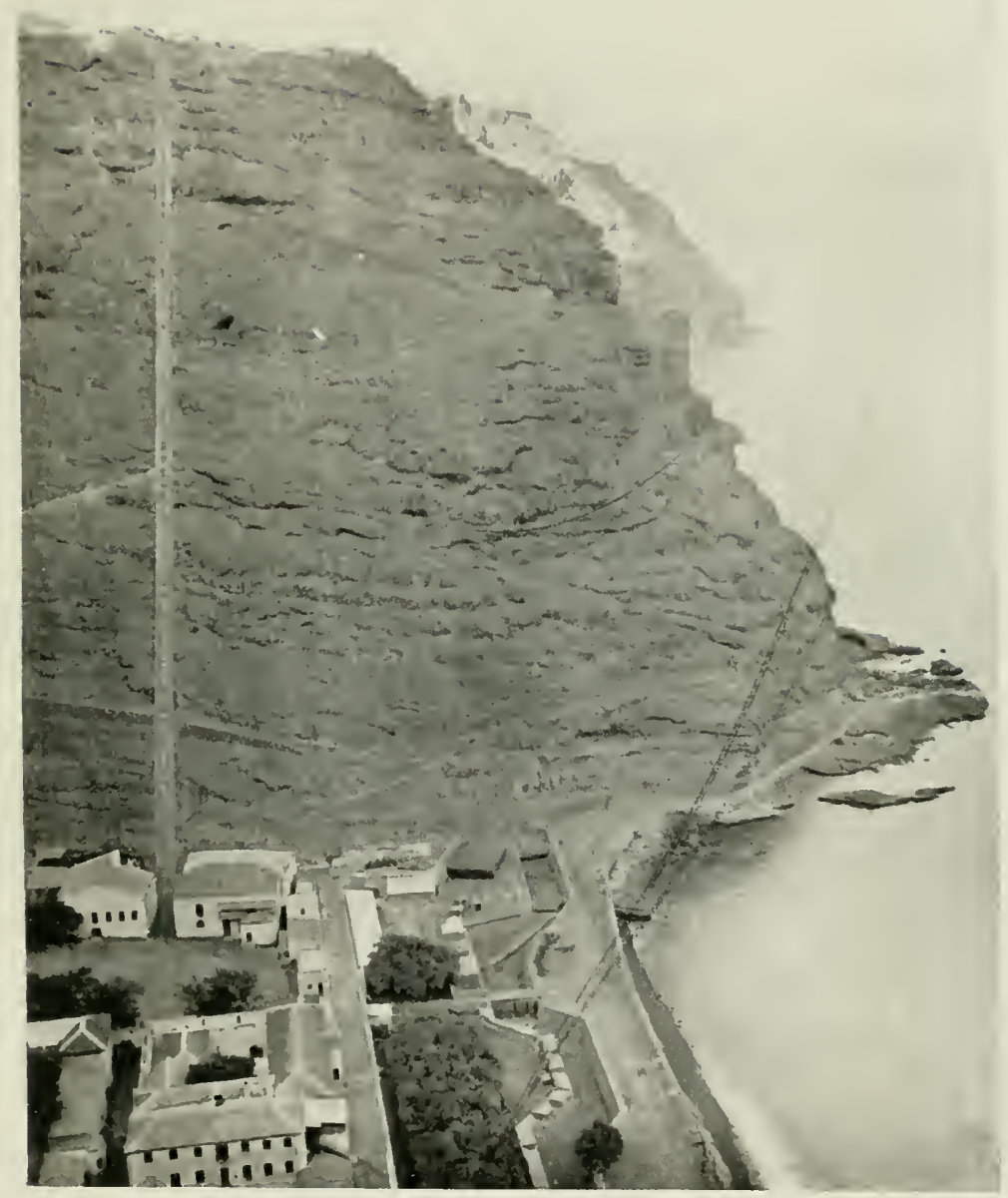

West Rocks, LAIDIER, ANI) LADder Hill Fort. 

prisoners of war from South Africa has altogether altered its appearance.

In this garden stands the public library, the telephone station and the museum. The public library contains 560 volumes of modern literature, in addition to a great number of old books which may be read on the premises but not removed; nine monthly magazines are there, and fourteen weekly papers, and during the stay of the prisoners of war those who were on parole, as well as the extra troops stationed in Jamestown, highly appreciated the privilege accorded to them of becoming monthly subscribers, and their support has cleared it from the financial difficulty it was in some time since. But the residents on the island do not take much interest in their library, as will be seen from the fact that there are at present in 1902 only ten yearly subscribers, the rest of the funds necessary having come from the casual visitors and monthly subscribers. The museum was started by his Excellency Governor Sterndale, C.M.G. It already contains much of interest, and is well worth a visit. Here may be seen specimens of cotton, flax, rope, dried fish, lantern fish, and a beautiful collection of St. Helena ferns, made by Captain Thomson, of the Bengal Pioneers. Specimens are here too of lace-work and wood-carving, done by the little fingers of St. Helena children, together with much more of interest to visitors.

In the centre of the garden stands a handsome fountain; this, when active, makes the hottest day seem cool, while under the shade of the trees are several seats. Just at the entrance to the gardens is a large building, which if utilized would form a spacious public hall, the need of which is greatly felt. This building was formerly a dwelling house, and it was here that Napoleon slept on the first night of his arrival in St. Helena. Strangely enough, the same room was occupied by Arthur Wellesley, afterwards Duke of Wellington, who slept there one night on his way from India to England. Concerning this I have come across in an old book of St. Helena papers the following :-

The Duke of Wellington on his return from India occupied the house in St. Helena, which afterwards was assigned to Buonaparte, 
on his being exiled there; and subsequently the Duke, during the occupation of Paris by the allied troops, occupied Napoleon's palace, which gave rise to the following letter to Admiral Malcolm who commanded at St. Helena. It is a literary curiosity, and ought to shame idlers :-

My dear Malcolm,-

PARIS, April $3,1816$.

I am very much obliged to you for Mr. Simpson's book, which I will read when I shall have a moment's leisure. I am glad you have laken the command at St. Helena, upon which I congratulate you. "We must never be idle if we can asoid it." You may tell "Bony" that I find his apartments at the Elisece Bourbon very convenient, and that I hope he likes minc at Mr. Balcom's. It is a droll sequel enough to the affairs of Europe that we slould cliange places of residence.

I am yours most sincerely;

(Signed) WeLliNGTON.

Main Street is wide and spacious; militiry quarters occupy the lower end, above which stands the hotel. On the opposite side are the United States consulate; and the pharmacy, a well appointed modern business, to which is attached a lending library and reading room. Solomon \& Co., the agents for the Union Castle line, have their offices in this street, above which are Jackson's stores, so well known to all passengers outward or homeward bound.

The mess house is an imposing building, and fronting it is the St. Helena club. Here the street widens and divides - the road on the left being Napoleon Street, leading to the Briars, St. Matthew's Church, the Tomb, Longwood, and Deadwood Camp. The street on the right continues past Thorpe's store and that of Galbraith \& Co. into the market place. Here are several shops, the principal being Messrs. Henry's, Thorpc, and Solomon's. Beyond the market is a long straggling street, which sadly wants rebuilding in many parts. One or two graveyards are here, but they have been closed for years past. About half-way up the valley is the middle parade, with officers' quarters. Attached were spacious barracks and a pretty little theatre; these have been demolished, and some years since new barracks were commenced, but they stand a few feet high, surrounded by the broken bricks which were imported by the Imperial Government at so great a cost. The Botanical Garden is the next place of interest. It was sold by the 
Colonial to the Imperial Government, and has been used as the Town Camp for military and prisoners during the war with the Transvaal. It contains many very beautiful trees and shrubs. Further up the valley stands the Roman Catholic church, the Government school for boys, St. John's church, and the two hospitals, civil and military.

The civil hospital is well worth a visit, being presided over by trained nurses. Beyond lies St. John's Villa (Government property), Maldivia House, which was occupied by the Zulu prisoners, but is now used as a military quarters, and Cambrian Cottage, where board and lodging may be obtained. From St. John's Church there are two roads, one going past the hospitals up the valley, where it again divides, one branch passing the waterfalls to the Briars, and so eastward into the Longwood road, and the other going up and winding round the cliffs called Barnes Road or Peak Hill on to Francis Plain, and so into the centre of the island. The chief road from St. John's church, however, is that called "Phillips" Road, which is the main approach to Ladder Hill. Here are barracks, signal station, fort, officers' quarters, etc.-quite a little village. The officers' mess (formerly the observatory) overlooks the town, and the view from it is very fine. Far below lie the houses of Jamestown, the neat church, upon whose summit the fish shows clearly and appears quite, near, so steep are the rocks; then on the horseshoe coastline, a fringe of white surf churning restlessly, and, beyond, a trackless ocean of most beautiful blue, over which on a clear day a vessel may be sighted at sixty miles. The fortifications entirely command the harbour. Passing through Half Tree Hollow, wholly destitute of trees except a few young saplings of recent planting, and continually ascending past clean little cottages, generally enclosed in a small patch of garden ground, " Kent Cottage," the home of Cronje while in St. Helena, comes into view. Above it on the left frowns that gloomy fortress, "High Knoll," where many of the more troublesome prisoners were kept. Schiel was lodged here for a short time directly on his arrival, when it was rumoured that he endeavoured to escape. Here Eloff was kept for the greater part of his time. One of the illustrations shows the prisoners outside the fort after the peace 
declaration and shortly before the departure of many from the island. Eloff is seated in the centre. From the road now can be seen "Prince's Lodge," owned and occupied by Mr. Solomon, and above it " Red Hill," the residence of Bishop Holmes. Near here is a Sanatorium for convalescent soldiers. At this point a view of the interior of the island bursts suddenly upon the traveller. Until now the journey has been up, up, over rocks covered with cactus and prickly pear, until High Knoll was reached, at whose base shrubs and trees of small size, mingled with aloes, relieve the monotony; the scene however from the hill top is one of great beauty. The central ridge outlined against the sky is some miles off, and at its foot pasture lands, sloping green and verdant, may be seen. On the extreme left is "Prospect," the property and residence of H. B. Morrice, Esq., also "Brook Hill," the farm of Mr. Louis Kinipe. In the foreground still to the left lie "Woodcot" and "Woodlands," both owned by Mr. W. A. Thorpe. Nestling in the immediate valley is II illow Bank, Mr. Liddy's residence, above which stands the cottage of Francis P'lain, lately used by Dinizulu, and Mr. Thomas Scott's house, where refreshments may always be obtained, the Baptist Chapel of Knollcombe, and "Knollcombe House," owned by Mr. C. Grey'lic in the valley, while higher and on the left is Rose Bower, the property of R. G. Short, Esq., the present (I902) sheriff. To the right of this stands out clearly the beautiful house and grounds of Oakbank. This property formerly belonged to the See of Saint Helena, but was a few years since bought by J. Homagee, Esq., supervisor of customs and police magistrate. Since the arrival of prisoners of war skilled workmen have been cmployed in renovating the house-with the result that it is, with its spacious verandah and balcony room, all that could be desired. The grounds are extensive and very beautiful, containing valuable trees, Chilian and Norfolk pines, Scotch firs, oaks and eucalyptus. In the valley cedars mingle with bamboos of immense size, the feathery tops of which present a beautiful appearance from the higher ground on which the house stands. A large stream of water flows through the valley, the banks of which are white with arum lilies. When these fail, up springs the delicate Easter lily in their place. This ground is noted too for the varicty of ferns which grow 
in wild profusion. On high ground to the right of Oakbank is Lufkins Towers, lately rebuilt by Government, the residence now of Surgeon-Colonel Mosse, while more in the foreground is St. Paul's Villa, a compact little house owned by Mrs. Lloyd Roe.

During the residence of the prisoners of war there were amongst them, as I have before stated, many excellent workmen. One, a builder (Mr. Otto Scheffer), undertook to erect for me a nine-roomed bungalow. With a staff of competent workmen he had completed this work when the news for their relief from captivity arrived. This bungalow, "Kingshurst," is, I think, with the exception of one built for Mr. Deason at Longwood, the only house erected during the time of their imprisonment, although nearly all the country houses have been repaired or enlarged by the addition of verandahs. On the summit stands St. Paul's Church (the Cathedral) of the island, surrounded by a spacious cemetery, and close by, on the finest property in the island, stands Government or Plantation House, the residence of the Governor of St. Helena. It is well built and commodious, containing about forty rooms, but it would be wonderfully improved by the addition of balcony and verandah.

It was erected in I79I, and stands in about I76 acres of picturesque and fertile park land studded with oaks, Norfolk and Chilian pines, Scotch firs, cedars, etc. ; in fact, trees from cold, from temperate, and from tropical climes abound, and it is situated about three and a half miles from Jamestown at an elevation above the sea of I,79I feet. The grounds contain a fund of amusement and recreation for the botanist. Here, in one of the valleys near some large clumps of Indian bamboos, the Chinese had their settlement and Joss-house, from which were taken the interesting tiles, etc., now in the museum, and the old laundry used by them has only lately been demolished. The view from the plantation is very extensive and beautiful; and the walks are delightfully cool and shady even during the tropical summer.

Following the main road from Plantation we get into the centre of the island near the heights of "Diana," "Cuckold," and "Acteon." But a road skirts Plantation House and 
St. Paul's Cathedral bearing west, leading through a pretty lane past "Sydenham," owned by the Misses Deason; Scotland, the property of the Misses Moss; St. Paul's Vicarage, Oaklands belonging to Mr. R. Henry, Farm Lodge, and Woodland, owned by Mr. G. Moss. Near here is "Broadbottom," on which the camp for the military and the prisoners from the Orange River Colony stood during I90I-2. Away beyond this the verdure suddenly merges into rugged and inaccessible cliffs, some of the paths round which are fit for riding, but many of which can only be traversed on foot. There are scattered over the landscape many cottages but none of any size. West Lodge, said to be haunted, was formerly a show place of the island; the lands are still beautiful, but the house is now in ruins; High Pcak, Horse I'asture, Man and Horse, Blue Hill, and Thompson's Wood are some of the best known places on the westward side. On the westward ridge is the curious rock named the Friar, so called from its striking resemblance to a cowled monk. At the base of the ridge is Friar's Lodge, and near by Clcughs' Plain, both owned by the Rev. Father Daine, R.C. chaplain to the troops.

Near Oaklands is a small knoll called "Mount Eternity," where slaves were formerly buried. Several headstones remain ; one very easily deciphered is that of "Diana." In Plantation grounds also, near the site of the Chinese quarters, are a few headstones of slaves; one of these is dated 1777 .

Seen from the main road the scenery is remarkable for its softness, until the road skirts the central ridge, from which is to be seen Sandy Bay in all its varied splendour. Houses are dotted about on the right; but out of sight from the ridge stand Fairyland, owned by Mr. Thorpe; and Rose Cottage, lately Bishopric property, but now owned by Mr. Adams. Fairyland was once a noted dairy on the island; even now the pasture land is excellent.

In view on the right is Mount Pleasant, the property of Mr. Barker; while to the left is Wranghams, not long since bought by Solomon and Co. In the centre of the huge basin of land is Coffee Grove and Bamboo Hedge, where Mr. Albert Henry grows what is determined as the best obtainable coffee. 
On a point may be seen Mrs. John's residence, while away to the left stand a little group of cottages on Green Hill. In the foreground soar the huge peaks with their wonderful tree ferns and cabbage trees; the distant panorama finishing with the sea. Continuing around the ridge, verdant pasture lands stretch as far as Halley's Mount, to reach which "Rural retreat" and "Hunt's Gut" is passed. From Halley's Mount the whole of the east of the island is in view -St. Matthew's Church, with its pretty vicarage, and Hutt's Gate, owned by Mr. Jackson. Around the Church, a path having now Diana's peak on the right, leads to "Teutonic Hall," the property of Messrs. Lewis; and Arnos Vale, belonging to Messrs. Deason Bros. Around the knoll of Arnos Vale this road continues to Silver Hill, Bell Stone, and many outlying cottages. The main road from Hutt's Gate, however, is that to Longwood and Deadwood. In the valley by the road is Willow Bank, occupied by Mr. Metcalf. The supplies of water are brought along here from the peak lands for the use of Longwood and the camp at Deadwood, beyond which rises the peak called Flagstaff. To the right of Deadwood is the historic plain of Longwood with its houses of Napoleonic interest-one occupied by Monsieur Morilleau, the custodian of old Longwood house and the tomb. Longwood is farmed by Messrs. Deason and is in an excellent state of cultivation. The late Mr. Thomas Deason was very keen on introducing modern improvements and implements. Here are to be seen silos for storage of fodder-a windmill for which he had bricks made on the island, and which he fitted with machinery of various kinds. He imported and improved greatly the breed of horses and cattle, ostriches also were imported by him, but the climate proved unsuitable, though one lived for several years; the feathers were of good quality but often much soiled by the red clay of Longwood, which is almost destitute of sand. The road leading to Longwood skirts the head of Rupert's or Seine Valley as it is called here in the upper part. The precipice from the road down is terribly dangerous. Mr. Deason planted this edge with flax which adds greatly to the comfort of travellers, breaking the sweep of wind and also to a great extent hiding the awful steep. In reality the danger of driving 
off the road is not much lessened, but visitors do not lose their nerve in riding or driving around, as they did when the edge of the road was bare, and a yawning chasm shewed beneath. Longwood and Deadwood do not now contain many plantations of trees, still young trees have been planted of late years. Further on is Prosperous Bay, (where the electric telegraph station is built) and the "Barn," a compact mass of land bearing a marked resemblance to a large barn. Here on certain days goats may be hunted. Returning from Longwood as far as Hutt's Gate, the town is approached direct instead of going by Halley's Mount. From St. Matthew's Church the road winds round Seine Valley in the verdant part of which is "The Tomb." This is a pretty spot and one much frequented by visitors to the island. On the height orerlooking the town and harbour is "Alarm House," the residence of Mr. Legge, while below are "Varneys," owned by Mr. Broadway, and the pretty little cottage belonging to Miss Marshall. The road winds around, and on the left is "Prospect," which was viewed from the High Knoll side. This is a well-built house standing in good grounds and lately made much more attractive by the addition of a verandah. From this point the road steadily descends past "Two-gun saddle" to the "Briars," which nestles most comfortably in its fertile valley. Here are the houses lately bought, and others recently erected by the Eastern Telegraph Company and in the Briar's house the Superintendent, Mr. Collard, resides, while the "Pavilion" (where lived Napoleon for the first two months of his exile), is occupied by the Assistant Superintendent, Mr. Marsden.

Below the Briars the road is called Side Path. From this a fine view of the waterfall as well as of the town and harbour is to be scen. Just under the path are the Commissiariat Stables, the Poor house and the Lunatic Asylum ; and near here the path merges into Napoleon Street, where are situate the Benevolent Society, the Hussy Charity and the Government Girls' and Infants' Schools. Napoleon Street is narrow; it opens out of the Main Street, which is very wide. It took its name from its being the strect which Napoleon traversed on first going to Longwood. 


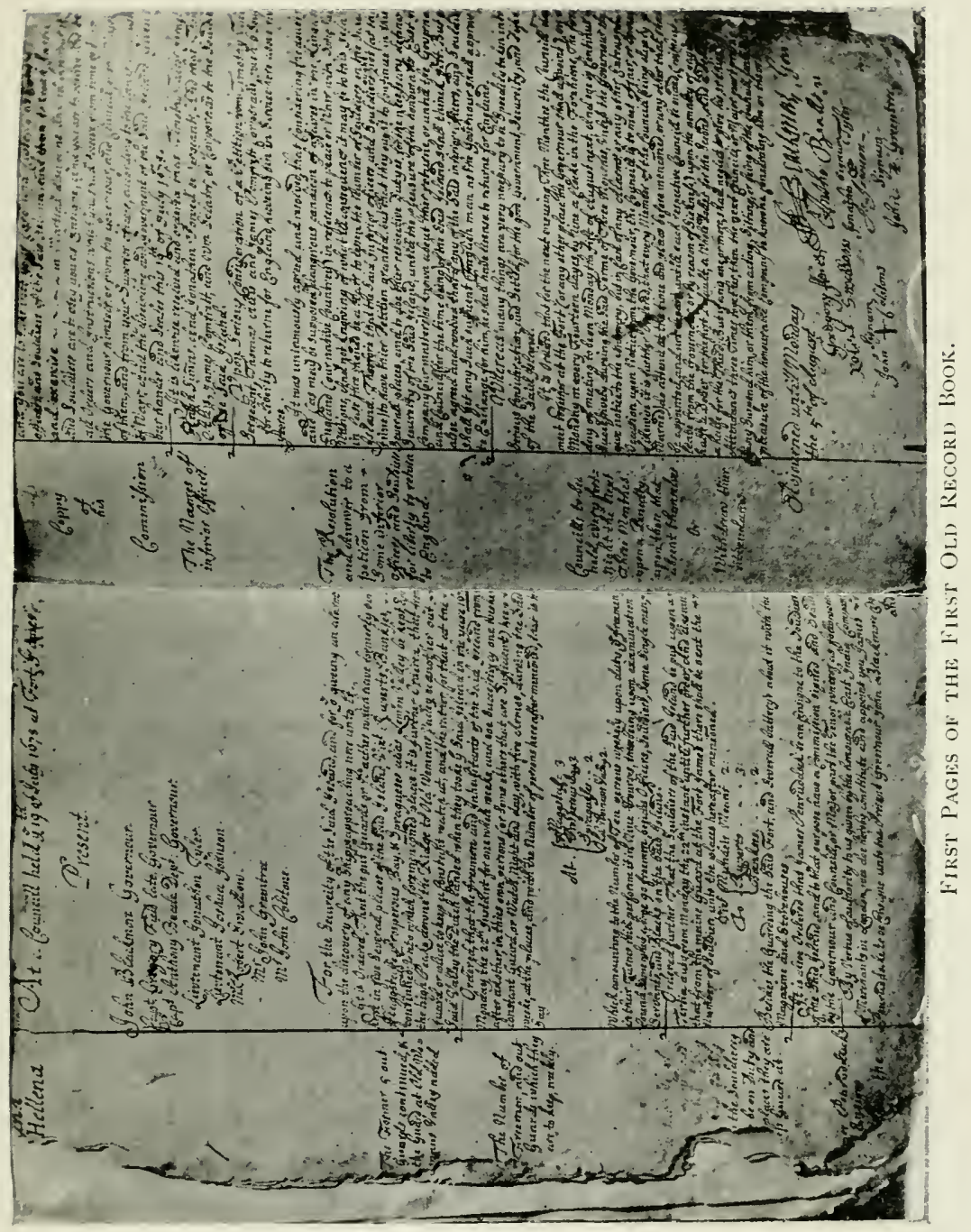





\section{JOTTINGS FROM ST. HELENA RECORDS.}

THE records of the island are very voluminous, but none are of earlier date than I673. They consist of I54 large (four quire demi) books of consultations of the Council during the period from 1678 to 1836 . The first volume, from I673 to I677, is unfortunately lost, and was said even a hundred years ago to be torn and illegible. Besides these, there are thirty-two volumes of letters from the Directors of the East India Company to the Government and Council, commencing from I673, and twenty-nine volumes of letters from the latter to the Directors. There are also eight volumes of registers of property and deeds of transfer, beginning with an account of the allotment of land to the planters, as it was given to the jury impannelled for that purpose on September 26, I682; also four volumes of registry of wills from I68I, and twelve volumes of trials at sessions, commencing I762. All the trials of earlier date are entered on the Council proceedings.

These records give us minute detail of the squabbles, jealousies and crime of the inhabitants for nearly 200 years. The majority of the people were honest, inoffensive and hospitable so in reading the ludicrous, sad, or sorry occurrences, we must remember that they only attracted attention because they were not usual.

Here it is impossible to give in detail all the interesting matter found in the records. The following table of the contents of the first two volumes forms a curious and interesting contribution to the Archæology of the island :-

June 27, 1678. Blackmore Governor-8 members of Council, 3 cannot sign their names. School held in country church. Mr. Wynne minister.

Council, 2nd Sept. 1678. Tanners; Wild cattle about High Peak. Places of publication of notices, church door in country, and flagstaff in the Fort St. James. 
3oth Sept. Church suffered some damage by extreme heat of weather. Sexton appointed. Churchyard enclosure, and hedge of lemon trees ordered.

Wild goats and wild cattle.

2 Ist Oct. Church to be inspected after the next rains, boards cracked by the sun.

Guard House at Spraqueses, i.c. Lemon Valley, to be repaired. Timber to be cut in the next adjacent place.

2nd Dec. Two soldiers killed in the Crane Battery by falling rocks. Timber viz. 240 pes. Gumwood trees to be felled in the next adjacent wood, that is nearest to the Fort St. James, to cover in the said battery-this timber was felled at the head of the Scine Valley vide -24 th Feb. 1678 .

$1678-79.27$ th Jan. Peter Williams, 21 lashes on his naked body at the Flagstaff for concealing two runaway blacks.

Lemon trees and their fruit, order for their preservation.

Church by report of Mr. Wynne in need of some repair, order for a voluntary collection. Order that all pigs in Chappell Valley be penned up on the firing of alarm guns, they fouling the water for the shippes.

Salto, a black, condemned to be hung, his hand and head cut off for wounding his master; and Rowland, a black, to be led to the place of Saltos execution, there to receive 40 stripes save onc on his naked body, and a pair of iron pothooks rivetted about his neck.

Page 86. Sarah Marshall to have 3 t lashes on her naked body for scandal-Asses.

A law against the wilful throwing or rolling down of rocks.

Page 85. Inquest on Thos. Green; body taken up; trial by touching the dead body ; 3 persons committed on verdict of manslaughter.

Page 84. Liberty given to inhabitants of E division to build a place for public worship and for schools.

Page 104. W. Melling to ride the wooden horse with a bag of shot at each hecl.

Page 105. $\$ 6$ was the expense of making the new line of batteries before the lines at Ruperts.

Settlers in St. Helena to have to acres of land and a cow on marrying-in some cases 10 acres more and another cow.

Page 124. Gaming; bowls, nine holes, nine pins forbidden.

Page 126 . Some soldiers through intemperance, and ill husbanding their clothes to rags (?).

2nd Aug. 1680. Council ordered for this day could not meet till a week after, a ship having arrived from England.

f5 10 s. od. the expense in repairing and making new the mount at Ruperts and the Batteries at Banks. Paid 129 dollars current at $5 /$ - each.

Women not to go on board ship without Governor's license, and then only in company with their husbands.

Page 143. School house in the E division-permission for requested 
IN SECOND BooK, I680.

Page 155 . That troops will be paid half in cash and half in goods. The ship Bridgewater with slaves from St. Laurence Island bound to Barbadoes.

Pinnace sold by inch of candle.

Page 163. Ship Friends Adventure with slaves from St. Laurence, alarm occasioned by her arrival.

Page I84. William and John free trader from Bengalla in a leaky state.

Page I 87. Ponds by the Saley port, Fort James.

Page 195. Mr. Church the minister exchanging a black woman for a black man.

Page 209. Permission to planters to take away fallen trees in the Great Wood.

Page 220. Church rate I/- per 20 acres or $\mathrm{I} d$. per head of stock.

Page 23I. Wm. Saddler is discovered to be a Quaker, for which and other bad behaviour he is ordered to leave the island.

Complaint by A. Wilson against Kersey for calling him wizard. A black man is distrained for debt and ordered to be sold.

Page 239. A woman whipped at the Flagstaff, Jamestown. Contract and agreement by a joiner to make a chest of drawers.

Page 24I. Asses-no increase in. Two acres of potatoes.

Page 253. 320 yams per month with beef, sweet oil, lamp oil, 30 candles, etc. allowed to Mr. Church the minister.

Page 256. Also rice, vinegar, and paddy for his fowls. Fish royal - the sea cow (royalty ciaimed on).

Page 269. W. Gates called Mrs. Powell a witch on the ground that he has never thriven since he took home his little daughter.

Page 277. Gates to ask pardon publicly in the church. Inhabitants have cut down much wood and building timber.

Page 289. Wood and timber in Sandy Bay. Thomstone wood.

Page 290. Extraordinary drought and failure of water.

Page 297. Timber and wood in Sharke's Valley and Fisher's Valley.

Page 299. Women whipped on their naked bodies at the Flagstaff in Jamestown.

Wood and timber at Hutt's plain.

Chubb's spring.

Page 33I. W. Melling to keep school in the church.

Page 336. The only boat at St. Helena blown out to sea and lost.

Page 396. Mr. Church the minister dead. Mr. J. Cramond appointed. Mr. Lufkin, being one of a sober serious life and conversation, appointed member of Council.

Page 404. Order for erecting Court of Adjudicature or sessions house. The market house near Fort James selected for the purpose.

Page 406. Mr. J. Sick the first sheriff. Prison to be appointed and made.

Page 607. Edmund Chubb killed by falling from a ledge of rocks 
at the seaside near Rupert's or Seine Valley. Inquest, verdict death by chance.

Page 410 . First sessions, scale of fees, etc. John Orchard doth run away to neighbour's houses and into the woods many nights and days, for some wecks together.

Pages 85, 102. Extraordinary verdicts, churchwardens appointed to collect money for repair of church.

Page 4it. Order of proclaiming sessions and fee.

Copy of First Page St. Helena Records as Illustration.

At a Council held at Fort James the $27^{\text {th }}$ of June, 1678 .

Present-

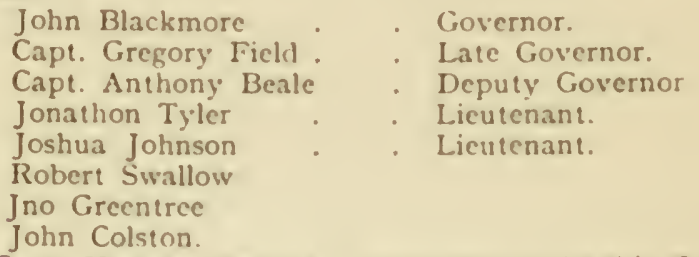

Capt. Hopefor Benbell, Commander of the ship Johann

The instructions from the Honourable East India Company dated the Twentieth of February last past and brought over by the Governor were openly read, and this being the first Councill after the present Governor's arrival, it was proposed by him (for the better management of the Government of the said island and free debates at all consultations) that all who are members of the Councill should promise and engage upon their reputation not 10 disclose, discover or declare to any person or persons, inhabitants or souldiers of the said island (except amongst themselves) or others that shall arrive thereon any of the said debates, eliscourses, consultations or resolutions that shall be at any time had or made at the Councill board but shall keep all words, passages, votes very privette and secret, excepting such orders of declarations as are afreed on to be made publicke, which said proposall was assented unto by all the members present and accordingly every one of us doe personally promise and engage upon our representations to perform the same.

In witness whereof we have hereunto put our hands. (Signed)

J. BLACKMORE, GOV :

GREGORY FiELD.

ANTHONY BEALE.

A mark 8 made by Joxathox Tilor afterwards spell TYLER.

Jo JoH:sox.

ROBERT SWALLOW.

A mark $\mp$ made by JOH: GREENTRER.

A mark $\times$ made by Jorı. Colstox.

The lot of the St. Helenians is very different now com- 
pared to that of the people in the old days of slavery. Owing to the wise and gradual process of emancipation adopted, i.e. the free children growing up with their slave parents, the evils of sudden manumission, so disastrously felt in the West Indies, were avoided in St. Helena, and the result is a manly, civil people, educated quite as well as the same class in the United Kingdom (in fact, the English tongue is spoken by them with as great purity as in the rural districts of England), living in many instances in their own comfortable cottages, with generally a neat, productive garden attached. Contrast this with life in the seventeenth and eighteenth centuries, when slaves were judicially tortured, hung drawn and quartered, and burnt alive on mere circumstantial evidence, while for open acts of diabolical cruelty their masters were acquitted or very lightly punished. The records give many instances of this :-

On January 2, I693, a slave of Deputy-Governor Keeling was found guilty of sorcery and burnt to death.

In November, I687, Peter, and in December, I689, Job and Derrick, slaves, convicted of poisoning their masters out of revenge, were burnt to death; all other slaves to be present, and to bring down a turn of wood for the purpose.

A black who was tried before a jury and acquitted was ordered to be flogged before being discharged! For stealing a piece of cloth from a sailor in the street, William Whaley was hanged on June 24, 1789; and on January I 5, I 800, Job, Mr. Defountain's slave was hanged for snatching a bottle of liquor from a drunken soldier. Both these cases were looked upon as highway robbery.

A young girl found guilty of burglary was sentenced to death. The jury were told to reconsider their verdict, but they adhered to it. She was respited for a time, but hanged herself in prison.

Terrible sentence on a negro: A slave attempted to kill his master by putting ground glass on his supper. He was condemned to be burnt in the presence of all the adult blacks of the place, each one of whom was compelled to bring in a load of wood to help in burning him.

Sunday was strictly observed throughout the island, and the following was enjoined by proclamation :-

"That the Lord's Day be religiously observed through the said island, and all persons hereby enjoined to abstain from all bodily labour, unnecessary travel, or any secular employment (except works of necessity and charity) and noe person presume to spend any part of that day in unlawful sports, but all (who are able) are required to resort every Lord's Day unto publique place or places where the worship of Almighty God is celebrated, and there joyne 
together in the solemn cxercises of Right Duties and attendance upon, God's holy ordinances. Also carefully to avoid the odious sinnes of profane swearing and cursing or commonly taking the holy name of the Great Glorious God in vaine, and to abstain from drunckenness, stealing, thicving and other horrid vices and wickednesses."

Sarah Marshall had thirty-one lashes on her naked body at the Flagstaft for scandalizing Captain Bendall.

Parnum was fined 5s. for working on the Lord's Day, and his wife is. for cursing the island.

A terrible punishment was this: Sottoc, a slave, was for some fault chastised by his master, and retaliated by attacking him with his knife; the result was, not much harm for the master, but terrible for the poor slave. There was just at this time a fear of insurrection amongst the blacks, and Sottoe was chosen as the instrument for maintaining order. He pleaded that a fellow slave named Rowland persuaded him to attack his master; also that he was under the influence of tobacco which he had stolen and smoked in a pipe ; this pleading was in vain. It was ordered that his hand wherewith he attacked his master was 10 be cut off; he was then to be hanged and when dead his head was to be cut off and placed on the top of the Market House as a warning to all transgressors. Rowland was not let off punishment, for he was to be led with a rope round his neck to witness his compranion's execution, and after forty stripes on his naked body he was to have a pair of iron pothooks rivetted round his neck until further orders.

The above terrible sentence was not, however, carried out in full. Sottoe's hand was cut off in the presence of all the blacks, but his life was spared.

Soldiers were generally punished by being compelled to ride the wooden horse.

William Melling for swearing and incivility "doe ride the wooden horse two houres with a bag of shott at each heel." Again, "that Richard Honeywood doe rid ye wooden horse halfe an houre with two musketts at each heele for slighting the Government and malitiously revenging himselfe.'

For attempting to get away from the island slaves were punished by seventy-five lashes, with five drops of burning sealing-wax dropped on the naked body.

They seemed in the olden time to be unfortunate in the choice of their clergy, but in reading all these records of cruelty we must remember that the times were cruel, and that in England also highway robbery, sheep stealing and forgery were capital offences.

Even the whites in St. Helena were made at times to suffer cruel punishments :-

In 1684 Elizabeth Starling was flogged and "duckt " three times. 
In November, 1728, Ensign Slaughter, accused of slandering the Governor, was flogged; and late in the records is a reference to this whipping which it is stated was done with wire whips and fish hooks tied to a cane.

\section{Interesting Record Concerning Lime.}

Capt. Edward Mashborne in digging of lime stone in Breaknect Valley, amongst 'em seat some that was mixed with other stones and dirt, which being tryed in the fier there was found with it several specks of gold. And Mr. Daniel Griffiths since hath sent to the Governor two sortes of minerals found the last week by Charles Rothwall, a soldr lodging at his house. The one is gold the other we take to be copper, samples whereof may be seen at the Governors. Wherefore for the encouragement of any person that shall be industrious towards finding a mine thereof shall have as a reward for his trouble two hundred and fifty pounds for the gold, and one hundred and fifty pounds for the copper mine. And this rainy season being the most proper time for looking into all the waterfalls and streams, we desire that they may apply themselves diligently thereabout, being assured that there are such mines upon the island.

Dated Fort James this 23rd February, 1708.

At a consultation held on Tuesday the 30 th day of May, I7 IO, at the United Castle in James Valley.

Present-

JNo. Roberts, Esq.

EDWD. MASHBORNE

WM. MARSDEN

Daniel Griffith :

MaTTheW BazeTt .
Governor.

Dep. Governor.

3rd in Councill.

4 th in Councill.

$5^{\text {th }}$ in Councill.

Capt. Mashborne reports that he findes the Governours project of mixing lime very serviceable to the ground in destroying the worms which were so destructive to the meaze planted, and has got the plow up, and designs to brak up more ground and manure it with lime, in order to plant more meaze.

"Let Capt. Mashbourne use his utmost endeavours to bring the meaze plantations to perfection, it being of so great importance in preserving the health of the people of this island. The people are very sickly and they sending down to the Governour every day for Brandy to supply their present Necessitys."

\section{Ordered.}

That a noat be put up at the Store that Monday next being the 5 th day of June, the Brandy will be served out at Eight Shillings a Gallon, in the mean while let Every one bring in an Account to the Storekeeper what quantity they want.

At a Consultation held on Tuesday, the I 5 th day of August, I 7 IO. Passed as above.

The Governour says he got a Receipt for making of sugar out of one of the last Shipps, and so he made an Enquire to Squeese the Canes, and with three Yam potts went to work Last week and 
Unhappily spoiled the first Lime, for it burnt to the bottom of the Pott, but be went to work again with it, Squeezed more canes, and it hit the second time, and made nine or Ten pound of as good sugar as any in the West Indies, and here it is-

\section{Ordered.}

That a Pound or two be sent to our Honble Masters by the next shipping and that they may be acqquainted that We have found the following articles Since Governour Roberts came here, viz:

Lime.

Tyles.

Sugar.

Brick.

Cut stones for building.

Rum.

Mineralls of severall sorts.

Upon which we are now resolved to fire Nine Guns, to drink our Hon'ble Masters good health and Success to the Island, for we are well sattisfied this Island will turn to account and not be a dead charge it Ever las been, if our Hon'ble .Iasters will please to Encourage it and supply these people with necessarys, and then there will be no Aversion against Improvements, but Sliowers of blessings of these people will come to them.

At a consultation held on Tuesday, 19th December, 1710 , at the United Castle in James Valley, present ] no. Roberts, Esq., Governor, elc.

The Chanell or Water Course that runs upon the side of a Hill that waters the Shipping and this Lower Garden by the soaking of the Water, occasioned a great deal of the Hill to Tumble down and made such breach that has taken us a great many blacks and Whites to Repair which is now over, although its to be feared other places will do the like if not timely prevented, and it seems hardly possible to prevent it under three months labour with fifty people at least, but having so many irons in the fire, the most needful is to be preferred, and that is planting pearsides. The Castle at Mundens point is finished all but one battery and a halfe, and the angles that joyn to the Hill, which we think to leave so, untill the guns are mounted, that being the properish place to purchase them up.

\section{RESOLVED}

That a path of communication be cut between Managers Castle upon Mundens point, and the United Castle in this Valley, that a file of Musquetecrs may go in a Breast, and that the same be done according to the Governors scheme.

At a consultation held on Wednesday, Itth of Feb. 1710-11, at the United Castle in James' Valley, present John Roberts, Esq., Governor, etc.

The Governor reports a Channell being cut from the Water Course in the Valley to the top of the Hill, as mentioned in consultation of the gth of January last. Yesterday in the afternoon, he turned the water out of the Valley, which now runs currant on top of the Hill as you all see, and says he has done it sooner than he expected, having had no more labourers than he expected, by 


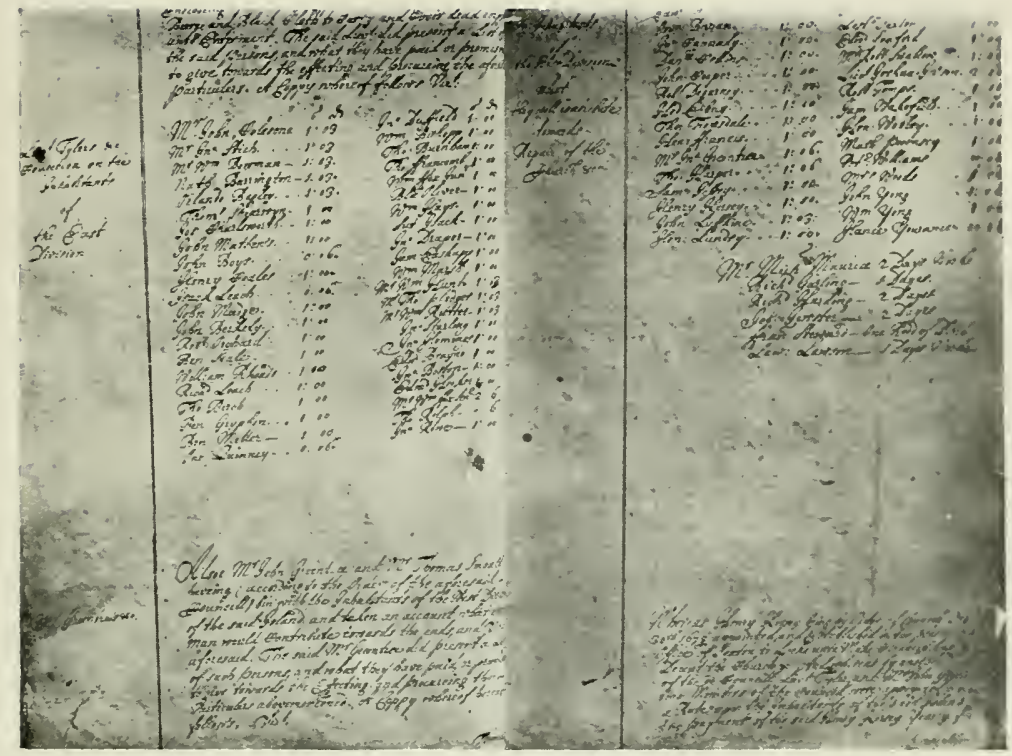

P'AGES FROM OLD RECORD BOOK.

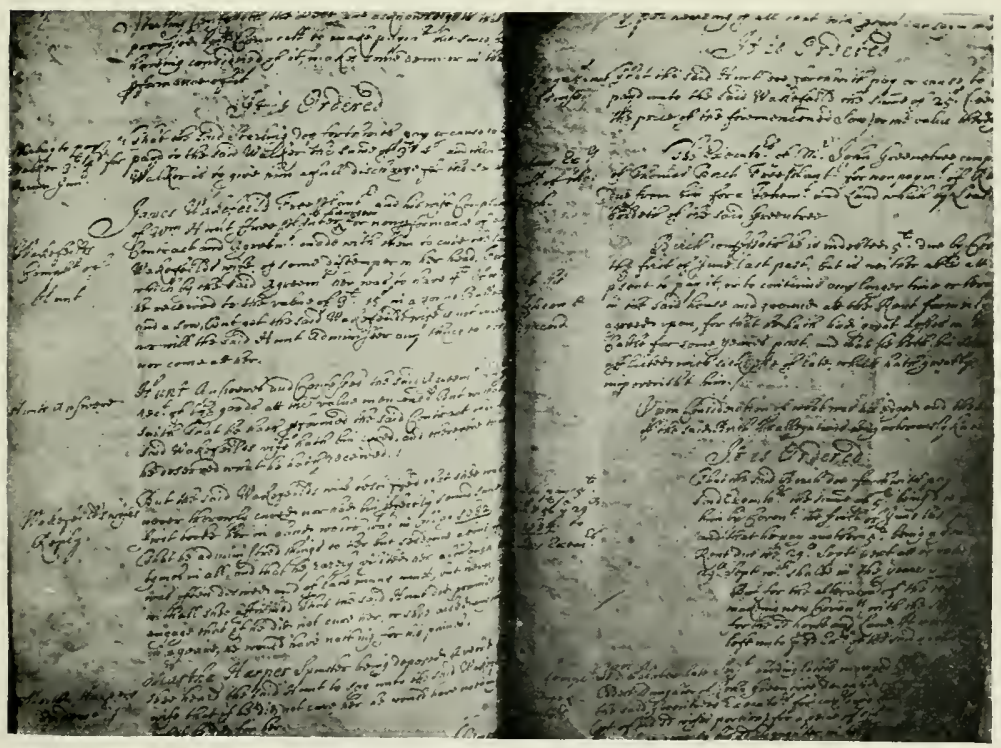

Pages lRom Old Record BOOK. 

which means we have saved the season, and believe the best way now is to fence in fifty or sixty acres of it immediately, and proceed in planting what grain we have, corn and beans, etc.

As also when fenced in to transplant all the Yam Succors in the upper part of it. And a pond must be made to resist the force and fury of the water course in the raines, as well as to save the water for the dry season, after the land is fenced in, and we must be obliged to burn lime with wood for that purpose, and if the season should set well in, we might make a shift with that one pond, till a ship comes from England that may bring coles, which will save the company a great deal of charge, nor will the charge he says amount to halfe as much money as he proposed in the consultation of the $9^{\text {th }}$ of January as aforesaid, because two-thirds of the watercourse is cut out of rocks and clay, so that it won't require above a third of it to be done with lime, and by what he can see yet there will be no occasion to repair the watercourse in many years, even as it is now cut, in the next place there will not be occasion for so many ponds for the current is pretty strong now, notwithstanding the long dry windy weather we have had, and we may reasonably expect that the current three-quarters of the year will be three times bigger than it is.

And as he has gained a great deal of ground by raising the water a-top of that hill by several acres higher than he first measured, so that that plantation, well managed, will supply a thousand people with yams, corn, beanes and potatoes, besides the advantage of sugar plantations, and vinyards. And the antient constant. custom of buying yams of the planters will be altered in twelve months time, if please God to give a blessing to our endeavours.

\section{Ordered.}

That the land and plantation aforesaid be fenced in, as the Governor shall please to direct, and that Capt. Mashborne do proceed in planting the same accordingly.

At a consultation held on Thursday the 29th day of March I 7 I, at the United Castle in James' Valley, present John Roberts, Esq., Governor, etc.

Mrs. Grace Coulson declares that black Oliver was her slave, and also his wife, and when the Dutch took the Island they went to Brazile, and there sold the said Oliver her slave to an English merchant one Mr. Abram by name; Capt. Anthony Beale, and Captn. Metford, Commander of the Humphrey and Elizabeth, hired a sloop at Brazile to come and cruise to the windward of this island, to give notice to all merchant men that the Island was taken by the Dutch and they persuaded Mr. Abram to let the said Oliver go in the aforesaid sloop because he knew the Island; being upon her cruise to the windward of the Island they met Sir Richard Munden to whom they gave notice as aforesaid, and black Oliver being well acquainted with the Island took him out of the sloop, and ordered him to conduct his men into the country to retake the island, which he performed, for that good service Sir Richard Munden gave him his freedom, and sent the money to his master to Brazile, and five pound 
more that he had paid for him to Mr. Coulson. And his wife the antient old company bought her of them, and sent her to her husband, and repaid Sir Richard Munden for black Oliver, who was made a free planter and bestowed this twenty acres of land upon him, and all other encouragements that free planters then had, as appears by the 33 rd paragraph of a letter from the antient old company dated igth September, 1673 , as may appear.

The following records on the names of localities will be found interesting :-

"Alarm House" called so from 2 guns (stationed here prior to 1692) which were fired as alarm guns whenever ships were signalled.

There is an order in Record of Sept. 12, 1692, that

"The alarm of two guns from Prosperous Bay is to be repeated by the alarm guns on the main ridge of two guns. But if more than one ship, then three or more guns, on which not only the planters but their blacks must also attend."

Governor Pyke proposed to plant this ridge with trees, being of opinion it would make this valley (James Valley) as healthy and fruitful as formerly, he says :-

" We are confirmed in this opinion by a sort of experience. Those who best remember this place say that the fine Lymon and other fruit trees that used to grow in such abundance in this valley thrived till after the cutting away of wood on this ridge, and it is a sort of demonstration that Mr. Powell, whose house stood on a ridge exposed to bleak winds and rain, people used by way of derision to call it Stark-naked House, yet, Mr. Powell being obliged by a most useful law made in Governor Roberts, his time, to plant part of that land with wood, since the wood has grown up, everything has flourished and he has now plenty of Lymons.

BANkses, mentioned by this name on June $27 \mathrm{th}, 1678$, but on Ist Mlay, 1734, called King William's Fort with an explanation that it was in the drift of the island called Bankses platform-the platform was first built there, and retained the Builders name, but at Bankses platform they could not call to any ships, and the men of war that came here, in King Whlliam's time contrived the fort above the hill above Bankses, which they called King William's fort; and it is this place that all ships that intend for the island go as near as they can, so that we usually hale them from this place, and they hear well what is said to them, but the wind there coming alway off the shore, we cannot so well hear what they answer-but, if they are heard, a messenger is always dispatched thence to the Governor, and they run along the side of the hill in a dangerous path which all strangers usually admire to sec."

Briars - mentioned as a Yam plantation of the Company on 16 th May, 1733. This plantaiton was given up in September, 1739. In August, 1827 , it was repurchased by the Company for $£ 6,000$ to make a mulberry plantation for feeding silkworms. Since then the property has been famed as the residence of Napoleon while Long. 
wood was being prepared for him. The day after his arrival he rode to Longwood and on returning was struck with the appearance of the Briars and expressed a wish to remain there. It is very probable he did not wish to return to the town where crowds were waiting to see him. Mr. Balcombe, the owner, readily gave him accommodation, and his daughter Miss Betsy (Mrs. Abell) gives in her book Recollections of the Emperor Napoleon numerous and humerous anecdotes, many of them remembered by old people not long passed away. Miss Betsy seems to have been a very livcly girl. In a steep descent she pushed her sister Jane with such force against Count Las Casas that to the horror of the old count he found himself made a catapult of on to the back of Napoleon who was leading the way. This was done to revenge herself on Napoleon who the day before held her while young Las Casas kissed her. Another time she with a drawn sword kept Napoleon pinned in a corner of the room. Napoleon's method of punishing her was to pinch her and call her Mademoiselle Betsee, and on one occasion when she expected to go to a ball at the Castle he ran away with her ball dress and kept it until Betsy was in despair at having to stay at home. Her father's method of punishing her was more severe, for he locked her up in a dark cellar infested with rats and terrorised her.

(The Briars for many years was the property of Mr. George Moss, but is now owned by the Eastern Telegraph Company.)

BROADBOTTOM.-Unlike many of the island ravines, which are generally narrow, this widens out at the bottom and forms a fine broad flat of arable land. On I I th August, I679, it is recorded that Lieut. Johnson had chosen his grant of thirty acres at Great Bottom near High Peak. This Lieut. Johnson afterwards became Governor Johnson and was shot by Henry Fogg, a confederate in Sergt. Jackson's mutiny in 1693, particulars of which are given in Brooke's History. The fact that the Governor had been warned but treated the warning lightly is not noted by Brooke. We find this, however, in the settlement of a private dispute between Hoskinson $v$. Rooker which took place nine months after the mutiny. A witness named Gargen then stated that he heard Fogg speak of their intent and " he told Governor Johnson what he heard from Fogg, which the Governor made light of," but that the Governor as an acknowledgement "sent him a clean pipe by his son Caleb." Governor Johnson's widow and son remained in possession of Broadbottom; the widow died in I I I 3 and the son in 1745 , when he bequeathed it to his son-in-law John Alexander in whose family it remained till 1843, when it was surrendered to Government for a mortgage to the Widows' Fund. The original allotments of land to first settlers very soon changed owners, and passed through many transfers, and this of Broadbottom is the only one that remained in the same family until the transfer of the island to the Crown.

(Broadbottom, which now belongs to the Hon. G. N. Moss, member of Council, has come lately into great notice as the camping ground for the prisoners from the Orange Free State during the Transvaal War.) 
Chubb's Spring.-Thus is a fine spring at the head of James Valley, discharging hourly 3,600 gallons of pure water. It is the chief source of the water supply of Jamestown. It takes its name from Chubb a soldier who landed with Governor Blackmore in 1678 . From Record, March, 1682: "Edward Chubb allowed half an acre a little below Peak Hill and High Waterfall. Chubb's Rock, where he was killed in 1683, is near Rupert's Valley; the great rollers of 1846 were so high and of such force that they split the wall of the battery on Chubb's rock, and swept the ground from it into the sea. Such force had been recorded before, and in 1737,12 th Nov. there was a violent surf; for the records relate that a gun or a large piece of iron ordnance was washed off the top of Chubb's rock (a demi culverin $43 \mathrm{cwt}$. Which was afterward recovered in three fathoms)." 


\section{CHAPPELL VALLEY.}

THE modern name of James Valley and James Town is seldom found in the old records. The Fort or Castle was called Fort James after James II., in whose reign it was enlarged and improved, but the valley in the records is named Chapel Valley-from a small chapel built by the Portuguese on their discovery of the island. This chapel is described by Captain Cavendish, the first English discoverer, who visited the island on June 8, I688. It is not certain whether the same site was used for the present church, or whether even any part of the original building was there when the East India Company obtained the island, but that the building used as a church in I7II was in a ruinous state is plain from a record, which says :-

7th April, I7II. The Churchwardens made a petition "That whereas our Churchyard at the Fort is very small, and hardly room to dig a grave for rocks and graves already digged, also our yard wall is very bad and irregular. . . that we may inlarge our yard backwards by cutting the water in a new course near the hill and have liberty of ranging the front wall with the street." Governor Roberts answered the churchwardens, "That it is commendable in them to promote the putting that piece of rubbish called the churchyard in order, it's for the credit of the island, and we advise you to repair the church or it will tumble down in a little time . . people will be apt to say that at this island the old proverb is true about settlements, that where the English settle they first build a punch house, the Dutch a fort, and the Portuguese a church."

Matters had not improved in 1732 , when we find on September 30 another letter from the Churchwardens to the Governor on

the ruinous condition both of the Chapple in the country, and the Chapple at the Fort, the former of which has lain level with the ground for two or three years past, and the latter is so much out of repair that it's shameful a place set apart for the celebration of Divine Service, and in the open view of all strangers, especially of the foreign nations, etc. But after we had proposed to rebuild "the Chapple in the country, it was objected that the poverty of the people was 
such that they could not comply therewith, though it was said that if they could be assured of having an honest good man for a minister they would be as willing as able to rebuild the Church as their own houses, but have had of late such worthless undeserving men, that unless they could have a man to sett them a better example by his own life and conversation, they have no encouragement to do anything.

The present church was not built until 1772 , and the following entries of records tend to show that it was not built on the old site, but near to it :-

April 2nd, 1772. In erecting the new Church we were obliged to pull down the Doctor's shops.

Feb. 6, 1774. That three houses were built upon the ground where the old Church stood for the use of the Company's servants.

These are the three houses still standing above the Church, belonging to and occupied by the Imperial Government, but formerly occupied by the Members of Council who had a town house allowed them, together with a good salary.

EGG ISI.AND is mentioned first in I6SI :-

Alarm caused at daybreak by discovering a vessel at anchor near Egg Island which proved to be the Friend's Adventure with slaves for the West Indies.

Other entries show that large numbers of seabirds' eggs were gathered at this island under Government regulations. In 1707 warning is given that liberty had been granted by the Governors from time to time to gather eggs upon the Egg Island on Tuesdays, Thursdays and Saturdays, and that boats which went on other days would be deprived of their privilege for the rest of the season.

In 1717 there is the entry:-

The birds called Egg birds beginning now to come to the island to lay eggs at Shepheard's Hole, notice is given to all persons not to go to the Egg Island until the end of this present month.

After October they may go on Tuesdays, Thursdays and Saturdays as usual.

FlagstafF is mentioned in June, 1678 , as one of five places where outguards have formerly been kept, viz. :-

Ruperts, Bankses, Flagstaff, Prosperous Bay and Spragues or Lemon Valley. It (Flagstaff rises perpendicularly from the sea shore to a height of 2,290 feet and on a clear day is one of the most 
commanding positions for a signal station, but from its height it is often hidden in the clouds and it is ordered Sep. 1692 that Matts mount or Flagstaff should be discontinued as a look-out, being mostly very foggy and hazey and inaccessible to an enemy. Prosperous Bay being much lower hath a very clear prospect.

FRIAR'S VALIEY is first mentioned July I4, I684, in connexion with Breakneck Valley. The shape of the pillarlike rock on the ridge of hills bears a close resemblance to a cowled friar, that there is no difficulty in knowing whence the valley obtained its name. (Friar's Lodge is now owned by Rev. J. H. Daine, R.C. Chaplain.)

HunT's Gutr, near Halley's Mount, was allotment ground granted to Sergeant Maurice Hunt on January I5, I683. It is described as adjoining Hutt's Plain, and next the grand ridge that leadeth to the wood.

HORSE PASTURE.--In the records are careful returns of all stock in the island, including cattle, sheep, goats, hogs, asses, and even poultry belonging to the Company, but horses are not mentioned before I733. We should therefore infer that no horses were on the island, yet a large common in I/I4 is called "Horse Pasture," which name it still bears, and "Horse Ridge" is named as early as I695. An account of the voyage of M. Rennefort in 1666 proves that horses had been introduced at an early date, but had become so wild that they preferred to break their necks over the precipices into the sea rather than allow themselves to be caught :-

On y avait porte des chevaux mais ils etoient devenues si farouches que lorsqu'on les poursuivoit jusqu'aus extremites de l'ile se precipitoient du sommet des roches dans la mer plutot de se laisser prendre.

The absence of any allusion to horses in records from I673 to I734 justifies the belief that these wild lovers of fleedom committed suicide rather than be captured. The first horse mentioned in the records was December, I734. It must have been of their stock, for we read :-

A young black horse of the Company being grown big enough for the saddle, the Government ordered him to be taken up and broke, but as they were bringing him home, he raised himself upright and fell with such force upon a sharp stick in a furze bush that it went through the bladebone of his shoulder, and penetrated into his heart, and killed him on the spot. 
HALlEy's Mount is called in the records Hawley's Mount, and was used by the famous Dr. Halley for his astronomical observations in 1676 . While here he observed a transit of Mercury, which suggested to him the method to which so much importance has since been attached, of ascertaining the distance of the sun by observations on the transit of Venus. The name Hawley's Mount first appears in 1682 , with the following order :-

Sundry families settled in Sandy Bay and other windward valley's, being at a great distance from the Alarm guns, the guns to be removed to Hawley's mount, and to be fired by any person discovering a ship.

Hutt's Gate.-In the time of the Company this was called "Hutts' Plain," or more frequently "The Hutts," from the buildings erected for the negro slaves. In I7 15 the Hutts plantation is recorded as the chief and best yam plantation, producing the greatest quantity, there being now 300,000 planted. It remained a Government plantation till March, I725, when it was resolved to throw up the land into pasture.

HaLF TreE Hollow, in the Records "Half Way Tree," first mentioned December, I6g6. Mary Tewsdale (a suicide) was ordered to be buried at Half Way Tree with a stake through her body and a heap of stones cast upon her as a monument.

In I7II it is ordered that Halfway Tree common, 3 miles in circumference, be reserved for the Company's cattle, hogs and goats.

LEMON VALLEY was first mentioned in 1678 as Spragues. In a record on its defensive condition in 1734, Governor Pyke says some of the Dutch landed here, but by throwing large stones down the hill they were beat off again. He says "The guns are much flamed and honeycombed. We have taken them away thence as useless, and placed them on the West Rocks as shoar fasts for any ship that has occasion to warp in there. We have placed an anchor and several guns there for that purpose." (This explains the presence of the old guns, leaded muzzle downward, in the solid rock on West Rocks, under Ladder Hill. The anchor was carried away by the heavy rollers in $x$. 46 .) 

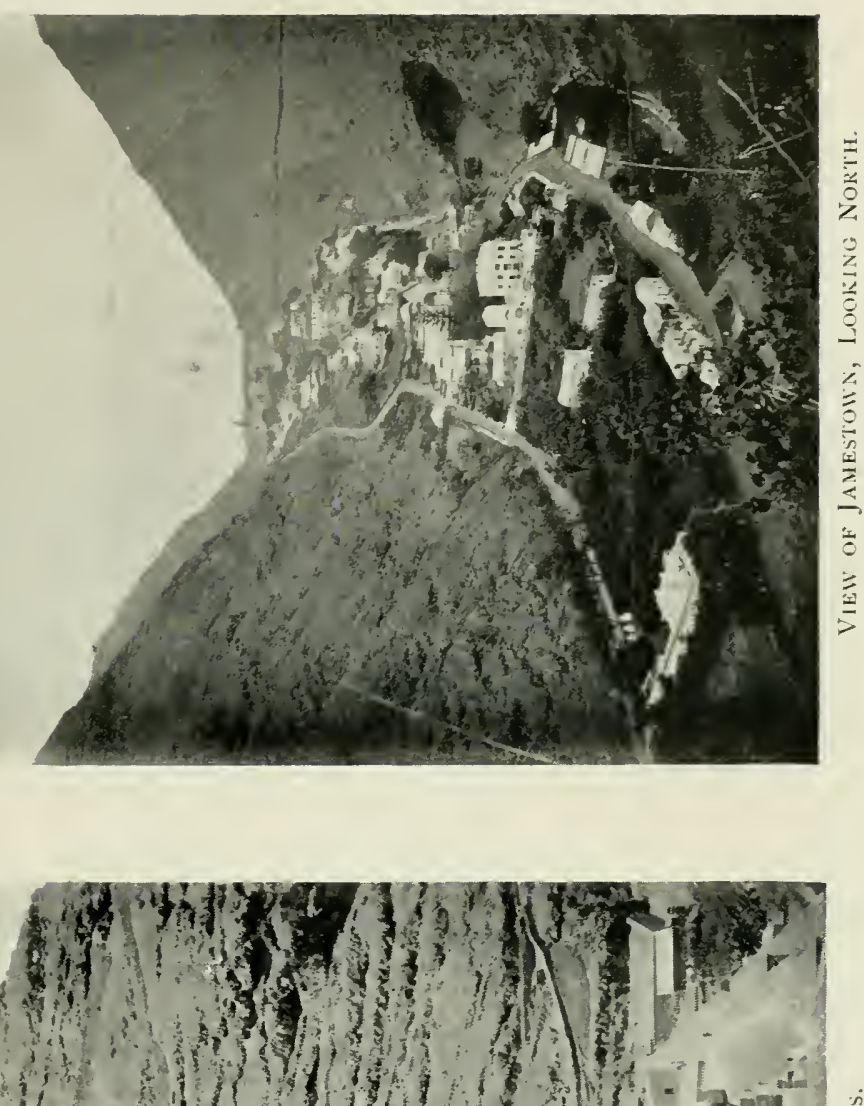

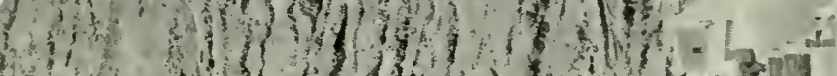
10 1)

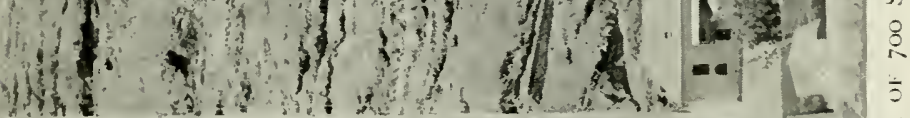

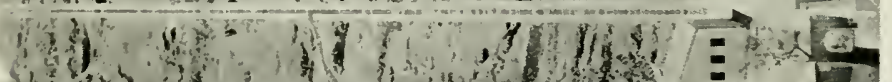

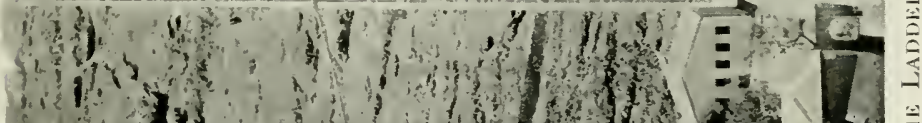

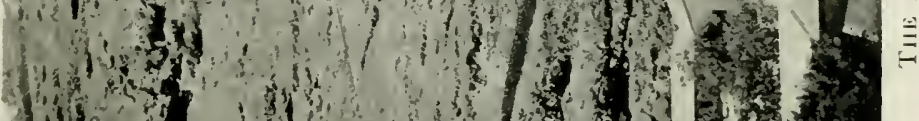
I)

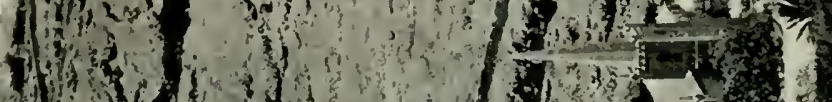
1 us 1,1010 

Lemon Valley, or SpRagues, was formerly the best watering place for ships, but in $\mathrm{I} 732$ there was a landslip of seven or eight acres of land (6oo yards long by 9I). This altered the taste and colour of the water, making it less pure than that of Jamestown or Chapple Valley.

LufFkins.-There are two places called by this name, Luffkins near Plantation, and Luffkins near Horse Pasture. Both derive the name from John Luffkins, one of the first settlers, of whom it is recorded in 1683 that the Mr. John Luffkins being one of a serious life and conversation, was chosen as fifth in council. He is referred to again in the Dennison rebellion as one of the planters without arms, who accompanied the soldiers to the Gate. The lands of those implicated in the rebellion were forfeit, except in the case of Luffkins, as "He wholly refused to make any agreement, alleging his estate was not forfeit." Luffkins, near Plantation, afterwards became Government land, not by forfeiture, but by purchase; June 1767 , Record says: "John Luffkins going to England, sold his house and 30 acres near Plantation to the Government for $£ 350$."

LADDER HILl appears in the records I733. It was more usually called Fort Hill, meaning the hill above the fort or Castle at Jamestown, for there were no fortifications on it. A curious steep zigzag path, with a shore ladder piece in the centre, can even now be clearly traced on the side of rocks. It was cut by Governor Pyke in $\mathrm{I}_{7} \mathrm{I} 7$, and for cutting this Governor Pyke received a lecture from England, for the Directors thought the labour and expense should have been given to the fortifications. The only use made of the top of the hill for the first hundred years of the settlement was as a position for the gibbet on which criminals were hanged in chains at the point where the flagstaff now stands. It commanded a view of the whole town and harbour, so that after an execution the cheerful spectacle was to be seen by all inhabitants. In I770 the carriage road was made. In I797, in anticipation of war, Governor Brooke relates that Ladder Hill had been strengthened by an additional tower, mounting two I2 pounders, to aid in covering the rear of the works, and by a battery of two I 8 pounders on a point over the sea. He says a "barrier gate has been constructed with works to flank it on the road 
leading from town to the hill, and stones have been collected in heaps in readiness to throw down."

Tire "Observatory," Ladder Hill, was proposed and built by Governor Walker, October I823, and Lieut. Johnson, of the St. Helena artillery, was selected to take charge of it. He showed such natural aptitude that his catalogue of stars, published by the East India Company in 1835 , is still a standard work. After the break up of the Company's St. Helena establishment, Lieut. Johnson obtained charge of the Radeliffe Observatory at Oxford.

LoNGs was the allotment ground of Francis Moore, a Chirurgeon, who died in 1682 , when the land was sold to John Long. On April 3, I7I7, Governor Pyke relates :-

There is a report run about the island like wildfire that there is a new Governor coming. On $9^{\text {th }}$ is another record, that John Long, rejoicing in the report of a new Governor and Council, walked 7 miles to town to defy" Capt. Haswell and tell him " a little time ago you threatened to cane me, now strike me if you dare. I don't care a D for you."

For this Long was sent to prison. The governor writes:-

It is very strange the Directors for the Honble Company should have such mistaken notions of these people, who never did nor could live peaccable, there being too many of them of John Long's temper. Tis pitty we have not some of the Committee to live among them, for that would certainly make them judge of these people's temper better.

This was a candid but hardly respectful hint to the Court of Directors that they needed a personal experience of St. Helena Billingsgate; and it was no doubt prompted by the following hint, written by the Directors to the Governor: "We have some complaints of our Governor's arbitrary temper. We expect that he give no cause for it."

In 1733 John Long was brought up for receiving stolen yam from the Company's plantation at the Briars, and ordered to be whipt. The warrant says :-

You are to whip the said John Long publicly with ten lashes, but in regard he hath been a planter here, you may for this first time let him receive the shame of this punishment with his clothes on. You are to make your prisoner fast to the tail of the wooden horse, and read this to him before you whip him.

And the said John Long was whipped accordingly in the 
presence of a great many people, who were only concerned that he did not receive the stripes upon his naked body, and in greater number.

LOT. This is only mentioned once in the records. (About a mile and half from Lot is Lot's wife, I,550 feet above the sea, the pillar itself 260 feet above the hill on which it stands.) It is a pillar 290 feet from base to top, standing I,444 feet above the sea. Record says :-

There has been two of your Honour's blacks, being strong mutinous fellows by some means got some weapons and tryed to get some more blacks to join them, and betook themselves to a kind of fastness which was at the foot of a spiral rock called Lot, and on the top of a high mountain almost inaccessible, and there in a large cave they took up their residence and withstood every body they could see, who came towards them from a great distance and by rowling down stones kept every body off, so that they were beseidged for three or four days. The soldiers, sent after them, desired leave to fire at them. The Governor sayd in case they could not be otherwise taken in one day more they should be fired at. The next day one Mr. Worrale, a brisk young man with two or three more did get up behind them, and above them, and then they hove down rocks in their turn and beat down the chief of them so much bruised that he dyed, at which all the people in Sandy Bay had great satisfaction for they suffered much for them. These rebels were in a cave at the foot of Lot.

The summit of the pillar, 290 feet higher, can only be gained by careful climbing, and it involves so much risk of broken necks that few persons have ventured to try it. On the summit the perpendicular sides of the pillar are invisible, and you see only the eight or ten feet of space on which you stand, nearly I,500 feet above the sea. This produces a terrible feeling of insecurity.

LoNGWOoD.-This and Deadwood were formerly known as one property, viz., "The Great Wood." The first mention of it is in 1678 , "that there were herds of wild swine in the Great Wood, and it was ordered that no person should presume to kill any unmarked swine."

In I7I6 a ground plan of the wood is inserted in the records, and it is said that the "Great Wood is in a flourishing condition, full of young trees but miserably lessened and destroyed within our memories, and is not near the circuit and length it was, but we believe it does not contain less now than I,500 acres of fine woodland and good ground, but no water 
but what is brackish. If wells could be sunk we should think it the most pleasant and healthiest part of the island . . . the Hutts was called the wood's end. But the wood is so destroyed that the beginning of the great wood is now a whole mile beyond that place. The destruction of the wood, though often spoken of and regretted, seemed to continue until a large portion of it received the name it now retains of Deadwood.

It was treated as a common; planters were allowed to pasture their cattle and obtain fuel from it. In 1789 , Governor Brooke proposed to carry water to Longwood in an open drain. At the close of the last century the forest both at Deadwood and Longwood had entirely clisappeared, but in August, 1745 , it is stated that 317,000 young gum trees had been planted at Longwood up to I720. The cost to the Company of fencing this property was $£ 5,400$ and in 1778 a further sum of $£ 5,000$ was estimated as the cost of renewing the fence at Longwood with a stone wall of three miles in circumference. Until the arrival of Napoleon, the house on it was used as a residence for the Lieutenant-Governor. In ISI5, Governor Wilkes names a carrying of water to Longwood as one of his improvements, that 3,226 yards of drain and lead pipes had been laid from Wells to Longwood at a cost of $£ \mathbf{I , 2 3 1}$. Longwood had then become the residence of Napoleon and staff. The grounds were used as a Company farm, and in June, I823, Governor Walker says "that the farm buildings at Longwood are in a ruinous condition, and their reconstruction would be attended with great expense"-he therefore proposed to appropriate the old dwelling house at Longwood used by Napolcon as farm offices, as they could not be consigned to a more useful or a more necessary purpose. This was practical and it did not then occur to any one it would be a desecration to turn the room in which Napoleon died into a threshing barn, or his bedroom into a horse stable.

In 1857 the enclosure called the "Old House" was conveyed by Her late Majesty's Government to Napoleon III, and it is now restored so as to resemble (as nearly as possible) its appearance as it was in 1815 to $182 \mathrm{I}$.

MUNdexs was named from Sir Richard Munden, who recap- 
tured the island in 1673 ; not because, as some reports say, " he landed his men there from the yard arm of his ship," but because with a sailor's eye he first saw the advantage of placing a battery on it to protect the anchorage and the shore from Sugar Loaf to Horse pasture point.

New batteries have since been built, but still, remains of the former fortifications can be seen. The old battery was formed of ancient rubble masonry, and it was thought a shell from a modern gun would ruin it. But while the Boxer was in harbour in May, I878, Captain Allington tried the effect of a couple of shells from his heaviest guns, a black mark being painted on the battery as a target. The Boxer was 400 yards distant with guns fixed by the Captain himself, with full battering charge. They were fired with such precision that both shots struck the same spot in the centre of the black mark; they penetrated some depth, but the aged battery seemed not a bit the worse for it, and it is to be hoped the modern casement will stand as well, if necessary.

Plantation.--This beautiful spot was set apart by the Company as the official residence of the Governor-at the first settlement it was merely a plantation for the supply of the Governor's table and for the growth of Yam to feed slaves-hence its name. In the record of December, I673, Governor Field ordered "that Plantation" is to be at the direction and disposal of the Governor for the supply of the table for himself and others that are appointed to dyett with him. In 1679 is a minute-'Captain Beale hath a house standing on the Honble Company's plantation which he erected by consent of the late Governor Field. The Company have no house but where the blacks lodgedthere being great need of such a convenient house as is the said Captain Beales, ordered four carpenters to appraise it. In I709 the land was so bare of wood that slaves were compelled to go once a week to Horse pasture to obtain fuel. Record says "Our Masters plantation is quite destitute of wood so that one day in the week it employed all the blacks to fetch wood from Horse pasture and the Great Wood-therefore ordered that fifteen acres be enclosed at Plantation Valley and planted with gum wood."

In I7I4 Governor Bourcher's successor complains that 
the house had been left very much out of repair and nothing in the garden but plaintain trees and pasturage for Governor Bourcher's asses. It was afterwards steadily improved under successive Governors, and Governor Wilkes, in I8I5, says he had expended during his time $£ 4,500$ in repairs and additions to the property, and had planted out 27,000 pine asters. It is now the best wooded property in the island and contains a number of rare and beautiful trees, fine vegetable and flower gardens, and spacious walks, that towards Green Gate being very beautiful.

PUTTy HiLl is so called from the stickiness of the clay on the hill in wet weather. Governor Blackmore, in December, I690, was killed by a fall on Putty Hill, but so low down that his body fell into the water. Captain Johnson, who succeeded him, stated at the inquest that he and Governor Blackmore with two boys were coming from the country at about six o'clock, and that the Governor slipped and fell down a steep place. The fall was so violent that he had only time to say, "Oh, help me." His body was taken out of the run of water near the waterfall, at the bottom of the steep opposite the upper end of Maldivia Gardens.

RUPERTS.-In May, I734, is an entry which says "Here Prince Rupert, son of the King of Bohemia and nephew to King Charles I., on his return from India, came to an anchor and stayed to refresh his ship's company." This event gave the place the name of Rupert's Valley. On the same date is an order that the 4 -pounder guns in Rupert lines were to be kept loaded with partridge shot-which looks as if the Frenchmen would have been fair game-had they tried to land there.

RowlaND's Cove.-This has been the scene of frightful accidents even of late years. It was first called Downing's Cove from a fatal accident to a soldier of that name.

In I73t Corydon, the Company's chief fisherman, going to Ruperts, carrying a small box of fish for his wife who lived in Rupert's Valley, was killed there, and later, a man named Rowley, carrying a small keg in the same path hit it against the jutting rock, when it hove him down and smashed him to pieces.

SOUthexs-near Friar's Valley-was allotted to a Sergeant Southens. It was his widow Sarah, who made 
the name notable. In January, I720, she was taken into custody with two or three others for writing the following complaint to the Company against the Governor :-

Whereas on the 29th November I719, that the Rev. Mr. Jones, the Right Honble Company's Chaplain on the said Island was celebrating of Divine Service according to his office, the collect of the day was interrupted by Governor Johnson saying very outrageously, "You are out to-day as you was last Sunday, for this is the 2nd Sunday in Advent," the which the Rev. Mr. Jones read to prevent any further indecency, but informing himself while a psalm was sung and finding he had committed no error proceeded on his duty till he came a second time to read the Collect for the first Sunday in Advent, was instantaneously interrupted by Governor Johnson, saying, "Why do you make these mistakes"; to which the Rev. Mr. Jones made no reply, but went on scarcely to the end of the Communion Service and published the Holy Day, viz. St. Andrews, being the next day, adding that prayers will be at church ; then the Rev. Mr. Jones had no sooner expressed himself thus, but Governor Johnson said, "Not by you, sir!" calling out very furiously "Officer, take him prisoner, bring him before me," and the order was immediately executed.

For this writing Mrs. Southens and several others were committed for trial. The evidence given agrees with above letter, except that the Governor called to Mr. Jones in a very mild manner and that Mr. Jones, without any regard to what mistakes the Governor had told him of, did persist and read on in open defiance of the Governor, which gave him cause to order Mr. Jones to be seized by the Officer of the Guard and to bring him to the Castle; where he appeared with an haughty countenance and vindicated himself in a very rude manner, who for his disobedience and violent behaviour then, as well as several other times before the Governor and Council, he was confined.

The jury found Sarah Southens and Dr. Civil guilty, and they were both sentenced " to be sett in the pillory for one hour, the pillory to be sett in the middle of the valley over against the store house (the present commissariat yard) they had to stand with their faces up the valley.

After these proceedings $\mathrm{Mr}$. Jones left the island, and while Governor Johnson remained no other clergyman would come. In the August following, there being no clergyman; Mrs. Swallow, the widow of the planter, and possessed of small property, was married to Joseph Bedloe, one of the 
garrison, by Dr. Middleton, surgeon of the ship Hartford Francis, but they had forgotten to ask the Governor's leave. As soon as he heard of it, he sent the Marshall in pursuit of the newly married couple and the record states:-

Bedloe led her down the Valley and introduced her into the Hall of the Castle by the hand as his wife. They both owned the fact before the Governor, and Bedloc offered to show the certificate. Upon this the Governor ordered Bedloe to be whipt, and to receive fifty lashes on his bare back at the Flagstaff, and to be confined to prison till the departure of the next storeship, and the said widow Swallow was ordered to receive twenty lashes on her naked back, but when she was affixed to the Flagstaff the Governor ordered the whipping to be remitted, hoping the sbame of being so publicly exposed would have the same effect on her, as the smart had on some.

The Doctor had hurried on board ship to be out of the way, but this did not avail him. The Marshall was sent to bring him on shore, and by the Governor's order he was tied up to the flagstaff and whipped with twenty lashes.

The Court of Directors seem to have taken very little notice except to hint to the Governor that he had better keep out of Dr. Middleton's reach. The Directors wrote on May 3I, I72I :-

The affair of Mr. Jones the chaplain taking him out of his desk in the time of Divine Service in that outrageous and unprecedented manner shockt us at the first hearing of it, and more so when it was further explained and the cause of it particularized. We are surprised.Mr. Johnson, who knows so much better, could be capable of doing it. We tell you we will never endure it. It seems he did while officiating in his office act unbecomingly, and the language thereof might be interpreted "Thou art the man," but if there had been no secret guilt, why such outrageous anger? W' have reason to believe Mr. Jones is not a man of the best morals, but that ought not to warrant unlawful revenge. Be angry and sin not, and avoid all appearance of evil, are two rules as necessary to persons in authority as to any of their inferiors, if not more so. Can any of you think that bearing all down before you, whether right or wrong, will ever make an Englishman easy-the common peoples judgement of things makes them sometimes argue wrong, but they always feel right when hardly dealt with.

On 23rd February, 1722, they say: "You were in the right to deny Bedloe the soldier marrying the widow Swallow, and censuring Mr. Middleton for presuming to marry them contrary to the settled custom of the island, but the manner of punishing Mr. Middleton is what can be no ways justified by any law of England or St. Helena, nor can we imagine what should induce the Governor to 


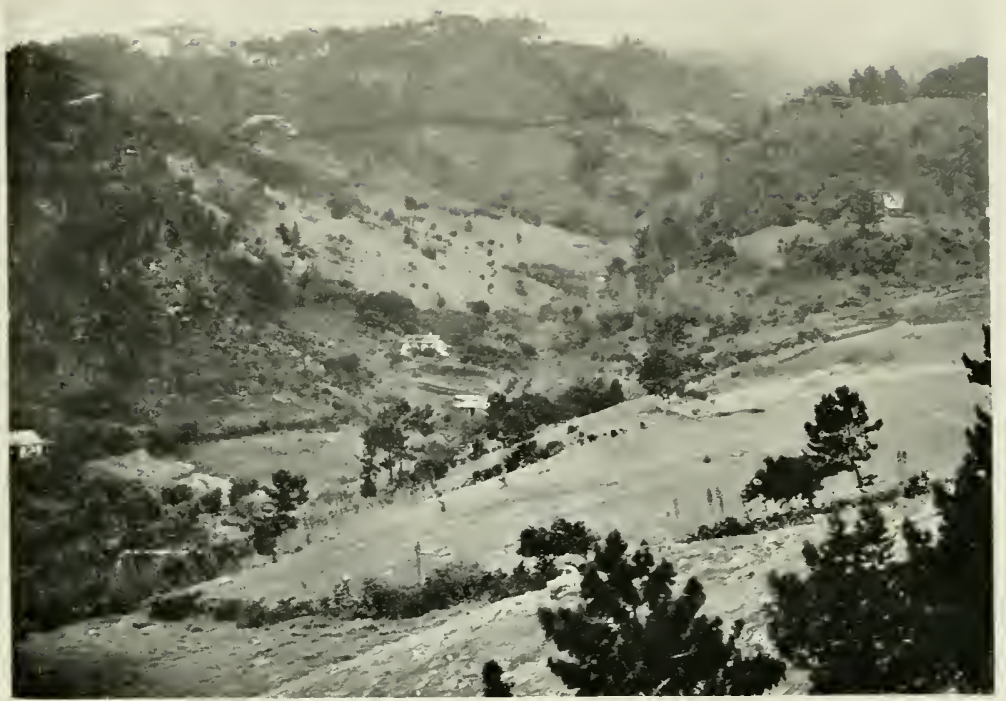

VIFW OF INTERIOR FROM FRIAR'S RIIGF, LOOKING WEST.

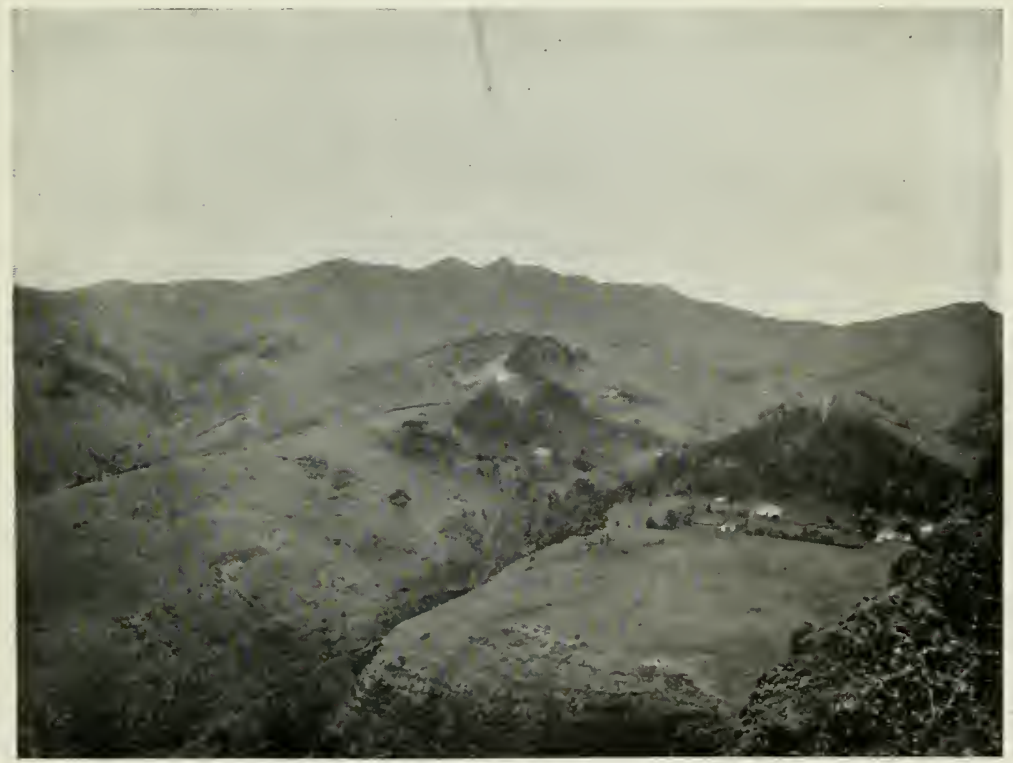

VIEW OF SOUTH RIDGES FROM IIMAH KNOLL FORT. 

take so large a step, but an apprehension of his own despotick power as if he were above all law. As to the present case, we are sorry for the occasion, let him take the consequence when he returns to England and finds that our mild laws will suffer no man to stretch his authority at this rate. The Governor's carriage towards Mr. Jones (mentioned in our last letter) has made such a general ill impression upon people's minds here, that we cannot hitherto get a Chaplain to be sent to you.

SEALES FLAT, a small plain at the upper part of Sharks Valley now forming part of Amos Valley, the original allotment in I682 of Benjamin Seale. In I695 Seale was accused by John Long (before referred to) of having said that godfathers and godmothers lied, when for a child they renounced the devil and all his works, and for this, Mr. Harewood the minister ordered him to appear in Church on August 25, and there openly confess his guilt in a form drawn up by Mr. Harewood in which form he styles the Church of England, "new part of God's Catholic Church." Penance of this kind may be good for some, but in Benjamin Seales' case the thought of it acted on body instead of on mind. When the Sunday arrived he was compelled to stay at home instead of going to church, and on the following day he appeared before the Council and " in a humble manner craved forgiveness and declared he could not possibly come to church, being then much troubled with 'grips in ye gutts.",

Thompson's Wood should be Tomstones wood. Mentioned first in September, I678, that Peter Williams' land of twenty acres in Tomstone wood is in a remote and desolate place far from neighbours, and it is ordered he is to share with Smoult at High Peak till some other inhabitant shall have land allotted, in or near Tomstones wood. A part of this land is called the Churchyard, for the huge boulders scattered over the ground are worn into a shape closely resembling at a distance, Tombstones-hence the name Tomstone which has been modernized into Thompson's.

There is an entry of May, I7I7 shewing that a planter could not then cut down his own trees with impunity.

Ripon Wills was summoned for wilfully destroying forty lemon trees. The complaint was "about fifteen days since, two of his ncighbours walking by his upper grove of lemon trees picked off somc of the fruit and cat them, which the old man secing, fell into 


\section{94}

ST. HELENA

a passion and sayed they robbed him and would be damned for it, and in his rage fetched an axe and cut those trees down forty in number, and very large with fruit on them, and then sayed he did it to save the people's souls, that would be damned for stealing." Wills on this prayed for leniency, and sayed that the trees grew in a very windy cold place, a quarter of a mile from his house and produced no profit to him, but he was in terrorem fined 20/- each tree $-£ 40$; but if he plant double the number in some other place his fine will be lessened.

PROSPECT. - This place is not mentioned in the records, but Grace Coulson, widow of the Coulson who was executed in 1685 for being concerned in the Dennison rebellion of 1684, was allowed to retain her husband's property on condition of paying a rent. It can be traced that this property was that which now forms the fine estate of "Prospect." Widow Coulson was a woman of spirit, for we read that she was before the Council on March 20, I690, where the rent was demanded from her. She answered she had paid none, and further peremptorily added that none would she pay, withal saying she had paid too much already, and soe in a womanly passion departed saying, "You may doe what you will and turn me with my children out of doors. I am bleeding cvery day and you may as well hang me as you did my husband." This Coulson was an original planter under the first Charter and was the owner of Black Oliver, who acted as guide to Sir Richard Munden, when he landed at Prosperous Bay.

So much has been written on the subject of Napoleon Buonaparte that it is difficult to sift the truth from tradition. He was such a "great criminal that he was not only permitted to escape the punishment due to his atrocious crimes," but from the Government he had striven against he received every necessary comfort, nay, every luxury, obtainable.

He was born at Ajaccio, in Corsica, on August I5, I769, and was the second son of Carlo Buonaparte, who was a professor of law, but who had, previously to the birth of Napoleon, quitted law for the sword ; and under the standard of his friend and patron Paoli, taken up arms with his countrymen to resist the cession of Corsica to France.

Napoleon carly evinced a strong predilection for military pursuits, and his father, through the interest of Mons. de 
Marbeuf, the French Governor of Corsica, procured his admission to the military school of Brienne, in Champagne in his tenth year. The military education received at the public schools was marked by a peculiar severity of discipline, and was strongly of a monastic character, so that while here, Napoleon's disposition, naturally reserved and unsocial, was not improved, while his military propensities received all possible encouragement. He pursued his military studies with ardour, and showed great fondness for mathematics, but paid little or no attention to writing, languages and fine arts, evincing a contempt for everything not military. At the school his conduct gave presage of an unusual character, for he associated very little with the other boys, and evinced a distaste for their amusements. By this he gained the name of "Spartan." In games and exercises of a martial nature, he excelled, always taking the lead, and influencing his comrades. In 1784 he was removed to the "Ecole Militaire" at Paris, where he studied mathematics under the celebrated Monge; his proficiency was so great that immediately after his first examination he was placed as an officer in the "Corps de Genie," a part of the French Service which combined both artillery and engineering.

In 1783 he left this school, having obtained a lieutenant's commission, but still continued with passionate ardour his military study, and his republican notions at this time frequently drew him into fierce disputes with his brother officers. When the elements of the Revolution showed themselves openly in France, Napoleon, with thousands of others, was fired with the ambition of taking a decided part in the scenes which it became evident would follow. An opportunity soon offered, for he, with his family, had been removed by General Paoli from Corsica to Marseilles, where he was introduced to General Barras, who obtained for him a commission in the French Artillery. He was ordered at once with his regiment to the siege of Toulon, which was occupied by the British, and so distinguished himself that he was during the siege raised to be adjutant-general, and then appointed general of artillery.

Soon after this he was ordered to Nice, where he became acquainted with Marat, who, with him was cashiered for 
misconduct. Napoleon went to Paris to complain of his sentence, but was not restored to his rank in the army. October, I795, saw him in command (under Barras) of the Conventional Army, to act against the Parisians, who were showing an active disapprobation of the measures of the Convention.

He acquitted himself in this contest so much to the satisfaction of Barras and fell in so entirely with his views in other matters, that he resigned the army of the interior to him, and then procured his appointment to the command of the army of Italy. Just before his departure for Italy Napoleon married Josephine, the rich widow of the Viscount de Beauharnois. Such were the steps by which he, at twenty-seven years of age, rose in a space of three years from the rank of Chef-de-brigade to that of cominander-inchicf of the most important army in the Republican service, and for this extraordinary promotion he appears to have been indebted principally to the good offices of Barras, who had sufficient penetration to discover his military talent. In a single campaign he over-ran the greater part of Italy, defeating three Austrian armies, commanded by the veteran Wormser. By celerity of movement, and dec ve manœuvres then unknown, he allowed the enemy no time to concentrate forces, or choose positions, but attacked with an intrepidity which even the bravery and discipline of the Austrian army could not withstand. By his brilliant and decisive victory over Archduke Charles in March, I797, and subsequent successes, he advanced so far into the Austrian dominions as to threaten Vienna itself. This state of things led to a treaty highly favourable to French aggrandisement and power, and ended the first Republican war under Napoleon. Under successive titles of First Consul and then Emperor (for the people wearied with scenes of anarchy and bloodshed, hailed him as their deliverer, and gave him sufficient ambition and address to mount the vacant throne, thus covering crime with military glory), he obtained a series of victories over the continental armies of Europe, conquests unparelleled in ancient or modern warfare. In the year 18 Io he had reached the zenith of his power. The battles of Marengo, Austerlitz, and Jena had compelled the great powers Russia, Austria, 
and Prussia to enter into treaties dictated by himself and consequently highly favourable to his ambitious views; the two latter powers had already seen their capitals occupied by his victorious armies, while the minor powers of Europe were either incorporated with France or acted under his direct influence. One splendid exception alone remained to this hopeless scene. England was not only unsubdued by him, but was preparing for the regeneration of Europe, by the resistance to his invasion of the Spanish peninsula; and the armies of England, under the illustrious Wellington, first convinced the world that the troops of Napoleon were not invincible. To this time his career had been one of uninterrupted success; he had never sustained a defeat in any general engagement, but his reverses now commenced, and he never after obtained a decided victory. He descended even more rapidly than he had ascended.

In I8I2 he was firmly seated on the throne of France, allied by marriage with Marie Therese, daughter of the Emperor of Austria, at the head of 500,000 men; and the year I8I4 saw Louis XVIII restored to the throne of his ancestors, and Buonaparte on the road to ignominous exile. One of the greatest military commanders that ever lived, he stands, perhaps, a solitary instance of the most consumate military talent, wholly unaccompanied by the generous and magnanimous qualities which generally dignify and exalt a military character.

On the day of the Capitulation of Paris to the allied troops he was at Rochefort endeavouring to escape to America. There were two frigates which the provisional government had placed at his disposal and on which, if he had not hesitated, he might very easily have escaped. But he lingered, hoping his army might recall him.

In the meantime he was busily employed in making preparations to depart. Wagons were bringing from the palaces valuable articles which he chose to consider as useful for his voyage, or necessary for his establishment at his future residence. He was repeatedly advised to embark, and boats were ready at every tide to convey him to the ship, but he was irresolute. At one time he resolved to return to Paris, and make a forcible appeal to his troops, then he contemplated addressing the Government requesting 
a command in the army; then he issued orders to embark and almost directly countermanded them, pretending that the whole of his baggage had not arrived. So day after day rolled on, until the British cruisers, hearing of his presence in Rochefort, blockaded the port, and so rendered his escape impossible. There he remained, awaiting news from Paris, and when it arrived he was filled with dismay indeed. Paris had surrendered to the Allies, the provisional Government which would have helped him to escape was dissolved, and Louis was daily expected in the capital. Too late he regretted his indecision, and for a while gave way to despair. Then a multitude of schemes presented themselves, one of which was to fortify the little town of Aix and there defend himself to the death. He went, landed marines, reviewed his adherents, inspected fortifications and commenced repairs, but almost immediately saw the absurdity of his idea : the fortifications would soon have been demolished and a blockade of a very short time would have starved him into surrender. Two ways of escape he determined on, one by a Danish, and another by a small French vessel, trusting under cover of darkness to elude the vigilance of the British cruisers ; but this also he abandoned as hopeless. All chance of escape was gone, when he suggested the expedient of sending a flag of truce by Generals Savary and Las Casas to the Commander of the British Squadron requesting to be allowed to pass out and giving his word of honour that he would proceed to America.

To this, answer was made by Captain Maitland, the British Commander, that the vessel would be attacked directly they quitted the harbour. His situation was indeed desperate for Louis was reinstated on the throne, and the wonder of Napoleon and all around was that orders had not been sent to arrest him, and at the hands of the French, he knew he would not obtain much consideration. In his desperation, he determined to appeal for protection to the generosity of the British Nation, and he despatched two officers again to Captain Maitland proposing surrender, on condition that his person and property should be respected, and that he sliould be allowed to live where he pleased in England as a private subject.

Captain Maitland made answer that he would convey him 
with his suite to England to be received as the Prince Regent might determine, and that he was unable to make terms. Napoleon was chagrined, but there was no alternative except certain destruction; he therefore embarked on a brig bearing a flag of truce. Seeing this, Captain Maitland sent his boats to meet the brig, and in about an hour the barge, in charge of the first lieutenant (Mr. Motts), returned to the Bellerophon accompanied by the "once great ruler of half the world," who, on ascending to the quarter deck, advanced to Captain Maitland and said in French: "I come to claim the protection of your Prince and your laws." He was received by the captain with all the respect due to his former rank-for at that time there were no orders to the contrary.

The appended letter, written by Napoleon to the Prince Regent, was sent to England by the Slaney with the despatches giving an account of his surrender to Captain Maitiand.

\section{Altesse Royale, -}

En butte aux factions que divisent mon pays et a l'inimitie des plus grandes puissances de l'Europe, j'ai termine ma carriere politique et je viens, comme Themistocle, m'asseoir sur les foyers du peuple Britannique. Je me mets sous la protection de ses lois, qui je reclame de Vc A. R. comme les plus puissant le plus constant et le plus genereux, de mes ennemis,

NAPOLEON.

Translated :-

Royal Highness, -

Exposed to the factions which divide my country and to the enmity of the great powers of Europe, I have terminated my political career, and I come like Themistocles to throw myself on the hospitality of the British nation. I place myself under the safeguard of their laws, and claim the protection of your Royal Highness, the most powerful, the most constant, and the most generous of my enemies.

NAPOLEON.

Writers have censured this allusion to the illustrious Athenian as puerile and absurd, for there was very little similarity between the surrender of Themistocles and Buonaparte. The former was the saviour of his country, and had made her mistress of Greece. In the height of his prosperity, that country was ungrateful, and he was doomed to banishment. Unable to find a refuge, he threw himself 
on the generosity of a monarch whose fleets he had before defeated, and whose father he had killed. Buonaparte certainly made France for the time supreme in Europe, and while she maintained her supremacy, the gratitude of the country was his. To him she gave her liberties and treasures; it was only when he had laid her prostrate before foreigners that she chased him from her shores; not to humble himself to one whom he had before conquered, as Themistocles, but to a people who had repeatedly beaten him, who had been in a great measure the cause of his dethronement. Still,

"Both were born of obscure parents; both shunned the socicty of their youthful companions, and both were sacrificed to the suspicions and apprchensions of their country."

The principal personages who embarked on the Bellerophon with Buonaparte were :-

Lieut.-General Count Bertrand,

Grand Marshal of the Palace,

Countess Bertrand and three children,

Licut.-General the Duke de Rovigo,

Licut.-General Lallemand,

Marslaall de Camp Baron Gourgand, aide-de-camp of Napoleon,

Marshall de Camp Baron Montholon Semonville, also aide-de-camp,

The Countess Montholon Semonville and child,

Count de las Casas, Counsellor of State, and son,

M. de Resigny, Chef d'Escadron, officer of ordnance,

M. Planat,

M. Autric,

M. Schultz,

M. Mercher,

M. Pointkorski,

M. Mamgault, surgeon of Napoleon,

as well as forty others.

When first the Bellerophon neared land in Torbay, Napoleon exclaimed "Enfin, voila ce beau pays." (At length, here is this fine country). As soon as the arrival in Torbay was announced, the ship was the centre of attraction, and innumerable boats set out to obtain a view of Napoleon, and although they were not permitted to come alongside, not less than a thousand put off daily.

By some of those on board the Bellerophon it is stated that he was quite at his ease, taking possession of the captain's cabin, inviting the officers to his table, and talking with 


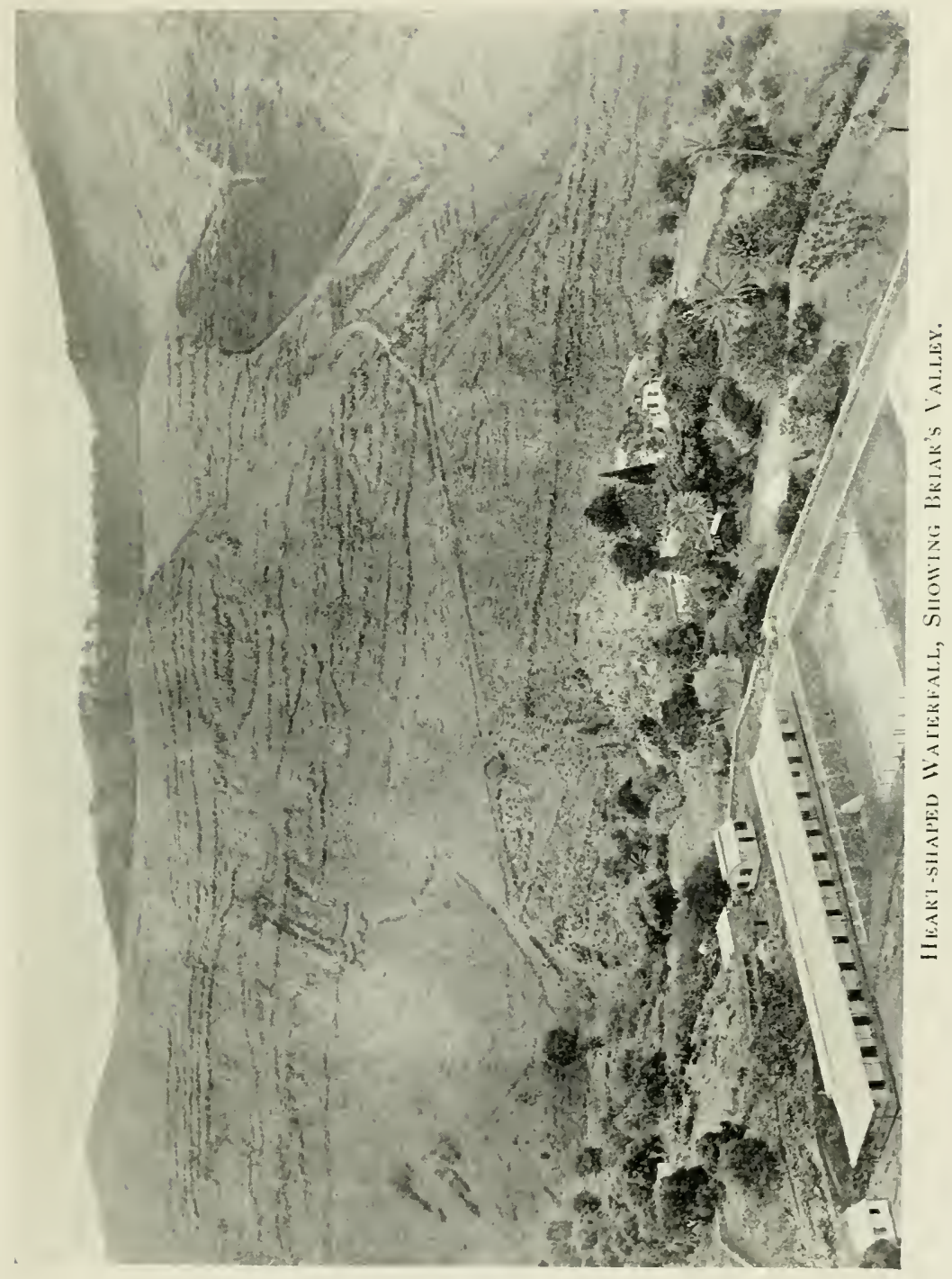



great freedom on the current affairs. Among others, he said that it was impossible for the Bourbons to govern France, and that Napoleon II would soon be recalled to the throne, that England alone had ruined his plans, that but for her, he would now have been Emperor both of East and West. He declared he would rather have perished than have surrendered to Russia, Austria, or Prussia, as the sovereigns of these countries were despotic; but by delivering himself to the British he was throwing himself on the generosity of a nation with just and honourable laws, affording protection to all persons.

The question now was, what was to be done with him ? In England he could not be allowed to reside-there would have been no security to Europe; nor could he be allowed to migrate to any neutral country, for there his correspondence with French agitators would have been unrestrained, and no guarantee could be accepted or given concerning his return.

A distant and isolated spot was required, where escape was impossible, so that many unpleasant restraints on his liberty could be dispensed with, and quietness and peace reign in Europe.

It was now that the little island of St. Helena proved its value.

Many hundreds of miles from continental land, having only one harbour, and landing from that easily guarded, naturally strong, and rendered impregnable by forts, bidding defiance to sudden surprise, commanding a view of the ocean from its lofty rocks of over sixty miles in all directions, this was evidently a safe prison, and here it was determined that the dethroned Emperor should be sent.

An official letter written by Earl Bathurst, Secretary of State to the Lords of the Admiralty shows that the British Government were anxious to contribute as far as possible to his comfort, though compelled to take necessary precautions for his security.

Downing Street, July 3 oth.

My LoRDs,-I wish your Lordships to have the goodness to communicate to Rear-Admiral Sir George Cockburn a copy of the following memorial, which is to serve him by way of instructions 
to direct his conduot while General Buonaparte remains under his care.

The Prince Regent, in confiding to English officers a mission of such importance, feels that it is unnecessary to express to them his earnest desire that no greater personal restraint may be cmployed than what shall be found necessary faithfully to perform the duties of which the Admiral as well as the Governor of St. Helena must never lose sight, namely, the perfectly secure detention of the person of General Buonaparte. Everything which, without opposing the grand object, can be granted as an indulgence will, His Royal Highness is convinced, be allowed the General. The Prince Regent depends further on the well-known zeal and resolute cliaracter of Sir George Cockburn that he will not suffer himself to be misled imprudently to deviate from the performance of his duty.

BATHURST.

\section{MEMORIAL.}

When General Buonaparte leaves the Bellerophon to go on board the Northumberland, it will be the properest moment for Admiral Cockburn to have the effects examined which General Buonaparte may lave brought with him.

The Admiral will allow all the baggage, wine, and provisions, which the General may have brought with him, to be taken on board the Northumberland.

Among the baggage, his table service is to be understood as included, unless it be so considerable as to seem rather an article to be converted into ready money than for real use.

His money, his diamonds, and his valuable effects (consequently bills of exchange also), of whatever kind they may be, must be delivered up. The Admiral will declare to the General that the British Government by no means intends to confiscate his property, but merely to take upon itself the administration of his effects, to hinder him from using them as means to promote his flight.

The examination shall be made in the presence of a person named by the General; the inventory of the effects to be retained shall be signed by this person, as well as by the Rear-Admiral, and by the person whom he shall appoint to draw up the inventory.

The interest on the principal (according as his property is more or less considerable) shall be applied to his support, and in this respect the principal arrangements be left to him.

For this reason he can, from time to time, signify his wishes to the Admiral till the arrival of the new Governor of St. Helena, and afterwards to the latter; and, if no objection is to be made to his proposal, the Admiral or the Governor can give the necessary orders, and the disbursement will be paid by bills on His Majesty's treasury.

In case of death he can dispose of his property by a last will, and be'assured that the contents of his testament shall be faithfully exccuted. 
As an attempt might be made to cause a part of his property to pass for the property of the persons of his suite, it must be signified that the property of his attendants is subject to the same regulations.

The disposal of the troops intended to guard him must be left to the Governor. The latter, however, has received a notice, in the case which will be hereafter mentioned, to act according to the desire of the Admiral.

The General must be constantly attended by an officer appointed either by the Admiral or the Governor. If the General is allowed to go out of the bounds where the sentinels are placed, one orderly man at least must accompany the officer.

When ships arrive, and as long as they remain in sight, the General must be confined to the limits where the sentinels are placed. During this time all communication with the inhabitants is forbidden. His companions in St. Helena are subject during this time to the same rules and must remain with him. At other times it is left to the judgment of the Admiral or Governor to make the necessary regulations concerning them.

It must be signified to the General, that, if he make any attempt to fly, he will be put under close confinement, and it must be notified to his attendants that, if it should be found that they are plotting to prepare the General's flight, they shall be separated from him and likewise put under close confinement.

All letters addressed to the General or to persons in his suite must be delivered to the Admiral or Governor, who will read them before he suffers them to be delivered to those to whom they are addressed. Letters written by the General or his suite are subject to the same rules.

No letter that does not come to St. Helena through the Secretary of State must be communicated to the General or his attendants if it is written by a person not living in the island. All letters addressed to persons not living in the island must go under the cover of the Secretary of State.

It will be clearly expressed to the General that the Governor and Admiral have precise orders to inform His Majesty's Government of all the wishes and representations which he may desire to address to it ; in this respect they need not use any precaution. But the paper on which such request or representation is written must be communicated to them open, that they may both read it, and when they send it, accompany it with such observations as they may judge necessary.

Till the arrival of the new Governor, the Admiral must be considered as entirely responsible for the person of General Buonaparte, and His Majesty has no doubt of the inclination of the present Governor to concur with the Admiral for this purpose.

The Admiral has full power to retain the General on board his ship, or to convey him on board again when, in his opinion, the secure detention of his person cannot be otherwise effected.

When the Admiral arrives at St. Helena, the Governor will, 
upon his representation, adopt measures for sending immediately to England, the Cape of Good Hope or the East Indies, such officers or persons in the military corps of St. IIelena, as the Admiral, eitler because they are foreigners, or on account of their characters or their dispositions, shall think it advisable to dismiss from the military service in St. Helena.

If there are strangers in the island, whose residence in the country shall seem to be with a view of becoming instrumental in the flight of General Buonaparte, he must take measures to remove them.

The whole coast of the island and all ships and boats that visit it are placed under the surveillance of the Admiral.

II fixes the places which the boats may visit, and the Governor will send a sufficient guard to the points where the Admiral shall consider this precaution to be necessary.

The Admiral will adopt the most rigorous incasures to watch over the arrival and departure of every ship, and to prevent all communication with the coast, except such as he shall allow.

Orders will be issued to prevent, after a certain necessary interval, any foreign or mercantile vessel from goung in future to St. Helena.

If the General should be seized with a serious illness, the Admiral and Governor will each name a physician who enjoys their conftdence in order to attend the General in common with his own physician; they will give them strict orders to give in every day a report on the state of his health.

In case of his death, the Armiral will give orders to convey his body to England.

Given at the War Office, July $30,1815$.

The decision of the Cabinet was made public through the press, and was therefore known to Buonaparte before it was officially announced to him. At first he was speechless, after which he abandoned himself to ungovernable rage, declaring that they should never take him from the Bellerophon alive, but after a few days he recognized the futility of his fury, and appeared more reconciled.

The duty of communicating to Napoleon the decision of the Government to send him to the island of St. Helena was delegated to Sir Henry Bunbury, who, with Lord Keith, waited upon him with the information. He was to have the choice of four of his friends to accompany him, as well as twelve domestics. He protested strongly, saying he had been compelled to quit the island of Elba owing to the breach of the treaty made with him by the allied sovereigns, that he had exerted himself to prevent the renewal of hostilities, but that when hostilities were unavoidable, and then unsuccessful, he, on being told that it was only 
against him they had taken arms, abdicated the throne of France, fully confident that the allies would keep faith and allow the French to choose their own form of Government. His first wish had been to retire to America and devote himself to literature; but, disappointed, he had resolved to seek protection in England, and had so placed himself in the power of the British Government, and in this predicament he protested against the decision now announced to him, as the Government could not consistently with the principles of the British constitution doom him to perpetual banishment without accusation or trial.

Sir Henry Bunbury replied that he was only delegated to acquaint him with the decision of the Cabinet, but that he would faithfully report the objections raised.

The Bellerophon and Tonnant sailed from Plymouth on Friday, August II, to Torbay, to meet the Northumberland, which came from Portsmouth and on which Napoleon was to be conveyed to St. Helena. Lord Keith and Sir George Cockburn went from her to the Bellerophon, and found Napoleon on deck to receive them dressed in a green coat with red facings, two epaulets, white waistcoat and breeches, silk stockings, the star of the Legion of Honour, and a chapeau bras with the tri-coloured cockade. According to instructions he was now to be treated only as a General, and the Admiral, approaching him, removed his hat, saying, "How do you do, General Buonaparte ?"

Buonaparte was surprised, and hesitated for a moment; then replied very distantly. After a moment's pause he broke out into invectives against the Government for their conduct towards him. Lord Keith and Admiral Cockburn remained silent, but an officer standing near remarked that " if he had not been sent to St. Helena he would have been sent to the Emperor of Russia!"

"Dieu me garde de Russes!" ("God keep me from the Russians!") was his ejaculation.

Sir George Cockburn asked at what hour he should receive him on the Northumberland. Instead of answering, Napoleon turned to Lord Keith abruptly, seeking his advice. His lordship said that he considered it would be better for him to submit with a good grace, on which Napoleon appointed the hour of ten. No sooner had he done so than 
he recalled his consent, and began again a furious harangue against his fate. Another officer standing by reminded him that if he had remained in Rochefort another hour he would have been taken and removed to Paris. This made him turn on his informer with evident indignation, but he controlled himself and made no reply.

Being addressed as "General " again, it once more roused his indignation, and he exclaimed, "You have sent ambassadors to me as a sovereign potentate; you have acknowledged me as First Consul."

To terminate all this unpleasantness he was reminded by Sir George Cockburn that the barge of the Northumberland would come up for him at ten o'clock the next morning, after which he, with Lord Keith, immediately withdrew.

There were on the Bellerophon about forty servants other than his friends, and these, with the exception of the number allowed by the Government, were to be sent on the Erolus (frigate). There was a great demonstration of affection, most of them begging to be allowed to accompany him; there was an exception, however, in the case of his surgeon, who refused to go, his place being then supplied by the surgeon of the Bellerophon. On the next morning (Monday) Admiral Cockburn went on board to superintend the inspection and removal of Napoleon's baggage, amongst which were two services of plate, several articles in gold, a most beautiful toilet of plate, together with books and beds. And, at half-past eleven, Lord kicith in the barge of the Tonnant went to receive him with his chosen attendants. Napoleon had already said farewell to Captain Maitland and his officers, and after descending the ladder to the barge he again remosed his hat to them. He was dressed in a cocked hat with tricoloured cockade, a plain green coat with red collar buttoned closely round him; he wore three orders, two crosses, and a large silver star, with the inscription "Honneur et Patrie"; white breeches, silk stockings and gold buckles; and about twelve mid-day the Tonnant's barge was alongside the Northumberland. Bertrand stepped first on the deck; Buonaparte next, with the agility of a seaman; the marines were drawn up, and presented arms as to a General. As soon as he was on deck, advancing to Sir G. Cockburn, he said, "Je suis a vous ordres." To Lord 
Lowther and Mr. Lyttleton, who were standing near, he made a few remarks, and then, taking leave of the officers who had escorted him from the Bellerophon, and embracing the nephew of Josephine, who was not to accompany him to St. Helena, he went into the after-cabin. Here were assembled Lord Keith, Sir George Cockburn, Lord Lowther, Hon. Mr. Lyttleton, and others. An interesting conversation took place between them, for in a tirade against the measures taken for his safety, he said, "You do not know my character; you ought to have relied on my word of honour."

One of those present said, "May I tell you the truth ?" "You may."

"I must then tell you that since your invasion of Spain no Englishman could put any confidence in your most solemn engagements."

He said : "I was called into Spain by Charles IV to assist him against the machinations of his son."

"No! No! Only, in my opinion, to place your brother Joseph on the throne."

After much discussion he concluded by saying, "Well, I have been deceived in your generosity-in confining me you have acted like a little aristocratic Power, not like a great free people." He afterwards added: "I do not say I have not for twenty years endeavoured to ruin England," and then, as if feeling he had said more than he wished to, he said, "that is to say, to lower you." "I wished to force you to be just-at least less unjust." Again he broke out into a furious tirade against the conduct of the allies, calling it both perfidious and treacherous. He said, "I would have given my word of honour to remain quiet, and to hold no political correspondence in England; I would have pledged myself not to quit the place assigned me, but to live as a simple individual. Why not let me remain in England upon my parole of honour ?"

He delivered a protest to Lord Keith (in writing) against his banishment to St. Helena, as follows :-

I solemnly protest, before God and man, against the violation of my sacred rights, in disposing of my person and liberty. I came voluntarily on board the Bellevophon; I am not a prisoner, I am a guest of England. As soon as I was on board the Bellerophon 
I was under the protection of the British people. If their Government, in giving orders to the Bellerophon to receive me and my suite, only meant to entrap me, it has forfeited its honour, and tarnished its flag. If this act is put into execution, it will be in vain that the English boast of their fidelity, their laws, and their liberty. British faith will be obscured by the hospitality of the Bellerophon. I appeal to history; whether an enemy, who, after having for twenty years waged war against the English people, comes deliberately, in his misfortunes, to seek an asylum under the protection of their laws, can give a more convincing proof of his estecm and confidence; but how have the English answered such confidence and magnanimity; they pretended to extend a friendly hand to this enemy, and when he relied on their good faith they sacrificed him.

On board the Bellerophon at sea, August 4,1815 .

\section{NAPOLEON.}

The British Government-for "Napoleon" its inveterate enemy-determined by the express wishes of the Prince Regent to furnish him in his exile with every possible comfort, so an order was given by Earl Bathurst to one of the large London houses. It included every kind of furniture, linen, glassware, clothes, musical instruments and music he could need for a period of three years. No stipulation was made as to price, everything was to be of a pure and simple elegance, this reservation only being made, that no ornament or initial letter should appear on anything. The order was to be completed in six weeks, and four hundred men were employed to execute the same in the given time. Report on finished work says :-

The whole has been executed in British materials; the chairs and tables are formed of the finest British oak, inlaid with polished brass ; the breakfast service is of Wedgewood's most beautiful palc blue composition, with a white cameo device in relief, modelled by Flaxman, in best style; the dinner service is white and gold, the centre of each plate, dish, etc., containing an elegantly executed landscape of British scenery; the glass, of the finest quality, is plainly but elegantly cut, with a fancy border of stars supported by fluted pillars; the table cloths and napkins are of the finest damask; the evening service is white and gold; the Imperial plate rendering it unnecessary to furnish him with a service of British manufacture; but a few dozens of spoons and other minor articles of that description, to meet the wear and tear of domestic accidents, form a part of the present supply. The cushions and curtains are of light blue silk, with a black border and small black wreaths. Some are of blue with a rich yellow border. Both the colours and styles of this part of the furniture, and indecd of the 


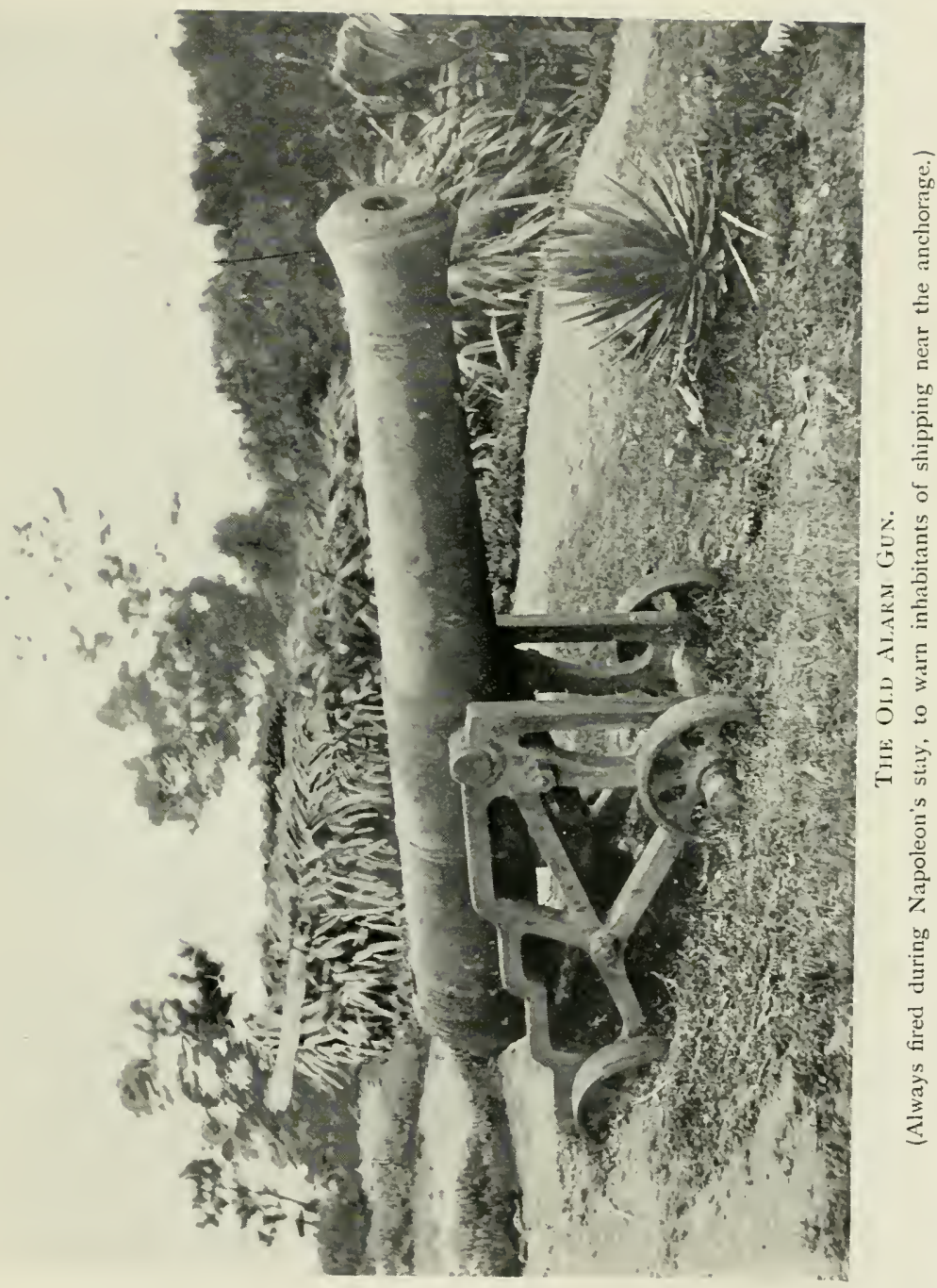



whole, are admirably suited to the climate for which they are intended. In Buonaparte's wearing apparel, his favourite colour (dark green) has been preserved. Shirts, cravats, pocket handkerchiefs, boots, shoes, stockings of every description, are also provided for him. His friends and suite are no less attended to, for they are equally to be provided with suitable equipments. A pianoforte and articles of dress are furnished for Madame Bertrand. (Madame Bertrand was born at Martinique of Irish parents. Her maiden name was Dillon).

Directly stores and provisions were on board, the Northumberland sailed for St. Helena.

Buonaparte ate and drank, conversing familiarly with the officers on board who could speak the French language, and playing whist in the evenings. At dinner he helped himself to a mutton cutlet, which he ate from his fingers without the use of either knife or fork. Indisposition compelled seclusion in his cabin, but he would not acknowledge to sea-sickness ; and it is said his suite, who still paid him all the attention the most despotic monarch could desire, were courtiers too refined to question the veracity or discernment of their imperial master when he ascribed his illness to different causes. But he was soon on deck again, assailing all whom he met with questions. To one of the midshipmen he put the question as to how long he had been in His Majesty's service, and on being told "Nine years" remarked on the length of time. "Yes," replied the midshipman, "but part was passed in imprisonment in France, and I happened to be at Verdun when you, sir, set out on your expedition to Moscow." At this answer Buonaparte shrugged his shoulders and ended the conversation.

Amongst the baggage brought on the Northumberland were two camp bedsteads which had accompanied him in several campaigns. They are described by one who was on board as being about two yards long and one wide, with furniture of green silk, the frames being of steel and so extremely light that they could very easily be carried. Napoleon used one, and the other was set apart for Madame Bertrand. He much wished to see Madeira, but unfortunately the weather was cloudy, and the island was not seen till the vessel got between Desert Island and Puerto Santo: Desert Island was pointed out to him as having a slight resemblance to St. Helena, in that its rocks are almost per- 
pendicular; whatever his feelings may have been in viewing this and comparing it, he said nothing. After crossing the line with the usual ceremonies, they were compelled to make a sweep off the Gulf of Guinea in consequence of a wind from the north-west, but soon the lofty peak of St. Helena was dimly seen about sunset on October I4.

Sir George Cockburn in his diary notes written during the voyage says :-

I cannot but remark that his (Napoleon's) general manners, as far as I am yet able to speak of them, are uncouth and disagreable. To his Frencls friends they are most overbearing, if not absolutely rude.

\section{On August 12 the diary reads :-}

Buonaparte came on deck this day earlier than usual, that is to say about three o'clock. He docs not generally quit his bed till about ten or eleven, and, like most Frenchmen, he breakfasts on meat and wire, reads, etc., before he makes his toilet, but does not come out of his cabin till he is dressed; then he takes a short walk on deck and plays until dinner, when he cats and drinks a great deal.

August 17. - In the course of conversation, Buonaparte remarked that he had been placed in chicf command as a general officer at twenty-four years of age, and that he made his conquest of Italy at twenty-five. That he had risen from nothing to be the sovercign of his country (as Consul) at thirty, and if clance had caused him to be killed the day after lie entered Moscow, his would have been a career of advancement and uninterrupted success without a parallel-the misfortunes which afterwards befell the French army would have tended rather to the advancement of his fame.

In these days of electricity it is difficult to place ourselves in the position of the inhabitants of St. Helena in I8I5.

With no cable and no steam, the news on the arrival of H.M.S. Icarus that Napolcon Buonaparte was a prisoner in the Northumberland, and within a few days' sail of the island, caused an astonishment which it would be difficult to describe. It was entirely unexpected; no communications had reached the Governor, and the captain of the Icarus could only tell them of the fact of Napoleon's proximity and that the second battalion of the 53rd Regiment lad embarked in the squadron. The St. Helenians felt that the consequences to them of the appropriation of the island as a prison might not be pleasant; they also feared the 
removal of their Governor, Colonel Mark Wilkes, who had gained their esteem by his firm but kind policy. Many were the discussions during the few days which intervened between the arrival of the Icarus and the Northumberland as to whether the island would be transferred to the Crown, and as to what would become of all the present servants of the colony. But the time passed, and soon all uncertainty was over.

It was on October I5 that the Northumberland, bearing the flag of Rear-Admiral Sir George Cockburn, anchored with his illustrious prisoner, who was attended by the following friends and servants.

Grand Mareschal Comte de Bertrand.

Madame de Bertrand and three children.

One female servant and her child.

One man-servant.

General Comte de Montholon.

Madame de Montholon and one child.

One female servant.

Comte de las Casas and a son of thirteen years of age.

General Gourgaud.

Three valets de chambre.

Three footmen.

One cook.

One usher.

One lampiste.

One steward.

One Chef d'office.

Of which seven were to dine at the Admiral's table, twenty-seven souls in all.

It was found that the island was still to belong to the East India Company, but that, as the appropriation of it would necessarily involve a deal of expenditure, it was arranged that the Company should bear the annual expense of the place to the extent of the average sum which had been spent in former years, and that the Crown should bear the remainder. Sir George Cockburn landed at once, and had a conference with Governor Wilkes, who returned with him on a visit of ceremony to Napoleon.

The King's Ministers were, of course, responsible to the nation and to Europe for the safe custody of Napoleon, so they were vested with authority to appoint that person; and it was deemed essential that the same person should be 
the administrator of both civil and military law in the island.

Sir Hudson Lowe was appointed and made Governor of St. Helena. In announcing this to the island, the Court avowed to the St. Helena Government that they could not contemplate without pain the attendant consequence of the removal of Colonel Wilkes, whose conduct had entitled him to their entire approbation. Until Sir Hudson Lowe arrived, Sir George Cockburn was in power, and consequently the disposal of the troops was in a way subservient to his wishes. This placed Governor Wilkes in a secondary position, which was heightened by the fact that there was now a senior officer to Colonel Wilkes.

Brookes say's :-

The arrival of the second battalion of His Majesty's 53rd Regiment, with detachments of other troops, brought into operation the clause in the act of the $27^{\text {th }}$ of George II, chap. ix, which transfers from the Company's Government to the senior officer of the liing's forces serving in the settlement, the authority for holding general courts-martial.

That senior officer (Sir George Bingham) held also a Colonel's commission of prior date to Colonel Wilks', but as the charter vests the powers of Captain-General in whatever person holds the office of Governor, Colonel Wilks consequently still remained paramount in military as well as in civil authority. These circumstances formed altogether rather an unusual assemblage of powers, but the characters of those in whom they were severally lodged, precluded all risk of the consequences which might have arisen from a want of unanimity. Inconvenience was effectually prevented by a general order issued in the name of the Governor and Council, appointing Sir George Bingham Commandant of the troops, and by another order immediately after from the Governor directing the Commandant to comply with all requisitions from Sir George Cockburn, which conld in any way be connected with the safe custody of his charge.

The island was well guarded, for on the day the Northumberland anchored a ball of twenty-four was fired at her from one of the fort batteries because Admiral Malcolm had omitted to send some one on shore in a boat to announce his arrival. After the sunset gun no vessel of any description was permitted to enter or leave the port, or even to alter its position, there being officers appointed for the sole duty of watching vesseli after the firing of the gun.

The curiosity excited in the colonists by the arrival of 
one who had for so long agitated and convulsed the distracted nations of Europe, may be more easily imagined than described. In consequence of arrangements necessary for his accommodation, he remained on board until the evening of the I7th; then, when all the inhabitants had retired to rest, he (with the Lieutenant-Governor and Sir G. Cockburn) walked to the house situate by the gate of the Government garden, which had been hastily prepared for his reception. It is strange that this house should be that in which the Duke of Wellington also remained for one night when, some time previously, he had visited St. Helena on his return from India (see letter from Wellington to Admiral Malcolm given on page 162.)

Horses were obtained on the following morning, and the streets were crowded with inhabitants eager to see Napoleon, and he, with Sir George Cockburn and Count Bertrand, rode to Longwood to breakfast with Colonel and Mrs. Skelton. Colonel Skelton was Lieut.-Governor, and occupied the house proposed as residence for Napoleon, who, Sir George Cockburn states in his diary, expressed himself as well pleased with it and desired to remain there, until it was pointed out to him that the Lieut.-Governor's wife and family would be inconvenienced by so sudden a move. The party then proceeded toward town, but Napoleon was dreading the curiosity of the people on his return. About a mile from the town is a pretty house called The Briars (now owned by the Eastern Telegraph Company). The property occupies about two acres of ground, the greater part of which is level, and well supplied with water. It exhibits a scene of luxuriant vegetation which contrasts greatly with the rocky cliffs above and below. Here they rested, and Napoleon, being much pleased with the picturesque spot, begged to be allowed to remain there in order to avoid the curious gaze of the assembled inhabitants awaiting his arrival in the valley. Mr. Balcombe, the owner, raised no objection, so it was decided that he might remain until the house at Longwood was vacated and prepared for him. At a short distance from the Briars house is a smaller one named the "Pavilion," now connected with the Briars house by a balcony, and there he resided for nearly two months. The ground floor was set apart for 
him while the upper story was occupied by Las Casas and lis son, with the valet in waiting; accommodation was required for his suite, so two large marquees were pitched on the lawn. An English officer resided there also, and was responsible for the security of the exile. Certain limits were assigned for exercise, surrounded by a cordon of sentinels ; and in case he wished to go beyond an officer was appointed to accompany him. It was also determined that no person should be allowed to visit him unless provided with a pass from the Governor or the Admiral. (These arrangements are very similar to those made for General Cronje while on the island, save that an ordinary guard accompanied him on his excursions.)

These strictures were highly offensive to Napoleon, and as his remonstrances on the subject proved ineffectual he gradually confined himself to the grounds surrounding the louse. As a rule he joined the family in the evening at cards, which he played with the ladies of the house for sugar-plums, and there was very little restraint between Napoleon and the two young daughters of Mr. and Mrs. Balcombe. He was much amused at their playful ways, especially those of Miss Butsy; the youngest. He taught them geography, played blind man's buff, and was generally to be seen surrounded by a group of playful admiring children. Betsy in her geography lesson asked him "Who burned Moscow ?" "I did," he answered, tapping his chest.

Beef was scarce on the island, and the sensations of those in authority may be imagined when the mastrc d'hotel of Napoleon ordered, a few days after his arrival, four bullocks, so that he might prepare a dish of brains for his master. It is only fair to state that Napolcon himself knew nothing of this until Sir George Cockburn explained why the demand could not be complied with, and the refusal is said to have been received with utmost good humour. The house at Longwood being ready for his reception, he removed there; and an extent of several miles was at his disposal, within the limits of which he enjoyed perfect freedom. Even the guards could only approach the house after sunset, when it was surrounded by the military until morning. Very strict discipline was kept for his surveil- 
lance. During the day a pass from the Governor was needed even for the inhabitants to walk or ride in certain directions, and at night the sentinels on all parts made it utterly impossible to move out of town or towards town unless the countersign was known. In all directions were sentries and patrols. When Napoleon wished to pass out of the space allotted to him, which was always surrounded by a cordon of military camps and defended by artillery, he was compelled to accept the escort of a British officer, the one appointed being Captain Poppleton, of the 53rd Infantry Regiment, who had to live at Longwood, and was held responsible for the security of his clarge. His apartment was close to that of Napoleon, and it was his duty to see him every day. News of Napoleon was conveyed by him to the Governor by a system of signals, and directly he left the enclosure, Poppleton had to follow, being ordered not to lose sight of him. Naturally he was, though only doing his duty, held in detestation by all the French. The signals used were very simple, and an old sentinel of Napoleon's time, James Smith, of Basingstoke, says :-

If Napoleon went out, a soldier's hat was hoisted on a bayonet, and this was continued from one sentinel picket to another. We had strict orders never to speak to him or salute him in any way. ... .

\section{He adds :-}

During the latter part of his life, he took very little exercise and grew fat, becoming so stout at last, that it was painful to look at him, for the fat hung over his ankles.

Las Casas, as a rule, also accompanied Napoleon, and in his almost daily rides, he got to know well the various families resident on the island, greatly interesting himself in their agricultural pursuits, and for some time he was sociable even to the extent of giving dinner parties. He much liked to converse with Governor Mark Wilkes, their conversation being mainly about chemistry. He was very irate, though, at having an escort, and did much to annoy Poppleton. In a conversation with Admiral Malcolm, who succeeded Sir George Cockburn, he complained of the surveillance exercised. He said: "Are you frightened 
that I shall escape? I admit that I should be prohibited from going into the town, but beyond the limits of the town I should have liberty." Malcolm replicd: "So you have. You are not even prevented from visiting the town." "Yes," he said, "with that officer at my heels " (referring to Poppleton) "I degrade myself if I admit that I am a prisoner." "Still," said Malcolm, "it would be impossible to treat you as a sovereign." To which Napoleon said, "Why! they might leave me my honours to amuse me. It could do no harm on this rock." "But," then replied Malcolm, "you would have to be styled Emperor." Napoleon was silent for a moment, and then said, "No, they could not do that; I have abdicated." "Yet you object to be called general," said Malcolm. "That is bebecause I am no longer a general," retorted he, "not since I returued from Egypt ; but why not call me Napoleon?" One day, when out for his riding exercise, he suddenly wished to examine a slope. Putting spurs to his horse, he was quickly outside the boundary. Poppleton followed, but, being a poor horseman, was unable to overtake or keep up with them, and was quickly left behind. This so annoyed and worried Poppleton, who was evidently afraid of losing sight of his charge, that he commenced shouting, "Stop!" After some little time the cavalcade allowed the poor officer to gain on them. He was on the point of delivering a reprimand, when a look from Napoleon stopped his intended speech, and he substituted it with "Une autre fois, messieurs, je prendrai garde a vous." Of this little incident, incorrect accounts have been given, which state that Napoleon was fired on by Poppleton.

Sir Hudson Lowe arrived on April I6, ISI6, and Governor IVilkes being relieved, sailed a week after. From all sides he received messages of regret at his departure, and, as Brooke say's, "He left behind him a veneration for his name which will be long affectionately cherished on this island." In November Count Las Casas and his son were arrested for having tried to bribe a native of the island named Scott to secretly send letters to Europe. When Napoleon and his suite arrived in St. Helena, Scott was enganged as a servant for Count Las Casas, who tested his fidelity by entrusting him with a secret message. This was faithfully 


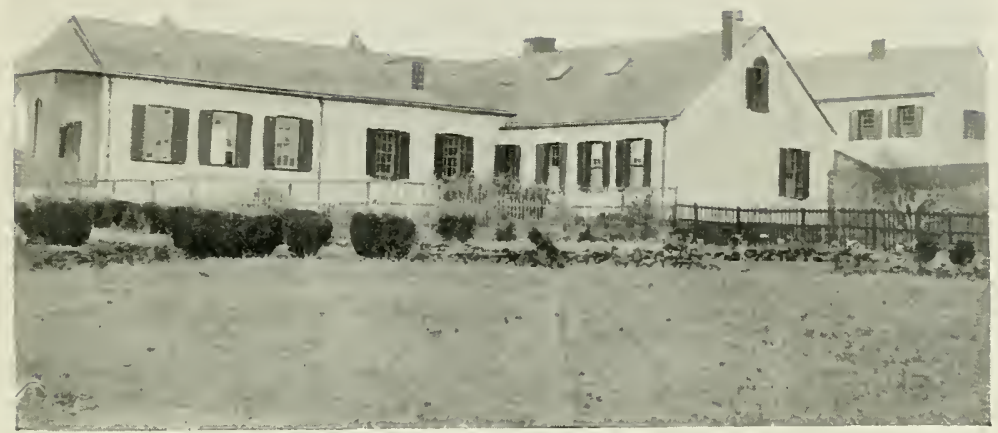

Loxgwoon Ol. Hotse, Where Napoleox Died.

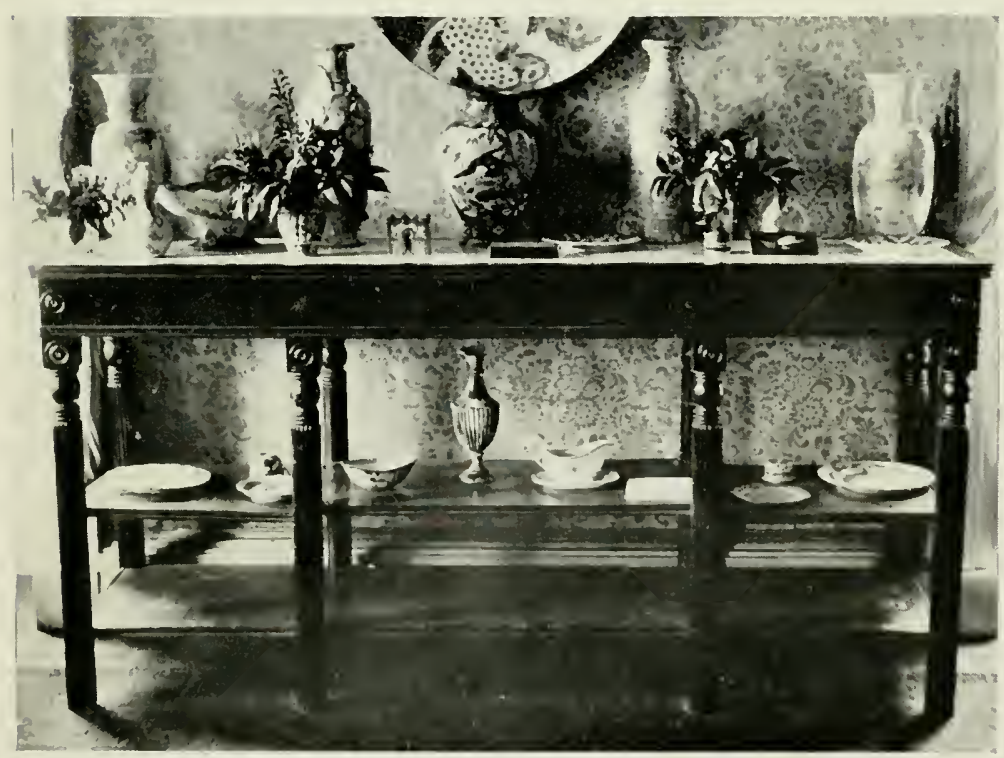

Sidebodri, Forderly Part of Naboleox's Furniture, Now in Planiation house. 

delivered, and the Governor was informed by the person to whom it was sent; so the young native was ordered to leave the service of his master. Las Casas kept on good terms with the man, being anxious to use his services later ; and hoping for a good reward, the lad consented to go to England by the first sailer. Young Las Casas wrote in almost imperceptible characters on white silk handkerchiefs, which they sewed into the lining of a waistcoat to be worn by Scott, and given on his arrival in England to Lady Clavering, a French lady, but the widow of an English officer. Scott agreed to all this, but became afraid of detection, and asked his father's advice. The latter, very irate, ordered him to disclose the whole affair to the Government ; and, on his refusal, seized him, tore off the waistcoat, obtained the handkerchief letters, and carried them to Plantation House to the Governor. Scott was immediately imprisoned, and Las Casas and his son removed from Longwood and placed in custody. It is said that Napoleon knew nothing of this, and it is the general opinion that Las Casas followed the fallen Emperor not through devotion, but to collect material for memoirs of Napoleon. Having accomplished his object, he became tired of the island, and evolved this plan in order that he might be sent home. All the handkerchiefs were sent to Lord Bathurst, and Las Casas and son remained under surveillance; but on December 25, I8I6, they were allowed to go to the Governor's residence in Jamestown, and were allowed freedom on parole. Las Casas declared that he had no wish to return to Longwood, being disgraced in his Emperor's eyes. The whole affair seemed really of little moment, and simply devised to render a pretext for their home going. He had before written a letter to the British Government full of abuse of the Governor, and placing the worst construction on affairs in the island. This he knew must pass through the Governor's hand, as, by orders of the English Ministry, all the correspondence of the Longwood people had to be read by the Governor before it could be forwarded or delivered. Very contrary to his expectations, the Governor allowed the letter to pass, thus compelling Las Casas to devise another plan, which he calculated would, even if the letters failed to reach England, 
ensure his expulsion. Napoleon was very downhearted at the loss of Las Casas. He affected indifference, but suffered much. "Why camot I dic this instant?" was his exclamation. "Let them send away all my Frenchmen, I do not wish them any longer near me.

Soon after Sir Hudson Lowe's arrival, Napoleon had become morose, declining to receive visitors, keeping himself almost entirely in the grounds of Longwood House. Though confined on a British island and guarded by British soldiers, he was officially recognized as the prisoner of the allied powers. France, Austria and Russia each sent a representative, whose duty it was to report to their several countries all that cane to their knowledge concerning the prisoner and his treatment of life.

The French commissioner was .Marquis de Montchenu, who was called by the English sailors "Old Munch Enough." He was very prejudiced against Napoleon, who was in his cyes not a Frenchman, but a "Corsican upstart."

The Austrian Commissioner was Buron Sturmer. With Baron Sturmer there was a person supposed to be at botanist. This man had brought with him a packet for Marchand, Buonaparte's valet, ostensibly from Marchand's mother; but she had it seems been employed by Marie Louise, Napoleon's second wife and the mother of his little son, to send a lock of the child's hair. The packet contained a little roll of hair, with the words. "I send you some of my hair. If you have the means of having your portrait painted, send me a copy.-Your Mother, Marchand." As soon as the Governor heard of it, lie sent an official note to Baron Sturmer, informing him that Welles had no special permission from the British Government to reside in St. Helena, and that, as three inonths were quite sufficient for him to make a collection of plants, he must depart; that he did not object to a father receiving a lock of hair from his child, but that the matter should not have been made a mystery of, but should have been first made known to him. The concealment therefore was an infringement of the law. The Austrian took great umbrage, and objected to Welles' removal, and there was a deal of bitterness shown on both sides, but Welles had to depart. 
Russia's Commissioner was Count Balmain, who, although he was a Russian subject, was of Scotch descent. His conduct was to be purely passive. The commissioners were to observe all, and to report to their respective countries, and in their dealings with the British officials always to bear in mind the friendship existing between England and their own countries, and implicitly to obey whatever rules the Governor might lay down.

The French and Austrian Commissioners were instructed to assure themselves each day of the existence of Buonaparte, and report once a month, which report was to be countersigned by the Governor. Sir Hudson Lowe, in June I8I6, announced the arrival of the Commissioners to Count Bertrand (who acted as master of ceremonies), and informed him of their wish to see General Buonaparte. Bertrand replied by asking whether they possessed letters from their respective Sovereigns, and stating the conventions of August 2, I8I5, had not been made known to the Emperor, who wished to see the terms. For days search was made for an authenticated copy of the Convention, but unfortunately it could not be found, and Sir Hudson Lowe then went personally to Buonaparte conce ning the admission of the Commissioners. "If these gentlemen desire to be presented in their capacity of private gentlemen, there is nothing against such a course; let them go to the Grand Marshall (Bertrand). If, however, they desire to see me in their capacity of Commissioners, let me see a copy of the Convention, and I will take the matter into consideration," was Napoleon's answer. The case was decidedly embarrassing, especially for those two whose orders were to see him every day. They could assure themselves each day of his welfare, but officially they could do nothing. Napoleon endeavoured to get them to visit him as private gentlemen, but this they would not do. But on July 7 the missing copy was found by Baron Sturmer among his papers. Balmain's instructions contained the following: "You will neither seek nor avoid occasions to see him, and in this respect will implicitly obey any rules laid down by the Governor," so that, while Montchenu and Sturmer maintained they could only see him in their capacity of commissioners, and that to do otherwise 
would be to nullify their mission and compromise their Courts, Balmain said he did not see that Napoleon's consent to the measure was necessary, as he did not consider himself in official relation with Napoleon, but with the Govermment. He therefore would waive the question of official intervicw, considering it quite sufficient to encounter him from time to time while walking. He was even willing, as was the case with Admiral Malcolm and many English persons, simply to announce an intention of visiting him. That he had not done so was simply due to the fact that he did not wish to seem opposed to the course taken by the Government or other Commissioners.

Sir Hudson Lowe remonstrated strongly with the other Commissioners. He said his own relations with Buonaparte were so strained that he could not compel himself to offer an indignity or humiliation to him in his fallen position. Montchenu and Sturmer then wrote this official letter to the Governor :-

The undersigned Conmissioners being desirous of fulfilling the principal object of their mission have the honour to beg His Excellency the Gosernor 10 procure for them as early as possible an opportunity of secing Napolcon Buonapartc.

This letter was forwarded to Buonaparte through Count Montholon, with the copy of the Convention of August 2. Montholon replied in a letter which in detail showed the ill feeling of the Frenchmen against the Governor and against the English nation, against the island, against his being called simply General Buonaparte, and against the world generally. The letter finished :-

Are your Ambassadors aware that the spectacle of a great man struggling with adversity is a spectacle than which there is none mere sublime? Are they ignorant of the fact that Napoleon amid persecutions of every nature which he meets with nothing but serenity is greater and more to be revered than if he were still seated on the first throne of the universe, a throne on which for so long he was the arbiter of kings?

This uncalled-for letter still left the Commissioners officially unacknowledged by Napolcon, who from this time became more morose and unbending. He adliered to his resolution not to see the Commissioners officially, yet was ill-humoured and annoyed at not seeing them as visitors, 
for his life was very monotonous. Still he, with his iron will, would not give in, and issued orders to his retainers to refuse admission to the enclosure of Longwood to any presenting passes from English authorities. This was to reserve to Marshall Bertrand only the right to give such passes. The Governor, unable to allow this, again came under his displeasure. His annoyance was so great that he sent a letter to Sir Hudson announcing his desire that he would not present any strangers to him, that for the future he would receive nobody; and from that day no one intruded upon him. Travellers who had always paid Longwood a visit were kept from it ; the inhabitants and military also avoided it, and he was left in his gloomy solitude. At about four in the afternoon he might be seen pacing slowly on a path near the house, but he avoided leaving the enclosure, hating to see the guards, and hating more the surveillance of the English officer on duty. Another source of annoyance to Napoleon was caused through a present sent to him by an Englishman domiciled in Calcutta. This present was a most beautiful set of chessmen elaborately ornamented with oriental designs, with a French eagle well carved on each. It was not allowed that $\mathrm{Na}$ poleon should have anything reminding him of his former rank, but these eagles escaped the notice of Sir Hudson Lowe at the time, and the chessmen were handed over to Napoleon. Being told afterwards of the eagles, the Governor wrote to Bertrand stating that a mistake had been made, and making a formal protest against such a present having been made; and similar foolish bickerings rendered the lives of all concerned most miserable.

In I8I7 O'Meara, Napoleon's physician, was ordered to issue bulletins, so that the Commissioners might be informed on matters relating to his health. These bulletins were often very trivial, as under :-

General Buonaparte is so much recovered from his indisposition as to be able to dine at table yesterday; very trifling catarrhal symptoms at present exist.

And again as follows :-

I have the honour to inform your Excellency that General Buonaparte is entirely free from any catarrhal symptoms, and has resumed his customary mode of living. 
The sum of $f 8,000$ allotted for the Emperor and suite did not appear to cover the cxpenses. They were continually applying for money; and Montlıolon says :-

We can only come into possession of our own money by bills on Balcombe and $\mathrm{Co}$. for $£ 50$ at a time. On one occasion, asking for $£ 60$, difficulties were made about it.

The Imperial plate was broken up and sold gradually at 5s. per ounce, and this gave them funds for daily expenses and additions to their table alllowance. They complained that the meat was tough, the poultry undersized, and the vegetables watery, and all provisions of inferior quality.

On September, 1817 , there occurred slight shocks of earthquake. O'Meara, in writing to Sir Hudson Lowe, say's :-

The whole of the house was shaken with a rumbling, clattering noise, as if some very heavy body, such as a londed waggon, was dragged along the upper apartments, which was succeeded by an cvident trembling motion of the ground; the glasses rattled on the table and the pictures receded from the walls. General Montholon stated that his son Tristan, who was asleep, was wakened by the shock, and explained that somebody was endeavouring to throw him out of bed. General Buonaparte informed me that on fecling the first shock he thought the Conqueror had taken fire or blown up, or that an explosion of powder had taken place on the ishand. He said he felt three distinct shocks and was of opinion that the duration of them inight be about twelve or fourteen seconds.

Admiral Malcolm had been recalled and succeeded by Admiral Plampim, who reached St. Helena in June, ISI 7 , on board the Conqueror, a ship of 94 guns (Capt. Davis). The second battalion of the 53rd Infantry and the second battalion of the 66th Infantry, each about 600 strong, were relieved by the ist battalion of the 66th Infantry, numbering I, 300 and Captain Poppleton of the 53rd therefore gave place at Longwood as orderly officer to Captain Blakeney of the 66th.

It was possible in the enclosure to drive about eight miles, and Napoleon would drive as fast as six horses could carry him; but even this came to an end, and for three months he did not leave the louse. alone, and took no exercise.

During this time he was quite Naturally he was ill-humoured 
and capricious, continually changing his hours for food or rest. Still, he looked well and grew stouter, having a voracious appetite, which often led to fits of indisposition.

In October I820, however, he advised Sir William Doveton of his wish to breakfast at his house if agreeable to him ; and soon after servants were seen conveying in baskets the breakfast, followed by Napoleon and Counts Bertrand and Montholon. Breakfast was laid on the lawn in front of the house, and Buonaparte did the honours, treating Sir William and his family as honoured guests. It was hoped from this that he would throw off his depression; possibly he was trying to do so, but his health was far from good. Even on the way back from breakfast (he was riding) he became so unwell that he had to seek shelter in a cottage on the road side, remaining there while his carriage was sent for. His pallor was great, and from that time he seemed to lose strength. In I8I9 the New House was commenced (a large building which is well described by a writer of the time) :-

To meet the difficulty for procuring for Buonaparte a suitable residence at St. Helena, the architect for the ordnance department at Woolwich was engaged to complete a timber frame-work for a building to be erected on the island, in the cottage style. The front is in the pure simplicity of the Grecian style. It is about 120 feet in length, containing fourteen windows and a fine open corridor. The depth of the building is about one hundred feet with a back corridor, almost making the whole building square. It is two stories high and will have an elegant appearance. The ground floor of the right division of the house contains Buonaparte's apartments. In the centre of this wing is his drawing-room which, as well as the other apartments for his accommodation, is spacious, being about 30 feet in length, by a breadth of 20 . This proportion runs through the whole. Next is his dining-room, with an adjoining library, behind which is a capacious billiard-room. His bed-room, dressing-room and bath, are of course connected. The left division of the edifice contains spacious and well-suited apartements for the officers of his suite. The rear comprises the servants, and store rooms. The kitchen is somewhat curiously constructed, being detached from the regular building, and yet perfectly convenient to the dining-room, without communicating any offensive fumes to the principal range of rooms. This is an improvement of no small value in a sultry climate. The corridor will furnish a cool and shaded promenade.

The drawing-room is coloured with various shades of green. The curtains are Pomona green, made of light silk tabaret, bordered 
with full green velvet, and edged with a gold-coloured silken twist to correspond. The green silk forms a fine ground for the border, and the style, in fitting up the upholstery, is chaste and simple; the curtain rings are concealed under a matted gold cornice, enclosing the rod on which they run. The supporters are gilt and carved patras, and the green velvet folds form into the architecture of the room by falling in straiglst lines at each side of the windows, where they draw smooth and compact, without interrupting the progress of two useful, but often excluded, properties of natureair and light.

The centre table is formed out of one piece of exquisitely veined British oak, polished in the very highest degree of perfection.

The pier table is of the same timber and quality, inlaid with a slab) of the verd-antique marble of Mona (the only place in which this precious material is now found), and surmounted by a pierglass with a frame of Buhl and ebony. The chairs in this apartment correspond with the table. There are also two Greek sofas with footstools; these are particularly elegant, being enriched with highly finished ormolu ornaments. The carpets are of the Brussels texture in shades of olive, brown and amber-colours fincly calculated to harmonize with the decorations in the room. The walls are of light tints of sage green, with beautiful ornamented panels in arabesque gold. The colours ascend from the darker shades upon the ground till they are lost in the cream colour of the ceiling. This produces a liarmony in the decorations, which is in the highest degree elegant. One of the drawing-room recesses is filled up with a pianoforte, and a few tasteful chandelicrs and candelabra are occasionally introduced with a pleasing effect.

The clining-room. A neatly finished table, supported by substantial claw and pillars, capable of being divided, to suit a company of from six to fourteen. The sideboard intended for the Imperial plate is of a new form, pure and simple in its construction and decoration. The wine-cooler is of bronze and rich wood, and slaped after the fashion of the Greck bacchanalian vases. The chairs are plain. The curtains are of lavender-coloured silk, with a rich black border, relieved by a gold-coloured silk lace and cord. The carpet and walls are shaded with the same colours, falling into a black and brown relief; the latter, in various hues, pervades the room.

The library is fitted up in the Etruscan style, with a number of dwarf bookcases. The curtains are of a new inaterial, composed of cotton, which produces the appearance of fine cloth. The library table is particularly elegant, and mechanical ingenuity has been laboriously applied to furnish it with desks and drawers suited to every convenience of study and accommodation.

The sitting-room is fitted up with several cabinets formed of ebony, inlaid with polished brass; the carpets are ethereal blue, intermingled with black.

The bed-room contains a high canopy bedstead, with curtains of fine straw-coloured muslin and lilac draperies of Persian; the 

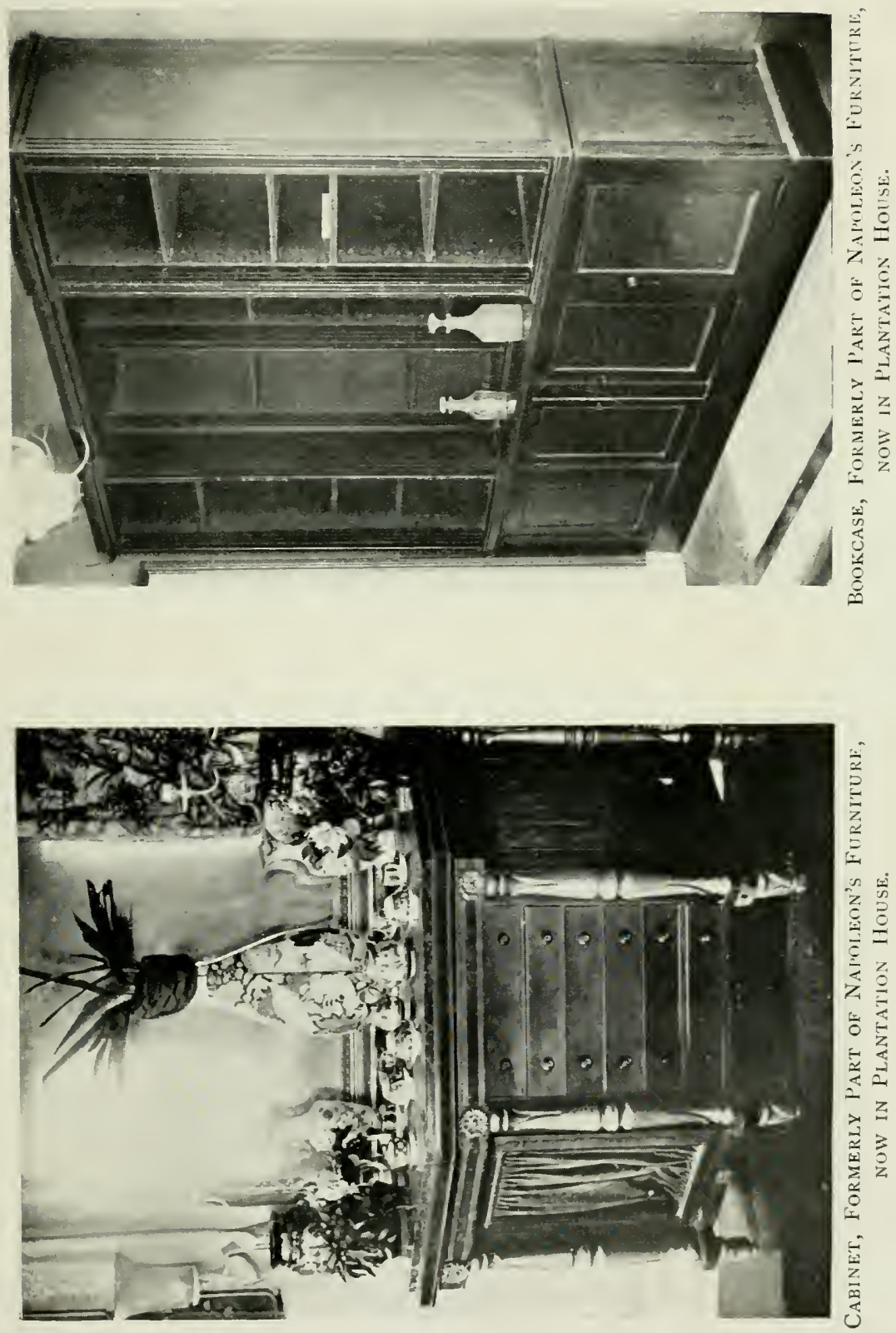

whole edged with a gold-coloured fringe ornament. The bedstead encloses a curious mosquito-net, formed of silk weft, embossed with transparent rich drapery. The dressing-room possesses the usual conveniences required by taste and comfort. The adjoining bath is lined with marble and so constructed that it can admit either hot or cold water.

The sets of china were selected from different manufacturers throughout England :-

Among other articles ordered by the Government for Buonaparte were two fowling pieces, one with double barrels and the other with a single barrel, finished in the richest style, having the patent lock, which is constructed upon a plan by which the guns may be fired under water, in the rain and without flint, besides priming themselves forty successive times.

It is a strange coincidence that this house, the ordering of which was relegated to Earl Bathurst so many years since, should, during the exile or imprisonment of the Boer prisoners of war here, have been occupied by the present Earl and Lady Bathurst; Earl Bathurst being Lieut.Colonel of the $4^{\text {th }}$ Gloster Regiment, stationed as guards of the camp on Deadwood, which is contiguous to Longwood.

Napoleon took great interest in the building of the house; still he was often heard to say he should never inhabit it. When it was complete and the removal from the old house expected each day, rumours circulated of his illness. His unsociability was no doubt due to the existence of a disease which, unsuspected by those around him, was silently but surely hastening his end.

The population had almost doubled since Buonaparte's arrival and as all vessels were prohibited from calling, except those belonging to the Company, the islanders found they could not live as heretofore. They had been accustomed, when vessels arrived, to take of the produce of the land and barter it with the shipping for supplies of which they were most in need, such as grain, salt-meat, China and India produce, and surplus ships' stores, as well as stores brought often specially by the captains for the purpose of trading. At first this inability to obtain what they required caused dissatisfaction, but a reaction soon set in. They found that the great increase in the population and the continual advent of men-of-war more than compensated them, for the squadron and the military created a larger 
demand for vegretables and fruit than had been the case previous to Napolcon's arrival.

The total garrison at the time was $2,79+$, i.e. officers and men. There were 500 camon in batteries, besides fifty field-guns and a number of mortars in good order. There were also a number of guns in store.

The naval strength under Admiral Pulteney Malcolm was made up of three large frigates of thirty-six to fifty guns, and cight smaller war-ships with from ten to twenty guns each. The frigates and two brigs remained to guard the island; the rest were cruisers in South Atlantic watersone brig was anchored at Ascension, where fifty sailors were also stitioned to defend the island.

The official letters by Count Balmain show that Sir Hudson Lowe was, although often maligued by his own combrymen, not unkind to his charge, for he writes :-

Sir Hudson Lowe tries his best to satisfy Napoleon; he treats him with respect and consideration; uncomplainingly puts up with his rudeness; tolerates his whims; does, in fact, the impossible. But to Xapoleon he will never seem anything but a scourge. There is 100 much incompatibility of temper between the two men. To sum up the situation in a phrase, the man who only knows how tn command is in the power of him who only knows how to obey. And there is no sort of annoyance that the prisoner has not inflicted on the Governor."

\section{Again he writes :-}

General Lowe treats him with all possible respect, and even, to a certain extent, humours him in his mania for playing the Emperor. In spite of this Buonaparte distikes him.

During this time Napoleon was compiling the account of his campaigns, and repeatedly was heard to say that he ought to liave died on the day he entered Moscow when he conceived himself to have attained "the highest pinnacle of glory."

The island of Tristan d'Acunha was now taken possession of by the British, a measure "adopted to prevent the Americans from establishing themselves there; as they might probably prove disagreeable neighbours, under the circumstances in which we are placed as guardians of the 'Disturber of the World.', 
An old St. Helena paper gives the following account of his later days :-

"The Emperor for some months considered himself attacked by an internal disease which would speedily prove fatal to him. He mentioned it, but he was supposed only to be imaginative. A few weeks before his death he laboured with a spade in his garden, so long and so severely as to be faint with fatigue. Some one suggested the probable injury to his health. "No," said he, "it cannot alter my health--that is lost beyond all hope. It will but shorten my days."

He gave but little time then to the memoirs of his life, and Bertrand urged him to labour with more assiduity.

"It is beneath me," he said, "to be the historian of my own life. Alexander had his Quintus Curtius, and I shall have mine. At all events my life is recorded in my achievements."

A short time before his malady became serious, he abandoned his reserve, and became familiar with all. He set a high value on Bertrand but did not like him. One day at table he said :-

"Bertrand, it was not your attachment to me, but your love of glory that brought you to St. Helena; you would immortalize your name as my Fidus Achates!"

It is scarcely known that a little girl of nine years of age, the daughter of a sergeant of the garrison, often kept him company; he took great pleasure in her presence, and constantly provided himself with fruits and sweetmeats for her. Shortly before he died he hung a gold watch and chain round her neck, saying, "Julia, wear this for my sake." He had with a penknife rudely graved on the cover (clumsily enough, it is true), "The Emperor, to his little friend Julia." Often he amused himself by giving her drawing lessons from the scenery round.

On April 2 he was seen to be very seriously indisposed. He rose early and walked in the garden, but after a few minutes sat on the bank apparently faint. Montholon, who was near, asked if he were ill. "Yes!" he said, "I feel nausea and sick stomach, the avant-couriers of death." Montholon smiled, but Napoleon, taking his arm, said, "My friend, we must not smile at death when he is so near us."

Just then Julia appeared and attracted his attention. 
He took her into the saloon where breakfast was prepared and filled her basket with different sweet things, adding a bottle of liquor with these words, "This is for your father to drink my health !"

One day he sent for a jeweller to alter or repair a trinket, and while talking asked him if he could make a silver coffin. The jeweller tried to shift the question, but Buonaparte, repeating it, said, "I shall die in a few weeks."

"God forbid that we should lose your Highness," said the man ; but "God grant that I may die soon," was the answer. "for I am well convinced that life is not a blessing, but a curse."

He often read from Telemachus. While lying on his sofa he one day inquired if an English journal could be precured him. With some difficulty a newspaper was provided. Taking it, and glancing over it hastily, he suddenly exclaimed, "Ah! Naples, Naples!-poor devils. Murat was the bravest king they had, but he did not know his subjects; they are all Lazzaroni from the Duke ofdown to the lowest!"

On the morning of his death he said, "Death has nothing to affright me; for three weeks he has been the companion of my pillow."

Ailing, as has been shown, for some months, depressed and weak, his illness at the end was of short duration, and he died on May 5, IS2I, at Longwood Old House.

His heart was placed in spirit, and in his military uniform the body lay in state on the two following days, the Star of the Legion of Honour on his side, and a Crucifix on his breast. The room was draped in black, and there were in attendance Count and Countess Bertrand, Count Montholon, the priest, physician and servants.

1 On the following morning about seven o'clock Sir Hudson Lowe proceeded to the apartment in which the body lay in state. He was accompanied by Rear-Admiral Lambert, the Marquis de Montchenu, Commissioner on the part of France and Austria, and other public functionaries. After riewing the body, which lay with the face uncovered, they retired, and at two o'clock on the same day the body was opened in the presence of six medical gentlemen, including Professor Autommarchi, Buonaparte's own physician. An 
ulcer was found, which had penetrated the coats and the internal surface of the stomach, nearly the whole extent being a mass of cancerous disease, or schirrous portions advancing to cancer. Buonaparte had frequently declared he knew his disease, that it was hereditary, and that his father had died of it. The official report appended shows clearly that the cause of death was cancer, although many have attributed it to heart disease.

This report on the dissection of the body (made by the medical men on May 6, I82I, appeared in the Scotsman of July I4, I82I.

With the report was forwarded to Earl Bathurst a letter from Sir Hudson Lowe, as follows :-

$$
\begin{aligned}
& \text { ST. HELENA, } \\
& \text { May 6th, I821. }
\end{aligned}
$$

My LoRD,-It falls to my duty to inform your Lordship that Napoleon Buonaparte expired at about ten minutes before six o'clock in the evening of the 5 th inst., after an illness which had confined him to his apartments since the 17 th of March last. He was attended during the early part of his indisposition, from the 17 th to the 3 Ist March by his own medical assistant, Professor Autommarchi, alone. During the latter period, from the Ist April to the 5 th May, he received the daily visits of Dr. Arnott, of H.M. 2oth Regiment, generally in conjunction with Professor Autommarchi.

Dr. Short, physician to the forces, and Dr. Mitchell, principal medical officer of the Royal Navy on the station, whose services, as well as those of any other medical persons on the island, had been offered, were called upon in consultaion by Professor Autommarchi on the 3 rd of May, but they had not any opportunity afforded to them of seeing the patient.

Dr. Arnott was with him at the moment of his decease and saw him expire. Captain Crokat, orderly officer in attendance, and Doctors Short and Mitchell saw the body immediately afterwards. Dr. Arnott remained with the body during the night. Early this morning, at about seven o'clock, I proceeded to the apartment, where the body lay, accompanied by Rear-Admiral Lambert Naval Commander-in-Chief on this station; the Marquis de Montchenu, Commissioner of His Majesty the King of France, charged with the same duty also on the part of His Majesty the Emperor of Austria; Brigadier-General Coffin, second in command of the troops; Thomas H. Brooke and Thomas Greentree, Esqs. members of Council in the Government of this island; and Captains Brown, Hendry and Marryat, of the Royal Navy. After visiting the person of Napolcon Buonaparte, which lay with the face uncovered, we retired. 
An opportunity was afterwards afforded, with the concurrence of the persons who bad composed the family of Napoleon Buonaparte, to as many officers, naval and military, as were desirous, to the Honourable the East India Company's officers and Civil scrvants, and to various other inhabitants resident here, to enter the room in which the body lay and to view it.

At two o'clock this day the body was opened in the presence of the following medical gentlemen :-

Dr. Short, M.D.

Dr. Mitchell, M.D.

Dr. Arnott, M.D.

Dr. Burton, M.D., of H.M. 66t/ Regiment, and

Matthew Livingstone, Esq., surgeon in the East India Company's service.

Professor Autommarchi assisted at the dissection. General Bertrand and Count Montholon were present.

After a careful examination of the several internal parts of the body, the whole of the medical gentlemen present concurred in a reprort on their appearance. The reprort is enclosed.

I shall cause the body to be interred with the honours due to a general officer of the highest rank.

I lave cutrusted this despatch to Captain Crokat, of Ilis Majesty's zoth Regiment, who was the orderly officer in attendance upon the person of Nappleon Buonaparte at the time of his decease. He cmbarks on board His Majesty's sloop Heron, which Rear-Admiral Lambert has despatched from the squadron under his command with the intelligence.

I have, etc., etc., ctc.,

H. I.OWE, Licut.-General.

To the IRight Ilon. the Earl Bathurst, K.G., etc., ctc.

THE Rerort of Afrearasces oN Dissection of the Body of Naioleon Bronaparte.

LONGWOOD, St. HELENA, May 6.

On a superficial vicw the hody appeared very fat, which state was confirmed by the first incision down its centre, where the fat was upwards of one incl and a half over the abdomen. On cutting through the cartilages of the ribs, and exposing the cavity of the thorax, a trifling adhesion of the left pleura was found to the pleura costalis. About three ounces of reddish fluid were contained in the left cavity and nearly cight ounces in the right. The lungs were quite sound. The pericardium was natural, and contained about an ot:nce of fluid. The heart was of the natural size, but thickly covered with fat. The auricles and ventricles exhibited nothing extraordinary, except that the muscular parts appeared rather paler than natural.

Upon opening the abdomen the omentum was found remarkably 
fat, and on exposing the stomach the viscus was found the seat of extensive disease.

Strong adhesions connected the surface, particularly about the pyloric extremity to the concave surface of the left lobe of the liver; and on separating these, an ulcer, which penetrated the coat of the stomach, was discovered, one inch from the pylorus, sufficient to allow the passage of the little finger. The internal surface of the stomach to nearly its whole extent was a mass of cancerous disease or schirrous portions advancing to cancer; this was particularly noticed in the pylorus. The cardiac extremity, for a small place near the termination of the oesophagus, was the only part appearing in a healthy state. The stomach was found nearly filled with a large quantity of fluid resembling coffee grounds.

The convex surface of the left lobe of the liver adhered to the diaphragm. With the exception of the adhesions occasioned by the disease in the stomach, no unhealthy appearance presented itself in the liver.

The remainder of the abdominal viscera were in a healthy state.

A slight peculiarity in the formation of the left lobe kidney was observed.

(Signed) Thomas Short, M.D., and principal Medical Officer.

Arch. ArNotr, M.D., Surgeon 2oth Regiment.

Chas. Mitchell, M.D., Surgeon of H.M.S. Vigo.

Francis Burton, MI.D., Surgeon 66th Regiment.

Mattheiv Livingstone, Surgeon E.I.C. Service.

At an exhibition held in the Mechanics' Hall, Dumfries, some years since, there was shown by Major Young, of Lincluden, a lock of hair, cut from the head of the great Napoleon after death, together with a letter which is of some historical value. Hitherto, French writers have asserted that the post-mortem examination of Napoleon's body was an unwarrantable liberty taken in opposition to the deceased's wish. The letter, together with the lock of hair, was discovered by Major Young in a secret drawer of an old writing desk belonging to his father, to whom the epistle had been written by Dr. Short (a native of Dumfries), who held the office of Principal Medical Officer of the British Staff at St. Helena, and who superintended the dissection, as stated in Sir Hudson Lowe's letter to Earl Bathurst.

$$
\begin{aligned}
& \text { ST. HELENA, } \\
& \text { May 7th, } 182 \mathrm{I} .
\end{aligned}
$$

MY DEAR SIR, - You will no doubt be much surprised to hear of Buonaparte's death, who expired on the 5 th of May after an illness of some standing.

His disease was cancer in the stomach that must have lasted 
some years, and been in a state of ulecration some months. I was in consultation and attendance several day's, but he would not see strangers. I was officially introduced the moment he died. His face in death was the most beautiful I ever beheld, exhibiting softness and every good expression in the highest degree, and really secmed formed to conquer.

The following day I superintended the dissection of the body (at this time his countenance was much altered), which was done at his own request to ascertain the exact seat of the disease (which he imagined to be where it was afterwards discovered to be) with the view of benefiting his son, who might inherit it. During the whole of his illness he never complained, and kept his character to the last. The disease being hereditary, his father having died of it, and his sister, the Princess 13orghese, being supposed to have it, proves to the world that the climate and mode of life had no hand in it, and, contrary to the assertion of Messrs. O'Meara and Stokoe, his liver was perfectly sound; and had he been on the throne of France instead of an inluabitant of St. Helena, he would equally have suffered, as no earthly power could cure the clisease when formed.-From North British Adretiser, May 2, 1873.

Preparatory to the funcral the body was placed in a leaden coffm in the dress in which it had lain in state, including boots and spurs. This coffin was enclosed in two others made of mahogany. The outer one had a plain top and sides, with ebony round the edges and silver headscrews. Pursuant to military orders for conducting the ceremony with the honours usually paid to the remains of a general of the highest rank the left side of the road, from Longwood gate in the direction of the burying-place, was, on May 9, lined with troops of the garrison; the Royal Artillery were on the right of the whole; then the 2oth Regiment, the Royal Marines, the 66th Regiment, the St. Helena Artillery, the St. Helena Regiment and on the left the St. Helena Volunteers.

(The instructions to Sir Creorge Cockburn had provided that in case of the death of Napoleon his body was to be taken to England, but it seems that counter orders were subsequently sent to Sir Hudson Lowe, and Napoleon had requested that in the event of his dying at St. Helena, he should be buried in the vale where his grave was made.)

The coffin was placed in a car drawn by four horses; the whole of the funcral procession passed along the front of the line of troops, the band of each corps playing solemn music. As the procession cleared each company it was 
followed by the troops till they took up a position on the road above the grave. At the moment of lowering the body, three discharges were fired from eleven pieces of artillery.

So by his own wish, in the shady valley close to the spring of water at which he so frequently quenched his thirst, he was laid with last honours. Here his body rested for nearly twenty years, from May 9, I82I, to October I5, I840. The little glen is shaded by beautiful Norfolk pines, cypresses, and firs, and the enclosed portion measures about twenty by thirty yards.

The vault itself is covered by a large flat stone, twelve by six feet, which at the present time is run over with cement much cracked, bearing no name, no inscrption. Formerly, overhanging it, were two willow trees, but they have long since disappeared. Outside the fencing is a thick-set privet hedge and a wooden hut or sentry-box, in which an attendant keeps a visitor's book. Here a notice is affixed to the effect that the grave and its surroundings are the sole freehold property of the French Republic.

Sir Hudson Lowe wishing to return to England, the question arose as to who should take command; Mr. Brooke was senior in Council, but it had been ordered in Council that in the event of death or absence of Sir Hudson Lowe, the custody of Napoleon as well as the Governorship of the island should devolve on the officer commanding the troops. The death of Napoleon was not anticipated or allowed for so Brigadier-General Pine Coffin was appointed Acting Commander-in-Chief, with charge of Longwood House and all properties belonging to the British Government, while the Civil Authority was vested in Mr. Brooke under the title of Acting-Governor.

On leaving the island Sir Hudson Lowe was presented with an address signed by the inhabitants generally, stating that as he was on the eve of resigning his authority they could not be suspected of views of an interested nature in respectfully offering their most sincere and grateful acknowledgments for the consideration, justice, impartiality, and moderation which had distinguished his Government.

After his departure the troops which had formed the military establishment were removed, and hard times fell on many who had lived in affluence. 
In Longwood Old House is a bust of Napoleon. There have been doubts raised as to whether or not a cast of his face was made after death. The present custodian of French property in St. Helena, in writing on the subject to the editor of the St. Helena Guardian, says :-

I regret to say I have not in my possession at present The Memorial of St. Helena, begun by Las Casas and continued by Dr. Autommarchi. If my memory served me right I read in the latter part of said Memorial that first of all the autopsy of the dead body of the great Emperor was made (probably on the 6th May) by Dr. Autommarchi, aided by Dr. Arnott (some spell Arnold), assisted also by other doctors of the garrison. Then a cast was taken of the great General, but a mishap occurred. When the doctors had mixed the plaster of Paris they found the quantity was not sufficient to complete the cast. Jamestown was ransacked but without success; 110 more "plaster" could be found. . . . The doctors were in a dilemma. Somcone proposed exploring the vicinity of Longwood to obtain a substitute to complete the cast, and they were so far successful as to find some argillaceous marl with a certain amount of adhesiseness, They burnt and pulverized it, and thus finished their almost hopeless task; the only fault with the cast was that it was of two colours.

Dr. Autommarchi, I believe, took the cast to Paris, and it was exhibited in the Louvre for ycars after.

There are but two busts of Napolcon I acknowledged as correct, one taken during lifetime by Canova, and the other taken from the cast after death, by Chaudet, which is still at Longwood old House, St. Helena, placed between the two windows of the saloon, where the mortuary bed was taken from the bed-room, a few days before the end of the Great Conqueror. This last bust in Carrara marble was brought to St. Helena by the late M. Gauticr de Rougemont (not Louis).

\section{I remain, dear MIr. Editor, Yours sincerely, (Signed) L. Morilleau.}

The copy of the Campaigns of Italy, which was written at St. Helena by Napoleon himself, was in the possession of General Bertrand who, when he was dying, delivered it to his brother, M. L. Bertrand, to present to the city of Lyons. Napoleon had made two copies of these memoirs ; the one he gave to Bertrand was (ats above) transferred to Lyons with a map of Italy by Albe (which Napoleon used in compiling the memoirs), together with the Cross of the order of the Iron Crown (worn by the Emperor) and an 


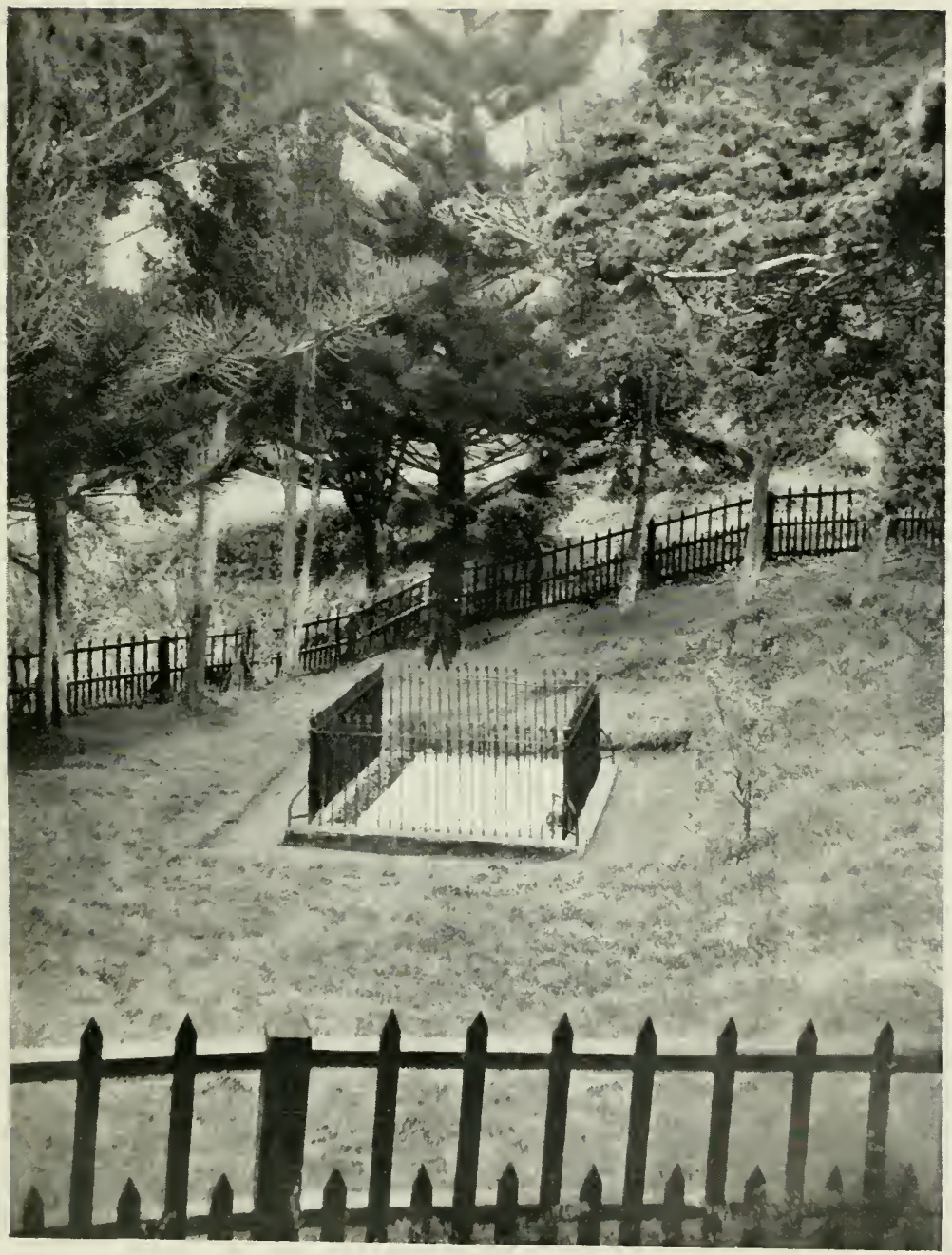

Napolfon's Tomb. 

eagle of silver, given to Bertrand by Napoleon, which constituted part of the plate broken up in St. Helena.

On October 8, 1840, the frigate, La Belle Poule, bringing the Prince de Joinville and suite, arrived, accompanied by the Favourite, a corvette. Their mission was to convey to France the remains of the late Napoleon Buonaparte. (See illustration of funeral cortège passing through Lower Parade.)

After exhumation, the coffins were deposited with funeral honours in the frigate which, on Sunday, I5, sailed for France.

Extract from the "St. Helena Gazette," Saturday, May 26, 1849, and June 9, entitled "The Two Funerals of NAPOLEON."

In the $\log$ of the Free Trader, homeward bound, by Robert Pastans, May 5, I82I, there appears this entry :-

"A memorable event occurred this day." Apparently, at the time these words were written it was supposed they would be sufficient to recall to the memory, at a future period, the circumstance they so briefly recorded, for the journal said nothing more about it. True, it was further stated lower down on the same page with nautical brevity, under the head of "Remarks ":-
"All useful sail set."
"Beat the best bower."
" Pumped ship."
"A stranger in sight."

To which was added, "Lat. by observation I6" $30^{\prime \prime}$ south, 5' $30^{\prime \prime}$ west." Assisted by the latitude and longitude, as well as by the date, I made two or three desperate dives into the stream of time, hoping to rescue from oblivion the event, and, after a hard struggle, succeeded in bringing to the surface of my memory the leading incident, and then the whole affair floated through my mind with all the freshness of yesterday. And, perhaps, it will be as well to state, for the information of the general reader, that on the day in question, the Free Trader was running before the south-east trade wind, over that aqueous portion of our planet which rolls between the Cape of Good Hope and the island of St. Helena.

It was my morning watch, and I recollect leaning over the capstan and lapsing into one of those paradoxical states, when, although attending to nothing in particular, yet almost every object within the range of our senses undergoes a sort of dreamy observation. I could see the man at the helm, and see how firm he kept the plunging ship in hand, his sinewy grasp seemed by a secret intelligence to impress his will upon the vast mass of the vessel. Without disturbing the process of observation, a shoal of porpoises would occasionally rush along, pursuing their earnest and busy 
passage at a velocity compared with which the progress of the swift ship was tardiness itself, for I could hear the hissing of the crisp sea as it curled a crescent of foam bencath her bows. Then came the busy hum of the "morning watch," mingling with the welcome sound of "eight bells" and the merry whistle of the boatswain piping to breakfast. The motion of the rolling vessel, the freshness of the delicious south-east trade, the thoughts of home, the dancing waters and the sparkling sunshine, each of these in their turn would for a moment slightly arrest the attention; but viglance is a cardinal virtue in old Neptune's domain, and bustling times were close at hand. A ship in the middle of the Atlantic, with a rattling south-easter whistling through the rigging, is not the bed where day-dreaming can be indulged in with impunity, and so it soon appeared, for a hoarse voice from the maintop-mast cross-trees, as if by magic, dispelled the illusion, and brought my senses 20 their duty.

"Sail, ho !"

"Where away ?" was the prompt demand.

"Iight ahead," returned the scannu. "I make her out a full-rigged ship lying to."

The officer of the watch had barely time to apply his "Dollond" in the direction indicated when the man aloft was again heard shouting " Land on the larboard how."

As the Irece Trailer had been traversing the ocean for weeks, with nothing to relieve the eyc but the "blue above and the blue below," the excitcment which was caused by the discovery of the stranger, coupled with the sudden cry of "land," is not surprising.

For it is in the deep solitudes of the ocean that man most keenly feels how dependent he is upon his kind for happiness. In such situations the most trifling incident arrests the attention-a foating spar or even an old tar-barrel become objects of speculative curiosity. Accordingly, as we neared the strange ship, the cut of her canvas and the mould of her hull were critically examined by the more experiencel seamen, who can generally guess from the appearance they present not only the nation to which a ship belongs, but her occupation also. But on the present occasion they were puzzled to give a reason why a large vessel like the stranger should be lying to just where slic was (that secined the mystery), and apparently waiting our approach.

This quict bearing lasted until the Free Trader was in the act of passing the strange vessel, and then, as if suddenly roused out of her lethargy, a thin volume of white smake was seen curling out of one of her forward ports. The explosion was followed by the appearance of a flag, which, after fluttering for an instant, blew steadily out, and, much to our satisfaction, displayed the blue field and red cross of the English ensign.

"What ship's that ?" bellowed a loud voice from our formidable. looking neighbour, who had ranged alongside the Indiaman close cnough to be within hailing distance.

"The Free Trader." 
"Where from ?" was demanded.

"Calcutta, and bound to London," replied our captain.

"Do you intend calling at the island ?"

"Yes."

"Then send a boat on board His Majesty's frigate The Blossom for instructions," was demanded in tones that left no doubt what would be the result of a non-compliance. An interchange of visits speedily followed between the frigate and the Indiaman, and soon after they were sailing side by side in the direction of the land, keeping company until the Free Trader had received such sailing directions as enabled her to stand in for the island alone. The frigate then took up her cruising ground as before.

It would require but a slight stretch of the imagination to convert the perpendicular cliffs of St. Helena in to the enormous walls of a sea-girt castle. There is an air of stern and solemn gloom stamped by nature upon each rocky lineament that reminds one of the characteristics of a stronghold. Not a sign of vegetation is outwardly visible. Headlands appear each in its turn looking more repulsive than those left behind. The sea-birds, as they utter their discordant screams, seem afraid to alight, but wheel about the lofty summits of the bald rocks in a labyrinth of gyrations, while an everlasting surf, as it advances in incessant charges at their base, rumbles upon the air in a hollow ceaseless roar.

It was during the operations of working the Free Trader round one of the points of the island that the heavy booming sound of a large gun was heard, slowly borne up against the wind over the surface of the sea. As the sun was just then dipping in the bosom of the Atlantic, it was generally thought on board to be the evening gun. But again the same solemn heavy sound floated by on the wind. Again, and again, it came in measured time, when at length, as we cleared the last projecting headland, the roadstead and the town came suddenly into view. At the same time the colours of the fort on Ladder Hill, and on board the Admiral's ship, the $V i g o$, of seventy-four guns, were seen fluttering at half-mast, denoting the death of some person of distinction.

While sailing into our berth, and after the anchor had fixed us to the land, the report of the cannon came upon us at intervals. Their sounds seemed bodeful of some great event. We all looked inquiringly for some explanation, but before any positive intelligence had reached the ship from the shore, surmise after surmise had given way to a settled conviction; for by one of those inscrutable impulses of the mind, every man in the Free Trader felt assurod those island guns announced the death of Napoleon.

Our suspense was brief, for soon after the anchor was down a shore boat came alongside, containing an official person, to demand the nature of our wants, and he confirmed our suspicions. This intelligence, although anticipated, created a feeling of disappointment, as every individual in the ship had speculated during the voyage upon the chance of seeing Napoleon alive. However, by an easy transition, now that he was dead, we wondered whether 
we should be permitted to witness his funeral, but as no communication was allowed from the ships in the roads to the shore between the hours of sundown and sumrise, we were obliged to pass the night in conjecture. Under these circumstances, we were scarcely propared for the news that reached us early in the morning. It was a general notice to all strangers and residents, informing them that they were permitted to visit the island and to see the body of Gencral Buonaparte as it lay in state.

After the lapse of six and twenty years, and now, when the passions of that mighty contlict which tulled liurope in the early part of the century are cxtunct, it would be difficult to make the present generation comprehend the profound emotions which the news had upon those who, like ourselves, happened to be at St. Helena at this eventful period. Consequently, on the second day after Napoleon's death nearly every individual on the istand, as well as those in the different vessels at anchor in the roads, repaired to L.ongwood, the place where he died. Of course the house was thronged with people, but as the greatest order prevailed, I was soon in the room wath all that was left of the most wondrous man of modern times. Suddenly coming out of the glare of a tropical sun into the partially darkened room, a few moments elapsed before the objects were properly defined. Gradually, as the contents of the apartment tumbled into shape, the person of Nappoleon, dressed in a plain green uniform, grew ont of the comparative gloom, and became the loadstar of attraction.

He was lying on a small brass tent bedstead, which had been with him in most of his campaims. I found it inspossible to with. draw my eyes for an instant from his countenance; it caused in me a sensation clificult to define, but the inupression can never be forgotten. There was a crucifix on his breast, and by its side glittered a large diamond star, the brilliancy of which strangely contrasted with the pallid face of the dead. The slin was of a most intense whiteness, and looked like wax.

What struck ne as most strane vas the mean appearance of the surrounding furniture and the "getting up " of the ceremony". There appeared to be no want of respect to the memory of the dead hero, whatever might have been his treatment when living. But the knowledge of this did not present a comparison between his fallen state and the magnificence and power with which imagination invested him when living. And although it may be idle to compare the deeds of a great man with the appearance of the man himself, yet it is what most of us are prone to do; and on this occasion it was impossible to avoid falling into the practice, for possibly the results of a comparison could not be more striking. Napolcon at Austerlitz or Zena, with continental Europe at his fect, and Napoleon lying dead in that miscrable room, presents to the dullest imagination a theme pregnant with emotion. It was indeed difficult to understand linw, even by the proverhial instability" of fortune, that insensible form lying in its utter helplessness could ever have been the 
"Man of a thousand thrones,

Who strewed our earth with hostile bones."

Solemnly and sternly the reality forced itself upon all, and I felt that $I$ was reading a journal of true romance, so absorbing, so wretched, that if I was to confine my studies to man, it would be unnecessary to peruse a second volume to grow perfect in knowledge or reflection.

The time allowed for the visitors to remain in the chamber was very limited and condensed observations into a passing glimpse. This could not well have been otherwise, as every individual on the island was anxious to obtain even a momentary view of one who had attracted so large a portion of the attention of the world. And not the least singular spectacle scen on that day was the motley group which Napoleon's fame had drawn around his funeral couch. For although St. Helena on the map may at first appear to be a secluded spot, yet in reality it is not so. A glance or two is sufficient to assure us that it is placed in the centre of the great highway of the world, where the necessities of commerce, and the wants and hazards inseparable from a sea-faring life, are the means of bringing together the antipodes of the human race. And if the dense masses of people which thronged to his second funeral at a more recent period, in his own dear France, were wanting, their deficiency in numbers was in some sort compensated by the variety of men; or if there was not a multitude, there was, at least, a medley of curious gazers.

Foremost in intelligence were the French and English; but apart from these stood the wondering African negro, the uncouth Hottentot from the Cape, the yellow Brazilian from South America, the fierce-looking Lascar from Bengal, and the quiet, inoffensive Chinese from remotest Asia. Some of these $\mathrm{knew}$ but little of Napoleon's renown; but being inoculated with the prevailing emotion, they came, like the more intellectual European, to gaze upon the embers of that dazzling meteor, the blaze of which had so recently expired.

The same tincture of corruption dyes all mortality, and hero dust, as well as common clay, soon becomes offensive in a tropical climate. Even on the second day after his death it was already time he should have been soldered up. With a knowledge of this fact, the Governor-General had ordered the funeral to take place on the 9th, thus allowing only four days to elapse between his death and his burial.

In the meantime the spot where the pioneers were digging the grave became an object of mingled curiosity and veneration, second only in importance to the illustrious hero who was so soon to make it his abiding place.

It was close to a small spring, of which Napoleon always drank, and occasionally he brealsfasted beneath the shade of two willows that bend over the bubbling water. The grave was singularly made. It was formed very wide at the top, but sloped gradually 
inwards, having the appearance of an inverted pyramid. The lowest part was chambered to receive the coffin, and one large stone covered the chamber. It was said that this covering was taken from the floor of the kitchen at Longwood, where it had been used as a hearthstone in front of the fireplace, though why it should have been removed for such a purpose it is difficult to comprehend, for the island is not deficient of the requisite material. The remaining space was to be filled up witl solid masonry clamped together with bands of iron. These precautions, it appeared, were intended to prevent the removal of the body, as much at the request of the French as of the Governor of the island. Divested of the associations connected with his fame, Napoleon's funcral at Si. Heiena was a simple, though heartfelt, affair. His long agony on that sunburnt rock commanded the reverence of every beholder. Consequently; on the gth, all the inliabitants and visitors on the island focked to the line of march. Like many others, I selected a prominent position on the shoulders of a hill from whence the soleinn procession could be traced, as it threaded its way through the gorges and ravines of this picturesque place, on its way to the grave. The coffin was borne upon the slioulders of English Grenadiers, and followed by the soldiers who had contributed more towards his downfall than those of any other mation. Their solemn tread and grave deportment contrasted strongly with the heartfelt sorrow of Count IIontholon and General Bertrand, who hore the hero's pall. Madame Bertrand followed next, in tears, and then came Lady. I. owe and her daughters, in mourning ; the officers of the English man-of-war next, and then the officers of the army, the Governor-General and Admiral I-ambert closing the rear. The 66th and 20 th Regiments of Infantry, the Artillery and the Marines were stationed on the crests of the surrounding hills; and when the body was lowered into the tomb, three rounds of eleven guns were fired. And thus the great soldier of France received the last tribute of respect in honour of his achievements, from the hands of his most constant, but, as he described them, the most generous of his enemies.

The last years of Napolcon's life, except so far as they derived a gloomy and awful importance from the remembrance of his terrific career of blood and power, were as insignificant as his first. He could neither act upon, wor be acted upon, by the transactions of the world. Ile secmed to be buried alive, kept as he was in close custody by a power, with whose strength it was useless to cope, and whose vigilance there was little chance of eluding.

On the following morning the sounds of labour were heard from every quarter of the Free Trader, and the long-drawn songs of the mariners were rising in the cool quiet of the early dawn. Then commenced the heavy toil which lifts the anchor from its bed; the ship, once more released, from her hold upon the land stood across the $\Lambda$ tlantic for England, and long ere noon the sun-blistered rock of St. Helena was shut out from our view by the rising waters in which it seemed to submerge. And thus ended the "memorable 


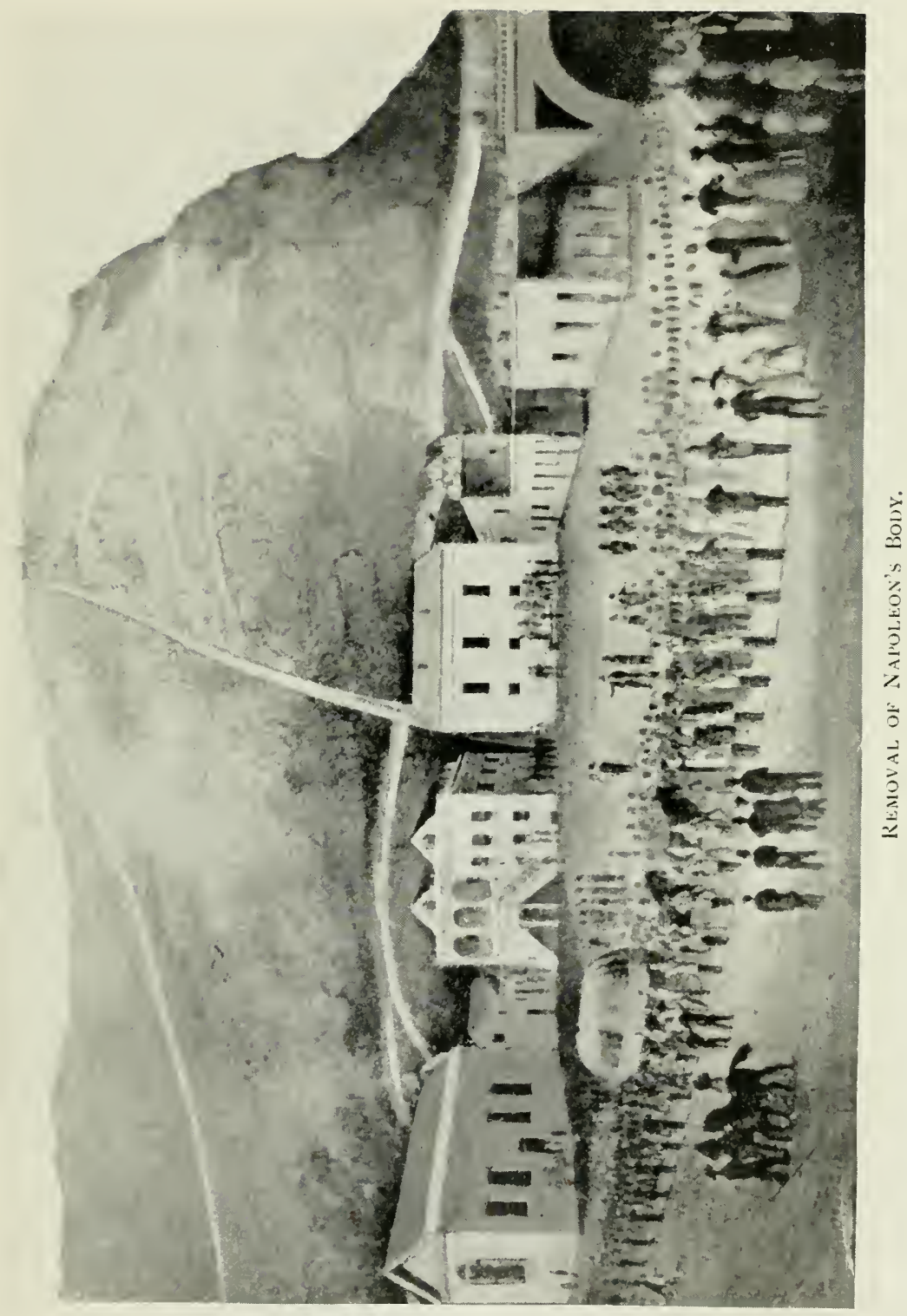



event" which formed such a singular episode in the otherwise monotonous voyage of the Free Trader.

On an intensely cold morning, some twenty years after the occurrences above narrated, I was proceeding to Paris as fast as a French diligence could carry me. After passing through a long winter's night, cramped and stiffened for want of exercise, it was with feelings approaching delight that I beheld the French capital. But as the vehicle neared the gay metropolis, it was impossible to avoid being surprised at the appearance of the populace. Everybody was going toward Paris, no one appeared to be going in any other direction. The multitude increased as we progressed, and when the diligence entered the Boulevard, it was with great difficulty the lumbering vehicle was urged through the living mass. On either side of us was a dense crown of heads, eagerness pictured on every countenance. Amid the jabber arising from so large an assemblage was heard the rolling sound of artillery, mingling strangely, nay wildly, with the solemn tolling of the great bell of Notre Dame, which every now and then fell upon the ear, without mingling with the great tide of sound, but each vibration seemed distinct in its isolation. It was impossible, from the vexed and confused nature of the tumult arising from bells, guns, and drums, to form an idea whether the people were celebrating a holiday, a spectacle, or a revolution.

Most human feelings are contagious, and I was soon inoculated with a desire to mix with the crowd, and see what was going on. Accordingly, as soon as the diligence arived at the Messagerie, I left my carpet-bag in the custody of an official, and set forth to satisfy my curiosity. Once fairly in the throng, I was soon urged along the Place de la Bourse, and from thence up the Pue Vivienne to the Boulevard des Italiens, happy in having availed myself of any change, whether of sentiment or situation, which would rouse my half-frozen blood into action, and enable me to compete with a temperature ten degrees below freezing.

Forward, forward, along the interminable Boulevard, I was forced by the dense mass, and extrication became hopeless. That broad thoroughfare seemed to be the main channel through which flowed the living tide; and, as it was continually being fed by the streets on either side, it was ultimately crowded to a dangerous degree.

At the magnificent church of the Madeleine, a divided opinion acted upon the people, and gave me scope for action. I followed that section whose destinies led them to the Place de la Concorde, where I had scarcely arrived when preparations of an uncommon description came at once into view. Salvos of artillery were still heard, or rather they had never ceased; the bells also tolled incessantly, and that intolerable beat of the French drum, mixed with the noise arising from a crowd of thousands of Frenchmen was most bewildering. But as well as the confusion would permit observation of the surrounding objects, it seemed that, on each side of the crowded 
avenue of the Champs Elysées, large statues had been raised, each symbolical of some mental attitude, such as justice, valour, fortitude, and the like, and between their colossal figures magnificent tripos of a great height were erected, supporting vases which were filled with flames. The spectacle had approached its crisis when I arrived at the Place de la Concorde, and my position afforded me a good view of the avenue. In the distance dense columns of horse and foot soldiery were slowly marching, preceded by military bands playing solemn music.

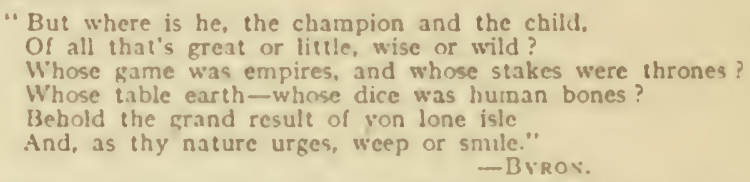

Column after column paraded by. The whole chivalry of France had assembled to do honour to some dearly-loved object, for every class of French soldier had sent its representative, and every department of the kingdom its deputy. The procession appeared interruinable. On it came, in every variety of uniform, the soldiers of Davoust, of Hoche, of Moreau, Jourdan, Massena, and Angereau, Ney, Murat, IEleber and Kellerman. Fragments of all "arms" of the Imperial Guard were there represented, strangely mingled with the picturesque dresses of Mamelukes and guides. At length a moving tower of sable plumes rolled by upon golden wheels, drawn by sixteen horses. Immediately following came the Royal Family of France and the great Ministers of State, decorated with glittering stars and orders. Twenty years back I had witnessed the funeral obsequies of this remarkable man, for, of course, by this time, I knew that it was the second burial of Napoleon at which I was a chance spectator. Since then a great alteration had taken place in the affairs of Europe. A quarter of a century of profound peace had rendered the entente cordiale apparently perfect. British ships of war no longer muzzled the mouth of every French port from Dunkerque to Toulon. The correction was done, and the rod was burnt, and in the fulness of time came the crowning act of graco, when, as M. de Rémusat stated in the Chamber of Députés, England had magnanimously consented to the proposal of the French nation to return the remains of Napoleon, thus surrendering the trophy of the most unparalleled struggle in modern history:

And yet, incredible as it may seem, when France was receiving from British generosity a boon which she could not obtain by any phy-sical appliance, the law and medical students of Paris displayed a base and infamous hostility against the country (which was in the very act of returning with a noble and chivalrous sentiment the undying token of her own supremacy and the humiliation of her enemies) using such expressions as " $A$ bas Palmerston," " $A$ bas les Anglais," which sounded oddly enough in an Englishman's ears, with these recollections still throbbing in his memory. It was to do honour to those precious remains that France, nay Europe, 
had assembled her thousands in the Champs Elysées on that day. His faults, as well as the unbounded sacrifice made to his daring ambition, seemed to be forgotten. Men appeared to point only to the bright and burning spots in Napoleon's career, without recollecting what they had proved to France and the world. It was a spectacle of a nation paying homage in the names of freedom and honour to the representative of military power. It has been said that French enthusiasm is easily excited, and that it as easily cools, seldom lasting long enough to ripen into the more dignified sentiment of traditional veneration. Certainly it inconsistently decreed the honour of national obsequies on Napoleon, whose fall was hailed by the great bulk of the nation, after the battle of Waterloo, as the end of their unbounded sacrifices, and as the second dawn of their public liberties. But little penetration was required to discover that curiosity was the strongest feeling exhibited, or at the most, it was a galvanized excitement-it wanted the reality of natural emotion. To these few, whose lot it was to witness both the burials of Napoleon, this must have been apparent. They could not fail to note the contrast between the gorgeous display of the second ceremony and the simple but deeply heartfelt funeral at St. Helena. In Paris everything seemed unreal. For a burial, the second ceremony was too far removed from the death; people, if they had not forgotten, had ceased to lament for him. The charger led before the hero's hearse had never borne the hero. And for a commemoration it was much too soon. True, the remembrance of his reverses and his sufferings at St. Helena commanded the sympathy and reverence of every Frenchman present ; doubtless they felt, and felt keenly, the return of their former hero, though dead; but the reflections were bitter to their sensitive natures; they felt that though the bones of their idol were amongst them, yet the sentence which indignant Europe had written on the rocks of St. Helena was not erased, but was treasured in the depths of men's minds, and registered in the history of the world.

As the catafalque slowly passed by, over the bridge, along the Quay d'Orsay, until it was finally hidden from the view by the trees of the Esplanade of the Invalides, it was evident, that, let his countrymen do what they would, let them fire their cannon, sound their trumpets, unfold their dusty banners of past wars, they failed to impart to the memory of the vanquished of Waterloo a becoming character; their funeral ceremony wanted moral grandeur; they converted into a theatrical show what was intended for a national solemnity, for mourners there were none; his own uniforms were not even seen around him, and the only eagles there were those which were cut in yellow pasteboard.

But the light had burned out which projected the gigantic shadow on the canvas, and what was left behind? nothing but a namethe sport of fortune and the jest of fame.

An amusing act of gasconade, the performance of which rumour awarded to the Prince de Joinville, was freely commented upon in 
naval circles about this period. It will be remembered that his Royal Highness was despatched by the French Government in La Belle Poule, the finest frigate in their service, to convey the remains of Napoleon from St. Helena to France. After the cxhumation of the body, which was performed in the presence of many English and Irench officers, the features of Napolcon were recognized, contrary, as It wasstated, to Frenchexpectations. The coffin, after being placed in a sumptuous one brought from Europe, was conveyed, after many compliments upon the honour and good faith of England, on board I. a Belle Poule, which with its sacred freight soon after put to sca. "I lie faitl of "perfide Albion" was not so bad as expected. A few wechs after the French frigate had taken her departure from St. Helcua, and was ncaring the coast of Europe, an English frigate hove in sight, and perceiving a French ship-of-war, she bore down upon her to speak her. From some unexplained reason the Prince imagined slie night he sent to capture the precious relic he had on board La belle Powle, and rushing on the quarter-deck he ordered lis crew to quarters and prepare for action. A word, however, from the captain of the English frigate was enough to dispel the gallant Prince's rain alarms, and the explanations which soon followed afforded the British tars a hearty laugh at the distorted view the Frenchumen had of English faith.

This rumoured hravado of the Prince is nevertheless in perfect keeping with his Bodadil pamphlet, pullished soon after his return with Dapolcon's remains, in which he alfompts to show "how easily he could invade Eingland, if he had only ships enougl, with men of the right sort to man them."

\section{SIR HLDSON LOWE'S MEMOIRS.}

The publication of these long expected memoirs was from time to time delayed from a variety of circumstances, the principal cause, however, being a disagreement between the publisher and Sir Hudson's family, respecting the mode of publishing. Sir Hudson's son wishing, naturally enough, to vindicate the character and memory of his father from the endless slanders so mercilessly heaped upon him, respecting his connexion with Napoleon whilst at St. Helena, thought it advisalule for this purpose to curtail the mere memoirs, and give as many original documents as it was possible to do; and from the number in his possession, and that of his family, he thought at least five volumes would be required. To this, objections were raised by the publisher, who, of course, looked upon the matter merely in a mercantile point of view, and considered three volumes ample for the purpose, and perhaps quite as many as would command a profitable salc.

When these objections were raised by the publisher and strictly insisted on by him. Sir Hudson's son declined having anything further to do in the matter, and left it entirely for his family and the publisher to arrange between themselves, which led to the MS. memoir and original documents being placed in the hands of Sir Harris Nicholas, who took them with him to France to re-arrange, 
but soon after died before much further progress had been made in the work, which fully accounts for the delay of the publication.

In their original form these memoirs would have embraced notices of his early occupations in Sicily, Corsica and Calabria, and would have made public many valuable letters and documents connected with affairs of that part of the world, from the most eminent soldiers and diplomatists of that eventful time.

To St. Helena, of course, the most interesting part would have related to the period while he was Governor and had charge of Napoleon. It has been confidently asserted that the scurrilous libels of Montholon and other Bonapartists would be shown in their true light, and the extent of their exaggerations and misstatements fully revealed, for young Lowe possessed all the qualifications for the task and had naturally a greater and more direct personal interes $\imath$ in the issue of the matter than a stranger could be expected to have. The change of editors is therefore to be regretted in more respects than one, although it cannot be doubted that posterity will do Sir Hudson justice, which Napoleon appears to have thought would be just only to his own reputation. Posterity has done justice to Napoleon, and will do so yet for the memory of Sir Hudson Lowe.

\section{The Expedition to Saint Helena.}

\section{Translated from the French of Arthur Bertrand.}

A voyage of five thousand miles, to fetch from the land of his exile, and render to this country the ashes of its hero, is an event without example in history, and a fact so remarkable that the least circumstance connected with it excites our interest. While events succeed each other so rapidly, and are so soon forgotten, the memory of Napoleon appears to revive each day. In the cottage, in the salon, in the palace and amongst the names of men of modern days, no one is so often heard of as that of Napoleon, and to no other can be applied with truth these two lines of one of the first of our lyric poets:-

\footnotetext{
"Ce heros n'est pas mort; beau de lui-mêmes Vit encore parmi nous."

"The hero is not dead; his better part remains And lives amongst us still.",
}

Two good anchors at length held us safely moored, and for the first time for twenty years I breathe the air of the land where I was born. I smiled upon these rocks blackened with age, I saw grace in these mountains, which lose themselves in the sky, which, however, others are slow to admire. It was in vain that I tried to prove to my companions that there is more of grace and majesty in the elevation of these rocks, than in the finest fields of Europe. I saw all here under a different aspect, d'un oeil amouveux; for it is the land of my birth, it is the cradle of my infancy, that I salute.

Before casting anchor we had perceived a man-of-war under the tricolour flag, the captain of which soon after came to the commander of the frigate. We had left Cherbourg on the 3 oth July, and had on board a pilot de la Manchi, for the Belle-Poule. Captain Doret, com- 
mander of this vessel, was highly estecmed in the navy, as mucl, for the nobleness of his character as for his services. He it was who in 1815 , in conjunction with several of his companions, proposed to the Empcror when he was at Rochefort to carry him to the United States. About an hour after our fine frigate had anchored in the roads of St. Helena the decks were crowded by great numbers of visitors who came to present their respects to the Prince. Mr. Solomon, the Croesus of the Isle, consul of France, Sardinia and sheriff of the country, ctc., came on board: he is an old friend of the French, and one who seemed happy to receive the old companions in exile of the great man. In the midist of all this noise, of the thousand questions put to me from all parts, of my brothers who had lived here, excited by the pleasure of seeing again my native land, the former house of the Emperor, the dwelling of my mother, the old Chinese who served us five years, I knew not what I did, I was so happl:.

We were all impatient to render homago to the tomb of the Emperor. This is the first duty which every Frencli heart must fulfil on landing at St. Helena.

The day after our arrival, the gth of October, about ten o'clock, Ilis Royal Ilighness discmbarked, attended by a party of his officers and by those who had lived at Longwood. The place where we landed is protected by numerous artullery : we saw a long range of mounted guns with their piles of shot. On our entry into the town we found the authorities of the plaee waiting for the Prince. After having received them with his customary politeness, he mounted on horseback.

The only town which we traversed in the whole way to Longwood is called James' Town. As in all English colonies, we remarked in this town a propriety and order which left nothing to be desired. The streets and walks by the sea remind us of the paths in our gardens ; it is a pleasure to walk in them. James' Town is commanded on all sides by lofty mountains covered with fortifications which threaten the town with their artullery.

I found a severe grandeur in these rocks, which threaten to fall upon the helpless inluabitants. In spite of the precautions taken to sustain them by little walls of masonry, the rocks suspended here and there do not unfrequently fall. The eye is terrified by the disorder of this wild and savage place, and the soul mourns over the memory of the great unfortunate who has immortalized St. Helena. It is dificule to suppress a sentiment of generous indignation against those who chose so well for him a prison and a tomb.

In leaving the town we followed the traverses of the mountains by a good road with a parapet; we had for our guicle Captain Alexander, of whom we all prescrve the best remembrance, not alone for the manner in which lie acquitted himself of the mission entrusted to him, but also from the amiable reception we had from him.

At a little distance from the town he showed us the "Briars," a pretty little house, of which the Emperor during two months 
inhabited a pavilion with the Count Las Casas and his son. It is placed in the same valley as James' Town, but we fear its proximity to that town was the cause of the Emperor's removal to Longwood:

We hurried on to reach the tomb. We descended into the valley by a road which had been newly made.

Cypresses and weeping willows, sufficiently mournful, with an iron railing round three large slabs, formed the tomb of the hero around which all is veneration.

Not a word, not an inscription is upon the three slabs. The eyes cannot distinguish a character, but the heart divines it, and you say, Here it is! Bow down ye children of ages yet to come, at the approach of this holy place-pray, pray for him !!!

This simplicity, the silence of the valley, the verdure at our feet, the rocks above us, the two old willows under which the Emperor lies, the one standing, the other on the ground dead from old age; there too, in the crevice of the rock, that spring where he was wont to drink, the contrast of such nothingness and grandeur, gave rise to impressions of unspeakable sadness. Near this tomb, so silent, our emotions were profound. We could not speak, we could but pray, and soon the tears rolled from the eyes of all those who knelt at the feet of the greatest man of modern days. His body is there, deep in the earth, decayed by time and death, but his spirit watches from heaven and protects La France.

Within the circuit of the tomb all has been religiously preserved. The willows are yet green, the cypress shelters the narrow home in eternal sleep of him who filled the universe with his name.

We remained an hcur in the valley. I have gathered up several branches and flowers of those geraniums which my good mother had planted before quitting the island round the borders of the tomb of the benefactor of her family, and the heroes of her country.

The guardian of the place had the goodness to look after and transplant these flowers, many of which we carried to France.

After having remained a little less than an hour at the Tomb, the Prince remounted his horse for the purpose of visiting Longwood. Each of the travellers said farewell to the tomb, and promised to revisit it again.

We had nearly forgotten Hutt's Gate, a villa situate in the summit of the valley, and which my father had inhabited during the first months of his sojourn at Longwood, while waiting to occupy the lodgings destined for him. As his family was numerous, Admiral Cockburn had built for him a commodious little house at the end of the lawn, about 50 yards perhaps from the Emperor's residence. Napoleon had the goodness to visit Hutt's Gate several times. In descending into the valley he observed a little spring under the shade of some willows; he drank the water from the hollow of his hand and found it good, and from that time two Chinese came every day to fetch it for his house. There, under the shade of the willows, he sometimes sought repose ; there he doubtless thought of France, of his son, the brilliant past, melancholy present, and sombre future. A few days before his death he sent for my father and ex- 
pressed the desire that if they would not permit his remains to be taken to France, that he should be buried under the shade of these willows, at the feet of which he had so often sat.

Hutt's Gate is at present inhabited by a lady, IIrs. Dickson, who at my birth received me in her arms and gave to me the first cares so necessary to infancy. She often passed whole weeks at Longwood. She is at present surrounded by a numerous and charming family. She showed to me all the tenderness of a mother, and it was a pleasure for me to press her to $\mathrm{my}$ heart.

After having left Hutt's Gate we were not slow to perceive its gum trees; these are small lank trees which grow upon the plateau, bent by the tiresome blasts and killing winds which never cease in this part of the island. Longwood itself soon came into view, sad and reglected. I fogEy atmosphere added to its sadness. The gardens ruined, the house of the Emperor in a miserable state, the room where he died turned into a mill to crush barley, his bedchamber a siable! What profanation!. It the tomb it was emotion, but here it was stupor that affected us. In wandering through these historical ruins, we could yet recognize the walles of the Emperor's garden, the place where his spade dug up the ground, and the squares where he cultivated his flowers. At the angle of a walk we saw the Prince collecting several herbs from the garden. We have since found that he had a commission to that cffect from his sister the Princess Clementine. I recognized very well the little balcony with its railings painted green, where the Emperor often sat, and also the lawn which ran hefore his house, as far as my father's pavilion. I reviewed the chamber where I was born. That is where my mother, holding me in her arms, on the day of my birth presented me to the limperor, say-ing, "Sire, I have the honour to present to you the first Irenchman who has entered Longwood, without the permission of the Governor."

There exists near Longwood a moderately good house (possibly the new house which Napoleon never iuhabited) which the cicerones of the island point out to travellers as one of the residences of Napolcon.

Ifter having ended our long visit to Longwood we took the rodu to James' Town, sad and dispirited, a prey to melancholy thoughts which had sprung from the places where we had been.

Visitors making a stay at St. Helena during the months of February or October in any year must always be interested in witnessing the long rolling waves which at those times come sweeping in over wharf and sea-front, often interrupting for day's communication with the shipping. These mighty and grand forces of Nature are termed"The Rollers."

On February 13, I902, and for several days, the "rollers" were very high, and heavy surf was raging; so furious was 


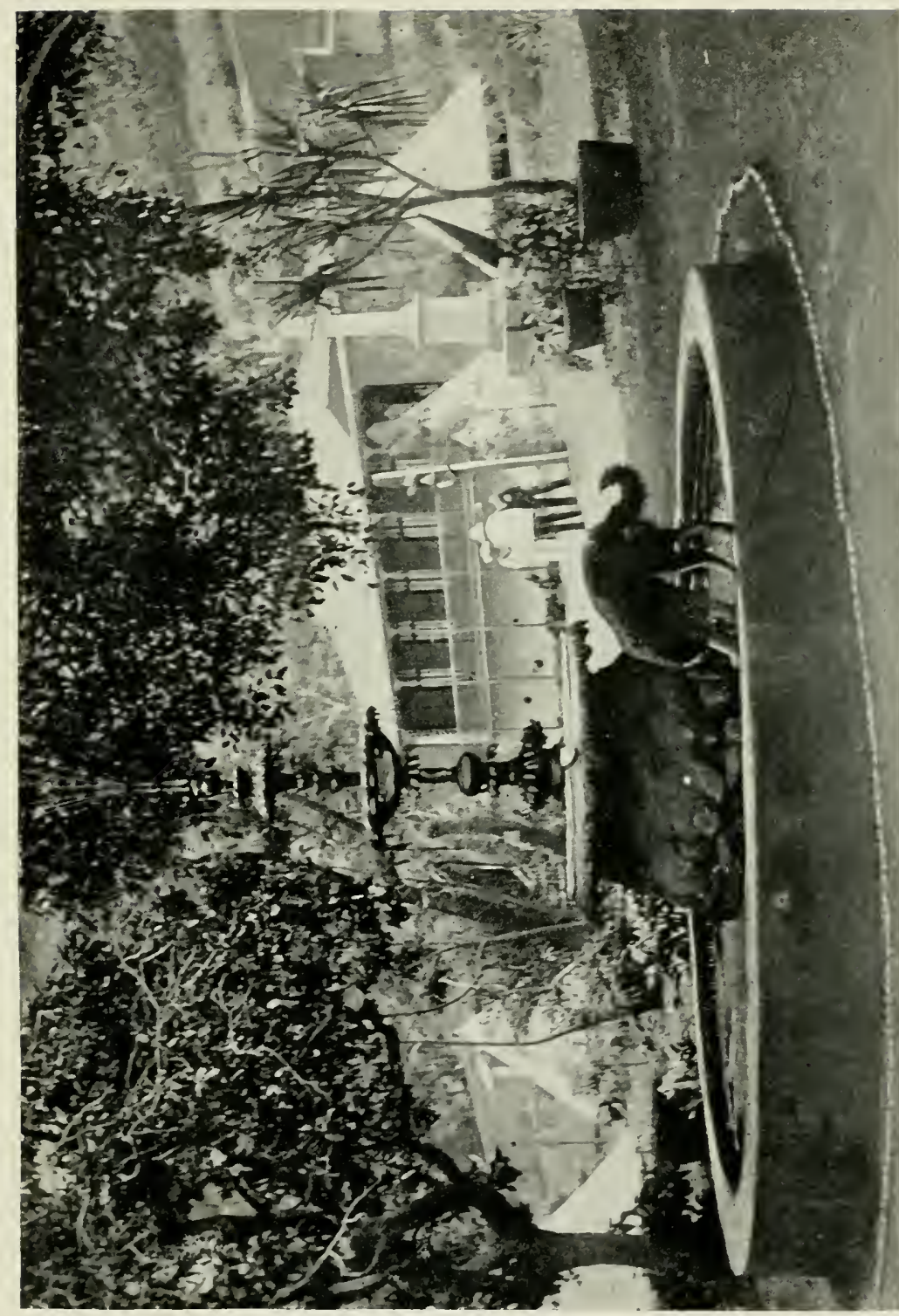



the sea that the roof of the wharf crane was destroyed, while the two iron girders were snapped with the force of one wave. The water must indeed be high even to reach the platform on which the crane stands, therefore the roof was considered quite out of danger. The damage done, although considerable, seems hardly worthy of mention when compared with that caused by the "rollers" of $1827, \mathrm{I} 828$, and 1846 ; but as time goes on, one is apt to imagine the accounts of them exaggerated, but that they are not so may be drawn from the accounts given at that time in the St. Helena Gazette, a paper published by the authority of the Government. A heavy surf is reported in this paper at Sandy Bay and along the windward coast as follows :-

On the $24^{\text {th }}$ July, I 827,8 a.m. the wind changed from the S.E. or nearly so, and blew with considerable strength from the S.W. By noon the sea was very rough and the surf higher than before seen; this continued until the $26 \mathrm{th}$, when the wind again shifted toward S.E. and the sea and surf gradually abated. During its violence it threw on shore a fine fishing boat which had been strongly moored and secured (the property of Capt. Wright and Mrs. Seale). It was dashed in pieces near the western cullis. It also bursted the door of the coal-hole (now in use many years), and by this day's measurement I find has washed 272 bushels of coal into the sea. It rendered the road lately made for a cart to and from the shears impassible, indeed almost useless for that purpose. So high a surf is not in the remembrance of the oldest inhabitant or foreman at Sandy Bay. It has totally changed the appearance of the beach, and the spray ascended to Crown Point and Horse's Head batteries, so as to run off in torrents. There was much lightning about ro o'clock at night with frequent and luminous flashes accompanied by heavy rain, but no thunder could be heard. The surf extended from South-west Point to Flagstaff and Barn Point, gradually subsiding as it ran north. It rose very suddenly at L.emon Valley and Egg Island on the 24th, continuing until the 26th. An account says:-I left this place for Egg Island with scarce a ruffe on the water, and by the time the boat got to Longledge the swell rolled in very heavy; and in going between the main and the ledge the boat began to fill with every sea. The non-commissioned officer and myself thought it prudent to make the boatmen pull back and go outside. The Lascars in the boat, for the safety of themselves as well as for every one else, deemed it necessary after bailing the boat to start the water out of one of the casks and all the small kegs, and then with difficulty we landed. During the two days the surf was so high here, it was low in James' Bay. It appears to have extended all round the coast except the short space between Bank's and Lemon Valley. 
In the year 1828 His Majesty's sloop Redwing was prevented from sailing in consequence of surf which precluded all communication (except by telegraph) between the shore and the shipping.

Besides several persons severely hurt, two lives were lost, one a woman washed off the wharf, and the other a Lascar who in the attempt to save her was so bruised that he could not survive.

The wharf was cleared of everything movable, including a wooden house and a sentry-box. The Governor withdrew the sea-gate guard as one of the sentrics narrowly escaped drowning with the loss of his firclock. Notling but the substantial manner in which the new part of the wharf and crane was completed could have saved them from destruction, for the wall and wharf showed serious breaches. The rollers beat over the counterscarp in Jamestown and filled the ditch, also rushing through the portcullis at Rupert's; while the lower battery at Bank's sustained much damage-in short, "neither the remembrance of any" person here nor tradition can furnish an instance of the sea having run so high at any former time."

On February 7, I $8+6$, the St. Helena Gazdle contains the following :-

Toward the close of last month the island was visited with unusually heavy rollers. By them the sea wall and wharf has been greatly damaged, and while they lasted the vessels in harbour were pervented from obtaining their ordinary supply of water. It has been remarked that heavy gales of "sind are usually felt at the Cape some days previous to having "rollers" at St. Helena. No "storms" are known at St. Helena, but it is not improbable that the rollers which occasionally visit us are consequent on some distant gale, the fag end only of which reaches this island.

And a week after this was written came the terrific rollers known as "Rollers of I $\$$ 66." These, which occurred on February 16 and 17 , were drawn by an eye-witness, and from the drawing an excellent paintiug has been made by Mr. Thomas Bruce (postmaster). By the kindness of Mr. R. R. Bruce, I am enabled to give an illustration from the painting.

From the Gazclle I append the account of an eyewitness :-

At sunset on the evening of Monday, $16 \mathrm{th}$, a few heavy rollers hroke upon the beach in front of the town and gradually increased during the night. At daybreak on Tuesday morning the sea was one mass of foam, with tremendous rollers breaking some distance from the shore. Eighteen slave vessels were lying in the roads, some of which had been condemned and sold and were partially broken up. About it a.m. the Descobrador slaver brig, 127 tons, lifted her anchors and fell broadside on the schooner Cornelia, both of which were by the force of the rollers carried on to the beach 
just in front of the sea-gate guard; the shipkeepers had not been relieved, and were consequently on board at the time. The Descobrador took the beach broadside on, with the sea breaking over her, and the shipkeeper with his wife and a Lascar were hanging on the rigging. Mr. Chatfield, master's assistant to the Flying Fish, attempted to gain the vessel with a rope, but was overwhelmed in the surf; still he was got safe again to shore. The Town Major then tried to throw a rocket with line between the masts, but it was too heavy and fell short. In the meantime an American dashed into the sea, gained the vessel with a rope, which he lashed round the woman, and jumped overboard with her in his arms; they were drawn ashore by the people on the beach, amongst whom were Lieut. Grant, R.A., and Dr. Tweedale, H.MI.S. Prometheus. The Lascar and shipkeeper afterwards jumped overboard with ropes and were safely hauled ashore. Whilst the Descobrador was beating about, another slaver, partly broken up, came on shore with the velocity of a steamboat and ranged herself by the Descobrador. Then both vessels commenced breaking up very fast. A slaver, name unknown, and a beautiful schooner, Acquilla, soon after broke anchors and came in as though propelled by steam; she took the beach close to the Descobrador, but continued whole long after the other vessels had gone to pieces.

It was evident from the fearful height and size of the rollers that other vessels would share the same fate, and about one o'clock the schooner Euphrasia was capsized; and the following sea beating upon the deck of the Esperanza, broke it into atoms. She was seen for a moment among the foam and surf, and then not a vestige of her was seen again. By this time the sea was covered with masts, yards, casks, and all description of wreck, and about sunset two other vessels, the De Marco and the Julia, were brought in with terrific force upon the west rocks under Ladder Hill. The Julia no sooner reached the rocks than she was dashed in pieces; indeed it was so sudden that at one moment you saw the vessel with her lower masts standing, and the next she was floating in the surge in ten thousand pieces.

So in seven hours no fewer than thirteen vessels were dashed to atoms within a few yards of the shore. Eleven of them were captured slavers; the others, the Rocket, belonging to Mr. J. Scott, and the Cornelia, the property of Mr. T. Cole, merchant. The glacis and ditch in front of the works was impassable from wreck of every description. The most extraordinary circumstance attending all this destruction of property was that several merchant vessels were laying at anchorage clear of the rollers with scarcely a move. There was not a breath of wind, the weather was sultry, accompanied with occasional showers. Some idea of the violence of the sea may be formed when the crane and lower wharf with the commissariat coalyard and one of the reservoirs containing water for shipping have been completely destroyed, together with the whole line up to the sea-gate guard. The glacis is so torn to pieces as to make it impassable. The damage to the wharf and line alone is estimated at 
E10,000. To add to this dreadful calamity the wholc of the passage boats lying at their moorings were destroyed and so many poor families deprived of support. Fourteen of these boats were overwhelmed by one sea.

The force and height of the sea is shown also by its breaking over Lower Chubb's Battery, taking with it a 24-pounder carronade, with a parapet wall on both sides; also splitting the solid rock at the landing steps, on which the foundation of the wharf is built, and detaching a mass of rock hundreds of tons in weight.

That the above was not an exaggeration is shown by the following, which corroborates it, and which, emanating from another eye-witness, was published also in the $S t$. Helena Gazelte of that time :-

The fearful height of the rollers which set in on our shores on Tuesday had at an early hour drawn many spectators to the wharf and lines, the writer among the number. The atmosphere was dense and heavy, the harbour at the outside filled with black heavy cloucls and fog, and everything betokened the scenes which followed.

The sultry and oppressive steam had the day previously brought forth a remark that it was such as preceded an carthiquake in the West Indies, and a remarkable fall of the barometer, a circumstance hitherto unknown at St. IIelena, had been also noticed.

At ten o'clock two prizes (one of them the Descobrador) with four persons on board-the shipkeeper, his wife, a Lascar, and an island bnatman attached to the Marine Department-were torn from their anchorage, and in a moment were drawn into the beach. The empty one was soon stranded and shivered into a thousand picces, but the other, after passing through the break of the rollers for a moment, lay quict in a lull, when the Lascar and the boatman scized the opportunity to jump over and swim to the beach. The vessel was immediately after driven into the eastern corner of the beach, leaving the spectators in breathless expectation of secing her hurled to pieces. There were some, however, who actually engaged themsclves in rendering assistance to the frightened couple on board, but without success, till an American seaman swam through the surf and got on board. He, with much coolness and self-possession, fastened the rope round the female's waist, and then jumped overboard with her, when she was dragged on shore safe from a watery grave, but apparently lifeless and helpless from fright. Several prizes were by this time dashed from their anchorage, although every one had been firmly fixed by four anchors each.

Fortunately the warning had been given and the shipkecpers had all been removed. I say fortunately, for neither ship that followed would have allowed the spectators the slightest chance of saving any human beings on board. Indecd in this the good hand of Him who in the midst of deserved wrath renembers mercy, was plainly manifest, for I had forgotten to mention that not only was 
she driven to the best spot in the harbour where assistance could be afforded, but whilst every eye was upon her one of the prizes which had been broken even with the water's edge was struck broadside on by an enormous wave, and instead of being forced onward to the beach was driven across the berth with fearful velocity head on to the Descobrador. Had she struck as she was driving she must have immediately sunk the Descobrador, but, like a thing of life, at the critical instant she suddenly turned from the point and quietly lay to, side by side with her, thereby keeping off in a great measure the force of the rollers which were dashing over her.

It would take much time to relate all the various incidents of the day, but the following were most striking. About one o'clock a mountain roller swept over the wharf, and, lifting the hull of the Rocket(an English merchant brig condemned some months since), for a moment hid all beneath it; when it had broken, the wreck it had made was truly awful-no trace of the Rocket could be seen. A number of boats lying round the Rocket had all disappeared. A large iron crane built in the lower wharf was washed away, and the balcony built quite at the back of the wharf entirely swept off.

In this case also the merciful hand of God was shown, for the height of this balcony above the reach of the water and its strength had caused it to be the resort of many seeking an advantageous spot for witnessing the wonderful prospect. But just half an hour before it was carried away a large roller came driving about fifty persons who were there (many gentlemen among the number) from the spot; not so much, even then, from any apprehension of serious danger in the balcony as the disagreeable prospect of being washed with the spray. The reader must understand that it was not by a gradual increase of the storm, but by one sudden and enormous roller that this place was swept off, and that with inconceivable violence.

At five o'clock another magnificent scene filled every beholder with amazement. A large schooner prize named Quatro de Marco at the westward of the harbour was by one wave torn from her berth, and although turned completely over in the boiling surge, thereby breaking out both of her masts, was by the same wave lodged high on the shore at the West Rocks! The two following waves moved her a little further back, and her entire hull now lies touching the bank of Ladder Hill, one of the most forcible proofs of the force of the water. The Julia, another prize lying alongside of her, followed next, but instead of being lifted over she was dashed against the rocks, and two minutes from the time her cable parted not an atom of her could be seen. The vessels lost were thirteen or fourteen in number, all of which were condemned prizes excepting one defended, and whose condemnation is uncertain, and two hulks of vessels condemned as unfit for sea, and used in harbour for receiving stores, etc., etc. The Rocket before named had several anchors, cables, etc., and two or three very fine boats on board at the time of her loss. The ships in harbour experienced 
no ill effects from the rollers, which only affected such as were within half a mile of the shore. The wharf is damaged so much as to justify one in calling it a total destruction, and will take $£^{10,000}$ or $\ell^{12,000}$ to repair. Nearly all passenger and luggage boats have been destroyed; but fortunately for the poor fishermen the storm broke in the night when they were fishing outside in caln water. Only three or four fishing boats were at moorings; these were lost.

We have now to relate the most painful part of the erents of this memorable day to the island.

Three men, viz. John Maggott, an old fisherman; James Craig, a shoemaker; and Robert Bath, a cook, had gone fishing at Sugarloaf Rocks on Monday evening. The Rocks are reached by one precipitous path from the land side; from this place the fishermen pass along about 400 yards of a narrow shelf at the water's edge of 10 or 12 feet wide to an opposite side of the cliff, where the shelf becomes much wider.

On Tuesday morning a fishing-boat went as near shore as it could venture, and could then see only two of the unfortunates. At three o'clock, when the boat again tried to come in to them, they were gone. They must have had a terrible experience all Monday night and part of Tuesday.

We have also heard of two others who had gone out fishing on the Sunday, but were caught in the profanation of the Sabbath, and held in fear and momentary expectation of being swept off by the raging waters till Tuesday; and though spared, we trust it will not be mercy abused by thein, and that a few more of their companions may profit by the warning.

Efforts are being made to remedy the losses by the passage-boat owners, and we earnestly hope they will not readily forget this fearful manifestation of the power of Him whose commands they have been in the habit of breaking every Sabbath as regularly as opportunity and profit gave them reason to do so.

Yet another account of the same was published as under :Further parficulars of the rollers of February, it th inst.

To the Editor of the St. Helena Gazelte.

Sir, - I do myself the honour to forward a few observations which I made on the 17 th as to the occurrences of the day; and should it be deemed worthy of a place in the St. Helena Gazelle, it will recompense me for the little time it has cost. I, however, earnestly hope that the want of language adequate to express the grandeur as well as the awfulness of what every spectator witnessed will be in a measure allowed for by the accuracy of the statement.

St. Helena has ever boasted of the safety of its roadstead, and that most justly, as no individual upon the island can remember a solitary instance of a ressel having been wrecked upon its shores. Those who witnessed the scene presented on Tuesday, alas, will have a different tale to tell. The roadstead, which only the day before was like a 
mill-pond, was on this day a sea of troubled waters. During Monday night the rollers for which St. Helena has ever been celebrated, the cause of which is altogether unaccounted for, began gradually to rise, and on Tuesday had increased to an awful height, like so many rolling mountains, one after the other driving everything before them. The English schooner Cornelia, condemned at this port a short time since, and purchased by Mr. Cole, was the first vessel driven on shore, being, no doubt, not so securely moored as other vessels, although in any other weather equally safe. If the person in charge of this vessel had been left five minutes longer on board it would have been out of human power to save his life, as the vessel some distance from the shore was buried in the tremendous seas and ultimately came in on the beach. In a few moments she was a mass of splinters. Immediately after the Cornelia disappeared, the Brazilian brig Descobrador, 127 tons, brought here by Lieut. Meynell, and condemned on January I 5 as a slaver (prize to H.M.S. sloop Star), lifted her anchors and was driven with force on to the beach between the drawbridge and upper crane; the shipkeeper, Robert Seale, his wife and two others were on board at the time she touched. Sea after sea broke over the vessel and she fell broadside on the shore. The larboard shrouds ultimately gave way, and the lives of the poor creatures on board were in imminent danger, not only by the vessel separating but by the falling of the masts. At this time two people from on board swam on shore, leaving Seale and his wife holding on the rail on the leeward of the ship, appealing to the numbers on shore, within hearing of them, for assistance. The Town Major endeavoured to convey a rope by means of a rocket, but it failed. Mr. Chatfield, master's assistant of H.M. sloop Flying Fish, attempted to swim off with a spar attached to a rope, and after arriving alongside roller after roller broke over him ; these buried him for a time and finally threw him on to the beach in an exhausted state. A whale-boat belonging to the Rose was launched, but she was no sooner in the water than she was dashed to pieces. At this period an American seaman, named Roach, who has been on the island some time as a boatman, nobly plunged into the sea and swam to the vessel, which he reached in gallant style. Taking with him a rope, the end of which was secured on shore, he gained the deck and hauled on board from shore a sufficiency of rope; then after attaching the end which he brought to the side of the vessel, he tied a rope round Mrs. Seale and plunged into the water (leaving sufficient rope on board to enable Seale the means of escape). They were dragged on shore by the spectators, amongst whom were Dr. Tweedale, of H.M. sloop Prometheus, and Lieut. Grant, R.A. They both plunged into the water to assist Roach as he approached, for rollers were knocking him over and over. Mrs. Seale was almost senseless, but soon rallied under medical aid. Seale, when he saw his wife safe, tied the rope he had round himself, and was drawn on shore without sustaining any injury. All this was done quickly, for from the time the Descobrador touched the rocks to the period of the people all being out of her could not have been more than 
ten minutes, and within another five minutes she separated and went to pieces. The shipkeepers of the other condemned slavers liad in the meantime been tatien off on a ressel lying outside the rollers.

While the Descobrador was on her beam ends upon the beach, a schooner, name and nation unknown, captured by II.M.S. Promethews on $22 n d$ November last, parted her anchor, and as if propelled by steam, ranged herself on the outside of the Descobrador; then about twelve o'clock the Brazilian schooner Acquilla, with another prize, St. Domingos, captured by Promethews and brought liere by Mr. Clark, naval cadet, lifted their anchors, and were driven upon the beach.

The Acquilla remained perfect for some time, but the other very soon went to pieces. The Acquilla was detained by H.II.S. Cyguet), and near one o'clock a tremendous heavy roller, which scemed deternined to sweep away everything before it, broke over the hull of the liorket and lifted her stem uppermost. She totally disappeared. The same roller swept away the lower crane and a verandah placed at some distance from the landing place against the hill-side, for the accommodation of captains and others awaiting ships or boats.

By this almost every passage and luggage boat had been swept from the moorings, some thrown on shore, some swept out to sea. The glacis, in front of fortifications, was impassable from the immense quantity of wood, masts, casks, bunks and matcrial thrown up. Then the Eupazia, captured by H.II.S. Prometheus, December 25,1845 , and brought here by Lieut. Pollard, also the brig Esperansa, captured on December 26 by H.M.S. Actaeon and brought here by Mr. Lowe, second master, were buried by a roller breaking over them; the former instantly disappeared, the latter, after lier masts went by the board, drifted out to sea, a total wreck. The rollers continued at an awful height, but the fishingboats, being out, fortunately escaped. They remained out and received assiztance from the merchant vessels riding in safety outside the rollers It was quite five o'clock in the afternoon when the Julia, captured by H.M.S. Star, was separated from lier companion, the Qwatro de Maren, and thrown up by a succession of heav rollers upon the West Rocks, and in an instant not a particle of her was to be seen. Almost immediately after the Brazilian brig. Quutro de Marco, was, with four anchors down, lifted by the gigantic rollers, and although buried for a time in the sea, was ultimately; by a heavy wave, lodged on the shore under Patton's Battery, near llest Rocks, the masts having been previously carried awav. This Qualro de Marco was captured by H.M.S. Cygnet isth December, i 845 , and brought here by Mr. Jones, Purser, with 540 slaves. When thrown up she came in contact with an old anchor which has for nearly a century been embedded on the projecting point of the West Rocks, and carricd it away. Thus ended the scenes of this memorable day, a day that will ever be remembered by all who were witnesses of what took place. In 


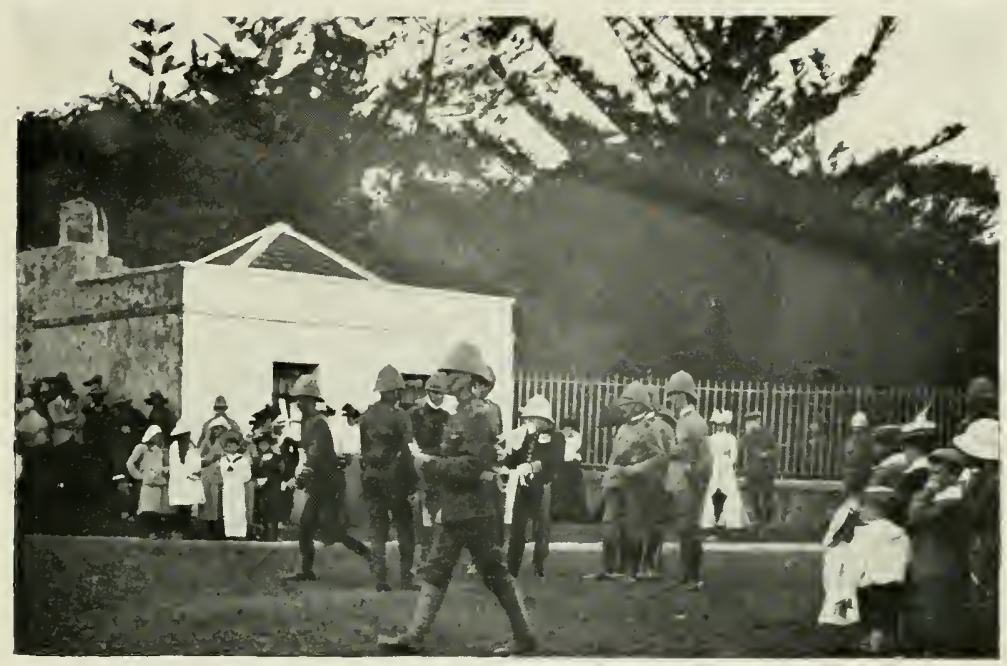

DISTRIBUTION OF MEIDALS BY GOVERNOR STERNDALE.

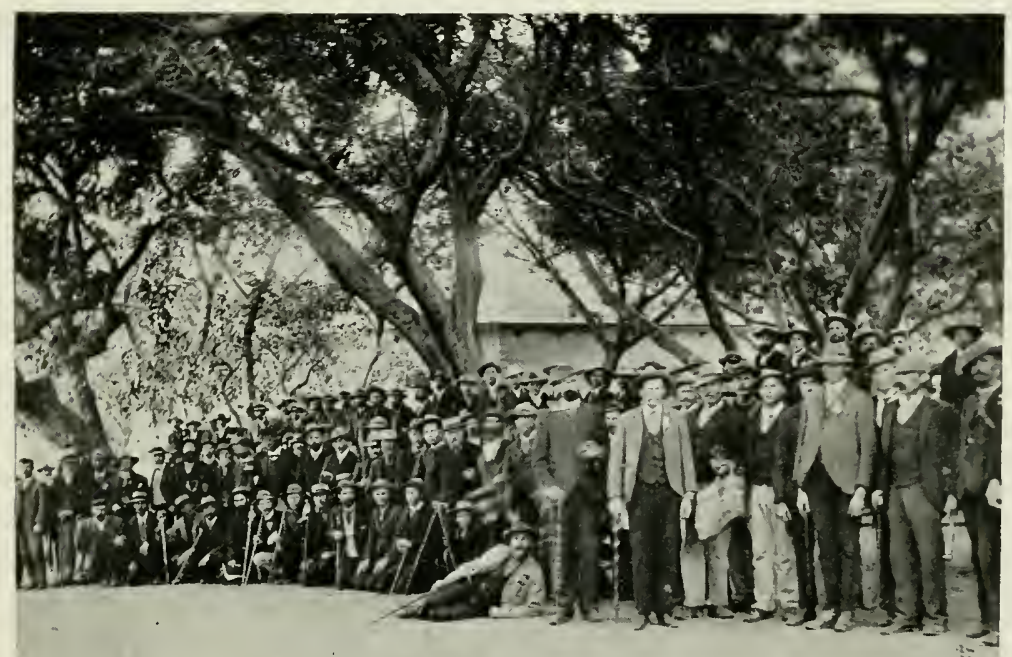

Group OF I'RISONERS PREVIOUS TO TAKING OATI OF Al.BGIANCE. 

addition to vessels already mentioned, there were three other condemned slave-vessels, names unknown. The loss of boats has thrown many out of employment, and deprived them of their little all and the means of supporting their families. Thus, after the savings of many a hard day's toil, they are deprived of a living; but God's will be done; and what has this day been experienced only reminds us of our frail state, and how little we ought to think of our earthly possessions.

The wharf from lower steps to the glacis is almost destroyed The Commissariat Coal Yard, which was erected at a great expense in 1834 , by General Dallas, the tanks for supplying water to shipping, are totally wrecked. The fortifications at Lemon Valley are much injured, and great damage is sustained at Rupert's, where the liberated Africans are located.

To attempt to give a correct idea of the violence of the rollers is impossible, but as this humble description may meet the eye of many who have spent happy hours on the Old Rock, and are now in England and elsewhere, they will be able to judge of what I am unable to describe, and I will simply close by stating that the sea rolled as far as the officer's quarters at Rupert's, that a 24-pounder carronade was taken from its platform at Chubb's, that a Battery was carried into the sea, as well as the parapet on both sides being destroyed. The wind for many days previous to the setting in of the rollers was from north and west, with close, sultry weather. The property lost by individuals and the estimated repair of wharf, coal-yard, etc., is upward of $f 20,000$.

That the bravery of Roach in saving the lives of those on board the Descobrador was not allowed to pass unnoticed is shown in the issue of the St. Helena Gazette for May 29, 1847, when at a meeting held in the library, the Rev. Kempthorne having been voted to the chair, addressed Roach as follows :-

"Joseph Roach, seeing that I am deputed by the Committee and other gentlemen present to perform this agreeable duty, I have called for the minutes of the Benevolent Society to show you that though it may seem late now to take this public notice of a circumstance which occurred in February of last year, yet but few hours elapsed before this Society took into consideration the propriety of awarding to you some testimonial which your heroic, your noble conduct, richly deserved. I did not myself witness the surf on the 17 th; it was from the scene on the Lines on the following day, and from the clever pencillings of some gentlemen of the island that I obtained some idea of the terrific circumstances. Some idea was still further conveyed by another incident. On Monday I passed a house in the upper street, where a father supported a wife and several children by the labour of his hands. On the Thursday I saw the widow and all those children in mourning, though no funeral bell had tolled, no prayers been offered up, and no grave had been opened save the great deep.

"To your courage we owe it under Providence that another family was not overtaken by a similar calamity. We cannot all 
do these things, but it is something to belong to a Society which renders this public tribute to your heroic conduct in venturing your own life for the woman now standing at your side. It is thus we seem to acquire in some sort a share in the credit of your action without any diminution of your own. I thank you, therefore, as a member of the Benevolent Society, as a member of the Community, as the minister of the parish. I trust that when any future history of St. Helena is written your name will be recorded on its pages, and that your brave act, combined with respectability. and good conduct, will be a satisfaction to you to your latest day."

The medal then having been attached to Roach's breast, Mrs. Seale (the person saved) cordially shook him by the hand, expressing with much earnestness her gratitude for having saved her from a watery grave. After which Roach returned his thanks in a fow very appropriate terms, remarking that he had sought no reward, nor did he claim any merit for his action, which had heen prompted only by the sight of a fellow-creature in such imminent danger.

The inscription on the medal is as follows:-

$$
\begin{gathered}
\text { Presented } 10 \\
\text { JosepH RoAcu } \\
\text { by the } \\
\text { Benevolent Sociels } \\
\text { of Helena. }
\end{gathered}
$$

On the reverse side :-

To commemorale

his preservation of the life of

Frorella Seale from the ureck of the

"Descolrador"

and from the fatal surf

in James' Bay

on the 17 th Febrian',

A D. 1846 


\section{ON SLAVERY AND THE WORK OF H.M. CRUISERS ON THE IVEST COAST OF AFRICA.}

It may be interesting to those unacquainted with slave shipment to learn something of the method employed when a shipping of slaves was about to take place. This account is taken from an old paper, the St. Helena Gazette of I848, when slavers were continually being captured and brought to St. Helena to be freed. It says :-

6 The slaves are taken out as if for their usual airing, perhaps ten or twenty on one chain, which is fastened to the neck of each individual at the distance of about one yard apart. In this manner they are marched in single file to the beach without any intimation of their fate, about which they seem quite indifferent, even when they know it. Every canoe is then put in requisition and the little piece of cotton cloth tied round the loins of the slave is stripped off and the gang on each chain is in succession marched close to a fire previously kindled on the beach. Here marking irons are heated, and when an iron is sufficiently hot, it is quickly dipped in palm-oil in order to prevent its sticking to the flesh and then applied to the ribs or hip, and sometimes even to the breast. Each slave-dealer uses his own mark, so that when the vessel arrives at her destination, it is easily ascertained to whom those who died belonged.

The slaves are then hurried into a small canoe and compelled to sit in the bottom, where they are stowed as closely as possible till the canoe reaches the ship. They are then put on board and again chained until they reach their destination, where they are given over to intended masters or their agents. Their food is generally farina and palm-oil.

Farina is made from the manioc or cassava root, the root being ground in the same manner as potatoes for starch, then dried in the sun and again partially ground till about the same substance as oatmeal. This farina constitutes the principal food of the slaves both during the time they are waiting to be shipped and also on the passage. (Ibid. p. 192.)

The palm oil imported into England is not the same as that used by the natives. The oil sent to England is merely the outside of the nut, similar to the outside of a plum, or any other stone fruit. The oil exported is extracted from the pulp, but the palmoil used by these people in cooking is extracted from the kernel taken out of the stone of the palm-nut, and is equal to our best salad oil.

In $x 839$ a Court termed "The Supreme Court" was established in St. Helena, by order of her Majesty in Coun- 
cil; and in 1840 the "Vice-Admiralty Court" was established for the trial of vessels engaged as slavers, this with the working of the Liberated African Depott, and the frequent visits of the several boats of the Naval Squadron engaged in the suppression of the slave-trade, brought into circulation a considerable amount of moner, and furnished employment for the islanders, though unfortunately of a kind to cause them to neglect the diligent cultivation of their fertile soil, which would lave been ultimately of greater benefit to them. The total extinction of the slavetrade after the American war led to the reduction of the West Indian Squadron and the abolition of the Liberated African Establishment, causing hard times to fall on the little island.

It was in the year I $\$$ fo that the slaves cap.ured by H.M. Cruisers were first brought to St. Helena. Depôts were formed at Rupert's Valley, Lemon Valley; and High Knoll, at which places the poor wretches were domiciled, until they gradually gained health and strength. When well and fit to travel, they were conveyed to the West Indies, where they engaged to work for various employers, as labour was there greatly in demand. The merchants and farmers in St. Helena, when requiring servants, went to the depots and made their choice, engaging to clothe and feed those chosen. A number of these slaves became so fond of their St. Helena masters and mistresses, that they elected to remain on the island instead of seeking their fortunes elsewhere. In many cases they took the names of their masters. One of the first slaves to arrive was baptized "Eve," her son being named "Adam." These freed African slaves must not be confounded with the 6If native-born slaves who were freed in $183 \mathrm{I}$.

That the authorities looked after them we find from the Gazelte, which say's :-

The Gorernment of St. Helena has engaged the services of Mr. Fry, of the Lutheran Church, to instruct the liberated Africans lately captured by H.M. cruisers and brought to the island, as well as those who may hereafter arrive.

Mellis in his book states that he himself went on board one of these ships as she cast anchor in Rupert's Bay even as late as $186 \mathrm{r}$, and the whole deck as 
I picked my way from end to end in order to avoid treading upon them, was thickly strewn with the dead, dying and starved bodies. ... A visit to a full freighted slave-ship is not easily to be forgotten; a scene so intensified in all that is horrible almost defies description.

The vessel of which he writes was one of one hundred tons burden, and contained a little short of one thousand souls, who had been closely packed for weeks together in the hottest and most polluted of atmospheres. The arms and legs of the poor creatures were worn down to about the size of walking-sticks and as they were passed over the ship's side, some living, some dead, others dying, it was hard to believe they really were human beings. Many died as they were in the act of being passed over the side of the ship. This Liberated African Depôt gave much employment to the people, and caused an immense influx of trade in the island, for they were brought by H.M. cruisers; and to stamp out this horrible traffic in human flesh a large squadron was placed in these waters. The following extract shows the number of Africans captured by H.M. Cruisers and brought to St. Helena between June 9, I840, and September 30, I847, and the manner of their disposal :-

Received .

Born

Emigrated to the West Indian Colonies :-

Total . . . $\overline{9,155}$

To Jamaica

To British Guiana

To Trinidad

To Cape of Good Hope- 4,344

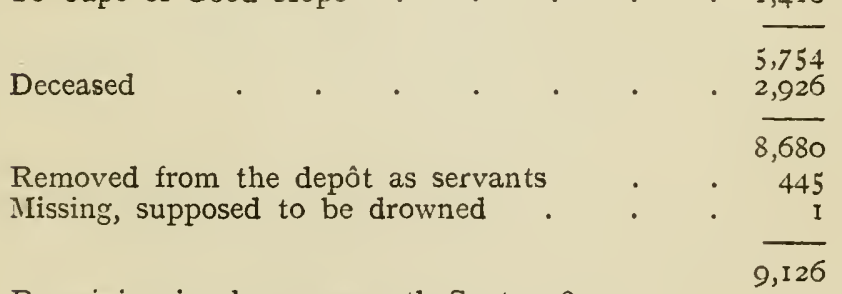

Remaining in charge on 30th Sept., 1847 . . 29

Total • . . . . . . 9,155 
In 1848 the establishment kept up for them was as follows :Clerk

Surgeon

Dispenser of medicines

Superintendent of station and store-

keeper . . . Mr. Joln Harris.

Mr. T. B. Kinipe.

C. H. Rawlins.

Mr. H. McDanicl.

On one occasion of a slaver being brought in (she was about Io0 tons), Bishop Gray, of Cape Town, was staying at I'lantation. On hearing of her arrival he sent to ask that the slaves should not be removed until he could see them. The poor famished creatures were brought up from below and there they waited for two long hours before the Bishop was able to come down. He wished to give them water from his own hands, but it is said he was so uvercome by the sight which awaited him that he fainted. On landing they usually recovered rapidly from the effects of their ill treatment and confinement between decks.

The Sty.x was noted for her conquests. I am told by an old resident that she made thirty-two captures. The Conquest, too, brought sixteen here, and the W'alcriailch was most active. A monument is erected in the Government Garden to the nemory of all those brave fellows who lost their lives while engaged in this work of rescue. The Watcrwitch brought the first consignment of liberated slaves.

The Cyclops is spoken of by one of the old men still living, and there are five I was able to photograph who came in her-two men and three old women, who are now in the poorhouse. The men, although over seventy, are still able to earn a little, but the women are helpless, and almost blind, being all of good age.

The taller man is named Duke Wellington, the other Blinker. Wellington says they were brought here in the Cyclops, and that soon after they arrived some officers came to Rupert's to choose servants, and, as he relates, Captain George Woolet (?), St. Helena Regiment, took him, Major Piggott chose Blinker, and Colonel Ross, officer, chose Caesar. They lived in tents, and had as rationsbiscuit, rice, salt meat, and fish, i.e. at Rupert's ; but when living in the mess-house they had food like soldiers.

During the past two years many have died-Old Cappy, who earned a living to the last by fetching watercress down for the shipping; Jack Fry Pumpkin, or John Janische (his master's name); Toby Morrison-here again the master's name-were for many years well known to all the 
shipping fraternity. Thinking the accounts would interest the descendants of those who so gallantly gave their lives to stamp out the curse of slavery, I have made extracts from Government papers between the dates I845 to $185^{\circ}$. For many years-in fact more than ten years-the slavers were continually arriving and discharging their human freight, and the whole account would be voluminous. Sufficient, however, is given to show what kind of work was done at that time by our "Handy Men" for their country.

The first Africans sometimes gave trouble, for we find that $f_{2}$ reward was given for the whereabouts of one, as under:-

Whereas an African negro has absconded from the Establishment at Rupert's, and is supposed to be secreted in the neighbourhood of Peak Hill; the above Reward will be paid by me to any person or persons who shall apprehend and deliver the said African to the Police Sergeant in Jamestown.

The African above alluded to has already been committing depredations, and the Public are hereby cautioned in the event of his being found trespassing.

Custom House, St. Helena,

John Young, Collector.

I th Jan., 1849.

But the majority were very grateful and well-behaved, as will be seen from the following address to His Excellency Sir Patrick Ross, Governor, received from the Liberated Africans located in this colony.

To His Excellency Major-General Sir Patrick Ross, G.C.M.G. and May it please your Excellency,Governor, etc., etc., etc.

We, the Liberated Africans residing at Saint Helena, do beg to return our most hearty and sincere thanks for the care that has been taken of us since our arrival in the British Dominions, and we have become the subjects of our beloved Queen, Victoria, Defender of the Faith, etc., etc., etc. We likewise return our most hearty thanks and praises to God for His merciful guidance in bringing us into the hands of Christian people from whom we have been taught to love and serve God, and who have been instrumental in bringing us to return those thanks which we cannot find words to express for our feelings towards our most Gracious Queen ; and it is the prayer of us all that she may obtain a Crown in Heaven when this life terminates. We were poor, forlorn, friendless and ignorant beings, and did not know there was a God, from whom we derived our being. We cannot return the thanks we wish, but if we were called upon to defend the rights and posses- 
sions of Great Britain, we will, one and all, endeavour to defend it with our last breath.

\section{BeNJaMt: VeMBa, John Marsch,
James George. Africans.}

The above-signed Africans inform His Excellency that their countrymen have requested them to forward this as a respect duc to the British Government.

ST. HELENA, August $18 t h, 18+8$.

An account of the prize money, etc., of H.M. brig Espoir (Commander Arthur Morrell) is interesting, consisting of "A moiety of the proceeds and of the bounty money for slaves captured on the Hclena, a Brazilian brig, on November 29 , I843, to be paid to them or their representatives duly authorized to receive the same, on and after the 25th June, at Messrs. Chard's, No. 3, Clifford's Inn." The amount was above $£ 2,000$, and the proportions due to each class were as follows :-

Commander Morrell
Ist Class
2nd ".
3rd ".
4th ".
5th ".
6th ".
7th ".

$\begin{array}{ccc}\text { b } & s . & d . \\ 252 & 10 & 4 \\ 119 & 13 & 9 \\ 71 & 16 & 3 \\ 35 & 18 & 1 \\ 23 & 18 & 9 \\ 11 & 19 & 4 \\ 7 & 19 & 11 \\ 3 & 10 & 9\end{array}$

HER MAJesty's BARK "CYGNet" (H. LAYTON, EsQ.), $18+5$

On the 5 th April last, H.M. brig of war Cygnet, while cruising in the neighhourhood of St. Paul de Loando, about thirty miles from coast, fell in with what appeared to them in the distance to be a canoe, but which proved to be a raft on which were seven men, who were taken on board in the last stage of exhaustion. They proved to be I.icut. Wilson and six men belonging to H.M.S. Star, who had been put on board a slaver prize. They said they had got on all right till the 16 th of the previous month, when at about three p.m. the prize was capsized in a white squall, the unfortunate crew had no boat, but lashed thirteen spars together with the main hatch and some sails. They werc able to pick up a barrel of pork and a little rum, but not water. The vessel sank and they tried for the nearest land, Cape Threcpoints, 200 miles distant, but could not keep their course. Having only sun and stars to guide them, they drifted for twenty days, but fortunately caught a few sharks and flying-fish. Their sufferings were from want of water, as they got none from the slaver prize. For nine days after leaving 


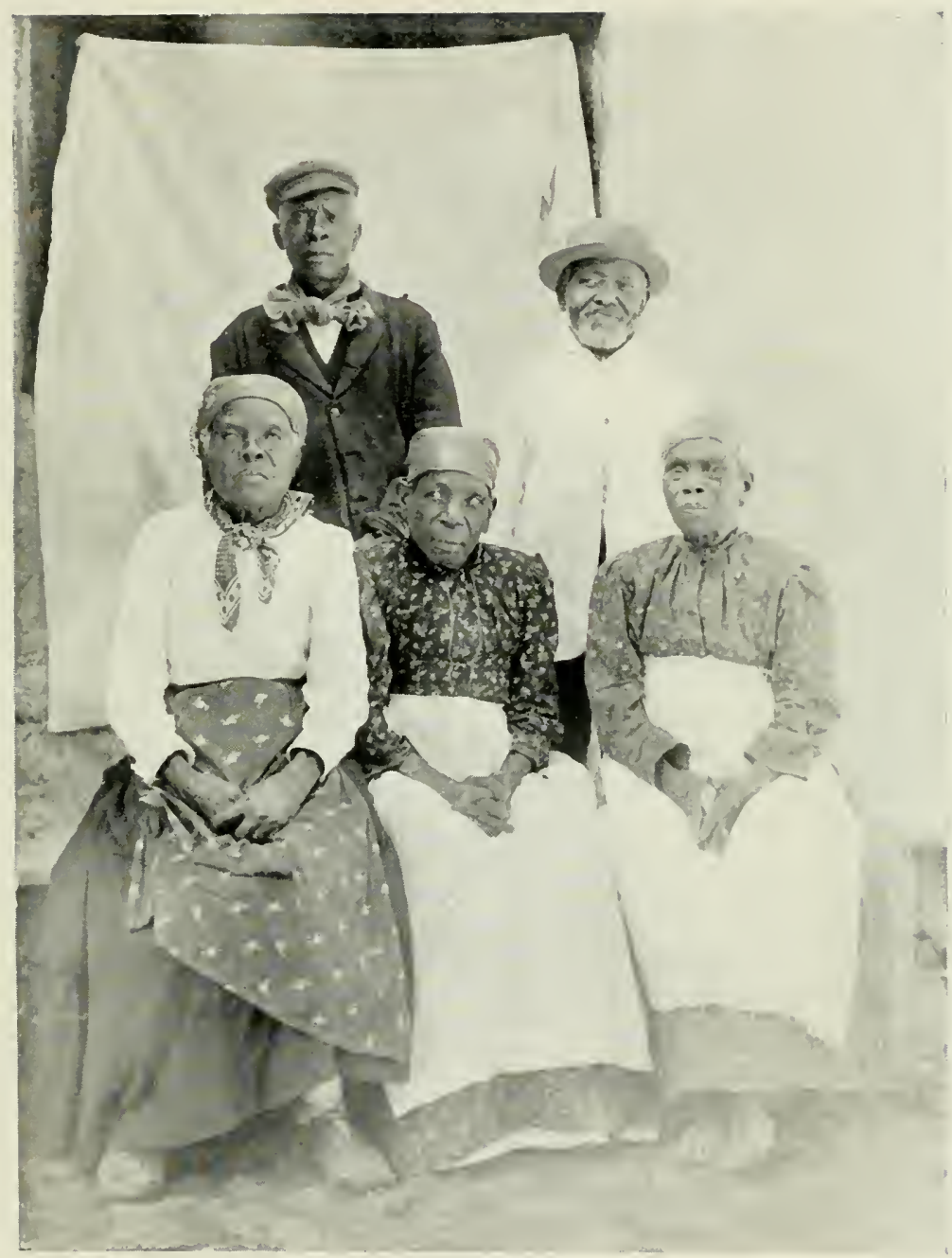

SHAKKY.

(Africans still living on St. Helena who were captured by H.AI. Cruisers and freed.) 

the wreck they had on two occasions only a mouthful of water obtained during a shower, but providentially it rained harder and they caught water in the rum cask. This was served out three times a day in the heel of Lieut. Wilson's shoe, and lasted them seven days. Whenever there was the least wind the seas broke over them, and they were compelled to stand as much as possible, which was terrible in their weakened condition.

The heat of the sun and the salt water lacerated their feet, ankles and legs in a dreadful manner, but on the seventeenth day they saw the coast in the neighbourhood of St. Paul de Loando, where the Cygnet picked them up. The master of the slaver and two of our seamen died as they persisted in drinking salt water, which drove them mad. The scene on board when Lieut. Wilson and crew were brought up was most affecting. They had travelled over 400 miles when picked up.

A strange circumstance is that the captain of the slaver, who died mad on the raft, had, previously to his being talien by the Star, recaptured his vessel from H.M.S. IVasp by murdering all the crew ; this was discovered by some of the slaver's crew turning Queen's evidence. The men spoke in the highest terms of Lieut. Wilson during the trying circumstances above narrated.

\section{VICE-ADMIRALTy COURT, I7TH JULy, I $8+5$.}

The slave-brig Alabes (master and nation unknown), taken by H.M. sloop Cygnet (Henry Layton, commander) on 4 th January, on West coast of Africa, after having been run ashore, scuttled, set on fire and abandoned by her crew, was pronounced in the Vice-Admiralty Court of this colony to be subject to condemnation as being equipped for, and engaged in the slave-trade.

\section{Capture of a Slaver.}

The Brazilian brigantine Saspiro, thirty-three days from Rio, was captured on the 6 th inst. by H.M. steam-sloop Prometheus, and sent to Sierra Leone for adjudication.

The Hydra, steam-sloop (Commander Young) has captured the notorious slave felucca, which beat off the Growler's pinnace, when Lieut. Lodwick was wounded. She still bore evident marks of the rough encounter with the pinnace of the Growler: the mizzen was completely riddled, the mainsail cut to ribands, and five men were killed in the action. Her crew was about seventy men. The Hydra has made a prize also of another equally famous slaver, the Pepita, which she captured at night after a most exciting chase, the felucca striving might and main to get away, but the Hydra's 68-pounders committed great havoc in her sails, crippled her speed, and shattered her hull and bulwarks. She carried on still, but found steam too powerful for her, as the Hydva gained fast and soon overtook her, when Lieut. Rooystra boarded her. He found every preparation made for a bloody resistance, a long I8-pounder being loaded with grape and round shot and pointed over her quarter, a cask of cartridges near, several swivels loaded with 
one-pound balls, four chests of arms, muskets and pistols all loaded, some with balls, others with slugs, the deck strewn with round and grape shot, and upwards of 200 rounds in her magazine. She had upwards of 300 slaves on board.

\section{Vice-ADMiralty COURT.}

The brig (name and nation unknown), taken by H.M.S. Albatross (Reginald Yorke, commander) on the I ith July last, on West Coast of Africa, in lat. $10^{\prime} 20^{\prime \prime} \mathrm{S}$. and long. $10^{\prime} 42^{\prime \prime} \mathrm{E}$., brought to this port under charge of Licut. J. A. Dunbar, R.N., on the 27 th, being fully equipped for the slave-trade, was condemned and forfeited to Her Majesty in the Vice-Admiralty Court of this island on Thursday last, Ifth inst, according to the provisions contained in the Act of Parliament, 2nd and 3rd of Victoria, chap. 13.

\section{Vice-admaty Colrt}

The brigantine or vessel (name and nation unknown), taken and seized on the $13^{\text {th }}$ July last on West Coast of Africa, in lat. $8^{\prime} 56^{\prime \prime} \mathrm{S}$. and long. 1.3' 2" E., by the pinnace of Her Majesty's sloop Albatross (Reginald Yorke, commander) which was run on shore upon Point Palmarinhas, and deserted by her crew after having set her on fire, was pronounced by His Honour the Judge of this Court on Thursday, the 2 Ist inst., liable to condemnation at time of scizure, being equipped for slave-trade, and the figurc-head of this ship brought here by Her Majesty's ship Albatross for adjudication, was at the same time condemned and forfeited to Her Majesty. When the pinnace first saw the brigantine or vessel, she was at anchor off Point Palnarinhas, but upon the approach of the boat the crew ran her on shore and set fire to her. Mr. Wilkinson, the officer in charge of the pinnace, with his boat's crew, used every exertion to extinguish the fire, but without success. A measurement was made, and her dimensions were as follows: Length, 95 feet 6 inches; breadth of beam, 24 feet 3 inches; and depth of hold 10 feet.

That the freed slaves were not always well behaved or grateful we find from the following extract :-

The Master John Roman, of the British bark Salzetle, of 422 tons, now in these roads, states :-

That he left St. Helena for Janaica in December 1843, with 206 liberated Africans; that about a fortnight after leaving the island a great number of the men showed symptoms of mutinous conduct, and threatened the lives of the Captain and Doctor, also to fire the ship, and became very troublesome and dangerous; so much so, that it became necessary to arm the crew and punish the ringleaders by confining them in irons and by putting them on diet of bread and water: this had the desired effect of restoring order and discipline.

The Captain further states that after a passage of five weeks he landed the whole of the emigrants at Savanuah le Mar in good 
health; that two births occurred on the passage, so that 208 reached Jamaica.

\section{St. Helena Gazette, September, $\mathbf{I} 45$.}

We learn from our vessels of war stationed on the Western Coast of Africa that from Ist April, I 844 , to 6 th July, I 845 , no fewer than seventy-five slavers have been captured by them, the Americans having during the same period captured one slaver, making a total of seventy-six captured vessels during a period of fifteen months and six days.

Commodore Jones, the senior officer on the station, arrived here in the steam frigate Penelope from Ascension, having left that island on Monday last, reports the death of Lieutenant Horatio F. Elliott, of H.MI.S. Albatross. Mr. Elliott was on his way to this island with a prize crew of H.M.S. Albatross, and when within a short distance off the island provisions fell short, and finding it difficult to beat up, they put back into Anna Bona. After obtaining what they wanted they sailed for St. Helena, when fever broke out and carried off Mr. Elliott and five men. Mr. Elliott was a promising young officer and son of Rear-Admiral Elliott.

Desperate Resistance of a Slaver, attended with Loss of LIFE. 1845 .

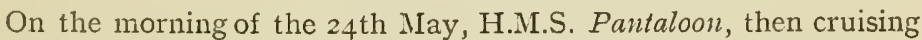
in lat. $4^{\prime} 30^{\prime \prime} \mathrm{N}$. and long. $3^{\prime} \mathrm{O}^{\prime \prime} \mathrm{E}$., made a sail, distant about five miles on the weather bow. It being dead calm at the time three boats from the Pantaloon were speedily manned, and sent after the stranger, which was soon ascertained to be a slaver. When the boats got within a mile of the prize-which turned out to be a Polacca brig (name unknown), of 320 tons, with six guns and fortyseven men-she hauled both courses up together, and fired a shot which fell short of our boats. She then commenced firing grape and round shot in good earnest without however doing any mischief. When our men were about a cable's length off the slaver, they gave three hearty English cheers, such as forebode destruction to all who resist, and swept alongside. Two of the boats made for the bows of the brig. Lieut. Lewis de J. Prevost, who commanded, ran his boat under the bumpkin brace. Mr. Crout, the master of the Pantaloon, at the same time gained a footing over the bows and the prize was boarded, not however before three of our gallant tars were wounded, in return for which one of the rascals was shot through the forehead.

The third boat, with the boatswain, attempted to board from the main chains, and being much exposed, had the misfortune to lose two men, he with three others being wounded. Our men had no sooner a fair footing on deck, than the crew vanished as if by magic; their fight was over, the cowardly rascals having done enough mischief for one voyage. Mr. Crout, on getting on board, was saluted with four muskets, fired close to his face, by which he was nearly blinded. Mr. Prevost likewise had some narrow 
escapes. A breeze having sprung up, they were joined by the Pantaloon, which was saluted with four guns from the prize which had been captured at such a terrible sacrifice.

The following General Order was issued just after the above resistance :-

By William Joncs, Esq., Commodore of the second class, and senior officer commanding Her Majesty's ships and vessels emplojed and to be employed on the West Coast of Africa.

General Order. - Whereas several instances have recently occurred on the station of piratical resistance on the part of vessels engaged in the slave trade to the visits authorized by Treaty with the powers whose colours such vessels were sailing under, and inany of the Queen's servants having been either killed or hurt in the performance of their regular duty.

And whereas it is necessary to check such lawless proceedings, which there is reason to impute to the 100 great lenity hitherto shown on our part towards the dealers in slaves, I have thought it right to order, and I hereby direct :-

1. That in every case of armed resistance to the lawful visits of her Majesty's boats, the crew of vessels so resisting and taken by assault shall be rigorously dealt with according to the laws of war.

2. The Commanding Officer on every sucl occasion is enjoined to bear in mind the necessity of having two or three witnesses belonging to a vessel which may be brought before the Courts of Mixed Commission; and he will therefore be careful to spare and to take alive at least three of the crew of such piratical vessel, if colours be shown.

3. All the survivors are to be strictly confined until their cases shall be finally adjudicated; and in no case of armed resistance is any part of the crew, passengers or other persons on board the prize, to be landed or disposed of, except at the port where the vessel may be tried.

Given under my hand on board H.M.S. Penelope, at Sierra Leone, this 26 th June, $18+5$.

To the respective Captains, Commanders and Commanding Officers of H.M. ships and vessels on the West coast of Africa.

The following, although not connected with the slave trade, is of interest :-

The brig Comel was captured at St. Mary's, Madagascar, on the roth August, by H.M.S. Conway, Captain Kelly, as she was not able to produce the papers required by Act of Parliament. The master of the Comel stated that he was from St. Helena, at which place he had transhipped a cargo of guano on freight to England; that, having been driven out of the St. Helena roads, he was then bound to an island known to himself only, where he expected to find an abundance of that valuable manure. In the meantime however be was disposing of all the brig's stores, which in itself 
was suspicious, and, together with the fact of his having no register, fully justified her being captured by the Conway, the impression of the Conway being that the original master of the Comet had met with foul play, and that the tale of the present master was a fabrication. The above is easily understood after reading the St. Helena Gazette for May ist, when the brig Comet suddenly disappeared from this roadstead during the night, carrying oft two women of the town and a soldier of the garrison to have a cruise ; and that Mr. Carrol, the agent of the vessel, was left minus some $£ 300$, which he had advanced for provisions, etc., little anticipating this result.

The Comet left this port without her register, which had been deposited at the Custom House.

Her crew was sent by the Conway to the isle of France to stand its trial.

October I8th, I845.-H.M. steam-vessel Penelope (Commodore Jones) after a cruise of nearly a month, returned to this island on the 12 th inst. During her absence she had taken two prizes, one of which was the Cacique, on September 26 th, a steamer with no papers but showing Brazilian colours, of about 290 tons, to carry 1,500 slaves, fitted out in New York. Her engine high pressure, similar to those in use on our railways, is fixed on the deck, the wheels being placed on each side abaft, each of which can be worked separate from the other. Her speed (which has not yet been ascertained), is supposed to be very great, although the engine is only a 40 -horse power. Previous to her capture by the Penelope she had refused to ship a cargo of I,060 slaves which were ready for embarkation at Cabenda, preferring to wait for 500 more to make her carrying number. Her crew numbered thirty-Portuguese, Spaniards, and four American engineers-and was furnished with small arms of every description, the present being the first voyage.

The stores, etc., of the Cacique were sold at St. Helena, and the vessel sent to Ascension. The second prize was a brigantine on the 30 th September with no papers, but showing Brazilian colours.

\section{Capture of the "Cygnet" (Capt. Layton).}

24th September.-The Cygnet was at anchor at the mouth of the river Congo when she observed a ship come down river and anchor. The Cygnet got under weigh and made sail in order to close the ship, which weighed anchor and stood up river under all sail. However, as the Cygnet gained on her, the crew set her on fire, and running her into the shore they abandoned her. Captain Layton despatched a boat's crew to extinguish the flames, but they found it impossible to board her, and she burned to the water's edge. She was afterwards discovered to be the Rose, 400 tons.

The Alert has captured a brigantine which has been sent to Sierra Leone in charge of Mr. London, master's assistant of that vessel.

H.M.S. Star in the short space of a fortnight, viz. from the Ioth to the $24^{\text {th }}$ October, captured three brigs fully equipped for the 
slave-trade, making a total of fourtecn vessels taken by. Captain Dunlop during this commission. Two of the brigs (name and nation unknown) arrived in St. Helena, have been entered in the ViceAdmiralty Court of this island for adjudication: one is armed with a long 12-pounder pivot gun aft, and the other has the remains of the pivot of a gun which has apparently been thrown overboard. The account goes on to say that the third prize was hourly expected to arrive here. This third was the Descobrador, an account of which will be found under heading " Rollers."

On December to we fund a notice: Arrival schooner, name unknown, captured by H.M.S. Prometheus, and sent liere for adjudication in charge of $\mathrm{W}$. J. Bridges.

17 th.-Arrival brig, unknown, detained by H.MI.S. Prometheus for adjudication, in charge of John IRussell, boatswain's mate. I.icut. O'Brien, the late prize officer, having poisoned himself, dued on the loth December. The prize was captured on and October.

These prizes were generally sold quichly after adjudication. The St. Helena Gazelie, of December $27 t h, 1 \$_{45}$, has the following notice, and we find similar notices throughout the records of that time :-

$$
\begin{aligned}
& \text { O X MONDAY, } \\
& \text { the } 12 \text { th instant, }
\end{aligned}
$$

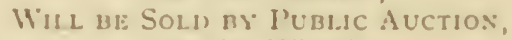

$$
\begin{aligned}
& \text { on the Wharf, } \\
& \text { The following Stores from the Condemneal liessel. } \\
& \text { Lnknown-1sth, } \\
& \text { Consisling of }
\end{aligned}
$$

Masts, yards, sails, stauding or rumuing rigging, farina, beans, rice, jerked heef, firewookt, watercasks, vinegar, copper boilers, bunls, medicine, large iron grajnel, slave-deck, sweeps, ancliors, and chain cables, ctc., ctc., etc. Nlso the

\section{IIUI.I.}

For ready money.

Sale to commence at eleven o'clock in the forenonn.

By decree of the Vice-Admiralty Court.

EDWARD GULLIVR, RN., Marshal V.A. Court.

ST. HELENA, inth Dec., $1 \varepsilon_{45}$.

On December 25 H.M. brig of war Cyguet arrived (Captain I.ayton) from Benguela. Also Descobrador, brig, detained bv H.M. Star, sent here for adjudication in charge of J. Maynell.

In January 1846 , there arrived the Esperance, detained by Mr. Lowe, R.N., second master, taken off the river Juna.

January 9.-An entry reads: Enfracia, schooner, Lieut. Pollard, R.N., in charge, detained by H.M.S. Promethews, and sent here for adjudication from off the river Congo.

January 12.- Lnknown brig, detained by H.M. hrig $C_{\text {ygnet, }}$ sent here for adjudication. I.ieut. Oakley in charge, has on board 525 slaves 
January I 3.-St. Domingo (brigantine), Mr. W. Clarke in charge, prize to H.M.S. Prometheus, captured off Congo, sent here for adjudication.

The issue of the St. Helena Gazette for the 24 th January, 1846 , says : There are at present no fewer than fifteen condemned slavers in this port. Two out of the above were full of slaves, prizes to H.M.S. Cygnet (Captain Layton). The first, arriving on 25th December, was a Brazilian schooner of about 100 tons, captured off Cape Palmerinho, having on board 547 slaves. The other arriving on the IIth, a brig, name and nation unknown, had 542 slaves on board, and was captured by the Cygnet on her return from St. Helena to the coast in lat. $\mathrm{II}^{\prime} 38^{\prime \prime} \mathrm{S}$., long. $\mathrm{I}^{\prime} 37^{\prime \prime} \mathrm{E}$.

February 6.- The Brazilian brig Eliza, a well known slaver, has arrived. She was captured during a calm by the boats of H.M.S. Flying Fish. She was considered the fastest vessel in the slave-trade, and it is said she once sailed round the Pantaloon, fired into her, and then got away.

February 9.-Arrived brigantine slaver, detained by H.M.B. Wasp, and sent here for adjudication in charge of Mr. F. Clementson, R.N., from Loando.

March I2.-Arrived H.M.S. Winchester, Admiral the Hon. Jocelyn Percy, C.B., from Simon's Bay, twelve days.

March 2I.-Arrived H.M.S. Larne (J. W. Brisbane) from Ascension, five days.

March 23.-Arrived the unknown brigantine, brought by Mr. Carrington from off Benguela, detained by H.M.S. Cygnet.

April I8.-Arrived the Brazilian schooner Gaio, prize to H.M. brig Wasp, on the 5 th, in lat. $7^{\prime} 18^{\prime \prime} \mathrm{S}$., and long. $2^{\prime} 10^{\prime \prime} \mathrm{E}$. The prize was observed making in towards main land when the gig and whale boat of the Wasp, commanded by Lieut. Hocking and Mr. Cave, midshipman, were sent in chase. The boats were fired upon as they approached the steamer, and three men wounded. Upon this the boats were ordered by Lieut. Hocking to return the fire, which they did with effect; and as soon as their ammunition was expended, boarded and carried the prize, after some resistance, in which the chief mate of the prize was killed. The master was found severely wounded, the iron gun of the vessel having burst in its last discharge at the boats, and carried away one of his legs; he was also wounded through the body, probably through the firing from the boats, and died about two hours after his capture. Three of the crew were brought up in the prize, as prisoners for trial, the remaining ten removed on board H.MI.S. Wasp, which vessel is expected shortly to arrive.

May I.-Capture of a slaver. Arrived the Galgo, a smart Brazilian brig of 320 tons, armed with three guns, captured by three boats of H.M.S. Wasp, under the command of Lieut. Hocking, on the 20 th April, in lat. $7^{\prime} 15^{\prime \prime} \mathrm{S}$. and long. $12^{\prime} 28^{\prime \prime} \mathrm{E}$. The crew of the prize, thirty-six in number, kept up a constant fire on the boats for an hour and a half, and after the boarding party got on deck continued it from the tops of the vessel until shot down by the captors. 
Of the Wasp three men were slightly wounded and two dangerously; on the part of the crew of the slaver thirteen were killed, viz. Captain Joaquin Antonio Perreira, the mate, and eleven men. With the Gaio the Wasp had three wounded, and the fearful massacre of her prize crew on board the Felicidade has left the crew of the Wasp in an exasperated state, while the escape of the murderers of their companions from justice has no doubt added fuel to the flames.

May' 14, 1846. - Three vessels were condemned for being equipped for and engaged in the slave-trade, viz. Brazilian brig Gabriel, taken by H.II.S. Waterwitch (Commander Birch); the schooner Gaio, taken by H.M.S. Wasp (Commander Ussher), after considerable resistance, in which three of the I'asp's crew were wounded, and three of the Gaio killed; and a brigantine, name and nation unknown, taken by H.M.S. Actaeon (Captain Mansel).

The Emprehendedora was detained by the Alert, but after trial before Vice-Admiralty Court, His Honour decreed the restoration of the vessel.

The following account of a trial by Vice-Admiralty Court will show how, after a hard struggle with the enemy, the officers and men of our Navy found themsclves placed in the wrong :-

\section{AdMiralty SEssions.}

24 th June, 18.46 .

A session of the Court of Commissioners for the trial within this colony of offences committed on the high seas was holden on Wedresday, 24th June, for the trial of the sessions of the crews of the Brazilian slave-vessels Gaio and Galgo, for resisting the boats of II.M.S. Wasp, and wounding several of the men on the occasion of their scizure.

The Court having assembled soon after ten o'clock, the Letters Patent under the Great Seal, by which the Commissioners are appointed, were read, and the oath of Qualification was taken by His Honour, Mr. Wilde, Esq., Chief Justice of the Colony; James Everard Home, Baronet, Captain of the Royal Navy, commanding H.MI.S. Star, then in the roadstead of Jamestown; the Honourable Najor Henry E. O'Dell, Saini Helena Regiment, member of the I.egislative Council ; and Ceorge Summer I Hand, Esq., Commander of H.MI.S. Espoir, then in the roadstead. The Grand Jury, consisting of the following gentlemen, were then sworn, viz. :-

\section{William Carrol, Fsquire, Foreman}

GLO IV. AlEXANDER,
THOMAS AlESWORTH,
THOMAS CHARLETT,
GEORGE CHADWICK,
THOMAS COLE,
JOHX DE FOUNAINE,
IV. K. DOVETON,
W. O. KENNEDY,

GEO WV. ALEXANDER,

THOMAS ALESWORTH,

THOMAS CHARLETT,

GEORGE CHADWICK,

THOMAS COLE,

IV. K. DOVETON:

W. O. KExNedY, 


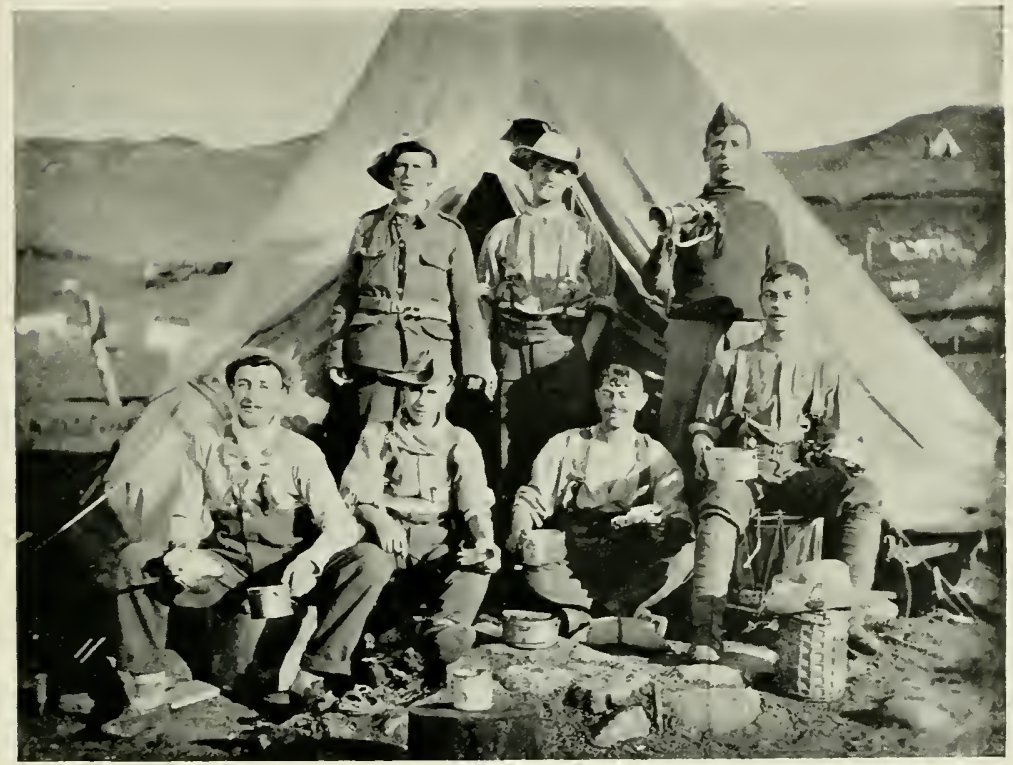

"Tea Thme," 3Ri Royal Sussex Reginext, Broadbottom Cami.

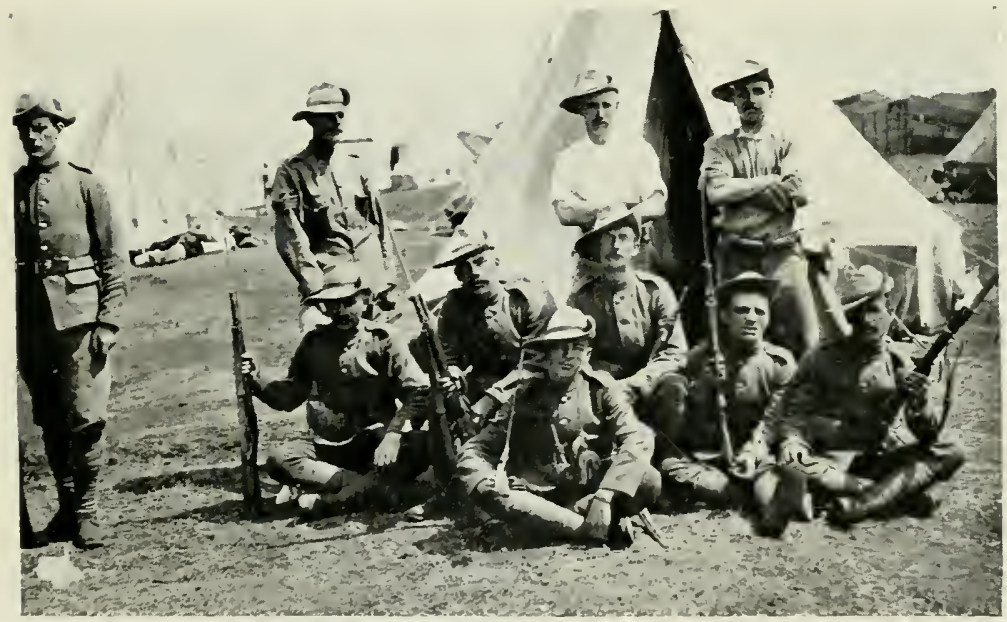

"Canp hafe," 97 th Company R.G.A., Deamoon Camp. 

His Honour the Chief Justice, in delivering the charge to the Grand Jury, made some preparatory observations on the origin and constitution of Courts appointed for the trial of offences committed on the high seas. He stated that, previously to an Act of Parliament passed in the reign of Henry VIII for the "Punishment of pirates and robbers of the sea," all such offences were brought before the Lord High Admiral according to the rules of Civil Law; but as that mode of trial was deemed inconsistent with the liberties of the subject, and as no man's life could, consistently with our laws, be taken away without judgment of his peers, a new jurisdiction was established by which all persons accused of felonies, robberies or murders committed on the high seas should be tried by a jury of twelve men according to the course of Common Law, as if such offence had been committed on land; and under this statute a commission was directed to cerlain persons named therein and afterward cxtended to the colonies to avoid bringing witnesses and prisoners from distant parts.

\section{Adirizalty Sessions.-" Slavery."}

An Act was passed in the reign of Gcorge III. by which the like powers and authorities were given to certain Commissioners to inquire, try, determine, in any of our islands, plantations and Colonies, offences committed on the high seas. His Honour referred to the various statutes relative to the subject of piracy. The crimes which would be brought before them originated in the resistance made by two slave-vessels against the boats of H.MI.S. Wasp on their approach to board and search the said vessels. A severe and desperate conflict had taken place, in which several seamen of the Wasp were wounded, some dangerously, and several of the slaver's crew were killed. The prisoners were also charged with feloniously shooting with intent to murder, to main, to disable, to do some grievous bodily harm, or to prevent lawful detaining. The number of prisoners were upwards of thirty, comprising the persons found on board the two Brazilian vessels Gaio and Galgo. The Grand Jury were doubtless aware of the great but unsuccessful cxertions made by England to suppress the slave trade; and had other nations been equally sincere in their professions to repress this guilty traffic, no doubt it had long since been extinguished, at least, so far as the civilized world was concerned. But slavery had existed under the sanction of Laws of Nations from the earliest ages of the world until the last half century. Commission Courts were established for the condemnation of Brazilian vessels engaged in the slave trade, and an Act of Parliament passed was to authorize the adjudication of Brazilian vessels engaged in slave-trade by Vice Admiralty Courts. But the 8th and 9 th of Victoria, which gave this authority concerning the vessels and the cargoes of such vessels, gave no authority with regard to the persons found on board; nor were foreigners (not being under the protection of our laws) amenable to them for any acts committed in a country or place not subject to the dominion of Great Britain, and so beyond the 
jurisdiction of any English Court. His Honour ob.nerved that the only exception to this was piracy; for all pirates, being rovers and robbers on the seas, are enemies to all, and sailing under no flag, every nation luad a right to inflict that punisliment on them which their crime deserved. But the slave-trade was not piracy by the law of nations nor by Treaty until made so by the Municipal Law of the countries keeping the Treaty; nor even then cognizable by a forcign country until a legislative measure is passed to sanction the jurisdiction of their Courts. For, notwithstanding the convention with Brazil, wherein the first article declares that the carrying on of the slave-trade by any person subject to the Emperor of Brazil shall be deemed and treated as puracy, yet there was no Act of Parliament which authorized a British Court to try and punish a subject of Brazil for carrying on the slave-trade; although there was an Act authorizing the confiscation of their vessels. So the two important questions arise in this case whether the prisoners are foreigners and whether they have committed any offence that amounts to piracy. It was for the jury to consider whether the resistance made was piratical or justifiable as made in ignorance of any right which H.Mf. boats had to search and detain them, and under an idea that they were only acting in selt-defence. His Honour endeavoured to impress on the minds of the Grand Jury the great importance of the subject submitted to their consideration, and the necessity of devoting their most serious attention to the arduous and important duties which they were called upon to perform-duties which were important as regarded the fate of the prisoners-important as regarded the great question of the slave-trade, and so affecting our relations with Brazil. The Bills of indictment being given to the Grand Jury, they retired, and on their return into Court found true bills against all the prisoners. The survivors of the crew of the Gaio, thirteen in number, were then placed in the dock. An interpreter, Mr. Peter Christian Gurner, was sworn in consequence of the prisoners not appearing to understand the proceedings. They were then severally arraigned upon the indictment, which charged them with piratically and feloniously shooting at one Austin Elson upon the high seas within the jurisdiction of the Court wath intent to kill and murder him; a sccond count charged them with being present aiding and abetting a certain person to the jurors unknown in committing the said piracy and felony.

Prisoners all pleaded not guilty.

Mr. T. E. Thompson appeared for the prisoners but made no objection, on their behalf, to the proceedings.

The Queen's advocate stated the case for the prosecution and briefly related the circumstances connected with the offence, with which they were indicted. He reminded the jury of the great exertions which had been made by Great Britain to abolish slavery and the slave trade throughout the world. He referred to the treaties which have been entered into with nearly thirty independent states for the suppression of the slave trade and particularly the convention 
between Great Britain and Brazil. He stated that a strong naval force was constantly employed on the coast of Africa for the purpose of searching and detaining vessels engaged in the slave trade : that the Wasp was one of Her Majesty's squadron employed in that service ; and whilst cruising off Ambrizette in the performance of that important duty discovered on April 5 last a suspicious-looking vessel which afterwards proved to be the Brazilian schooner Gaio. She was completely equipped for the slave trade, brought here for adjudication and condemned in the Vice-Admiralty Court.

Such were the facts of the case, and he, tle Queen's advocate, found it difficult to conceive what justification could be offered for this wanton attack on the boats of H.M.S. Wasp, approaching as they were with colours flying, the officers in uniform, and the Wasp in sight during the whole day, with the British ensign and pennant hoisted.

The prisoners at the bar wore found on board the Gaio, and no doubt were partakers in the transaction more or less. It might not appear in evidence which, or whether any of the prisoners actually discharged the gun which inflicted the injury, but it would be proved that they were all present aiding and abetting and werc therefore properly charged as principals in the indictment.

The evidence would admit of no reasonable doubt of their active participation in the attack on the boats. The commander of H.M.S. Wasp was fully authorized in sending his boats to ascertain the character of the vessel, whether she was a Brazilian slaver or not. The attack on the boats was therefore a resistance to lawful authority, and it is expressly laid down "That a lawful force cannot be lawfully resisted." The attack on the boats was wanton and unprovolied. There was no aggression on the part of the British. The attempt to escape from the boat was of itself a suspicious circumstance, amounting nearly to a proof that the schooner was 110 legal trader.

And she followed up her refusal to obey the usual signal of firing two or three muskets to induce her to heave to by piratically firing upon the boats with both large shot and musketry, and kept up the fire with only one interval, whilst the boats got near enough to enable them to renew it with more deadly effect, and never ceased until the schooner was carried by boarding: nor even then until two of the crew had forfeited their lives by their rash and obstinate resistance. She was then found to be the very description of vessel that the commander of the Wasp was authorized to detain : a Brazilian slaver, fully equipped for the reception of slaves and consequently engaged in the slave trade. After some further observations, the Queen's advocate left the matter in the hands of the jury, trusting that in the fulfilment of their important and responsible duties, though their feelings of compassion might dispose them to a merciful consideration of the prisoners' case, they would not lose sight of what was due to that gallant service devoted at the expense of life and health to the arduous duty of suppressing the foulest blot that ever disgraced humanity, denounced by assembled statesmen as the "desolation of Africa, the degradation of Europe and the 
afflicting scourge of humanity," and that their verdict would be such as to satisfy their own consciences, the country which had made such enormous sacrifices to abolish that abominable traffic in luman flesh, and the world at large. The first witness called was Mr. John Halliday Casc, midshipman, belonging to H.M.S. Wasp, who being sworn, stated: "On the 5 th April last I was ordered by Captain Usher to take charge of the whalc-boat belonging to H.M.S. IVasp, to chase and cxamine, under the orders of Lieut. Hockin who was in the gig, a schooner which had just hove in sight off Ambrizette about twenty miles from the land. This was about half-past seien in the morning The chase continued the whole day. A little after sunset I observed the schnoner firing musketry at the gig, which was abont two miles aliead of the whale-boat. At the same time I heard a loud report from a small gun. The gig returned the fire and about ten minutes after it ceased on both sides. About half an hour afterwards I succeeded in getling up with the gif when Mr. Hocking made me diside my ammunition with him, as his was expended, and ordered me to pull ahead of the schooner with him, and after we had got ahead, to separatc. I was to board on the port bow while Mr. Hockin boarded on the starboard bow. The colours were then hoisted in the gig and the whale boat. As soon as the boats got within range the people in the schooner began to fire again. They all seemed on board the schooner to be armed with inuskets, and it was during the time we were pulling ahead of the ressel that three of the men in the boat were wounded by muskets. One man in the whale-boat, Austin Elson, was wonnded in the thigh by a musket ball which was fired from the schooner before we got alongside. I also hearll Edward Campbell in the gig cry out, 'I am struck in the leng.' The firing from the schooner continued until the loats got alongside, when it ceased entirely. On boarding the schooner I saw only one man on deck-he was running to the hatchway and he was cut down. The rest of the crew all hid themselves. On going aft I saw a small gun, a threc or four pounder, which ap)peared to have recently burst; and about the same time the captain was handed up from below with onc of his legs off, which Jose Ignaceo Oliveiro, one of the prisoners, rave me to understand had been caused by the bursting of the gun. There was a great quantity of ammunition and arms of all descriptions lying about the cleck, consisting of muskets, boarding pikes, cutlasses, musket ball-cartridges, a case of canister shot, and a quantity of loose gunpowder. The schooner had no colours up at the time of boarding, and I satw none before. A Brazilian ensign was found below. She was completcly fitted up for slaves, had a slave-dcck laid, also farina beans, jerked beef, and sereral breakers of water. I had on my naval uniform cap with gold band and blue jacket with naval buttons. Cannot say whether IIr. Hockin had on his uniform. The crew of the schooner were put into the whale-boat and towed astern. A blue light was burnt as a signal to the Wasp which burnt another in answer, and we then procecled in the direction of the Wasp, and fell in with her about one o'clock in the morning of the Gth $A$ pril. 
Lieut. Hockin took the prisoners on board the Wasp. I remained in charge of the schooner till Lieut. Elliott came on board about two hours afterwards. The schooner was boarded in the dark. I was afterwards ordered to take charge of the schooner with three of the prisoners and proceed to St. Helena for adjudication. I was present when the Gaio was condemned in the Vice-Admiralty Court of this place for being engaged in the slave trade.

Edward Campbell, one of the crew of the gig when the Gaio was taken, deposed that when about a mile from the schooner three muskets were fired from the gig to bring the schooner to, the muskets were fired in the air. He was wounded in the leg before boarding : the ball went right through his leg. All the crew ran below when they boarded, except one man, who jumped from the port to the starboard side, and not knowing but what he was going to attack him witness struck him on the neek with his sword, and as that had no effect he ran him through and then threw him overboard; did not know whether he was armed or not. Lieut. Hockin had on his cap with a gold band and a naval uniform coat with straps on the shoulders. This witness corroborated Mr. Cave's evidence in other particulars.

Austin Elson, the man named in the indictment, was one of the crew of the Wasp's whale-boat when the Gaio was taken: he described the manner in which he was wounded and produced the leaden musket-ball which had been cut out from the under part of his thigh. His wound was severe, and for some time he was considered in a dangerous state; he had never done any duty since he received the wound, and was still in the hospital. The shot which wounded him came first through the boat just under the gunwale.

The other witnesses, one of whom, Wm. Norman, was wounded by a musket ball on the back of his head, testified to the same facts that the others had stated.

The ship's papers filed in the Registry of the Vice-Admiralty Court, the decree of condemnation, and a certified copy of Captain Ussher's authority to seize Brazilian vessels engaged in the slave trade, were then put in as evidence of the unlawful character of the vessel, and concluded the case on the part of the prosecution.

Mr. Thompson on the part of the prisoners produced no witnesses nor did the cross-examination of the witnesses for the prosecution in any degree tend to weaken or discredit their evidence. Two of the prisoners, Bastos and Sing Juan, produced passports in support of their assertion that they were passengers, and some of them denied taking part in the resistance, being below all the time.

They all professed not to have seen any colours hoisted either in the boats or on board the Wasp, and that they were not aware until the moment of boarding that the boats were manned by Englisl sailors, which was first intimated by the cheering of the boats' crews as they approached to board. The Chief Justice having summed up, the jury retired and after an hour's deliberation returned a verdict of guilty against the whole of the prisoners.

The Court then adjourned till the next morning at ten.

Thursday, 25 th June, 1846 . 
The Court of Commissioners for the trial of offences committed on the high seas, adjourned from yesterday, was re-opened this morning at ten o'clock, when the prisoners taken in the Brazilian brig Galgo were set to the bar and charged with piratically and feloniously shooting on the high seas at one George Horwood, a seaman of H.M.S. Wasp, with intent to kill and murder him.

The prisoners were twenty-two in number, and named in the indictment in the following order :-

Joze Percira Santos, Antonio Joze Peircrira, Francisco Marquis Couto, Joaquin Corcia Soaces, Hanwel, Ferreira, Dion isio Marinho, Francisco Mondes, Joze Francisco d'Almeida, Celesticno Emendes, Manvel Joze dos Santos, Joze Baptista Goncalves, Joze Francisco, Raphall Sanxes, Antonio des Santos, Joze Roura, Joas de Las Reis, Antonio Joze da Silva, Hilario Porie Bento I3clles, Joas Liosmay, and Antonio dos Santos.

Mr. Fowler appeared for the prisoners on their heing arraigned and prayed the Court to appoint an interpreter, as the prisoners were foreigners. Mr. P. C. Gurnet was accordingly sworn as interpreter, and directed to explain the procecdings to them.

Mr. Fowler then objected to the jurisdiction of the Court, on the ground that the prisoners were all foreigners, but on being desired to put his objection in the form of a plea, he withidrew it, and the prisoners severally pleaded "Not guilt:."

A jury, de medietale, was next applied for, on the part of the prisoners. The Provost Marshal was desired to return a sufficient number of aliens to be put on the jury, and the Court adjourned till two o'clock.

Upon the re-assembling of the Court, Mr. Fowler stated that a Brazilian vessel of war had just anchored in the roads, and that some Brazilian offecers were present who were desirous of being permitted to protest against the authority of the Court to try the prisoners, who were all subjects of the Emperor of Brazil. The Court refused to admit any interference of the procecdings, as the prisoners had already pleaded, and the jury was sworn, with one foreigner, all that the Provost Marshal was enabled to return. The names of the jury were :-

Fernandez Rosse, George Baxter, Robert Ramage, Richard Sparkes, Young, James Scoti, Stephen Young, Edward Greenland, Watthew Torbett, Jolın Bargo, William Seale, Charles Hogg, Stephen Stroud.

Mr. Firman, the Queen's Adrocate, stated the case for the prosecution, and produced Licut. David Flliot as a witness, from whose evidence it appeared that at daylight on the morning of the 2oth of April, a suspicious looking brig bearing $\mathrm{NW}$. was observed from the deck of H..II.S. Wasp, commainded by Captain S. H. Ussher, who immediately ordered three of his boats, viz. the pinnace, the gig, and the cutter to go in chase, and examine the strange brig. Lieut. Hockin was in the pinnace, Licut. Flliot in the gig, and Mr. Burnley, midshipman, in the cutter. The English colours were'hoisted in the boats; the officers had on their uniform jackets and caps; and the 
Wasp followed in the same direction, with her colours flying. The brig showed no colours, and when the pinnace got sufficiently near, which was after a chase of more than four hours, Lieut. Hockin ordered a gun to be fired ahead of the brig. This shot was immediately returned by two guns, whether shotted or not did not appear, from the brig; and the pinnace and gig then lay to for the cutter, which was some distance astern. Whilst waiting for the cutter, the brig took in several of her sails, and kept up a continuous fire on the boats. As soon as the cutter had joined, Mr. Hockin gave directions for boarding, and the boats pulled down to the brig under a heavy fire, the men cheering tremendously. Two of the boats were much injured by the shot, and the sail and mast of the pinnace completely riddled. Mr. Burnley and six of the men were wounded, two of whom, George Horwood and Henry Gully, were shot through the breast. The brig was instantly carried by boarding, but the resistance was continued by firing from the tops, which was only put an end to by shooting those who were in the tops. There was also some firing below, and some of the people were killed. On taking possession, the brig proved to be the brig Galgo with a crew of thirty-six men, well armed, and abundantly supplied with ammunition. She had both a Spanish and Brazilian ensign on board, and was completely fitted for the slave trade. The cargo consisted of farina and rice, with water sufficient for a thousand people. The vessel had ventilation in the deck with iron gratings, also iron bars across the hatches and a slave deck completely laid. The prisoners were put into the pinnace, and on nearing the Wasp, Mr. Hockin took them on board. In answer to a question from the prisoners, this witness stated that according to the orders of the Commodore, they were directed to treat all vessels that fired on them as pirates, and to stimulate the men he said, "Remember the Felicidade."

There was also something said about the judges.

From the testimony of the other witnesses it was evident that the resistance had been desperate, and the preparations for it of a most determined character; the boarding-pikes were slushed or greased on their points, two feet up the staff. One of the Wasp's men was wounded after getting on board, and when below, Mr. Burnley, the midshipman, and a man named Thomas Brown were wounded in the act of boarding. T. Cooper on going below, was seized by the throat, and thrown down by one of the Galgo's men, who was instantly shot.

The decree of the condemnation of the Galgo, under the seal of the Vice-Admiralty Court of this Colony, was produced in proof of the vessel being engaged in the slave trade. Also two letters, found amongst the papers on board; one desiring the captain on his return to Brazil to land such of his crew as were not entered on the crew list at a place therein mentioned, the other advising him to keep off the land, in order to avoid the English cruisers. The crew list was also put in, to show that, although there were thirtysix men found on board, only seventeen were regularly entered as her crew. 
Upon the close of the prosecution. Mr. Fonler applied to be allowed till the next morning for the defence. The Conrt thereupon adjourned till ten o'clock the next day, and directed that the jury should be kept together, and that accommodation should be provided for them.

On Friday 26 th the Court again sat. Mr. Fowler, for the prisoners, contended that the Court had no jurisdicion, as they were Brazilian subjects on board a Brazilian vessel: and that at the time of the commission of the oftence as laid in the indictment, no conversion of the vessel had taken place He observed that English Acts of Parlianent could not apply to Brazilian subjects in a Bra. zilian vessel which was Brazllian ground. He also observed that the indictment stated the prisoners to be late of St. Ifelena, whereas they wire taken out of the Galgo ; and that Capt. Ussher's authority being limited to the scizure of Brazilian vessels could not warrant his seizure of Brazilian subjects. He then read a paper which three of the passengers had prepared stating that they were passengers and took no part in the resistance: that some of the sailors commenced the firing without the Capt's. orders whercupon the passengers and the remainder of the crew went below : the firing from both parties continued for some time : at last it ccased for a few minutes, when the voices of those whom they afterwards found to be English sailors were heard on deck mingled with the ones from the Galgo's crew, who were being fired upon and killed by their opponents. As their hiding place was below the cabin, they could distinctly hear what was going on in the cabin, where the captain of the Galgo and two nthers who had concealed themselves were killed The captain (in French) beged the English to be merciful, to pity and spare hum, but in vain After which they (the Euglish) took their treakfasts in the Gulgo's cahin, which just before hand been the scene of so much horror and bloodshed. He then related the appearance of the decks, calin, and the other parts of the vessel after they had ventured from their hiding-place when all was quict, their removal to the II'asp, and the rough usage which they experienced from the exasperated seamen. Thirtecn of the Galgo's crew were killed, and one, who was wounded, died afterwards in the hospital at St. Helena. Another statement in writing was read from five others of the prisoners concluding with the assertion that those who were killed were the parties who had defended the ressel.

Mr. Fowler procecded, after reading the alsove, to maintain that the prisoners had taken no part in the resistance made to the boats, and that those who had wcre all killed. He insisted that no offence had been committed against the British laws, and said if the prisoners had been guilty of any crime, they ought to have been tried by the laws of their own country.

The crew list was again referred to for the purpose of showing that the prisoners were foreigners, also the affidatit of Licut. Flliot, on bringing the Galgo into the Vice-sdmiralty Court to prove her national character.

Licut. Filliot and William Hill, captain of the forecastle on board 


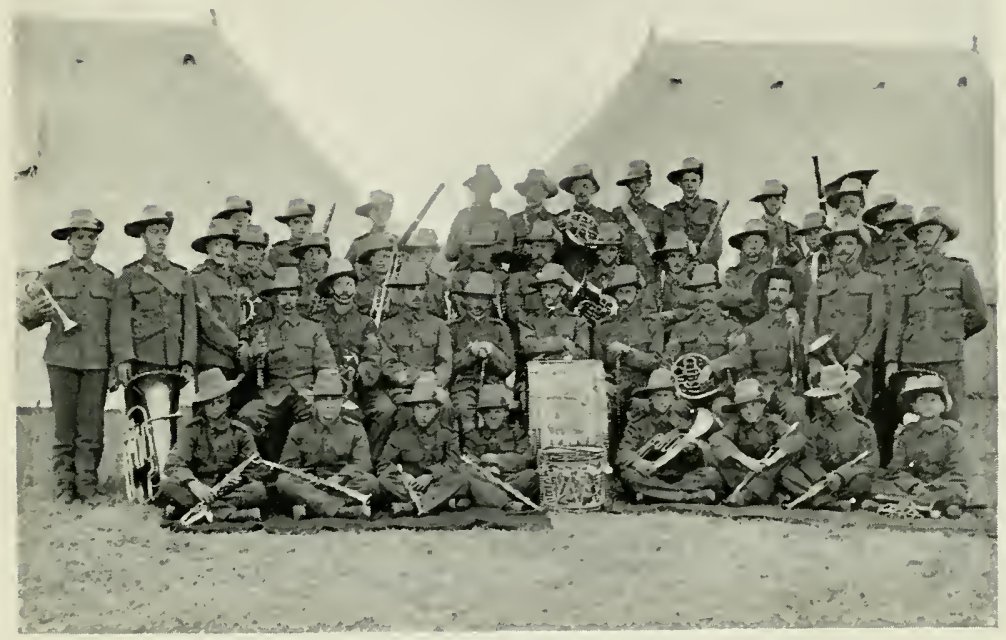

Bayd jRD Middesex Regiaext, Deadwoon Camp.

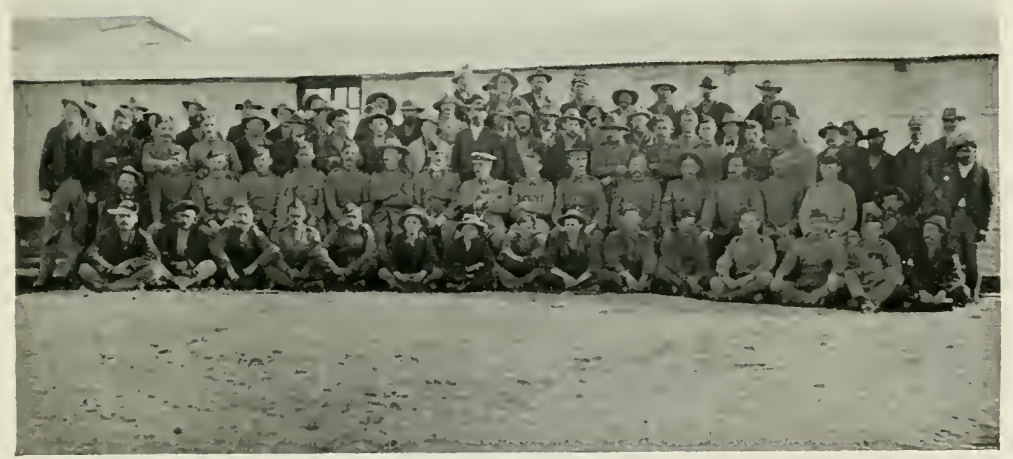

Royal Engineers and Fatigue from Prisoners of War, DFamool Cami. 

the Wasp, were then called and examined respecting some papers, which the prisoners stated had been destroyed.

The Queen's Advocatc addressed the jury in reply, to the effect that the objection made on the part of the prisoners was either immaterial, or should have been made at an earlier period of the proceedings, and maintained that the statements of the prisoners had not been substantiated by evidence.

The Chief Justice proceeded to sum up, and told the jury that if they were satisfied the prisoners fired the muskets or were aiding thercin, they must not consider whether, had the person fired at dicd, the offence would have been murder; and whether or not it would have been murder depended on the question of the resistance which the prisoncrs made, being lawful or unlawful. His Honour said that the authority which Captain Ussher possessed, to visit and search Brazilian vessels, was a lawful authority; but it did not follow, if the prisoners on board were Brazilian subjects, that they were bound to submit to be visited and searched. His Honour also said that if the prisoners were guilty of any offence in resisting the visit and search by the boats of the Wasp, this offence, being a felony created by an Act of the British Legislature, it could only apply to British subjects; and that no person, not under the protection of the British law, was liable to be punished for any infraction of that law committed at a time when not under the protection of it. Therefore if the jury should be satisfied that the offence was committed in a foreign ship by foreigners, they ought to find the verdict of Acquittal.

The Jury retired for a short time, and on their return into Court, brought in a verdict of " Not Guilty."

The prisoners from the Gaio, who were tried on Wednesday and found guilty, being brought up for judgment, pleaded that they were Brazilian subjects, and said that MIr. Thompson would speak for them.

Mr. Thompson on the part of the prisoners, moved for an arrest of judgment on the grounds that only three of them had been identified as being on board the Gaio when the ressel was taken, and that they were all Brazilian subjects; to prove which, as well as to show that he was not aware of there being some documents in the Registry of the Vice-Admiralty Court to that effect, he put in affidavits. The Chief Justice, in pronouncing judgment, told the prisoners that their objection ought to have been made on the trial ; but as the Court was satisfied that they were really Brazilian subjects, a sentence of a nominal punishment only would be passed upon them of twenty-four hours imprisonment.

Alert, 6, (Com. Bosanquet), Mr. Wasey, of this vessel, appointed Acting-Lieutenant nearly a year since, on the promotion of the late gallant Lieut. Lodwick, arrived at Liverpool last week in a merchant vessel, with some seamen belonging to the Alevt, from the south-east coast of America, and immediately reported himself at the Admiralty and related the circumstances under which he presented himself. It appeared that the Alert captured a Brazilian slave-vessel without colours, name unknown, having between seventy and eighty slaves 
on board, at Cabenda, and having put Mr. IVasey and a prize crew on board, ordered him to proceed to Sicrra Lcone for adjudication. The gales being unpropitious, he was driven by their force on the south coast of America. He managed, however, by almost superhuman exertions to reach Maranham, one of the northern presidencies of Brazil, although he had frequently seven feet of water in the hold, with fresh leaks breaking out at intervals, and only kept his ship afloat by dint of extraordinary perseverance in working the pumps. On his arrival at Maranham, the British Consul rendered every assistance and an endeavour was made to secure the offices of the Government in obtaining proper protection for the slaves until a vessel could be procured to take them. In the meantime, whilst Mr. Wasey was engaged on shore with the President, enleavouring to effect his object, a body of about forty-six to fifty armed men, in the uniform of the National Guard, proceeded to the vessel, saying to those on board that they were instructed to take the slaves and crew and conduct them to a place of safety for the night, it being then impossible for any one to remain on board, as the water was washing over the declis. The English seamen refused to leave the vessel in the absence of their offecr, but all the slaves, together with the captain and crew of the slaver, landed with their visitors. Mr. Wasey soon after returned, and finding the eighty slaves with the prisoners gone, he immediately instituted inquiries, when he ascertained that the visitors were a party of brigands in disguise of Brazilian soldiers, who had made themselves masters of the cargo and marched them off up the country. An ostensible attempt was made on the part of the Government to recover them, but of course without success, and finding all attempts fruitless, Mr. Wascy embarked his men on board a merchantman for Liverpool. Great credit is due to Lieut. Wascy for his conduct throughout the affair. He preserved lis vessel under the most disadvantagcous circumstances of wind, weather, and cargo, until she reached a place of safety, and on the voyage succeded in preventing an outbreak which he had reason to apprehend was meditated on the part of the slaves and the slaver captain, of which warning was given him by one of the slaves who could speak a little English. They had to work all day and night with their arms by their sides, bailing out water, or their vessel would have gone down.

Thursday. August 6 th, 1846. Queen $\%$ Brazilian brigantine Emprehendedora.

This vessel, which was formerly seized by Capt. Bosanquet of H.M.S. Alert, and restored by decree! of the Vice-Admiralty Court of this Colony, on the 11th May last, the particulars of which case appeared in the St. Helena Gazetle of May 16, was again seized while at anchor in these roads on the I t th June by Capt. Bircls of H.M.S. Wateroitch for being equipped for the slave trade, and put into Court. The case was adjudicated on Thursday.

Mr. Gideon moved on the affidavit for condemnation, upon the ground that the usual equipments for carrying on the slave trade were found on board at the time of seizure. 
Mr. Fowler for the claimant, Francisco Roderiques de Silva, opposed the motion for the condemnation, on the following grounds :

Ist. That there was no proof of the seizure or detention of the vessel by Capt. Birch or by any person on his behalf.

2nd. That the vessel was not at the time of the search and detention equipped for the slave trade, but was in the same state as when restored by decree of the Vice-Admiralty Court and regularly entered at the Custom House.

3rd. That Capt. Birch had no especial authority for seizing Brazilian vessels engaged in the slave trade excepting on the high seas.

4th. That the Emprehendedora was lying at anchor in the roads at St. Helena within range of the batteries and therefore the seizure was in violation of the convention. The judge was of opinion, that whatever might have been the intention of the original voyages of the Emprehendedora with regard to the siave trade, that intention had been evidently abandoned upon the release of the vessel from the seizure by H.M.S. Alert. The vessel had been regularly entered at the Custom House and permission had been applied for and obtained to land the cargo and slave equipments, before the seizure by Capt. Birch, which sufficiently proved that there was no intention to carry on the African slave trade. His Honour therefore decreed that the vessel be restored with costs.

Thursday, I3th.-The Brazilian brig Relampago, taken by H.M. steam sloop Hecate, Commander Joseph West, with 545 slaves on board, was condemned. This vessel arrived on the $24^{\text {th }}$ inst. under charge of Lieut. Hancock; upwards of forty slaves died on the passage, and about forty more since their arrival. The case was unopposed and prosecution conducted by Mr. Baker, the Queen's Proctor.

September 2.-Arrived Maria, schooner. J. C. Millett, Esq. R.N., in charge : a prize to H.M.S. Kingfisher, captured on the I 5 th August, off Juan Bay.

September 18.-Unknown, prize to H.M. brig Waterwitch, with 540 negroes on board. This beautiful little sloop Waterwitch captured on Sunday $13^{\text {th }}$, after a spirited chase, a large brig fifteen days from Ambriz, having a living cargo of 556 human beings. We regret to add that a number had fallen victims since their departure from the coast to the period of their capture.

September 26th.-Dios Ismaas, brig. H. B. Akaster, Esq., in charge, a prize to H.M.S. Promethens, captured on September 8th off Ambriz.

October 26 th. - The Izabel brig, detained by H.M.S. Hydra, off Palma, zoth September, in charge of Lieut. Charleton, R.N. Brought here to be adjudicated.

Mareval Allvoisie, schooner. Detained by H.M.S. Brilliant on 8th October, in charge of Lient. Corkroff, and brought here to be adjudicated.

27th.-Rolia, brigantine, detained by H.M.S. Styx on 17 th Sep- 
tember ofi Little Polri, in charge of Licut. C. Rainier. Brought here to be adjudicatcd.

November 3.-Bonorto Porlo, brigantine Detained by Sealark, on October 21, in charge of Mr. Fenwick. Brouglit here to be adjudicated.

November 4.-Angle, brigantine. Mr. S. Waith, R.N., in charge. Prize to H.M.S. Sealark, captured October 22 off Ambriz.

November is.-Victoria, brigantine. Mr. A. Dewar in charge. A prize to H.M.S. Kingfisher, cajutured on October 16.

23.-Genie, brig. Detained by Kingfisher, in charge of J. Millet, Esq., R.メ., captured on October 17, off River Iermanyas.

December 5.-Adelaide, urig. Detained by 11.11. Sloop Biltern off River Congo 21 st November, in cliarge of Licut. P'owell, R.X. Here to be adjudicated.

January 16, 1847 - From a private letter disted Jamary 6, 1847 , an cxtract states that Commanders Layton, late of the Cygmet, Brisbane of Larme, loung of Hydra, and Oake of Ferrel all posted. Capt. Morell of Tortoise is to be superseded by Capt. Hatton as Post-Captain. The Penclope is coming out to be Flagship to Commodore Hotham, who is made a Commodore of the first class and Conmander-in-chicf. Cant. Ilenry. Wells Gifford is the captain of the Penelope, so that Courts-martial wall be held on the station.

Commander Morell takes command of the Mydra, and his fanily. go home in her. The Grappler is expected daily with Capt. IIuti on board.

Sir Charles Hutton has improved many things on this island, which adds very much to comfor: of the cruisers Eurydice sails in evening for Cape in relieve Comivay. Hydra is also here refitting. Devastation has gone the round of the station, taking the northern division first and working round to the south to St. Helena, liserefore will probably be at St. Helens in Marcls. Puntaloon goes to liest Indics.

This gives an idea of the state of shipping in the days of St. Ifelenas prosperity.

\section{VICE-ADMIRALTY COURT. $181 \%$ Felruary', 1817.}

Thursclay, I8th February, 1847.-Qucen versus Brazilian Brigantine Felina. Jose Antonio Cordeiro, Master. This vessel was seized by F. F. Birch, Fisq., Commander of H.MI.S Hatemeitch, for being equipped for and engaged in tlse African slave tracle, and arrived at this colony for adjudication under charge of Mr. M'Clune, Master's Assistant of the Wateruitch.

Tlie prosecution was conducted by Mr. Gicleon, the Proctor for the captors, and being undefended, the vessel was condenned upon the usual affidavits, under the 8 th and 9 th Victoria, cap. 122, and ordered to be broken up and sold.

Queen v. Brazilian Brigantine Rolla. Joze Gregoria Pereira, Master. Seized by H. Charls, Fsq., Commancler of H.MI S. Sigr.

This was an undefended case. The Rolla arrived at this port the 
27th of last October, in charge of Lieut. Rainier. The prosecution was conducted by Mr. Solomon, Proctor for the captor, and the defence by Mr. Fowler. The proceedings were by plea and proof, and the voluminous nature of those proceedings, consisting of libel, answers, examinations of witnesses, survey translations of documents, etc., had necessarily protracted the case until now.

The judge decreed the vessel to be condemned under the provisions of the 8th and $9^{\text {th }}$ Victoria, cap, 122. Mr. Fowler intimated the probability of the decision being appealed against.

Within the last few days we have had at anchor in these roads four steamers, and a fifth which passed through the harbour. One of them is H.M. steam frigate Penelope, Commodore Sir Charles Hotham, who arrived on Monday afternoon, the 5th April. This vessel has had the good fortune to capture three prizes since the 2oth ult., one of them having 320 negroes on board, another of the three being captured the afternoon before his arrival here.

In the St. Helena Gazctte of I846 I found a description by Captain C. A. Kellett of a beautiful Chinese junk, the Keying, which put into St. Helena. She does not appear to have been in any way connected with the slave trade, still I venture to think an account of her here will be interesting, and not out of place :-

The junk Keying left China December 6th, I 846 ; arrived at St. Helena I 7 th April, I847; having had very light winds nearly the whole voyage, having been at anchor six weeks in the Java Sea, and Sunda Straits, with light southerly and south-west winds. Off the Mauritius experienced some very lieavy weather on the 22nd and 23rd March, but found her to be a most beautiful sea boat, and easy, never having shipped a drop of water since leaving China, or leaking. Her masts and rudder are of immense size and weight, being made of iron-wood, her rudder is hung to three large ropes, and drawn into her stern by two others, going underneath her bottom and coming over the bows, and when the rudder is down draws 23 feet, but when hoisted only i 3 feet. It sometimes takes twenty men to steer her ; but in fine weather, running before the wind, she goes so steady that the tiller rarely requires to be touched, and then two men can steer her. She is built in compartments, having fifteen, several of which are watertight; she has a main deck, raised quarter-deck, two poops and a raised forecastle, with a high verandah above that again; her main deck is arched. Her anchors are made of wood, and the shanks about 30 feet long. The cables are made of bamboo, the ropes made of bamboo, rattan and grass; she has three water tanks built on her decks; her sails reef themselves by lowering the halyards, so that one man to each mast, at the halyards, can either reef the sail or take it in in a minute; her stern and bows are open, but she is so very buoyant that she never takes in any water at either end. Her main cabin or saloon is 30 feet long, 25 feet wide, and i 2 feet high, painted with various birds, beasts, etc. She has 
also six small cabins on the first poop, with the joss house in the centre, in which a light is constantly kept burning. Her stern is 32 feet high of the water.

Her Majesty's steam Irigate Penclope 'H. W. Giffard, Esq., captain,' bearing the broad penmant of Commodore Sir Charles Hotham, K.C.B., Commander-in-Chief of the squadron on the West Coast of Africa, arrived in these Roads on Monday, 5 th inst., with three prizes in company, viz.:-

The Brazilian felucca Saron, captured on the isth March, 1847. The schooner, name and nation unknown, of 52 tons, with 317 slaves, captured on 30 th March, 18.47 , and Brazalian schooner Joanito, captured on fth April, 1847 , which vessels beuring 315 surviving slaves were condenned in the Vice-Adniralty Court on Thursday, 2nd instant.

The Brazilian schooner Jupuler, captured by H..11. sloop Filying Fish, on joth March, 1847 , arrived on the Gth instant under the charge of Mr. Simpson, Midshipman, this was also condemned on the azd instant ; and the felucca, name and nation unknown, captured by the same cruiser on the $17 t_{1} \lambda$ pril, 1846 , and run on shore by the crew of the vessel, was also pronounced liable to condemnation by His Honour the Judge.

\section{Slave Sieamer.}

Information has just been received that a large black steamer, brig-rigged mounted with a large traversing gun on her top-gallant forecastle, was seen in the River Congo by the boats of H.M.S. Siren.

On the boats nearing her, with a view to boarding, a shot was fired across the steamer's bow, which she returned with round and grape from her pivot gun on the forecastle, and another on her starboard quarter, but showed no colours; and although a quick tire was kept up from the boats, and every exertion made to get alongside, it was without success, owing to the steamer's great speed. The boats had the satisfaction, however, of secing that part of her starboard paddle-box and fore-rigging were shot away ; the speed of the steamer gave her cvery advantage of choosing her position, as it enabled her to direct lier fire on the pinnace from her sternquarter, and forecastle gun, with the greatest precision. The ammunition in the boats being expended, and the pinnace's gun liaving several times capsized from the boat's pitching, it was found inpossible to board her, and therefore it was decmed hopeless to continue the chase; the boats then stood in for the shore, under a heavy fire which the steamer continued to keep up while she was going down the river at full speed. The gun on the steamer's forecastle was a 24-pounder. Grape shot passed through the ensign, and two oars were shot away. The men had been forty-six hours on their oars. The pinnace was commanded by Senior Lieut. Jackson of the Siren, in which was Mr. J. W. Lowe, Master of H.MI.S. Hound. The cool and determined manner in which the officers and men conducted the affair descrves the greatest praise. 


\section{Vice-ADMiralty COURT. \\ 4 th September, I 848.}

In the Vice-Admiralty Court of this Colony a case has been adjudicated, which for some time past has been contested. From the unusual number of persons present, on judgment being pronounced by His Honour William Wilde, Esquire, the Judge of the Court, on Monday last, the $4^{\text {th }}$ inst., it seemed to have excited very general interest.

This was the case of a Brazilian schooner named the Bella Maria, taken by Her Majesty's brigantine Kestrel, commanded by Lieut. Baker, and sent to the Colony for adjudication, as engaged in the slave trade. The vessel, by the affidavit of Mr. Winnicott, the Prize Officer in charge, appeared to have been detained immediately after she had left the harbour of Rio de Janeiro, at a distance of about I 4 miles from Santa Crux. She was fitted and provided with all the equipments, etc., usually found on vessels engaged in the transport of negroes from the African coast, having a slave-deck laid, a larger number of shackles, rice, farina, beans, and jerked beef, than could possibly have been requisite for the consumption of her crew ; a number of mess tins and kids, large boilers and other articles employed in that trade. A monition was therefore issued citing the Master to appear and show cause why the vessel should not be declared to be subject to forfeiture to her Majesty, upon which a claim by the Master on behalf of the Owner, with an affidavit in support thereof, was filed and MIr. Proctor N. Solomon was retained to defend the vessel. The points on which the defence rested were four :-

Ist. That the vessel when taken was without the jurisdiction of the Courts.

2ndly. That the authority under which the Seizor acted was not valid.

3rdly. That the vessel was not charged with what alone she was subject to confiscation for, that of being engaged in the African Slave Trade; and

4 thly. That she was not engaged therein.

The first and last of these points were the only material ones, the other two having been merely technical objections as to whether the slave trade and the African slave trade were, in this case, to be considered as one; the treaty under which Brazilian vessels are seized extending only to the African slave trade, whil ein the authority given by the Admiralty to Lieut. Baker to seize, and the charge made against the vessel, the word African was omitted.

The Queen's Proctor, Mr. Knipe, conducted the suit on the part of the Seizor. The following is a very brief and imperfect sketch of the clear and elaborate judgment delivered by Judge Wilde on decreeing the condemnation of the vessel. His Honour, after going through the evidence contained in affidavits filed by the Counsel on the day of final hearing, proceeded in the first instance to detail the reasons which had induced him to decide that the Bella Maria was engaged in the slave trade. This point he considered most 
clearly proved by the equipment of the vessel, before detailed; added to her having had a large quantity of arms and ammunition, and a greater number of men on board than was necessary to navigate a vessel of her size. He, however, remarked that had it been the first case of a slaver brought before him for adjudication he should have felt great difficulty in deciding that a vessel taken on the southeast coast of Amcrica, within a few miles of her port of regisiry, and ostensibly bound as appeared by her papers, as was the case of the Bella Maria, to Macalic, (a port about 150 miles to the northward of Rio de Janciro) was, esen though fully equipped in the manner described, engaged in the African slave trade, but that after his experience of several years as judge, during which time a number of Brazilian vessels had been condemned in this Court, fitted out in the same manner, and as appeared by an affdavit filed in this cause, fourteen since the ist of January this year, four of them with slaves on board, and taken on the coast of Africa, though by their papers they appeared to have cleared out from Rio de Janciro for the very port in question-the port of Macahe-he thought very little faith could be placed on such papers; and therefore, since he knew of no other slave trade than that of African, (at least in this part of the world), he was convinced that the Belle Maria was intended for the transport of negroes from that coast, and lsaving actually sailed on her destined voyage was when seized engaged in that trade. As to the question of the jurisdiction of the Court, the vessel having been scized within so short a distance of her own territory, llis Honour regretted that no precise calculation should have becn made of the exact position of the vessel at the time of scizure. In the affidavit of Mr. Winnicott, supported by that of a seaman of the liestrel, it was laid down as between of and 5 miles, whilst in thest of the Master of the Bella Maria, it was stated to have been made within 2 iniles of the island of Raza, lying off the mouth of the Rio harbour. By reference to the extract from the log of the liestrel, aided by data taken from Mr. Winnicolt's affidasit, His Honour remarked he was of opinion the distance was slightly within 3 miles of Raza; but as the balance of evidence was in favour of its having becu + or 5 miles, he considered himself bound to decide that the Bella Maria was captured on the high seas His Honour staned his opinion, however, that it was a point with which this Court had mothing to do, as the Act of Parliament authorized Vice-Admiralty Courts to adjudicate upon vessels which had been scized. Had any violation of territory been committed it would have been matter for settlement between the two Governments. The technical objections were overruled, as in no way fatal to the validity of cither Licut. Bakcr's authority to scize Brazilian vessels, or of any of the procecdings which took place in the cause. His Honour accordingly pronounced for the condemnation and demolition of the vessel.

Notice of appeal was immediately entered by the claimants Proctor; but in consequence of his inability to give the necessary bail to secure the costs of such appeal, the ressel will be broken up and sold, as decrecd. 


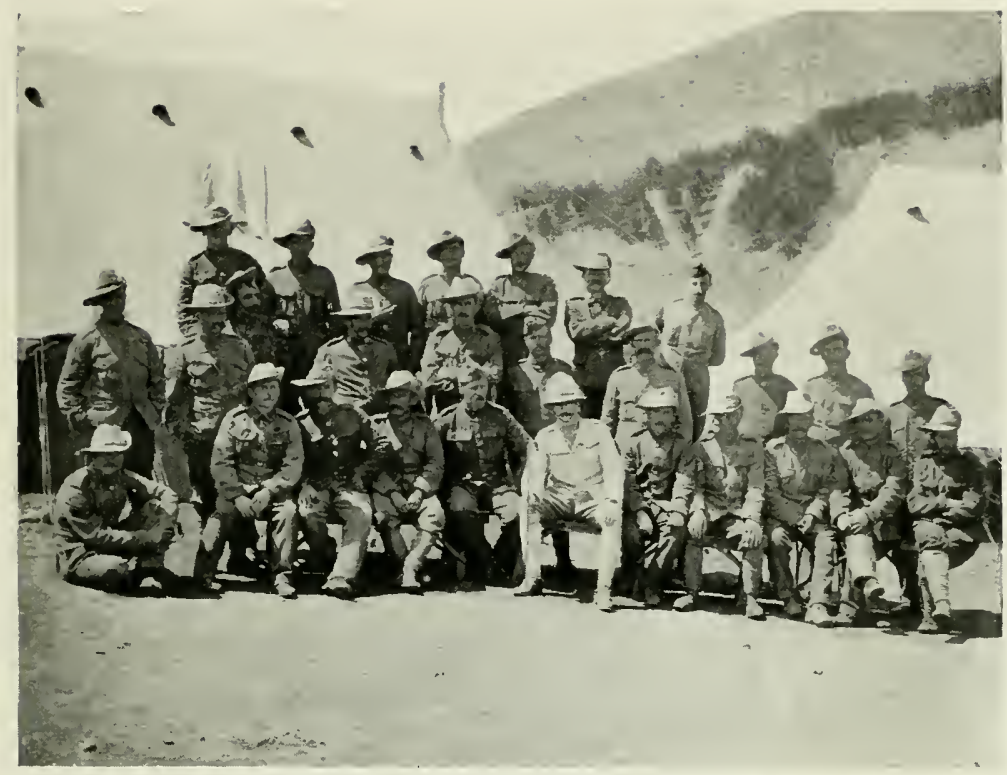

Sergeants, 3Rd Buffs, Broadbottom Camp.

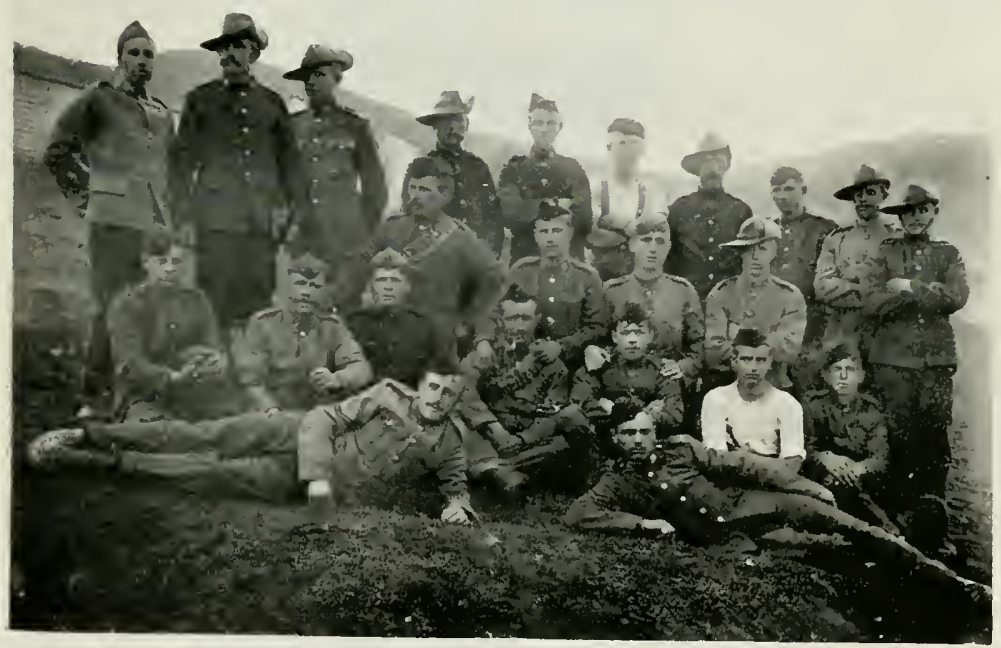

Grour rrom 3RU BuFf, BroADbotton CaMP. 

Space will not permit of further accounts, although they are full of interest.

The foreign coins current in St. Helena in I844 were the gold doubloon of Spain, Mexico or South America ( $£ 34$ s.), and the silver dollar of Spain, Mexico or South America (4s. $2 d$.).

From the records we find that, although payments to the military and civilian servants were expressed in sterling, yet sterling coin did not circulate.

In the seventeentl century the commercial coin was the Spanish dollar (or piece of eight). This was rated at $6 s$., but copper money and pieces of eight to the value of $f 400$ were brought from England in 1673 , though dollars or pieces of eight must have remained in general use, for we read:-

Fines for non-attendance at Council were: absence, $\frac{1}{2}$ dollar; second absence, I dollar; third time, $I_{2}^{\frac{1}{2}}$ dollars.

In I678 a fine of 4 dollars was imposed for picking lemons, and of 2 dollars for throwing rocks into the sea ; and in 1707 a fine of 6 dollars was paid by Mrs. Clavering to escape being "duckt in the sea at the Crane for scandalizing the whole island."

In 1683 figures ("two setts"), engraved in iron from I to Io, were sent out to stamp copper money; these stamped coppers were $I d$. the ounce. Obstacles arose concerning this copper, and orders were issued in 1687 that not more than half of any debt should be paid in such currency, the remainder was to be paid in coined money. In I708 we find that "Crowns and Spanish pieces of eight were to pass at $5 s$. instead of $6 s$.," but "they may be paid into the store for old debts at $6 s . "$

The reduction of the value from $6 s$. to $5 s$. produced a disastrous effect on the currency, for in November, I708, it was recorded that "Cash is all gone from the island: in selling $£ 800$ worth of stores only 7 dollars was received in ready money." The explanation given in I716 is that dollars (being worth 20 per cent. more than $5 \mathrm{~s}$. in Madras) could not be kept in the island. After this the colony was in considerable straits for a circulating medium, and in $\mathrm{I} 7 \mathrm{I} 3$ it petitioned for one whole ton of Chinese money, called "Petiese," which would be of advantage here, of the value of farthings; or allowing them to be passed at six for one 
penny, there would be a profit of roo per cent. Then again, the island authorities suggested that copper farthings should be sent out to pass as pence (this being customary in some parts of the IVest Indies). The pice of Madras were not liked by the people because they were badly shaped. They were worth three to the penny, and were very heavy. In I7I5 petition was again made for English half-pence and farthings, which were sent. We know this, for in 1716 small holes were drilled in "dollars and farthings to keep them on the island." Paper money was in use in I750; there were bank bills and cash notes, of the value of $40 s$., 20s., 5s., and 2s. 6 d.

In 1717 the amount of the Government balance was £700. E4So was in these cash bills, and the remainder was $£$ Ioo in "bits," or Spanish rials or reals, valued at $7 \frac{1}{2} d$. in I750. There were also double reals and half reals.

floo was in fanams or Phenams in $17+2$, valued at $3 d$; and $£ 100$ in copper pice. July 1740 show's a great improvement in circulating medium.

The items then in the Government balance were as under :-

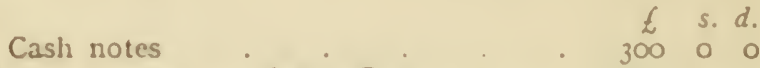

$$
\begin{aligned}
& \text { Pagodas. 6,413 (a) 9/- . } 2885170
\end{aligned}
$$

(These were the standard gold coins of Madras.

Dollars . 1,140 (a) $5 /$. 28500

Venetians $\quad 1,234$ (a) 10/- . 61700

(Venetian sequin, or chicken, e.g. Chicks of India.)

Madras Rupees 1,525 @ (a) 2/3. 171 i1 3

Ducatoons . 146 (a) 6/- . 43160

Small money . . . . 0410

$$
64,30391
$$

Moriscoes are first mentioned in $\mathrm{I} 742$; also Half St. Thomas and gold gubbers, rechoned at $6 s$. each. There were also gold rupees at $30 s$, and Dudoes, Is. $2 d$. French copper money came into use about 1750 , valued at $2 d$. each.

In 1750 the Govermment balance in treasury is given in pieces of gold bullion :-

Venetians.

Gold rupees.

Pagodas.

Dollars.
Ryals.

French pieces, and

Cash notes. 
In I760 gold rupees and ryals are not mentioned, and no alteration is mentioned in value of silver, for, after this, the treasury balance is written only as "Specie" and "Cash notes."

But St. Helena was in the direct homeward track of vessels from India and, as many Anglo-Indians settled here, it formed, although so far off, a part of the Indian currency area, and the gold coins of the island were pagodas and Venetians. During the exile here of Napoleon, naturally French money was current. Still Indian money, especially the pagoda, was the chief circulating medium.

In I8I9 the coins were rated as under:

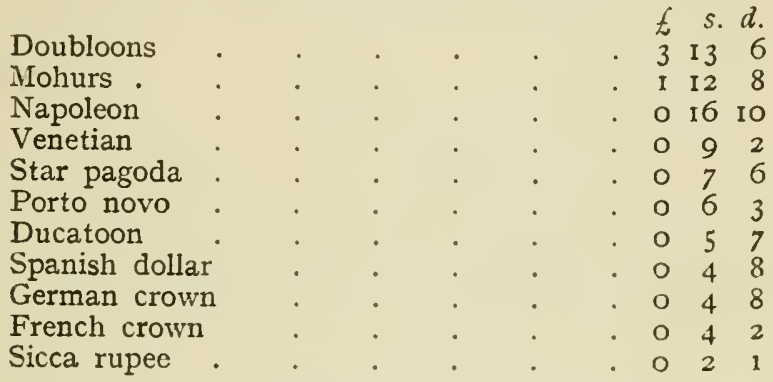

And to prevent their being sent off the island they were taken by the treasury in payment for goods, etc., at 7 per cent. above their prices. But even this did not avail, for in 1818 the Company had to import $£ 50,000$ in dollars. In I82I the Company struck a copper half-penny, and conttemplated, it is thought, a silver coinage, for patterns of a half-crown of 1823 are known, and of a shilling of 1833 . Small coin was scarce, and all small copper coins, even farthings, were counted as halfpence, which latter coin is still the St. Helena minimum.

In I 823 values of coinage were determined by the Governor and Council as under :-

Spanish and American dollars

(The Maria Therese dollar still in use

Doubloons in Africa and Abyssinia.)

Jose Portuguese

(With star) Bengal mohurs Bombay and other mohurs

ts. $d$. - 0 46

3 io 6

- $\begin{array}{lll}1 & 15 & 3\end{array}$

I II 6

I 80 
Moidures

Louis d'or and Napolcons

Venctians

Star pagodas.

Porto noro pagodas $\cdot .4059$

American dollars, German and French crowns $0+0$

Bengal sicca rupees

Bombay and all other rupees . $\quad 0$. 1 ro

Ducatoons

British 3/- tokens

0 54

$\begin{array}{lll}0 & 2 & 8\end{array}$

Johannes $4 /$ - pieces . . 039

Dutch and Ceylon guilders and Rix dollars . $0 \begin{array}{lll}1 & 6\end{array}$

Colonial pieces

(The anchor $\frac{1}{2}$-dollar coined in 1822 for Mauritius)

All 10d. pieces

Old English and all other slillings

Old English and all other sixpences

$\begin{array}{lll}0 & 0 & 0 \\ 0 & 0 & 9 \\ 0 & 0 & 4\end{array}$

We read in the St. Helena record that no change was made in the rating up to 1829 , but in 1830 the Spanish dollar was again reduced to $4 s .2 d$. and the doubloon to $\{3$. 5 . This was the actual sterling value clsewhere, and in this year the ratings fixed by the Governor and Council were :-

\begin{tabular}{|c|c|}
\hline Doubloons & \\
\hline Jose & \\
\hline Witly star) Bcugal & \\
\hline $\begin{array}{l}\text { mohurs } \\
\text { Other inohurs: }\end{array}$ & 11 \\
\hline $\begin{array}{l}\text { Other inohurs. } \\
\text { Moidores }\end{array}$ & 1 \\
\hline $\begin{array}{l}\text { Moidores } \\
\text { Napolcons and Louis }\end{array}$ & \\
\hline d'or & 0 \\
\hline
\end{tabular}

t s. d.

Velletians $0 \quad 0$, o 0

Star pagodas. $\quad 070$

l'orto novo pagodas $0 \quad 54$

Ducatoons a o 52

i-guilder pieces $0+6$

Dollars Spanish and American . $04=$

Dollars, United States

5-franc piece.

L s. d.

Half-star pagodas

Colonial pieces (English coined

Sicca rupees (Star)

Other rupecs

Dutch guilders . . . . 016

2 -franc pieces. . . . 0 1 10

This rate was in effect in I834, when the Imperial Government took charge of the island. In name the currency was 
sterling, but when treasury money was handed over by the Company's officers in March, I836, the whole of it was in Spanish dollars. It was supposed that this was managed in order to get the $2 d$. extra on each dollar, as in the following proclamation :-

As the correct value of the dollar (4s. 2d.) clashed with the incorrect (Imp) rating, and as other ratings were also at variance with existing Treasury regulations for military pay, The Secretary of State ordered, in October, I835, that-

All receipts and payments on behalf of Government should be in British currency, or in foreign coins at regulated military rate. This led to the retrograde proclamation by the Governor, February, I 836 , when

GoLD

Doubloons were valued

\begin{tabular}{|c|c|c|}
\hline & & \\
\hline Jose Portuguese & & \\
\hline Bengal mohurs (star) & & \\
\hline Other mohurs & & \\
\hline oidores & I & \\
\hline apoleons and Louis & & \\
\hline & & \\
\hline tians & 0 & \\
\hline agodas & 0 & 7 \\
\hline ovo & o & \\
\hline
\end{tabular}

Silver

Ducatoons @ - 0 3-guilder pieces $\quad$. 0048 Dollars . . o 44 Half-star pagodas . 030 Colonial pieces (English coined). $\quad \begin{array}{llll}0 & 2 & 4\end{array}$ Sicca Rupee star : $0 \begin{array}{lll}2 & \text { I }\end{array}$ Other rupees . . I II 0 Dutch guilders $\quad 0$ I 6 5-Franc pieces $\quad 0 \quad 4 \quad 0$ Franc . . 0 o 10

There was such a variety of coin on the island that merchants, when applying to the commissariat for bills on London, seldom knew what coins they had, and Ducatoons, rupees, francs, etc., etc., etc., were all mingled. They were many short of the right weight even, but that did not prevent their circulation.

In I843 a proclamation was issued by Order in Council that the dollar was to be $4 s .2 d$., the doubloons $64 s$., and all other non-sterling coins to be de-monetized. These were exchanged for British silver by the commissariat officer to the amount of nearly $f_{12}, 000$, the money being shipped to England and sold as bullion.

Dollars still at $4 s .2 d$. here were valued at $3 s .8 d$. at the Cape. So they began to pour into St. Helena. This caused an ordinance to be passed that the dollar should be valued at $4 s .2 d$. for only three days after date. Consequently the dollars were all paid in. And now it was 
decided that the doubloon was unnecessary. Trade relations were chiefly with England and the Cape, and a 40 s. limit was imposed on silver, with Is. limit on bronze, and the gold, silver and bronze coins of England are now the legal tender of the Colony.

There are no banks except the Government, and no paper money, so the treasury has its money in gold, and the Colonial Government issues bills at $5 s$. $8 d$. and I per cent. instead of P.O.O. as formerly, which could only be obtained for $£$ IO.

Money orders may, however, still be obtained. No foreign coins are in circulation; if we except the time when foreign gunboats are at anchor or the months when whalers are in port. During the latter time American money circulates. but it quickly disappears when the vessels leave port.

\section{Goveriors of St. Helexa.}

From the first possession by the English East India Company, 1657, with the dates on which they assumed the Government.

\section{Dutton}

Stringer

Swallow

Concy

Bennett

Beale

The island taken by the Dutch 1672 "Dyke" is supposed to be the name of the Dutch officer who held the Government until the island was retaken by Sir Richard Munden 7 th May, 1673 .

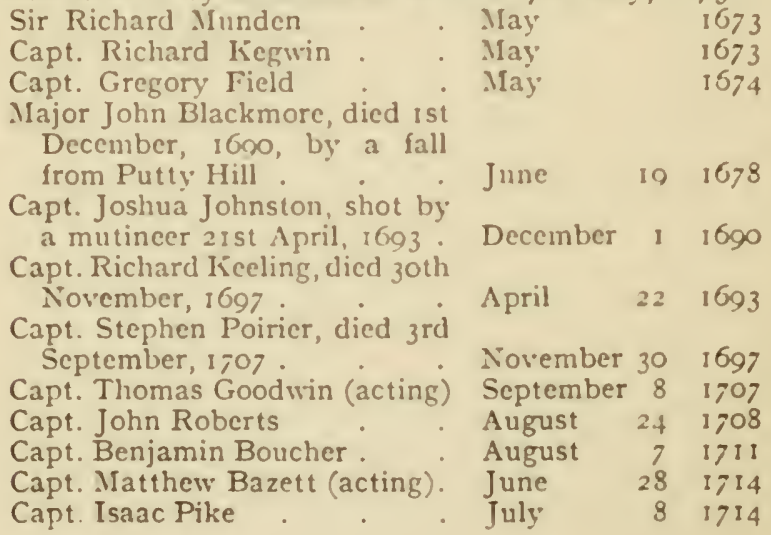


Edw. Johnson, Esq., died I6th February, I 723 . . Edw. Byfield, Esq., (acting) . Capt. John Smith. (a second time)

Capt. Isaac Pike (a second time) died 28th July, I738

John Goodwin, Esq., died August, I 740 •

Duke Crisp, Esq. (acting)

Robert Jenkins, Esq. ${ }_{\text {Major Thomas Lambert, died }}$ gth July, 1742 .

George G. Powell, Esq. (acting)

Colonel Daird Dunbar .

Charles Hutchinson, Esq. .

John Shottowe, Esq. . .

Daniel Corneille, Esq
Colonel Robert Brooke :

Lieut.-Colonel Francis Bobson (acting) . . .

Colonel Robert Patton . .

Lieut.-Col. William Lane (acting)

Major-General Alexander Beatson

Colonel Mark Wilks

Lieut.-General Sir Hudson

Lowe, K.C.B. B
Thomas Henry Brooke, Esq. (acting) $\cdot$ Brigadier-General Alexander Walker . • .

Thomas Henry Brooke, Essq. (a second time acting)

Brigadier-General Charles Dallas

Major-General George Middlemore, C.B. .

Colonel Hamelin Trelawney (died 3rd May, I 846)

Lieut.-Colonel G. C. Fraser (acting)

Lieut.-Colonel J. Ross (acting) Major-General Sir Patrick Ross, G.C.M.G., K.C.B., died 28 th August, I 850

$\begin{array}{lll}\text { June } & \text { I3 } & \text { 1719 } \\ \text { February } & \text { I6 } & \text { 1723 } \\ \text { May } & 28 & \text { I723 }\end{array}$

February $26 \quad 1727$

March $24 \quad$ I73I

July $\quad 28 \quad$ I778

August I740

May

$\begin{array}{lll}\text { March } \quad 22 & 1742\end{array}$

$\begin{array}{lll}\text { July } & 20 & 1742\end{array}$

March II I744

March I4 I747

March Io I764

$\begin{array}{lll}\text { July } & \text { I5 } & \text { I7 } 782\end{array}$

$\begin{array}{lll}\text { June } & 22 & \text { I787 }\end{array}$

July I3 I8OI

March II I802

$\begin{array}{lll}\text { July } & \mathbf{I} 3 & \mathrm{I} 807\end{array}$

$\begin{array}{lll}\text { July } \quad 4 & \text { I } 808\end{array}$

August I2 I8I3

August I4 I8I6

July $25 \quad$ I 82 I

March II I823

April I4 I828

$\begin{array}{lll}\text { April } & 29 & \text { I } 828\end{array}$

February $24 \quad$ I 836

January $\quad 6 \quad \mathrm{I} 842$

May $\quad 4 \quad I 846$

July $\quad$ I $8 \quad 1846$

November $23 \quad$ I 846

Lieut.-Colonel Clarke (acting) . August $28 \quad$ I850

Col. Sir Thomas Gore Brown, K.C.M.G., C.B. • • • July I8 I85 I Col. H. N. Vigors (acting) December I5 I854 
Sir E. H. Drummond Hay, Kt. October $10 \quad 1856$

Admiral Sir Cliarles Elliot, K.C.B.

Hudson Ralph Janisch (acting)

Vicc-Admiral C. G. E. Patcy

Hudson Ralph Janisch, Esq., C.MI.G.

July $\quad 3 \quad 1863$

January $29 \quad 1870$

Fcbruary +1870

Lieut.-Colonel Grant Blume, R. F. (acting)

V. Gray Wilson (acting).

R. L. Antrobus (acting)

W. Grey Wilson, C.MI.G. . 1890

Robert Armitage Sterndale, C.M.G.

Licut.-Col. Julian Penrhyn

June

$7 \quad 1897$

Evans (acting during absence of Governor)

Colonel Price, C.M.G. (acting during absence and after death of Governor Sterndale, October 3, 1902).

Licut.-Col. Gallway. C.M.G.,
D.S.O.
- $=$ :
November

C.M.G.,

1902

1901

Robert Armitage Sternclale, C.Ml.G., died of lieart failure on the 3rd of October, 1902, at the age of sixty-three.

He saw service in India during the .Iutiny, and afterwards entered the Indian Civil Service. From December, 1895, to July, 1896 , he administered the Government of St. Helena during the absence of WV. Grey Wilson, Esq. Appointed Governor and Commander-inChief in 1897, he was in England on sick leave at the time of his death. He was the author of several books. Mammals of India, An Aghan Kinife, ctc.

\section{CIVIL ESTABLISHMENT, 1902-1903.}

1902. Governor and Commander-in-Chief, also Colonial Secretary,

His Ex. Robert A. Sterndale (deceased), C.M.G.

1903. Governor and Commander-in-Chief, also Colonial Secretary, His Ex. H. L. Gallwey, C.M.G., D.S.O.

Members of Council :-

Thomas Julian Penhryn Evans, Senior Military Officer in command of troops (succeeded by Col. Price).

Honble. Col. Price, O.C.T. (During August, September, and October acting Governor, during absence and after death of H.E. Governor Sterndale.)

Honble. G. H. Mosse, sworn in Scptember, 1897.

Honble. H. Borell, sworn in Angust, 1898 . 


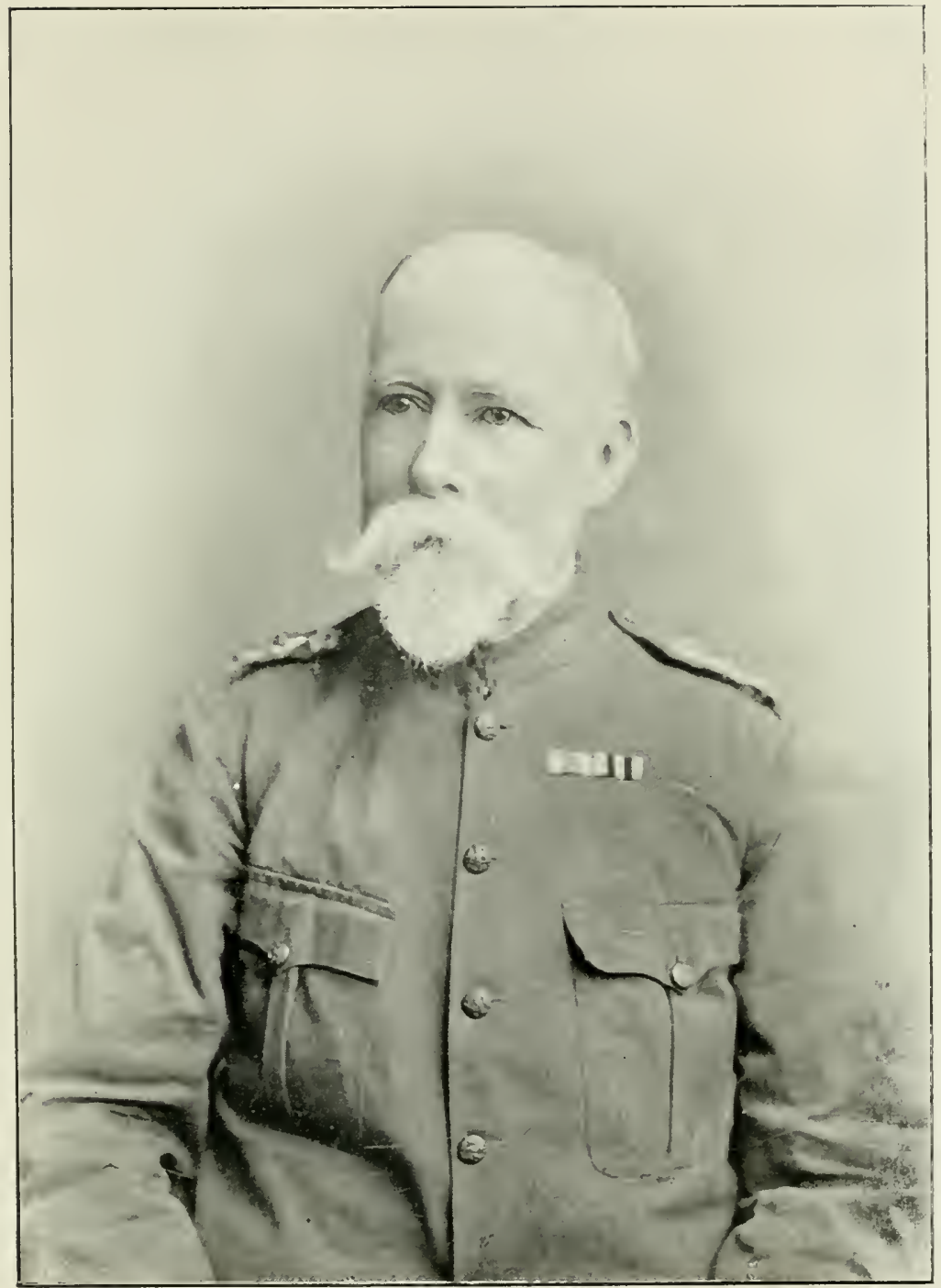

The late Robert Armitage Stervidale, C.M.G.

(Governor of st. Helena from June, 1897, to October, xgo2.) 



\section{Secretarial Department.}

I903.

Chief Clerk . . . E. H. Merivale Drury, Barrister-at-Law.

1902.

Chief Clerk . . . R. R. Bruce, Esq.

2nd Clerk . . . A. Hands, Esq.

Harbour Master . . R. R. Bruce, Esq.

Receiver General's Department.

Superintendent

J. Homagee, Esq.

and Officer . . . S. Cullen.

Landing Waiter . J. Boyd.

Assistant Landing Waiter. T. Clayton.

Surveyor and Colonial Engineer Department.

Colonial Engineer . . His Excellency the Governor.

Clerk of Worlss . . Mr. T. Broadway.

Naval Agent . . . R. R. Bruce, Esq.

Post Office.

Postmaster . . . Mr. R. T. Bruce.

Clerk . . . . Mr. Edwin Grant.

Medical Department.

Colonial Surgeon . . Colonel Mosse, R.A.M.C.

Sanitary Inspector . . Mr. C. Cottrell.

Lady Superintendent of Hospital . . Miss Williams.

Nurse . . . . Miss F. Lindon Saunders.

Nurse . . . . Miss Wrigley.

Nurse . . . . Miss Dando.

\section{REgISTRAR'S OFFICE.}

Registrar and Shipping Master . Mr. C. Bruce.

Emigration Agent . . Mr. R. R. Bruce.

Government Schools.

Town Boys . . . Mr. Brady.

Town Girls . . . Miss Short.

Town Infants. . . Miss Harris.

Country School . . Mr. J. A. Stover.

Judicial Establishment.

Chief Justice (deceased) . His Excellency R. A. Stern-

Chief Prosecutor, Clerk of the Peace. . J. Homagee, Esq.

Sheriff . . . . R. G. Short, Esq.

Coroner . . W. A. Thorpe, Esq.

Colonial Chaplain . . Rev. Canon Porter. 


\section{Police Court.}

Police Magistrate and Clerk of Summary Court . J. Homagee, Esq. Inspector of Police. . Mr. C. Cottrell. Policemen V. Kennedy, J. Smith, A. Hall, N. Constantine, E. Fagan, J. Moyee, J. Thomas, G. Sylvestre.

COURT OF COMIISSIONERS.

\section{SHERIFT'S OFFICE.}

Sheriff.

Justices of the Peace

GIOL.

Gaoler

C. Cottrell.

Matron

A. Cottrell.

\section{SAITIS BAXK.}

Manager . . J. llomagee, Esq.

The island forms one Diocese under Bishop Holmes.

\section{CHURCHES.}

A.NGLICA.N.

St. James', Jamestown

St. John's,

St. Paul's, Western Division
Priest in Charge.

Canon Porter.

Rer. H. Gibbons.

St. Matthew's, Eastern

Dirision . Canon Hands.

Roman Catiolic.

Military Chapel, Jamestown Rer. Father Daine.

\section{BAPTIST.}

Chapel Jamestown . Kinollecombe

". Sandy Bay.

". High Peak, West.

The Eastern Telegraph Company laid their cable between St.

Helena and the Cape . November 24, 1899.

Between St. Helena and Ascension . . December 15, 1899.

Tariff Europe. $\cdot 3 /$-(per word).

"East Coast of Africa $6 / 3$,

". South Coast of Africa $2 / 2$

". Ascension . . I/2

Government messages half rate 


\section{LOCAL INSTITUTIONS, ETC.}

Widows' ANd ORPhans' Fund or Social Society.

Established, November I8, 1845 .

Objects.-To raise from time to time by subscriptions among the members or by voluntary contributions, or by donations, a stock or fund for the benefit of the widows and orphans of the members and a Burial Allowance for the members. The Society is under the management of a Committee, consisting of a President, Treasurer, Secretary, and four other members, three of whom retire annually by rotation, but are eligible for re-election.

A general meeting to be held quarterly, when the accounts are submitted for inspection.

The anniversary of the Society is held on the I 8 th November, on which occasion the members attend Divine Service.

\section{BENEVOLENT SOCIETY.}

Founded in I8I4.

\begin{tabular}{|c|c|c|}
\hline atron & & His Ex \\
\hline Vice-Patrons & . & $\begin{array}{l}\text { The Honble. Memb } \\
\text { Council. }\end{array}$ \\
\hline President & & The Bishop. \\
\hline Committee & & $\begin{array}{l}\text { Rev. Canon A. Port } \\
\text { Harry Gibbons, } \\
\text { W. Solomon, Mr. } \\
\text { Barker, Mr. G. L }\end{array}$ \\
\hline $\begin{array}{l}\text { Hon. Secreta } \\
\text { surer }\end{array}$ & & 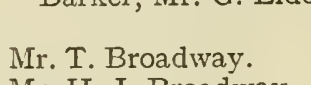 \\
\hline Clerk & & Mr. H. J. Broa \\
\hline $\begin{array}{l}\text { Mistress of } \\
\text { Mistress of }\end{array}$ & $\dot{1}$ & $\begin{array}{l}\text { Miss Burchill. } \\
\text { Miss Barker. }\end{array}$ \\
\hline
\end{tabular}

The capital in the year 1883 was $£ 3,000$ but it is greatly diminished, and is, according to the report issued in IgOI, $£ \mathrm{I}, 887 \mathrm{Os}$. IOd.

\section{PUBLIC MARIET.}

This was opened to the public in May, 1865, under ordinance No. 5 of 1865 .

The Committee of Management is elected at an Annual General Meeting of the inhabitants convened by the Sheriff, and held in the Market each year in the month of May, and is composed of five members, of whom three form a quorum and two retire annually. This Committee has the power to frame Bye-Laws and Regulations for the proper conduct and management of the Market and to impose rents, dues and charges subject to the approval of the Governor. They appoint a market clerk and apportion the stalls, benches, and public space in the market.

\section{LIBRARY.}

The Public Library is in the Government Gardens and contains a number of valuable boolss of reference. Under the present 
control it is well managed and a good supply of periodicals and literature kept up. It is, however, very badly supported by the inhabitants, of whom only ten are yearly subscribers.

There is also a good lending library and reading rooms in connexion with the Pharmacy, Main Street.

\section{HOSPITALS.-ONE CIVIL, ONE IILITARY.}

The Jamestown Civil Hospital is supported by Government, and by a fund placed in charge of trustees by Major Prenderville, late St. Ielena Regiment. In 1860 the sum of $£ 325$ was paid by the above trustees to the Colonial Government for enlarging the female wards of the Hospital, on condition that patients could be admitted by them to the Hospital free of all charge to the extent of 650 dicts annually.

Labourers
Paupers
Seamen
Prenderville Patients
Master mariners and private paticnts,
exclusive of wines and spirits

Rates of Admission.

$1 /$ - per day.

od. per day.

1/- per day.

Frec.

Presest Hospital Stafy.

Miss Williams
Miss Dando
Miss F. I indon Saunders
Miss Wrigley.

Lady Superintendent.

Nurse.

$10 /-$ per day.

"

In 100 i the numbers admitted were :- IIales, 60 ; females, 5.1 .

\section{MILITARY TELEGRAPHS}

Jamestown,

Ladder Hill,

High Knoll,

Prosperous Bay,

Woodlands,

S. IV. Point,

Constructed by the Imperial Gosernment with a contribution of ftoo from the Colonial Government, and worked by the Royal Engineer Department. Sixty-four miles of line, military included.

\section{COMIMON GAOL.}

In 1001. Committed sixty-four, viz. Men, twenty-two. Women, thirty-four. Juveniles, eiglit.

In this goal the sexes are lept separate, and persons placed in separate cells, when practicable. There are three wards, into which open eight cells, all secured. The labour given is, for males, on the Public Works, such as cleaning strects, and sanitary work under Colonial Engineer; for females, cooking, cleaning, washing etc., etc. The profit of their labour is paid into the Colonial Treasurg: 
Cost of the prison in IgOI was $6_{152}$ i $3 s$. II $d$. Prisoners are allowed nine hours sleep, with lighted dormitories, visited at uncertain hours. The chaplain is generally the Vicar of S. James', and prisoners attend divine service on Sundays. Prisoners of Roman Catholic or Dissenting persuasion are allowed their own ministers.

Prisoners on hard labour have full diet.

Prisoners without hard labour a reduced diet, solitary confinement. Rice and water.

No deaths occurred in I90I. Health very good.

AGRICULTURE.

Forty-seven Square Miles.

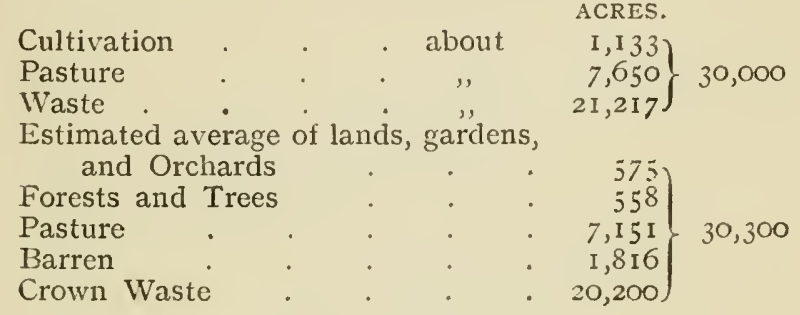

MIASONIC LODGES.-I902.

The St. Helena Lodge, No. 488, E.C.

IV.M.

Bro. Lieut. IV. F. Box.

I.P.M. : Wor. Bro. George Finch.

S.W.

J.W.

Treasurer

Secretary

S.D.

J.D.

D.C.

Organist

I.G.

Steward

Tyler

Bro. Herbert Jameson.

„, Francis N. Reed.

Wor. Bro. T. L. M. Adams.

Bro. Arthur W. Pegge.

IcIntyre.

John MIcCullough.

P. Fellows.

"Major Horniblow.

,W. Kirkdale.

"A. Joshua.

" P. Truebody.

The Old Rock Lodge, No. 9i2, E.C.

W.M.

I.P.M.

S.W.

J.W.

Treasurer

Secretary

Organist
Wor. Bro. A. L. Innes.

Bro. G. T. Craik.

Bro. Lieut. J. McCullough.

R. M. George.

T. Clayton.

A. Godwin.

Maj. F. Horniblow. 


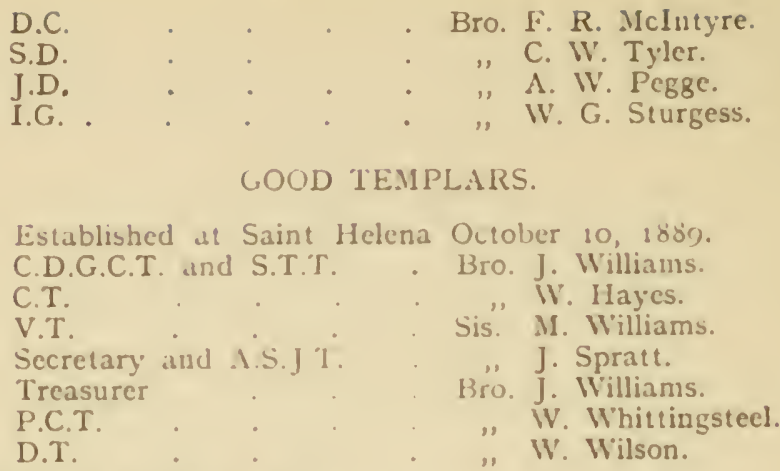

Number of menbers, sixty.

Self-supported by members' subscriptions.

Mectings held twice in every week.

MECHANICS' AND FRIENDI.Y BENEFIT SOCIETY.

Established November 10, 1838 .

Capital, £800.

Committce :-(1902)

President

Mr. T. M. Adams

Secretan

Mr. Jas. Williams

Treasurer

Mr. R. Adams.

Committec-man

Mr. J. Richards.

Mr. T. Le Breton

Mr. T. George.

Number of members, nuety-teven.

Mr. T. Duncan

POOR SOCIETY.

Established August 19, 168 ;

Capital, 25,7837 s. .4d.

President

Committce (1902):-

Secretary

Mr. A. S. Brady.

Treasurer

Mr. F. J. Broadway.

Comnittce-men

Number of members, 780 .

Mr. T. M. Adams.

Mr. Rich.

Mr. W. Spratt.

- Mr. J. E. Watson.

Relief issued yearly is $£ 1$ o.

Burial allowances range from $t_{8}$ to $t^{i} t$ according to term of membership. 


\section{ST. HELENA}

\section{ANCIENT ORDER OF FORESTERS.}

Established at St. Helena December I2, I871.

Chief Ranger

$$
\text { Officers (1902) :- }
$$

Sub. Chief Ranger

Secretary

Treasurer

Senior

Junior

Senior Beadle

Junior

Trustees

,

s)
Bro. Shoesmitl.

A. S. Brady, P.C.R.

T. M. Adams.

Thomas.

J. Rich.

J. Fowler.

M. Bennett.

E. Jameson, P.C.R.

J. E. Watson, P.C.R.

E. J. Warren.

WORKING MEN'S CHRISTIAN ASSOCIATION.

Established February 6, 1873 .

Capital, $£ 663$.

Committee (I9O2) :-

President

- . Mr. WV. Harrison, sen.

Vice-President . . . Mr. J. E. Watson.

Secretary . . . Mr. I. Boyd.

Treasurer . . . MIr. G. Greentree.

Committee men. . . Mr. I. Williams.

Number of members, 492.

- Twelve Stewards.

CHURCH PROVIDENT SOCIETY FOR WOMEN.

Established Narch I6, I878.

Capital, $£ 104$.

Committee (1902) :-

President

Secretary

Rev. Canon Porter.

Treasurer

Mr. A. J. Young.

Committee-n

Mr. A. S. Brady.

. . Mr. T. Bennett.

" . . . Mr. R. Henry.

- Mr. J. George.

Number "of members. 26

. Mr. W. Burton.

CHILDREN'S BENEFIT SOCIETY.

Established December 28, 1887.

Capital, £147 3s. $5 d$.

President

Committee (1902) :-

Secretary

Treasurer

Rev. Canon Porter.

. $\quad \cdot$ Miss E. Short.

. . Mr. J. E. Watson. 
Associates

Number of members, 180 .

Weekly subscription, id. Relief weekly, $2 /$ - each member. Burial allowance, $£ 3$.

\author{
Miss M. Burchill. \\ Miss G. Moss. \\ Miss E. Barker. \\ Mr. T. Clayton. \\ Mr. A. G. Broadway. \\ Mr. J. Sim.
}

\section{POOR RELIEF BOARDS.}

\section{Chairman}

Elected (Easter, 1902):-

"

Overseer of poor

Assistant do.

Medical Officer

Keeper of Asylum

Matron

Matron of Poor House
Mr. H. Solomon.

Mr. H. Jameson.

Mr. E. Thorpe.

S. P. Young.

Mr. T. Bennell.

Mr. J. E. IVatson.

Mr. C. Grant.

L.t.-Col. Mosse, R.A.M.C.

Mr. J. Fowler.

Mrs. J. Fowler.

Miss H. Mortiner.

Nuinber of lunatics, seren.

Number of inmates of Poor llouse, thirty-two.

Supported by Rates levied on Proprictors.

Out-door relicf averages between 225 to 230 per quarter.

Medical attendance and medicines supplicel to all poor people, also burial and hospital treatment.

CONSULS AND CONSULAR AGENTS RESIDENT AT ST. HELENA.

Amcrica, Unitcl States R. P. Pooley, Esq.
Denmark
11. W. Solomon, Esq. (Acting).
France
Germany
L. Norilleau, Esq.
Nictherlands
H. W. Solomon (Acting). Esq.
Portugal
Russia
H. W. Solomon, Esq.
II. W. Solomion, Esq. (Acting).
H. W. Solomon, Esq., Vice-
Spain Consul (Acting).
L. Morilleau, Esq.
Sweden and Norway H. W. Solomon Esq. (Acting).

\section{RATES OF LABOUR.}

Labouring hands, per day, about $2 /-10 \mathrm{~A} / \mathrm{-}$ without food. Mechanics, about $3 /-106 /-$.

Servants from about $£$ 10 to $£ 24$ a year. 


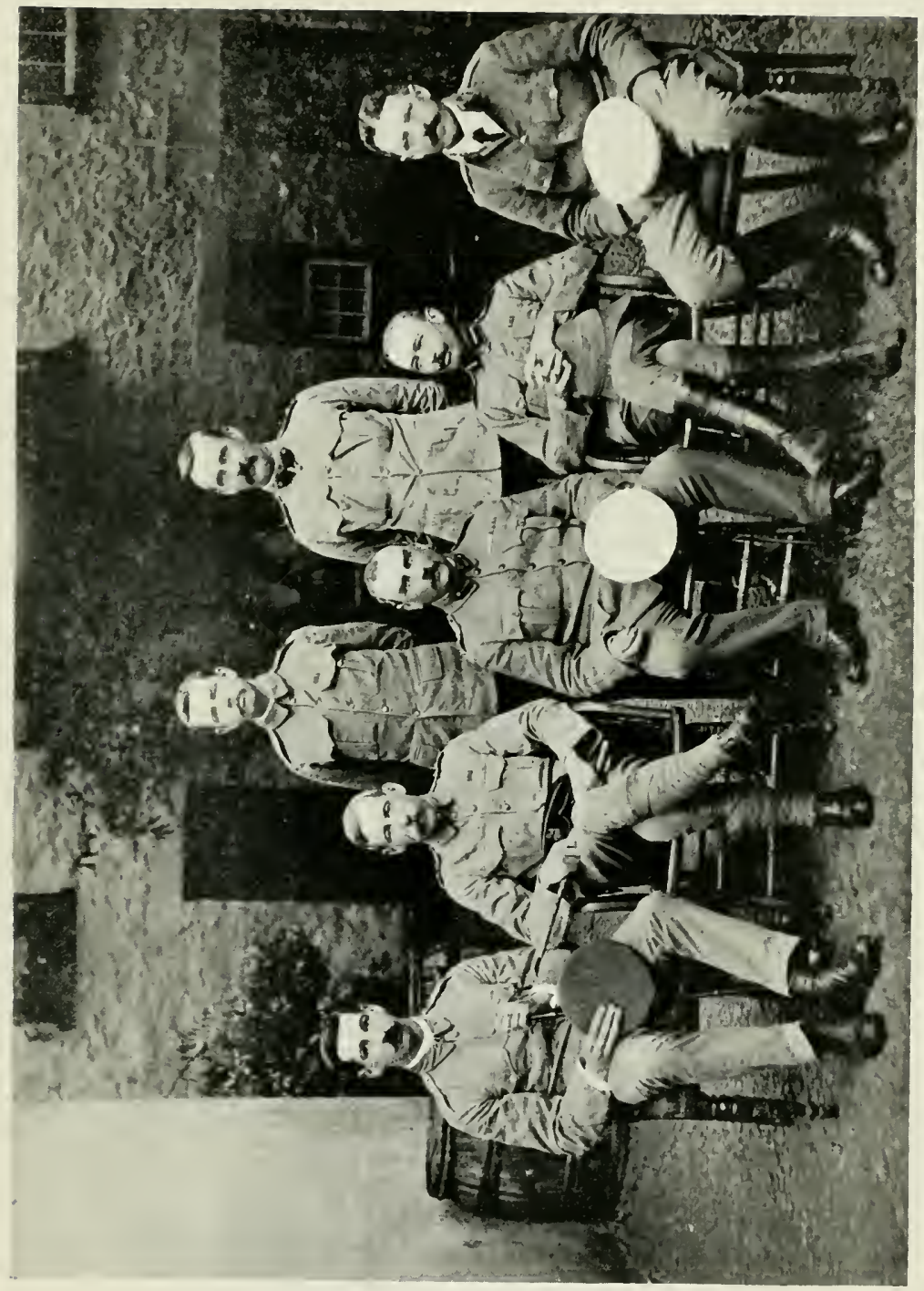

告 



\section{ST. HELENA}

CENSUS TAKEN, APRIL 7, I90I.

MALES. FEMALES. CHILDREN.

Jamestown . $\quad \cdot 687 \quad 881$

Country . . $\quad . \quad 847 \quad$. 927

Garrison : . $\quad 1,428 \quad 35 \quad 69$

Shipping . $\quad 320$

Prisoners of war . . 4,655

Population : 9,850 .

BIRTHS, MARRIAGES AND DEATHS.

Births .

Marriages $\cdot{ }^{\circ} \cdot{ }^{\circ} \quad 129$

Deaths . $\quad . \quad+\quad . \quad+\quad . \quad$ I 25

The number of vessels calling at the port with Cargo during :-

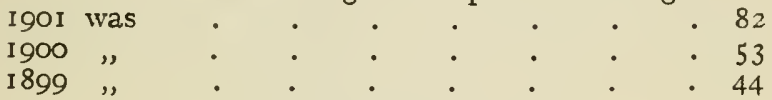

ROADS.

Country, maintained by Imperial Government 60 miles. Town, maintained by Colonial Government, about $2 \frac{1}{2}$ miles.

NEWSPAPER.

"St. Helena Guardian."

Circulation weekly . . . . 290 copies.

The Military Staff in 1902 consisted of :-

His Excellency the Governor and Commander

in Chief . . . R. A. Sterndale, Esq., now deceased.

Aide-de-Camp . . Lord Guernsey.

Private Secretary . A. Hands, Esq.

O.C. Troops - . Col. A. J. Price, C.M.G., Acting Governor after July.

Aide-de-Camp • . W. P. B. Fraser, 3rd Wilts.

Garrison Adjutant . Capt. W. H. C. Davy

O. C. Royal Artillery . Major C. C. Wiseman Clarke.

O. C. Royal Engineers Lieut. E. M. Jack, R.E.

Senior Medical Officer . Lieut.-Col. C. D. D. Mosse, R.A.M. Corps.

Chief Ordnance Officer . Lieut. J. Nicholson.

District Paymaster (Acting). . . . Lt. T. S. M. Hardinge, R.G.A.

O.C. Army Service Corps Maj. F. Horniblow, A.S.C. 
Command: Prisoners of War, Deadwood Camp Lieut.-Col. J. IV. Hind.

Command: Prisoners of War, Broadbottom Camp Lieut.-Col. H. O. P. Wright

O.C. Prisoners of War, Jamestown . Capt. Fisher.

Camp Quarter-Master, Deadwood

Camp Quarter-Master, Broadbottom

Manchester Regt., 3rd Batt. Buffs

Lieut. H. J. Carden, R.G.A.

Lieut. and Qr.-Mr. McCullough, the King's (Liverpool Rt.)

- Col. T. Brinckman.

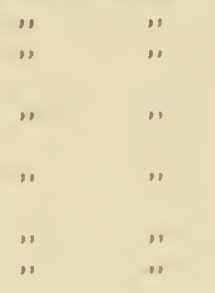

Capt. J. Walker.

Lieuts. Mouillet and Blackhall.

2nd Lieuts. Wells, Bentley, Wisder.

Major and Adjutant $R$. Bayard.

Capt. and Qr.-Mr. Cumber. Lieutenants M. H. Coode, A. H. P. Pepper, W. P. B. Fraser, F. H. Booke. and Lieuts. C. B. Long, D. J. Johnson, R. G. H. Challoner; H. C. C. Reynolds, F. H. Bailey, Lord Guernsey, Attached Capt. E. P. Lewis, and Volunteer Batt. Wiltshire Regiment.

Relieved 4th Battalion Glos'ter Regiment, 8 th July, 1901. In 1901 and 1900 the forces were:-

Medical Staff

The King's Own lorkshire

Light Infantry 2nd Glos'ter Regt.

Royal Berks Regt. 3rd Wilts Regt.

"
" :
"

Dr. Arnold, M.D., Lloyd Roc.

Lieut. A. R. Keppel.

Lieuts. Baker, Law, Inglis Phelps.

Lieut. A. H. Bathurst.

Col. E. C. A. Sanford.

Lieut.-Col. Barclay.

Captains C. H. Stillwell, C. W. Spiller, F. R. Cockburn, J. P. H. Winterscale.

Major and Adjutant L. H. Warden. 
3rd Wilts Regt. . . Lieut. and Quarter-Maste1

G. Pepper.

97th Company, R.G.A. Captain Galway.

" . . Lieuts. Page and Watson. 3rd Batt. Sussex relieved 3rd Buffs.

3rd Sussex Regt. . Major Clarke.

" " . . Captains Hurst, Clark, Papillon.

" . . . . Lieuts. Parkin, Bidder, Ot-

" " . . . ter, De St. Croise, Vallentin, Nicholson.

" . . . 2nd Lieuts. Sandeman, Winter, Meller Powys Lybbe, North, Bell.

" ". . Capt. and Adj. Aldridge.

Relieved" detachments of Glos'ters, Berks, Yorkshire Light Infantry.

3rd Batt. Middlesex Regt. Lieut.-Col. E. V. Bellers.

Majors Longe, Bennett, Stephenson.

Captains Fisher, Abell, Davy, Thompson.

Lieut. Cunningham.

and Lieuts. Trafford, Cloete, Wienholt, Large, Phillips, Rowe, Hill, Drew.

" " Lieut. and Qr.-Mr. Tulcher.

84th Company R.G.A. . Major Wiseman Clarke.

" ". . Captain Bellairs.

" . . . Lieuts. Hardinge, Hall, Larmour.

43 rd Comp. Royal Engin. Captain Michie.

Lieut. Jack.

4th "Batt. Glos'ter Regt. Lieut. Col.-Earl Bathurst.

Major (Hon. Lieut.-Col.)

A. L. Paget.

Major (Hon. Lieut.-Col.) Goodlake.

Capt.-Adj. J. S. Hobbs. Capt. Quarter-Master B.N. Spragett.

Captains J. D. Gouldsmith, C. H. Harding, W. J. P. Marling, C. Capel, Hon. B. Bathurst, M.P. Winkfield.

Lieuts. H. Hicks-Beach, J. B. W. Robinson. 
4th Batt. Glos'ter Regt.2nd Lieuts. R. H. Pollen,

C. H. Smith, R. C. Hopkinson, C. E. Limbecke, F. C. Ingham, Inglis, Ponsonby and Marsham Townsend.

Sergeant-Major Adkins. Qr.-Mr. Sergt. Vince.

\section{MILITIA.}

There is no Militia Regiment in cxistence, but the Governor of St. Helena may call out and embody upon any pressing emergency wherein the safety and security of the colony may be involved all and every male inhabitant of the said island between the ages of fifteen and fifty-five, as the local Militia of the island, and at all times when it may seem expedient to him so to do, the Governor may enrol a certain number of the inhabitants not exceeding 360 , in all, to serve as the Local Militia. The force enrolled may be required to parade for drill not more than twelve times in each year, and will not be entitled to any pay or allowance on such occasions. Recruits are entitled to 1/6 per day when being taught their exercise. If ealled and embodied for permanent duty, the Loeal Militia will be entitled to the same pay and allowances as officers, non-commissioned officers and soldiers of His Majesty's Army. There has been no enrolment of the force since 1874. The act in force for regulating the Militia is Ordinance No. 2, of 1874 , entitled, "An Ordinance to amend and consolidate the Laws relating to the Iocal Militia."

VOLUNTEER SHARPSHOOTERS.

Commandant . His Excellency the Governor.

Capptain . J Deacon.

Licutenant . A. Hands.

Full force not more than fifty all told. 


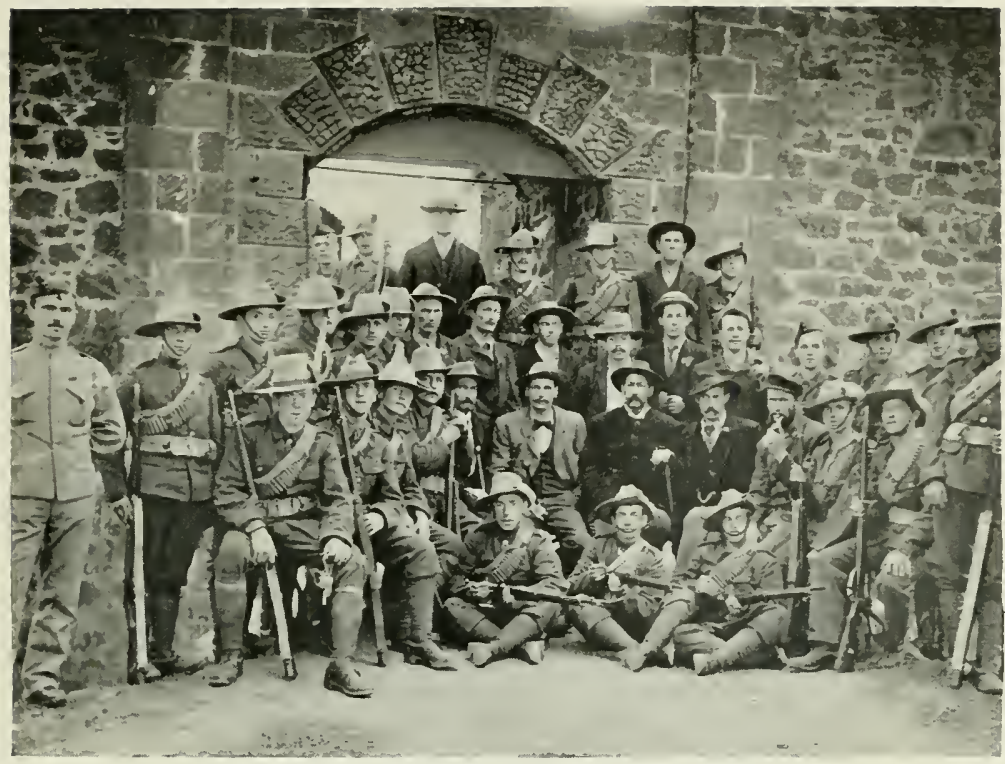

Turbulext Boers outsile High Kxoll Fort.

(Taken after Declaration of Peace.)

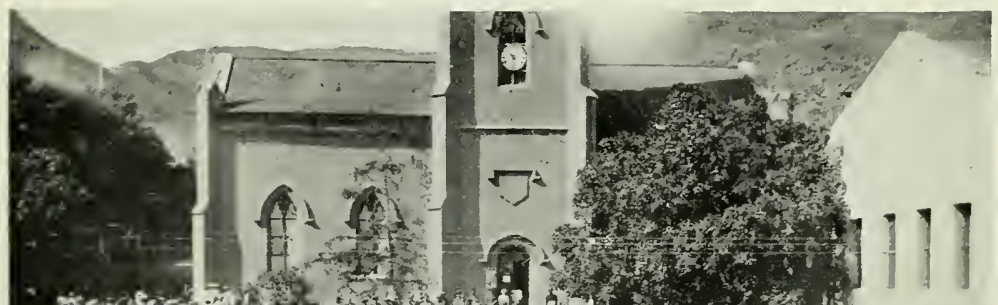

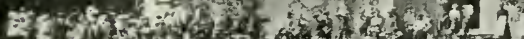

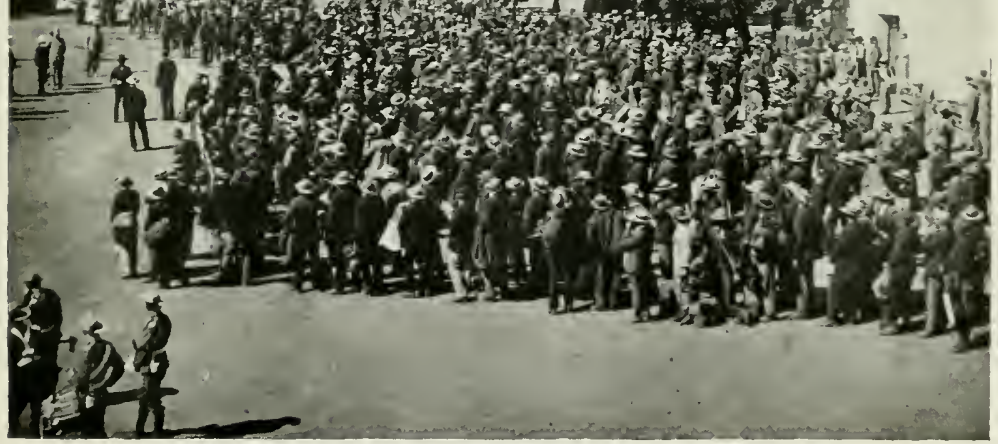

BOERS ON PARADE BEING ADDRESSEl, BY THE GOVERNOR. 



\section{TRISTAN D'ACUNHA.}

Tristan D'Acunha is closely associated with St. Helena, therefore a short account of it will not be out of place. It is one of a group of three islands, Tristan, Nightingale, and Inaccessible, in $37 \mathrm{~S}$. lat. I2 W. long., and was taken possession of by the British during the residence of Napoleon in St. Helena. Upon his death the garrison was withdrawn, with the exception of three men, who, with certain shipwrecked sailors, bccame the founders of the present settlement. For a long time only one of the settlers had a wife, but subsequently the others contracted with a sea captain to bring them wives from St. Helena. They are a peaceable community; no drinking is allowed, and there is no crime. The inhabitants are spoken of as long lived, healthy, moral, religious, and hospitable to strangers. A supply of stores and provisions was granted by Parliament in 1885 , and sent out by a man-of-war, as nearly all the able-bodied men had been drowned while attempting to board a vessel. It lies I,200 miles due south of St. Helena and I,500 miles to the west of the Cape, which is the nearest land. This is explained by seamen; for to sail direct to Tristan from St. Helena is quite impossible. A vessel has to tack again and again to reach her destination. The Peak, 8,325 feet high, is covered with snow in winter. On the north side there is a good anchorage from twenty to thirty fathoms, and generally a safe landing place, while abundance of pure water can be obtained. But the sea is at times very rough around the island, and ships are unable to get in to land either stores or people. During June, July and August the island is almost inaccessible.

The Rev. E. Dodgson (brother of Lewis Carroll), while Vicar of St. James', wrote a very amusing letter to the St. Helena Guardian, which gives an idea of the difficulties he had to contend with while resident there as minister. 


\section{A Short Account of Tristan d'Acunha.}

A long time to talk of, but a very short time while actually passing, for as a general rule the days were almost exactly alike, and after a short time the regular routine of work made them pass very quickly. The first question which is naturally asked is, "Where is Tristan d'Acunha?" It is onc of a group of threc, Tristan, Nightingale and Inaccessible, lying 1,200 miles due south of St. Helena, and 1,500 miles to the west of the Cape, which is the nearest land. This sounds like a paradox, but it is perfectly truc. I leave it to your readers to discover the solution for themselves, I will only say that I once gave this puzzle to two English clergyinen, and the reply of one of them was, "Oh, indeed I I didn't know that the land went out so far!" But the other was very irate, and said, "Do you take me for a fool ?" The only person who has ever accepted the truth of this seeming paradox without demur was a certain sea captain, who at once explained it. The way in which it came about that I went to this outlandish place was rather curious. An uncle of mine saw in a newspaper a letter from the captain of a man of war which had just been to Tristan saying how anxious the people were to have a resident clergyman who would also act as a schoolmaster. My uncle cut this letter out and sent it to me, saying in a joke, "Here is the very place for you to go to." He was much horrified when I made up my mind really to go there! After arranging matters with the S.P.G. I left England in the mail for St. Helena in September, 1880, hoping to be taken on to my destination in some whaler, but this I found to be impossible, as no whaler was willing to take me at any price; indeed, one old captain declared that he wouldn't have a parson as passenger in his ship for $\ell_{100}$. I was beginning to despair of getting a passage to Tristan until the next man of war went down there, which was expected here some time in the following January, but after staying on the island for three or four weeks, during which time I had charge of St. John's Church, a small English schooner came in, and the captain agreed to take me down to Tristan at once on pre-payment of a very large sum of money, and considerably more than the expense of a passage to England by the mail. The crew of this schooner consisted of a mate who would have been much smaller if he had ever been washed, a boatswain who also acted as cook, his sole qualification being that he knew nothing whatever about cooking, and two apprentice boys. There was only one cabin in the ship, which contained no bed, but the crockery was kept there, and a very strong smelling cheese. After about a week of this luxurious travelling I reached Tristan with considerable difficulty on one of the Saturdays in October, and the schooner was wrecked on the Tuesday or Wednesday following. At first the sea was quite smooth, with a light breeze blowing off shore, but as the vessel was heavily insured, the captain, who was also the owner, gained a good deal of moncy by the shipwreck. There was a horse on board whose body was washed on 
shore, to the great astonishment of the children, who had never seen one before.

Among the many things which I lost were all my boots, so that for nearly a year I had to content myself with home-made moccassins (mogsins) made of pieces of the hide of bullocks dried in the sun. These got so hard during the day time that they had to be soaked in water all night, and in this wet and flabby condition to be put on each morning-each pair lasted me about three weeks. I was accommodated with a room in one of the houses (with a sofa bedstead within) eight feet long, eight feet high, and six feet wide; there was just room for one chair by my bedside, which had to be on the bed whenever I wanted to be on the floor. I afterwards got one of the men to make me a small wooden bedstead and some book shelves in another room, which I was given the use of. I believe I was thought rather greedy for wishing to have two rooms ! Of course nothing could be done about a church for the first Sunday, the day after my unexpected arrival; the services had to be in one of the dwelling-houses on that day; but during the following week I had the best and most central house given up to me for a church and school. Fortunately, many pieces of the altar I was taking out with me were washed ashore, and all the requisites for the Holy Communion, also the font-the wooden box containing it was dashed to pieces on the rocks; but the font itself, though made of Bath stone, more brittle than wood, was picked up uninjured. The houses are built only one story high (stairs, I am thankful to say were unknown), divided into two or more rooms by wooden partitions and thatched with tupock grass. The walls are of stone, of which there is abundance on the island, about three feet thick (five feet at the gable ends), and eight feet high. The walls are obliged to be made very strong and low because of gales of wind. The house placed at my disposal was turned into a church by the simple expedient of removing the partitions and so turning it into one long room which just held all the people. Every family had to provide enough benches for its own members, the wood coming from wrecked ships, and the vestry was formed at the west end by screening off one corner with a sail-a blue dungaree curtain, cutting off the altar, made the church into a school on weekdays. There was soon a very fair choir of men and boys, and a full choral service, except the Psalms, twice daily. The choir boys had to learn the canticles, hymns, etc., off by heart, as they could not read at first. Holy Communion was celebrated every Sunday and Thursday, at first at eight a.m., but eventually at five a.m. There were to start with only twelve communicants, who had all been confirmed by Bishop Gray, but this number quickly increased to thirty-five, an average of seventeen every Sunday and four every Thursday. There were only ro4 people on the island. On the day of a funeral there was always early celebration, at which all the communicants generally received. On every Sunday afternoon was a children's service, followed by a choir practice, which was attended by many of the congregation, but we had no 
musical instrument except a pitch pipe. The number of the population gradually decreased to about ninety, as the people (young men chiefly) got a chance of going to the Cape, for a man of war has for a long time been in the habit of calling there on its way to the Cape about once a year. Soon after my arrival the men offered to build a proper church, and also a home for me to live in. They asked which I should like to be built first. Of course I said the church, and I drew some simple plans for one. Accordingly, they began to build a church, but after a few months I calculated that at the pace at which they wero proceeding they would be about eighty years in building it. In fact, it was abandoned altogether after six months, and I had the stones removed to form a wall around the graveyard. Each man, I believe, promised to give two or three days' work a week to the church, but one by one the promises became as pie-crust on some paltry excuse or other, for, like other people I know, they were very keen at first, but soon got tired of exerting themselves! I need hardly say that my house was never even begun.

The village is called Somerset Town, in honour of Lord Charles Somerset, and consists of several dwelling houses of one story, with numerous outhouses for cattle.

A visitor there in 1835 says the principal inluabitant is William Glass, who is alway's styled the "Governor." $\mathrm{He}$ is a native of Kelso, N.B., and resided there with his wife and children, of whom lie had twelve, for nineteen years. The present governor, however, is Peter WV. Green. Her late Majesty Queen Victoria forwarded to this veteran sailor, and headman in the lonely island, a framed portrait of herself in recognition of his self-denying efforts in saving life from shipwreck during the last sixty years. The aged recipient of her Majesty's gift wrote as follows to his friend, Mr. G. Newman, of 47 , Finsbury Road, Woodgreen, Middlesex, whose relative he saved from drowning long ago:-

\section{TRISTAN D'ACUNHA.}

DeAr old Friend Newman, - This letter comes in a different style from all the rest of my letters. I do not suppose you know about the handsome present I received from Her Majesty Queen Victoria! Such a picture never came to Tristan before. The height of the frame is nearly four feet, the breadth is nearly three feet, and the crown is on the top, all beautifully carved and gilded. The address on the outside was :-

\section{Peter Green, Esq.,}

Tristan d'Acunha, Care of Commander, H.M.S. Magpie, St. Helena. 


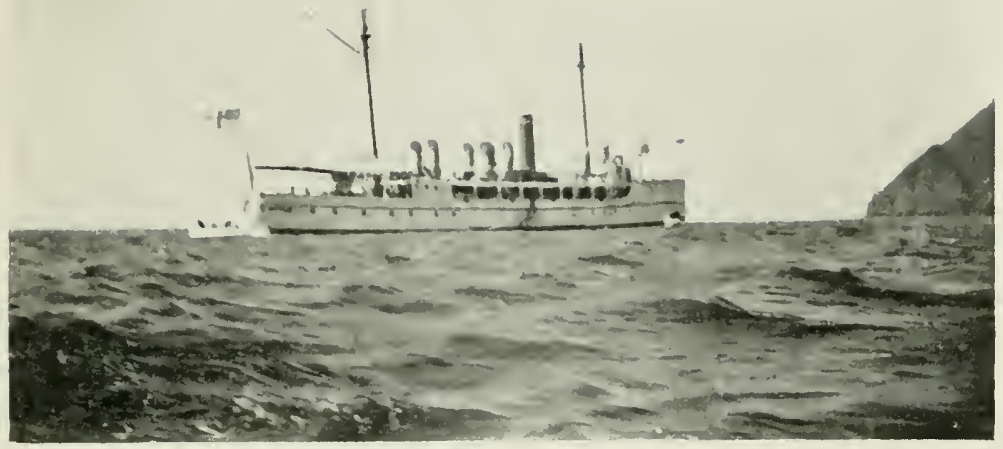

H.MI.S. DWARF.

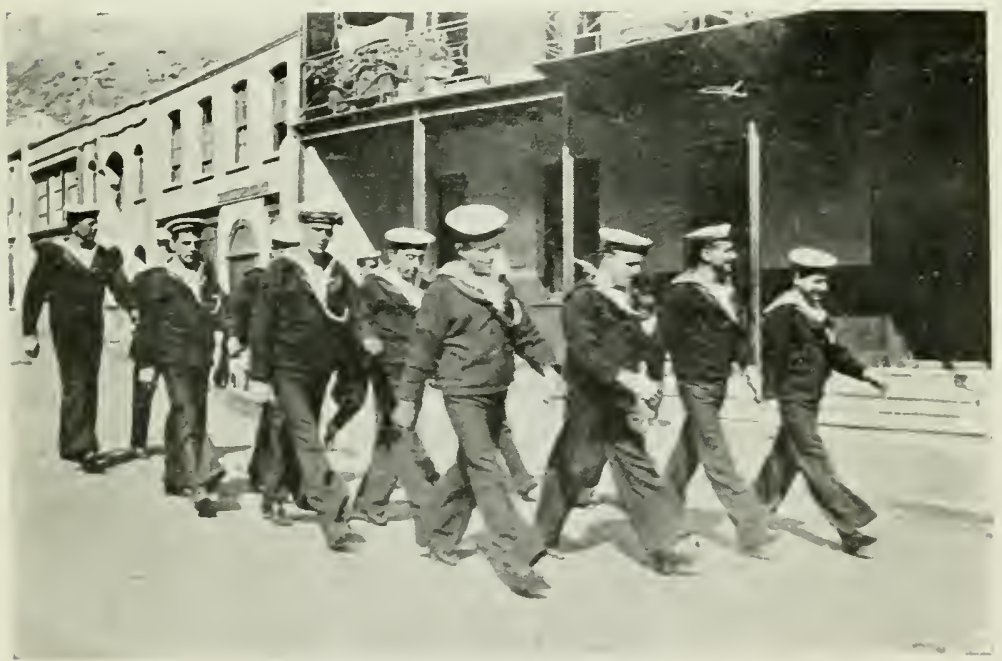

BLUE JACKETS From H.M.S. DWARF. 

To wait customs office, St. Helena.

FROM THE QUEEN.

As I have to thank Her Majesty for the Royal present that I received, will my old friend Newman be kind enough to do it for me? You are the right man in the right place, and it would only be as a kind man speaking to a very kind Queen. I remember His Royal Highness the Duke of Edinburgh well. When he came to Tristan in Her Majesty's ship Galatea I had the honour of carrying him from his boat to the sand beach, as recommended by Captain Fullerton, R.N. I hope he is an admiral now. Our settlement has been called Edinburgh since that time. I should not like to try to back the Duke ashore now. He was as much as I could carry thirty years ago. On boarding the Galatea afterwards I was carrying a large bundle, and His Royal Highness said to the officer who was with him, "What is Mr. Green going to do with that bundle?" "I want to find a gentleman," I replied, "to take charge of it, and deliver it at Government House, Cape Town, where I have two daughters in the service of the Governor, Sir George Grey." The Duke kindly said at once, "I will be the gentleman," and then told one of his servants to take the bundle from me and put it in his cabin. I afterwards received a letter from my daughters thanking me for the present; it was a double present, for His Royal Highness also left some money for the servants at Government House.

If I get no chance to write any more this time let me still remain, Your old friend,

Peter W. Green.

In 1897 (November) the island was visited by H.M.S. Widgeon, under the command of Lieut. and Commander A. F. Gurney. The special object of the visit was to convey to the islanders a whaling boat, which was supplied by the Admiralty. The total population then was sixty-four, composed of eighteen men, nineteen women, fifteen boys and twelve girls. The island is capable of affording pasturage for some 500 head of cattle, and as there were between 800 and 900 cattle on the island, as well as 500 sheep, the inhabitants were anxious to dispose of their surplus stock. If a ship fetched cattle from there, they could supplement their load by guana from the neighbouring isles. The labour for such a purpose would readily be found by the inhabitants of Tristan d'Acunha. The wants of the islanders are few, but they are always pleased to receive presents of vegetable seeds.

They seem very contented, and enjoy good health, sickness being very infrequent. On Sundays they meet together 


\section{I 4}

for public worship, after which they make friendly calls.

The only wild animals are goats, which are very numerous. There are few species of fish, but great quantities are caught in fine weather. The land birds are the island cock, similar to our moorhen, the thrush and green linnet.

Apples, peaches and grapes are produced, but the two last seldom ripen thoroughly. Mails are conveyed at uncertain intervals by H.M. ships. The inhabitants grow a large number of potatoes, and these, with beef and milk in abundance, form the chief article of diet. The potatoes are exchanged, when they have opportunity, for bread with the American whalers.

The ships comprising the Naval Squadron in these waters during the Boer war were as under :-

Note.-Although pains have been taken to ensure accuracy, the correctness of names of officers cannot be vouched for, on account of the changes in appointments which took place during the three years and which make correct compilation difficult.

Niobe, Twin-screw Cruiser, ist Class, 11,000 tons.

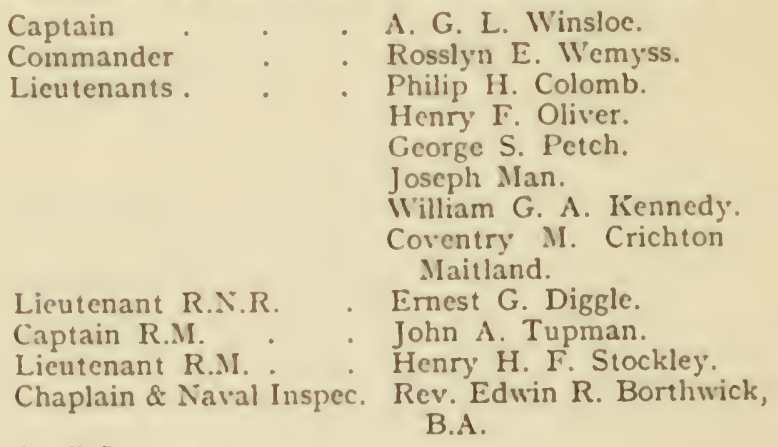

Staff Surgcon

Staff Paymaster

Fleet Engineer

Surgeon

Staff Engincer

Sub-Lieutenant.

Assistant Paymaster

Assistant Enginecrs

James H. L. German.

Everard H. Saunders.

John W. Craig, M.B.

Arthur J. Johns.

Hugh P. Pritchard.

C. Betton Roberts.

Richard R. Jury.

Joseph J. Kirrin.

William H. Rosevere.

Francis W. Hamblin.

Arthur E. Lester. 


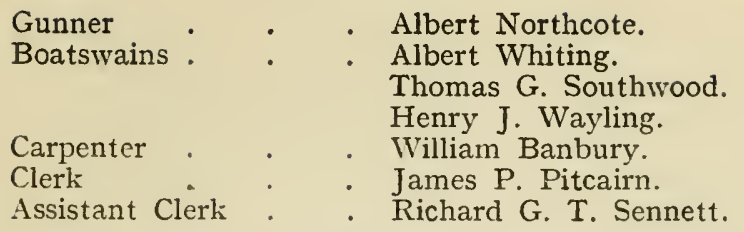

Thetis, Twin-screw Cruiser, 2nd Class, 3,400 tons. Captain . . William Stokes-Rees.

Lieutenants . . A. G. Davidson.

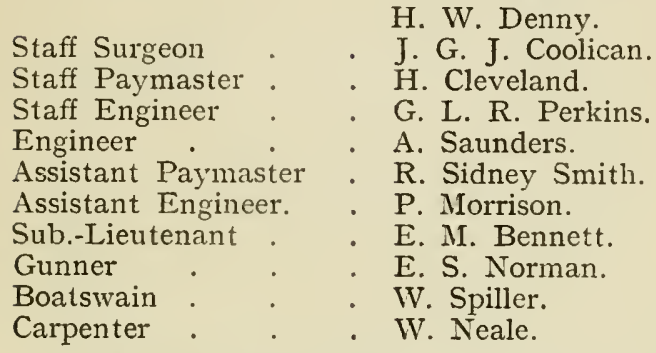

Philomel, Twin-screw Cruiser, 3rd Class, 2,575 tons.
Captain
Chief Engineer : Charles Laughton.
Gunner . . Joseph Rowe.
Carpenter . . John C. Sole.
Beagle, Twin-screw sloop, I, I70 tons.
Commander . Henry V. W. Elliott.
Lieutenants . John E. Cameron.
Richard Horne.
Humphrey T. Walwyn.
Paymaster . . Wilfred J. A. Carter.
Sub.-Lieutenant . Horatio S. Bland.
Surgeon . . Alexander G. W. Bowen,
Engineer $\quad . \quad$ B.A., M.B.
Gunner $\quad . \quad$ Edward W. Liversidge.

Naiad, Twin-screw Cruiser, 2nd Class, 3,400 tons. Captain . . Hon. Alexander E. Bethell. Lieutenants . Ernest S. Carey.

Herbert R. M. Williams.

Richard J. Shee.

Edward M. Bennett.

Hugh J. Middleton. 
Lieutenants . . Thomas L. S. Garrett, R.N.R.

Francis J. Vanzellar.

Paymaster . . Francis C. Leonard.

Chicf Engineer . . Henry R. Teed.

Engineer . . Albert G. Archard.

Assistant Engineer - William S. Torrance

Gunners . . George Booth.

Joln C. Souhamy.

Clerk . . Charles M. Tonge

Assistant Clerk . Harold C. F. Pinsent.

Dwarf, Twin-screw Gun-boat, Ist Class, 710 tons.

Lieut. and Commander William N. England.

Surgeon . Warren G. IVestcott.

Sub. Licutenants. Jolın White.

Paul .M. Broster.

Gunner . Harry Batcy.

Assistant Engineer Herbert W. Fookes.

John Hindmarsh.

Magpie, Screw Gun-boat, ist Class, $80 ;$ tons.

Licut. and Commander John ki. Laird.

Lieutenants. . . Robert A. Richards.

Roger G. Kenyon.

Surgeon . . . Henry C. Whiteside.

Gunner . . Frederick S. Gidley.

Assistant Engineer . Laurence Jackson.

Rattler, Screw Gun-boat, ist Class, 715 tons.

Licut. and Commander Charles Tibbits.

Lieutenant . . Henry E. F. Aylmer.

Surgeon . . Percy H. Bannister.

Sub-Licutenant . . Henry L.. Street.

Gunner . . . George E. Ford.

Assistant . . James D. Gardiner.

Terpsichore, Twin-screw Cruiser, and Class, 3,400 tons.

Captain - Charles H. Coke Feb. 7, 1901.

Lieutenants Frank C. Grover. Feb. 7, 1901.

Charles Bissett. Feb. 7, 1901.

John K. P. Dooner March 18, 1901.

George P. Leith. Feb. 7, 1901.

Charles H. Davey. Feb. 7, 1901.

Paymaster . . Wingficld W. Alton.

Staff Engincer . . Sidney G. Haddock.

Surgeon . . Henry W. Finlayson, M.B.

Engincer : William Dawson.

Sub.-Lieutenant R.N.R. Edward P. W. Stroud.

Assistant Engineer . Ernest W. Roberts. 


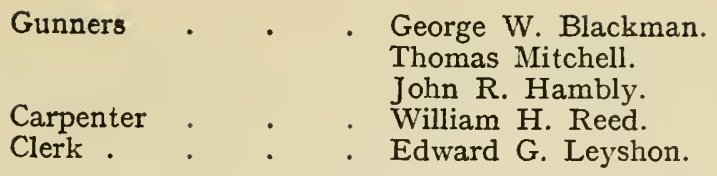

Thrush, Screw Gun-boat, Ist Class, 805 tons.

Lieut. and Commander Warren H. D'Oyley.

Lieutenant . . Harold N. Key.

Surgeon : : Francis T. Lobb.

Sub. Lieutenant . Dashwood F. Moir.

Gunner . . . Samuel A. H. McCulloch.

Assistant Engineer . Robert W. Kingston.

Barracouta, Twin-screw Cruiser, 3rd Class, I,580 tons.

Commander . . Selby H. B. Ash.

Lieutenants . . Hubert S. Cardale.

Montague $\mathrm{H}$. Lubbock.

Harry W. C. Hughes.

Staff Surgeon . . Charles M. Beadnell.

Paymaster . . Henry Horniman.

Engineer . . Alfred H. Maysey.

Sub.-Lieutenant R.N.R. Louis A. Brooks-Smith.

Gunner . . . William Hall.

Assistant Engineer. Thomas J. Johan.

George G. French.

Blanche, Twin-Screw Cruiser, 3rd Class, I, 580 tons.

Commander . . Murray T. Parks.

Lieutenants . Algernon W. Abbott.

Arthur G. Warren.

Robert C. Hocking.

Staff Surgeon . George A. S. Bell,

Paymaster . . John K. Watson.

Chief Engineer : William W. Pearce.

Sub.-Lieutenant R.N.R. Harold E. Jackson.

$\begin{array}{ll}\text { Gunner } & \text { : } \quad \text { Albert Whiting. } \\ \text { Boatswain : }\end{array}$

Assistant Engineer . Thomas J. Wells.

Captain . . . Robert C. Sparkes, C.M.G.

John D. Kelly.

Lieutenants . Francis E. Massy-Dawson,

Percy Johnson.

John H. Steel.

Hugh D. Marryat.

Lieutenant R.N.R. . Harry W. Wright.

Chaplain . . . Rev. Walter MCL. Tod, M.A,

Paymaster . . . Charles F. Petch.

Staff Engineer . William R. Appis.

Surgeon

Christ. L. W. Burton, M.B.

Algernon C. Bean. 
Engineer :
Assistant Paymaster :
Assistant Engineer :
Gunners $:$ James Oliver.
Boatswain : $\quad$ Edward Holland.
Carpenter : $\quad$ George S. Steel.
Assist. Clerk $\quad$ : Hemas H. W. Deacon.

Forle, Twin-screw Cruiser, and Class, 4,360 tons. Captain Peyton Hoskyns, C.MI.G., II.V.O.

Licutenants Frank E. M. Roe. Hubert S. Monroe. Bernard W. .I. Fairbairn. Chaplain . . Rev. David L. Williams, B.A.

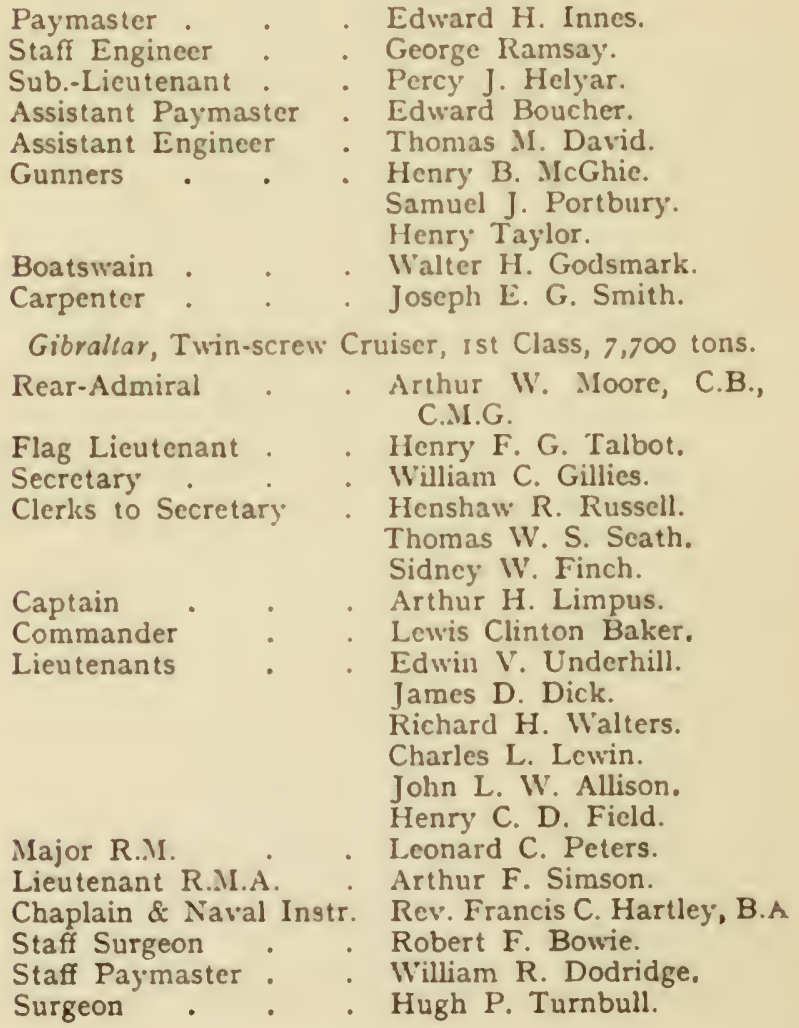




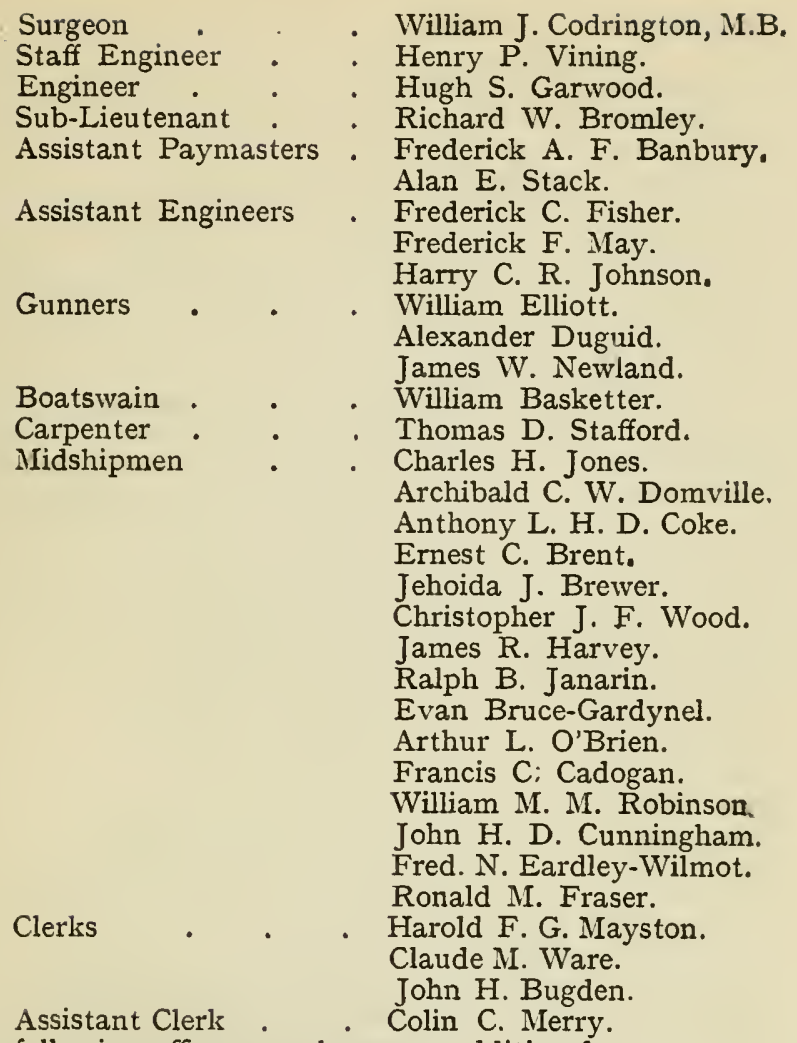

The following officers are borne as additional :-

Captain Frederick St. C. Luscombe,

(For service as Principal Transport Officer, South Africa.)

Captain Herbert G. King Hall, D.S.O.,

(Divisional Transport Officer, Durban.)

Commander (Retired) John T. Hardinge,

John Martin,

(Divisional Transport Officer, East London.)

(Divisional Transport Officer, Port Elizabeth.)

Villiam J. V. Hudson,

(For Transport duties.)

Lieutenant James $O$. Hatcher,

(For Transport duties.)

Lieutenant (Retired) Charles W. Pleydell-Bouverie,

(For Transport duties.)

Staff Paymaster William M. C. Beresford Whyte,

(Secretary to Principal Transport Officer.) 
Chief Engineer John Richardson,

(For Transport duties.)

Boatswains :- Henry Penfound, Charles Jones, Charles G. Reypert.

(For Transport duties.)

Carpenter Solomon J. Lacey,

(For Transport duties.)

Herald-Stern-wheel Steel Vessel, 82 tons.

Lieutenant and Commander . . Ernest Stevenson.

Surgeon - : Herbert L. Geoghegan, B.A., M.D.

Monarch-Screw Battleship, 3rd Class Armoured, 8,845 tons.

Captain

Commander

Lieutenants .

Staff Commander :
Captain R.M.
Lieut. R.M.A.
Staff Surgeon :
Fleet Paymaster :
Paymaster :
Chief Engineer :
Surgeon :
Engineer Pajmaster
Assistant Paymast
Assistant Engineers

Gunners
Charles H. Bayley.

Cunningham R. de C. Foot.

- Charles W. N. McCullock.

Arthur J. Payne.

Richard M. T. Stephens.

Edward Union.

Frank E. M. Roc.

- Francis Roberts.

- Robert D. Beith.

George Y. Russell.

James T. C. Whicker.

Thomas Guard.

Charles D. M. Horne.

Frank R. Stuttaford.

Fred C. B. Gillings, M.B.

Ernest E. Petbwick.

Charles H. Carroll

Vernon A. Brook.

John A. T. Fielder.

William J. Talbot.

James Wood.

Frank Smith.

Walter W. L. Newnham.

Boatswains . . Francis J. Camble.

Henry Snell.

Carpenter .

The following officers are borne as additional for various services For service of Naval Establishments.

Fleet Engineer George Elbrow.

Chiel Gunner - . Joseph Mitchell.

(For charge of Torpedo boats and stores at the Cape.)

Christopher H. Deighton.

(For Charge of Ordnance stores at Cape of Good Hope.)

Chief Boatswain. James Thornback.

Gunner . Thomas J. Shyne.

(And for charge of Rifle Range, Simonstown.) 


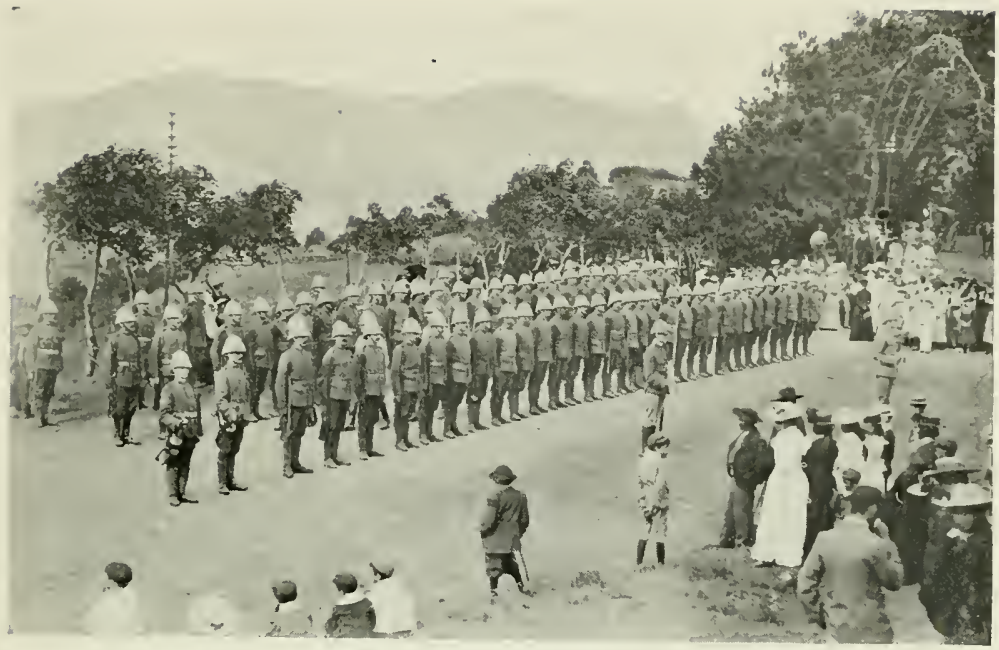

R.G.A. DRAWX UP TO RECEIVE MEHALS AFTER THEIR RETURN FROM SOUTII AFRICA.

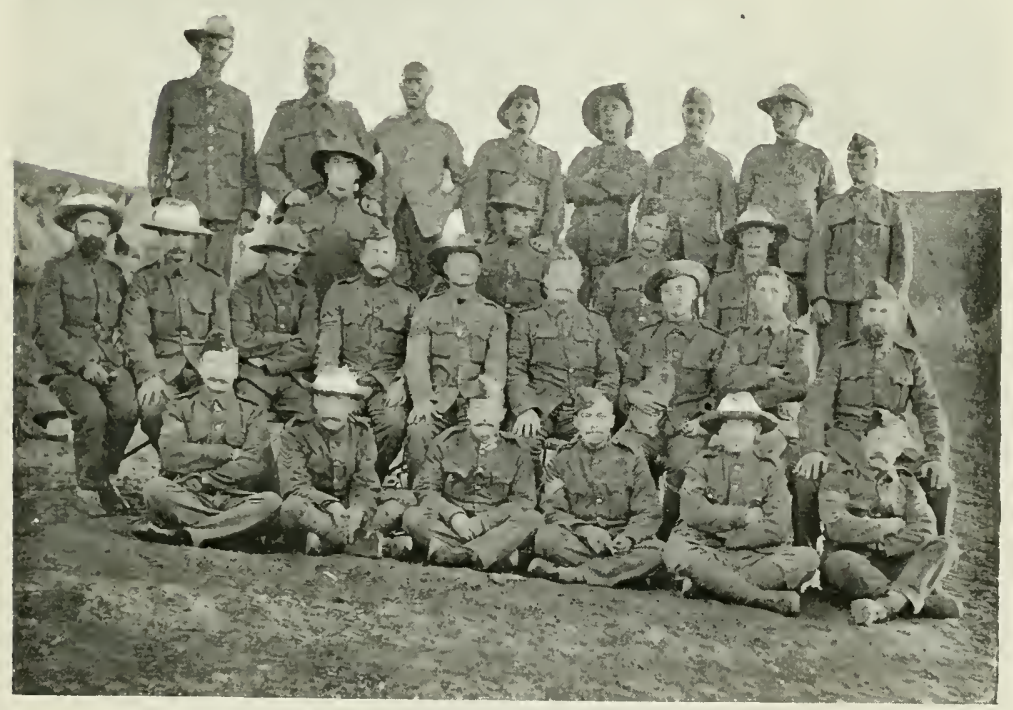

Sergeants, 3rd Royal Sussex Regiment, Broanbottom Camp. 



\section{ST. HELENA}

(For service at Ascension.)

\begin{tabular}{|c|c|}
\hline $\begin{array}{l}\text { Captain } \\
\text { Lieutenant : } \\
\text { Captain R.M. } \\
\text { Lieutenant R.M.A. } \\
\text { Chaplain : } \\
\text { Staff Surgeon } \\
\text { Fleet Paymaster : } \\
\text { Surgeon } \\
\text { Assistant Paymaster } \\
\text { Gunner }\end{array}$ & $\begin{array}{ll}\text { - } & \text { Robert IK. McAlpine. } \\
\text { - } & \text { Crthur J. D. Macauley. } \\
\text { - } & \text { Richarles J. Thornton. } \\
\text { - } & \text { Rev. Dallas G. Food. } \\
\text { - John Anderson, M.B. } & \text { George J. Mills. } \\
\text { - } & \text { Richard A. Ross, M.B. } \\
\text { - } & \text { Harold Radham. } \\
\text { Villiam Simpson. }\end{array}$ \\
\hline
\end{tabular}

Mosquito-Stern-wheel vessel, 82 tons.

(For charge of Ordnance stores)

Boatswain . . John U. Vinnicombe.

Lieut. and Commander .

Surgeon

- Theodore Marles Thomas,

Partridge-Screw Gun-boat, Ist Class, 755 tons.

Lieutenant and Commander . . . Eustace La T. Leatham.

Lieutenants . . Hon. Richard O. B. Bridgeman Thomas B. Scott.

Surgions . . . Harold E. Fryer. John Whelan.

Sub-Lieutenants . . Walter Scott.

Cecil N. Reyne.

- Charles J. Hayward,

Frederick J. Baker.

Monatgue J. Speer.

Pearl-Twin-screw Cruiser, 3rd Class, 2,575 tons

Captain . . . Edward P. Ashe.

Lieutenants . . Alan E. Hudson.

Alfred W. Gush.

James $\mathrm{H}$. Thom.

Lieutenant R.N.R. . Robert H. W. Hughes.

Staff Surgeon - . Joseph Chambers, B.A., M.B.

Paymaster . . . Charles M. Luckham.

Chief Engineer · . Harry G. Andrews.

Sub-Lieutenant . . George S. Hallowes.

Assistant Paymaster . C. Betton Roberts.

Gunner . . . Joseph Brown.

Carpenter . . . Alfred C. Smith.

Assistant Engineer . .William O'Keefe.

Juno-Twin-screw Cruiser, 2nd Class, 5,600 tons.

Captain . . . Henry P. Routh.

Commander : . Albert S. Lafone. 
Lieutenants. . Montague L. Hulton.

Alfred A. Ellison.

Thomas E. Wardle.

Francis R. Wood.

Lieutenant R.M. . Philip H. Wateran.

Chaplain and Naval Instructor.

William W. Godfrey.

Staff Surgeon : Richard A. Fitch.

Rev. Henry Blackwcll, M.A.

Paymaster . . William C. Davy.

Fleet Engineer . William W. White.

Surgeon . . . George Ross, B.A., M.B.

Engineer . . John C. Pearson.

Sub-Licutenant . . Richard B. Ward.

Assistant Paymaster , Reginald F. Brown.

Assistant Engineer . Frank M. Attwood.

Gunners

Frederick J. Russell.

William J. Bonscy.

Boatswain . . . Frederick W. S. Crocker.

Carpenter . . John B. Watson.

Midshipmen . . Herbert L. Lucas.

Arthur G. Sparrow.

Herbert G. Briggs.

Trevor R. Chamberlain.

Gordon I: . Markwick.

Cuthbert P. Blake.

Deporest J. D. Noble.

Arthur .11. Longmore.

Charles E. Maconochic.

Assistant Clerk . . Alexander Organ.

Si. George, Twin-screw Crusser, ist Class, 7,700 tons.

Captain

Secretary

Commander

Licutenants
Captain R.MI.

Chaplain and Naval Instructor

Staff Surgeon

Fleet Paymaster

Staff Engincer

Surgeon

Engineer
Alfred L. Winslowe, C.Y.O.,

C.M.G. (Commodore and Class).

Walter Gask.

Alexander L. Duff.

Herbert J. Savill.

Henry W. Grant.

Clarles W. Trousdale.

Cyril P. Ryan.

James L. S. liirkness.

John H. Bainbridge.

John H. Lambert.

Rev. William Hall, B.A

Alfred Cropley.

Francis B. Pritchard.

William J. Blake.

William $\mathrm{H}$. Thompson.

Alfred E. Everitt. 


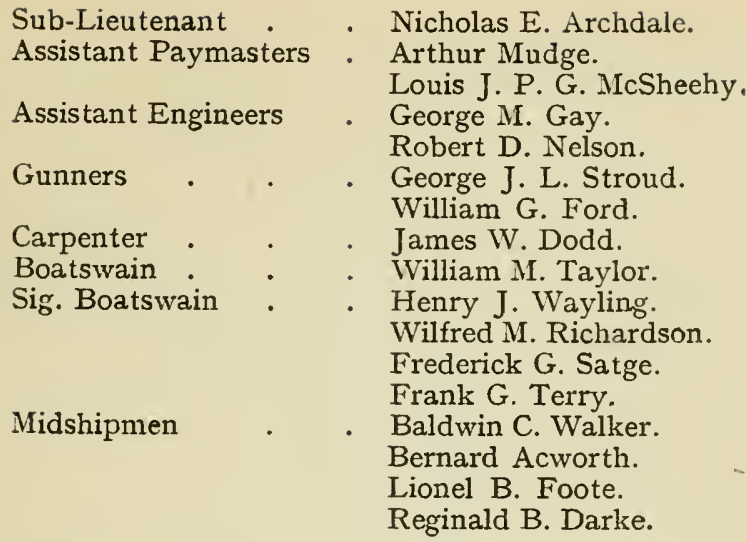

An alphabetical list of plants reported as seen by Dr. Roxburgh, and growing on the island of St. Helena in I8I3-I8I4, as given by Melliss.

(I. means indigenous; E., exotic). Several of the most conspicuous of the undetermined species are briefly described; and Dr. Roxburgh's names are distinguished by the letter R.)

E. Abrus precatorius. Willd. 3. p.911. 1025.

I. Acalypha rubra. R. Red Acalypha or string-tree of the islanders. Arboreus. Peduncles axillary and between the leaves: one or more female flowers near the base, the rest a long, pendulous, filiform, glomerate male spike : involucres cuculate, entire. Leaves petioled, ovate, ereuate, three-nerved. A beautiful small tree, a native of elevated parts of the south face of Diana's Peak $(2,760)$, and called a string-tree by the natives on account of its numerous beautiful red male spikes, which hang in great profusion from every twig. Ultimate branches tubercled with the scars of the fallen leaves; above, where the leaves remain coloured, red and smooth; the petioles, nerves and veins are also red and smooth.

E. Acer pseudo-platanus. Willd. 4. 2. 983. Common maple or sycamore tree.

E. Achyranthes aspera. A weed in gardens.

I. Acrostichum bifurcatum. A delicate, small, beautiful, smooth species growing in crowded tufts about six inches in the most shaded fissures of the rocks about Diana's Peak.

I. Acrostichum lanceolatum. R. Stipes runcutaceous : fronds simple lanceolar, strongly veined, entire: the fertile longer stiped. Fructifications occupy the whole of the inferior surface.

E. Aeschymomene sesban and grandiflora. 
E. Agapanthus umbellatus.

E. Agave buberosa. Gucca superba.

E. Agave lurida. Used for fences.

I. Agrostis purpurascus. Purple bent grass. Indigenous of the hills of St. Helena where it grows to from 2103 feet high, perfectly erect, very naked of leaves, as they are not only few in number but short and very slender. The inflorescence a long slender panicle composed of numerous small purple or compound appressed branches, crowded with numerous small pedicelled smooth flowers. Calcy'me valves unequal, scarce half the length of the corol, which has its two valves nearly equal and rather acute; but nothing like an awn either here or in the calyx.

Agrostis lenta. Forked bent grass.

Agrostis stellata sec Panicum dactylon, and compare with Agrostis linearis or wire grass.

E. Alewrites tribola. Three-lobed alcurites.

E. Allium cepa. Porum aecalonicum and of satebuw two varicties. Onion, leck, shallot and garlic.

E. Aloe perfoliala. Two or threc varicties in gardens.

E. Aloe spicala and three or four undetermined species, all cxotics.

I. Alopecurus paniculatus. R.

E. Alihaea rosea. Hollyhock.

E. Amaranthus blitum. $A$ weed in gardens.

E. Amaranthus candatus and tricolour, cultivated for ornament.

E. Amaryllis belladonna. Belladonna lily:

E. Amaryllis formosissima. Jacobea lily.

E. Amygdalas persica. Peach, two or three varieties and almond, but the latter does not succeed here, whereas the peaches grow luxuriantly and are productive.

F. Anagallis arensis, threc varieties, bluc, red, and whitc.

E. Andropogon schoenanthus, or lemon grass. Cultivated in gardens.

E. Amona muricala. In one garden only (Major Hudson's).

E. Annona charinoya. In one garden only (Major Hudson's).

E. Annona squamosa in few gardens f Custard apple.

E. Annona reticulata\} but rare \{ Bullock's heart.

E. Angelica bracteata. Bracted angclica.

Leaves pennate: floral ternate. Leafets petrol-clasping subcordate, $3 \rightarrow 7$ nerved, fincly laciniate-serrate.

Angelica the vernacular name. It grows to be a stout, erect perennial of 8-12 feet in height, with columnar, fistulous, smooth, bright green stem and branches. Leaves sparse, in some parts grown unequally pennate, those next the umbels from pennatepalmate to three-lobed: leaflets of the inferior larger leaves from four to twelve pairs, opposite, closely embracing the smooth green columnar petiole, cordate-nerved, smooth, finely laciniateserrate; each serrature ends in a green bustle; at the base of each petiole a pair of large simple or compound suborbicular bractes, and generally a single one between the leaflets, and all 
subalate serrate like them. Umbels terminals, numerous, compound subglobules and many rayed. Involucre and involucells of 6-Io broad lanceolate leaflets each. Flowers numerous, small white but turn pink by age. Petals subequal oval and oblong uncurved, stamina unequal, anthers purple. Styles short erect. Receptacles naked.

E. Anthoylza oethcopica. Flag-leaved antholyza.

E. Anthoxanthum odoratum. Sweet scented vernal grass.

E. Apumi toseluran. Parsley and gravèolens or smallage.

E. Argemona mexicana. The most common weed on the island.

E. Artemesia absenthium. Wormwood.

E. Arum colocasia. St. Helena yam: of this there are several wild varieties but only the white is cultivated.

E. Asclepias fructicosa. Shrubby asclepias.

E. Asclepias carassewica. Bastura ipecacuanha.

I. Aspidium reparumi. Stipes villous flat above. Fronds oblong, bipinnatifid: pumice linear segments linguiform or falcate and deeply divided. Spots in one crowded row a little removed from the margin: involucres veniform. Found plenty over the south side of the mountains immediately above Major Seal's in Sandy Bay, where it grows in tufts from 2 to 4 feet high.

I. Aspidium pulchrum. Base of the stipes and tuberous-like runners chaffy, the rest brown and smooth. Fronds ovateoblong, firm, sub-bipennate ; pumice opposite generally pinnatifid : sequients oblong obtuse, subcrenate. Spots, generally one, rarely two or three to each sequent of the pinnae, involucres veniform. A small (6-I 2 inch) plant of a hard texture, but not glossy, with the stipes about as long as the fronds: a native of Diana's Peak.

I. Aspidium vestitum. Stipes and divisions amply clothed with large brown soft scales. Fronds oblong, bipinnated leaflets linguiform, obtuse crenate. Grows on Diana's Peak to about 2 feet high.

I. Aspidium capense. Stipes green and channelled. Fronds ovate, smooth bipinnate: pinna opposite, apices ensiform and sharply serrate; pinnulæ from serrate to pinnatífid, with obtuse dentate apices. Spots in two rows a little removed from the nerve: involucres reniform. A native of Diana's Peak where it grows to be from 20 to 30 inches high, is of a soft delicate texture, the spots numerous and very large.

I. Aspidium corraceum. Stipes as long as the oppositely bipennate ovale fronds. Leaflets linguiform, crenate serrate and pinnatifid. Spots in one line half way between the nerve and the margin: involucres veniform. Is also a native of south face of Sandy Bay range of mountains where it rises to the height of 2 feet and generally amongst bushes. It differs from $A$. Capense in little else than the shape of the apices of the pumice and the single row of spots, whereas in that species it is double.

I. Asplenium tenellum. R. Stipes polished. Fronds linear recurved apices rooting, alternately pennate : leaflets numerous, 
obliquely linguiform, obtuse crenate, anterior side of the base cnlarged, posterior alternatc. A pretty small (6-8 inch) species with the habit of adiantum candatum, found indigenous on the tops of the high mountains in the centre of the island.

I. Asplenium falcatum. Stipes long as the lanceolate, altcrnately pennate firm smooth fronds, three-sided, threc-grooved, pretty, smooth and black. Lcaflets short petioled, falcate lanceolate lobatc; lobes and fine cnsiform apices serrate. A most beautiful species growing in snall tufts on the top of Sandy' Bay ridge to be about 2 feet high.

I. Asplenium proemorsum.

I. Aspleniun frlamenlosum. IR. Stipes longer than the thin ovate, alternately tripennatifid frond, channelled, base clothed with long, black chaffy scales; pumice remote; leaflets pinnatifid; segments shori linguiform serrulate obtuse. A stout species of from 2 to 6 feet high; a native of the south face of Diana's Peak.

I. Aster glutinosım. R. (Compare with herbus.) Shrubby, tender parts woolly. Leaves from cuncate to spatulate; apices rounded and grossly serrated, fleshly veguose with very prominent veins underneatli, pedicels terminal ultimately axillary subsolitary, length of or longer than the leaves, one-flowered. A native of the most naked barren rocks on the south side of the island, where it grows to be a middling-sized shrub. The clammy leaves are fragrant. Bractes scattered over the long clammy peduncles, and of a long clavate shape. The flowers are large, pure white. Goats are said to be fond of it and while browsing on it the clammy exudation thereof is collected on their beards. (See history of Mastich.)

E. Atriplex triangwaris. Triangular atriplex.

E. Atropa physaloides. Blue-flowered atropa.

E. Bambusa Arundinaceae. Common bamboo.

F. Barringlonia speciosa. Laurel-leaved Barringtonia.

Beatsonia. R. Pentandria monogynia. Generic character. Calyx five-toothed. Corol five-petalled, campanulate. Germ superior, one-celled contaning many ovula attached to the two opposite sides of the cells. Style bifid. Stigmas globular. Capsule one-celled, two-valved. Seeds a few. Named in honour of Col. Alexander Beatson, Governor of St. Helena.

I. Bealsonia portulacefolia. R. St. Helena tea, the vernacular name on that island, where it grows on the naked rocky mountains and hills on the south side, to be a very famous shrub of a middling size. Trunk short, soon dividing into numerous branches crowded with innumerable small delicate vellous subarticulate brittle ramuli. Bark of the old ligneous parts, dark brown and pretty smooth. Leaves opposite sub-rotund, fleshy, convex and smooth above, hollow underneath; size of a large pin's head, ctc., almost exactly as in Portulaca quadrifida even to the quartern florat leaves. Petroles short stem-clasping. Flowers terminal, solitary, sessile in the bosom of the four 
floral leaves. Calyx subcylindric, five-grooved, five-toothed, withering. Corol five-petalled, campanulate, large for the size of the foliage, pure white and like the calyx withering. Filaments five nearly as long as the petals and with them alternately inserted in to the receptacle : at the base broad and seem united there but are not. Anthers yellow, germ superior, ovate smooth, one-celled and contains several ovula attached to the lower half of two opposite parietal receptacles. Style, length of the stamina apex bifid. Stigmas globular. Capsule ovate, hid in the withered calyx and corol, one-celled, two valved, opening from the apex. Seeds few attached as in the germ.

E. Beta vulgaris and sicla. Red and green beet and mangel wurzel belong to the first and the common white beet to the second.

I. Bedeas arborea. R. Arboreous. Leaves opposite short petioled, oblong ventricoso, serrate. Panicles terminal, bracheate, corymbose. White-wood cabbage-tree, the vernacular name in St. Helena, where it grows on the south face of Diana's Peak to be a large tree with straight upright trunk and dark coloured smooth bark. The young shoots are rough with much short brown hair. Leaves from oval to oblong, very equally gland serrate, smooth above, somewhat vellous underneath. Stipules none. Panicles terminal while young in flower, large subcorymbose, pretty well crowded with opposite hairy ramifications and their subdivisions. Flowers conical. Calyx scarce calycled, composed of a very few leaflets, and most of them embrace a floret like the scales of the receptacle. Seeds foursided strigose, particularly the four angles, each crowned with two very short scabrous arista, which are about as long as the tubes of the florets.

I. Boerhaavia repanda is common among the rocks in James' Valley.

E. Borago Zeylanicu. Ceylon borage.

E. Brassica oberacea. The common useful species and varieties of cabbage.

E. Browallra elata.

E. Buxus sempervirens. Common box tree.

E. Cactus opuntia. Common cactus.

E. Cactus cocinellifera. Cochineal fig.

E. Cactus chinensis. Chian cactus.

E. Calla othropica. Aithiopic calla.

E. Camellia-japonica. Two or three varieties.

E. Canna indica. Three or four varieties.

E. Cannabris sativa. Common hemp.

E. Calendula.

E. Calendula officinalis. Common marigold.

E. Capsicum cerasiflorme. Cherry pepper.

E. Capsicum grossum. Bell pepper.

E. Capsicum frutescens. Shrubby pepper.

I. Carex pedunculata. Spikes androgynous, pedicelled erect cylin dric, alternate on a terminal rachis: male flowers (when present) under the female: scales striated, apices serrate-dentate : 
corol striated. Style tritid, seed triangularly obovate. A native of the south face of Diana's Peak under the shade of trees, where kept most by fogs which rest on the Peak. It grows in small tufts to about the height of 3 feet when in flower. Radical leaves numerous, very long striated; kecled, hard and smooth; colour similar but smaller; culus, three-sided, smooth, leafy.

E. Cassia microphylla.

E. Cassia aurea.

E. Cassia alula.

E. Cassia esculenta.

E. Cassia sophera.

E. Costarea vesca.

E. Celsia Archurus.

E. Centaurea moschata.

I. Cheiranthes Temmpbia. Found on Diana's Peak where it grow's in large masses to be from $\sigma$ to 8 inches high, with long slender crooked dark coloured (brownish black) stipe and divisions. Compare with Adiantum assemile.

E. Cheranthus cheiro. Wallflower.

E. Cheranthus incanus. Gilly flower or stock. Several varieties.

E. Cheranthus odoratissimus. Persian stock.

E. Chenipodum ambrosioides. Mexican chenpodium.

E. Chenipodum album and viride. White and green chenpodium.

E. Cichorain Intybus. Wild succory and endive, garden succory or endive.

E. Cicer arielinum. Chick pea.

E. Citrus, including lemon, citron, orange with varieties.

E. Clevodendrum incrona.

E. Cliboria ternatea.

E. Clujtia pulchella. A Cape flowering shrub.

E. Cocas nucifera. Cocoa nut palm, very few and to not thrive.

E. Coffee Arabica. In Alexander's garden at Sandy Bay were some of the finest coffee trees I ever saw, and at the same time (Fehruary) in every stage from the blossom to the ripe berry.

E. Conchium gibbosum of Dr. E. Smith is Hakes' Gibbosa of Brown.

I. Cony'za gummifera. R. Arborcous, leaves sparse, approximate subsessile but not decurrent from lanceolar to cunneate oblong, subserrate soft rugose and more or less woolly underneath. Peduncles axillary solitary, drooping, one flowered; flowers globular. Gum-wood tree of the islanders, it grows on the more elevated land over the interior parts to be a tree of considerable size with short crooked trunk and still more crooked spreading branches and ditrichotomous branchlets. The bark of the trunk and large branches are a deeper or lighter brown and smooth except for the numerous scars of fallen leaves. The leaves are crowded about the ends of the branchlets, often broad lanceolar, particularly in old trees; while young. gummy and more hoary; length, $2-4$ inches by $\frac{1}{4}$ inch to $1 \frac{1}{2}$ broad. 


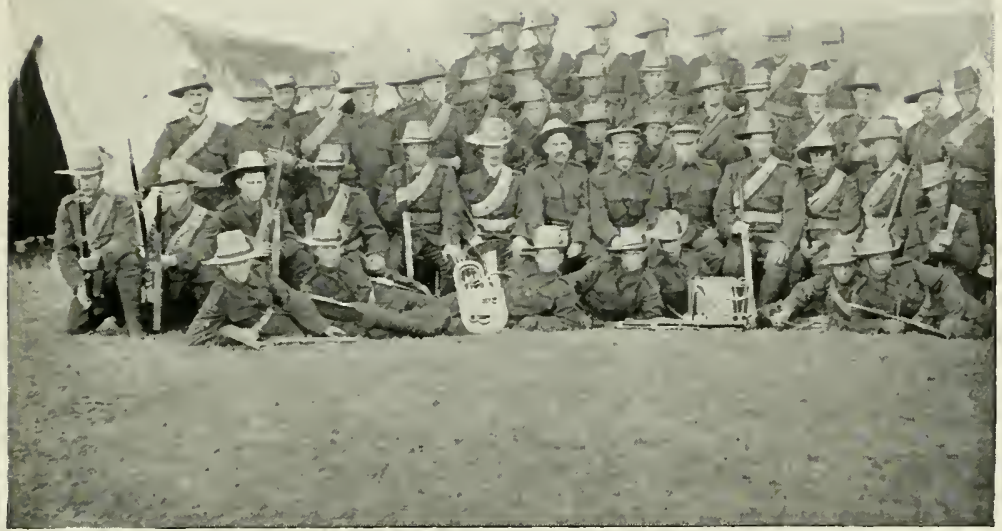

“B" Company, 3RI Midnlesex Reginent, Deadmood Camp.

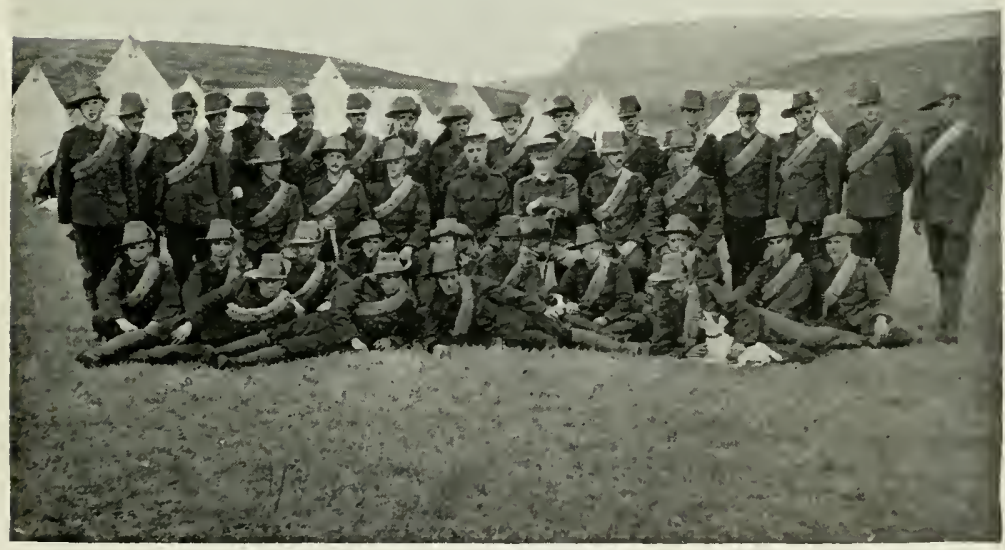

"E" CoMpany, 3RI MIDdesex RegameNt, DEAmWOOn CaMP. 

I. Conyza robusta. R. Leaves subsessile (not decurrent), lanceolar crenated, entate rugose. Penduncles axillary, solitary length of leaves, one flowered. Bastard gum tree is the vernacular name on St. Helena, where it grows to be a tree very similar to the last, and possessed of nearly the same qualities. The dwarfish, very crooked, antique habit of these trees makes them very conspicuous. The bark on the old parts is very thick and deeply cracked; the branchlets generally dichotomous and marked with the scars of the fallen leaves. The leaves while young, hoary with soft pubescence; the flowers few but large and white.

Conyza rugosa. Aitons, Kew, 3, I84. (See solidago cuneifolia.)

I. Convolvulus Brasitiensis. Willd. I. 877, and another undetermined indigenous species.

E. Purpureus. Willd. I. 352. Convolvulus major.

E. Convolvulus batalas. Willd. I. 853. Sweet potato, the red and white variety.

E. Cookia punctata. Willd. 2. 558. Wampee of the Chinese.

E. Cordia macrophylla. R. A large tree from Bengal.

E. Cordia campanulata. R. A small tree from the Moluccas and South Sea Islands.

E. Cotula coronapifolia. Willd. 3.2167. Pagoda plant of the islanders.

E. Crassula cultrata. Willd. 3. 1552. Sharp-leaved Crassula.

E. Crassula obliqua. Willd. I. I553. Oblique leaved.

E. Crinum toxicarium. R. And two or three other species which were not seen in blossom by Dr. Roxburgh.

E. Crotalaria retusa. Linn. Retuse leaved crotolaria.

E. Crotalaria laburnifolia. Linn. Laburnum leaved.

E. Crotalaria incanescens. Linn. Hoary.

E. Croton sebiferum. Linn. Tallow tree of China.

E. Cucurbita lagenaria. Willd. 4. 6I6. Bottle gourd.

E. Cunonia Capensis. Willd. 2.634 .

E. Cuvtisa faginea. Willd. I. 687. Hassegay tree.

E. Cupressus sempervivens. Two varieties of the Cypress.

E. Cupressus lusitanica. Lamb Pin t-42. Goa Cypress tree.

E. Cycas revoluta. Revolute leaved Cycas.

E. Cynara scolymus. Willd. 3. I69I. Artichoke.

E. Cyperus rotunda. A very common weed in gardens.

E. Cyperus tennifloras.

E. Cyperus Pepo et citrallus. Linn. Pumpkin and water melon.

E. Cucumis sativus. Linn. Garden cucumber.

E. Costas speciosus. Willd. I. Iо.

E. Dalbergie Lissoo. R. I From Bengal where they grow to

E. Dalbergie frondosa. R. $\}$ large timber trees.

E. Daphne odova, Hort. Kew. Sweet scented Daphne from China.

E. Datura fashiosa. Willd. I. I003.

E. Datura metel. Willd. I. I009.

E. Datura tatula. Willd. I. I008. 
E. Daucus carola. Linn. Common Carrot.

E. Draecoena cernus. Willd. 2. 157.

E. Dianthus barbatus. Linn. Sweet William.

E. Dianthus chinenses. Linn. China Pink.

E. Dianthus curophyllus. I.inn. Clove.

I. Dicksonia arborescens. Willd. 5.485 . Stipes, raches and subdivisions compressed and somewhat woolly, but not scabrous. Fronds ovate-oblong, hard glossy above, suboppositely tripinnate; ultimate segments from oval to oblong and crenate serrate. Spots on the margin until they open transversely oval after round. Grows on the tops of the highest mountains, such as Diana's Peak. 'Trunk single, straight; gencral height when full grown twenty or more feet, and of various thicknesses up to that of a man's body; covered with the bases of the decayed stipes, mosses and parasites of various kinds; at the apex clothed with long soft tawny-brown wool like that of which the finest shawls are made. When the woolly substance is removed, the parts over which it extends are found to be scabrous. Fronds (including the stipes) from four to ten feet long.

E. Diosconea alats. Linn. Winged lam. (Here they do not

E. Diosconea acaleata. R. Thorny Yam. Ihrise, but are of the

E. Diospyrus Kanki. Linn. Japan Diospy ros, fruit large and edible.

I. Dombeya Erythroxylon. Willd. 3. 725. Pentapetes Erythroxylon. Hort. Kew, Ist edit, $2,+38$. Melhavia, and edit., $\$-146$ of the same work.

Arboreors. Leaves ovate-cordate, crenulate, acuminate, smooth above, reticulate underneath, while young hoary obscurely 3-5 nerved. Peduncles axillary solitary 2-3 flowered, flowers pentandrous. Red wood tree, the vernacular name on St. Helena where it is indigenous on moderately high lills, where, if the soil is suitable, it grows rapidly with a straight trunk to be a middling sized tree of great beauty. Bark dark brown, even and pretty smooth. Branches numerous, spreading, tender twigs hoary. Stipules subulate. Peduncles about as long as the petioles. Flowers larger than in the following (d. Melanoxylon), colour the same and also changeable. Nectarial filaments flesh coloured. Style twice the length of the stamina. Capsules oblong, pointed, very hairy and somewhat shorter than the permanent calyx; cells $3-5$ seeded. This tree furnishes the islanders with a hard, close-grained mahogany-coloured durable wood.

1. Dombey'a melanoxylon. R. Melhania melanoxylon, Hort. Kew, and edit., 4-46. Leaves ovate-cordate, long petioled subentire, firm, smooth above, ferruginously hoary underneath, obscurely three-nerved. Peduncles axillary solitary, I-2 flowered, flowers pentandrous. Capsules ovate, obtuse, greatly shorter than the permanent calyx. Cells $2-3$ seeded. Fbony the 
vernacular name. Is a native of the barren rocks near the sea, and not far from Sandy Bay, on the south side of the island, I saw it in two gardens only, where it had in many years grown to the height of only three feet, with many longer branches spreading flat on the ground, well decorated with abundance of foliage and large beautiful flowers. Bark of the old ligneous parts rather rough and of a dark olive-coloured colour. Of the young shoots, hoary with stellate pubescence, each starlet thereof has a ferruginous centre. Petioles under-side of the leaves, peduncles, branches and calyx have the same colouring. The leaves are greatly smaller than in D. Erythroxylon, but more entire; stipules subulate. Peduncles, length of the leaves, I-2 flowered. Flowers large campanulate; when they first expand white, becoming pink or rosy by age. Bractes turn ovate, lanceolate pressing the base of the calyx. Stamina five, shorter than the five dark purple clavate nectarial filaments. In some parts on the south side of the island near the sea numbers of the dry trunks were found in former days, now few remain, the greater part having been carried away for fuel ; these little trunks are but a few feet in length, generally very crooked, and run from one to three or four feet in circumference near the root; those parts of the root and branches which remain spread nearly horizontal : the exterior surface is pretty even, and of a dark lead colour, having been exposed to the weather for probably some hundred years; within, it is nearly as black as common ebony, and as closegrained, hard and heavy; in short, it is so very like ebony as to have procured it that name from the islanders. The few trees now found alive in their native soil and situation are from ten to fifteen feet high, their trunks crooked and about as thick as a man's thigh; the branches very numerous, spreading, etc., etc., and at this season, when the young foliage is expanding, the flower buds are also to be seen, and in this state generally two on each peduncle; whereas in the cultivated plants rarely more than one.

E. Eleùsine covacána. R. Cynosurus corocanus. Linn.

E. Eleusine indica. Gaert. Cynosurus. Linn.

E. Eleusine calycina. R.

E. Erodium sempervivum. R. Pelargonium Colyledonis. Willd, 3-74. Shrubby, succulent, and extremely tortuous, umbels long-peduncled, decompound. Leaves subcordate, downy, rugose, some lobate-crenate, some peltate. A native of the barren rocky precipices on the south side of the island, and known by the name, "Old father live for ever." It grows to be a large spreading shrub, with innumerable, thick, succulent, extremely crooked branches, the apices obtuse, and thence both leaves and umbels spring. Bark thick and fleshy, the surface dark brown and peels off in small fragments. Leaves long, petioled, and soft with down. Stipules small, triangular and acute. Peduncles terminal, generally single, 
very long, erect, coloured and villous : the umbellets numerous and all the divisions long, coloured and villous. Involucres scarcely any, involucres of a few small acute scales. Flowers numerous, pure white calyx, five-tooth. The rest as in the genus. Every part is to me void of sinell.

E. Erythonia cafficu. Willd. 3.914. Cape-coral-tree.

E. Euphorbia rosea. Willd. 2. 895 . French grass of the islanders.

E. Euphorbia peplus. Willd. 2. 913. Small spurge.

E. Engenia Jambos. Willd. 2. 959. Rose apple.

1.. Ficus carica. The common fig grows freely here, and produces good crops of excellent fruit; but like all else in rural economy, is too much neglected.

E. Ficus indica, or the famous Banyan Tree of India.

E. Ficus religiosa. Willd. 41134 .

E. Ficus terebrala. Willd. 41445 . Is the most common tree in James Valley, where it grows freely and furnishes excellent fuel, the wood of the species being much firmer than any other species of this genus known to me.

I. Fimbristylis textilis. R. Culius naked, columnar until alove the middle, then somewhat compressed. Leaves nonc. Spikelets numerous in a hard sessile head $1-2$ inches below the subulate grooved apex; flowers $1-3$ androgynous; scales boat-shaped, rather obtuse, style 3 -fid. St. Helena thatching rush; is a native of the interior of the island, and is in plenty for every purpose; in moist elevated situations, it grows io the height of $3-6$ feet perfectly destitute of leaves and quite straight, about as thick as a crow's quill, of a firm texture and smooth glossy deep green colour. A good substantial covering of this rush is said to last from ten to fifteen years and keeps out wet effectually.

E. Frageria vesca. Willd. 2. rogo. Strawberries a few varieties, but little or no care is taken of them; they consequently do not thrive.

E. Fraxinus chinensis. R. China ash, a small slow-growing tree.

E. Fumaria capreolata. Willd. 3. 868. Running Fumitory.

E. Fuchsia coccinea. Willd. 2. 340. Scarlet Fuchsia, grows most luxuriantly in Sandy Bay.

E. Gardenia forida. Willd. 1.1225. Cape Jasmine.

E Gardenia thubergia. Willd. 1. 1226.

E. Gardenia radicans. Willd. I. 1225 .

E. Gledetschia horrida. Willd. 4. 1097. This tree is one of the most stately and most beautiful on the island, but unfortunately, there is but a single specimen to be seen; it grows in the garden at the Governor's country house, where it has attained to the height of fifty feet or more; with trunk and coma proportionately large. It has not produced seeds, nor have they hitherto been able to multiply this charming tree. The large ramous species are confined to the trunk and larger branches. 


\section{ST. HELENA}

E. Gmelina asiatica. Willd. 3. 313. A large thorny shrub with large drooping yellow flowers.

E. Gnaphalium americanum. Willd. 3. 1887. Everlasting.

E. Gomphrena globosa. Willd. I. I32I. Annual globe-amaranth.

E. Gossypium latifolium. Willd. 3.806. Grows freely and yields a large produce of fine cotton.

E. Gossypium barbeodense. Willd. 3.806. Barbadoes cotton.

I. Graminetes marguella. Willd. 5. 139 .

E. Hibiscus populus. Willd. 3. 209. A useful timber tree of considerable size.

E. Hibiscus populeoides. R. A tree similar to last but larger.

E. Hibiscus mutabilis. Willd. 3. 817. Changeable flowers.

E. Hibiscus syriacus. Willd. 3. 818. Syrian Hibiscus.

E. Hibiscus sabdariffa. Willd. 3.821. Or West Indian sorrel.

E. Hibiscus cannabinus. Willd. 3. 822. Hemp Hibiscus.

E. Hibiscus abelmoschus. Willd. 3.826. Musk Hibiscus.

E. Hibiscus trionam. Willd. 3. 836 . Bladder Hibiscus.

E. Hibiscus diversifolius. Willd. 3.820. A tall tree of short duration.

E. Hibiscus ureus. Willd. 3. 817.

E. Hibiscus rosa sinensis. Willd. 3.812. China Rose or Shoe Flower.

E. Hibiscus phoeniceus. Willd. 3. 8I 3 .

E. Hibiscus armatus. Or Rock-rose of the islanders.

E. Haeinanthus. From Cape of Good Hope; species uncertain.

I. Hedyotis arborea. R. Dog-wood of the islanders. Arboreous, leaves opposite, short petioled, oblong, acummate, entire, glossy, recurved ; stipulary sheath cylindric, with one or three unequal denticuli on each side; Corymbs terminal, bracheate, subglobular. Capsules globular. A small tree, a native of the dark forests which decorate the misty Alpine tops of the most lofty mountains in St. Helena.

E. Helianthus annures. Willd. 3. 2237, Annual sunflower.

E. Heliotropium indicum. Willd. I. 740. A weed in gardens.

E. Hemerocallis fulva. Willd. 2. 197. Day Lily.

E. Hordeum hexastichon. Willd. I. 472. Spring barley.

E. Hordeum distichon. Willd. 1. 437. Common barley.

E. Hyderocopyle-asiatica. Willd. I. I362. Pennywort.

E. Hydrangea tortensis. Willd. 2.633. China guelder rose.

E. Hymenophyllum capillaceum. R. Parasitic, surcald and stipes capillary, the former creeping. Fronds lanceolate, bipinnatifid; sigment linear, margins entire. Involucres terminal, solitary, more rarely paired subrotund. A most beautiful, exquisitely delicate, small creeping parasite, found mixed with moss on the trunks of trees over Diana's Peak.

E. Hypericum monogynum. Willd, 3. 1442. Chinese St. John's wort.

E. Jasminum officinale and odoratissumum. Willd. 1. 40. Common yellow jasmine.

E. Impatiens balsamina. Willd. 1. II75. Garden Balsam. 
E. Indyoffera tinctoria. Willd. 3. 1237. Common Indigo Plant.

E. Ipomera quámoclit. Willd. $1 \frac{1}{2} .879$, and Grandiflora, R.

E. Justicia betonica. Willd. I. 96. Betony leaved Justicia.

E. Issa. Several species from the Cape which thrive well in elevated gardens.

Kyelinga monociphyla. Willd. 1. 256.

Kyelinga sumatrensis. Willd. 1. 258.

E. Lachuca sativa. Willd. 3.15a3. Lettuces some few for varietics.

E. Lammen purpurean. Willd. 3. 88. Red Dead nettle.

E. Laura peisea. Willd. 2. 480. Avocado pear. Saw only one tree on the whole island, and no care taken of it; indeed no person knew what it was. It blossoms freely every year, but has not produced fruit.

E. Leontodon taraxacum. Willd. 3. 1544. Dandelion.

E. Limodoresm aloefolium. Cymbedium. Willd, 4.101.

I. Lobelia scoevolifolia. R. Shrubby erect branchlets, succulent and polished. Leares sparse, crenate-lanceolate, 3mooth serrate. Peduncles axillary, solitary, shorter than the leaves, one-flowered. Capsules clavate-turbinate. A native of the thick well-shaded forests which clothe the south face of the Sandy Bay range of mountains, where it grows to be a pretty large shrub, the flowers rather large and pure white.

I. Lonicera Periclymenum and Caprifolium. Two species of Honeysuckle.

E. Lupinis. Lupin, two or three species in gardens on hills.

I. Lycopodium cernuum. Willd. 5. 30 (compare with P. Saururus Willd, 5.30). Grows in great abundance on the mountains, where it is called Buckshorn. General height, from one to three fect, and uncommonly raucous.

I. Ly'copodium axillare. R. Stems erect, simple, unbracated on all sides with numerous glossy, entirely acute, subappressed ensiform leaves. Capsules axillary; solitary sessile. Found indigenous among grass on rather dry rocky situations over the higher parts of the south face of Diana's Peak.

E. Magnoliac pumila, obovala and fuscata. All from China and grow luxuriantly here.

E. Malca mauritiana. Linn. Ivy leaf mallow.

E. Mangifera rudica. Linn. Common mango thrives well at Briars.

E. Melia semperivens. Willd. Grows abundantly to the size of a small tree over most parts of the island, and highly ornamental, being in flower and seed the whole year.

E. Melia superba. R. A large timber tree from India.

E. Melia robusta. R. Also a large timber tree from India.

E. Melia Azedarach. Willd. 2.558. A good and beautiful timber tree, a native of China.

E. Melissa officinalis. Willd. 3. 146. Balm.

E. Mentha rividis. Lii and two or three undetermined species of mint.

E. Mesembryanthemum. Fig marigold. Several species Dr. Roxburgh saw in garden, from Cape of Good Hope originally. 
E. Mespilus japonica. Willd. 2. Ioro. Louquat of the Chinese. This most elegant useful tree is perfectly at home here, and in time, with a little care, will be highly beneficial to St. Helena.

E. Michellia champaca. Willd. 2. 1260. In one garden only.

I. Mikania arborea. R. Arboreous with straight trunk. Leaves alternate, petioled, oblong, smooth gland dentate serrate. Panicles, terminal drooping. Calyx simple, cylindrico, five toothed, five-flowered. She-cabbage tree, the vernacular name, In the forests which decorate the south face of Sandy Bay ridge it grows plentifully to be a tall slender straight tree, particularly while young; for by age it becomes bent to one side and well furnished with crooked brittle branches. The wood is white and is used for timber in very large quantities. Young shoots smooth, of a bright purple colour; while the trees are young (say under six to eight feet), simple with the leafy tops, resembling a highly coloured colewort, hence the vernacular name. When in this stage the leaves are generally from one to two feet long by four to eight inches broad; in old stunted trees two to three inches long by one to two inches broad. Panicles rather thin sub-dichotomous, coloured like the petioles, etc., corymbiform. Branches single, smooth and small under each division, besides others on the pedicells and round the base of the simple cylindric, smooth five-toothed calyx, which when the seeds are ripe splits in five linear recurved leaflets.

E. Mimosa arabica. R. Acacia. Willd. 4. I085.

E. Mimosa sressa R. Or Mauritius blackwood.

E. Mimosa cinerea. Linn. Acacia cinerea. Willd. 4. I057.

E. Mimosa glaucescens. R. Acacia glancesceas. Willd.4. 1052.

E. Mimosa juniperina. Acacia juniperina. Willd. 4. I099.

E. Mimosa lunfolia. Linn. Acacia lunfolia. Willd. 4. I05I.

E. Mimosa glauca. Linn. Acacia glanca. Willd. 4. I075.

E. Mimosa farnesiana. Linn. Acacia farnesiana. Willd. 4. Io83.

E. Mimosa scandens. Linn. Acacia scandens. Willd, 4.1057. On the windward side of the island the seeds are cast on shore and vegetate. Beside the above there are some other exotic species which I had no opportunity to determine.

E. Mimusops Eleuji. Willd. 2. 325. Bocul of the Hindoos.

E. Mirabilis jalapa. Willd. I. 999. Common marvel of Peru.

E. Momordia charantia. Willd. 4.601. The fruit before maturity much used in the diet of the Hindoos.

E. Moreae chinensis. Willd. I. 245.

E. Morus nigra. Willd. 4. 369. Common Mulberry tree.

E. Morus atropurpurea. R. A quick growing tree from China

E. Murrays exotica. Willd. 2. 548. China box tree.

E. Musa sapientum. Willd. 4.894. Banana.

E. Musa paradisicea. Willd. 4. 893. Common plantain tree.

I. Myrstica moschata. Willd. 4.863. Banda nutmeg. One sickly plant in Major Hudson's garden, James Valley.

E. Myrtus pementa. Willd. 2.973. Introduced by Dr. Roxburgh 
in 1805 . It thrives well in the garden near the south island, where it is cool and often moistened.

Myrtus communis. Willd. 2.967. Grows most luxuriantly to the size of a small, very ramous tree. Besides the common myrtle there are two other varieties thereof.

E. Narcissus tazetta. Pseudo Narcissus and Jonquilla. In gardens.

E. Nerium tructorium. R. and ordorium. Willd. I. I235.

E. Nicotiana Tabacum. Willd. 1. 1014. Common Virginian and Havana tobacco.

E. Olea esuropea. Willd. I. 44. Common olive. Grows luxuriantly to be a tree of considerable size, and might be advantageously reared for fuel independent of the fruit.

I. Ophioglossum lusitanicum. Willd. 5. 59.

E. Origamum majoraioides. Willd. 3, 137. Stout shrubby species Marjoram.

E. Oriza sativa. Willd. 2.247. This highly useful grain, rice, does not thrive on any part of the island, at least such is the report; and Dr. Roxburgh saw nothing to make him think otherwise.

E. Osteospeimum pesiferum. Willd.

Panicum aliare. Willd. 1.344.

Panicum aegyplicum. Willd. I. 343.

Panicum dactylon. Willd. 8.342 . Wire grass the vernacular name, and supposed to be a native of the island. Agrostis stellata and lincarrs of Willdenow. I am inclined to consider this very identical species consequently the East Indian dup-grass or dupa.

E. Panicum italicum. Willd. 1. 336. Is much cultivated in many parts of Asia, but does not thrive in St. Helena.

E. Panicum molle. Willd. I. 340, or Scotch grass.

E. Panicum verticillatum. Willd. 1. 343. Rough Panic grass. Besides the above six there are two or three more which Dr. Roxburgh had not a good opportunity of ascertaining.

E. Parkinsonia aculeata. Willd. 2. 513. A most beautiful quick growing tree.

E. Passifiora cerulea. Willd. 3.623. Common Passion Flower.

E. Pelargonium betulinum Pelargonium capitatum.

E. Pelargonium angulosum.

E. Pelargonium cucullatum.

E. Pelargonium inquinans.

E. Pelargonium denticulatum.

E. Pelargonium graveolius.

E. Pelargonium hytuidim.

E. Pentapetes. Linn. Plerospermum suberifolium. Willd. 3.723 Saw only one tree on the island. It was reared in the Company's nursery from seed sent from Bengal by Dr. Roxburgh.

E. Phaseolus rulgaris. Willd. 3.1030. Several varieties of kidney bean. 


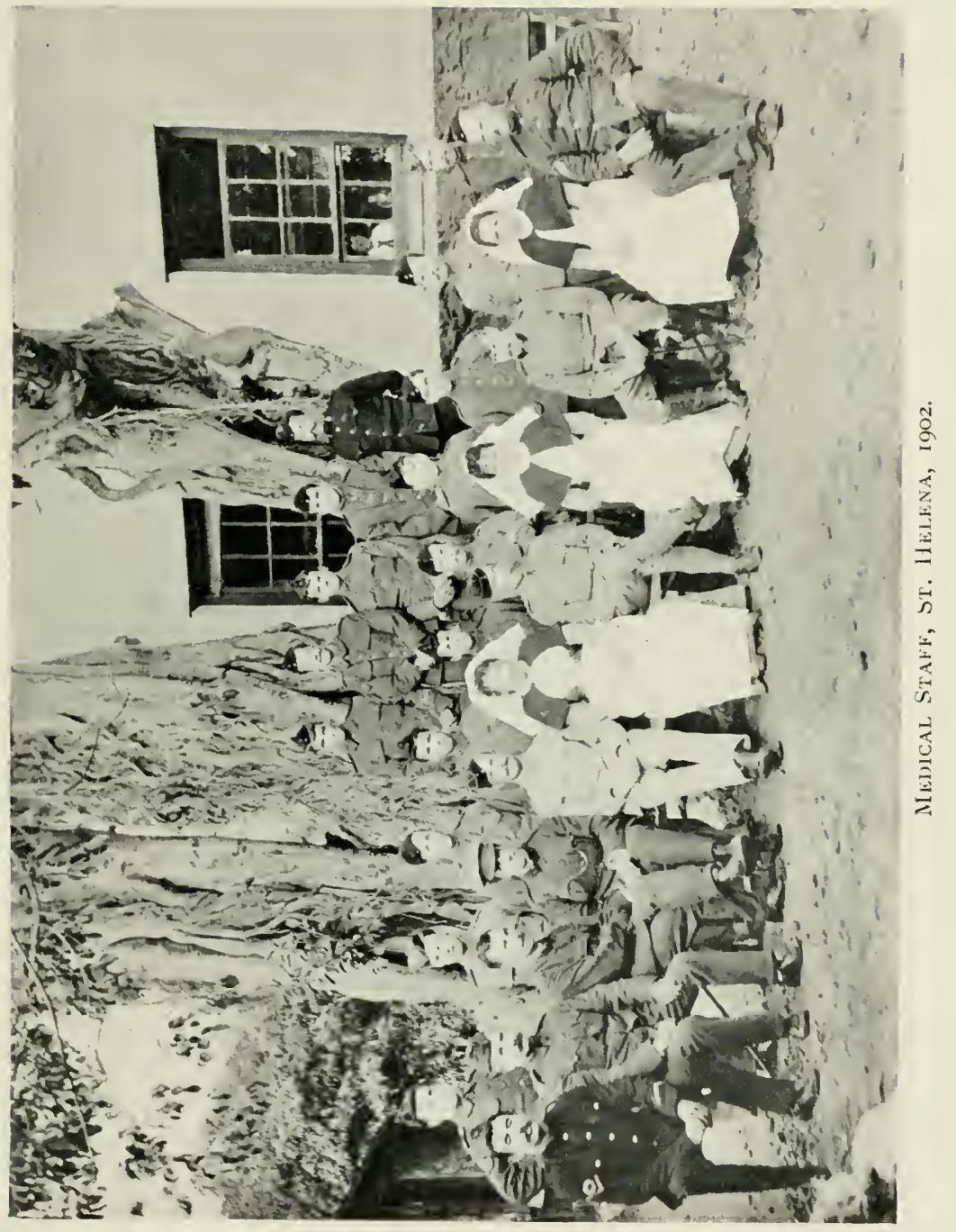



E. Phaseolus lumatus. Willd. 3. ro31. Lima Bean.

E. Phillyea. Willd. I. 42. Common Phillyrea.

E. Phlomis nepetifolia. Willd. 3. 1236.

I. Phylica elliptica. R. Shrubby. Leaves opposite, short petioled, elliptic, rarely subovate, thick and hard, hoary and concave underneath. Stipules four tern, ovate, concave. Flowers in peduncled, axillary, hoary heads. Capsules turbinate. A native of the most elevated parts of Diana's Peak and of the Sandy Bay range, where it grows fairly large, but is a low spreading tree, there called the wild olive; flowering in July and the seeds ripen in March. The wood is dark coloured, hard, and very useful.

I. Phylica rosmarifolia. R. Arboreus, very ramous. Leaves alternate, short petioled, lanccolar acute, lucid above, hoary underneath, margins revoluto. Stipules subulate. Flowcrs axillary subsessile. Wild Rosemary it is called by the islanders; and is found indigenous on moderately high mountains, where it grows to be a middling sized useful timber tree of great beauty and fragrance. The bark tolerably smooth; the trunk short, thick and crooked. The leaves bear resemblance to those of Rosemary: lucid above and white beneath. Flowers minute, pale greenish white. Capsules size of a pea, oval, until dry-ripe bacciform, after they split in to three.

E. Phoenix dactylifera. Willd. 4.730. A few trees only were seen, though they thrive well and promise much benefit to the island if carefully managed.

E. Phyllanthus andrachnoides. Willd. 4. 575 .

I. Physalis begonifolia. R. Shrubby and very ramous. Leaves in pairs, petioled, unequally ovate-cordate, entire and soft. Peduncles axillary, solitary, drooping, one-flowered. Calyx campanulate, larger than the whole corol, its borders divided in to five, broad short unequal rounded segments. A native of the rocky hills on the east and south sides of the island and known by the name of box-wood. The trunk grows single from two to four feet in height, and about as thick as a man's arm; its bark tolerably smooth and brownish. Branches numerous and divide into innumerable alternate villous branches.

E. Physalis peruveana. Wiild, I. I022. Brazil cherry, is very common everywhere because the goats do not eat it, and furnishes the island folk with ample supplies of large palatable berries, without requiring the least care.

E. Pinus longifolia. Lamb pin-tab 21 . Of this magnificent pine there arc but one or two young trees in the Governor's garden.

Pinus pinaster. Willd, 4. 496. Grows well and to a great size on the south side of the island, also in the Governor's garden and plantations.

E. Pinus pirea. Willd. 4. 497. Stone pine.

E. Pinus sylvestors. Willd. 4. 494. Scotch fir. 
Pisum sativum. Willd. 3. 1070. Garden pea, a few varieties.

1:. Pillo spormm. Tobira. Botanical Magasine, 1396.

I. Planlago robusta. R. Shrubby. Leaves crowded round the apices of the robust ligneous branches, linear entire, withering. Spikes few, axillary, cylindric, long peduncled. A native of the top of the moderately ligh hills over the island, where it grows to be a stout shrub, with but few very thick simple somewhat woody branches; bark strongly marked with the innumerable scars of the fallen leaves.

Plantago major. Willd. * * Three qualities of rather inferior
Poa japoniea. Willd. 1. 394. Poa pratensis. Willd. 1. 385 .

Poa lara. Willd, I. 386.

E. Poinciana pulcherimm . Walld. Priclily flower fence.

E. Polyanthes tuberosa. Willd, 2.164. Tuberose.

I. Pobypodium macrocarpum. Willd, 5.147. Surculi crecping, slender and very scaly, rootiug on trees, rocks, etc. Stipes short, slender, polished dark brown and somewhat winged while young, scaly. Fronds ( $4-6$ inch) narrow, lanceolar, tapering most at the base, entire rather obtuse, smooth thick firm, veinless surfaces, particularly the under dotted with ferruginous specks. Spots in one row on the exterior half large, round and distinct, but intermixed with many peltate scales, which while young unite and form a complete polyphyllous involucre. Is a pretty delicate species, growing over the south face of Diana's Peak. It may be referred to Pleopeltis of Humboldt and Bonpland.

I Polvpodium molle. IR. Stipes decply channelled with the rachis, covered with soft hair and large hrown ramenti. Fronds ovate, soft and hairy underueath, sul, oppositcly bipinnate. I.eaflet decply crenate. Fructifications numerous, small fenerally in two ill-defined rows equally distant from the nerve anil margin. A native of Diana's Peak, grows in tufts in most thickets to be $2-4$ fect ligh.

I. Polypodimm rugulosum. Willd. 5. 20.4\%. Stipes hairy. Fronds oblong, alternately bi-ternate, texture thin and soft, pinnoe, lanccolate, obtusc. Leaflets dentate. Spors sub-marginal. Found on Diana's Peak growing to the height of 2-3 feet, but slender and every way delicate.

1. Polypodium dicksonifolism. R. Stipes brown channelled and scabcous. Fronds lanceolate, sub-triplinatc, sub-opposite, linear oblong, obtuse decply obtuse crenate. Spots large, one or two on each of the ultimate segments of the frond, the margins of which turn down, and in part cover them. A pretty, delicate, divided plant growing on Diana's Peak to height 8-12 inches.

I. Polypodium viscidium. R. Surculi flexuose, brown and shaggy, stipes, etc., channelled and clothed with clammy headed diverging solt hairs on a brown ground. Fronds ovate, sub-oppositely triplinnate and superdecompound; 
leaflets linear oblong, obtusely crenate or pinnatifid. Spots distinct, few or numerous, under the recurved crenatures of the segments of the leaflets. Common about stone dikes, ctc., etc., Sandy Bay, where it grows to the height of from 6 inches to $2-3$ feet and fructifies all the year.

E. Populus alba. Willd. 4. 802. White poplar or Abele tree thrives well.

E. Portulaca oleracea. Willd. 2.859. Common Purslane.

E. Protea argenta. Willd. I. 529. Silver tree.

E. Protea mellifera. Willd. I. 522. Honey-bearing Protea.

E. Prenus armeniaca. Willd, 2.989. Apricot. Does not succeed here.

E. Psidium pomiferum. Willd. 2. 958. Common guava.

I. Psoralea pennata. Willd. 3. I 342. Goble-gheer, the vernacular name.

I. Pteris semiserrata. R. Stipes length of the ovate, oppositely binatifid, flimsy fronds, polished smooth green and channelled. Pinnœ lanceolate; segments divided nearly to the base, linearlanceolate barren apices serrate. A native of Sandy Bay, where it grows to be $2-5$ feet high.

I. Pteris palaceae. R. Stipes and surculi denscly clothed with long brown black scarious scales. Fronds suborbicular, bitripinnately pedube, leaflets falcate-linguiform obtuse. Raches of the punia spinulosa on the upper side. A robust scarce species of about 2 feet in height, a native of the south face of Diana's Peak.

E. Punica granatum. Willd. 2.98I. Pomegranate.

E. Pyrus chinensis. R. China pear. Large but very indifferent.

E. Pyrus mallis. Willd. 2. Iо16. The apple and but few sorts on the island.

E. Pyrus cydonea. Willd. 2. IO20. Quince.

E. Quevcus vobur. Willd. 4. 450. Common British oak.

E. Quercus ilex. Willd. 4. 433. Evergreen oak.

E. Quercus suber. Willd. 4. 433. Cork tree.

E. Ranunculus bulbosus. Willd. 2. 1324. Buttercups.

E. Raphanus sattvus. 3.560. Radish.

E. Rhus vernex. Willd. I. I 497. One tree in Deputy-Governors' garden.

E. Ricinus commune. Willd. 4. 564. Common Palmi Christi. This grows luxuriantly.

I. Roella angustifolia. R. Perennial, diffuse; branches long, slender and scabrous. Leaves alternatc, sessile linear lanceolate, remotely and acutely gland-serrate, denticulate. Peduncles lateral many times longer than the leaves, dichotomous, many flowered. Common in fissures of the rocks about Major Seals' farm in Sandy Bay, where fogs prevail and the thermometer ranges from 60 to 70 . Is in seed and flower the whole year. The flowers are pure white, erect and pretty large. I think it would be an ornamental plant for a flower garden.

I. Roclla paniculata. R. Shrubby, erect, branchlets hairy, 
Leaves sparse, sessile, cuneate-lanccolate, serrulate, hairy. Panicles terminal hairy. A slender upright shrub with but few erect branches. A native of the thick forest of the south face of Diana's Peak; the flowers are large and white.

I. Roella huofolia. R. Shrubby sub-parasitic (or Dicksonia arborescens). Leaves sparse, sessiles numerous, linear, smooth, very acutely serrulatc. l'eduncles (racoures) terminal, few flowered. A pretty little ramous ditfuse alpine plant found in the top of Sandy Bay Ridgc, chiefly on Diana's Peak. l.eaves crowded round the somewhat villous columnar branches. The flowers white, with a tinge of pink and highly ornamental.

E. Rosa-triphylla. R. Scandent icrnatc-leaved, large whitc single rose.

E. Rosa centifolia. Willd. 2. 1071. Common Rose.

E. Rosa muscosa. Willd. 2. 1078. Moss Rose.

E. Rosa chinensis. Willd. 2. 1078.

E. Rosa semperforens. Willd. 2.1074.

E. Rubus pinnatus. Willd. 2. 1081. Shrubby. Leaves pinnate, leaflets five or seven, rarely threc ovate-cordate lucid, strongly veined, doubly serrate. Panicles terminate. Stems, branches, petioles and peduncles armed ; tender shoots villous and hoary. Bramble, the vernacular name on St. Helena, where it proves a most noxious plant running over large tracts of the best land; on account of the rapidity with which it grows to a much larger size than the common bramble of Europe (Rubus friticoseus). It has hitherto baffled every attempt to extirpate it. The roots grow to a great size, and every bit left in the ground grows. Stem scarce, and what there is grows to be as thick as a man's leg sometimes. Branches numerous, very long and scandent, when their apices rest on the ground they strike root and produce other plants as in the other species of this genus. The young shoots glaucous and downy, the bark of the old dark brown; all are well armed with numerous recurved prickles. Leaves alternate, pinnate 6-12 inches long, leaflets ovatc and ovate-cordate, smooth doubly serrate. Petioles and ribs armed. Stipules petiolary, ensiform. Panicles terminal, with their peduncles and sub-divisions armed and downy. Brackes like the stipules. Calycine segments lanceloate, nearly twice the length of the ovate, pink petals, and they are rather longer than the stamina and styles. Berries in shape, size and colour very like those of the common bramble, but scarcely so palatable. Some of the old inhabitants say it was brought originally from England for the common bramble of that country; others, and with nreater probability, say it was brought from the Cape of Good Hope.

E. Runex vescicarinis. Willd. 2.256. Bladder sorrel and Acctosa or common sorrel.

E. Rumex paticuta. Willd. 2. 249, and one or (wo species, which Dr. Roxburgh had no opportunity of ascertaining.

E. Ruta graveolens. Willd. 2. 542 . Ruc. 
E. Salex babylonica. Willd. 4. 67I. Weeping Willow and two other unascertained species.

E. Saccharum officinarum. Willd. I. 321. Sugar-cane.

I. Salsola salsa. Willd, I. I312. Common over the most barren parts of the island.

E. Salvia officinalis. Willd. 3. 129. Common sage and coccinea scarlet sage.

E. Sambuci nigra. Willd. 1. 1495. Common Elder.

E. Sanseviera zeylanica. Willd. 2. I 59.

E. Scytalia litchi. (see Gacrt sem, I. 197.) Litchi of China, a wellknown fruit.

E. Scytalia longa. R. Longan or Dragon's Eye, the small round grey Litchi.

E. Scytalia rambootan. R. Nephelium cappaceum. Lini1. Rambootan of the Malays.

E. Senecia jacobea. Willd. 3. 1997. Common Ragwort.

E. Sida lanceolatea and microphylla. Willd. 3.736 and 739 .

E. Sigesbeckia orientalis. Willd. 3.2219. A weed in gardens.

E. Solanum tuberosum. Willd. I. I033. Common Potatoes, several varieties.

E. Solanum lycopersicum. Willd. I. 1033. Love apple.

E. Solanum pseudo-capsicum. Willd, I.1026. Bastard capsicum

E. Solanum sodomann. Willd. 1. 1043. Black spined Solanum.

E. Solanum jacqumiri. Willd. I. IO4I.

E. Solanum nigrum. Willd. I. I035. Garden solanum leaves used as spinage.

I. Solidago spuria. Willd. 3. 2053. Conyza rugosa, Ait, Kew, 3.I84. Arboreous. Leaves short petioled, cuneate-lanceolate, obtuse serrate-dentate, tomentone underneath. Corymbs terminal (ultimately in the forks and length of the leaves) much crowded. Bastard cabbage tree of the islanders. On the tops of the highest mountains it grows to be a large but inelegant tree. The wood close grained, white and durable, but chief use for fuel.

I. Solidago leucodendron. Willd. 3. 2054. Arboreous, very. ramous. Leaves sessile, cuncate-lanceolate, anterior margin serrate, smooth. Corymbs terminal, length of the leaves. many flowered; flowers sub-cylindric; female florets 6-IO in the ray and 4-6 hermaphrodite in the centre. Cabbages tree gum-wood the vernacular name on St. Helena, where it is indigenous on the mountain at an elevation of from I, 500 to 2,000 feet above the sea, and grows to be a pretty large ramous tree, its ultimate ramification tricholomous with dark brown bark, rendered scabious by the numerous elevated scars of the fallen leaves. Leaves smoother and less clammy than in the other species. Corymbs terminal, several together; peduncles and divisions cylindric and smooth; flowers numerous, small and white, the female florets revolute, branches subulate; scales of the calyx decrease so as to be very minute at the base. The wood used for fuel chiefly. 
I. Solidago integrifolia. R. Arboreus with far-spreading branches, and smooth glossy branchlets. Leaves sparse, approximate, sessile, cuncatc-lanceolate, obtuse entire, margins revolute, glossy above while young, slightly woolly underneath. Corymbs terminal, length of the leaves, very ramous and large. Black cabbage-tree. The vernacular name. On Sandy Bay Ridge it grows to be one of the largest, some say the largest indigenous tree on the island, the trunk about $5-6$ feet in circumference; the coma very ramous, large and spreading; wood white, hard and serviceable for various purposes, but fucl chicfly. Flowers white, appearing in January, female florets $20-30$ inclies the ray; male in the disk and numcrous; receptacle naked, convex pappus liairy. Calyx subcylindric, imbricated scalcs numerous, lincar, acute.

1. Solidago cuncifolia. R. Arborcus. Leaves sessile, cuneiform, grossly serrate on the anterior margins, very rugose (but scarce villous). Peduncles terminal, length of the leaves, few flowered. Hermaphrodite and female florets about two of each. He-cabbage tree of the islanders. It grows to be a middlesized tree, its ultimate ramufications dichotomous, bark thereol olive brown. Leares less crowded than in Leucodendron but larger, anterior half decply serrate; posterior half entirc and taper much, all are very rigose and villous underneath. Peduncles terminal, simple and one flowered, or soon divide into two, three of four long, slender, smooth, one flowered pedicells; flowers white; calyx cyllndric, etc., as in Leucodendron; the fenale florets are nearly as numerous as the hermaphroditc lanceolar, apices threc dentate, spreading at first, but by age become revolute.

1 Solidago olundifora. 1R. Arboreus. Leaves alternate, long petioled from oval to sub-rotund, scrrate-dentate, smooth, whle young shining with clammy varnish. P'anicles terminal, spreacling, length of the leaves very ramous and sub-rotund. A native of the licights of St. Helena, where it is called the Bastard Gum-wood by some, and Cabbage tree by others. On the hills and mounlains it grows to be a tree of about 20 feet in height, with a crooked trunk, which is thick in proportion to the size of the tree; its bark and that of the branches also almost black, but pretty smooth except for the numerous scars lett by the decaycd leaves. Wood white, hard and durable. P'etioles channdled, nearly as long as the leaves. Panicles terminal when they first appear, but by the growth of two or three branchlets from the apex of the twig they soon stand in the fork thereol; this is the general habit of all those sy'ngenesious trees found by me in this island. Flowers numerous, small and white, 3-10 ligulate revolute female florets in the ray, and $7-\delta$ tubular male in the disk. Sonchus oleraceus and lacvis. Common sow thistles.

E. Spaclium junccum. Willd. 3. 926. Broom.

1. Spilanthus tetrandra. R. Shrubby. Leaves opposite, short, 
petioled, oblong serrate, convex reticulate, underneath. Peduncles axillary solitary, one rarely, two flowered, bracted; florets tetrandous. Indigenous on the mountains, where it grows to $4-5$ feet high.

E. Spinacia oleracea. Willd. 4. 766. Spinage (Common).

E. Spiraea corymbosa. R. A pretty China shrub already described by Dr. Roxburgh.

F. Swietenia mahagoni. Willd. 2. 557. Mahogany tree introduced from the Botanic Garden at Calcutta.

E. Swietenia febrifuga. R. East India Fever bark tree.

E. Syringa vulgavis. Willd. I. Common Lilac.

E. Tagetes patula and evecta. Willd. 3.2136. French and African Marigold.

E. Tamanucus indica. Willd. 3. 577. Tamarind tree.

E. Taxus elongata. Willd, 4.857. Cape of Good Hope.

E. Taxus chinensis. R. China Yew.

E. Tectona grandis. Will, r.1088. Teakitree.

E. Terminalia catappa. Will. 4.967. An elegant and useful large tree.

E. Tetrantheae macrophylla. R. Brought from Bengal by Dr. Roxburgh, being the food of the Mogadooty silkworm.

E. Thea. Tea. Saw one or two stunted plants in the Governor's garden.

E. Thuja oracutalis. IVilld. 4. 508. Chinese arbor-vitae.

E. Thuja cupressoides. Willd. 4.510. African arbor-vitæ.

E. Thymus vulgaris. Willd. 3. 139. Common Thyme.

E. Tradescantia discolor. Willd. 2. I8. Purple leaved Tradescantia.

E. Trichosanthes anguina. Willd. 4. 598. Snalie gourd.

E. Trifolium clover. Several sorts have been repeatedly tried but with little success; in some places a little white clover is seen growing amongst the grass in gardens.

E. Triticum aestuum and hybericum. Summer and winter wheat.

E. Tropalum majus. Willd, 2.298. Indian cress.

E. Ulex eurapeous. Willd. 3. 969. Common whin.

E. Ulimes virgata. R. A small trec from China.

E. Urtica tenacissima. R. Calvoee of the Malays; from the fibres of its bark the China grass cloth is made.

E. Vicia faba. Willd. 4. I I.I I. Garden bean.

E. Vinca rosea. Willd. I. I233. Rosy periwinlile.

E. Vilts vunferae. Willd. I. I I8o. Grape vine.

E. Volkameria inerme. See Clerodendron.

E. Viola tricolour. Willd. I. I 68 . Pansy.

E. Zea màs. Willd. 4.200. India corn is common in gardens but does not seem to make anything like a profitable field crop.

E. Zamia. One small plant of an uncertain species in the public nursery. 

1 


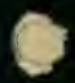

24 


$\begin{array}{lcc}\text { DT } & \text { Jackson, E } & \text { L } \\ 671 & \text { St. Helena } & \\ \text { S2J3 } & \end{array}$

PLEASE DO NOT REMOVE CARDS OR SLIPS FROM THIS POCKET

UNIVERSITY OF TORONTO LIBRARY 
